Louisiana State University

LSU Digital Commons

1937

\title{
A Sociological Analysis of Rural Education in Louisiana.
}

Marion B. Smith

Louisiana State University and Agricultural \& Mechanical College

Follow this and additional works at: https://digitalcommons.Isu.edu/gradschool_disstheses

Part of the Sociology Commons

\section{Recommended Citation}

Smith, Marion B., "A Sociological Analysis of Rural Education in Louisiana." (1937). LSU Historical Dissertations and Theses. 7786.

https://digitalcommons.Isu.edu/gradschool_disstheses/7786

This Dissertation is brought to you for free and open access by the Graduate School at LSU Digital Commons. It has been accepted for inclusion in LSU Historical Dissertations and Theses by an authorized administrator of LSU Digital Commons. For more information, please contact gradetd@lsu.edu. 


\section{MANUSCRIPT THESES}

Unpublished theses submitted for the master's and doctor's degrees and deposited in the Louisiana State University Iibrary are available for inspection. Use of any thesis is limited by the rights of the author. Bibliographical references may be noted, but passages may not be copied unless the author has given permission. Ciedit must be given in subsequent written or published work. A library which borrows this thesis for use by its clientele is expected to make sure that the borrower is aware of the above restrictions. 

A SOCIOLOGICAI ANALYSTS OF WURAL BDUCATION

IN IOUTSIAHA

\author{
A Thesis \\ Subnitted to the Gradunte Faoulty \\ of the \\ Loulslang state University \\ by
}

Marion Bush Bmith

In partial Fulfildent of the Requirements

for the

Degree of

Ductor of Fhl Losongy

May

1837 
UMI Number: DP69164

\author{
All rights reserved
}

INFORMATION TO ALL USERS

The quality of this reproduction is dependent upon the quality of the copy submitted.

In the unlikely event that the author did not send a complete manuscript and there are missing pages, these will be noted. Also, if material had to be removed, a note will indicate the deletion.

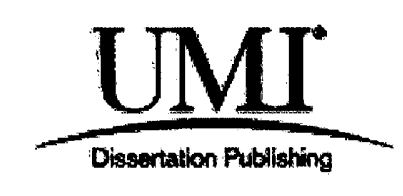

UMI DP69164

Published by ProQuest LLC (2015). Copyright in the Dissertation held by the Author.

Microform Edition ( ProQuest LLC.

All rights reserved. This work is protected against unauthorized copying under Title 17, United States Code

\title{
ProQuest
}

ProQuest LLC.

789 East Eisenhower Parkway

P.O. Box 1346

Ann Arbor, Ml 48106 - 1346 


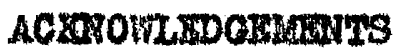

The author wishes to aoknowledge his indebtedness and to oxpress his appreolation to all wo assiated in this study and in saking it possible.

He desires to express his thanks to the members of the faculty of Teaohers Colloge and the Depertreant of Sociology of the Loulslana state onlversity, eapeolaliy to Dr. T. Iynn smith for his tireless efforts in roading and construotively orit1oizing the manuseript, and to Dr. Homer L. Carrett for h1s timely suggestions, encouragentent and advioe.

To the Bhoolmen of Loulsiana-- the parish superintendents and the sohool principels tho opened tholr sohools to the writer to alke this study, partioulariy la. T. 0. Brotm, superintendent of Oueobite Parish, vr. John I. JoDurf, Superintendent of Franklin Par1sh, 14r. Jack Hayes, Prinolpal of the Ouaohita Parish High Sohool, Lr. T. A. Judd, Prinolpal of the Mangham Algh Sohool, and Lr. E. I. Talbot, Frinolpel of the Terrebonne High sohool-- the witer wishes to express hil gratitude for their courtesies and cooperation.

Without the oooperation of the state Department of Hacation of Loulatana, this atudy would have been Impossible.

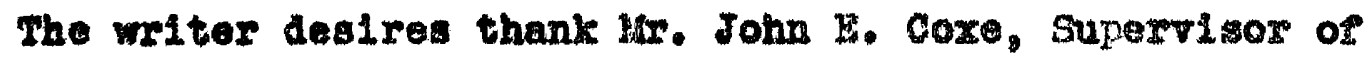
H1gh Sohools, Dr. 2R. P. Rogera, Assoolate Supervisor of IIIgh Sohools and Lr. John IF. Lombard, Diroctor of Teachor-Certirloation and Trainine for thelr cooperation. 
The writer foels deoply grateful to Dean B. F. Hitohell, Doan Frod C. Frey and Dean C. A. Ires for thelr ald whloh made Ohls study possible.

Finaliy, Without the selr-saorifleing support and encouraganent of the author"s wife, Luola Forsyth smith, this study would not have been undertalien and could not have been completed. For this assistance the writer wishes to express his deepent appreolation. 
TABLE Or COWTHNTS

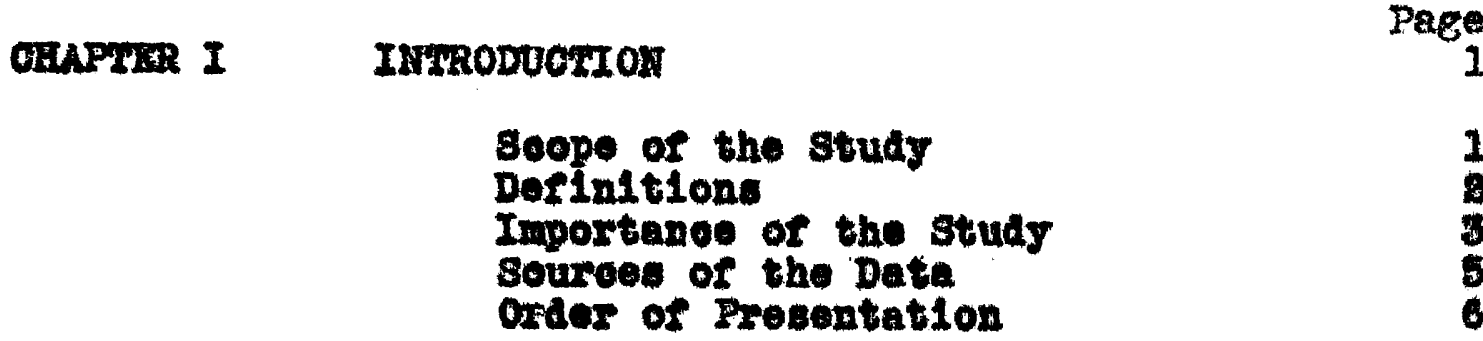

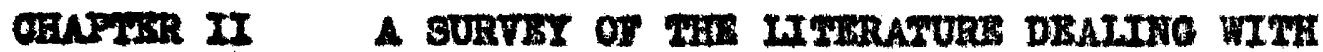
RURAL BDUOATIOA

The Defeots in Rural Sohools

Sugseations for Inprevenent 18

Comolueton 22

GEAPIR III FOPULATIOA GRARACTERISTIC8 OF LOUISIAMA 28

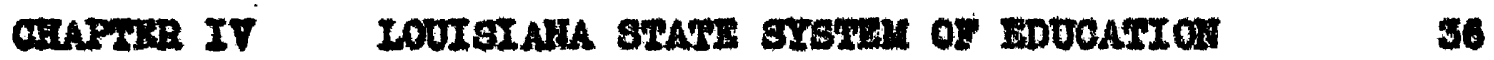

Sohool organization 36

Clases of Public Sohool. 37

Congolldation of Bohools 39

Subjeote studied 18

Toaghing Perconnel

Conolusion 62

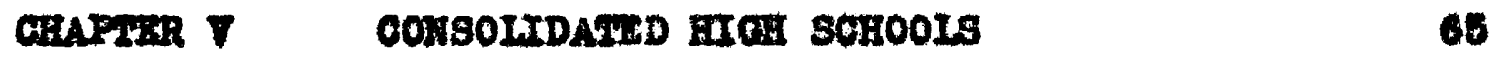

Bootion A Tho Rural Consolldated High Sohool Loented in the Open Oountry 65

Tho Walker High Sohool 66

The rronoh 3ottloment nigh sohool 81

The Removilie High sohool 00

Conolusion 104

8eotion B the Rural Consolldated High Bohool Iooated in the V11lage Conter 128

the Kanghan High sohool 118

The Iutehor HIgh Sohool 135

coneluelon 150 


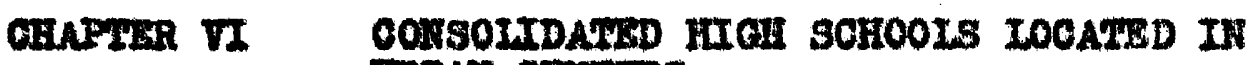

$\operatorname{Iacos}$ URRAR OAtrugas

The Oanohita Parloh High Sohood

161

The Tarrobonne Elgh Bohool

Conoluston

178

180

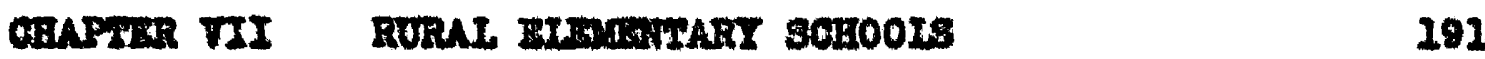

Eeotion A The Oonsollated Rural

Elenentary sohool

198

The Fondale sohool

The Sanstom Bahool

192

801

Sootion B Nelghborhood Sohoole

204

The Belmont sohool

tho Maway Sohoel

894

the Mren Nelghborhood

807

Comelualon

209

812

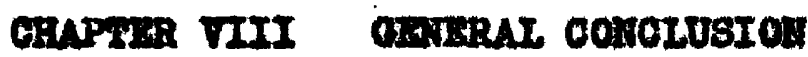

219

APPADIX A

1

Tab10 I

1

2ab1e IT

-oxtr

APPIDIX $\mathrm{B}$

$\times 18$

zable I

$x 17$

xb10 IT

$x+21$

BIBIT OeRAFix

xIr111 
Ixse of 2antes

zablo

rage

I. Whte Popalatien of Louldiana

27

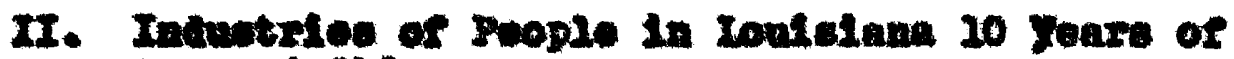
Ape and orar

IX. wite Popriation in Louledina of Behool Age 30

I. achool Attondanes in Ioulatana 30

T. IIfteracy anong the the Popriation in Ioutining

I. Tunoluont and Trunoportation in Loulalam rub2lo sahoole for the seation 2044-1035

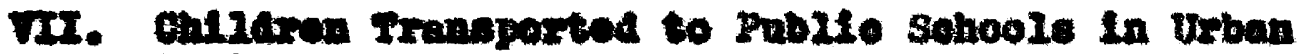
conters.

VII. Bobeol chileren Irangported to sohools in VIIInges Ath a Popelation of from 1,000 to 2,560 . 46

I. Subjopte studted by Bigh sohool Fup11s 51

x. Comporicon of Rural-Rarm stetus of Mat17e vite Population and the subjoote Targht In Mifteon Parichon.

x. Leveational Intitutions in Whioh Loulatane Babool Soachere war Irained.

II. Teeching Inportence of Toulatina Touchers. 60

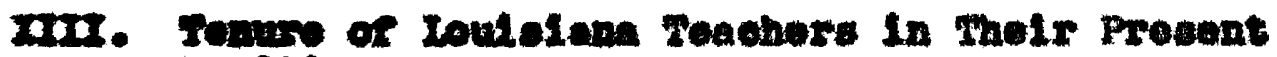
Poatsteas.

II. Gecapations of the Parente of students of the walles sethoad.

27. Cectpatlonal Proforence of the 3tudents of the Entrar sohool.

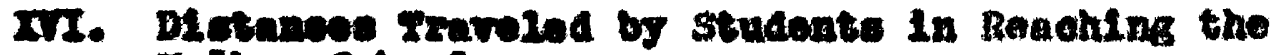
Ealus sobool.

III. Orgendastons to mi oh the students of the walwer 71 ch Boboel Bezons.

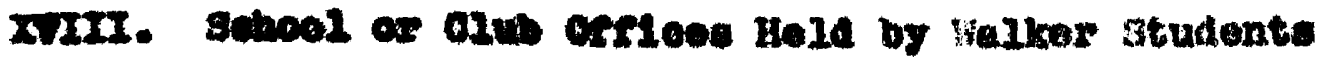




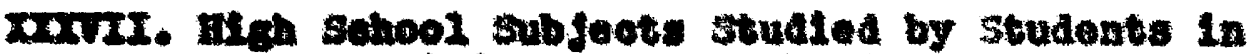
Throe Loulelane Rural johools.

WrmII. Decupations of the Parents of students of the Kanghan scheol.

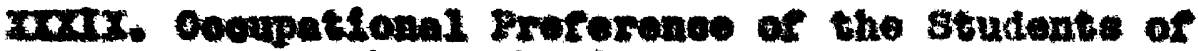
the Innghina sohool.

xi. subjecte Felon by the studente of the Enghan Elgh sohool.

XI. In of Arrivel, Distanos Traveled, Capaolty

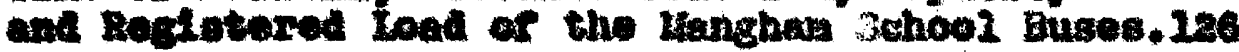

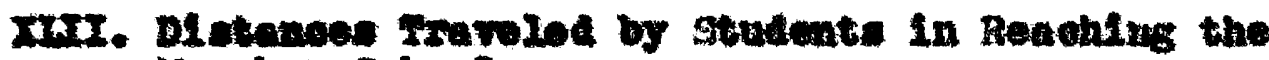
Lunghan sohool.

rinI. Ace-Grade DIotribution of students in the Danown sehool.

Xrr. Leedente qualletiontone end Tonure of the Hanehna Sobool reachart.

xx. Ase-grede Dietribution of 3tuctents in the Inteher sebool.

XII. Oedupatlons of the Parwnts of the students of the Intehor sohoel.

XIxI. Deoupntional Proferenee of the studente of the Inthor 3ehool.

arrx. Partiolpation in Strdont Aotivities and CrsenInatioas in the Iutoher High Sohool by Rod dence.

7ux. Bohool or club orfloes Held by Luteher students Leoording to molr Raslcenoe.

L. Contente in Wuloh Students Have Hepresented the Intohor 30hool Acoording to Resldence.

II. Ecuparison of open-Courtxy and VLInge Strconte of the Irtaher Bleh sohool on the Basie of sohool Bonors and sonteots in fol on Strdente Have Ropresented tholr School

III. Subjeote Faben by the Studeate of the Intoher Elem sohoor. 


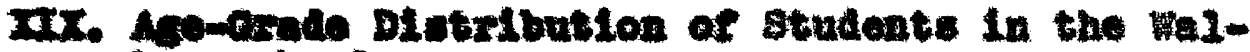
war sohool.

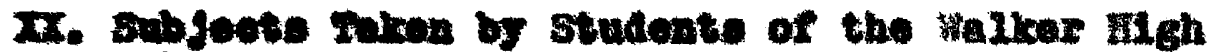
Sabool.

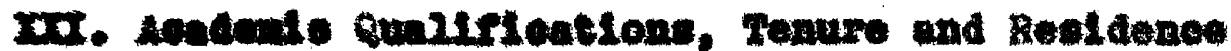
of tho Wurtror sobool zeabhore.

WII. Oeangatione of the Perents of the French Botetroot sobool students.

DIII. Decupatlonal Prarezrenes of studenes of the Frenos sothemant gehool.

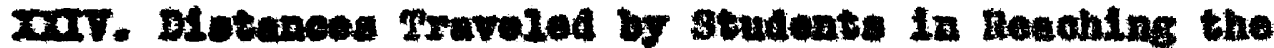
runeh Satticunt sohool.

2x. Lgemrade Uletribution of Students in the rendh sotrieriont sphool

XIX. Swo jeete Feken by the studente of the Frenoh Bothiment Ilich sohool.

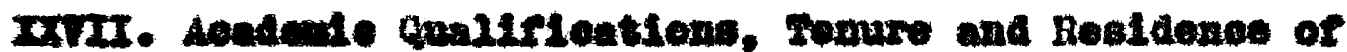
the French 3ettionont Sehool Teachors.

xxIII. Oedupation of the Parente of Students or the Benorille sobool.

Xax. Oecupational Prorerenes of the students of the Domotille sobool.

2x. Age-oxade Dietribution of students in the Ronom Tile sehool.

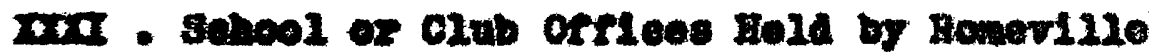
Btudonte.

Xrox. Irente in mieh strdente Bave Represented RomeVIIe 3ehool.

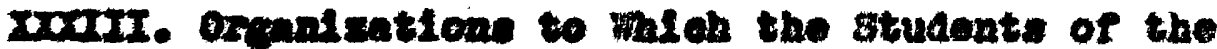

Bowntlle High Sohool Belons.

xodT. sabjeote Talen of studenta of the Romer112. Bte sohool.

noxr. Aeadede Trelaing and Tonure of Teachers in the Bewerlile Sahool.

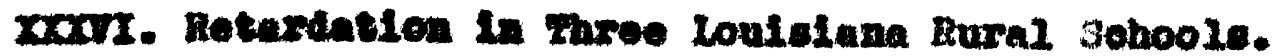


III. Aondente Goniletentlons and renure of the Intahes sahool redohers.

IT. Oevupatlons of the Parente of inrml chliaron Attendine the Ounohlta Parioh High Sohool.

W. Oocupations of Hothers end 31eters of Rurmi Btutents Attodiding tho Ounahite Parish Kigh soboed.

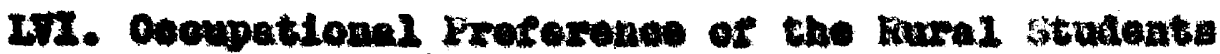
of the Ouadulta Parish High sohool.

LrI. Subjeets Paken by Rural studonts Attonding the Ounchite Partah Hich sonool.

17II. Distances Trovelad by Rurul Ohllaren to Heach the Ousohita Parleb High Bobool.

2Ix. Cooupations of the Paxents of Rurel Chlldren attondlus the Terrebone ItIeh Behool.

IX. Cochpations of Erothers and Sletere of Rural strudents Attending the rerrebonne HLh sohool.

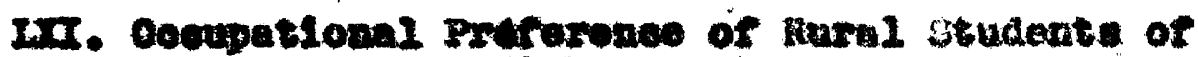
the rerrobonne iflech sohool.

IxI. subjeote studied by studente of the Terrebonne High Soheol.

2xII. BLetences Travelod by Rural. 3tudents of the zorrobonne tilgh Sehool. 


\section{CEAPTER I}

INTRODUCTION

Thio study is an analysis and an eraluation or the rural public sehools of Loulsiane in which white children are trained. More speoifioally it undertakes to examine the Loulglane publio sohoole for the following informatlon:

1. The qualifloations and tenure of the rural sohool teachers.

2. The character of the rural sohool plants and their furnishings.

3. The size of the rural sohools.

4. The course of atudy in rural schools.

5. The adaptation of the course of study to the noeds of the community or nelghborhood in which the sohool is 10oated.

6. The rate of pupil progress in rural sohools.

7. The extent of consolidation of sohools as indicated by the transportation of pupila to school.

8. The provisions made in rural schools to ald in the soolal derelopment of the ohlidren.

9. The recognition on the part of the sohool of 1ts obligation to the oommunity.

20. Fossible inadequecios or werknesses in the syster of consolidated rural schools. 
Sape of the study: This study is lint ted to the achools for whte ohildren of Loulalane in general and to 13 sehools distributed in different sectiona of the stote in partioular. For this study the sohools are olaswlied as followa

2. The Rural Consollated HLgh Sohool.w.

a. Those located in the open oountry of in uninoorporated hamiete.

b. Those loeated in Imeorporeted rillage oenters.

2. The fural Conaolideted Figh Eohoole Located in Erban Centere. Those which eduont the mural chlidren of lts hinterland by moane of transportating thom to sohool. 3. The Rural plementary sohools.

a. The Consolldated Fural IHIementaxy Sohool.

0. The Helghborhood sohool.

At least two schoole were seleoted to represent wak olass, one from the Brench and one from the Anglo-Saxon oulture areas of the stato. These sohools mere ohosen as representative aftor

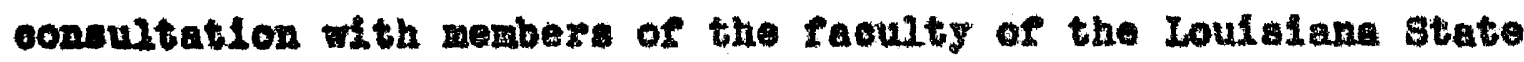
Univeralty in both the Mduoation and the soolology Departmentes.

Dorlationg: Definition of oome of the terms used will aid in an maerstanding of the study.

"Rural sohool" is used to moan any gohool which trains ohlidren who cone from homes looated in "rurfil" areas. "Rural" 1. used as it is dorlned by the United states Census Bureau, 1.0., those living within area with population of lose than 2,600 .

A "high school" may wan simply tho fehth through tho - Levonth grades (as 14 ig organtzed in Loulstana) or at times 
It may refer to a partioular educational institution in which the ohildren from the primary grades through the secondary department are eduoated.

"A consolidated school" is a sohool serving an area larger than the usual school distriot and so removed from a portion of the students that a system of transportation must be furnished those members. It is usually formed by closing the smaller schools in the nearby neighborhood and trensporting the children to a centrallzed institution.

In referring to agglomerations of people within an area, the following olassifications wll be adhered to:

1. Hamlet--unincorporated center with few residences and one or more comerolal institutions to supply the primary needs of the immediate population, but which is situated within the "trade arean of a nearby village or town.

2. Small Village--inoorporated center of population with fewer than 1,000 people.

3. Large Village--incorporated center of population of 1,000 to 2,500 .

4. Small Town--having a population of 2,500 to 5,000 .

5. Large Town--center of 5,000 to 10,000 population.

6. Small City--population of from 10,000 to 100,000 .

The Importance of the Study: The importance of the subject of this study can be judged by the fact that although 77.2 per cent of the white papulation of Loulsiana outside of New Orleans 18 classed as rural, and 64.1 per cont of all white children of school age (aix to 17 inclusive) are rural, jet no

1. This classification 18 used by Dr. T. Lynn Smith, professor of soclology in Ioulsiana State Unlversity, in his classes in rural soolology. 
deferentiation is ade in louslan between rurel abovia and urban sohools.

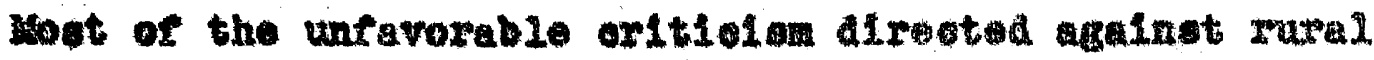
whoole has beon aimod the mall "alstmot sohool" of the "one-roem school." Assoviated with this oritldias of the small rurgl seliool has oon the adrowey on the part of educators and soolologiste for consolidatod or centrulized sohools. The cosaclidation of shool has been attended with the closing of one-roon rural sohools. In Loulalan, between 1910 and 1934, 1,334 onomroon sohools mere alther olowed or onlargad so that they wero no longer one-room soboole. The total number of

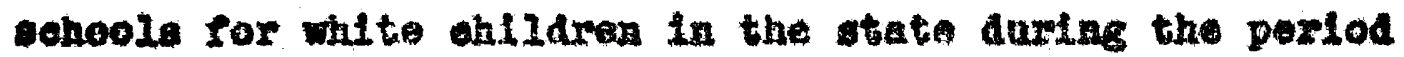
coareased from 2,300 to 1,210 - a dourase of 1,090 mohools wthin 24 jearg. At the aase tine the number of whte eduoables Inereased from 304,157 to 399,998- an ineroase of $95,842-$ and the aotual school abtendano inoreasod from 131.667 to $245,258-\cdots$ - galn of 113,585 in the wite gohool exrolinent. In other words, wile the number of gohoole wes decroasiag yy 47.4 per oent, the aeteal white sohool onrollwont was inoreasing by 06.3 por cent. It has been generally cooepted as an eduoatlonal axion that the oonsolldated sohool is the panacen fol the lils attributed to rural sohools. Certaln wural parishos in the state, with white wohool enroliments ranglne from 2,500 to 4,073 , have coneolidated thoir sehools to auch an oxtent that from six to ${ }_{3} 10$ sohools take care of the sohool enxollmont within oah parlah.

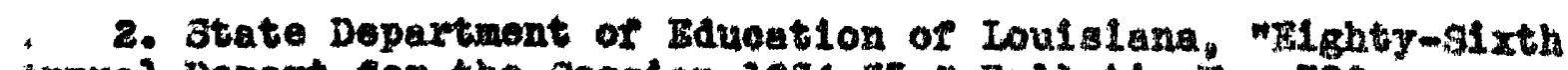

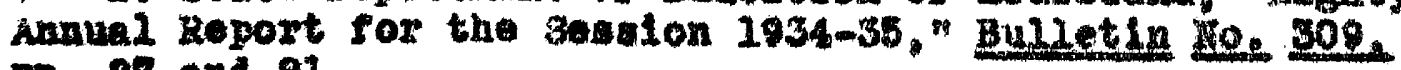
219. 87 and 81 .

3. Ibid. DP.52-38 and 156-137 
There has been no orftical exantnotlon of tho work done in the new type sohoole of the state. Such an exanination is noeded. It ceens desireble that a study of the present sohools be made to deternalne thel: merfts and possible deteots.

Sources of the Data: Data for this otudy were obtained from the following souroes: the United States Gensur Reports for 1930: the andual reports of the state Department or Ituration of Joulatana; the flieg of the High Sebool and College conetistion of the State Deperticent of Iduontion of Loutglama; the t1108 of the state High sohool supezvisor: the flign of the state Budget comitteo. In addition to these courees, personal vialts were wade to each of tho mohools soloated for Individual ones study. During the vigita information was sooured from the prinolpals! offloe records oonoerning the sohoed enrollment and the trenaportation of pupils, the qualiefoaslons and tenuro of teachers, and the extra-ourrioular ectivities of the sobools. The oheracter of the gohool plants and the ir furnighing was observed. rinally, cohedule of questions, made out in two rorms fone for the elementary sohool ehlldren ebove the thir erede and the other for the high sohool pupilis) was fiven to och ohlld

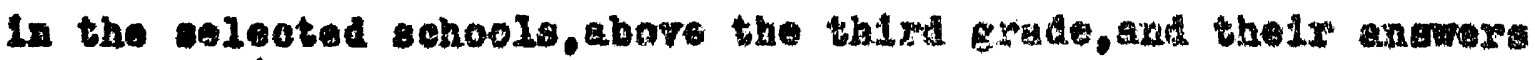
tobulatod.

Order of Eresentation: A surmary of the Itterature dealing Ath raral eduoution da prosented Ilset. This is collowed by

4. For a copy of thase sohedulen ses Traline I and $\mathrm{XI}$, Appondix 
a ohapter arroted to an analysis or the Loulstan populetion. The tollowing ohapter to concerned wt th the state ahoola in general, in whloh a brief snalysis of the sohool oxganfation. coneolldation of sohools, the courwe of study and the teaching permennel is given. Tho remeinder of the study is then devoted to anaiyala of the Individunl sohools, beginning with the "Rural Consolldated High Sohools," then the "Rural conaolldeted IIIgh Sohoole Loented in Urben Centors, "and Plnally, the "RuraI Blementary Sohools." A aunnary of the coneluslong of each ohapter 1s then rede. 
reoomended that the eduoation be made pre praetieal by adding certaln olomonts of induntrial exaining appropriate to the Iife end environment of the otudente:

Oubbexloy; writing in 2914, found groat need for ohange In the subjeot atter taught in rural sohools. Not only were many aubjecte 111-oulted for mural 11re; but muoh of the material In the essential sohool aubjeots wa of 11 thlo praotieal value to rural pupli. Ite malntalned that now material showi be used In the old wooln subjects and that new subjeets shovld be added which would be of praotical value to rural residonts. Among the new subjects wioh he suggested were nature otudy and agrioulture, donestle selenoe (home eoonomi od), manual tralning and organized play for the elementary bohools; and subjeots douling wth soolel, coonople and polltioal problens, muslo, ext, phyoloal edveation, agriculture, comestio oolence, and manual work should be inoluded in the high sohool onrrioulw. He saw Ilttlo need for Latin or for modern langrages. At a at111 later cate, 2020. Claxton, writing on the Arorioan Rural Sohool, stated that the otudise in Iural sohoola

21. Op. a1t. p. 281. Cubberley also malntainod that. "Edueation. unrelated to one's envirommont and da11y Ifre, is booklah and Ifkely to bo inerfeotive eduoation alosely tied up vith one's rlohest IIre expexlenoes. whatever these may be. Is $11 \mathrm{ke}$ Iy to prove efreotive anywhere. It realiy mattexs ilttio whether the ruture man or woman IIves on the farm or in the elty. for tho kind of training which will adupt man or woman to IIve In the open country w1II prove ueerul anywhore and it wiI prove. userul Iargeig beoause it had been been erreotive in awakening thinkins, ostablighlne standards, and rerining judements." zo uses as axuments for the subjoets to $\mathrm{flt}$ the needs of rural ohllaren when applied to those who will 1ive in urban centera. the usual reasons advanoed for studying forelgn language, algobm geometry and other traditional high sohool subjeots. In hia statement ho Indlater a pragmatio philosophy of edusetion -inilar to that pronounead at later date as basi for the projeot Hethod ox Teaching. 
objectione have been tade to the atudies taught 1 the marel schools. The one polnt on whoh all otvients of raral eaveation have apparentiy agread is that the raral pehools do

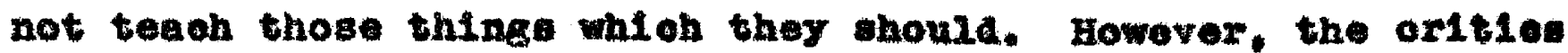
hare alfered widely in thels oplntans at to what ahould be taughto.

In 2897 the comatitee of Ivelve abjected to the eubject mater vaught on the ground that there wat no uniromity that aubjects rarked rrom one school to exother and oven within the

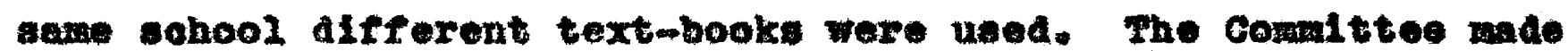
Feomendetione that antform oourae of atudy substantialig the same as that for the urban sahosis, should be elopted. In the report of the comittee on Induetrial Baveation; osoasion was again found to object to the oouree of atudy $1 \mathrm{n}$

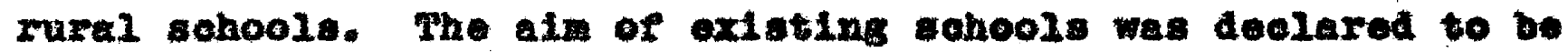
to acquire knowledge from booke and to bequre mental braining through the acquiatolon of that knowlodge. The commtto

19. Thl resomendation geens to have bome rruit later and to have been very geverely oondenmed by later writera. The the recomendations were carried into ofreot in Loul iana 18 eridant.

20. 0. ext. p. 18. The Comat tee meported, nIt is oustomary to admit that thelr oourses of atudy ahoula be srama 1th referene to the preparation of the pupila for thelr $11 \mathrm{~s}$ work rather than for advaneed work in schomi. They are not we Iramed. This comint tee does not hesitate bo agy that in its Judgement the rural chool. wioh train neariy one-half of tho chool population of thie country as far as ahool tralning goes, should leriniteig reogentze the faot that the major portion of those crolned ili continue to live upon the farms and

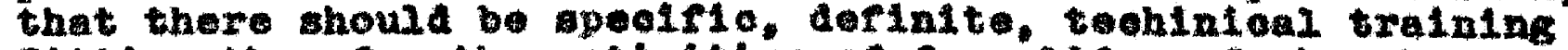

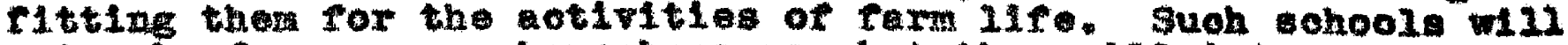
not wake 1 araers nor housekeppere, but they 111 intoreat boy.

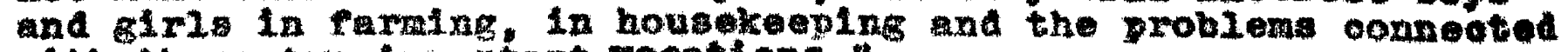
wth these two luportant rooations." 
the ruxal sohool houtes were typleally unsatisfactory. a. The slze of the thural sohool: unoh unfavorale ortticlam has been heaped on the rural sohools on the grounde that they are too amali for soclalized development on the part of the ptudents. Whe complaint was made by the comaltese of Twelvo

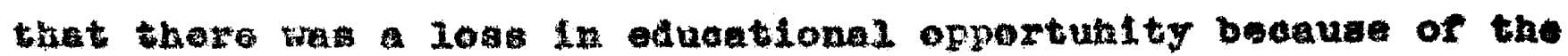
1ack of association with numbers of students of the zame age 17

and degree of udvancerent. In 1986, Caunaltz otudied the problem to see if there really was a dereot there. He round that the arerage enroliment for onempon sehools of the nation was not more than 20 puplis and the everage attendanoe was not 18

more than 26.

- The Course of Study of Mural Sohoole: Many different

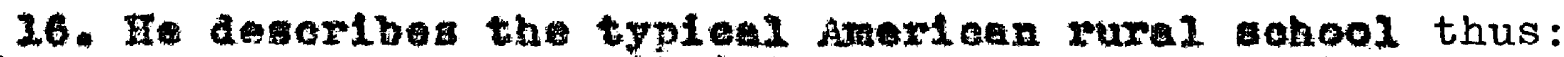
It 1 s one-atory raso bulidins about twenty-rour by thirtytwo foet in also, palnted alngily if at ali, fith one or two deoxe In one ond, and having two ox throe windows in ach of

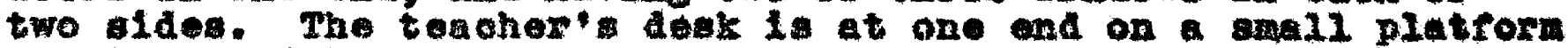

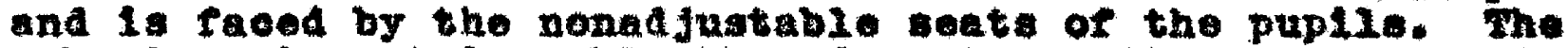
sohool equipment it bleckboart ox two, orten poor or out of

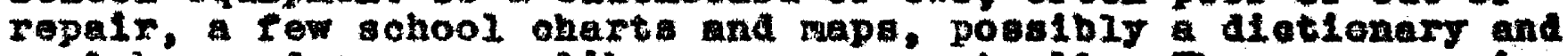

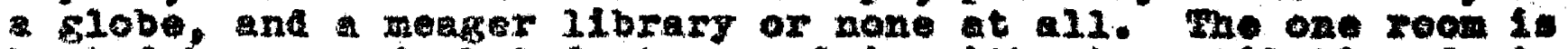
heated by an unjacketed atove nd 1 without rentilation derions,

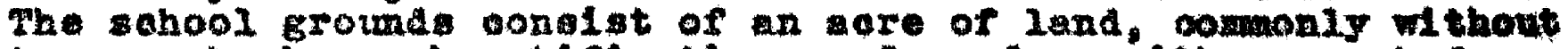

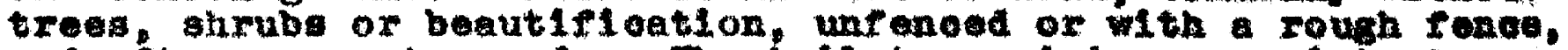
and oftem srown to weeds. The tollet provisions conalat ar

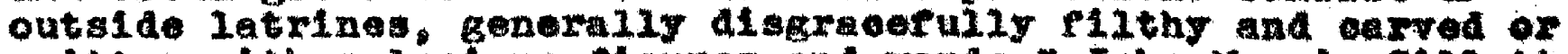

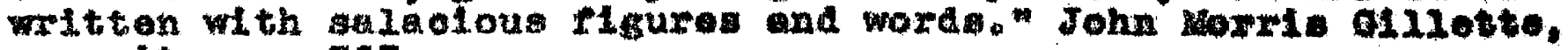
on. elt. 367.

17. OR. Q14. DD. $94-129$.

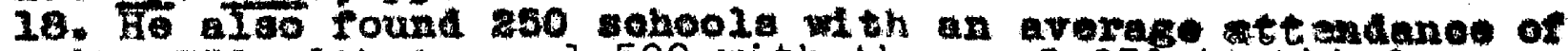
one pupli; 750 ith two: 1,500 with three; 2,250 taught four;

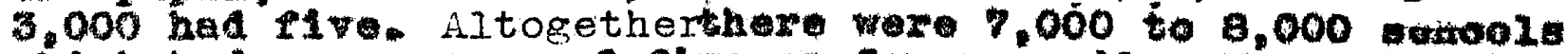

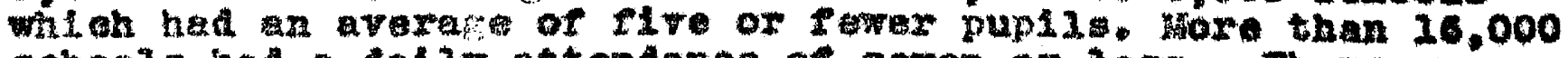

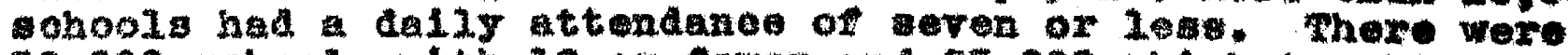

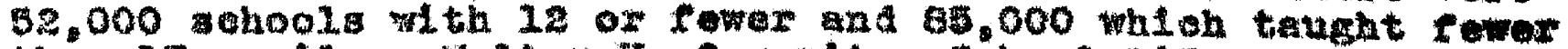

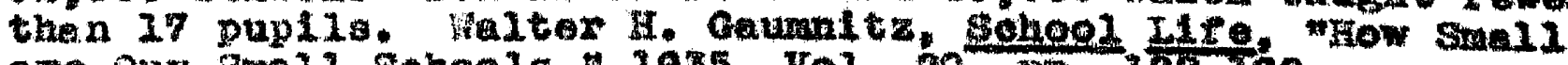

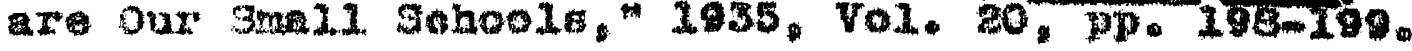


0. The Character of Sohool Bullalngs ard Furnightngs: one oan read soaroely any acoount of the rural cohoole of Anerloa without rinding reterence to the poer physionl atruetures in which the Inatitutiens are housed. This wae true the tine of the Renert

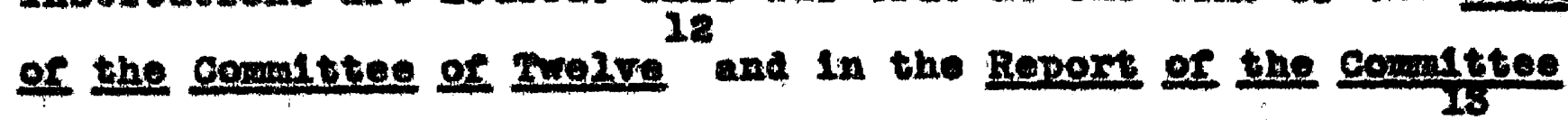
on Induatriel Eduoation in sohoels for Eurel comunitieg, in 1905. It was pointed out that the rural abhool bullalngs were 111-kopt, poorly furnilined, lnadequate and wh surromalnge most dopresaing. In the report of the atate eduoational ourver mate in Kentueky, 1020-1922, the mural sohools were pletured as poorly housed and poorly equipped. Very sialler conditlone were found in the state oduentional wurvey of Indian. 1981-1988. In his Rural soatologt. written in 1985. Gillette stated that

12. OP. At. . PP. 73-75.

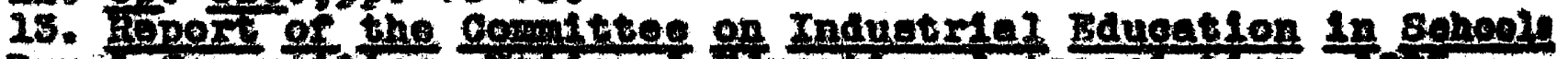

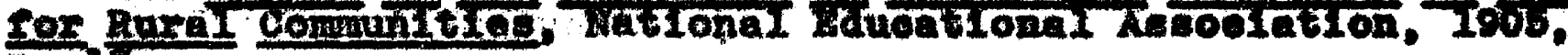
P. 28

14. wor the 8,070 raxal and craded alderlet sonoolnouses of the btebe. 50 pax oant have been expeted alnee 1908. The great

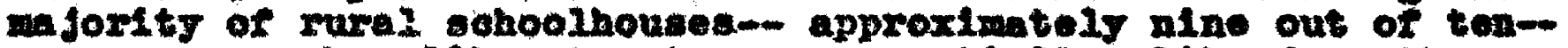
are one-roem, box-11ke atruatures, essentially allke Pram the mountalne to the MLesiselppl, and Srom the oblo to ronueses. These tox-11ke struetures, have in the ma1n, a single olaseroom; oloax rooma are rarely provided, and adaltional room for manual training. pooklng, agrioulture, or for fuel, alwoot nover. They vary in elze, number of windows, and in having ox not having porohea; but in all easential reapecte thoy are

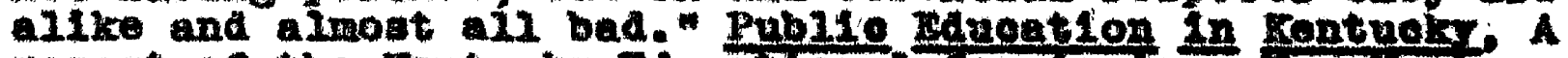

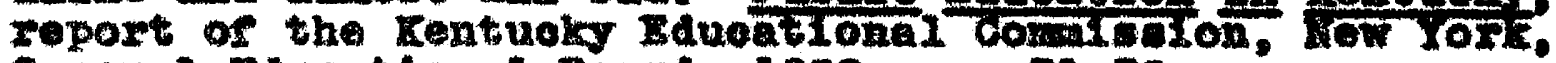
Generaz Educatlona1 Board, 1028, pp. 71-78.

15. MThex axe about 4.500 onettenoher cohoolhouses in the atate. practionily all located in the opon country.... About 2,600 of these old one-teacher bulidinge are box-11ice Prame strustrues. Whioh have, in the maln but one room. cloaluooms and additiond room sox maval trainirs. agrioulture. ox how hold axt are zarely provided. In ail cesontlal reppoeto

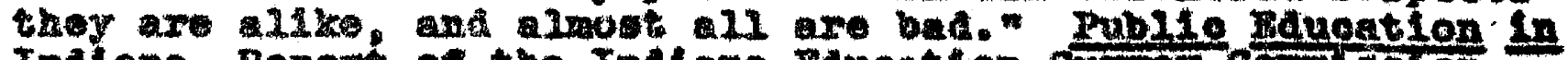

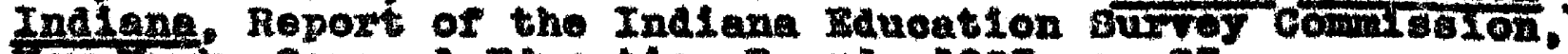

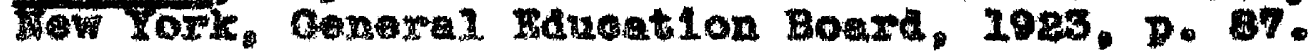


that not more than one-third of the zural wohool teachers had as nuob as six goars training beyond the elementary gradea. and for the mall alties or 10,000 population about ninetenths of the elementary sohool teachors had that ampunt or 8 wore or acaderulo training.

0111ette, In quoting from a etudy by Dr. H. W. Foght, formerly rural sohool expert for the Foderal Bureau of Eduoation, polnted out that of 61,000 one-room zural sohool teachers, frem Ifv to alx thoueand had only ono rear's gohooling beyond the - lementary $10 \mathrm{rel}$ and that approxlmate $1 \mathrm{y}$ another 4,000 had only two jears of tralning of seooncary level. He further etatod that the tenure of the rural sohool teacher was rery 1nsecure, and that for the Undted states as a whole the average atay of a rural toachor in a position was about two years with the majorits conelderably 1ees.

b. The Longth of the Bahool Texm: It has been repeateds polnted out by rarloug students of the subjeet that the sohool term in rural seotione is ahorter than that of tho urban sohoola. In1s condition was true at the time of the Report of the Comattee of 10 DureIre. Kolb and Brunner tated that in 2930 the ohool term ter the olty was 283 days and for tne onuntry 16 was $286 \mathrm{c}$

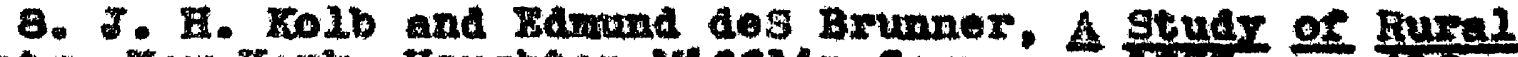

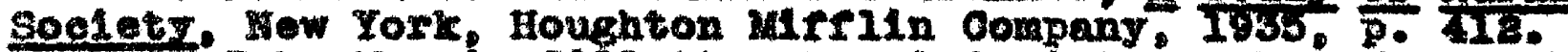

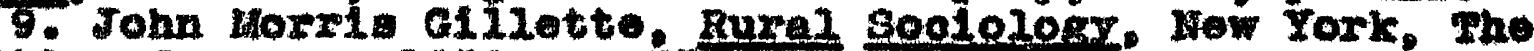
Hacml12an Company, 1936. P. 374.

10. It 1 thated that unt11 two jears priar to this report. 1. . 1895, the legal Jaar $1 n$ Manlgan was three monthe and at the tint of the report 1 wa but ilve monthe many of the rural ohoole of the rest and of the south ald not operate ros longer than four wonths, at the timo of the report op. alt. p. 146.

11. Kolb and Brunner, Op. at. p. 307. Gr. Unltod statea

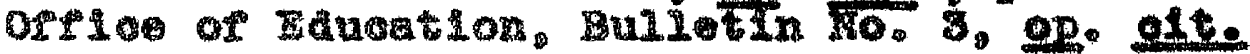


This proportion increacee in the two-teacher and viliage chools, mbut in no one of the groups do teachers with atandard training conatitute anything like a moxity." This elearis Indioated the Inferloxity of mural sohool teachers in the watter or eduoational qualifientions when ecmpared with those of the thira-aiase 01t1es, whiten have 80.1 per oent with two joars of normal-gohool or "gtandard training."

Though there was no coubt improvenent in the exalning of rurel sehool teachore alnoe the eariler report, is wa eloar that advancenent of academis atendarde of teachere in rural sohools had not kopt pace with that of the viliage of olty cohool teachera.

This was further indicated in a bulletin published in 1038 by the Dnited states orf10e of Education, whioh showed that the arerage one-room rural sohool teacher had an education equal to high achool graduation plus attendance at one suraer sohool, and oxperience amounting to a total or two years and six monthe. Kolb and Brunner, writing in 1956, found that raxal teachers were not so well tralned as olty or town teachers;

7. United Btatea OPrloe of Iducation, "gtatua of Teachere and Prinelpals imployed in the Rural Bohools of tho United States," Mullotin 10. 3. 1982. Thla atudy points out that nearly 40 per aent of the entire group of teaohers employed in rural sohools are teaching 1 in onemroom sohoola, that for the mural sohool as a molo 400,000 tenchers are employed who here a wedian eduoational ablerement of less than one year beyond exaduation from hlgh shool, and toechlng expexienos of a total of thre yes and elve monthe. 
that dogree of training oould wevre better salaries in the urben sahools or larger rural athoole. In thon, f the ruxal sohools) as a gonoral thing, are youns graduated frow the vilag. high sohool, or some ravorite among nolghborhood ramiles, or a type of andient teacher whose plecte I17 is not alsturbed by the rexing probleme of his profosaton."

There can be 11ttle surpribe at the lnadequacy of training for teaching when it 1 s rovealed in the sane roport that in the mural sohoola in Calhoun County, Mohigen, 158 toachera wore required, got in one year 342 arforent teacher: wore omplojed. The average length of the achool sem in tho alatriet was 8.4 nonthe, whereas the average term for which teachers were employed was but 3.B nonths. It was polnted out that this oondition was typleal of the otate an a wole.

Twonty-aix yeax Iater in a survey of the rural sohools of Wow Tork, It was found that the nore inexperienoed teaohers taught in the onomroom sohoole; that 21.24 per oent taught one year or $10 a s$ oompared with 9.7 per cent for the two-room cahools and 5.64 per cent for the rillage elementary eohoole. The median yoars or experionoe in teaching was 3.16 years for the onemroom sohools, 6.36 Jears for the two-room sohools, and 6.50 yeare for the village olementary sohoole. The same survey reports that, of 8,400 toachera in one-teagher sohoole, only about IIve por oent (420) have had as much profosslonel and

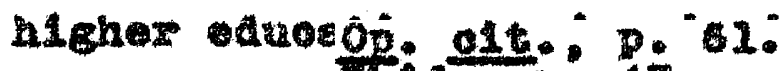
Ibla.: $5.7 \%$ Ceorge $A$. Works, (Dlreotor) Eurel sehool surrey of

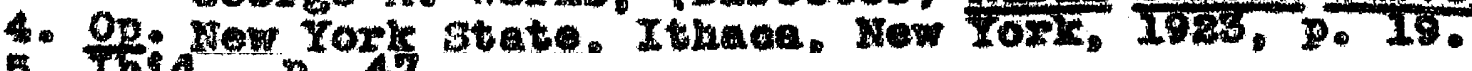

5. Ibla.: 2. 47.

6. Ceorge A. Works. (Direotor) Aural sehool survez or

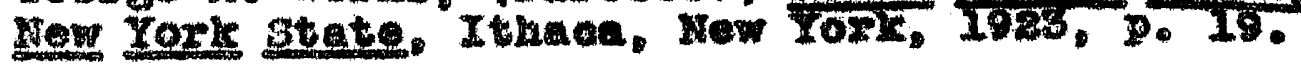


under the following divialonst

I. The defoots oxisting in ruxal sohoole.

a. Qualle lotions and tonure of rurel toechors.

b. The length of the sohool term.

- The oharaoter of Bohool bulidings and rurnlenings.

d. The slze of the rural sohools.

- The course of atuas in ruxal sohools.

II. Euggest1on for improting murel echoole.

a. Realreation of rural eatuation.

b. Coneolldation of bohoolv.

I. The Derects In Bural Bohoels: Huch of the 21terature

on the aubjoct has been deveted to polnting out the dorects

or Inadequacles found in the rural sohools.

a. Qualifleations and renuxe of guxal Teaoheres One ooule hnrdiy alseuse the wealeness of raral sohools without condidoring the oharator of the teachors-othelr training, thelr experienee, and their sounity in the podtions they hold-for to a rexy high degree the avecess or fallure, the strength or weakness of the sohool reats on the type or teacher employed. Reeder loed not ororstate the oase in saylng. "Al is the teacher. so is the

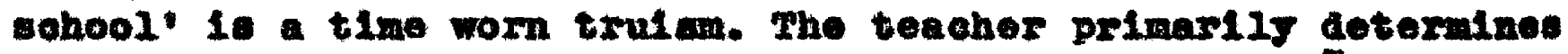
whether the school 1111 be errielent or inerrielent." "For that reanon 14 it not aurprising to rind so muoh written on tho oheracter of training and experionoe found among rural sohool teachers.

The Combettee of zwelve alsoovered that moat of the teachers In rural sohool. were inoxperleneed. Fow of the rural tokehor: were 1-mool exaduatos, because of the fact that those who hr

3. Ward 0. Reeder. The Fundamentele of Publlo Sohool Adminletrat1on. New York, The Macmlilin Compqny, 1930, p. 55. 
OKAPWAR II

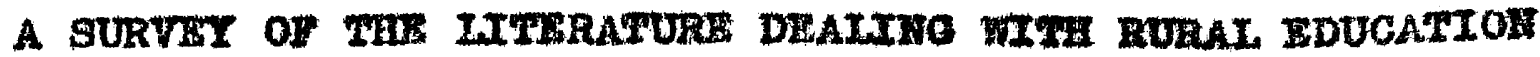

"The main alngle derlotenoy in rural ife to-dey is the lack of enough of the right kind or dueation." ${ }^{2}$ so wrote Cubbexley in his Rural Life and Edugetion. publiehed in 1914. And yet Cubberley wa not the flrst to senee thls impertant truth, for 20 years prior to the publieation of his book the rooognition of this fact oauged the Rational Baveational Aseodation to appoint its now famous Comatteo of Iwolve to 3 atudy rural sohools. Hor have conditions besn so much improved that the educators and sodologiats or our present time are completely satiafled with the achlevementa whioh hare been me.

A rather formidable mass of material has been writton on various aapeota of the problems of rural education in the form or roports of comisalons appointed to study the subjeot. books dealing with oduoation, books concorned with rural soalologr. magazine artioles treating varlous aspeots of rural Ifte and maral sohools, reporta of aurreys in counties and atates, governuent bulletins, and agrioultural experiment station pubileations.

In sumarizing the important oontributions in the rield. whloh is the ald of this chapter, they will be oonslaerea

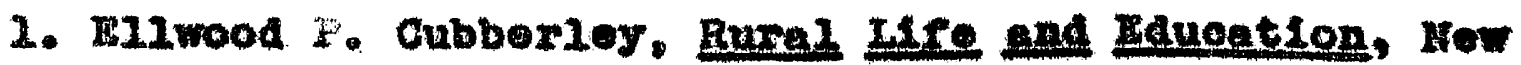
Tork, Houghton Mirfin Company, 1914, P. 108.

2. The Cont tee of Twelve was appolnted at the annual meeting of the National Iduottional Aagoolation, JuIy $9,1895$. The report of the comittee was punilined in 1897. 
were preetielly whout exception the same as those taught in 89

alties. Rapees, In suggesting what rural sohools should teech, saw no need for the teaching of any language other than Engllah or any mathesation other than arlthrotic. All courses should be assoelated with agrleulture and the opeolal type of agrloulture 23

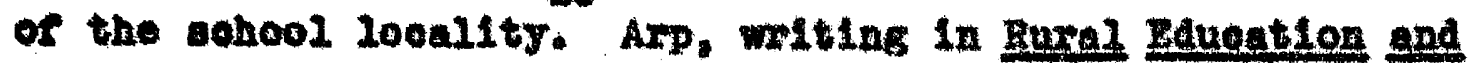
the Cossellated sohool, hold that the greatest need was a reconstruoted curriculum for mural cohoold. He folt that the entire program of sahool work chould be bullt around agrioulture. A afferent point of rlew was preasnted by Brim, who felt that the course of study in rurel schools was aefinitely too sural and emphasizod agrioulture and homsmaking to too great an extent. If felt that the sohool course should be broadened se as to give rural onlidren a broader outlook on Iffe.

In his Ruxel Cosmanitr, printed in 1952, Sanderson seene rery optiniat16 coneerning rural education. He ass:

Tormerly the oontent and method of education ware Imitations of those of the of ty and Inovitubly made proteselonal, oonerolel and Industrial ocoupations the Ideals of the pupils.... Farn peoplo Iingily devanded that oducation fit for oountry as well as elty Ife, and the Introduction of nature study, agrloulture and how conond os in beocming genoral in rural sohoole. Rural edueators do not desire to trein mural ohildren solely for fars lifo ane thus establiah a segregation of farm elabs. - ron were that posalble; but thoy are attempting to give oqual exphas to the values of country

28. Fnilender P. Olaxton, The Amorioan Rural Sohool" in Louls W. Repeer (Id), The Conbolldeted Rurrel Sohool. Now Tork. Charles Boribnor's sonf, 1920.

28. Iouls W. Rapeer, or. 2t. . Pp. 284-316.

24. Jullue B. Arp, Buret gurioation and the Consolldated

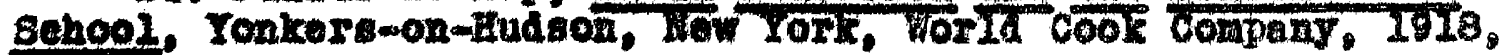
p. 60.

25. 0. O. Brim, "Countxy Commity Bducation." Prooeadings De the Irth Hational Country IIfe Conference, 1922. 
2ife, so that 1t may prove as attraotive as eity Iffe to the more Intelisent as well as the less intelilgent rural youth." 86

Cubberley, writing In 1834, did not soe the stuation oxisting in rural sohools, wh thererence to the subjeots taught, in the same 11ght as Senderson. He oomplained that, though the courses of atudy had been mode unfform and revisad, they had been revised with on eyo to the needs of alty iffo rather than to those of the rural seotlons. He concluded that, "The netural reawl is that our rural and v1liage schools have remained booklsh, thelr work unrelated to farm life or national needs, and their influenee away from the fara," 27 II Suggentions for Inproving Rurel Mhools: Dootors orten agree in alagnosing the patient a 111, but not so often in preseribing a treatment whioh will eure his allment. However, In the situation regarding the rural sohools, there is almost general agreoment in the remedy preacibed. It is usually: (2) Redirection of Rural Edusation; and (2) Consolidation of Rurel Sohools.

26. Dwight Sanderson, The Rural Compunfty, Boston, the Athenaeura Preas, 1032, pp. 525-530.

27. Fllwood P. Cubberley, Publio Fdueetion in the Un1ted States, Cambridge, Hassachusett, the Riverside Prese, 1934,

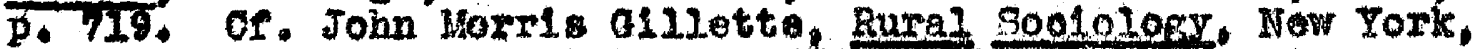
The Macmilian Company, 2936, po 374. Criletto goens to agree with Cubberley for ho says, it is surprialing to alsoever to what slight extent rural sohools are consolous of theis aurroundings and how reoentis the few state whloh recognize the rolation of edusation to the omandty intereats and aotivities have taken aotion...... Agrloulture la roquired in the rural schools of but dozen states, domestio solence is a recent innovktion, yot the farm home is near the prine source of food. Ilterature and history are remote from farm I1f as yot, and leadorshis otudiog, such rural soolology and rural conomlos, are practlority unknown." 
c. Redireotion of Rural Sdueationt It wa in the Revort of the Gongecton on Country Life that the comand for a rundamenteliy redireoted eduvational progran was made. It demanded that new type of ingtitution bo oreated with a teacher who was himeole a part of the communtty and not a migratory bird of passage.

Cubberley jolned wh this conattee in demanding redireoted oducation, in his Bural Life and Equeation. Ho mateined that the moat inportant single remedy for the defoote of rural life lay in a redirected educational progran for rural sehools. He mainteined that it was nocessary to broaden the outlook of rurel 11fe. The soolel llfe of the adult as well as the youth should be provided for. Country 11fe should be made attractive to women and girla. The remuneration from farming ahould be inereased and the "awayfrom-the-fara" movement oheaked. All of these oould be acoomplished by a rodireoted educational program. The sohool should be dreoted toward the lire and aotivitios of the oosmunity of which it is a part rathor than toward oarrying out the tradtional sehool program. 29

Arp maintained that rural sohool hould be direoted toward rural comunity neede. He opposed the looation of rurel sohools in urban centers, or rural chlldren's being sent to urban schools.

28. The Comaselos on Country Life was appointed by President Roosevelt. Ite report was made in 1911. 29. Op. alt., pp, 263-175. 30. OP. CIt. PD. 01-210. 
b. Consolidation of Rural sohools: From the Renort of the Comaittee of rwelre up to the present t1we theme has been an almost oontinuqus demand on the part of alusators and fural soclologlate alke to consolidate the small schools as meano of correcting the weaknesses assoclated wh the rural 31

Institutions.

There seans to bo no definite agreosent a to what

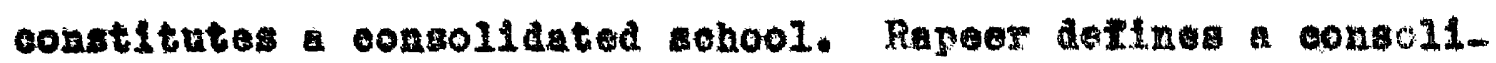
dated sehool as, "f sohool produed by bringling together the puplis of two or mor singlemroom or other sohsols in gradel school of at least two rooms and two teashere for the purpose of botter educationel adrantages " 32 Ary defines $1 \mathrm{as}$, "A weil graded oentral sohool in legally and opmplotely consolldated sohool distrlot, anploying rous, fite or more teachers and ofioging from two to flvo years of high achool work in addition to the usual elementary subjetson oubbriey

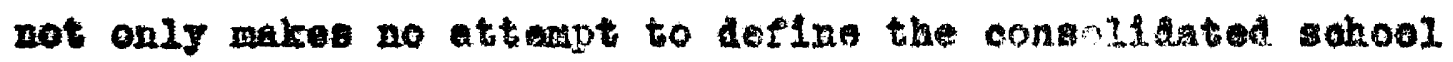
but uses the term interohangeably whth "contralked" sohools. wore recentiy rolo nd Brunner ceseribe it as a comblnation of two or more amalls school brought togother for the sake of greater erflolenoy and for the purpose of serping all the

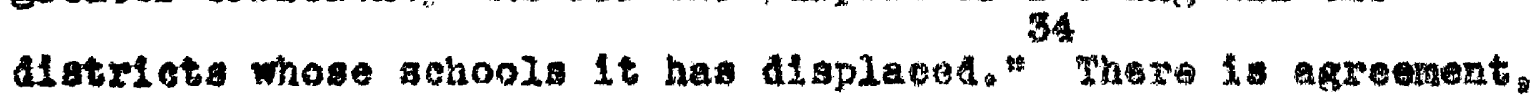

31. Among the euthoritles who presented songo11dation of rural sohools a a mothod of correcting the rural sohools are: Gubbarley, in Rural Ife and pdueation? Axp.

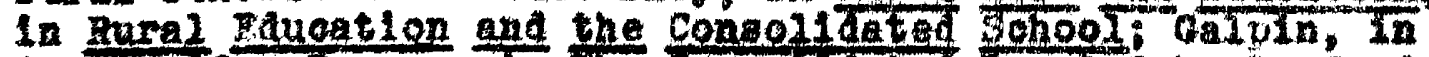

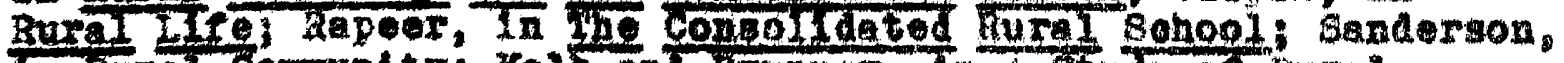

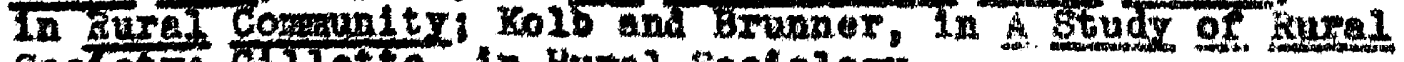
Eoelaty Gillotte, in Mural Bonlolon:.

S2. ㄷ. Q1E., p. 7 .

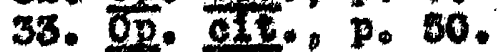
34. 도. EIf, p. 406 , 


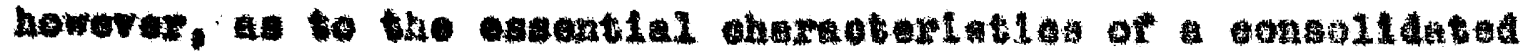

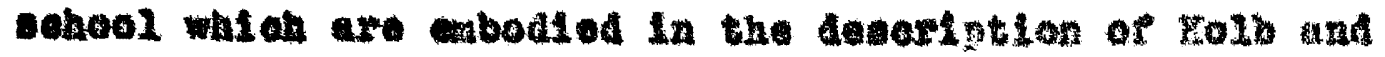

Rrounes:

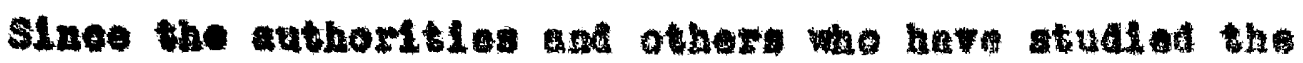

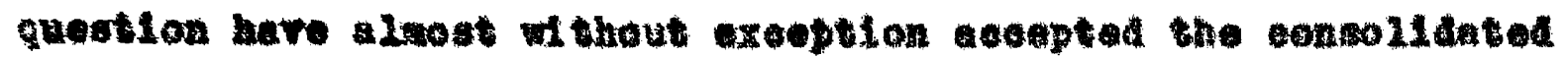

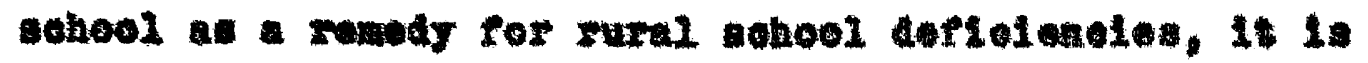

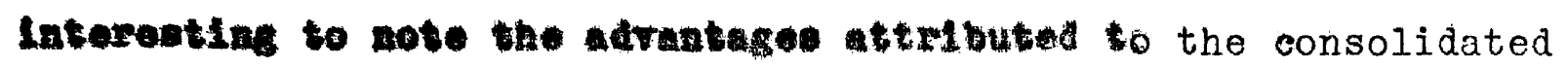
cohod1. In oertaln of these adrantiges there la ganoral

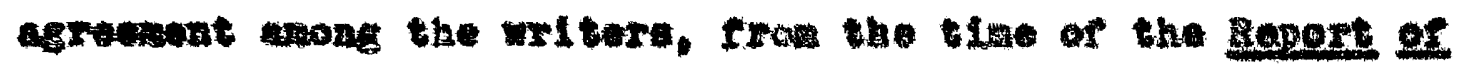

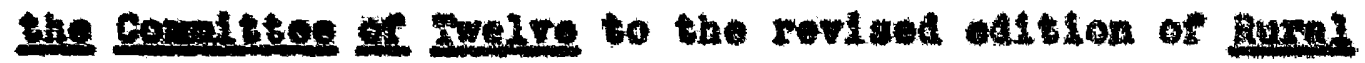
indologr by alliete. Thor ext:

1. It would funith boter equippod tomohere and a wore

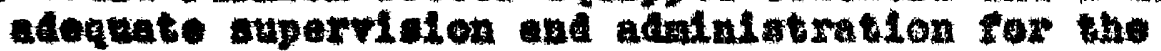
nohoble.

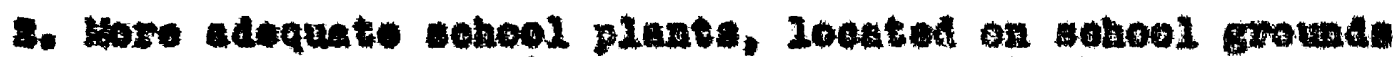

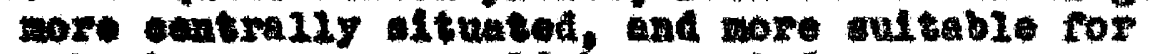
conool parpores, would be arosted.

3. whe thool sers would be lengthened.

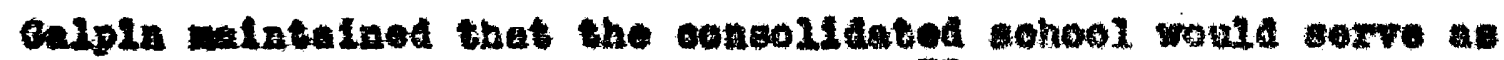
a matural coelal center for the area. Bedtes these adratuges,

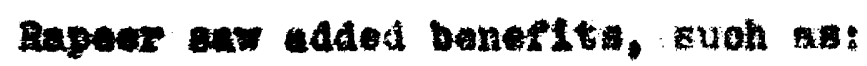

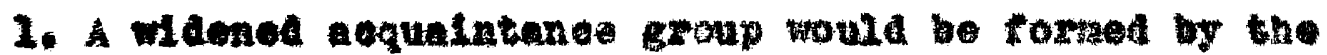
ohildern.

2. It waia baten proviston for the extanaton of rork to bigh semool 2 evel.

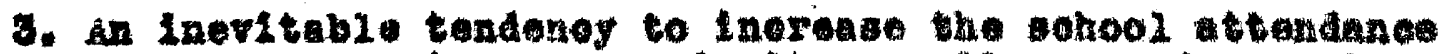

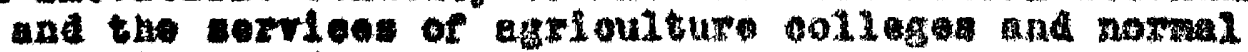
waools woule reandt.

35. Amone thoee tho muboribad to the edvantagos alaimed

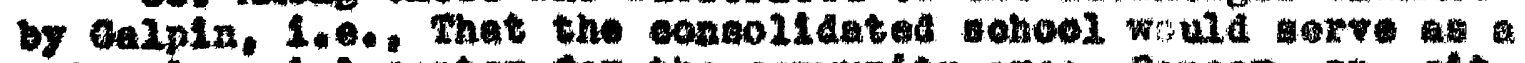

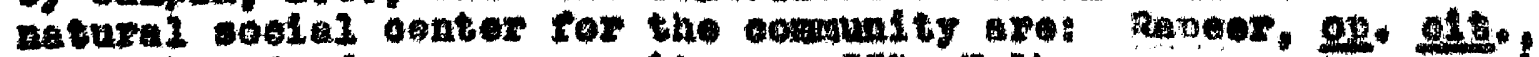

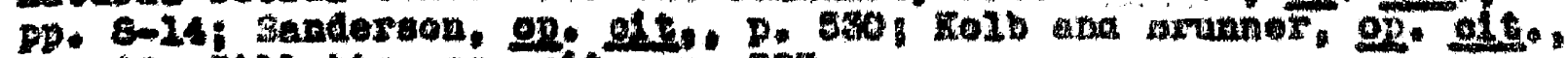

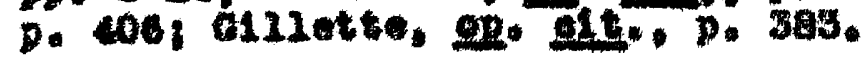


4. A bettex program of studies oould be provlded, based on the social needs and the peture of mental and phyraloal erowth in enlidren.

To the liat of adrantages Kolb and Brunner added:

1. It turnished the number necessary ror holasone competition and stimulus in sohool work, to oarry through adequete grading, to develop group and projeot worix, and to organdze many soelelly olgnifloant bypes of extra-ourminiar aptivit1es. 37

2. The average sohool attendanoe would inorease.

Q12lette at111 further extended the 11 at by inciudiag:

1. Eduoation of the adults of the coratunity would bo rostered.

2. The health of the ohlldren would be sareguarded.

3. Improvonont of roads would result as a means of transportlag the onlidren to achool. 38

cenelunten: From the time of the comalttee of Twelve to the present, Investigators in the problemil of the rural sohools have found mol ground for oomplaint. In the in there has been quite genoral agreement in the interpretation of the varlous etudies of raral education. It has boen agreed that certain woaknesses are oharaoter1at1 of rural sohoolo, and it has been quite gonerally agreed that these weaknesaes oan be correated or rellered by inereesing the size of the sehools through consolldation of anall sohools, and through tho rediretion of educetional aotirity.

36. 0p. 소. pp. 8-13.

37. Op. Q15., p. 408 .

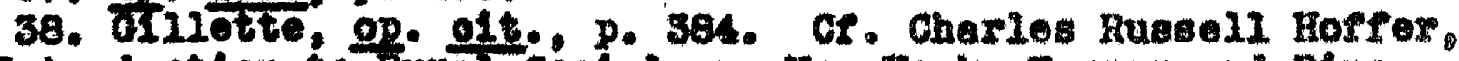
In Introduet1on to Rural soololon, Hew York, Farrar and Rineheart, Inc., 1084. Horfor egroos as to the need for and the relue of consolldated sohools but he feels thet there w11l be a necessity to oontinue the one-room shool under oertaln conditions. Fo foels that men of the eduoatlonal $111 \mathrm{~s}$ assoolated with rurul sobools are not nocossarliy inaurnountable. He further seod cortain soolal value in the gmall sohools looded 12 rural nolghborhoods. 
The rollowing ahaptera are devoted to a atudy of the mural

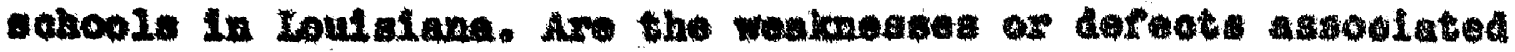

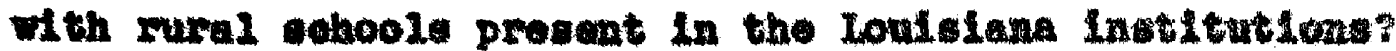
Are the consolldated achools moeting th noeds in atis-

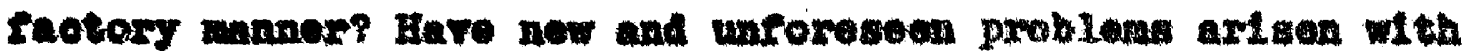
the comeolldation of mural sohooler the at of the following pages is to enwor these questions.

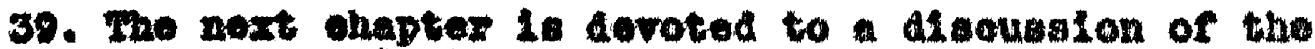
population charactentetios of Loulotane as an ald to an underatanding of the cohool problems. 
OEAPMU IIX

POPULATION GHARAOTRRIBTTCS OF LOUISIANA

The sohool is not an agenoy of soolaty in the sense that it ahould or may funotion as a separat ingtitution. It Is rather an aspect of soolety. It is soolety funotioning a edueator of its om Impature nombors. " I In these words Tutt1e, Loturex on Bdueation in the college of the city of Few Yark, seta rorth the relationghtp between the sahools and soolety. With this conception in mind it secm desirable that an enalyals of the Ioutalan sobools should be proceded by a presentation of sose faets oonverming the soctoty supporting the sebools.

Aocording to the 1930 census, the population of Ioulatana was 2,101,593, of witoh 776,326 or 36.9 per cent were Negroes. of the wite population of the stete 1,203,250 or 07.4 per cont were elageed as netive wites, and $1,172,572$ or 69.0 per oent wore of native parentage. This means thet 89 per cent of tho whte population of the state have 11red in Louislana or come other atate in the United states for at loast two generatione.

The wite popuiation of Loulsian is drided into three somenhat distinet exoups, each oocupylne rathor dofinite

2. Harold Saxe Tutt1o. A Soatal Bagla of Eduoation, New York, Crowell, 1934, D. 335.

2. Ifteenth consug of the Dnitod States, 1930, "Population,"

V01. III, Part 2. 
3

geographle regton of the state. The gouthern axea of the atate is larcoly populated by poopio of rrenoh deacent repreasting two group of arferint genosis. One group is ocmpoed of demoendanes of the Agadieng tho formad sottism

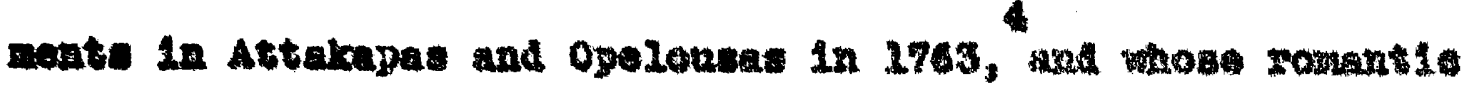
history has booene wdoly lonow through the pow Erengeline. by Iangfellow. The other group is made up of oreoles, proud Coseondants of the pardy French sottiers of Loufalana. Whin

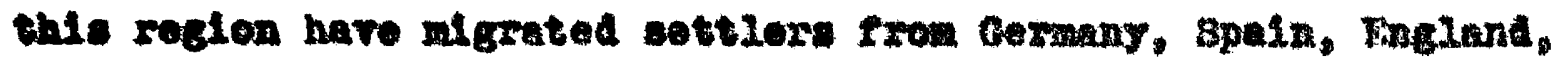
and Irolend, but thoy were all aborbed by the Eronoh, and today they have beowe analgannted axuept that their mathonality is

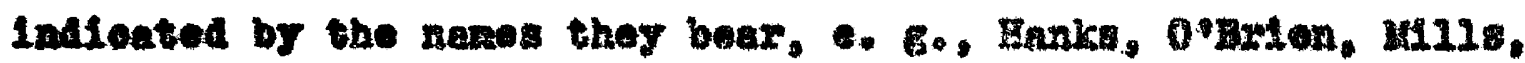
Folts, and she 1120. Theiz rellgten is Iargely Catholse: the edulte gonerally opeak a Frenoh petols, and nuber of the outure braits of the early prench atill persist. In this recion, whioh conalote of lowlands, the augar cane and woh of the rive of the otmte are grom. Here are sound the great angar

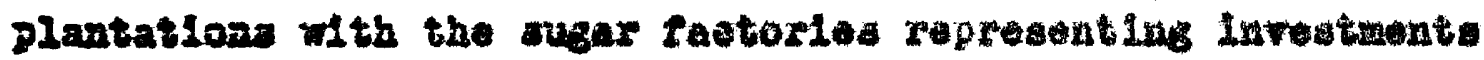
or man thousand of collars.

In tho northern, oatorn, and wetern area different trpes of population ar found. One of these types, atrellers in the

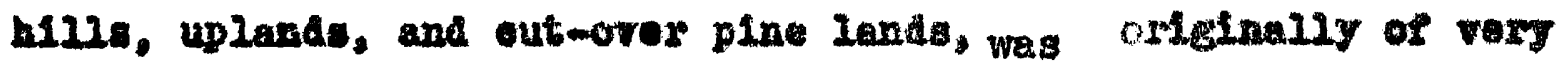
Moterogeneous origln (Ingliah, Sootoh, Irlah, and oorman were

3. Onprinted manusoript bJ EIno H. Lott, Loulalana State Univeraity, 1836.

4. Ohasios oagarre, Flatory of Loulalang. Now Orleans,

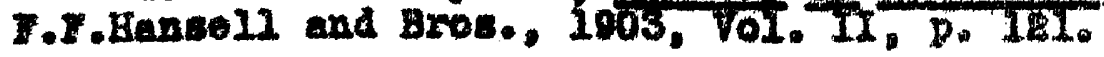




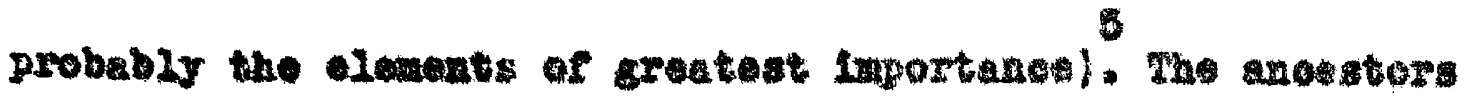

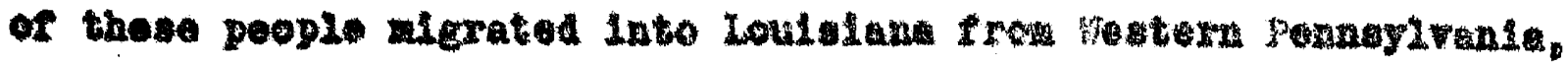

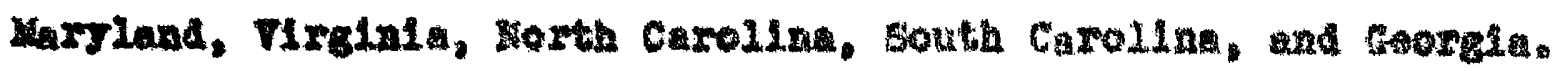

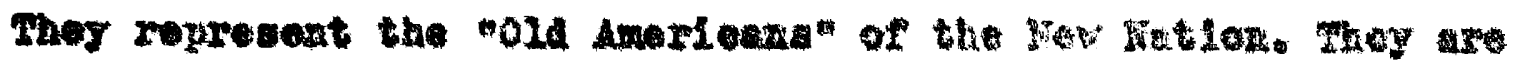

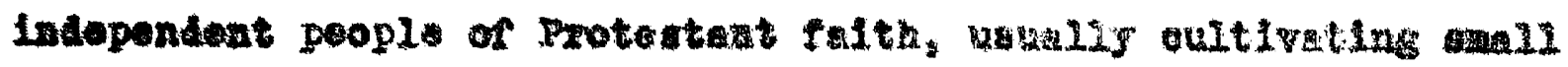
tracte of land which they own. Their chler agrioultural wopo

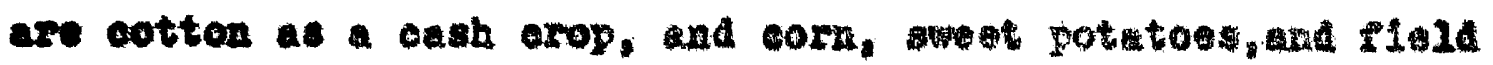
poes as forage orops. They had no later durlate tho anto-bellum perlod and they have little or no vegro labor todey. These

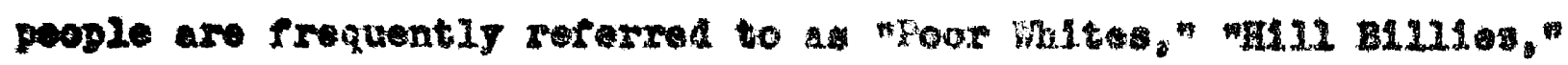
or "Red reake."

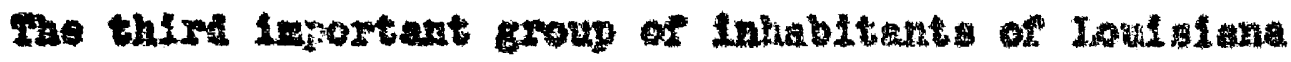

is found in the river ralleys and 20wlencs of the northern part of the atete, ad to lesax cegres in the southern part 1nteroperued awous the descenduta of the prenoh. It is oubalrided into two croups:

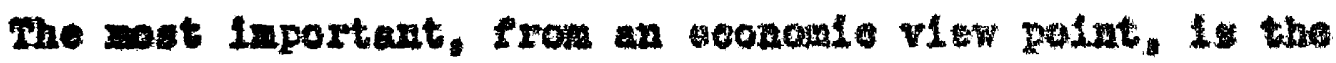

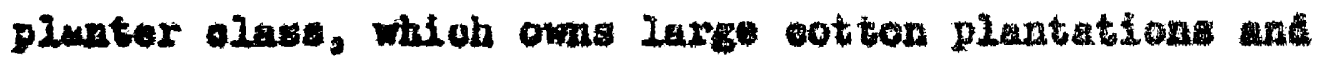
operates then by moans of liegro or white, lenent or hired

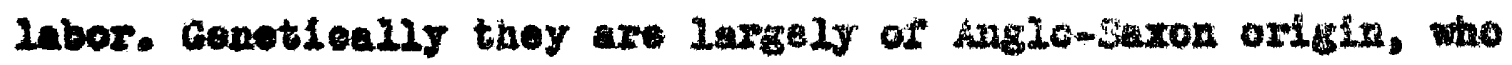

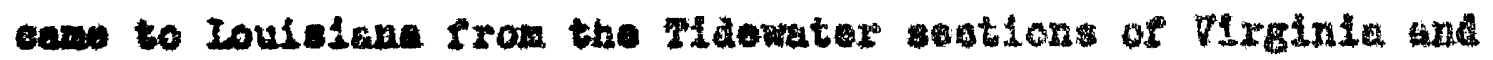

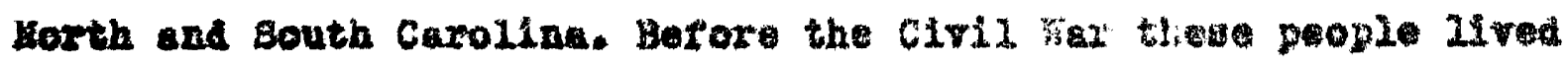
In the luxury and atylo ohoraoterintlo of the "Southern centiemen" In antu-belium days. They are the atorybook poople of the south.

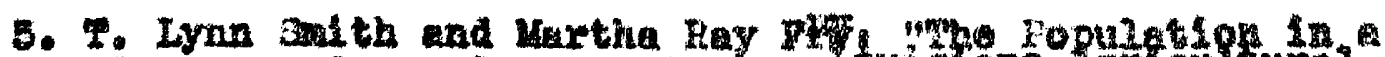

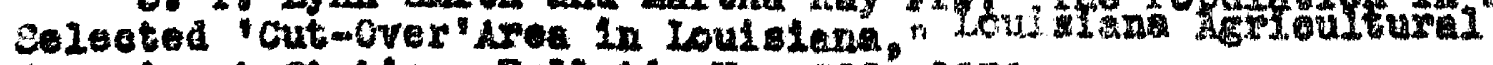
Bxperiment Btat 10n, Buliet1n 10. 288, 1936 . 
2. At the other end of the coononto Bonle are the moor mites." They raigrated during the oarly part of the nirationth century fron the seaboard states and settlod in the riter valleys. Nore recentig their numbers have been augnented by

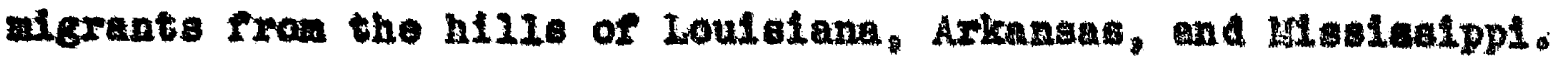
Tho older settlers of this group are, as alas, mall landomers, who work land usually olassed as marglnal and rreguentiy subject to overflow. The nore recent lmalgrants are froquentiy eroppers on the plentations of the landlords belonglng to this same group.

There ere other minor groups represented atong the white population of the state: Itallang ocoupy oertain looelitie devoted to truok gardening and strawberry oultivation; cortaln portions of the state, ospecially the floe growing areas, where machine oultiration is possible and the cut-over pine lands areas, have felt the influenoe of migration from the Mid-Weatorn states; and Ilaally cortain groups of Bohomlans, Hungarians, Germans, Soandinavians, and others have settied in widely soctered 20eal1ties.

The population of Loulslans is prodoralnantiy rural. Thls oen be seen by Table I, whloh ahowe that 56.4 per oent of the wite population are olassed as rural, 65.2 per cent of with are rural-farm, and 43.6 per oent are urben. Agrioulture is the wost 1mportant industry from the standpoint of the number emploged. It engages 237,226 wh1te poople 10 years of age and older, or 29.3 per ont of those gainfully esployed 
Table I

mite Population of Loulsiana*

\begin{tabular}{lrc}
\hline & Mumber & Per Cent \\
\hline mite Population & $1,318,100$ & 100.0 \\
Drban & 574,249 & 43.6 \\
Mural & 743,011 & 56.4 \\
Rural-farm & 451,063 & 34.2 \\
Rural-nonfarm & 292,848 & 22.2 \\
\hline
\end{tabular}

Data for rables I, II, III, IV and V from the rifteenth

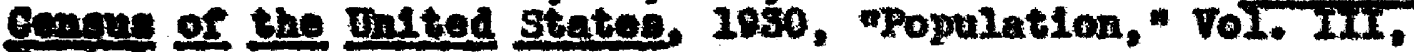
Etri.

Table II

Irautries of People in Loulalene 10 Teare of Age and orear

\begin{tabular}{|c|c|c|}
\hline Irduetr: & Nunber & Per Cent \\
\hline Abloultare & 136.877 & 29.3 \\
\hline 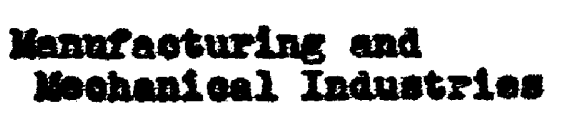 & 200,477 & 21.3 \\
\hline Eratiepertation & 38,780 & 8.2 \\
\hline Erade & 68,463 & 14.6 \\
\hline Froreasional & 30,404 & 6.5 \\
\hline Denertie and Pexwonal & 26,025 & 5.6 \\
\hline orertoal & 41,547 & 0.9 \\
\hline
\end{tabular}


manufacturing and mochanical industries engage 100,477 or 21.5 per oent; trade exploys 68.468 or 14.6 per cent: nnd elerioal work oceuples 41,547 or 8.8 per ont, (Table II.)

The census reports show that between the yors 1890 and 6

1950, Loulsiane 1noreaged in wito population 135.1 per eent whle the inorease in population in the thited statos as a whole wag 95.0 per oent. Durlng that period of time Loulsiana recelved practicaliy none of the willons of linalgrants from forelgn oountries end, It contributed more ratgrants the the other states in the Union than it has roeeited erom them. In 1930. 386,208 persons bom in Loulsians wero living in other states, wherea only 269,260 persons bort in other states vere ifring In Loulgiana. This means that the gtate has made a net contribution to the other stato of 216,230 persons. Hoat of thene ongrants were Negrees $(107,428)$, so that the net loss of Whites was only 8,784 . From this 1 t an be sean that the 1aerease in population has been reault of the natural inorease, dee to aurplus of birthe over deaths, and not to migretion.

The trend of migration of population to the alties of the Untted states ean be seen in Loulolana, iut to gonewhat loss degreo than for the nation as whole. In 1910 the whites or Louloians ifving in Fural distriots represented of. per cent of the thito population; in 1920 it had been reduesd to 60.1 per cent; and in 1930 it was at1I further roduoed to 56.4 per cent. In apte of the urban migration taking place in the atate, in

6. T. Iynn Sralth, "Growth of Fopulation In Loul siane 1890 to 1930," Loulalana Agrioultural Experinont station. Eulietin 프. 264, 1236 . 
1930 there were only three parishes which were predoduantiy urban. They were: Orloans wh th urban population of 456,762 and no rural population; Caddo th an urben population of 76,655 and rural population of 46,015 ; and Ouadhita th ans urben population of 32,594 and rural population of 32,594 and a rural population of 21,743. If the state as wole is considered, exeluding New Orleans, the population is 7\%.2 pex oent rural end 22.8 per oent urban. The urban population for Loulgiana is largely concentreted in fow olties of the state. For example, Hew Oxleang sontalas 55 per aent of the urban population, and Hew Orloans, Shraroport, Baton Rouge, Honroe, Alexandria, Late Charles, und Bogaluse acoount for 77.4 per oent of the urbay population.

Bot only is the population as alo predominanty rural, but the nubler of ohildren to be eduosted in the rural distrata is graster in jroportion to thal total populetion than is found in the urban centers. Whis agres ath statenents by Giat and Iflbert, sima, 8 a Sorokin, zimernan and Galpin. all of whon state that the birth rate tendas to be higher in Fural than in urban aistricta, wal among thoza ongaged in

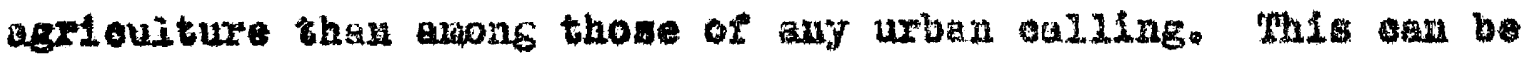
seea by Table III whloh show that the rural sations of Loulalasa

7. Hoel P. tist and I. A. Halbert, Urben Soajology, Hew York, orowell, 1933, D. 380.

B. Reweli lerol gins, glements of Mural soclologz, kew Tork, Crowell, 1826, p. 70.

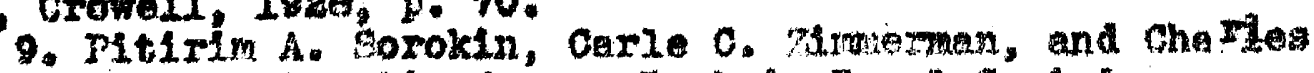

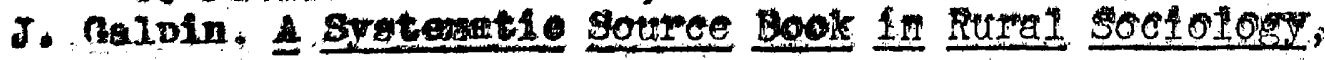
University of Hinnesota Press, 1932, Vol. III, p. 135. 
Table III

White Population in Ioulslana of Sehool Age

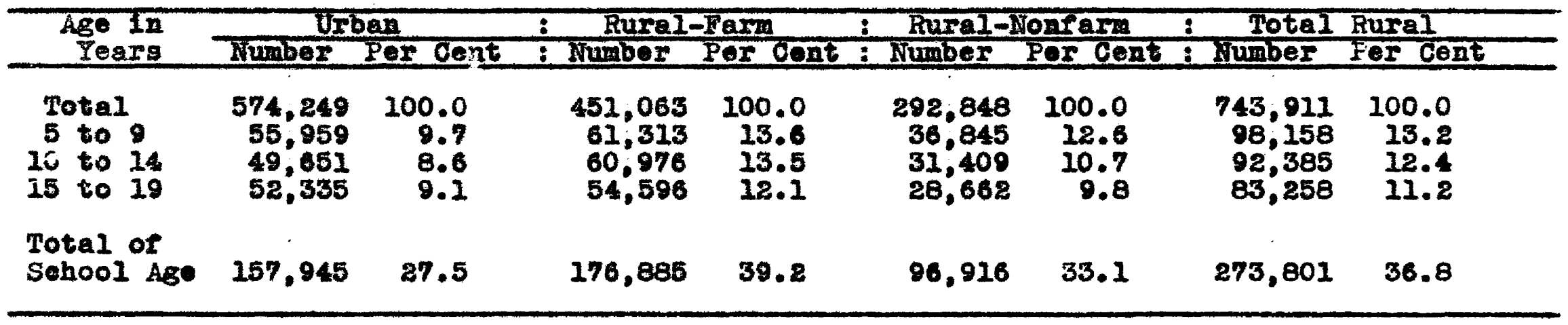

Table IV

School Attendance in Ioulalana

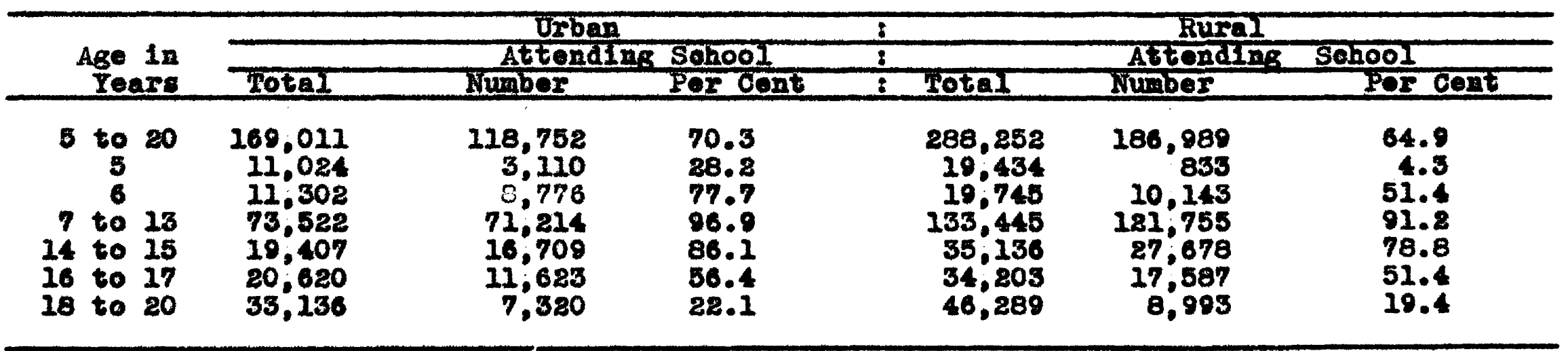


have 30.6 pex oent of thelr population of school age, five to alnotoen years, whereas the cities have 23.6 per cent of their group of the same age ditribution. Anong tho rural- Farm group. 39.2 per cent are of sehool ago, whereas the rural-nonfarm group have 33.1 pes cent of that age. Although there are more ehlidren anong the rural population of the state there is Iorer pereentage of onllaren of Fural parentage attending the sohools of the atato at all age lerela then 2 txue for the urban groug, as can be sean from Table IV.

Fubllo bohools hare boen the acepted means of educatins the children of the state for the past 75 to 100 years. It is to be expected that the seotion or group whioh ghows the 10 wast rate of public nohool attendanee anong the ohllaren of sonocl age would ahow the highest rate of 1111 teracy, uniess there were other factora to altex the expested reaulbs such modifylng reotore do not soen to be prosent in Loulglana, for acooralng to Fablo $V$, the 1111 teraoy 1 e greater arang all roups and all eges of the rural white population than for the oorresponding age groups in the oities: for example, among the native whites or native parentage, there aro 11.6 per oent ton yeara of age and over of the rural population classed as 1111tergte, whereas of the urban population there are 2.4 yer cent and of the ofty of Few Orlaans there are 1.3 por oont 1111terate. In other words. the netive mites of native parantage 1 iving in the rural sootlons of the state have almot nine tiues as high rote of

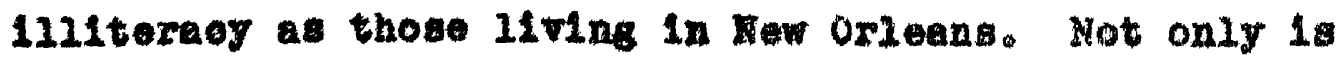
1111teraoy cor the rumal coetions of the bat groter than 
Table $v$

Illteraey Anong the White Population in Ioulalana

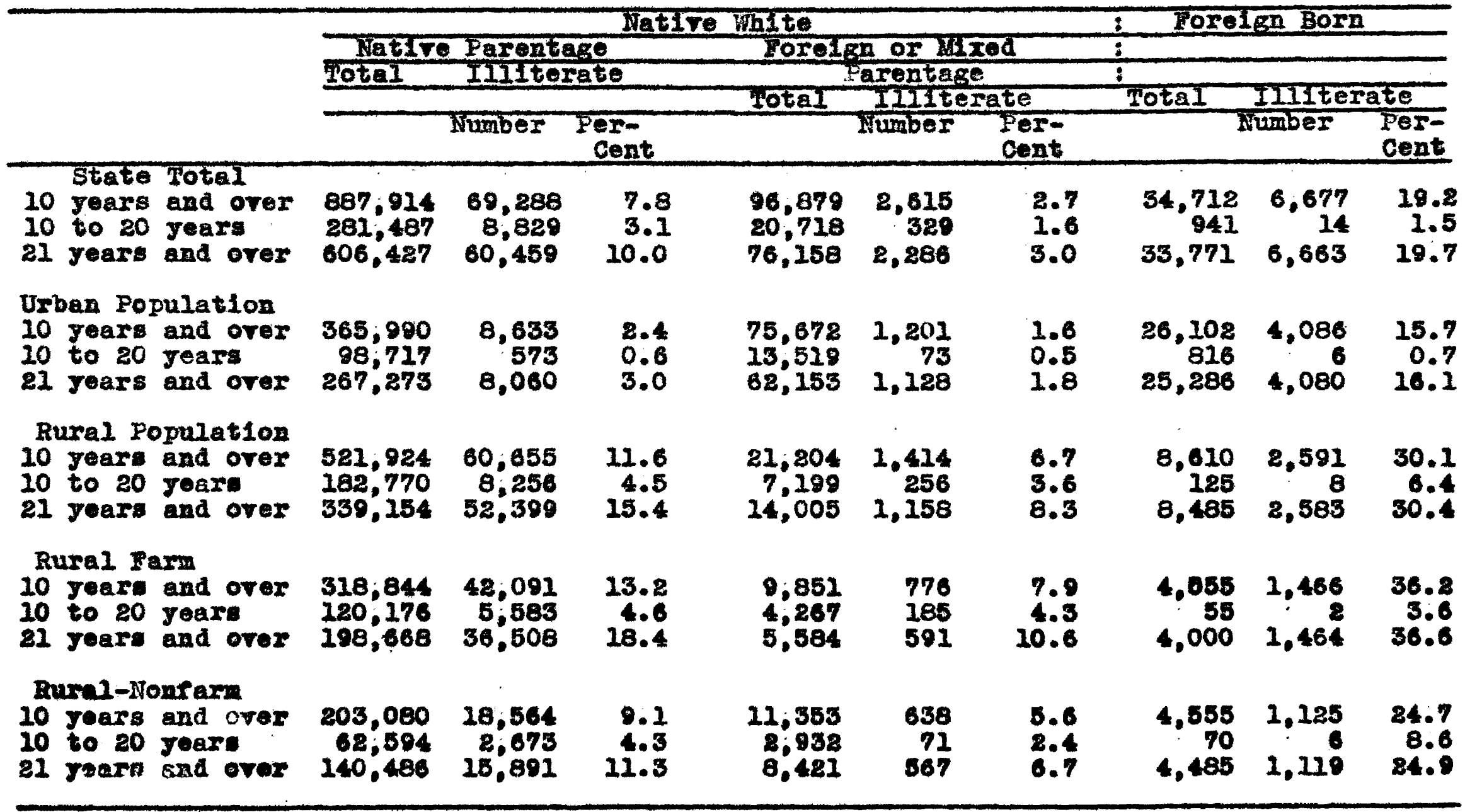


the IIIteragy found in urban aenterg, but tho rate is higher In the rurel-farn distios than in the rural-nonfara groups: for example, anong the native whtos of native parentage the rate of illiteray in the rurel-farm soctions wa 23.2 pex cent and in the rural-nonfare ceotions groups was 2.1 per cert. For that portion of the population whith represents the pextod of sahool attendanoe, 10 to 20 years of age, the urban onters have 0.6 per oent of the native lte of native parentage clased as illitarate; the zural-nonfarm eotions 4.3 per cent and the rural-fars diatriets 4.6 per oent 30 clabsed. Although, it is the usual condition that illiteracy of a state is hlgher in the rural seotions for native whites than In the urban, It is not usual for the rural-fara to have a bigher rate of 1111 teracy than the rural-nonfarm group. This ean be shown by the elgures for Callfornle ther the ruralmarta group have an ililteracy rate of 0.4 per ent oompared with 0.7 per cent for the rural-nonfarm; Colorade with a rato of 2.1 per oent for the rural-farm and 1.2 per cent for the rural-nonfarm; III1nois th 1.0 per cant for the rural-tarm and 1.5 per sent for the rural-nonfarm; hiohlgan wh 0.6 per aent for the ruralfams conpared with 0.9 por went for the rural-nonfarm; Hassachusetts with 0.5 per cent for the ruraluofarra as to 0.8 por cent for the rural-nonfarm; and Conneotlout with 0.4 pers ont for the sural-parn and 0.5 par cent for the ruralononfarm. In all the above casas only the fleurea for nutive whitea are consldered.

The raet that the rural-rarm population ot the atato la 


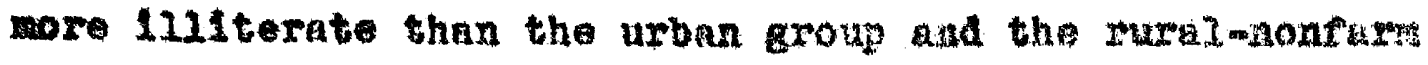

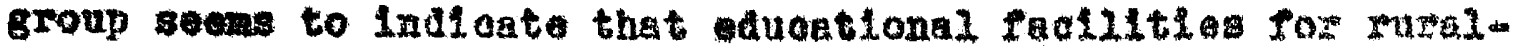
farm obliaren have not been equal to those arallable for afty. town, or vilinge obsidren.

Conolnaton: The population of Loulatana is wade up of descendents of the Fronoh, learly Imetgranta from Franoe and the Acedians who settled here after belng deported from their native land in Hova Sootia) and the Anglo-Saxons, (maliah, Im1sh, Sootoh and Cerman). The Frenoh are settled mostiy in the southern part of the stats, whereas the others are looated in the northern, westerm. end eastern parts of the state.

The Loulslana population is predominantly rural with 56.4 per oent of the Inhabltants olased as rural and 43.6 per oent olassed es urben. There are obly three parlahes whloh are prodosinantly urben, orleans, Caddo, and Ousohlta. Hot only Is Loulelana predominentiy rural in population, but asrioulsure is the most important industry from the stendpolnt of the number of poople galntully employed in that ocoupetlon. The urban population of the state la largely conoentrated in not moro than seren oftles, 1. ., New Orleans, Bhreveport, Baton Rouge, sonroe, Alexandria, Lake Oharles, and Bogalusa. Now Orleans contalne more than one-half of the urban population of the -tate, and if Hew Orleans is excluded, the stato has more than three-fourths of 1to people olassed as rural.

The rural seotions contribute more than thelr proportion of the sohool population of the state: yet there is a lower ercentage of rural onliaren attending sohools than is true 
of the urban children. The 1111teray rate is oonalderably higher arg the rural inhabitants, at all age laval, then among the af ty dwellers. Also the rate of Illiteracy is higher for the population classed as rural -farm than rot those classed an rural-nonfarn. This goons to lndionte that the rural arvilers, especially the rural-faral population have not

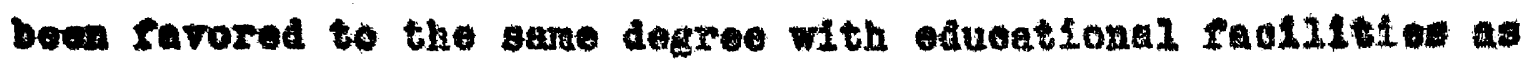
bare the residents of the oldies, town, and ridges. 
GHAPTIR IV

LOUISIANA SLATE STGTHW OF MDUCAPTOW

In order to understane the poeul1ex atruature of the

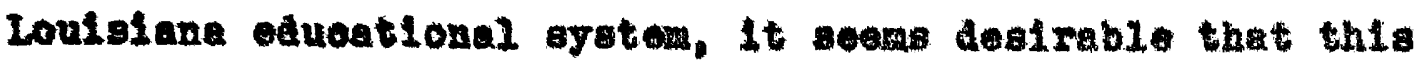
ahapter be deroted to an anelysis of the argtem, 1ta organiaation, the olasses of sobools, consollation of schools end trangportation of gohool ohlldren, the aubjeats taught, and the teaching personnel. With an understanding of the state argantzation of sohools a more avourate oraluetion of the otuales of indiridual sehoels, to be found in later ohaptors, an be mado.

Sehgal Orranlzation In Loulatengs control of oduontion in Loulsiana 18 eantrallad in atate board composed of alowon mendere, elght eleoted by the voters of the state, one ifrow each of the congreasional distriots. for pexiods of elght joare, of th orerlapping terms; and three appointed by the Coremor of the State; one from each of the public serrice comalasion asatriota, for perlod of four yoars. a advisor and exmorelolo seoretary of the board and aotual had of the state chool aysten a state superintendant 1 alonted by the voters of the state each four years. All publio achools In the gtate of Loulslana, Ith the exoeption of the Louldana state University and Agrieultural and Moohanioal arts colloge. 
are diroetly under the oontrol of the stato Board of Rducation.

Created as an 1 id to the State Board of Bducation, the state Dopartment or Edueation, funotions under the disection and appointment of the state superintendens. mils Dopartient 1a made up of a disision of high sohools, a drision of - lementary sobools, and diristons of spocial tields such as musio, athlet10s and health, home osonolalos, sgrioulture, Hogro education, and others.

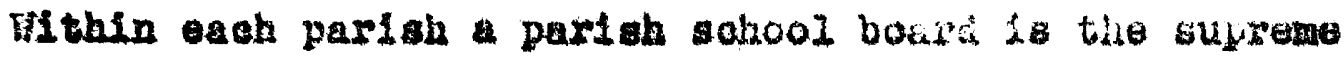
gorezning body, subjeat only to the regulstions of the state Board of Edueation. As active secretary of the sohool board and nominul and, in some cases, actual head of the paribh mroten is a Parich Superintendent appointen for four yoara by the parish achool bourd.

The state through the Department of Rduoation preasibes the eourses of study to be pursued in the sehools, the qualifloatlons of teachers, the standards to be madntalned by - lementery and high cohools, and tho degres or attalmment neceseary for crecuating from bleh school. The atate furalshes Eroe sohool texts to all sohool ohildren in the state below the crade of college whether they are attending publie sohools ox privete inatitutions. In addition to the rre texta, ilbrary books, and penolite, paper and sohool oupplio in general aro I1kewte furnishod to the ohilaren of the state. In mome Ingtanoes ohildren attending paroohial sclools are transported In buses operated by the parish shool boerde for ohiliren of publlo sohools. 
Classes of publio Schoola: In Loulglena there are two matin - 2asses of pubilo sohools: the state upproved four-yent high sohool-that school willoh taohas four yara of geoondary worl and neets the standards set by the state Board of Jdueation-and the eleatentary soinool, which lyoludes all grades in publlo sohools from the flrst througit the seventh grade. Completion o: the prescrlbed work in the lementary sohool, entitles the ohlld to enter the nigh sohool.

There are $368 \mathrm{high}$ sohools in the atate that weot the standards set of the state Board of Edueation for beling "state approved," of those nigh sohools, 125 have been approved by tho Southera Assoolation of Secondary Sohools and Colleges. The graduated rron these sehools are entltled to enter any college in the United States which adrat ts students on the presentetion of a high sehool diplons. Minety-one of the h1gh sohools are $11 \mathrm{sted}$ as four-yoar sint th-liughes A6rioulturel High Sehools.

In connection th proctioally all of the stotempproved hlgh schools are found seren-year elersentery gohools. In many casor the elenentary sohool is houted in the anme buliding wth the high sehool, and in nearly all oases under the angerviaton of the Bare princlpt. For thet reasor when the high achool is roforred to, It is rrequently meant to inoludo the elenentary grades as wall we the secondary aiviaion. Astde fron the high oohools, and the olonentary sokools $2 \mathrm{n}$

2. Btate Departinent of Jduoation of Louls1ana, "Bdueational birectory," Bulletin No. 304, 1835-36, p. 22。 
the state, there are 13 sohools alassed as "junior high sohools;" in whioh three years of secondery sohool work is offored-uthe seventh, elghth and ninth gredes reapeotively. In these sohools the puplis may earn ons-half of the required work for high sohool graduation. In the in they would not neot the spectelcetions necessary to be olessed as a "funlor high sohool" by Koos. They would rather be classed as "olementary sohoola" wherein oertain amount of secondery work is offered to meet partially the educational requirement of the ohlidren dealring more advanoed work than the regular elenentary oourse.

Coneollation of Bahoelg: Iouldiand wa a ploneor in the fleld of sebool consolldation. It has been sald that:

Whe blessings of the new school entered the state by a side door, so to speak. A eyelone in the parlsh or lafayette had destroyed ono-room sohool buliding during the sohool term and in order to arold 1083 of time for the ohllaren, two public-apirited altizen: of the distrlet offered the board oonreyanee free or oharge to take the ohliaren to a nelghboring graded. sohool in the town of Seott. This renture proved so ovecesoful from the beginning that the parion board deolded not to rebuild the one-room sohool but to furniah wgonotte and make the transportation permanent. $n$

Th1s occurred in 1802. The 1dea spread so that in 1910 there were 210 sehool transfors operating to carry 4,088 ohildren to sohool, and in 1934-35 there wero 2,425 transfers oarrying 121,341 onlidren to cohool. In 1910 there were 2,300 pub110 sohools for white ohlldren, and in 1984-35 there were 10210 ,

3. Leonard V. Koos, The Junior H1gh Sohool, Naw York, 1927, P. 229.

4. Jullus Bernhard Arp. Burel Education and the Consolidated School. How York, World Book Company, 1920. D. $18 \%$. 


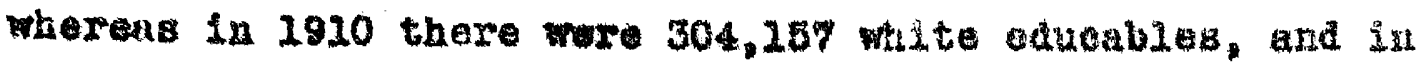
1934-35 there were 399,998. In 1910 there were 1,559 oneteacher sohools, and in 1934-35 there were 2ats such solools. In 2910 thare were 208 clased as "cormolldated shools, and In 2934-35 these rere 385 such.

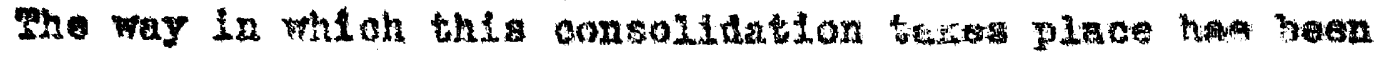
deserboed as follows:

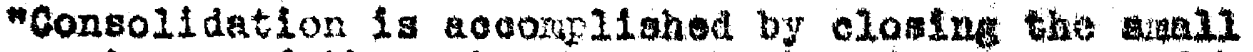
one, two, and three-tencher bohools of an area and by establiahling in thelr stead the thecogible anter a large contral ingtitution having feollities sufrieient to oare for the puplis of all of the school olosed. The prinary purpose of the ohange is to provide conditions whioh will permt grade organlzation betbes qualifled teachera, Improved supervision and adrinistration, and laiger library and jabratory faoliltias, and the developient of atatemapproved high schools." 6

Consolidation of cohools is not uniform throughout the state. In Iafourohe lurish there are no consolidated sohools and no eohool trangrers, wheroas in Cameron Iariah 94.5 per vent of the migh sohool enrolinent and 54.7 par oent of the olemertary sohool ensollment ere taken to sehool by buses. the fact thet Ioulsiana has gone far in the conoolidation of sahools ean be seen from Tablo VI, which ahow the numbor of

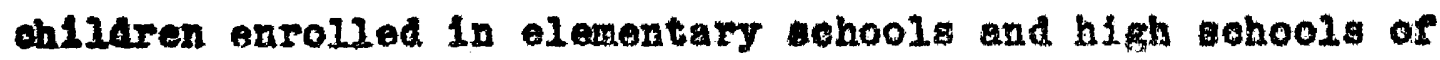
each parlsh, and the percentage of sach tranoported to their respective cohools. In thle bable only thos sohools are ooneldered wioh are controlled by the paxish wohool boards.

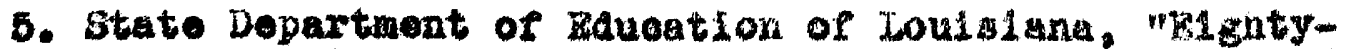

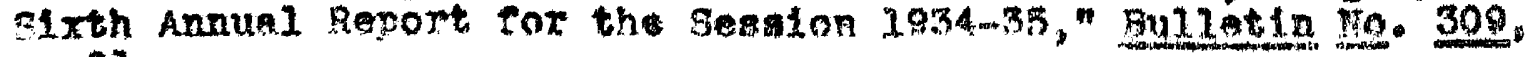
p. 91. b. Ibla, 90 . 
rabie $\mathbf{n}$

Barollmant and Transportation in Ioulstane Pablio Bohools for the Seenion 1954-35

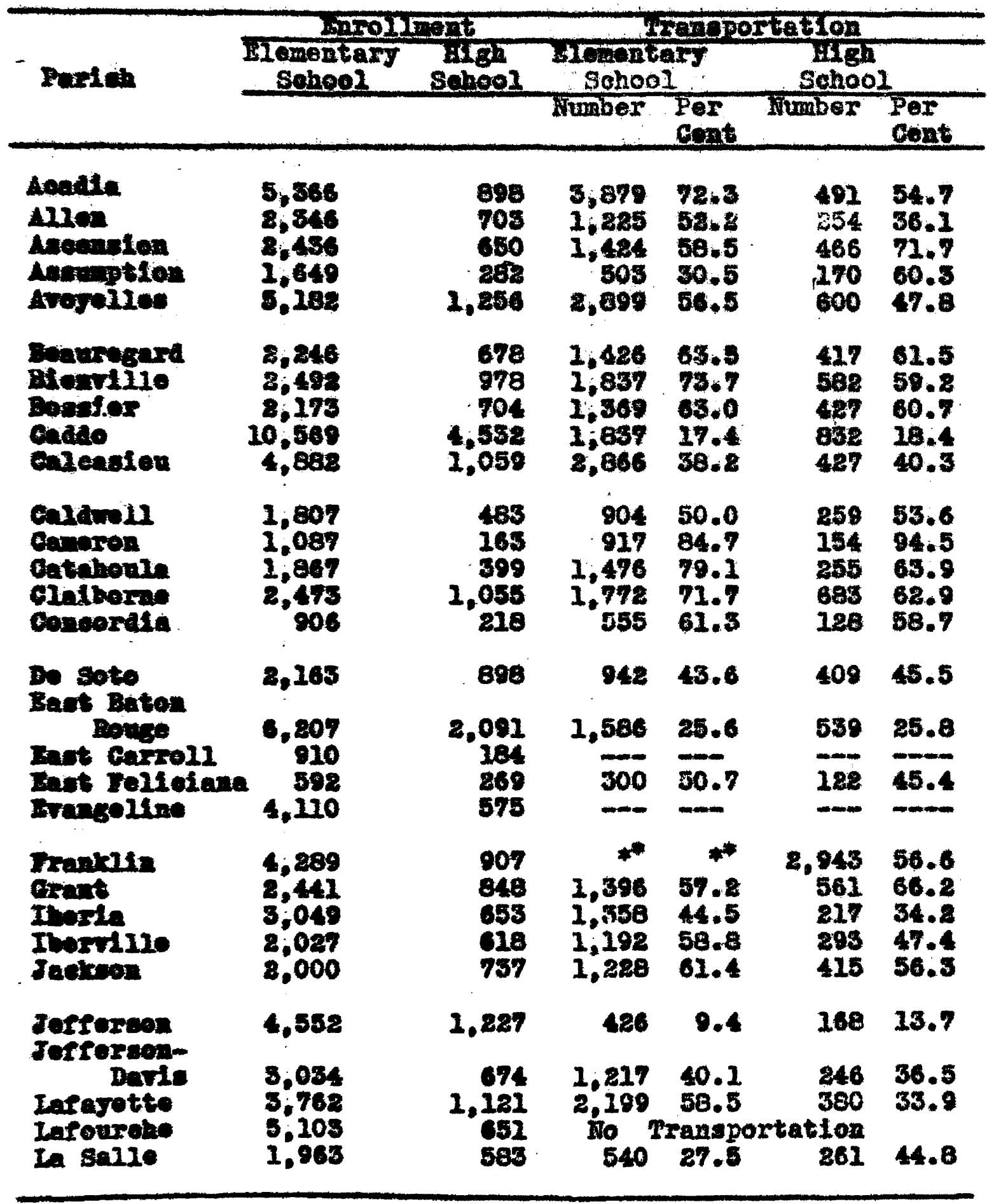

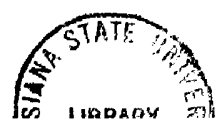


Table VI (Continued)

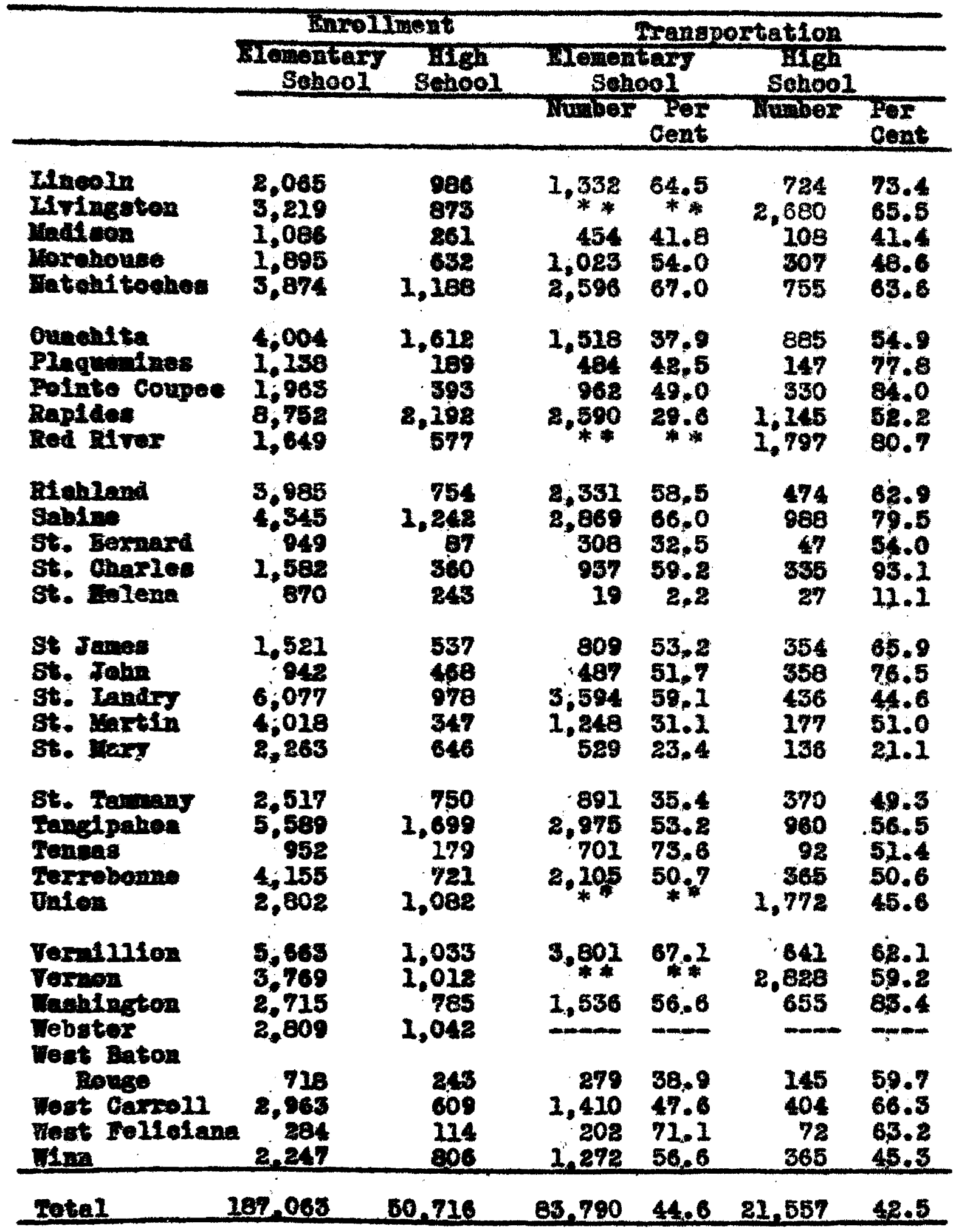

- Data giver for partah as a molo. omm Data not arailable.

- Date rrom the P1Les of the Hich Sohool and College Commission of the Ionfalana state Bopartent of Iduoation. 
Th1s exoludes the New Orleand yohools, the Honroe city ohools, the Lake Oherles schools, and the nchools of Bogalusa. all of which hove speolal ofty sohool boarde and are prifiarliy under urban control. Whll the sehools of shreveport. Alexandila, Baton Rouge, and Lafayette are primarily urban, they are Ineluded sinoe they are under the alreotion of the respeative parish school boards. Thus, as oan be seen, many schools are Ineleded wich are privarizy urben and to wh 1 oh there are very fow if any chlidren brought by transfer. such schoode as Byra and rairperk Eigh Sohools in Shroveport, Baton Rouge Junior and Senior Figh Schools, Lafayette HIgh Sohool, and the elementary shools of Shreveport, Alexandria, Iafayotte, and Baton Rouge. Tet ineluding those urban unoonsolldeted sahools it san be seen by Table II that 42.5 per oent of the high wohool onroliment are transported to sohool from distant points and 44.6 per cont of the elenentary ohool ohilaren are 11kewise tranoported. Tables YI and VII show the tendeney to transport the ohilaren to schools in villages or urban conters. Fron these tablas It can be soen that those towns jassed a urban in Loulslana. with the exceptions mentioned above and also excepting all of the sohools of Jefrerson P'arish, because of thet proximity to Hew Orleans, edueate in their school: 21.6 per oent or the elementary sohool ohlidren and 22.6 por sont of the high school oilldren. Looelltios not populous enough to be classed as urban but with populations of fror 1,000 to 2,500 people oducate in the1r gchools 13.2 per oent of the elementary sohool oblidren carried in buses and 26.3 per oent of the high sohool 
Table VII

Chllaren Transported to Publio Sohoola in Urban

Centore *

\begin{tabular}{|c|c|c|c|c|c|}
\hline $\begin{array}{l}\text { Groan } \\
\text { Eutes }\end{array}$ & $\begin{array}{l}\text { Popuiation } \\
\text { 10so }\end{array}$ & Irmb & $\begin{array}{l}\text { 1tary } \\
2 \text { pout }\end{array}$ & $\begin{array}{l}\text { Dish } \\
\text { Huber }\end{array}$ & $\begin{array}{l}\text { Sonoo } \\
\text { Per 0ent }\end{array}$ \\
\hline $\begin{array}{l}\text { 210 } \\
\text { matis } \\
\text { Donse }\end{array}$ & $\begin{array}{r}4,856 \\
25,085 \\
8,850 \\
5,121 \\
30,789\end{array}$ & $\begin{array}{l}141 \\
881 \\
580 \\
608 \\
808\end{array}$ & $\begin{array}{r}44.5 \\
17.1 \\
55.2 \\
47.5 \\
5.5\end{array}$ & $\begin{array}{l}157 \\
481 \\
203 \\
144 \\
104\end{array}$ & $\begin{array}{r}53.8 \\
35.8 \\
35.8 \\
41.0 \\
8.7\end{array}$ \\
\hline 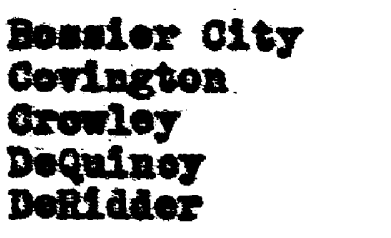 & $\begin{array}{l}4: 005 \\
5 ; .908 \\
7: 658 \\
5 ; 589 \\
8.747\end{array}$ & $\begin{array}{l}190 \\
108 \\
484 \\
190 \\
550\end{array}$ & $\begin{array}{l}27.0 \\
25.4 \\
51.7 \\
13.7 \\
48.2\end{array}$ & $\begin{array}{r}77 \\
256 \\
00 \\
28 \\
250\end{array}$ & $\begin{array}{l}30.0 \\
61.0 \\
26.3 \\
11.5 \\
45.3\end{array}$ \\
\hline 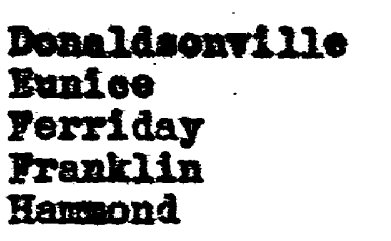 & $\begin{array}{l}5,798 \\
3,597 \\
2,502 \\
3,271 \\
6,072\end{array}$ & $\begin{array}{r}200 \\
182 \\
192 \\
96 \\
533\end{array}$ & $\begin{array}{l}87.0 \\
48.8 \\
48.6 \\
25.6 \\
58.9\end{array}$ & $\begin{array}{r}81 \\
46 \\
58 \\
90 \\
139\end{array}$ & $\begin{array}{l}42.0 \\
26.9 \\
53.2 \\
45.0 \\
34.3\end{array}$ \\
\hline 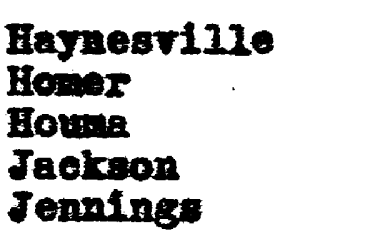 & $\begin{array}{l}2,541 \\
2,909 \\
6,531 \\
3,966 \\
4,036\end{array}$ & $\begin{array}{r}642 \\
287 \\
396 \\
35 \\
202\end{array}$ & $\begin{array}{l}68.2 \\
52.5 \\
27.5 \\
19.0 \\
27.0\end{array}$ & $\begin{array}{r}262 \\
106 \\
324 \\
11 \\
39\end{array}$ & $\begin{array}{l}59.7 \\
49.1 \\
54.7 \\
1.2 .8 \\
14.0\end{array}$ \\
\hline $\begin{array}{l}\text { Iafayetto. } \\
\text { Lake Providence } \\
\text { yansileld } \\
\text { leriville } \\
\text { Henden }\end{array}$ & $\begin{array}{r}14,635 \\
2,667 \\
3,857 \\
2,626 \\
5,623\end{array}$ & $\begin{array}{l}243 \\
--5 \\
158 \\
279 \\
--\end{array}$ & $\begin{array}{l}20.1 \\
25.6 \\
54.9 \\
-\infty\end{array}$ & $\begin{array}{r}58 \\
-58 \\
-\infty\end{array}$ & $\begin{array}{l}9.3 \\
--. \\
30.6 \\
44.3 \\
---\end{array}$ \\
\hline 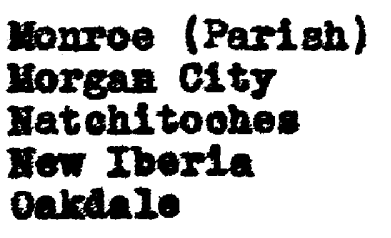 & $\begin{array}{r}26,028 \\
5,985 \\
4,547 \\
8,003 \\
8,108\end{array}$ & $\begin{array}{r}155 \\
86 \\
369 \\
187 \\
244\end{array}$ & $\begin{array}{l}25.6 \\
12.9 \\
58.8 \\
51.4 \\
50.1\end{array}$ & $\begin{array}{r}728 \\
23 \\
136 \\
116 \\
68\end{array}$ & $\begin{array}{r}51.3 \\
8.2 \\
43.5 \\
35.5 \\
24.5\end{array}$ \\
\hline $\begin{array}{l}\text { Opelouras } \\
\text { Plneville } \\
\text { Plaguenine } \\
\text { Ponehatonla } \\
\text { Rayo }\end{array}$ & $\begin{array}{l}6 ; 290 \\
5 ; 618 \\
5 ; 124 \\
2 ; 890 \\
8,710\end{array}$ & $\begin{array}{l}78 \\
265 \\
210 \\
413 \\
\mathbf{8 8 7}\end{array}$ & $\begin{array}{l}28.5 \\
28.6 \\
30.4 \\
56.1 \\
64.2\end{array}$ & $\begin{array}{r}92 \\
00 \\
113 \\
202 \\
65\end{array}$ & $\begin{array}{l}34.6 \\
00 \\
33.8 \\
67.3 \\
49.2\end{array}$ \\
\hline
\end{tabular}


Table VI (Contluned)

\begin{tabular}{|c|c|c|c|c|c|}
\hline $\begin{array}{l}\text { Uruan } \\
\text { Conter }\end{array}$ & $\begin{array}{c}\text { Popqlation } \\
1950\end{array}$ & Numbe & thary & $\begin{array}{l}\text { Hifgh } \\
\text { Number }\end{array}$ & $\begin{array}{l}\text { hool } \\
\text { Per Cout }\end{array}$ \\
\hline 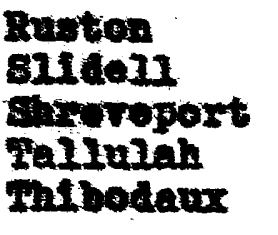 & $\begin{array}{r}4,400 \\
2 ; 607 \\
76 ; 655 \\
3,332 \\
4,448\end{array}$ & $\begin{array}{r}244 \\
240 \\
57 \\
277 \\
00\end{array}$ & $\begin{array}{l}45.0 \\
27.3 \\
1.8 \\
47.8 \\
00\end{array}$ & $\begin{array}{r}328 \\
92 \\
201 \\
108 \\
00\end{array}$ & $\begin{array}{l}66.6 \\
39.7 \\
6.0 \\
40.2 \\
00 .\end{array}$ \\
\hline $\begin{array}{l}\text { Weat llonree } \\
\text { Winntield }\end{array}$ & $\begin{array}{l}6: 566 \\
3,781\end{array}$ & $\begin{array}{l}148 \\
368\end{array}$ & $\begin{array}{l}14.6 \\
48,2\end{array}$ & $\begin{array}{r}00 \\
105\end{array}$ & $\begin{array}{l}00 \\
28,6\end{array}$ \\
\hline Total & & 9,788 & 11.6 & 4,810 & 22,3 \\
\hline
\end{tabular}


Table VII

Sehnol Ohildren Transported to Sohools in Villages

Wh the Population of from 1,000 to 2,500

\begin{tabular}{|c|c|c|c|c|c|}
\hline \multirow{2}{*}{ 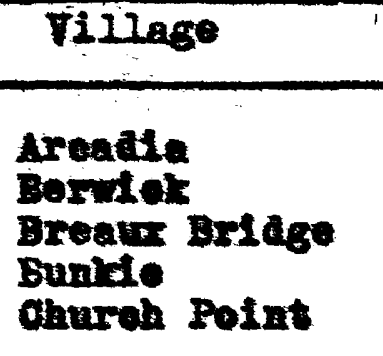 } & \multirow{2}{*}{$\begin{array}{c}\text { Population } \\
\text { I0s0 } \\
1,000 \\
1,678 \\
1,599 \\
3,664 \\
1,057\end{array}$} & \multicolumn{2}{|c|}{$\begin{array}{c}\text { Blementary } \\
\text { Dumber Per cent }\end{array}$} & \multicolumn{2}{|c|}{$\begin{array}{l}\text { High } \$ 0 h o 0 I \\
\text { Number Per cent }\end{array}$} \\
\hline & & $\begin{array}{r}247 \\
58 \\
268 \\
174 \\
559\end{array}$ & $\begin{array}{l}67.6 \\
14.8 \\
59.7 \\
42.3 \\
88.9\end{array}$ & $\begin{array}{r}75 \\
7 \\
37 \\
39 \\
117\end{array}$ & $\begin{array}{l}45: 6 \\
17.9 \\
39: 4 \\
21.5 \\
69: 6\end{array}$ \\
\hline $\begin{array}{l}\text { Colfar } \\
\text { Cottenpert } \\
\text { Cotton valley } \\
\text { Delni } \\
\text { Donhen springe }\end{array}$ & $\begin{array}{l}1,141 \\
2,015 \\
1,133 \\
1,045 \\
1,002\end{array}$ & $\begin{array}{l}235 \\
241 \\
321 \\
-4\end{array}$ & $\begin{array}{l}68.9 \\
56.8 \\
62.9 \\
-. .\end{array}$ & $\begin{array}{l}79 \\
59 \\
59 \\
\end{array}$ & $\begin{array}{l}59,8 \\
50.0 \\
48.3 \\
\end{array}$ \\
\hline 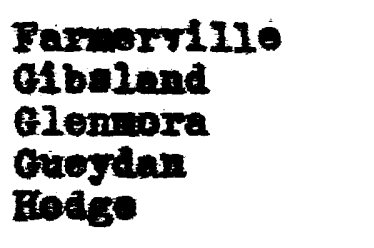 & $\begin{array}{l}1,287 \\
1 ; 080 \\
1 ; 675 \\
1 ; 313 \\
2,807\end{array}$ & $\begin{array}{l}188 \\
318 \\
439 \\
97\end{array}$ & $\begin{array}{l}-5.5 .3 \\
54.2 \\
55.4 \\
35.1\end{array}$ & $\begin{array}{r}74 \\
706 \\
76 \\
\text { No } 131 \mathrm{gh}\end{array}$ & $\begin{array}{r}\overline{56,0} \\
57,6 \\
58,8 \\
\text { Seho61 }\end{array}$ \\
\hline $\begin{array}{l}\text { Thdependenee } \\
\text { Jeanerotte } \\
\text { Jena } \\
\text { Jonesbore } \\
\text { Jonosille }\end{array}$ & $\begin{array}{l}1,700 \\
2,228 \\
1,007 \\
1 ; 948 \\
1,123\end{array}$ & $\begin{array}{r}418 \\
37 \\
112 \\
240 \\
320\end{array}$ & $\begin{array}{l}81.0 \\
33.0 \\
29.2 \\
44.4 \\
78.4\end{array}$ & $\begin{array}{r}190 \\
32 \\
60 \\
125 \\
71\end{array}$ & $\begin{array}{l}61.5 \\
26.2 \\
38.8 \\
42.4 \\
54.2\end{array}$ \\
\hline $\begin{array}{l}\text { Junotion oity } \\
\text { Japlan } \\
\text { Jentwood } \\
\text { Iake Arthwir } \\
\text { Iocente }\end{array}$ & $\begin{array}{r}388 \\
1,653 \\
1 ; 726 \\
1 ; 608 \\
1,247\end{array}$ & $\begin{array}{l}51 \\
514 \\
142 \\
212 \\
198\end{array}$ & $\begin{array}{r}100.0 \\
62.4 \\
37.6 \\
40.3 \\
56.9\end{array}$ & $\begin{array}{r}12 \\
76 \\
65 \\
44 \\
122\end{array}$ & $\begin{array}{r}100.0 \\
45.8 \\
34.9 \\
43.1 \\
83.6\end{array}$ \\
\hline $\begin{array}{l}\text { Logansport } \\
\text { Lutohor } \\
\text { Mandeville } \\
\text { Mansure } \\
\text { Yany }\end{array}$ & $\begin{array}{l}1 ; 040 \\
1 ; 401 \\
1 ; 069 \\
1 ; 067 \\
1,889\end{array}$ & $\begin{array}{r}137 \\
70 \\
13 \\
168 \\
641\end{array}$ & $\begin{array}{l}43.1 \\
22.9 \\
11.2 \\
56.4 \\
88.1\end{array}$ & $\begin{array}{r}55 \\
218 \\
8 \\
52 \\
216\end{array}$ & $\begin{array}{l}36.9 \\
39.7 \\
13.1 \\
54.8 \\
53.7\end{array}$ \\
\hline $\begin{array}{l}\text { Merkerilie } \\
\text { Yelvilie } \\
\text { Hapoleonville } \\
\text { Mow Roads } \\
\text { Oak Grove }\end{array}$ & $\begin{array}{l}1,527 \\
1,541 \\
1,180 \\
1,478 \\
1,241\end{array}$ & $\begin{array}{r}309 \\
93 \\
38 \\
160 \\
304\end{array}$ & $\begin{array}{l}56.1 \\
30.7 \\
13.8 \\
51.9 \\
54.8\end{array}$ & $\begin{array}{r}103 \\
17 \\
42 \\
122 \\
95\end{array}$ & $\begin{array}{l}51.0 \\
25.8 \\
33.3 \\
77.1 \\
51.4\end{array}$ \\
\hline
\end{tabular}


Table VIII (continued)

\begin{tabular}{|c|c|c|c|c|c|}
\hline V111eed & Population & $\begin{array}{l}\text { Eileme } \\
\text { Number }\end{array}$ & $\begin{array}{l}\text { ntary } \\
\text { Per cent }\end{array}$ & $\begin{array}{l}\text { Eigh } \\
\text { Number }\end{array}$ & $\begin{array}{l}\text { Sehool } \\
\text { Per cert }\end{array}$ \\
\hline $\begin{array}{l}\text { Pattorson } \\
\text { plain Bealing } \\
\text { Pext Alien } \\
\text { Rayilie } \\
\text { Doseland }\end{array}$ & $\begin{array}{l}2,806 \\
1,418 \\
1,584 \\
2,076 \\
1,189\end{array}$ & $\begin{array}{r}40 \\
578 \\
106 \\
643 \\
71\end{array}$ & $\begin{array}{l}15.3 \\
76.8 \\
35.1 \\
75.6 \\
81.6\end{array}$ & $\begin{array}{r}8 \\
168 \\
54 \\
226 \\
46\end{array}$ & $\begin{array}{l}21.9 \\
77.4 \\
46.6 \\
61.7 \\
88.5\end{array}$ \\
\hline $\begin{array}{l}\text { St. Uartinar } 110 \\
\text { 8pringhil } \\
\text { Salphur } \\
\text { Vidalla } \\
\text { Vilie Platte }\end{array}$ & $\begin{array}{l}2: 455 \\
1 ; 546 \\
1 ; 883 \\
1 ; 141 \\
1,728\end{array}$ & $\begin{array}{r}264 \\
254 \\
59\end{array}$ & $\begin{array}{l}57.8 \\
34.7 \\
52.7\end{array}$ & $\underset{-\infty}{68}$ & $\begin{array}{l}40.9 \\
31.0 \\
32.1 \\
-\infty\end{array}$ \\
\hline $\begin{array}{l}\text { Tlnton } \\
\text { VIvian } \\
\text { Washlngton } \\
\text { Pelsh } \\
\text { Whito castio }\end{array}$ & $\begin{array}{l}1 ; 909 \\
1 ; 646 \\
1 ; 004 \\
1 ; 514 \\
1,499\end{array}$ & $\begin{array}{l}300 \\
387 \\
236 \\
169 \\
158\end{array}$ & $\begin{array}{l}54.9 \\
51.0 \\
71.1 \\
70.6 \\
60.8\end{array}$ & $\begin{array}{r}96 \\
245 \\
35 \\
90 \\
78\end{array}$ & $\begin{array}{l}47.3 \\
62.0 \\
49.3 \\
52.5 \\
48.8\end{array}$ \\
\hline $\begin{array}{l}\text { Thinclose } \\
\text { Zwolle }\end{array}$ & $\begin{array}{l}1,965 \\
1,264\end{array}$ & 2003 & $-\infty 8.5$ & $--\infty$ & $-\overline{66.7}$ \\
\hline Total & & .068 & 13.2 & 5.504 & 16.5 \\
\hline
\end{tabular}


pupils 80 transported. In a.1, approximately 25 per oent of the - lemontary sohool ohilaren of the atate, who are transported to scbool, are transported to centera or population classed a urbea or having certain urban oharaoteriatios, and 38.6 per oent of the high sohool puplis are similarly transported. It is whown that where there is transportation of rural ollidren to school there is a sowewhat greater tendenoy to place the hidh sehool in an urban center than to so locate the consollated elementary sohools.

Subleats Studied in Publio Schools: The studies whioh the ohilarea in Loulsiana take are detemined by the state Department of Education aoting In bohalf of the State school Board and the State superintendent. Frograms of studies are arranged for the various grades of elementary school and high sehool. In the lergentary sohool no variation is allowed. The teacher may adust her aterial, 28 she is able, to fit the needs of the children, but the chlidren in the elementary schools of Honroe, Lake Charles, or Shreveport use the same textbooks and study the sano waterial as children in the nost isolated rural ocmanities. In high sohool wach greater fredos is perzitted and half of the sixteen units required for greduation way be selected by the students themselves. The required subjects are four years of Rnglish; two yenrs of social solonoe, one or which must be American Hiatory; one year of selenee, elther general solence or blology: and one year of algebra. The elcotive abjects may be additional courses in 
colonee, coolal sclenoe, nathomatioe, rorelgn language, or roeational subjoste.

What woh hlgh sohool aotually tenohes after the properibed oourses are provided for lis left inost ontiraly with the 100al sohool 1tsels or, as 1s usually the oase, the parlish apexintendent aeting through the loosi sahool prinol pal. It is in this say that the deolaion whether the mool wil offor howo ooononies or Iatin, agrloulture or somaroe or a forelgn language 1s made. The state Departiant takem no part in Alotating what a partloular hich sohool shall teak within the lintte proseribod by it for graduntion. It dosa, howerer, caution the sohool prinoligal to study the sese of ach atudent to see that the course pursued will be of such a nature as to allow hin to euter the ooliege or university he may dasire. In so far as the Loulalena state University is ooncerned that catition 18 unneseseary af it will enfoll, in the lower Division, any hlgh sahool graduate 1rrespective of the courses pursued in high sehool.

Lable IX show the courees aetually taken by the ehlidren of the high sohools of the state. From thie table it oun be sean that 29.1 per cont of the high sohool students take home

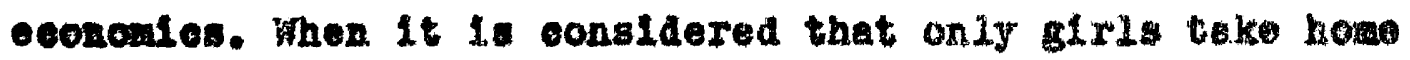

7. At a mesting of the state Bonfa of Gaucation. held Deedaber 19, 1936, the high school course of gtudy wa modis led so that the following subjecte re required for gradnation:

Ragl1 gh-n-- - -

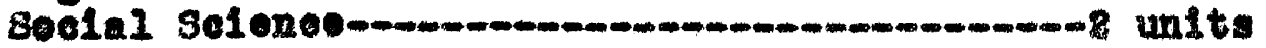

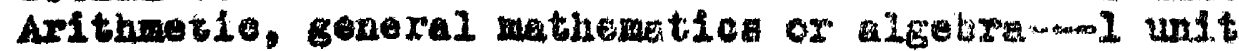
Selence-1

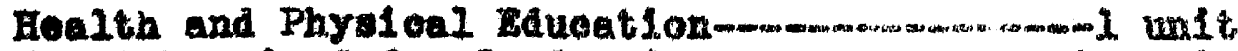

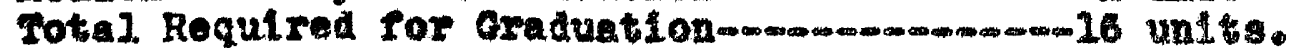


- conoutes, It is seen that over 80 per oent of the giris - Ilstblo to take homo evonomios do so. Tot muoh rarlety is formd in this regard for hove coonomi os is not taught in Asouption, Bat Follolana, Lafourohe, gt, John, and Terroboane parishos.

Hext to home eoonoul on is rorelgn language with 25.7 per cent of the hich sahool ohlldren of the stute studying 1t. Though sow parlahes do not reoore any forelgen language, it is doubsful If an pariah fails to teaoh it in wome of Its sohools, and only those sohools, as a rule, fall to offer it whloh oubotitute rooational cources ouch as home conoules for glis and pomaroe or agrloulture for boys.

Compros-intah in Loulatana consiats of one or two reare of typencltiag, one or two yeara of bookkeeping and one or two $y$ reare of ahorthand- Is atudied by 13.8 por oent of the hleh cabeol puplis of the atate. It has been the rule in the past that oaly the sehools $200 a t e d$ in the larger oenters had comeralal departaonte. This is not now the oase as aso partoh mich are predoninantly rural offer oomerolal aubjeats In thols sohools, but they do not offor elther agrleulture of the induotrial arts, 1.0., Blonvilie, Tenses, and Weat Carroll pariones.

Agriculture which, wa noted by Table II, oonstltutes the most importent induatry or ocoupation in the stete fros the standpolnt of the number of people exployed therein. Is puraned as a subject in hieh wehool by only 3.9 per cent of the 
Table IX

Subjeots Studied by Elgh Sohool Puplis

\begin{tabular}{|c|c|c|c|c|c|}
\hline Bexlin & Elome & $\begin{array}{l}\text { Agri- } \\
\text { ouiture }\end{array}$ & $\begin{array}{l}\text { Cone- } \\
\text { merce }\end{array}$ & $\begin{array}{c}\text { Industrial } \\
\text { Arts }\end{array}$ & $\begin{array}{l}\text { Yorelen } \\
\text { Ianguage }\end{array}$ \\
\hline $\begin{array}{l}\text { Asadia } \\
\text { Allen } \\
\text { Asoenstion } \\
\text { Assumption } \\
\text { Arojelles }\end{array}$ & $\begin{array}{l}812 \\
295 \\
273 \\
48\end{array}$ & $\frac{135}{160}$ & $\frac{75}{166}$ & $=$ & $\begin{array}{l}151 \\
278 \\
167 \\
362\end{array}$ \\
\hline $\begin{array}{l}\text { Beauregard } \\
\text { Blenvilio } \\
\text { Bosaler } \\
\text { Caddo } \\
\text { Caleasieu }\end{array}$ & $\begin{array}{r}138 \\
360 \\
850 \\
417 \\
389\end{array}$ & $\begin{array}{r}45 \\
108 \\
35\end{array}$ & $\begin{array}{l}82 \\
193 \\
124 \\
735 \\
328\end{array}$ & $\bar{m}$ & $\begin{array}{r}454 \\
284 \\
+681 \\
212\end{array}$ \\
\hline $\begin{array}{l}\text { Calawed } \\
\text { Camaron } \\
\text { Catahoula } \\
\text { Clatberne } \\
\text { Concordia }\end{array}$ & $\frac{189}{165}$ & $\frac{131}{36}$ & $\frac{41}{201}$ & $\frac{129}{-\infty}$ & $\begin{array}{r}48 \\
139 \\
178 \\
46\end{array}$ \\
\hline $\begin{array}{l}\text { De Soto } \\
\text { Dast } \\
\text { Baton Ronge } \\
\text { Rast Garroil } \\
\text { Eat lelleiana } \\
\text { Brangeline }\end{array}$ & $\begin{array}{r}314 \\
885 \\
50 \\
195\end{array}$ & $\frac{38}{108}$ & $\frac{190}{\frac{13}{34}}$ & $\begin{array}{r}30 \\
414 \\
11 \\
-1\end{array}$ & $\begin{array}{r}169 \\
1,032 \\
238\end{array}$ \\
\hline 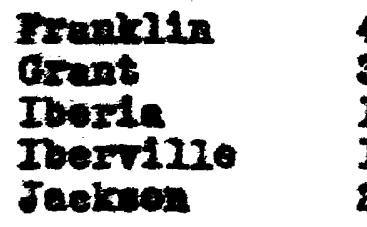 & $\begin{array}{l}415 \\
362 \\
120 \\
100 \\
200\end{array}$ & $\begin{array}{r}\frac{21}{121} \\
23 \\
-84\end{array}$ & $\begin{array}{r}50 \\
155 \\
89 \\
179 \\
109\end{array}$ & $=$ & $\begin{array}{r}423 \\
44 \\
393 \\
135 \\
73\end{array}$ \\
\hline $\begin{array}{l}\text { Jefrurwon } \\
\text { Jerferaon- } \\
\text { Davis } \\
\text { Infajette } \\
\text { Iafourahe } \\
\text { If Ealie }\end{array}$ & $\begin{array}{r}187 \\
81 \\
356 \\
256\end{array}$ & $\frac{18}{189}$ & $\begin{array}{l}227 \\
104 \\
122 \\
124 \\
-\end{array}$ & $=$ & $\begin{array}{r}468 \\
247 \\
198 \\
210 \\
86\end{array}$ \\
\hline $\begin{array}{l}\text { Mincoln } \\
\text { Ifringston } \\
\text { Madison } \\
\text { Morehouse } \\
\text { Matehl tooher }\end{array}$ & $\begin{array}{r}330 \\
234 \\
67 \\
91 \\
473\end{array}$ & $\underset{-\infty}{-\infty}$ & $\begin{array}{r}10 \\
-37 \\
119 \\
109\end{array}$ & $=$ & $\begin{array}{r}240 \\
47 \\
117 \\
--0\end{array}$ \\
\hline
\end{tabular}


Table IX (Continued)

\begin{tabular}{|c|c|c|c|c|c|}
\hline Parlah & $\begin{array}{l}\text { Home } \\
\text { sonomies }\end{array}$ & $\begin{array}{c}\text { Agri- } \\
\text { cuiture }\end{array}$ & $\begin{array}{l}\text { Com- } \\
\text { meree }\end{array}$ & $\begin{array}{c}\text { Industrial } \\
\text { Arts } \\
\end{array}$ & $\begin{array}{l}\text { Forelgign } \\
\text { Ianguage }\end{array}$ \\
\hline $\begin{array}{l}\text { Ougahita } \\
\text { Plaquemines } \\
\text { Pointe coupee } \\
\text { papides } \\
\text { hod RIVer }\end{array}$ & $\begin{array}{l}\frac{376}{101} \\
685 \\
\end{array}$ & $\frac{-\infty}{36}$ & $\frac{280}{64}$ & $\frac{96}{-21}$ & $\begin{array}{l}325 \\
124 \\
523 \\
-2\end{array}$ \\
\hline $\begin{array}{l}\text { Al ohland } \\
\text { Sablive } \\
\text { St Bermaxd } \\
\text { St Oharles } \\
\text { st Eolona }\end{array}$ & $\frac{278}{387}$ & $\frac{131}{36}$ & $\begin{array}{l}121 \\
145 \\
-\infty-\infty\end{array}$ & $=$ & $\begin{array}{l}145 \\
585 \\
109 \\
\end{array}$ \\
\hline $\begin{array}{l}\text { st Jomes } \\
\text { st John } \\
\text { st Iandry } \\
\text { st Jartil } \\
\text { st Iary }\end{array}$ & $\begin{array}{l}106 \\
266 \\
126 \\
175\end{array}$ & $\begin{array}{r}74 \\
44 \\
218 \\
26 \\
28\end{array}$ & $\begin{array}{r}90 \\
125 \\
141 \\
193\end{array}$ & $=$ & $\begin{array}{r}177 \\
111 \\
453 \\
98 \\
124\end{array}$ \\
\hline $\begin{array}{l}\text { St Tamany } \\
\text { Tanclpahoe } \\
\text { Tonitys } \\
\text { Terrebonne } \\
\text { Unien }\end{array}$ & $\begin{array}{r}268 \\
421 \\
56 \\
441\end{array}$ & $\frac{-32}{\frac{42}{94}}$ & $\begin{array}{r}224 \\
450 \\
34 \\
98 \\
-\end{array}$ & $=$ & $\begin{array}{r}190 \\
396 \\
77 \\
533\end{array}$ \\
\hline $\begin{array}{l}\text { Vermilison } \\
\text { Terrion } \\
\text { Wabhlugton } \\
\text { Woboter } \\
\text { Wott } \\
\text { Baten Rouge }\end{array}$ & $\begin{array}{r}274 \\
413 \\
497 \\
480 \\
36\end{array}$ & $\frac{102}{101}$ & $\begin{array}{r}104 \\
47 \\
.155 \\
157 \\
-\end{array}$ & $-\infty$ & $\frac{\frac{837}{594}}{157}$ \\
\hline $\begin{array}{l}\text { Weet Camell } \\
\text { Weat Feliciane } \\
\text { Wimn }\end{array}$ & $\begin{array}{r}185 \\
32 \\
280\end{array}$ & $\overline{827}$ & $-\frac{20}{25}$ & $=$ & $-\frac{52}{66}$ \\
\hline 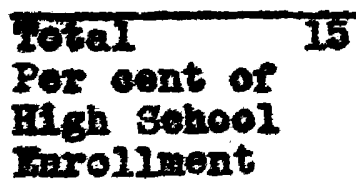 & 5.010 & 3,062 & 6.873 & 1,200 & 13.269 \\
\hline
\end{tabular}

- Hot 21sted in that sohool. 
hlgh ahool student body. Twenty-three partshow do not offer any courses in agrioulture, in spite of the jrovision whereby the Federal government bears ontwalf of the gost of the

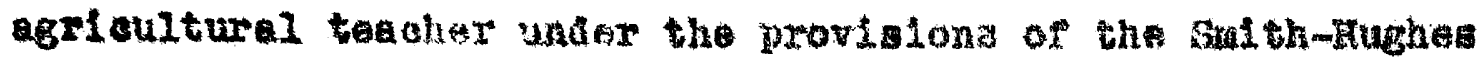
Aot.

Industrial art hold very inglgntegent pouftion in the perishes of the state wh only 2.2 per osnt of the high sohool students pursulng that braneh. As rule oniy the lerge urban nigh shoold offer the industrial arta, suol wchool as Byrd and Faizpark High Sohools, Shrereyort: Baton Rouge Junior und senlor High Sehools, Baton Eouge; Ouachlte Parioh High sohool, Honroe; Bolton in Alexandrle; and Bogelusa plgh; yot in Celdwell Parish, Without center of population of 1,000 peoplo. Industrial are ineluded in three out of the five high sehools.

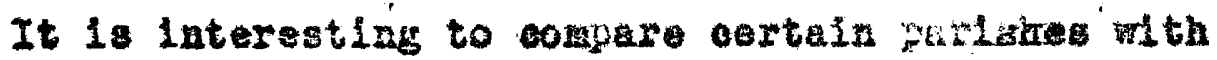
rererence to the per cont of their population classed as

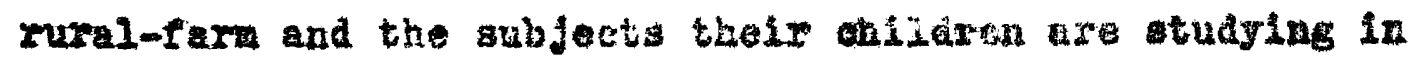
high sohool. (Seo ruble $2_{0}$ ) It is noted, for axample, that ilringston jarish, with 77.0 ger oert of it poyulation -lased a rural-farm has 27.5 per oent of the sudents taing rorolgn language, ond agriouture is not orfered in the high

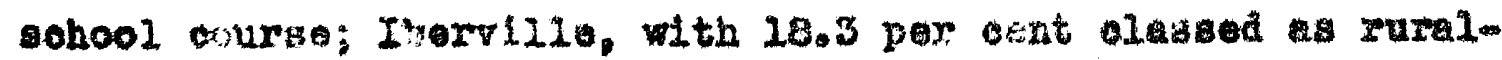
tarm has 29.0 per oent of 1 ta students tablat comerea, 21.8

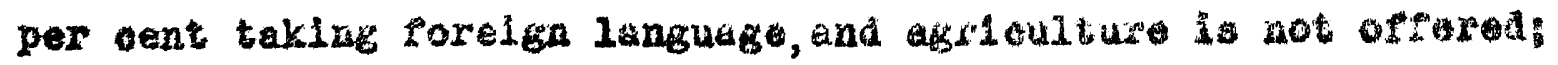

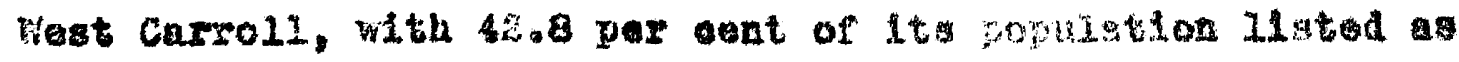
rural-tarm hes 8.5 per cont of lts high solool student studylap 
Table $\mathbf{x}$

Compertoon of Iural-Farn Statue of Netive Wh1te Population and the Subjects Taught in Mtreen Paxishos

\begin{tabular}{|c|c|c|c|c|c|c|}
\hline Partion & $\begin{array}{l}\text { Popol } \\
\text { Raral- } \\
\text { Taxa }\end{array}$ & $\begin{array}{l}\text { Bon } \\
\text { Rotal }\end{array}$ & $\begin{array}{l}\text { ox dont } \\
\text { tural- } \\
\text { Faris is } \\
\text { Total }\end{array}$ & $\begin{array}{l}\text { Por oont } \\
\text { Sohool Po } \\
\text { Studying } \\
\text { Poxalgh } \\
\text { Langergo }\end{array}$ & 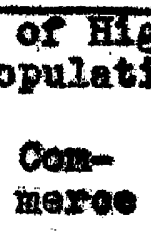 & $\begin{array}{l}\text { Lon } \\
\text { Age- } \\
\text { ontbure }\end{array}$ \\
\hline mowiption & 4.879 & 9.565 & 45.7 & 59.2 & 0 & 0 \\
\hline 120 & 9.983 & 18,14 & 60.3 & 46.4 & 10.7 & 0 \\
\hline & 2.480 & 3.927 & 62.0 & 0 & 7.1 & 0 \\
\hline Foneten & 1,680 & 5,356 & 28.2 & $40: 9$ & 0 & 0 \\
\hline Dored15e & 3.248 & 12,404 & 20.5 & 21.8 & 29.0 & 0 \\
\hline Intourabe & 11,976 & 26,962 & 44.4 & 32.3 & 19.0 & 0 \\
\hline Iivingston & 10,000 & 15,761 & 77.0 & 27.5 & 0 & 0 \\
\hline Madron & 8.805 & 5.159 & 52.0 & 18.0 & 14.8 & 0 \\
\hline Soxohowes & 4.181 & 10.080 & 41.7 & 18.5 & 18.8 & 0 \\
\hline Polnt coupea & 5.350 & 8.635 & 73.3 & 31.6 & 16.3 & 0 \\
\hline & $\mathbf{5 . 0 8 8}$ & 4,805 & 72.8 & 43.1 & 19.0 & 0 \\
\hline an Rouse & 1,355 & 3.498 & 38.0 & 64.6 & 0 & 0 \\
\hline $1 x 211$ & 9.120 & 21,015 & 78.8 & 3.2 & 8.5 & 0 \\
\hline Foltelana & 926 & 2,522 & 36.7 & 33.3 & 0 & 0 \\
\hline Potal & 46,998 & 1.285 .250 & 54.8 & 25.7 & 13.3 & 5.9 \\
\hline
\end{tabular}


comeroe, and 3.2 por cent taking forelen language, but agrioulture is not a sohool subject: Tensas with 72.8 per cent or Ita population olassod as rum-farm, has 19 per cont taklng the comaroe, 43.1 per sent taking forelgn language, and there also agrioulture is miseing.

The Teaching Perannel: qualifioatlons for teachers in the Loulsiana publ10 sohoola are proseribed by the State Dopartment of Bdueation. Frery teacher to recel ve pay from the state or parish school fund mast meet the quallfleatlone eatablished by the State Dopartinent of Education and must hold e certirleato from that department entitilng him to teech,

The certiflcatea lasued by the state Depertment of Hducation are of four maln 0lasses. The first oless denla with the qualiflcation required for high sohool tenohers, and for the sohool supervisory or adminlstrative posttlons. This olass is aubdivided into two mals divialons of of chich is sublivided.

The first divialon of the high sohool or adminlatrative eroup, require professional training enulvalent to bacealaureate degree together with a mingu or 18 semester hours of profosslonal training, four of which wust be in prectice teaching. This certiricate entities the teacher to teach the subjeots speolfled in the nigh achools of the state ror the perlod of plve years from the date of lsaunnee the subdivialovas rolate to the tegohing experience in addtion to the academio

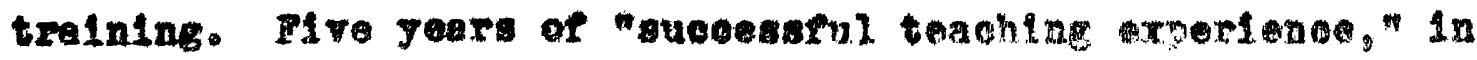


addition to the training IIsted above, makes a toacher eligible to mploysent as a parish supervisor of partsh superintendent, whereac only three years'experience is necessary for liglblitity to a high sohool prineipalahip.

The aecond aubdivision of the high sohool group, requires a buecalaureate cogree or better, togethex with 12 somester hourg of proressional training, four of whi ah must be in praotio teabling. This oertirlonte is ralld for only three geara and entities the holder to toeoh the aubjeota speelfied in the nigh mehoels of the state, and arter three gears of "subeessful teaching exporience," to be employed as a high sohool prinolpal.

The eecond main eless pertains to elementary sohool teachers and is Iikerise subdiridod. The minimua requirements for th1s olass are elther the completion of a two-year teachertraining course designed for the preparation of elomontery sohool teachers or the completion of two Jearm of college training,together with not less than Ifre years of "guecessful teaching experience." This alass of oertifloate entitles the holder to ooure employment in the lementary sohools in the state for a poriod of $11 \mathrm{ve}$ years from the date of granting the eertifleato.

A third olase perteine to teachers in the state-approved trade schools. Here the completion of the equivalent of a high sohool course plus tour years'experience an apprentioe,

10. After September 1. 2937 the approved oourse for - lementary sohool teachors w1l bo thre years in both oases. 
or graduation from a state approved trade soherol and foux jears of aotual eaployant in the trede are required. This cortifleate entitles the holder to serve for two jears after the Issuance.

The fourth olass of certifleate is issued in order to take eare of the fow old teaohers who rere in service under the regulations up to Karoh 11, 1924. Th1s type of certifloate eat1ties the bolder to contlnue the type of work wh the old certirleate authorized under cortain conditions sot forth. At the presont time there ure relatively fow touohers of this class at111 umployed.

prior to the adoption or the ruled for pertification of teachers outilned abore, the requirements for obtainlng the teachers' certirioate wore essentialiy the same, but the certifloate was ralld for the life of the holder instead of for five years.

Haring noted the degree or truining required in order to secure a teaching certifleate, it 1 a of latorast to see were the toachers recelve tholr tralning. The Loulalan Hormal College train wore elomentary sohool teachers than 211 the other major Louls lan collegea somblned. The Louldana State Uniroraity leads in the training of high sohool tecohers. There are relatively fow elomentary sohool teachers trained in out of atat institutions. (Soe Table X.)

11. State Department of Rduoation in Ioulatana. "Certifloation or Terahere" Bujletin No. 275. 1834.

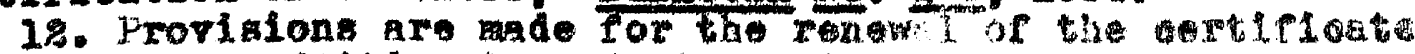
by oridenos of aditional acadomie trainine. 
rable $\mathbf{x}$

Ituantlosel Ingtitutions in wioh Ioulaiana Sohool

Teachore were Trained*

\begin{tabular}{|c|c|c|c|c|}
\hline Inctitutens & $\begin{array}{l}\text { ithontary } \\
\text { Iuner }\end{array}$ & $\begin{array}{l}\text { 80nool } \\
\text { Per cent }\end{array}$ & $\begin{array}{l}\text { Hibh: } \\
\text { Number }\end{array}$ & $\begin{array}{l}\text { Sohoor } \\
\text { Per Gont }\end{array}$ \\
\hline $\begin{array}{l}\text { Oat af state } \\
\text { Collegos }\end{array}$ & 181 & 4.3 & 256 & 14.5 \\
\hline $\begin{array}{l}\text { Iovineiena state } \\
\text { univerefisy }\end{array}$ & 175 & 6.3 & 473 & 87.7 \\
\hline $\begin{array}{l}\text { Loviofane state } \\
\text { Eormal }\end{array}$ & 1,857 & 4.8 & 370 & 82.7 \\
\hline $\begin{array}{l}\text { Iouistane } \\
\text { Pelvtechnse }\end{array}$ & 345 & 12.4 & 167 & 9.8 \\
\hline $\begin{array}{l}\text { Bouthrost Ioal slana } \\
\text { Inot 1 tute }\end{array}$ & 550 & 29.8 & 198 & 11.6 \\
\hline $\begin{array}{l}\text { Tuleme and } \\
\text { reweens }\end{array}$ & 20 & .7 & 75 & 4.4 \\
\hline Iorvin & 10 & .4 & 11 & .6 \\
\hline Centenary & 24 & .9 & 41 & 2.4 \\
\hline Ioulatana college & 28 & 1.0 & 96 & 5.6 \\
\hline Othere & 847 & 8.9 & 16 & .9 \\
\hline Mone & 6 & .2 & 0 & 00 \\
\hline Total & $\frac{2,761}{a_{12}}$ & $\frac{90.8}{9.89}$ & 1.708 & 89.2 \\
\hline
\end{tabular}


Sinee the acadenis qualiflations of Loulatane teachers has been analyzed, the enount of teating axperlane thoy have reosived is now examined. (5e* Table $\mathrm{KX}_{0}$ ) It oan be seen that elementary school teathers are nore experienced than high achool teachers. The median expertenoe for the - Iamentary teachers 186.3 yoars, wh110 for the high sohool group 1t 18 two yeara 1ess. Furthermore. 7.1 per sent of the elementary teacherg are Inexperlenoed corpared 1 th 11.3 per eent of the high sohool sroup.

Not only are the elementary teachors more experienced than the high sehool teachers, but, by Table XIII it can be ceen that they are wore seoure in thelr positions than the high eahool teaohers. The median tenure in thalr present

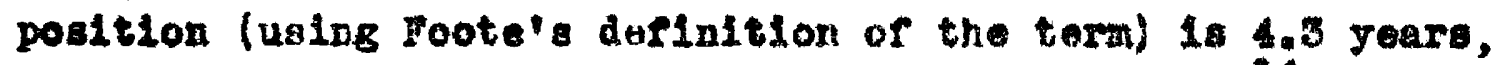
wile for those or becondary level it is 3.6 years. 14 This acrees of th the statement by cooke, Froressor of Rducation In Gorge Pabody College for Teaohers, that "The rate of tumover among hlgh sohool teacherg it ereater then that of 25

elementary sehool tencherg."

Gogeluglon: Loulslana has provided a centrallzed gystea of pnblis edueation, hoaded by the Btate Buperintendent of

13. This Information 18 from the 1 lise of the Department or Education for the 3tate or Loul siana. Jee aloo: Jumer Nonroe 3mith, The Irainlng of High Sohool Teschers in Louls ians, New York, Bureau of FubIIoations, Teachers college, columbla Univeralty, 1920。.

Irving F. Foote, Penure of Heh Sohool Tanahora in Ioulalang,

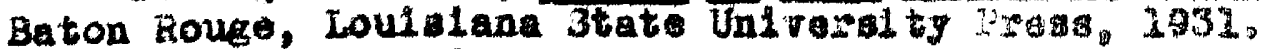

14. IbId., D. 2.

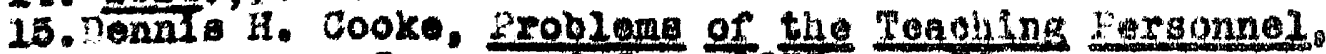
now York, Longmans, Groen and $\mathrm{Co}_{0}, 1933, \mathrm{p}, \mathrm{Vg}$ 
Tavle XI

Teaching Bpertenoe of Ioulslana Teachers*

\begin{tabular}{|c|c|c|c|c|}
\hline \multirow{2}{*}{$\begin{array}{c}\text { Soperionoe } \\
\text { in } \\
\text { Ieax }\end{array}$} & \multicolumn{2}{|c|}{ MIenontary Sahool } & \multicolumn{2}{|c|}{ File Sohool } \\
\hline & Numiber & Per Gent & Namber & Per cont \\
\hline $\begin{array}{c}\text { bore than } \\
\text { of }\end{array}$ & 224 & 4.7 & 42 & 3.1 \\
\hline $15-80$ & 207 & 7.9 & 43 & 3.2 \\
\hline $10-14$ & 368 & 13.9 & 116 & 8. 6 \\
\hline $8-9$ & 317 & 12.8 & 116 & 8.6 \\
\hline 7 & 153 & 5.9 & 55 & 4.0 \\
\hline 6 & 108 & 7.4 & 99 & 7.5 \\
\hline 5 & 181 & 6.9 & 110 & 0.1 \\
\hline 4 & 228 & 8. 2 & 137 & 10.1 \\
\hline $\mathbf{3}$ & 209 & 8.1 & 271 & 28.7 \\
\hline 2 & 247 & 9.5 & 170 & 22.6 \\
\hline 2 & 196 & 7.5 & 138 & 10.8 \\
\hline Fone & 196 & 7.2 & 153 & 11.3 \\
\hline Total & 2,596 & 99.3 & 1.350 & 99.8 \\
\hline Medien Iear & Then & $\begin{array}{l}\text { Eleme } \\
\text { HIgh }\end{array}$ & Snhool & $\begin{array}{l}6.3 \\
4.3 \\
\end{array}$ \\
\hline
\end{tabular}


Table XIII

Tenure of Loviclena Toachors In Their Pregent Posttion *

\begin{tabular}{|c|c|c|c|c|}
\hline \multirow{2}{*}{$\begin{array}{l}\text { Tears in } \\
\text { present } \\
\text { poeltion }\end{array}$} & \multicolumn{2}{|c|}{ Elementary school } & \multicolumn{2}{|c|}{ High Sohool } \\
\hline & Dumber & Per cent & Number & Per Cent \\
\hline $\begin{array}{l}\text { Wore than } \\
\text { Is }\end{array}$ & 70 & 8.7 & 17 & 1.1 \\
\hline $10-15$ & 183 & 7.0 & 54 & 3.7 \\
\hline $8-9$ & 207 & 7.9 & 70 & 4.8 \\
\hline 7 & 168 & 6.8 & 61 & 4.2 \\
\hline 6 & 184 & 7.0 & 91 & 6.3 \\
\hline $\mathbf{b}$ & 270 & 10.4 & 133 & 9.2 \\
\hline 4 & 309 & 11.9 & 183 & 13.4 \\
\hline 3 & $\mathbf{s e 2}$ & 14.6 & 260 & 18.0 \\
\hline 8 & 366 & 14,2 & $\mathbf{2 3 0}$ & 25.8 \\
\hline 1 & 264 & 10.1 & 176 & 28.2 \\
\hline Hone & 104 & 7.4 & 253 & 10.6 \\
\hline Total & 2,598 & 99.4 & 1,438 & 98.4 \\
\hline Sedian $\pi$ & Bzer & $\begin{array}{l}\text { ary sehool } \\
\text { heol }\end{array}$ & $\begin{array}{l}4.3 \text { yea } \\
3.6 \text { yea }\end{array}$ & \\
\hline
\end{tabular}

* For the cohool eesalon 1633-1934. 
Eduoation and the state Board of Bducation. Within och par1sh a centrallzed board of control funotions withln spedile IImitations presoribed by the State Boaxd of Education. Sohools are olassed as ol mentary and atate approved high schools. The aubjeots taught in the elewentary grodes are flied by the state Board of Iduation and the chlidren in the elties sueh es Shrereport, Baton Rouge, Alexandria, study exactiy the game material from the same toxta as the ohlldron of tho wost isolated rural sohools. In high sohool, whin the lintts presoribed for high sohool graduation, froedon of ahoice is allowed each parish and each oohool.

Loulatana has oarried on an intensive program of school consolidation for the pest thirty joars and todes, not Inoluding the olty sohools of New Oxleang, Laice Charles, Monroe, and Bogalusa, 42.5 por cont or the high sohool enroliment and 4.6 per cent of the elementary chool enroliment are transported to consolldated cohoola. Almost one-hals of the otudents of the state are transported to sahools. Also, a higher percentage of the elementary sohool children is tranaported to Bohool than hlgh oohool pupils. That may be interpreted in the 11ght of three possibilities: That the Lewer sohoola of Loughelane are consolideted to a greater degree than the high sehools of the state: that there is a greater elimination of the rural children as they reach the high sohool levelg then for the town ohllaren; or that ways are provided for the transporting of elenentary achool onlidren, whereas the high achool pupila are required to walk to school. 
The last possibility has 11ttlo upport as in establishing the bus soutes the achool authoritied provide that they nust plok up all sohool onllaren 21 ring along the route 1rreapeotive or the raot whother thoy are of high sohool or elementary sohool 69.

In the consolldation program in the state it has been a coumeon prectloe to traneport the ehlidren from rural aletrlota to urban oentere or centers having urben characteriotios. Approxinately 25 per oent of the elementary sohool and 39 per oent of the hleh. sohool puplle who are tranoported to sohool are tranoported to centers of population of 1,000 Inhabitants or wore. A hiehor por cont or rural hlgh sohool students than of the rural olomontary sohool puplis are transported to the centere or population.

In the courses of etudies actopted by the high sohools of Loulatane a great deal or variation is found. Hose esonomies eeems to be the nost popular of the subjects not required for craduation irom high sohool or Ilsted as the ceneral Aeadeate course; 29.1 per oont of the hIgh sohool pupils take howe economlos, yet homo coonomics is not offered by all the schools, and in some parishes no sohools teach It. Forelen language ranks a elose second to home economlob, from the polnt of number of pupils taking 1t, with 25.7 per oent of the state's hlgh sohool pup1ls atudying that subjoot. It must be noted that in the garall high sohoole or any except the large high schools only two yoars of e forelgn language are offored, woreas three and cometimen four yeare of home obonomlos are taught. Furthernore, those who take the roational oourses, 
home oconomies, conemeree, efrloulture, or Industrial arts usualiy do not take fordgn language.

Comeroe, which consigta of on or two years of bookreeping, one or two years typewriting and one or two yearm of shorthand, is studied by 13.3 por oent of the high sohool enrollment.

Agrloulture is pursued by 5.9 per oent of the high sohool students of the state and Industrial arts by only 2.3 per oent.

Some of the parisher of the state whloh have a large majority of thelr population elassed as "rural-iarm" offer comeres in their sohool but orfer no agrioulture. 


\section{CHAPF V}

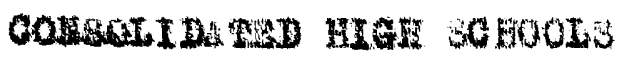

The provions chapters have beon covotod to an ensilyel of rumal edacation, the chrateristios of the Iontelano pepulation and 1 to industries, and the mohool oxgangation If the atate. In the following abapters tho study 11 be

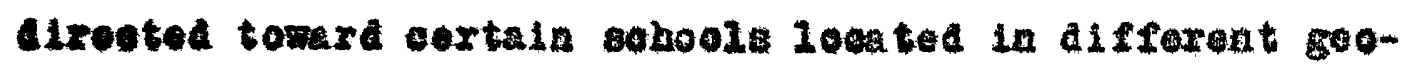
graphion and oultural axoas, in an attanpt to dlsoover to what

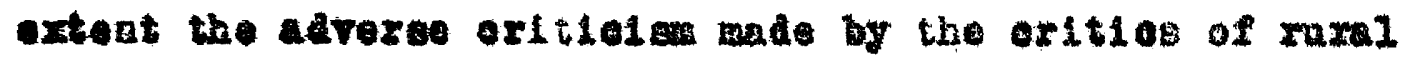

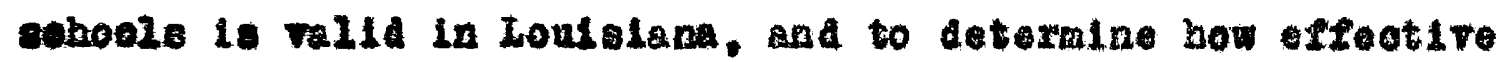
the cencolldation of soluode the ben in bringing about the prodicted obange日.

The present obaptor 58 an analgsio of tive raral consol1deted hlgh eohoole. Por the purpose of this otidy these are diriced into two olabers: the consolideted high gohool 100ated in the open oountry or in an anineorporsiced hamlet. and the coneolianted high sohool 200 ted in a village oenter.

\section{Section A}

The Rural Coneolids tod righ Sahool Looktod In the open Country

In this section the otudy li be arotod to the oon-

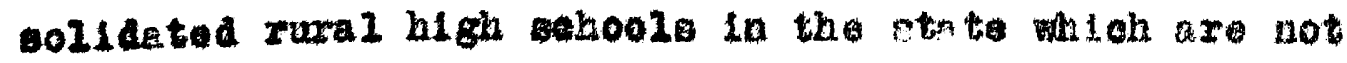

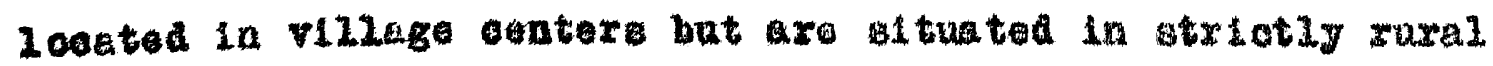

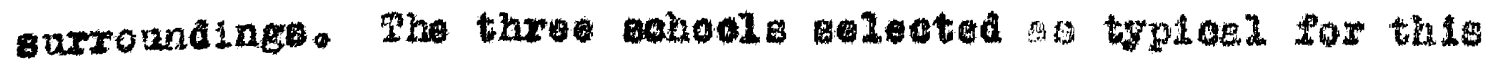




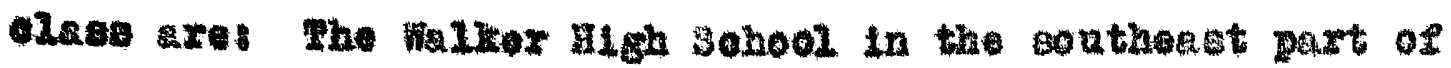
the etate, to repreasnt the Anglomsaxon group, and the Prenol Settlement and the Fonerizle Hlgh Bohools, to reprogent the Irenoh gootion of the ats te.

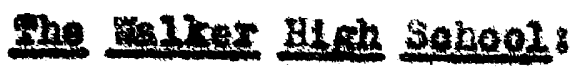

The falker High sobool is looted in approximately the

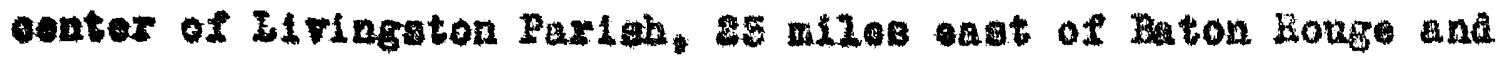
- 1gat miles east of the village of Denham springe. It has an enmolment of about 300 olementery and 286 high sohool ohlidren. It is 2000 tod at Lound a good-olied Baptlet charah, throe genoral stores. four

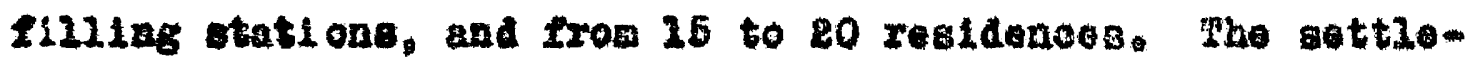
eont is served by gravel roada ia addition to a paved highway. 7axing of a self-sufflelag type is the ohiof ocoupation of the patrons of the sohool, wh bot of the poople ownlag thelr 2and. In lact, of $94 \mathrm{hlgh}$ gouool studeats who ansmered the guestion as to whethex tzelr parento owned or rented the zand on weh they 11rod, 82 anmered that they owned the land sa oomparod wi th 2 tho rentod. If the high oohool atrdents

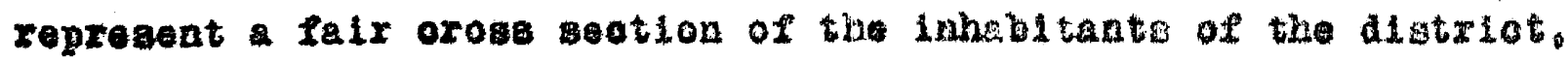
about or per cent of the people own their lond.

The in bulding of the sohool conolate of a briak

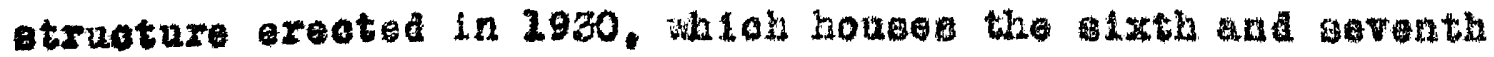

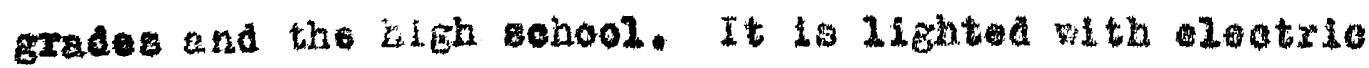

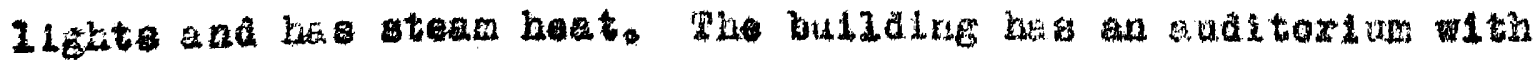

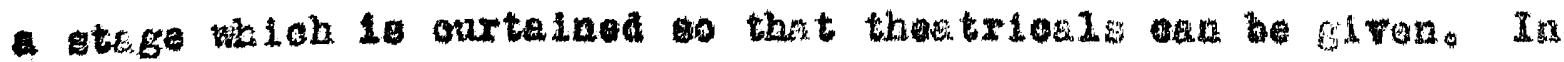




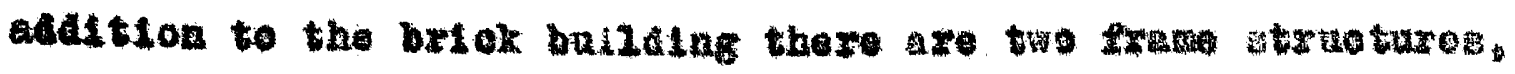
In ahioh axe tought the grader below the stith. fypuratiy those aze the bulldinge whleh honeed the sobool prios to the

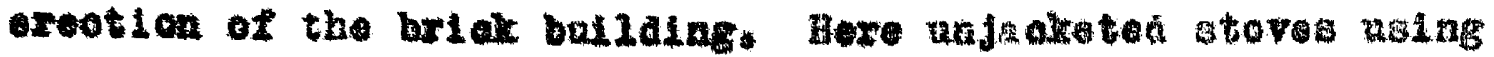
wood a trol are the mans of houting the rooms. Both boys and gixla of high wehool age play baket-ball, and as is true In most raral echools of the otate, haget-ball reoutres the

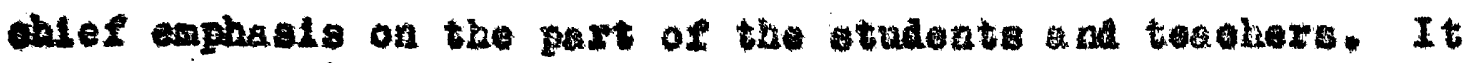
we listed tbo only foris of athlotios in will the cobool childron onerged in interechols stie comptition. For the Litie oblleren there 10 no equipment. A period of 25 minutea each des is provided on the sohodule; dizing this thas the

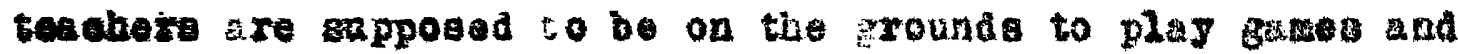
to apervise the phyeical selvitlog of the children of their grades.

Is Investigeting to detemine the pt the sabool playe an a commity conter for the sdilts in the distriet, one

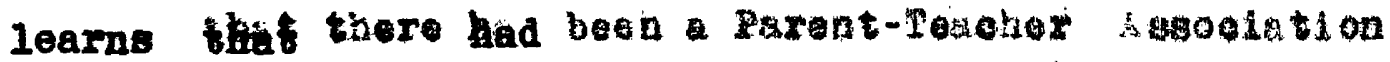
but the It is not noa Pnotioning. Shere sixe no other

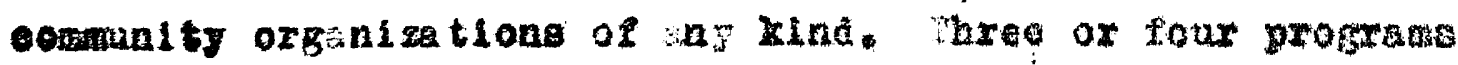

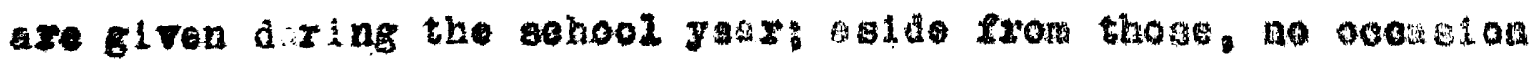

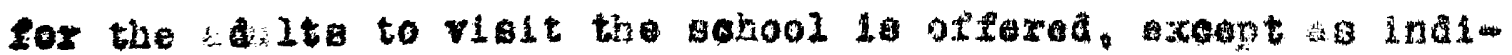

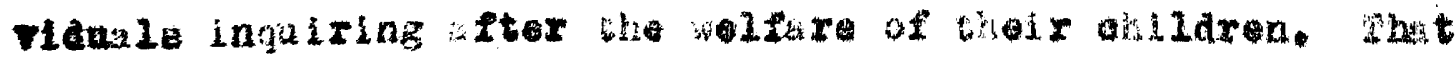

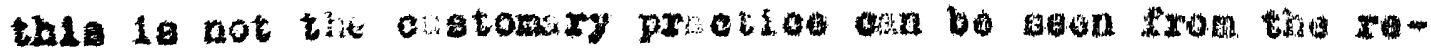

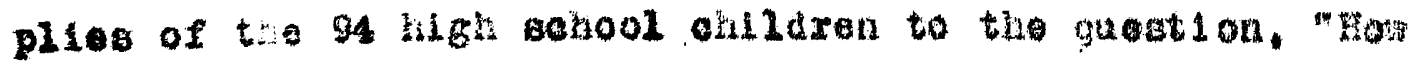

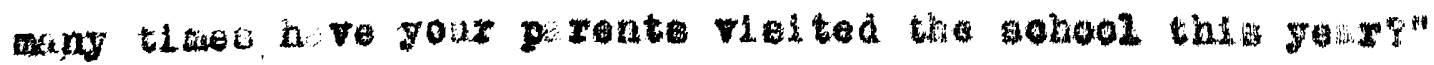
co this quection 48 repliod that their parats had not boen

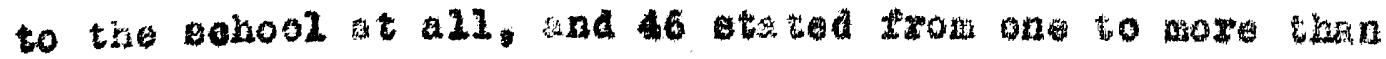


three thes. Fer the elowentary sahool chlaron, the sehol seens to be furthex renoted frow the how for out or 248

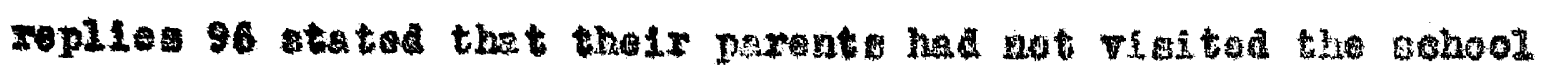
this yeax. Of 106 raplies from high ashool puplla to the

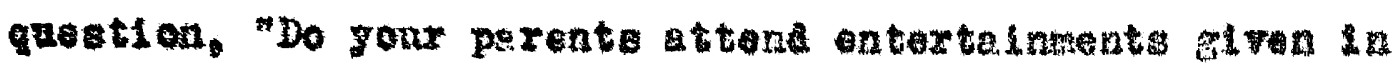

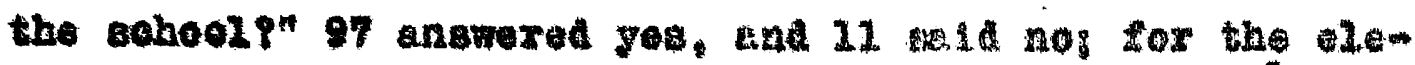
mentary gradea, 104 angwerod jos, and 55 roplied no.

the sehool pogulation of iraker in rether ablle, as oan be juaged fros the fact thet 22 of the MIgh gehool atudento

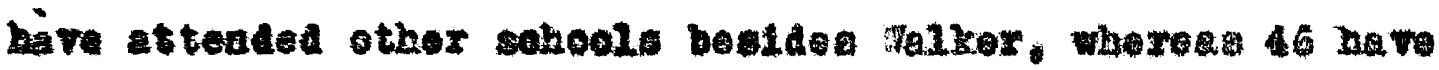
not. Fox the elementaxy gradeo, the number who have gone to wo other ohool is 84, comparea ith $n$ who heve gone to othe* wahools.

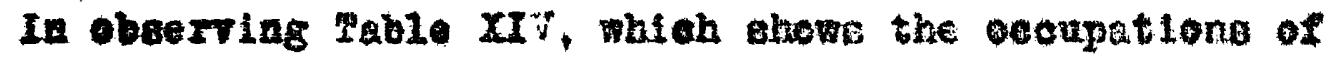
the parente, faxing is soon to rank first 1 th 69.3 per oent

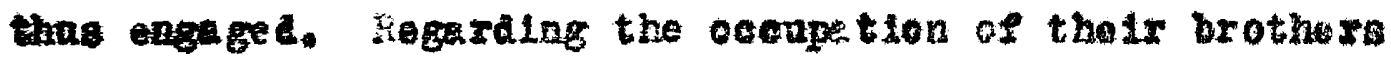

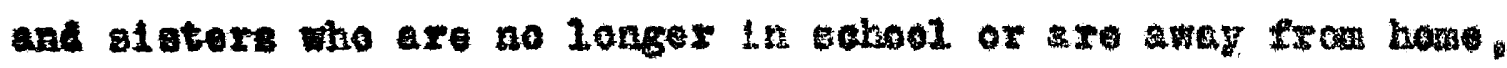
94 are tound to be working for Ing), 19 farmlag, ad fev are ongat in othor occuptions. zoplies to the guestion to the the students lintond to

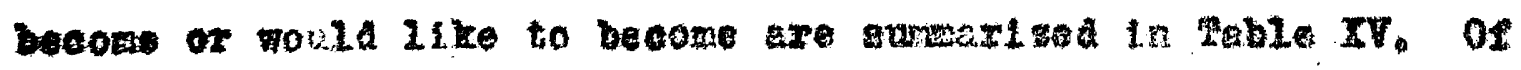

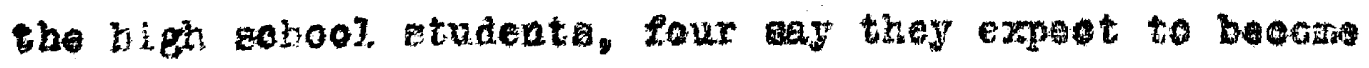
farvers, whorea 20 as they do not. cheries ar offles work hulas 13xet place, with 26 preferring that onempation:

1. In reforring to the olecontary grads, unlono otated othervio, only the grade a bove the third are ooneladered.

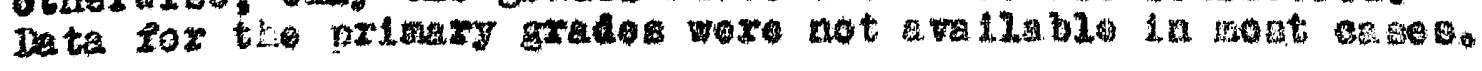


Table XIV

Qeeupations of the Parents of Students of the thalfer Sehool

\begin{tabular}{|c|c|c|c|c|}
\hline Decenpetions & $\begin{array}{l}\text { 2igh } \\
\text { Araber }\end{array}$ & $\begin{array}{l}\text { Sowool } \\
\text { Per Cent }\end{array}$ & $\begin{array}{c}\text { Fiemio } \\
\text { Number }\end{array}$ & $\begin{array}{l}\overline{x y} \text { Senool } \\
\text { Per Cent }\end{array}$ \\
\hline $\begin{array}{l}\text { Famex } \\
\text { Pubile Verizor } \\
\text { Eochinie } \\
\text { Loger } \\
\text { Pulintex }\end{array}$ & $\begin{array}{r}79 \\
6 \\
1 \\
5 \\
1\end{array}$ & $\begin{array}{l}71.7 \\
5.6 \\
0.9 \\
4.7 \\
0.9\end{array}$ & $\begin{array}{r}108 \\
12 \\
5 \\
2 \\
4\end{array}$ & $\begin{array}{r}67.5 \\
7.8 \\
3.8 \\
1.8 \\
2.5\end{array}$ \\
\hline 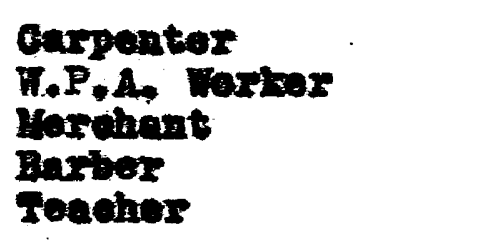 & $\begin{array}{l}8 \\
2 \\
2 \\
1 \\
2\end{array}$ & $\begin{array}{l}2.8 \\
1.9 \\
1.9 \\
0.9 \\
0.9\end{array}$ & $\begin{array}{l}3 \\
4 \\
3 \\
2 \\
2\end{array}$ & $\begin{array}{l}1.9 \\
2.5 \\
1.5 \\
1.5 \\
1.3\end{array}$ \\
\hline \multirow{2}{*}{ 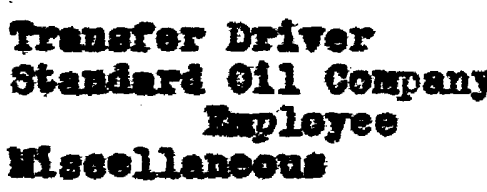 } & 0 & 0.0 & 2 & 1.3 \\
\hline & : & $\begin{array}{l}0.0 \\
7.5\end{array}$ & $\begin{array}{r}2 \\
11\end{array}$ & $\begin{array}{l}1.3 \\
7.0\end{array}$ \\
\hline Total & 107 & 100.0 & 157 & 100.0 \\
\hline
\end{tabular}


Table XV

Decupational Proferenee of the students of the Walker

Sehool

\begin{tabular}{|c|c|c|c|c|}
\hline Dowupation & $\begin{array}{l}\text { Alg } \\
\text { Nuber }\end{array}$ & $\begin{array}{l}\text { Sanool } \\
\text { Per Cont }\end{array}$ & $\begin{array}{l}\text { Blene } \\
\text { number }\end{array}$ & $\begin{array}{l}\text { Sohool } \\
\text { Per Dent }\end{array}$ \\
\hline 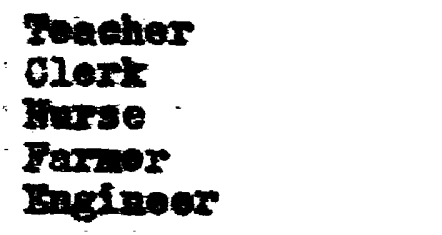 & $\begin{array}{r}18 \\
86 \\
10 \\
4 \\
8\end{array}$ & $\begin{array}{r}12.6 \\
25.2 \\
9.7 \\
3.9 \\
7.8\end{array}$ & $\begin{array}{r}58 \\
6 \\
19 \\
22 \\
5\end{array}$ & $\begin{array}{r}35.8 \\
3.8 \\
12.8 \\
14.1 \\
1.8\end{array}$ \\
\hline 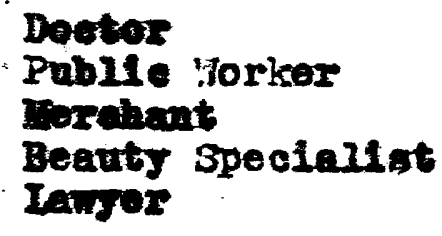 & $\begin{array}{l}4 \\
6 \\
4 \\
2 \\
4\end{array}$ & $\begin{array}{l}3.9 \\
5.8 \\
3.9 \\
1.9 \\
3.9\end{array}$ & $\begin{array}{l}9 \\
4 \\
5 \\
4 \\
1\end{array}$ & $\begin{array}{l}5.8 \\
2.6 \\
3.8 \\
2.6 \\
0.6\end{array}$ \\
\hline $\begin{array}{l}\text { Boldier } \\
\text { MEloter } \\
\text { Horester } \\
\text { lateler } \\
\text { Aviator }\end{array}$ & $\begin{array}{l}2 \\
2 \\
4 \\
4 \\
3\end{array}$ & $\begin{array}{l}1.9 \\
1.9 \\
3.9 \\
5.9 \\
2.9\end{array}$ & $\begin{array}{l}3 \\
2 \\
0 \\
0 \\
0\end{array}$ & $\begin{array}{l}1.9 \\
1.3 \\
0.0 \\
0.0 \\
0.0\end{array}$ \\
\hline Mrseollaneous & 7 & 6.9 & 23 & 14.7 \\
\hline Total & 105 & 100.0 & 156 & 100.0 \\
\hline
\end{tabular}




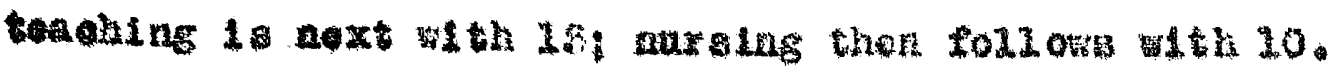

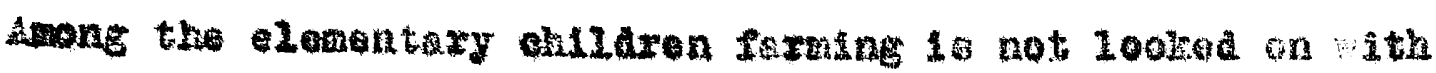

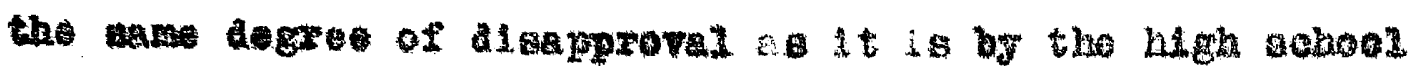

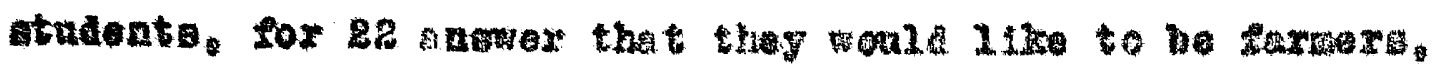
and 257 say thoy would not wat to be farmers."

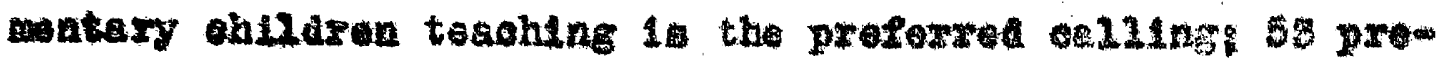
fer that, and 19 ohoose naxilng. fhis would angeget that the foller sohool borwo to wean chlidren away frov farmas.

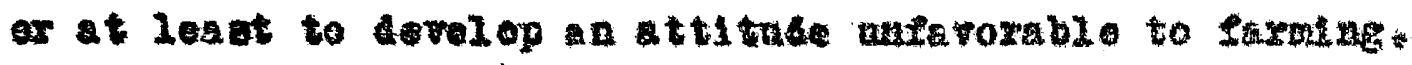
In oonoldering the transportation of puplus to sobool. it was fonnd, that of 28 in the elewentary grades, 289 ride the sahool bus, 01,2 pex cent of the school enrolluent. Fox the primary grade the number axe a follawe: Pret grado,

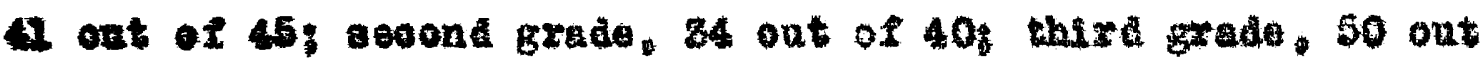
o2 57-88.2 por eant ride to sohool on the sobool bab the

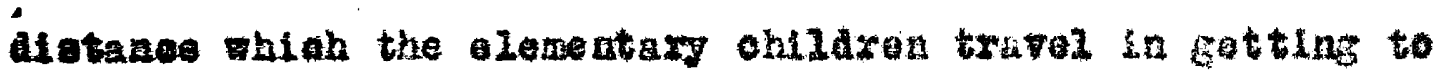

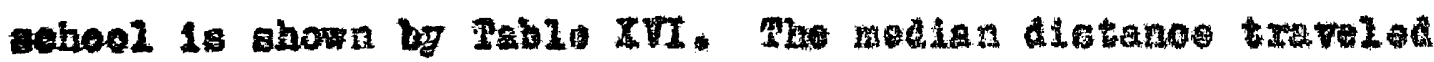
by elomentary children in raghing gohool is appoximtely

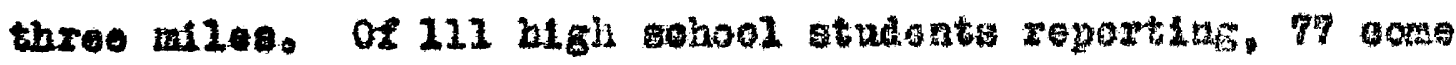

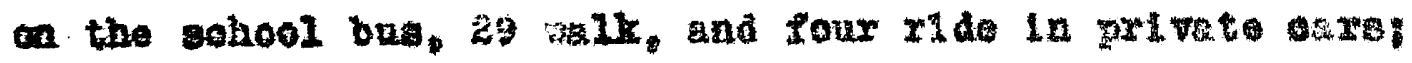

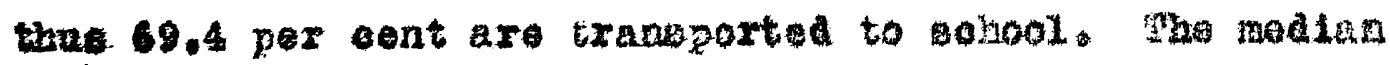
Qtetenee treveled to gout 2.75 mas.

The atifitieg ongaged la by the etudents are, bealde

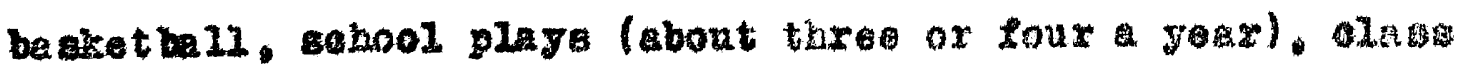

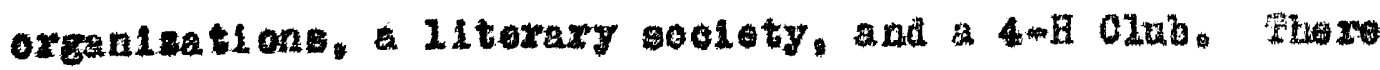

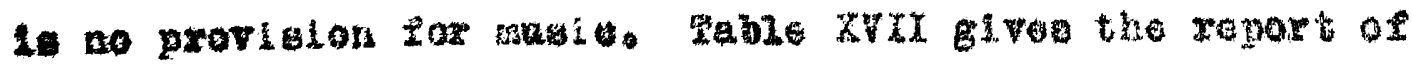
the atudenta on the actititiog in which they take pert and 


\section{$-72-$}

Table XII

Blstanoes Traveled by Students in Reaching the Walker

Sehool

\begin{tabular}{|c|c|c|}
\hline Distanes in Miles & Hiph Sohool & Blementary Sohool \\
\hline $\begin{array}{l}\text { Ione than one } \\
1 \text { to } 1.98 \\
2 \text { te } 2.99 \\
5 \text { te } 5.99 \\
4 \text { to } 4.99\end{array}$ & $\begin{array}{r}24 \\
19 \\
16 \\
8 \\
10\end{array}$ & $\begin{array}{l}29 \\
23 \\
28 \\
22 \\
13\end{array}$ \\
\hline $\begin{array}{l}5 \text { to } 5.99 \\
6 \text { to } 6.99 \\
7 \text { to } 7.99 \\
8 \text { to } 8.99 \\
9 \text { to } 9.99\end{array}$ & $\begin{array}{l}8 \\
5 \\
7 \\
2 \\
6\end{array}$ & $\begin{array}{r}10 \\
8 \\
9 \\
7 \\
5\end{array}$ \\
\hline $\begin{array}{l}10 \text { to } 10.99 \\
11 \text { to } 11.99 \\
12 \text { to } 12.99 \\
13 \text { to } 13.99 \\
14 \text { to } 14.99\end{array}$ & $\begin{array}{l}3 \\
1 \\
0 \\
1 \\
0\end{array}$ & $\begin{array}{l}3 \\
0 \\
1 \\
0 \\
1\end{array}$ \\
\hline 25 to 15.99 & 1 & 0 \\
\hline Potal & 121 & 159 \\
\hline Veaien D1stanee & $2.8 \min 20$ & 2.8 miles \\
\hline
\end{tabular}




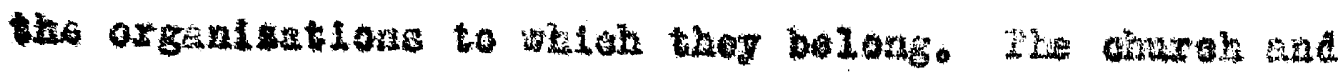

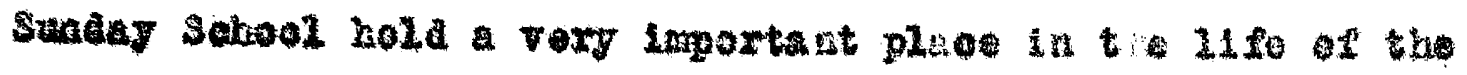

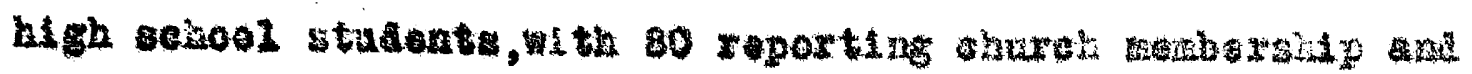

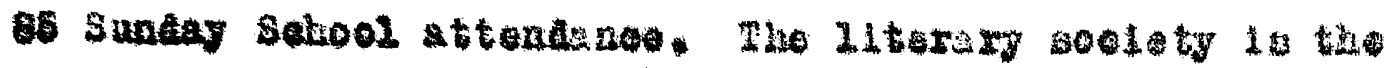
wost impertient achool organitation frot the sterdpolat of

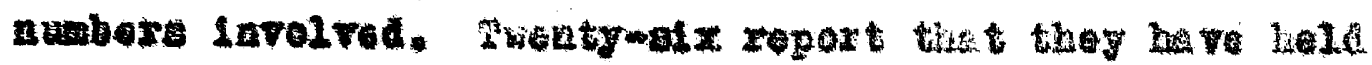

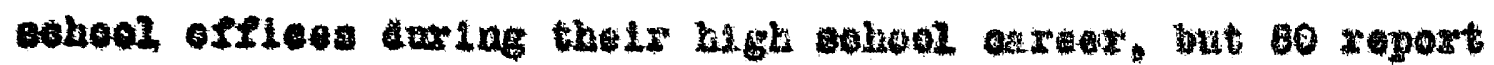

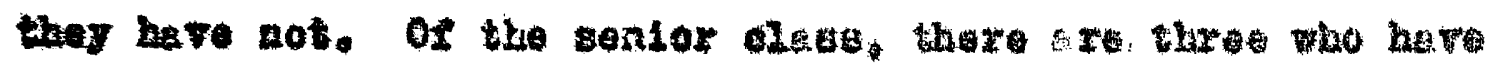

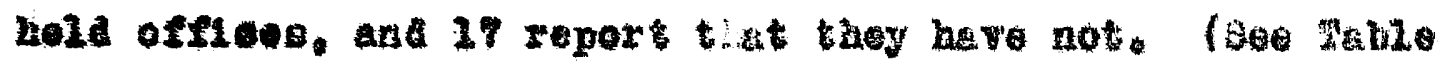

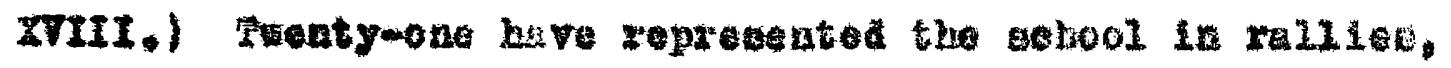

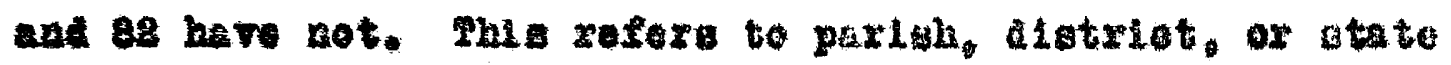

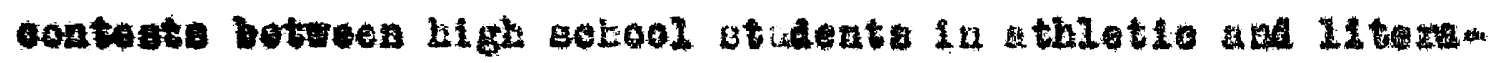
ry eventef get of the 22 who have represented their sohool

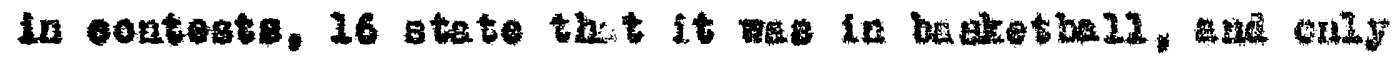
Aive opolisy gon isterary oventa.

In reply to the atoation. "Do you atene notion pioture

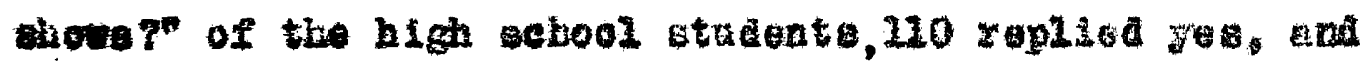

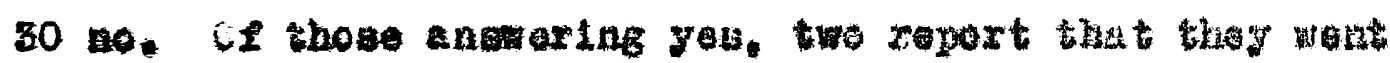

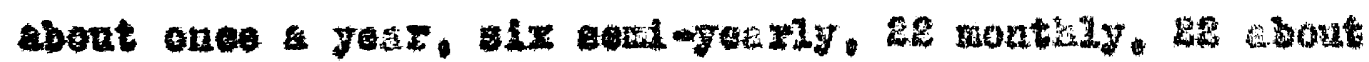
twioe a month, ane wio others wore Irequentiy.

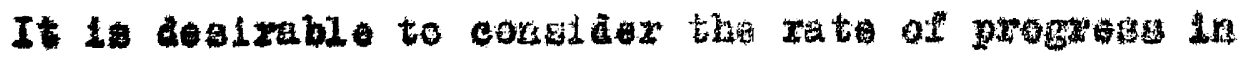

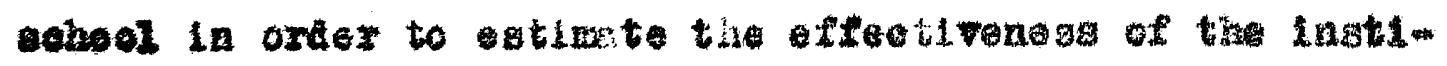

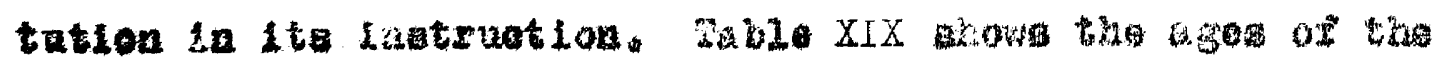

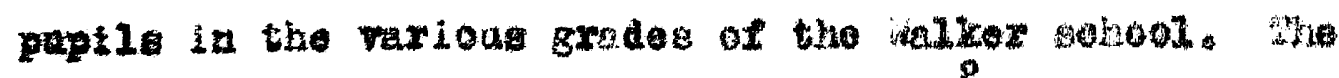
wodlan ages for tho varions gradoe axo:

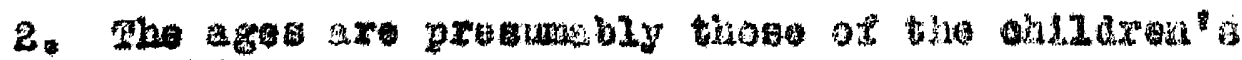
netest birthdage. 


\section{Table XVII}

Organizations to Whioh the students of the

Walker High School Belong

\begin{tabular}{|c|c|}
\hline Orsanization & $\begin{array}{c}\text { Tumber of Thembers in } \\
\text { Sohool }\end{array}$ \\
\hline $\begin{array}{l}\text { 4-F Clubs } \\
\text { ruture Fermers } \\
\text { Boy joours } \\
\text { Chureh } \\
\text { Sunday Sohool }\end{array}$ & $\begin{array}{r}13 \\
1 \\
7 \\
80 \\
85\end{array}$ \\
\hline $\begin{array}{l}\text { Sekool Honor Soolety } \\
\text { How Bconomies Club } \\
\text { Literary Soolety } \\
\text { Bablet-ball Toang } \\
\text { Tolley Ball Foang }\end{array}$ & $\begin{array}{l}6 \\
35 \\
64 \\
28 \\
20\end{array}$ \\
\hline Basoball Teans & 18 \\
\hline
\end{tabular}

Table XVIII

Sehool ox Club orfloes Held by Walker students

\begin{tabular}{|c|c|}
\hline $\operatorname{osc} 100$ & Inumber * \\
\hline $\begin{array}{l}\text { Prealdent } \\
\text { Vico-President } \\
\text { Seoretary } \\
\text { Mreaturer } \\
\text { Captain }\end{array}$ & $\begin{array}{l}6 \\
4 \\
8 \\
2 \\
2\end{array}$ \\
\hline $\begin{array}{l}\text { Student Iibrarian } \\
\text { Song Ieader } \\
\text { Combilt te eman } \\
\text { Hews Reporter } \\
\text { Critio }\end{array}$ & $\begin{array}{l}2 \\
1 \\
1 \\
3 \\
1\end{array}$ \\
\hline
\end{tabular}


Table $\mathbf{x x}$

Age-orade Distribution of students in the Walker sohool

\begin{tabular}{|c|c|c|c|c|c|c|c|c|}
\hline Age & 4th & 5 th & 6th & $\begin{array}{r}\text { Vumber } \\
7 \text { th } \\
\end{array}$ & $\begin{array}{c}\text { Per Grad } \\
\text { Bth } \\
\end{array}$ & gth & 10 th & $12 t h$ \\
\hline 8 & 3 & - & - & - & - & - & - & - \\
\hline$\theta$ & 10 & 2 & - & $-\infty$ & - & - & - & -- \\
\hline 10 & 18 & 12 & 2 & - & - & - & - & - \\
\hline $\mathbf{u}$ & 6 & 11 & 8 & 2 & - & - & - & - \\
\hline 18 & 5 & 18 & 13 & 11 & 1 & - & - & - \\
\hline 13 & 2 & 7 & 5 & 9 & 10 & $x$ & - & - \\
\hline 24 & - & 2 & 4 & B & 13 & 6 & 2 & - \\
\hline 25 & - & 2 & 3 & 6 & 3 & 8 & 10 & 2 \\
\hline 16 & - & - & 1 & - & 4 & 6 & 5 & 8 \\
\hline 17 & - & - & - & 1 & 1 & 4 & 5 & $\mathbf{5}$ \\
\hline 18 & - & - & - & 1 & - & 4 & 4 & 6 \\
\hline
\end{tabular}

* The numbers Inelosed in black lines represent the age medians for the crades in the Walker Sohool. Those inolosed in red lines represent the normal or expected age for the erade.

See Hard G. Reeder, Iundenontals of Public School Aduinistration. Dew York, Vacililan Compuny. $1930,0.334$. 


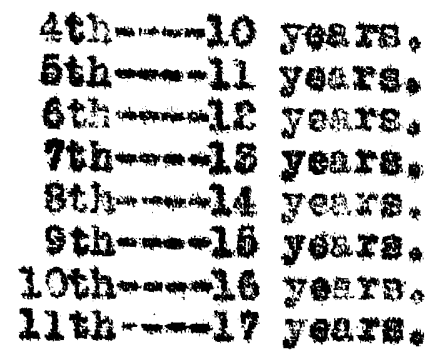

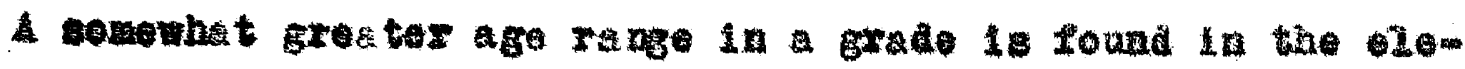

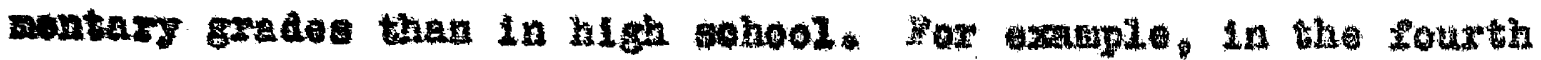
grade the range is from elght yearo of age to $1 D^{\prime}$ ta tho wrenth fron 21 to 18 Jesre, and tor the eleventh grade tho rage 18 frow 25 yeare to 28 gen $r$

Fabie Xxoms the jubjeote taxon of the studente in high gehool. Bngligh is the wost povalar gubjoot, from the Btadpoint of the aubber otudying 1t, having 208 pupile onrolled. Poor years of inglith is roulred for high sehool gratuation, and so all studenta nust ta it orery year.

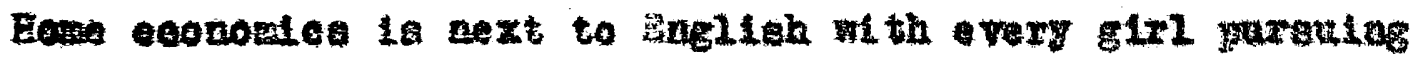

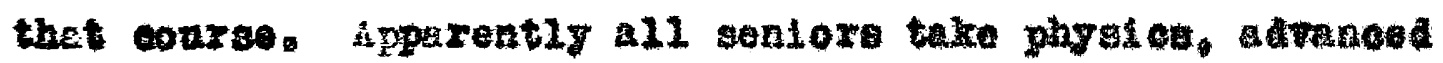

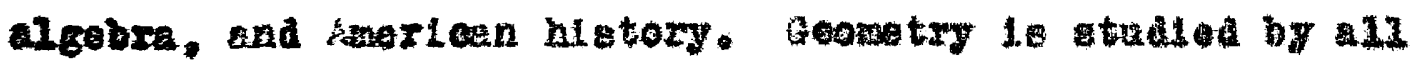

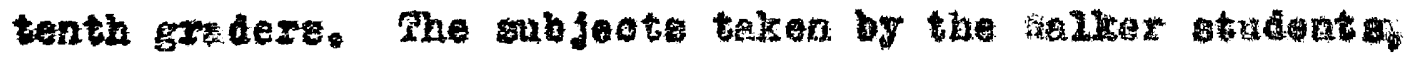

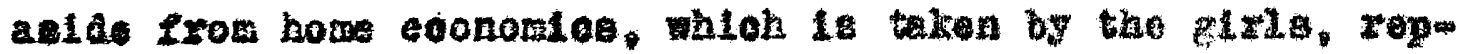

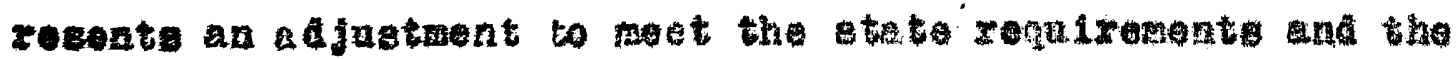

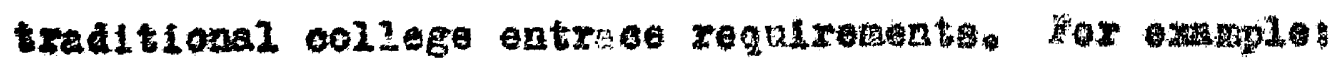

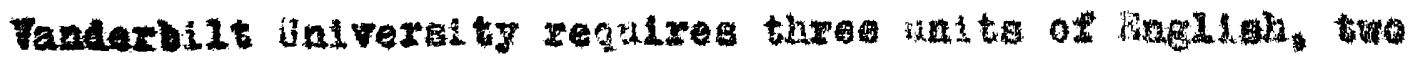

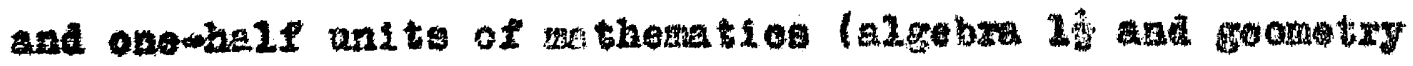

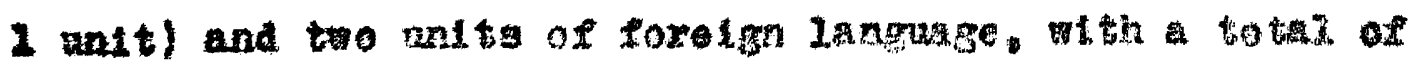
25 ral ta goolal gotenee. 
Pable $\mathrm{x}$

Subjects Taken by Students of the Walker High $50 h 001$

\begin{tabular}{|c|c|c|c|c|c|}
\hline spleats & $\mathbf{g t h}$ & $\begin{array}{l}\text { Numbe } \\
g \text { th }\end{array}$ & $\begin{array}{l}\text { T PeI } \\
\text { 10th }\end{array}$ & $\begin{array}{r}\text { Grade } \\
\text { IIth }\end{array}$ & getel \\
\hline 8th Crade Wathomatios & 38 & $-\infty$ & - & $-\infty$ & $\mathbf{s e}$ \\
\hline Mrgilah & $\mathbf{3 9}$ & 30 & 30 & 25 & 108 \\
\hline General Salenoe & 58 & $\mathbf{z}$ & - & - & 34 \\
\hline Erow Beonentes & 27 & 29 & 16 & 12 & 64 \\
\hline comorelar eseswephy & $\mathbf{2 5}$ & $\mathbf{1}$ & - & $-\infty$ & 16 \\
\hline Biolsty & - & 27 & 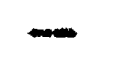 & - & 87 \\
\hline Algebra & $-\infty$ & 29 & 3 & 19 & 51 \\
\hline civies & $-\infty$ & 10 & 1 & - & 11 \\
\hline Geomotry & - & $-\infty$ & 28 & - & 28 \\
\hline History & - & - & 84 & 22 & 46 \\
\hline Prenoh & - & - & 11 & 9 & 80 \\
\hline Physies & - & - & - & 21 & 21 \\
\hline $\begin{array}{l}\text { Subjest } \\
\text { Inglibh } \\
\text { Uathematios } \\
\text { Selence } \\
\text { Social Sclence } \\
\text { Home Beonomi es } \\
\text { Torelgn Ianguage }\end{array}$ & Branana: & $\begin{array}{c}\text { Number } \\
108 \\
105 \\
82 \\
73 \\
64 \\
20\end{array}$ & & $\begin{array}{c}\text { Por cent } \\
100.0 \\
97.2 \\
75.9 \\
67.6 \\
59.3 \\
18.5\end{array}$ & \\
\hline
\end{tabular}




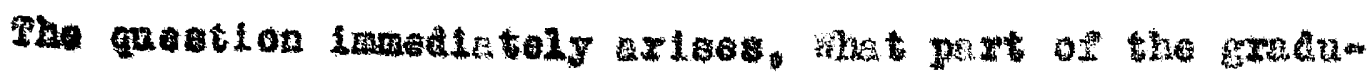

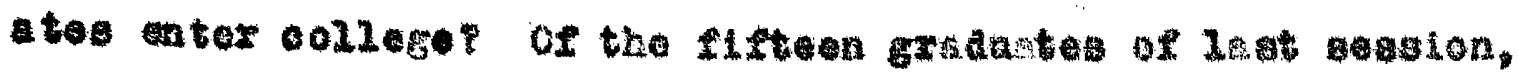

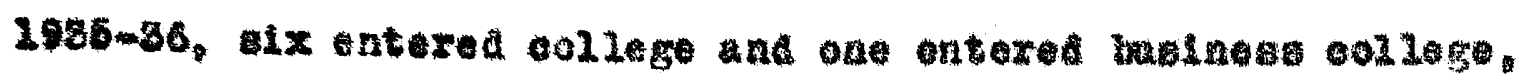
1.0.. 40 per cont of the graduter entered college. A ap peare later in the oheptor, the traditiond conzse la not requixed to prepare high gehool etratents for colloge in Loutintina.

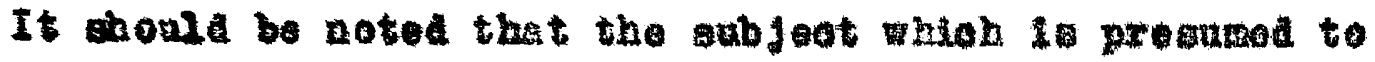
teech the dutles of af thenshl and soctal responsiblilty (atries) 18 tagh to only 21 high ohool gtwenta, about

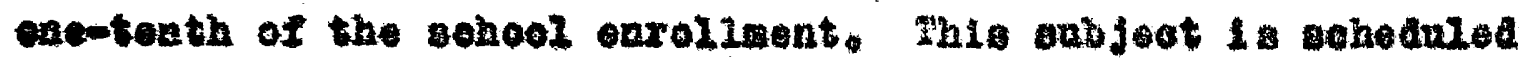
to bo taken in the alnth grade, jet of a niath grade onrollwent of s0, only one-third are teking ofvios. on would frege that al eobra has three thes and goosetry trice the

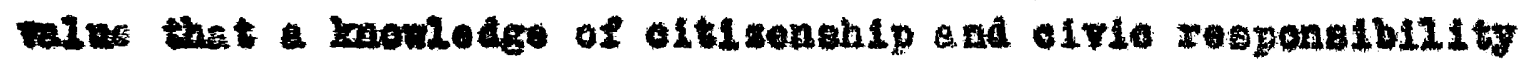

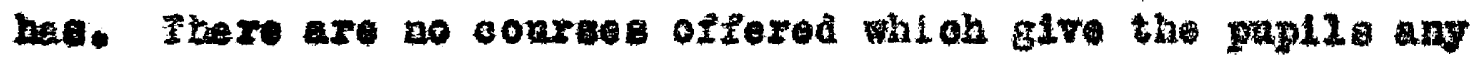
Areet knomledge or underatanding of thelx government, of

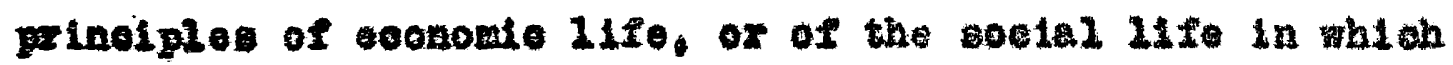

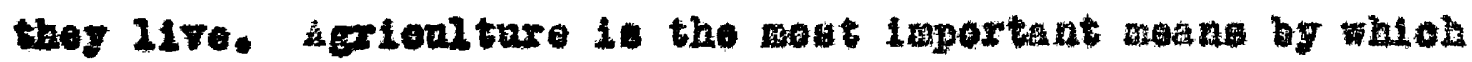

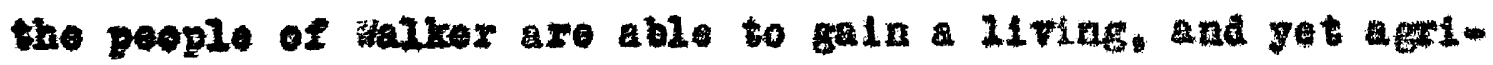
enture is no sore part of tho courso of etady for thee

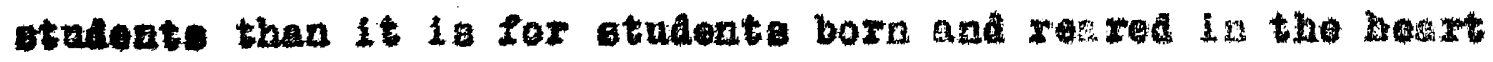
of 0x10ane.

The chool 26 no stronger than ito teconers. The tatout 18 wade that ruxal zohool teachers generally aro pooriy trained

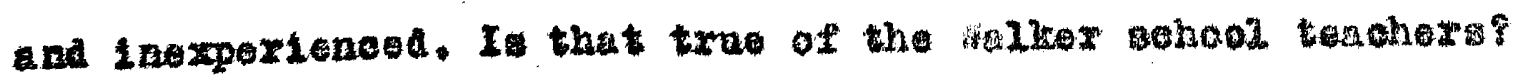

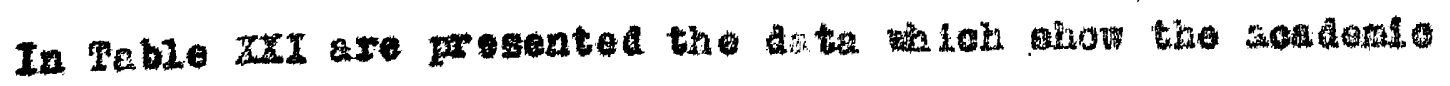


$\operatorname{Iable} \mathrm{xx}$

Neadente Quallfioations. Temure and Regldenoe of the Walker Sohool Teaohers

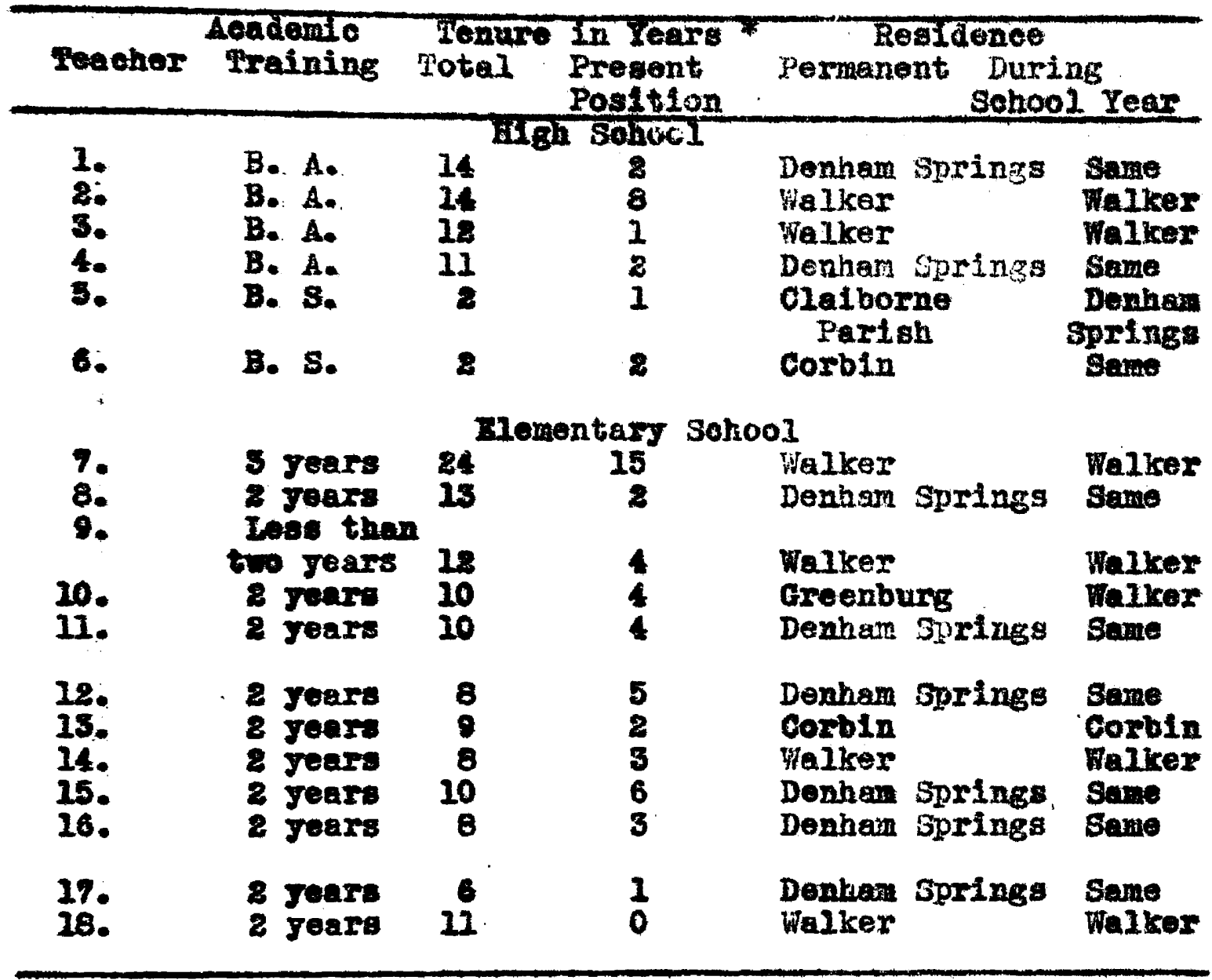

The term "Tenure" is used in the sense in whloh Foote uses 1t, 1.e.. "Total tenure refers to the entire teaching servioe." romare in Present Fosition refor: to the number of years the teacher has taught in the position held at the present time.

Irving P. Foote, Tenure of High Sohool Teeohers in Ioulsiana, Baton Rouge, Toulsiana State Unirergity Press, 1081, P. 2. 


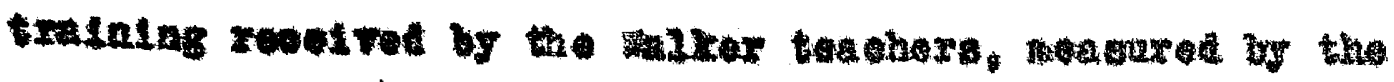

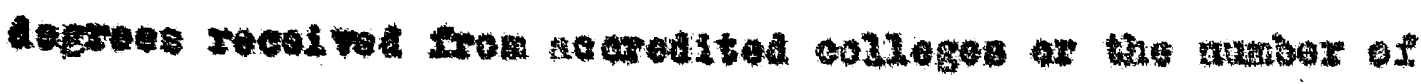

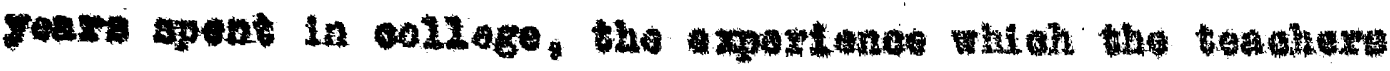

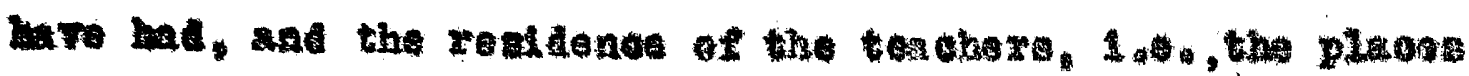

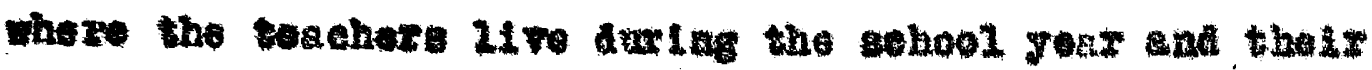

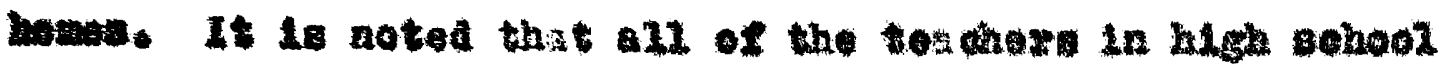

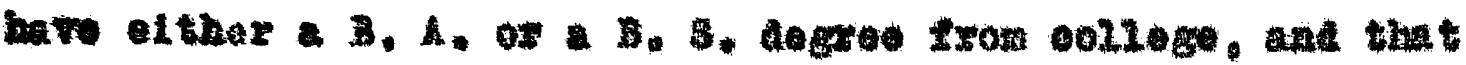
ouly on ont of 12 tehohoze in the gralos ha lose than two

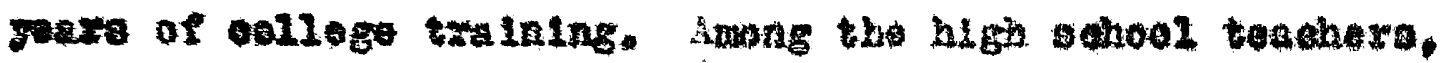

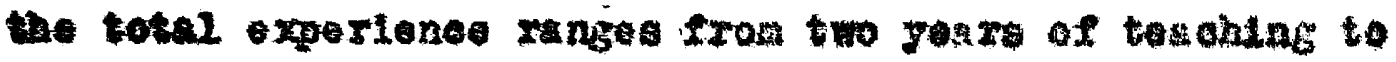

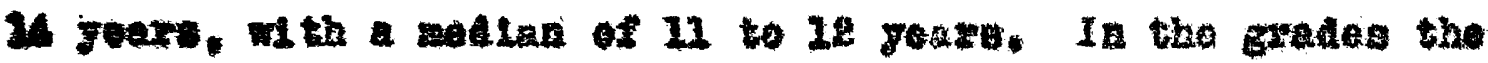

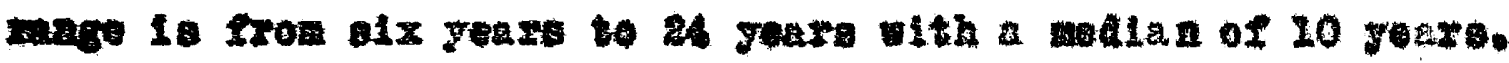

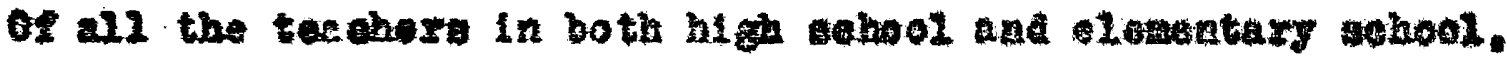

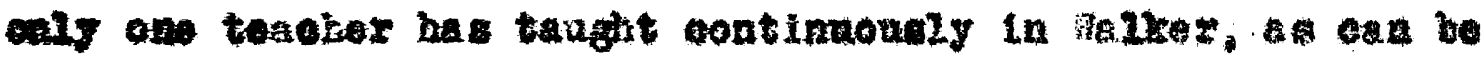
soen bompring the total years of oxpertenoe with the years tangt in ather. Wht one is toching for ber third geax in

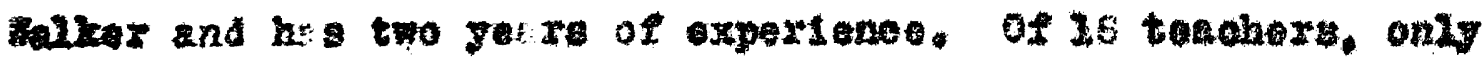

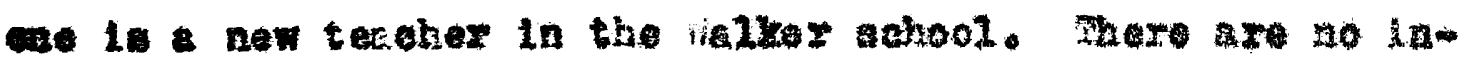

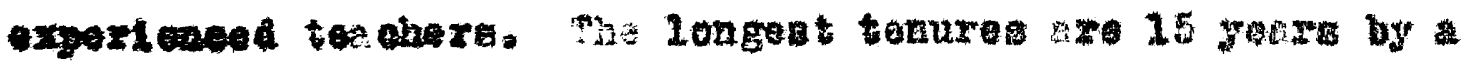

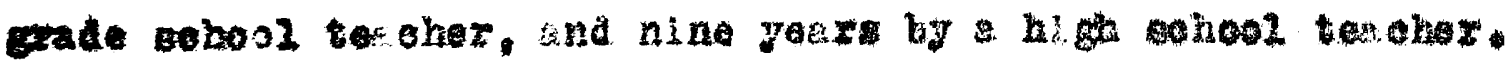

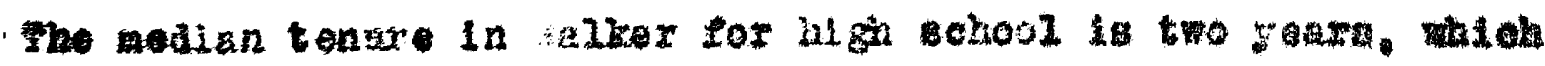

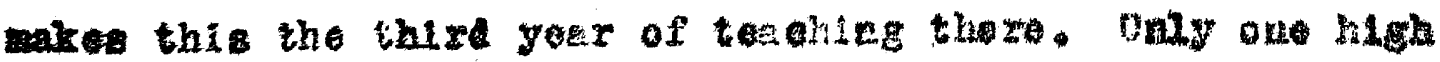

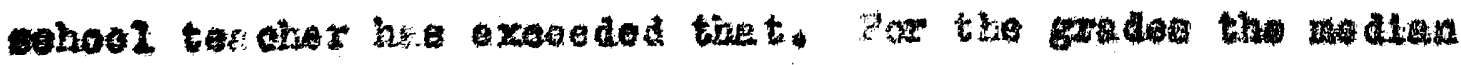

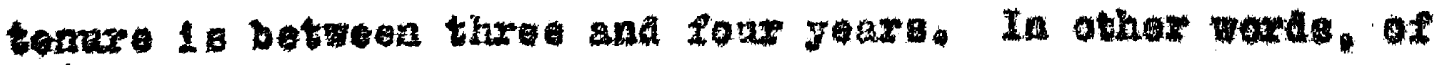

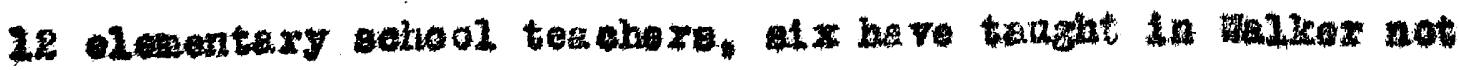

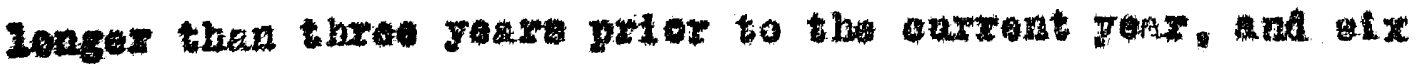
have axeeded the throemyar perlod. 


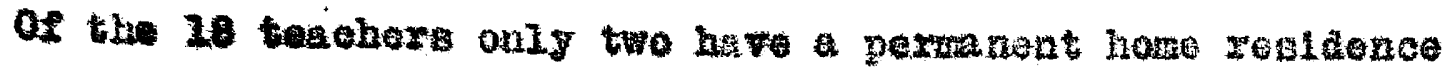

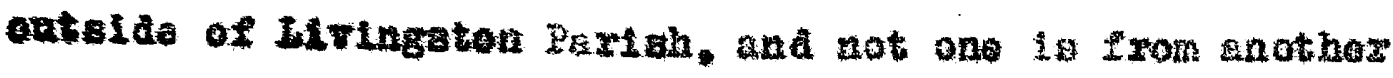

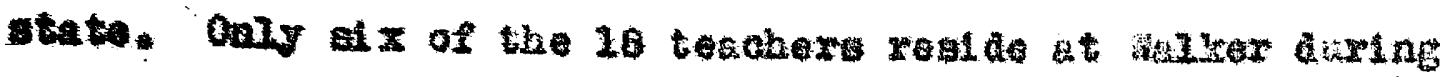
the sehool gesr; 12 of thas 11 re al sewhere an go to and

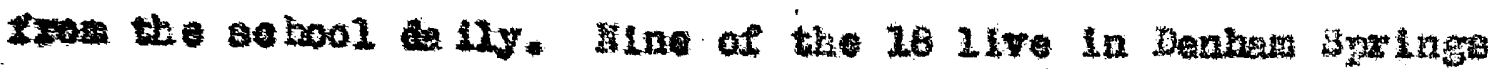
and arive the elght or akne rlles oud woxning to sohool and returie the datano in the ovening aftex sehool. Thio is true eres of the high oahool prinoipal.

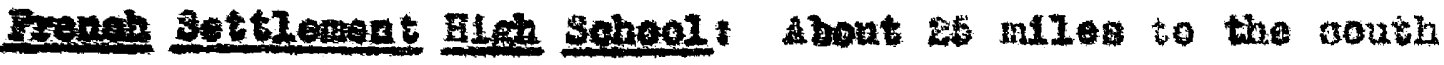

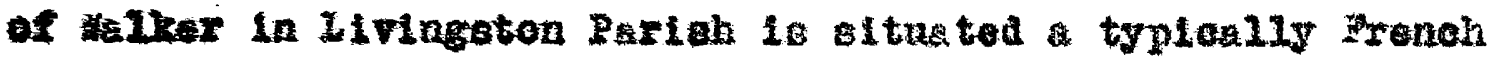
teamanty eallod reneb settlement. It is a rather old cemenaty, aith of ita homes oonstruted in charaeter1etle Lonisiana Franoh fabion often 75 gearo old and still in sood repaly. She peplo are thrifty and hard working. They Live in a otyle lithont ang of the modern oonveniences. This ean been by the fact that not a atudent 13 esther tho higt weol or the elenentary gradeo reported a tel aphono in his hom : only five ot of an enxollwent af ase roported oleotrio 118hto, and only tro reported an indoor toilet lof the fivo reporting alectio lights only three indiles a repre sented as three are Irom the home and both thow who report infoor tollete are frow the sme homel. The students do not atteal wotion gioture ous opton. judelng from the roplies

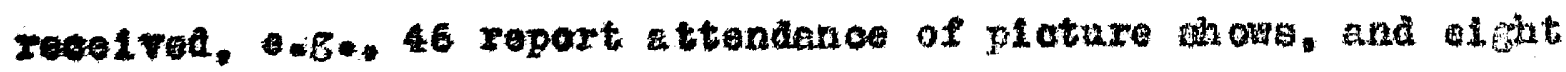
ata to they do nst attend. Only nino roport nttaphace as often ae once weok, is attend nonthy. and boven attend 


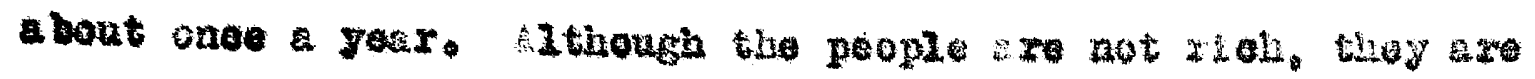

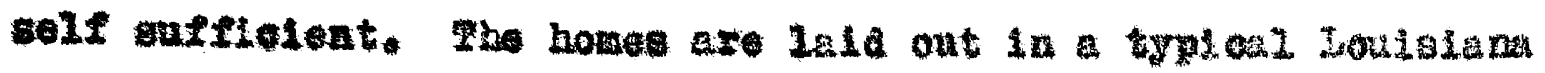

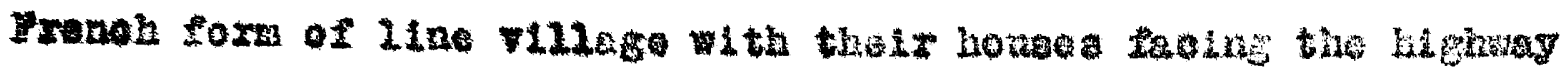

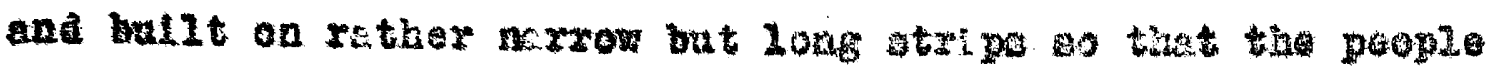

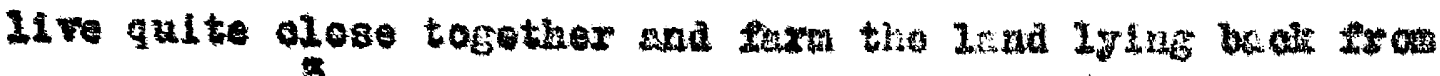
the highery.

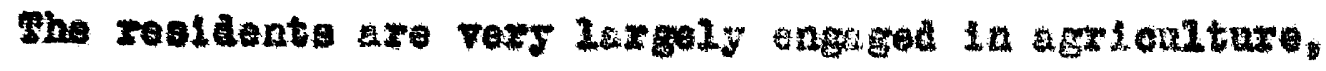

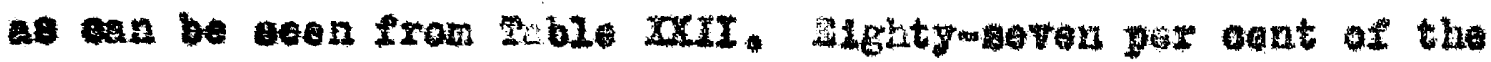

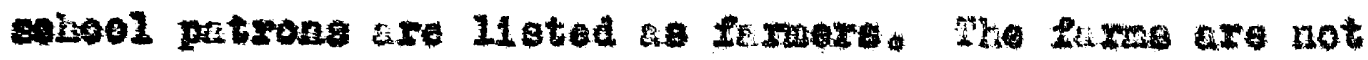

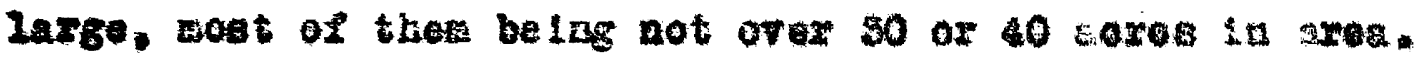

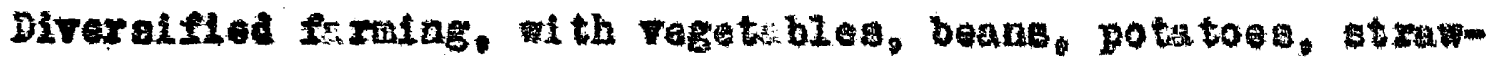

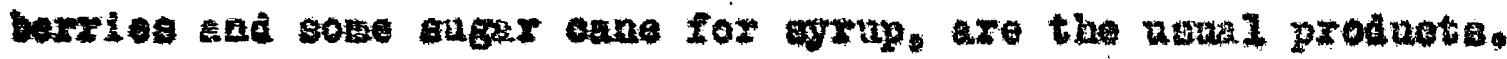

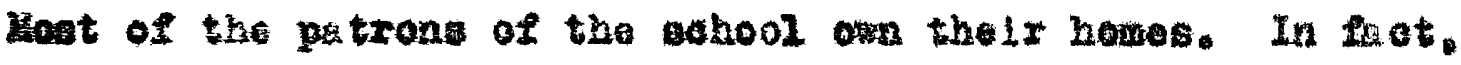
of 58 high echool stuanto reporting ony two atrted the

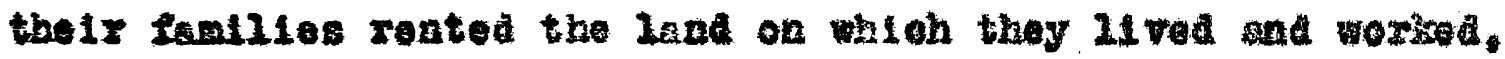
wheres 50 reportad omerohip.

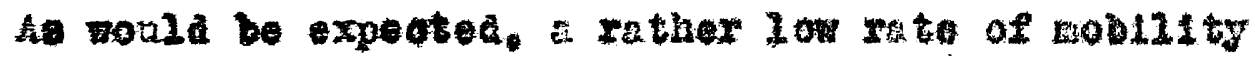

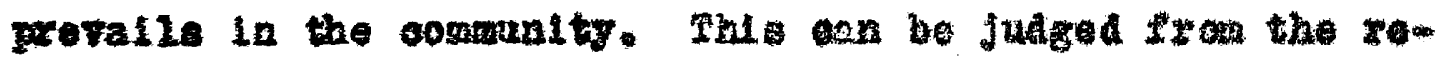

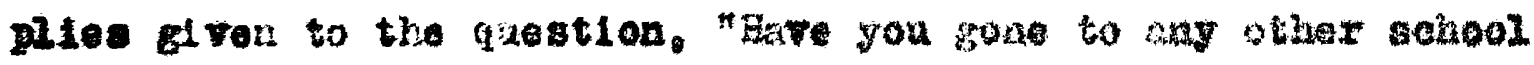

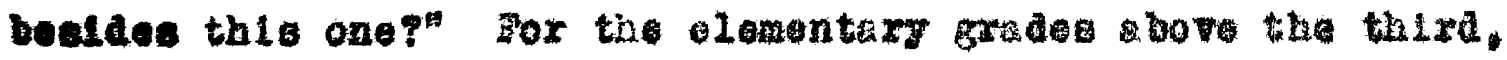

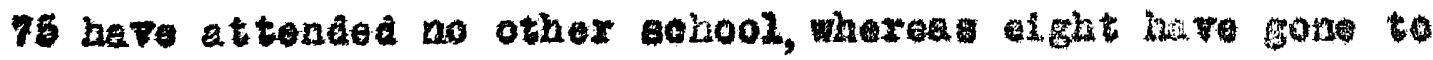
other sohoolb. Fox the high aohoal, out of 45 xporting. 14 have gone to other mohoold and 29 lutre not.

8. Hor dewoription of tho Loutgina frenoh boelal

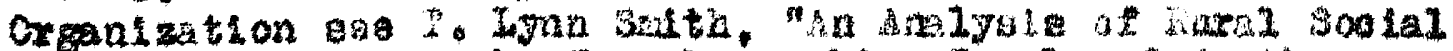

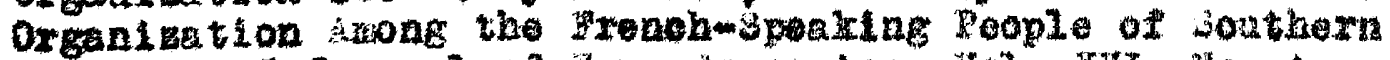

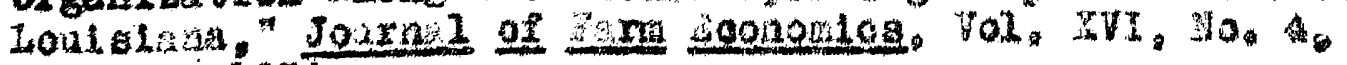
oatober; 1934 
Table Xatr

Oceupations of the Parents of the French Settlement Sohool studentis

\begin{tabular}{|c|c|c|c|c|}
\hline Deeupetions & $\begin{array}{l}\text { Blgs } \\
\text { Number }\end{array}$ & $\begin{array}{l}\text { Sobooi } \\
\text { Per Cent }\end{array}$ & $\begin{array}{l}\text { Pilexe } \\
\text { Number }\end{array}$ & $\begin{array}{l}\text { Sohool } \\
\text { Sor Cent }\end{array}$ \\
\hline $\begin{array}{l}\text { Dermer } \\
\text { Derahant } \\
\text { Butoher } \\
\text { Janiter } \\
\text { Eousekeeper }\end{array}$ & $\begin{array}{r}44 \\
3 \\
2 \\
1 \\
1\end{array}$ & $\begin{array}{r}81.5 \\
5.6 \\
3.7 \\
1.9 \\
1.9\end{array}$ & $\begin{array}{r}71 \\
3 \\
3 \\
3 \\
1\end{array}$ & $\begin{array}{r}91.0 \\
3.8 \\
1.8 \\
1.3 \\
1.3\end{array}$ \\
\hline $\begin{array}{l}\text { Public Worier } \\
\text { Blaeksmith } \\
\text { Saloon Keeper } \\
\text { Ioger }\end{array}$ & $\begin{array}{l}\frac{1}{1} \\
\frac{1}{0}\end{array}$ & $\begin{array}{r}1.9 \\
1.9 \\
1.9 \\
0.0\end{array}$ & $\begin{array}{l}0 \\
0 \\
0 \\
1\end{array}$ & $\begin{array}{l}0.0 \\
0.0 \\
0.0 \\
1.3\end{array}$ \\
\hline Fotal & $5 \%$ & 700.0 & 78 & 100.0 \\
\hline
\end{tabular}

Iable SIII

Decupational Preforence of Students of the French

Sett lement school

\begin{tabular}{|c|c|c|c|c|}
\hline \multirow{2}{*}{$\begin{array}{l}\text { Ocoupation: } \\
\text { Feacher } \\
\text { Furse } \\
\text { Farwer } \\
\text { Sallor } \\
\text { Doctor }\end{array}$} & \multicolumn{2}{|c|}{$\begin{array}{l}\text { Hegh Sohool } \\
\text { Inmber for Cent }\end{array}$} & \multicolumn{2}{|c|}{$\begin{array}{l}\text { IIementary School } \\
\text { Number Por Cent }\end{array}$} \\
\hline & $\begin{array}{r}16 \\
9 \\
6 \\
6 \\
1\end{array}$ & $\begin{array}{r}32.7 \\
10.4 \\
12.2 \\
12.2 \\
2.0\end{array}$ & $\begin{array}{r}32 \\
11 \\
14 \\
4 \\
5\end{array}$ & $\begin{array}{r}42.1 \\
14.5 \\
18.2 \\
5.3 \\
6.6\end{array}$ \\
\hline $\begin{array}{l}\text { Dentiat } \\
\text { Bus Driver } \\
\text { w Ecellaneous }\end{array}$ & $\begin{array}{l}3 \\
0 \\
\mathbf{3}\end{array}$ & $\begin{array}{r}6.1 \\
0.0 \\
16.3\end{array}$ & $\begin{array}{l}0 \\
3 \\
7\end{array}$ & $\begin{array}{l}0.0 \\
3.9 \\
9.2\end{array}$ \\
\hline Total & 49 & 100.0 & 76 & 100.0 \\
\hline
\end{tabular}




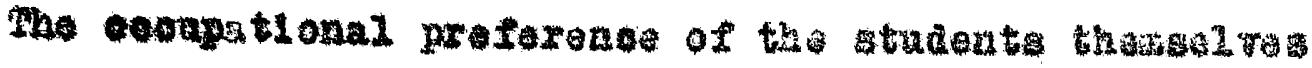

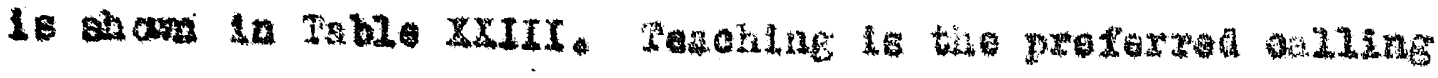

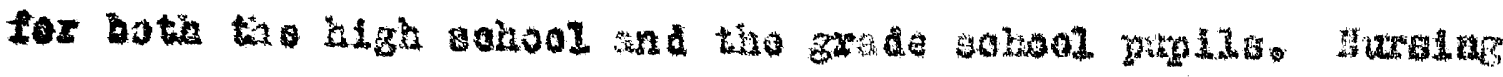

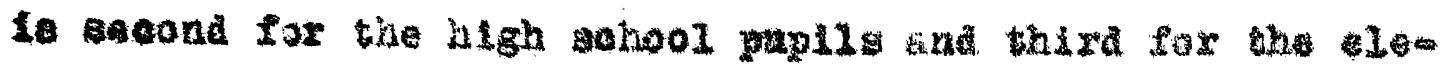

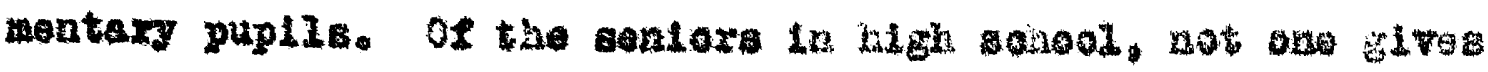

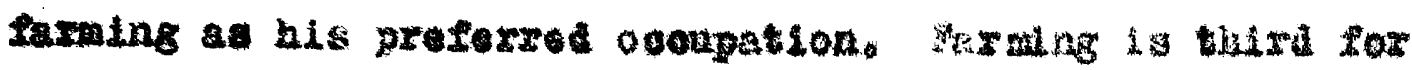
the bigh wohool and second for homentery puplis.

The distanoes traved by the stacents of the ahool

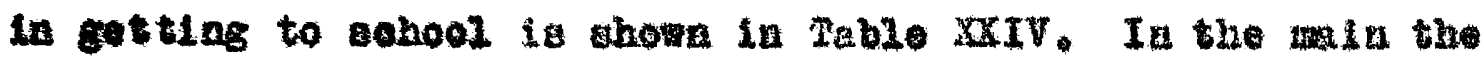

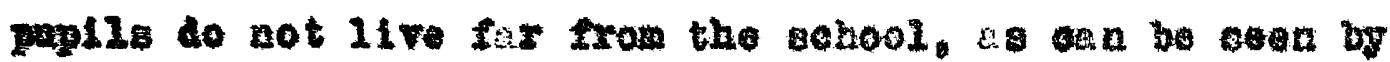
the fact thet 21 ont of $56 \mathrm{high}$ gohool atudeats 11 ve within a wis of the sohool, and 28 of the 78 elerontary achool pupils Ive within thet distenee. Aere, to is true of the Walter chool, the elenontary sohool puplle ra required to go alight28 tarther then the bigh sahool papils, the median diats ace beigg 1.6 alles for high ohoel paplis, compared with 1.0

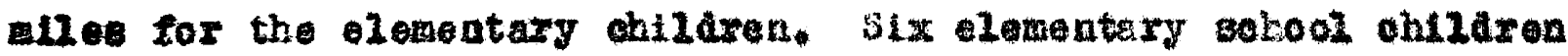
are tranoported over olght fnlles, bat no ingh wohool student trevels that far. Qf the ontro olementary sohool 107 out of

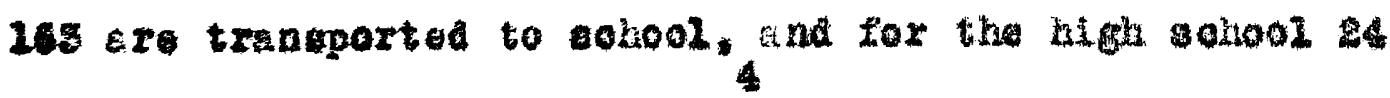
out of 57 ride the sehool bus.

4. It is latereatiag to note frow the replise recelvad. only one out of geven soniors in algh gohool 11 ve ta par as

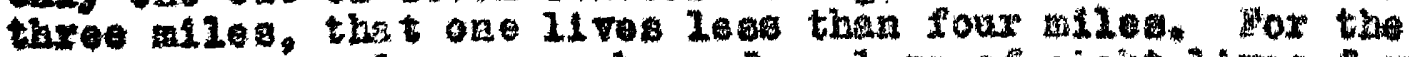

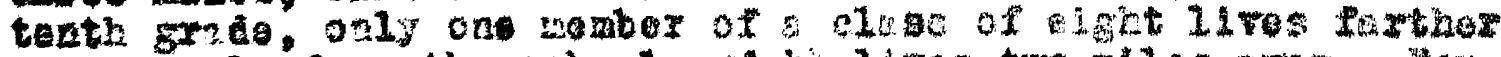

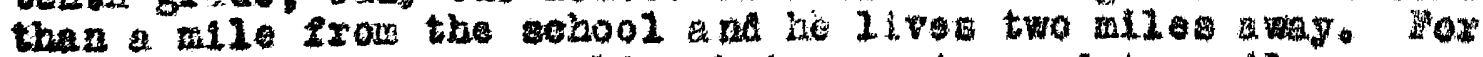

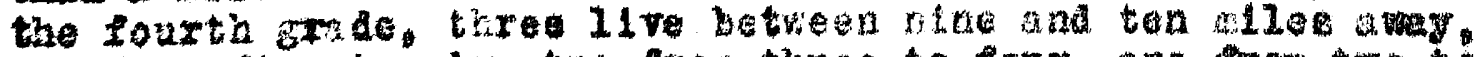

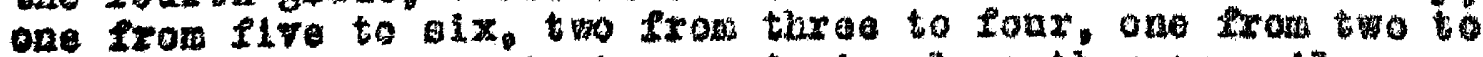

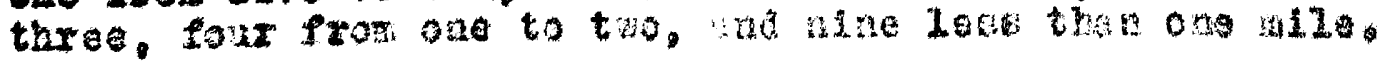


nate Twa.

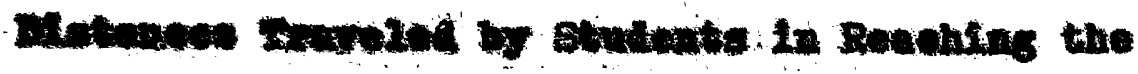
Demel sobthengat sohed

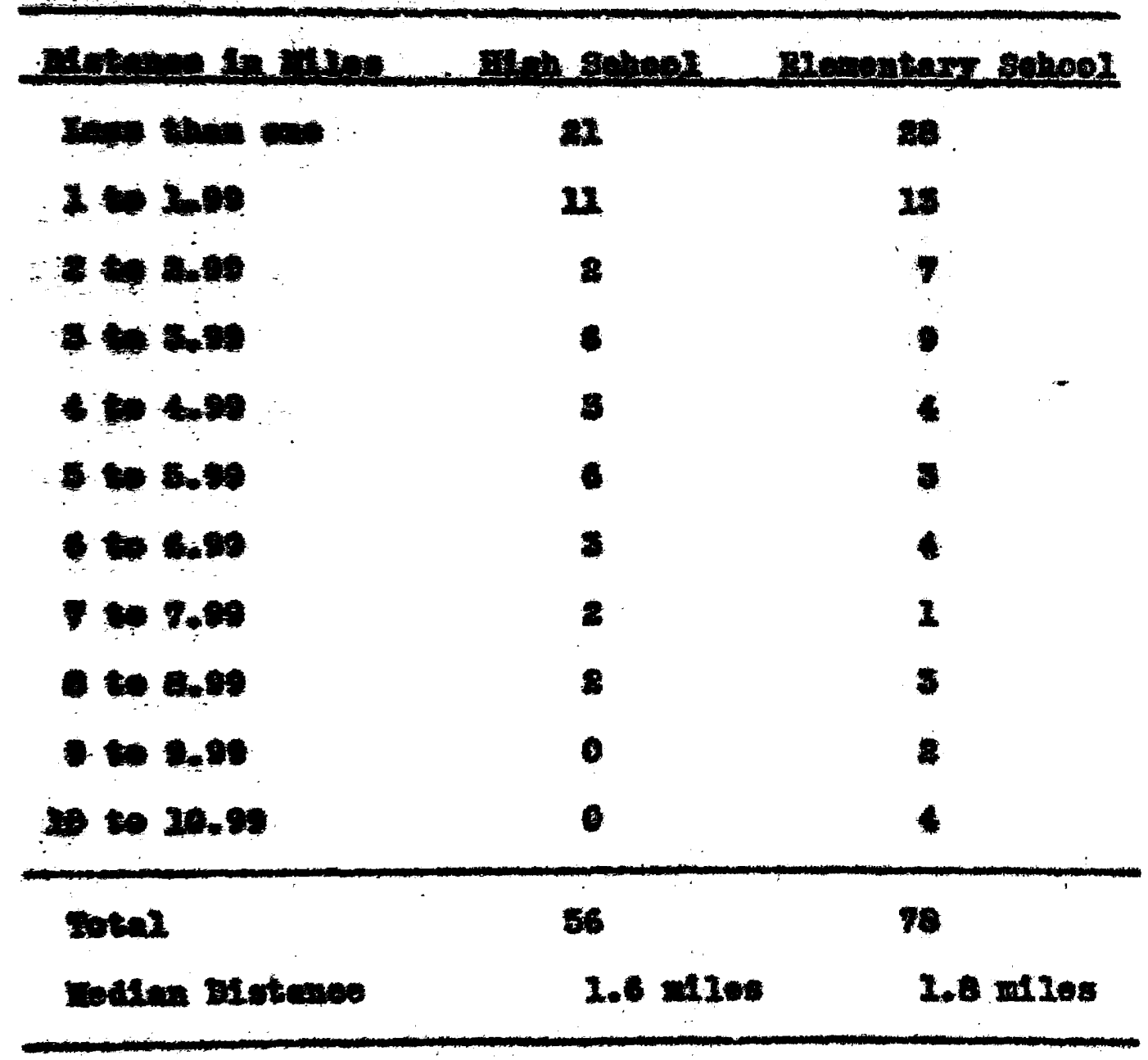




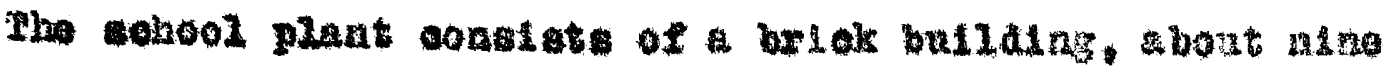

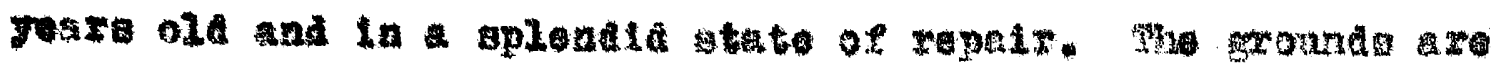

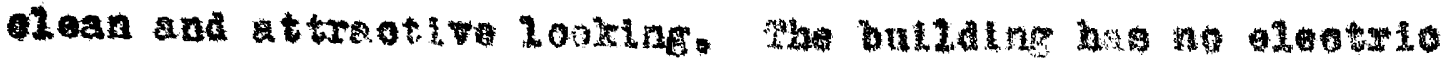

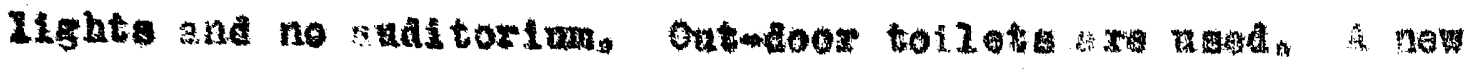

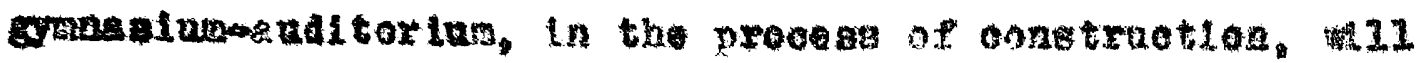
peorle ladoor tollets an shower ba the for the bays ad

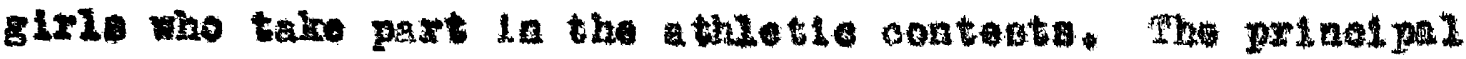
IIves in boum near the sebool.

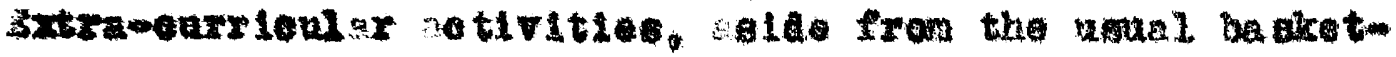

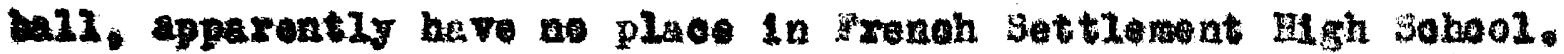

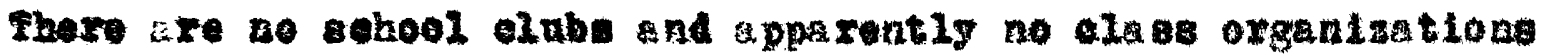
of acy zind. for ane of the high cohool studente 11 sted ant

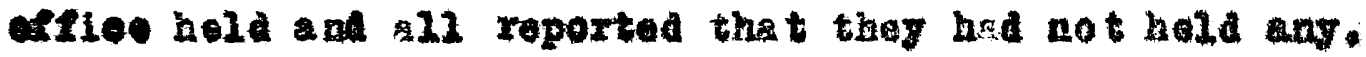

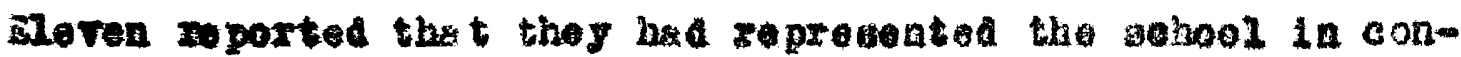
teste in baket-ball. When the new

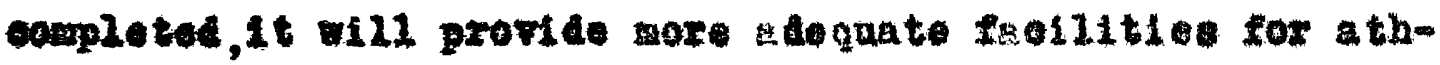

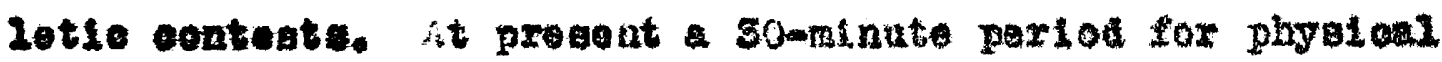

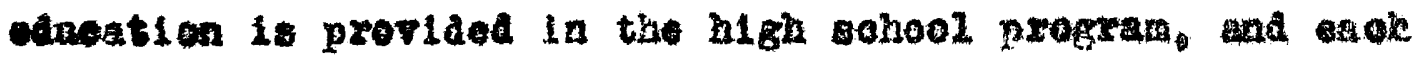

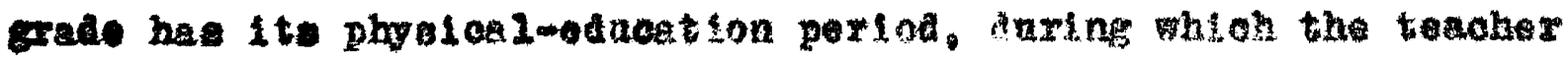

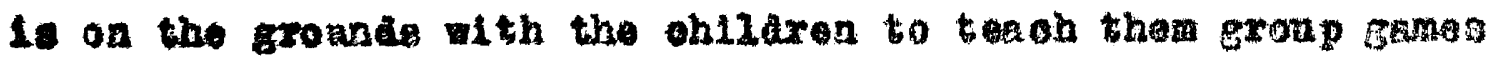
and to expervise the ix ativitiono

Sinee thore his been no raltoxlut for the gat two

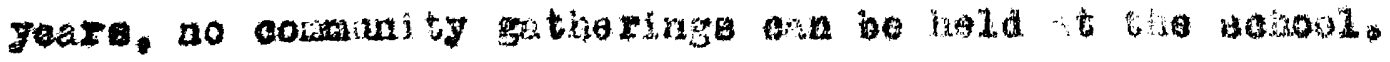

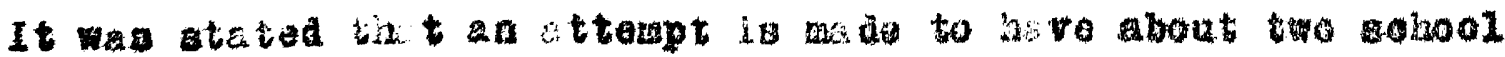
plays each yor.

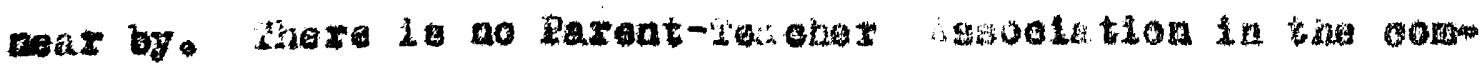

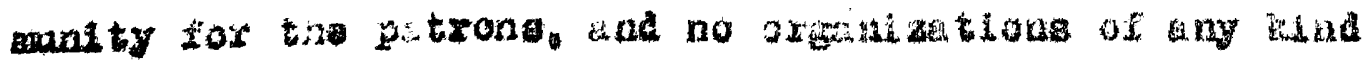




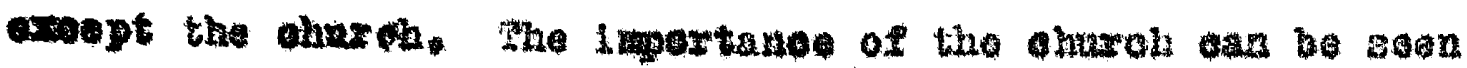
by the fuot that although no sohool organzations wore 11 at

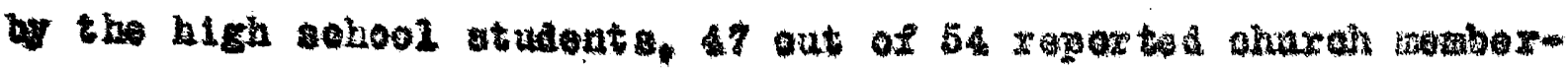

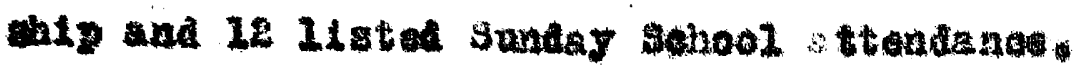

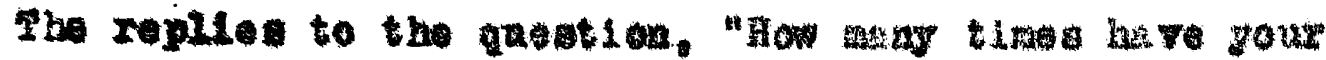

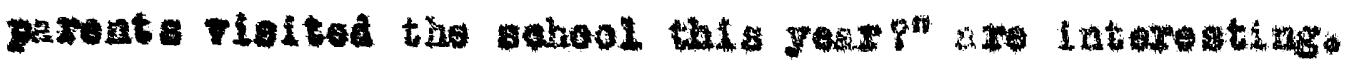

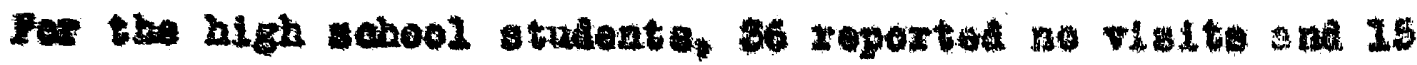

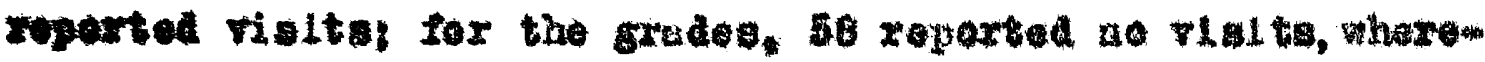

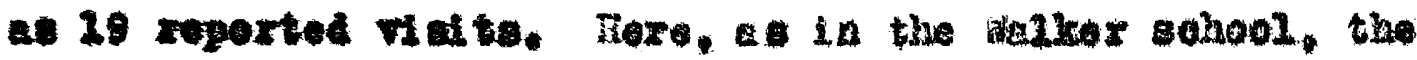

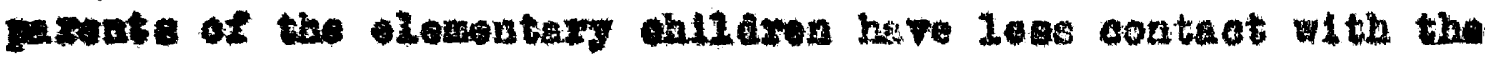
emool then pareate of the papils of soondary gohool level. Pro ago-grade aletribation for tho Fronoh Settionot

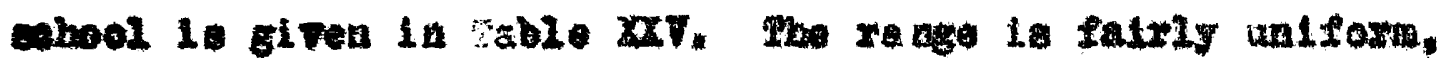

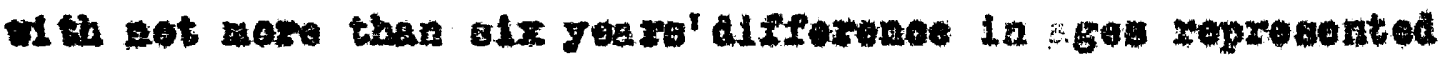

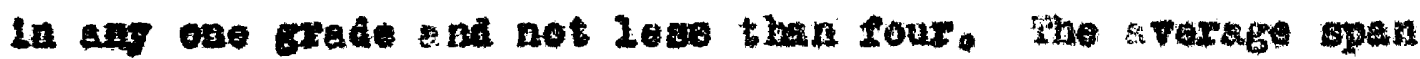
ser ocel grado is about ifo years.

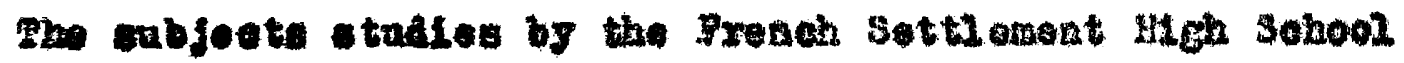

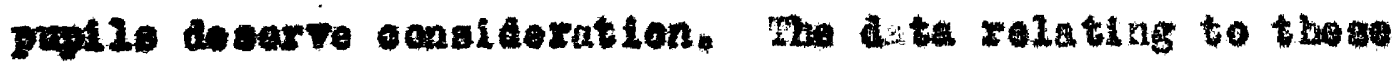

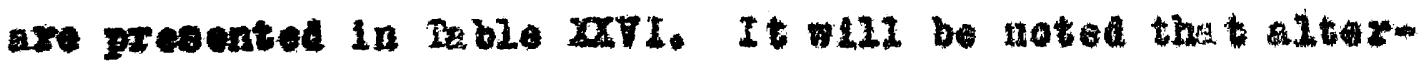

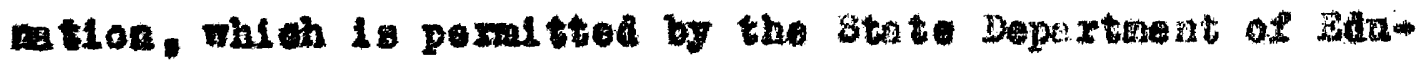
eaten, is practioed in the goloction of abjects teught.

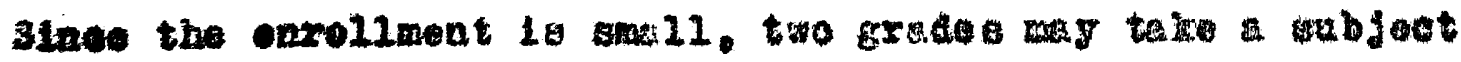
togethox, and in thio way a pertiould suldeat wll not be

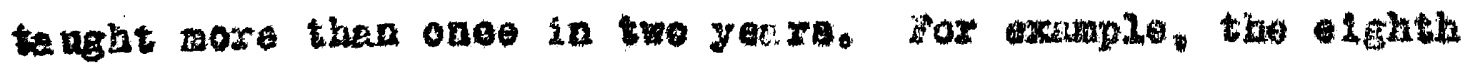
and ninth grater will take gonortl bekenes together ou yoar

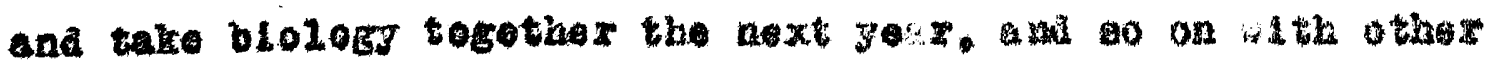


Table $\mathbf{X T}$

Age-Orade Distribution of students in the French

Settlemont sehool

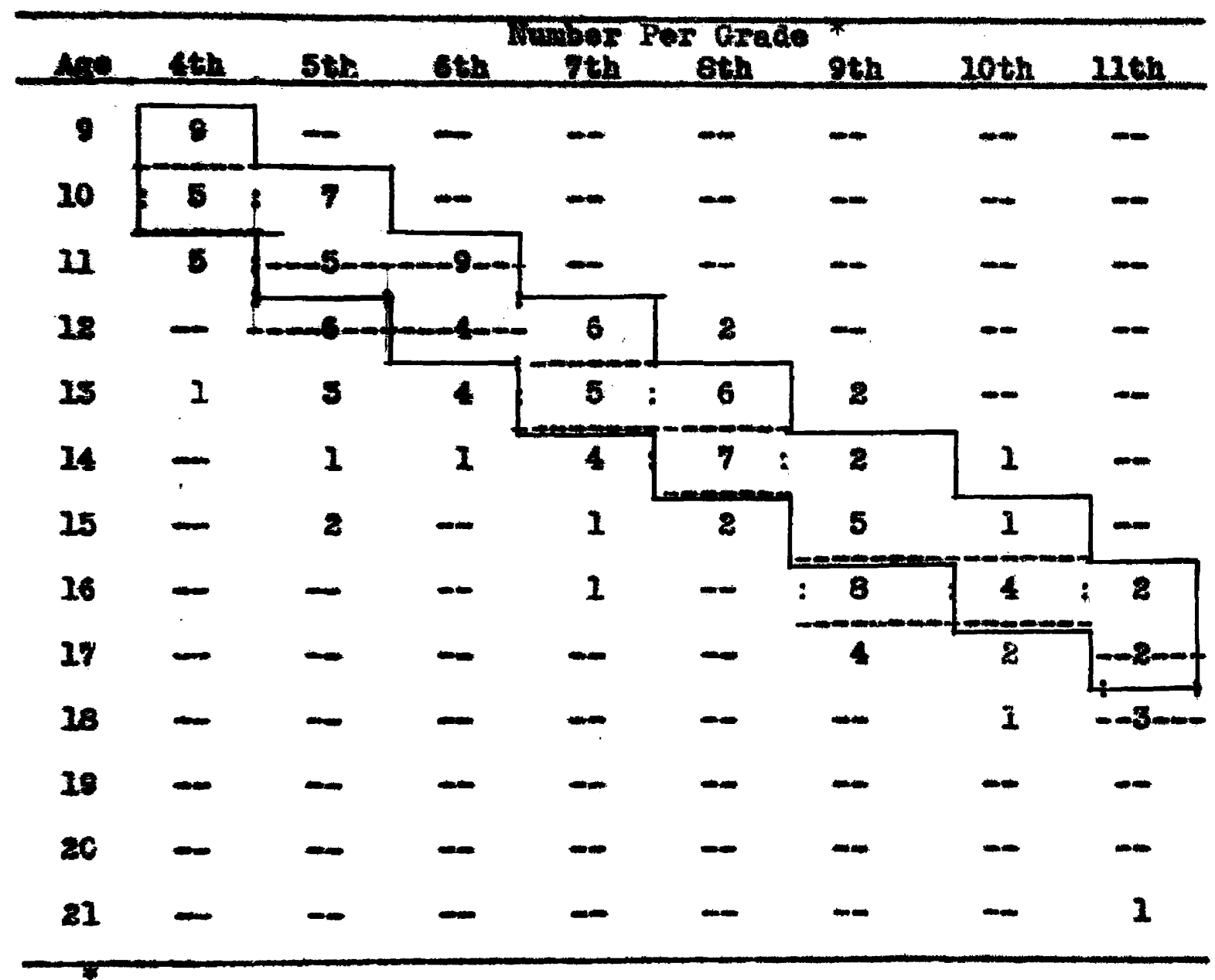

The numbers ineloced in bleck 11 mes represent the age medians for the grades in the Frend Settlement School. Those inolosed in red Iines reprenent the normal or expected age for the grade. 
TabIs XXVI

Subjects Taken by the students of the Irench settiement Algh Shool

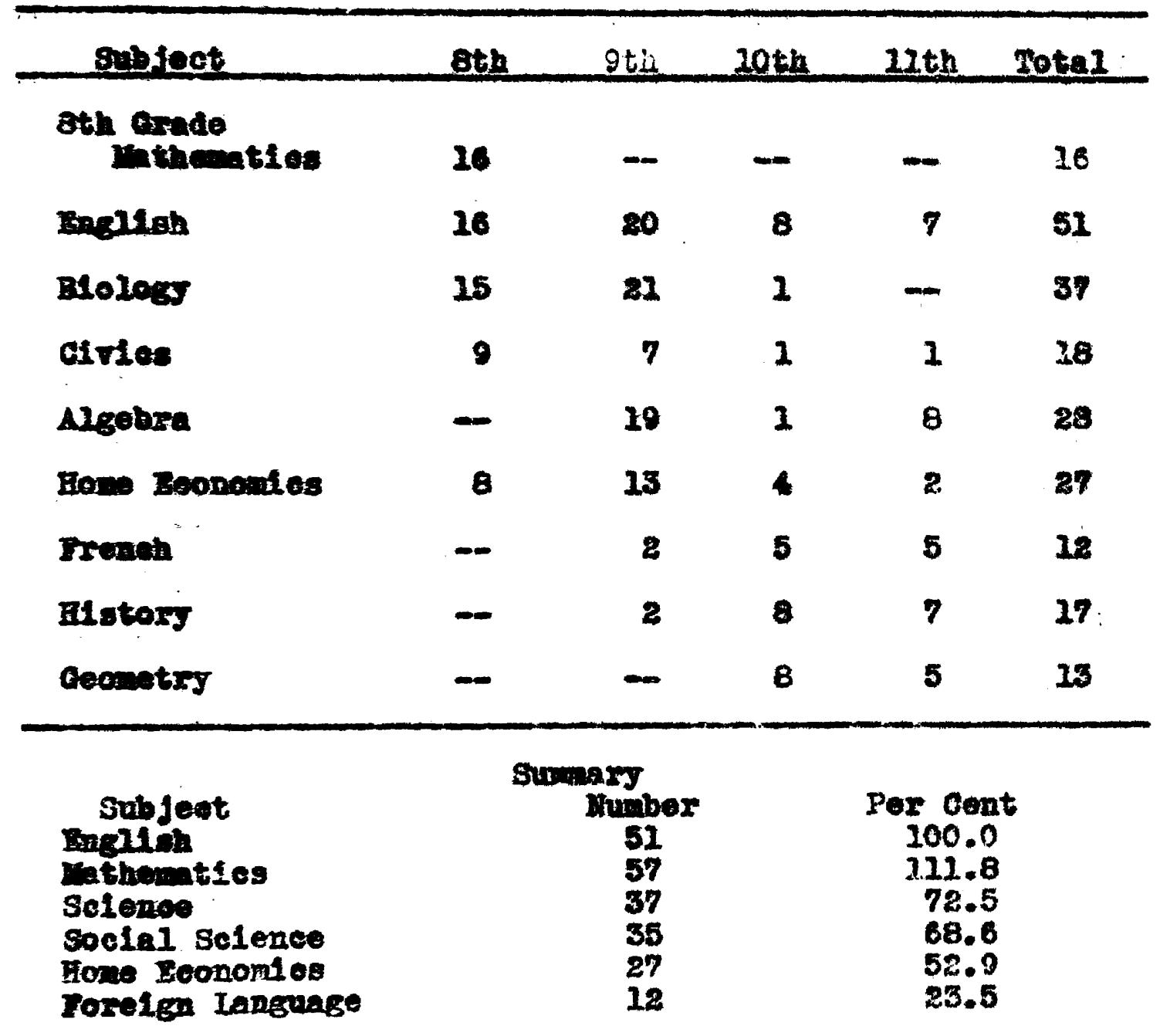




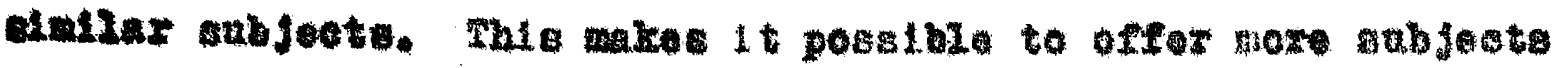

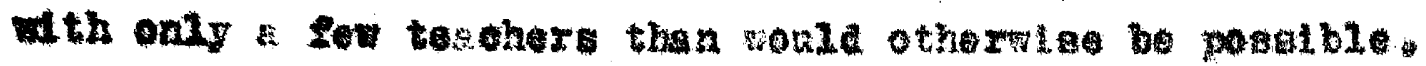

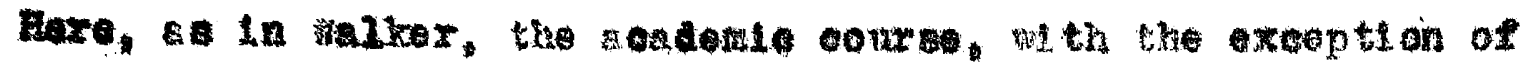

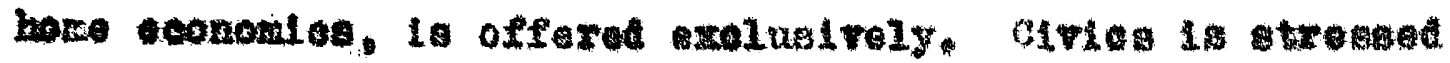

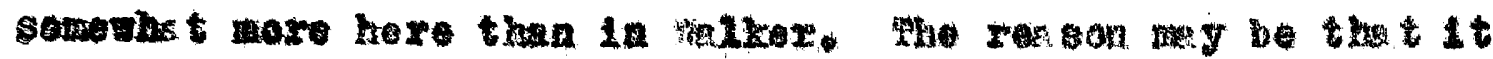

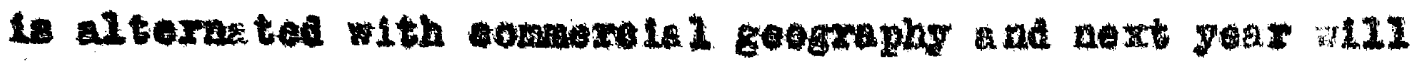
wet be extermat

Dota oonseming the readeule tretning. experienos, and

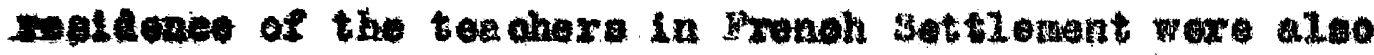

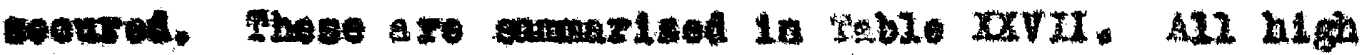

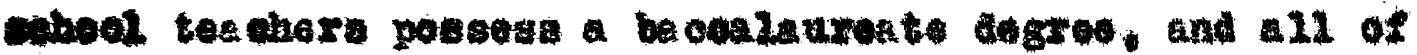

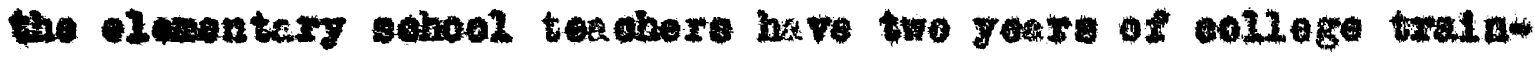

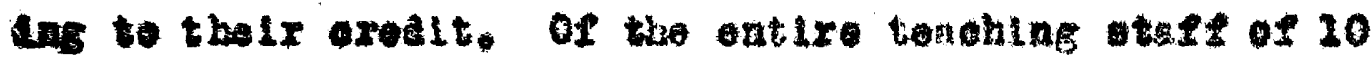

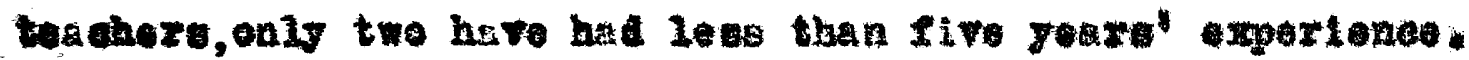

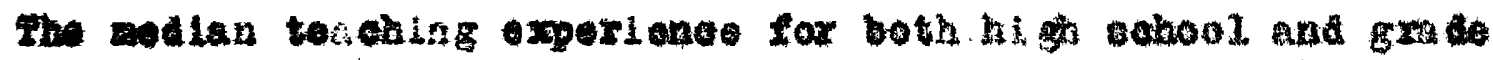

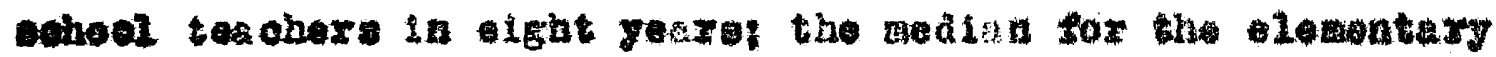

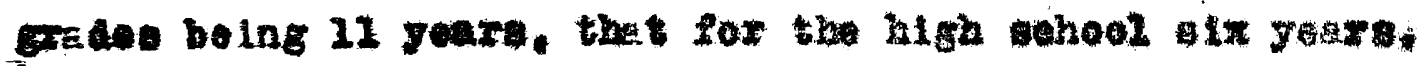
Henaver. of the 20 tesohers, only two bive taght in the

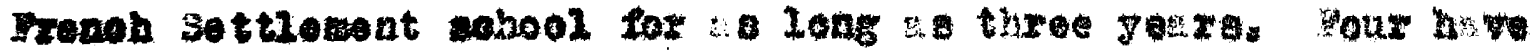

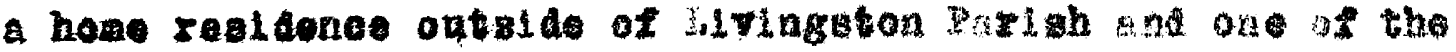

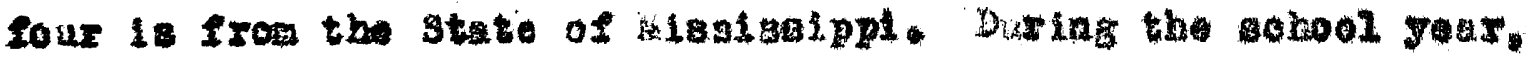

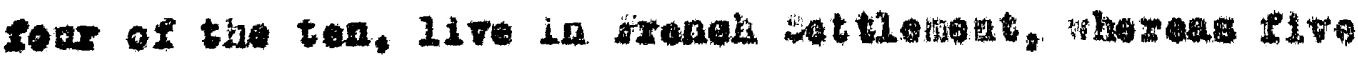

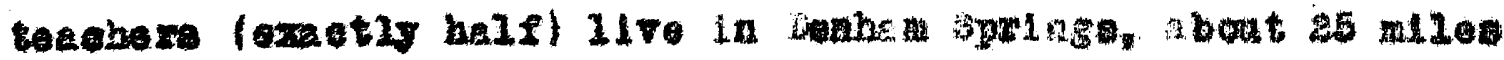
anar.

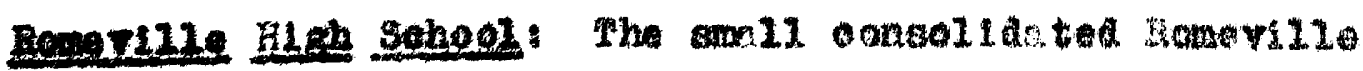

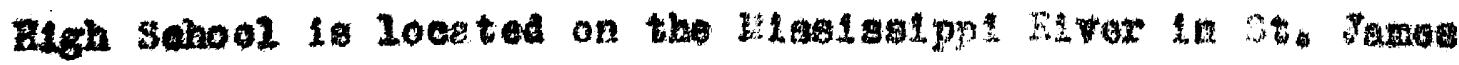


Tabie XrII

Aeadonic Qualirleations, Tenure and Residence of the

Ironch Settilenent sehool reachers

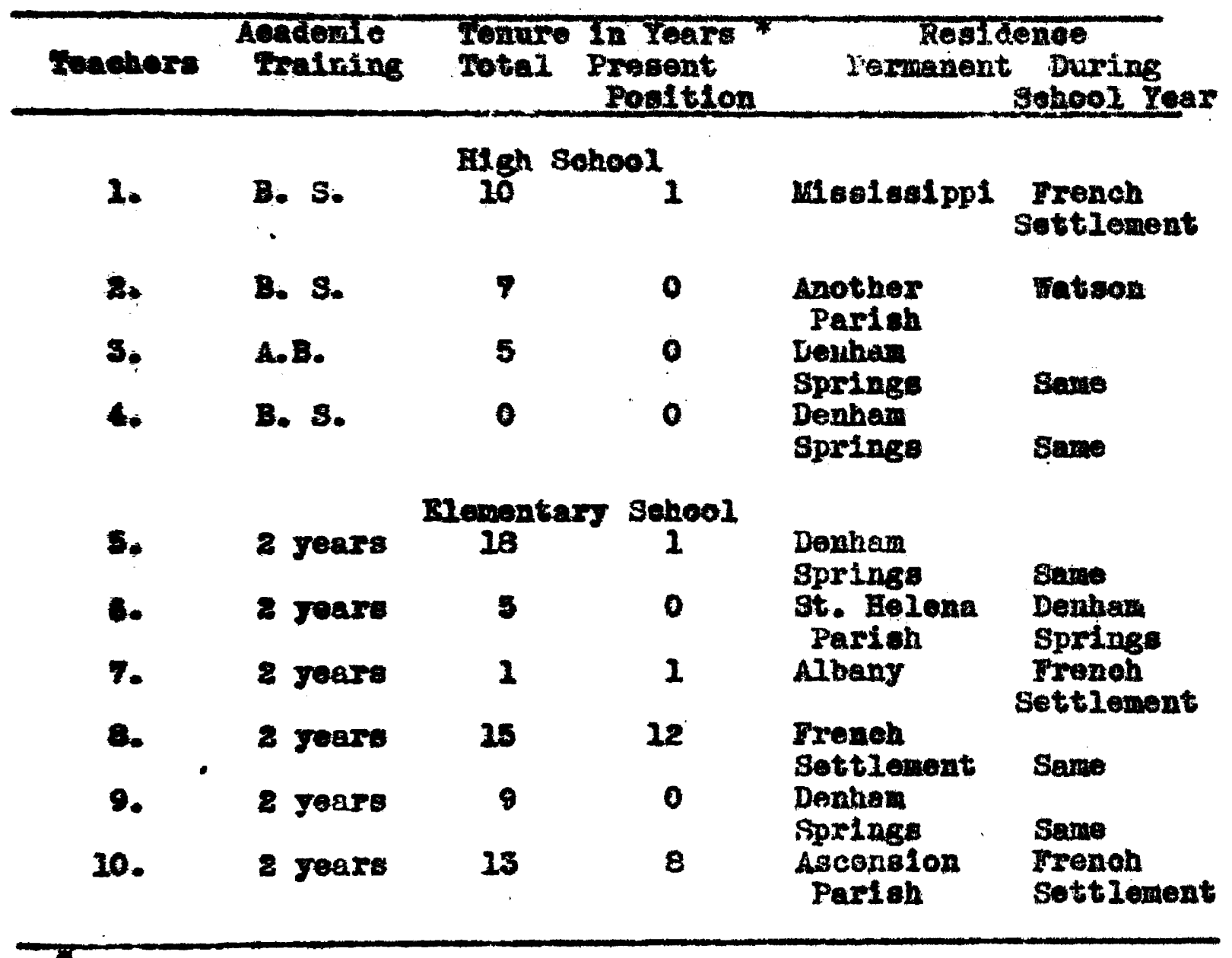

The tern nTomire is ueed in the aense in whioh Foote uses 1t. Op. 1t., I. 2 .

by " 2 Jeare" the complation of the required two year teachera" tralning course in some college is implied. 
Ferish to the south of Baton Bouge. soooxalug to the report of the High sehool and dolleze commiation, the onrellnent Is about 215 papile for both the elementary gradeo and he

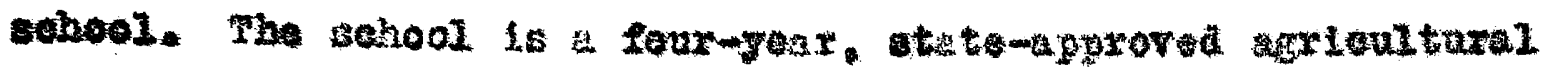

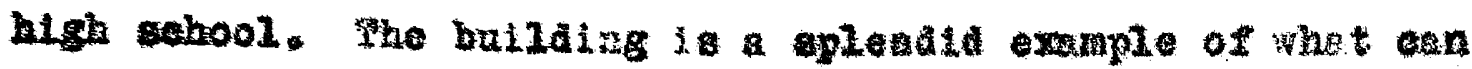

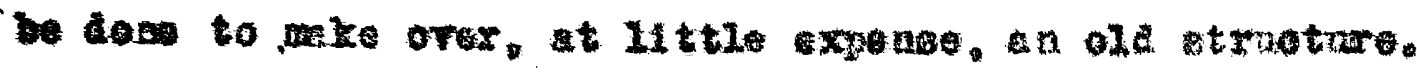
Exlox to 1931 tive plent was an old bulldng ralsed nhout light or ton foot off the ground a a fogurd agalnat an overhow

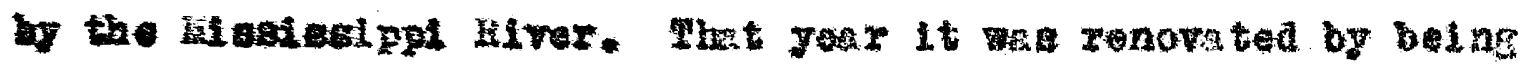
rateva high onough so that a groven noor conda be mate of the

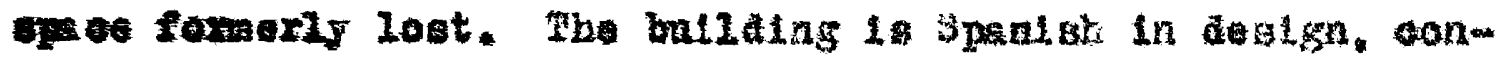

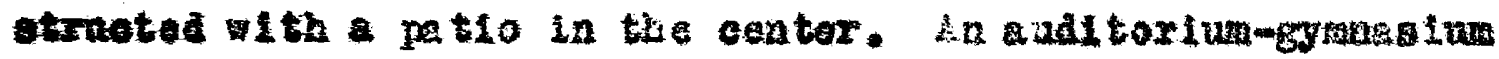

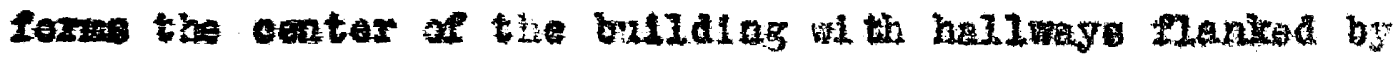
alase zooms sarronaling it. In the frout, on the ground foor

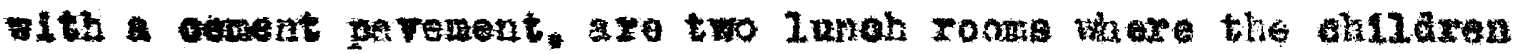

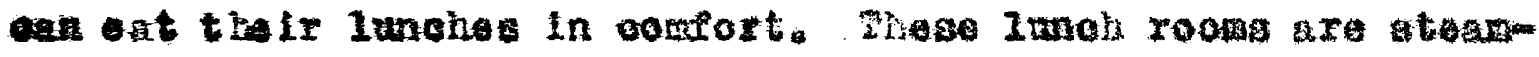

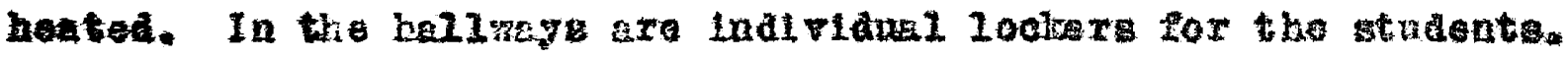

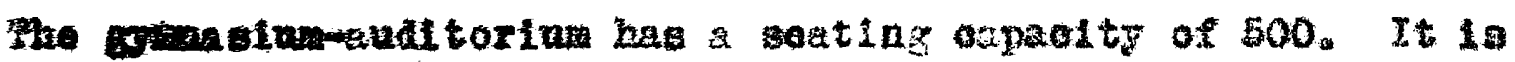
equpped with a atrge, oxtaln, and geonory. In eadition. a connd potare machine in rontad by the gehool and ptotares ax ahown thex for a mil foe por pereon.

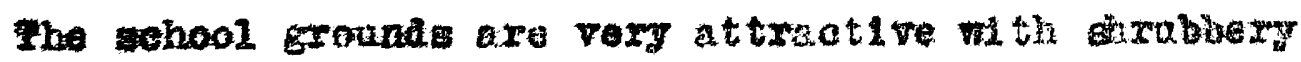
planter in sront of the bullatus ond ample gpeo in the zeta

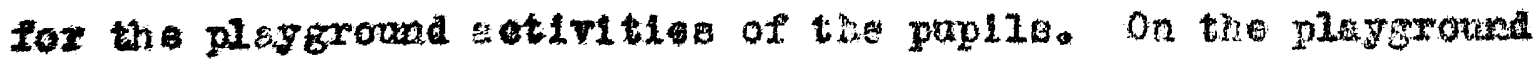

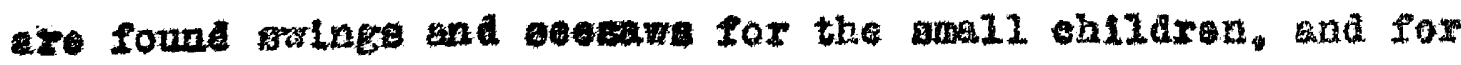

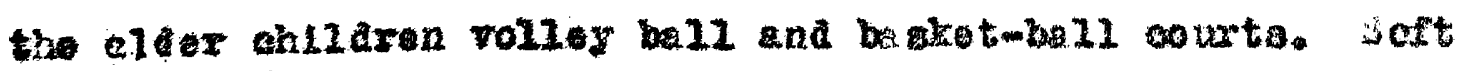

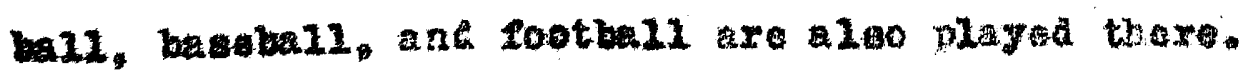


The Romerille school was romed by the unlting of two comenitles; the rillages of Convent, about rour niles away, and Central, about two miles distant, together with the $x$ outlfing open-oountry distriots. Praotically all of the enileren are transported to sohool by bus, but no bus rune farther then six miles.

Te sohool 1: looktod in ono of the old Frenoh rarming detriota of Louldana. It is a reglon of large sugar plantations and truck-faralng patohes. Through this seotion ax rove some of the wost magnifleent of Loulalana's antebellum homes. The zost laportant Induatry, frow the standpelnt of the number of people engaged in 1t, is farming. (seo sable xarII.) As one would expeot fros this type of comandty, there are a large aumber of other ocsupatlons. The people listed as store keepers, oarpenters, bus arirers, sherift, and the like, engege in egrieulture as a side line for thelr own food supply, and so agriculture thus plays an oren nero inportant part in the IIres of the sohoel petrons than would be judged by the table.

Aecording to the report of the high sobool students, the majority of the patrons own the land on whioh they 11ve. Out of 68 students, 46 reported oxnershlp of the lend, whereas 22 reported that their parents ronted 1 t.

The moblilty of the chool population sems to be much greater for noneville than for elther Walker or Franch settloment, for 82 report that they have attenied othor sohools and 60 report no other gohool attendanoe. For the high sohool 
Table XXIII

Oecupations of the Parents of Students of the Romerille

Sohool

\begin{tabular}{|c|c|c|c|c|}
\hline 0ooupations & \multicolumn{2}{|c|}{$\begin{array}{l}\text { Hifeh Sobool } \\
\text { Number Fer Cent }\end{array}$} & \multicolumn{2}{|c|}{$\begin{array}{l}\text { Elementary sohoor } \\
\text { Number Pes cont }\end{array}$} \\
\hline $\begin{array}{l}\text { Farmer } \\
\text { Vegetable Shipper } \\
\text { Garponter } \\
\text { lerohant } \\
\text { reeeher }\end{array}$ & $\begin{array}{r}29 \\
3 \\
4 \\
2 \\
2\end{array}$ & $\begin{array}{r}38.2 \\
3.8 \\
5.5 \\
2.6 \\
2.6\end{array}$ & $\begin{array}{r}25 \\
4 \\
2 \\
4 \\
4\end{array}$ & $\begin{array}{r}36.8 \\
5.9 \\
2.9 \\
5.9 \\
5.9\end{array}$ \\
\hline 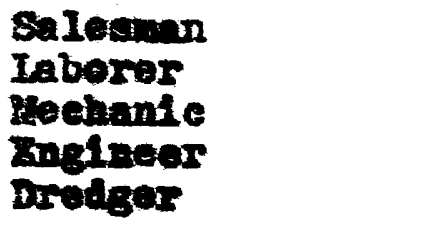 & $\begin{array}{l}1 \\
3 \\
3 \\
3\end{array}$ & $\begin{array}{l}5.3 \\
1.5 \\
3.9 \\
5.3 \\
2.6\end{array}$ & $\begin{array}{l}2 \\
4 \\
1 \\
0 \\
1\end{array}$ & $\begin{array}{l}2.9 \\
5.9 \\
1.5 \\
0.0 \\
1.5\end{array}$ \\
\hline $\begin{array}{l}\text { Sugar Drier } \\
\text { Bleetriofar } \\
\text { Blaetent th } \\
\text { Migenllangous }\end{array}$ & $\begin{array}{r}8 \\
1 \\
16\end{array}$ & $\begin{array}{r}8.6 \\
1.3 \\
1.3 \\
21.1\end{array}$ & $\begin{array}{r}1 \\
1 \\
2 \\
17\end{array}$ & $\begin{array}{r}1.5 \\
1.5 \\
2.8 \\
25.0\end{array}$ \\
\hline Total & 76 & 100.0 & 68 & 100.0 \\
\hline
\end{tabular}

Tab10 DaIX

Oeoupational Proferenos of the Students of the Romerille

Sohool

\begin{tabular}{|c|c|c|c|c|}
\hline Decupations & \multicolumn{2}{|c|}{ High Sohool } & \multicolumn{2}{|c|}{$\begin{array}{l}\text { HIementary } 30 \text { coor } \\
\text { Number Per Cent }\end{array}$} \\
\hline $\begin{array}{l}\text { Pazmof } \\
\text { Clerk } \\
\text { Meohenio } \\
\text { Teacher } \\
\text { Turae }\end{array}$ & $\begin{array}{r}17 \\
15 \\
8 \\
2 \\
10\end{array}$ & $\begin{array}{r}23.6 \\
20.8 \\
11.1 \\
2.8 \\
13.9\end{array}$ & $\begin{array}{r}8 \\
2 \\
7 \\
12 \\
2\end{array}$ & $\begin{array}{r}12.9 \\
3.2 \\
11.3 \\
19.4 \\
3.2\end{array}$ \\
\hline $\begin{array}{l}\text { Figineer } \\
\text { Lanyer } \\
\text { Dootor } \\
\text { Merohant } \\
\text { Avlator }\end{array}$ & $\begin{array}{l}7 \\
2 \\
2 \\
0 \\
2\end{array}$ & $\begin{array}{l}9.7 \\
2.8 \\
2.8 \\
0.0 \\
2.8\end{array}$ & $\begin{array}{l}3 \\
7 \\
3 \\
4 \\
1\end{array}$ & $\begin{array}{r}4.8 \\
21.3 \\
4.8 \\
6.4 \\
1.6\end{array}$ \\
\hline $\begin{array}{l}\text { Druggist } \\
\text { ified Laneons }\end{array}$ & $\begin{array}{l}1 \\
6 \\
\end{array}$ & $\begin{array}{l}1.4 \\
8.3 \\
\end{array}$ & 2 & $\begin{array}{r}3.2 \\
17.7 \\
\end{array}$ \\
\hline Motal & 72 & 200.0 & 62 & 100.0 \\
\hline
\end{tabular}

"Clerk inclites stenogrepher, secretary and bookkeeper. 


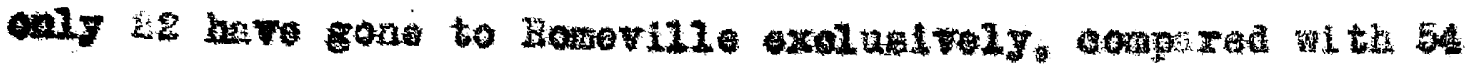

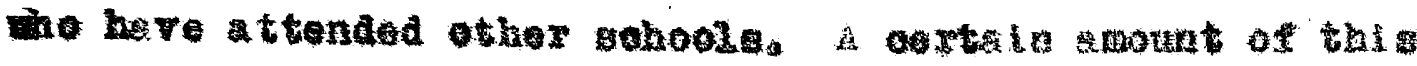
nag not repreaent ohnge of restdone, but ching trow one

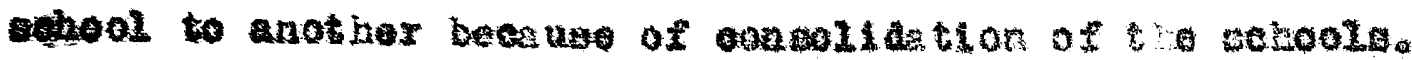

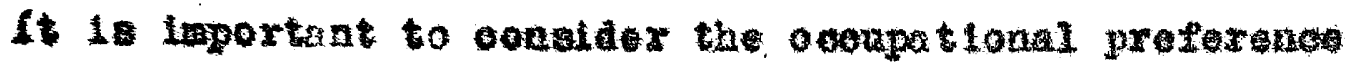
of the students in relation to the cocupation of tholx parants.

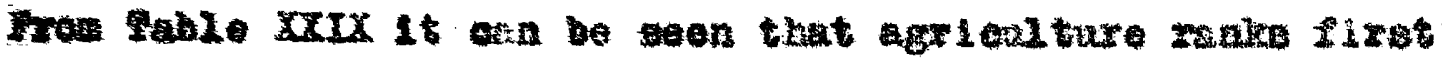

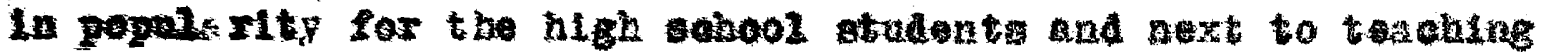

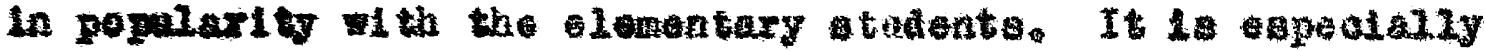

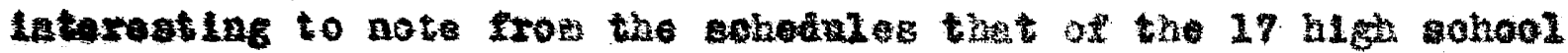
otalents wo ote they profer faxing 15 are gislo. (It was otated that "Do yea expoct to bootre farmer?" weant "Do you

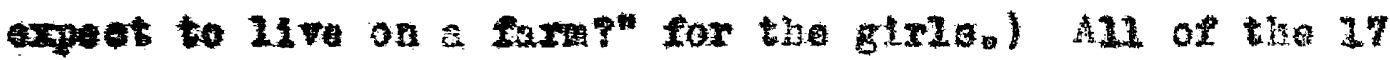

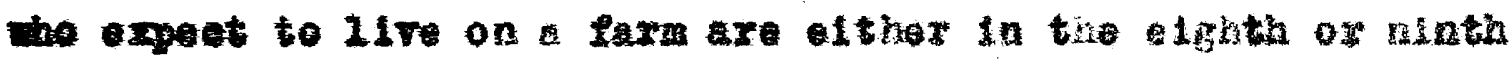

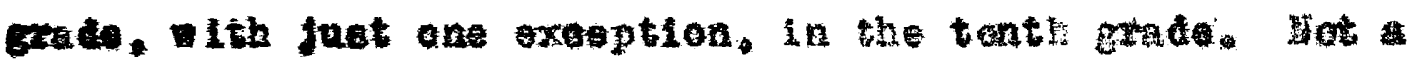

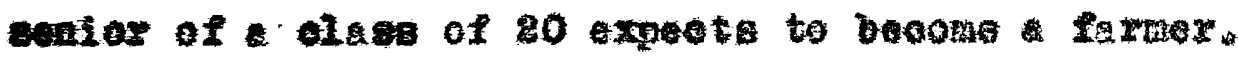

The age-graco afatrlbution of papile in the olker ad

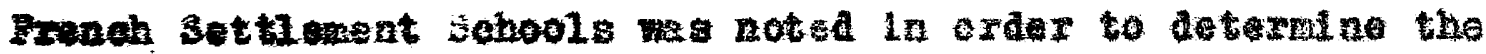

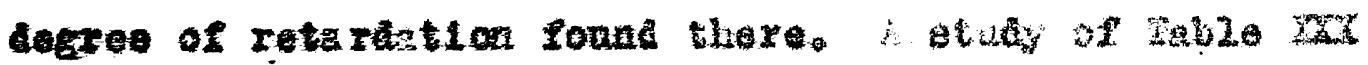

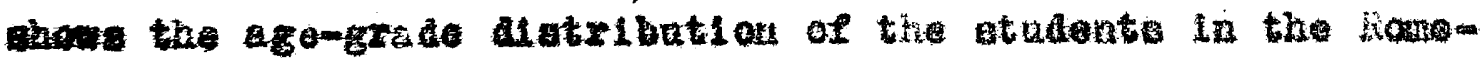
The sobool. The median age for the grades are:

$$
\begin{aligned}
& \text { 4th grado-m-9 yera. } \\
& \text { Eth Gxade-m-n yearo. } \\
& \text { 6th gadem-11 yeers. }
\end{aligned}
$$

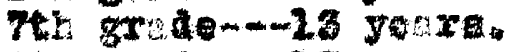

$$
\begin{aligned}
& \text { ath Grade-m-1.Z yore. } \\
& \text { 9th } x \text { dem-15 jocta. } \\
& \text { 10th gxde-n-10 years. }
\end{aligned}
$$

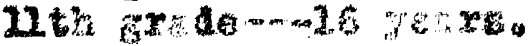


Table $x \mathbf{x x}$

Age-Graje Distribution of Students in the Roneville Sehool

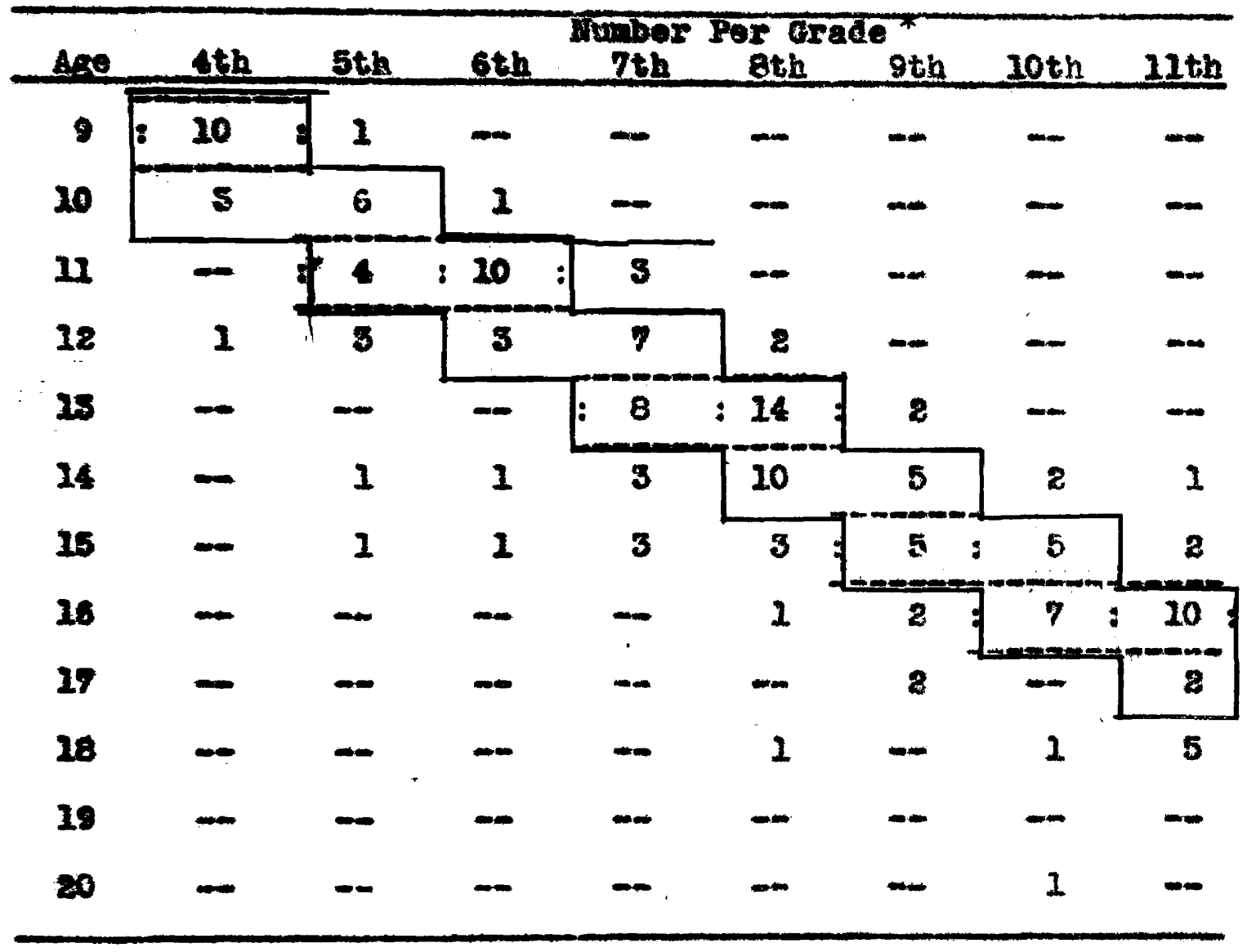

The nubers inclosed in black lines represent the age medians for the erades in the Bomeville Sohool. Those inelosed in rod ilnes represent the normel or expeoted age Ior the grade. 


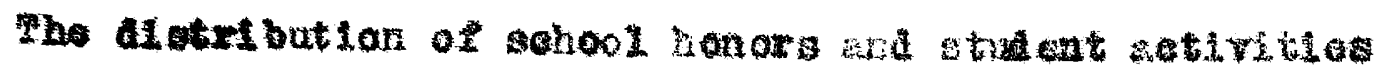

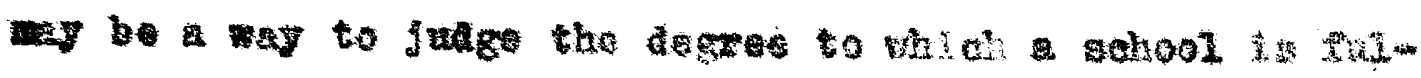

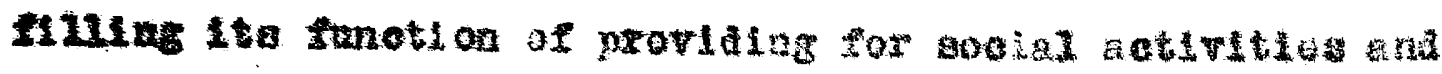

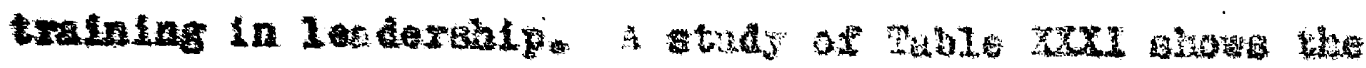

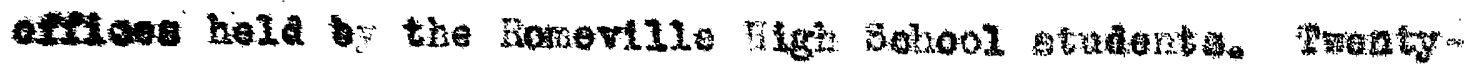

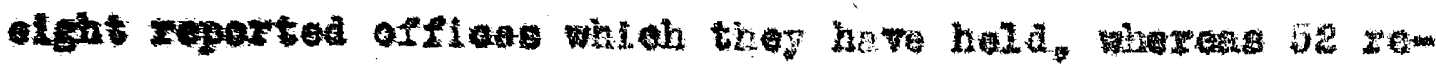

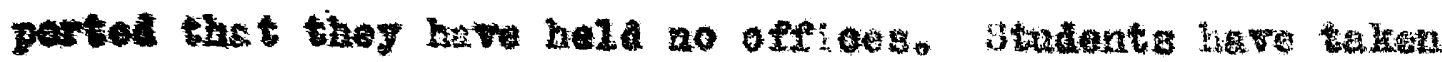

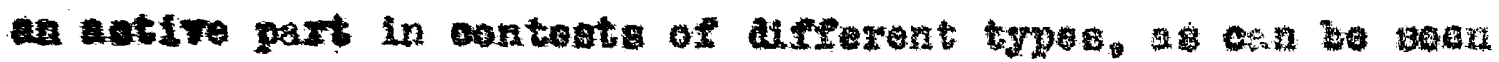
tron Palle KXXII. Altbongh athetios bs recested the jox

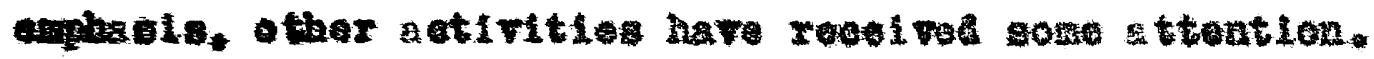
Forty-alx report that thoy have repreaented tho. sehool in

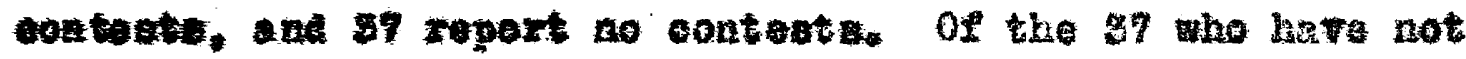
represeated the gelinol in contegte, 17 have hela varlous sehool

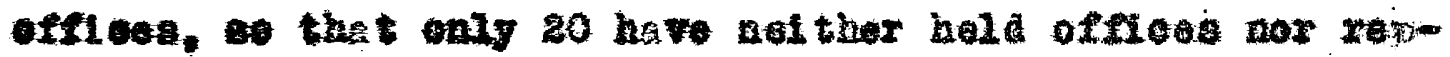
resented the sohoel in conteation.

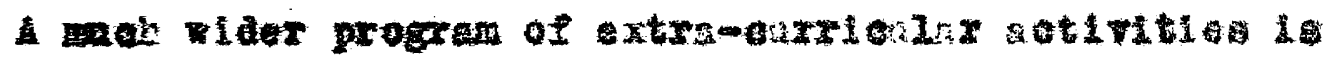

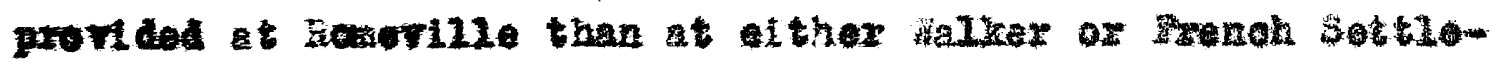

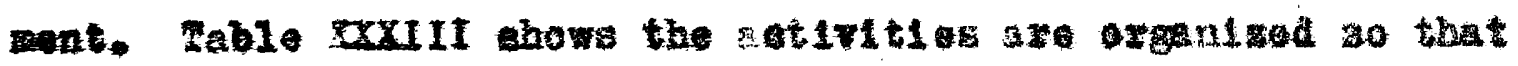

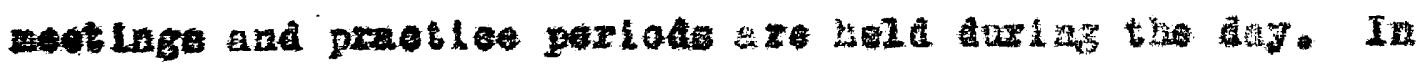

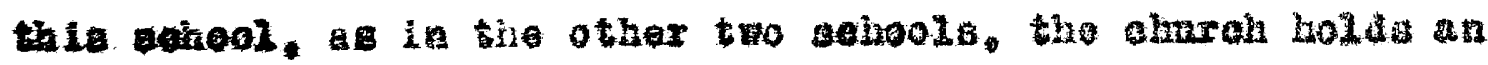
inportent plse in the 11 of the stidonts, fudging fros the

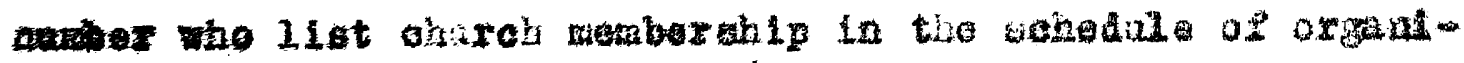
satione to when treg balonge

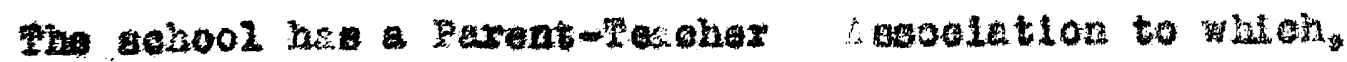

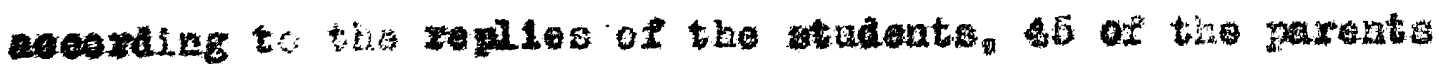

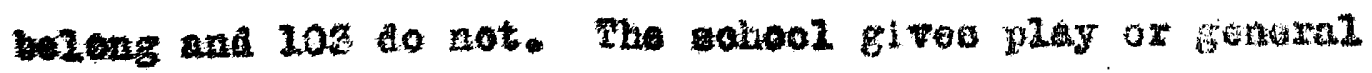

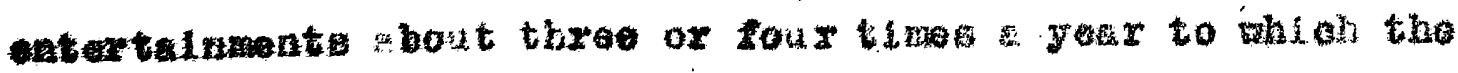




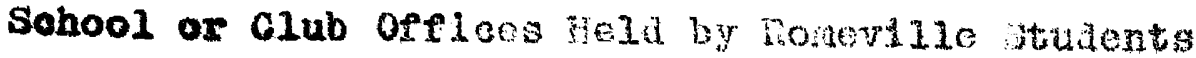

orree

Claies President

V1e0-Prealdent

Secretary

Treasurer

Preatient Hone Beonorites CIub

Seervtary Howe Eeonomlee GIub

Freasurer Hone Beonomice CIub

gepertax

Secretary-Treasurer 4-\$1 Club

Breamuser Iuture Farwer:

President Ilbrery CIub

Chalrman Progran Comittee

Captaln Football Tean
Nuraber

7
4
6
4
3
3
1
4
1
1
1
1
1

\section{Table 200II}

Breats in thioh Students Have Represented

Homerille High Sohool

Brent

Track Athletion

Baseball

Basket-ball

Boxine

Bingting

Hone Boonomice

Future Farwere Hoetinge

Jubing

Number

15

11

7

1

13

1

5

1 


\section{Mable MUTII}

Organizations to infoh the Btudents of the Romevilie

$$
\text { High Sohool Belong }
$$

\begin{tabular}{|c|c|}
\hline Oreanization & $\begin{array}{l}\text { Whabers in } \\
\text { Sehool }\end{array}$ \\
\hline 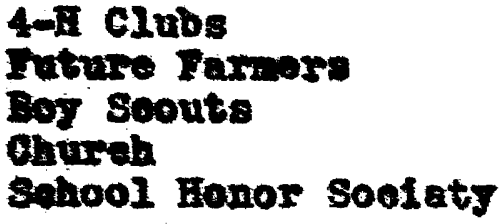 & $\begin{array}{l}21 \\
17 \\
14 \\
81 \\
3\end{array}$ \\
\hline 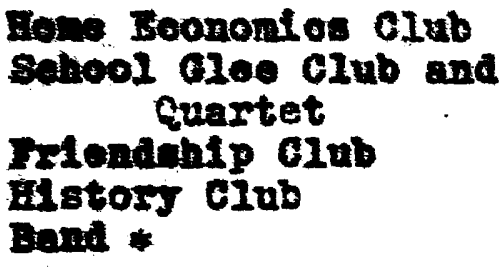 & $\begin{array}{r}30 \\
43 \\
4 \\
13 \\
7\end{array}$ \\
\hline 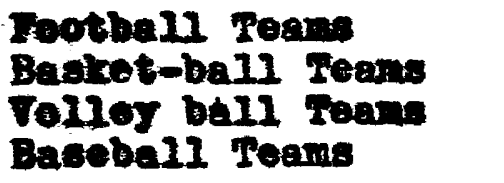 & $\begin{array}{l}23 \\
31 \\
19 \\
30\end{array}$ \\
\hline
\end{tabular}

- The wehool band is alvided into two geotiona with both erade chool and hifh sohool pupils taling part. The table abore coes not include the grade cehool pup11s. Tho sohool has a special practioe recm tor the band and prattioe poriods are provided during the day. 
General publie is invited. In the replies to the question at to how many times thelr parents had visitod the sahool this joar, the rollowing results were found: In the olementary gredes, 40 children reported that thelr parents had not rialted the sohool durine the year, and 22 rejorted that thair parents had Visited; in the high school, 44 oblldren reported no visits and 54 reperted visitg by their parents. The rollowing answers to the question, "Do your perents attond cohool entertainnents?" were rocelved: for the elenentaxy school Jee and 24 no; wereas for the high sohool 66 yos and 15 wo. Here also less interost on the part of the eleneatary school parents in the school and Its aotivities is to be round than for the high sohool parents.

The Romerille school mas included in this study beoase 1t is olasged as Four Tear Agrloultural High Sohool looated In the French erea. Although it is listed as a four yoar agaloultural high sohool, only six students aro taking agriculture as a sohool subject. All of these six atudents are in the alghth grade. Evidentiy this is an agrioultural sohool in name only. in sharp oontrast to the seagre enrollment in agreulture, thirty-five students liat typing. strangely enough, there 1s not a typine ingtructor; thare re only sew typewelters with a nual for eaon molne. The typlag is direoted, by the sohool prinelpal, who enploys the project mathod of teaching. Home econorates, also, is taught only in the plrat two years of higa sohool, and chenlatry is taught to all the aenlors; geonetry, which Is alternted vilih algebra, fs taught 


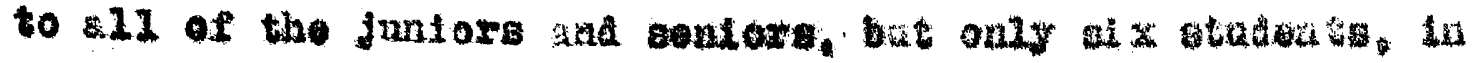

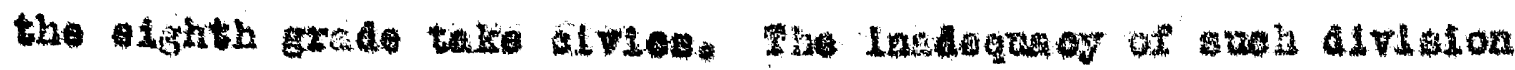

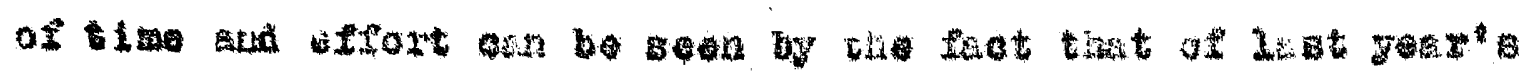

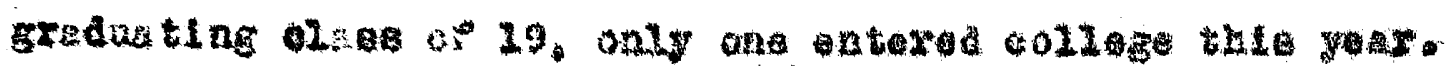

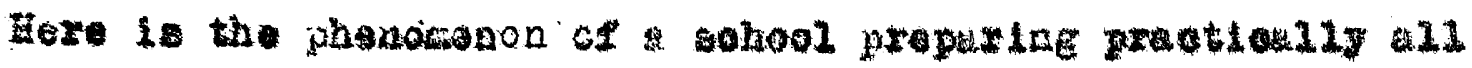

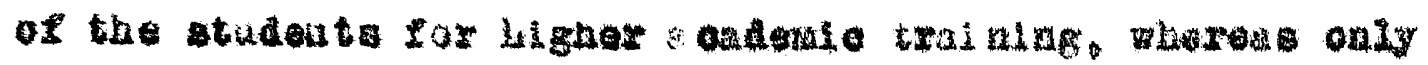

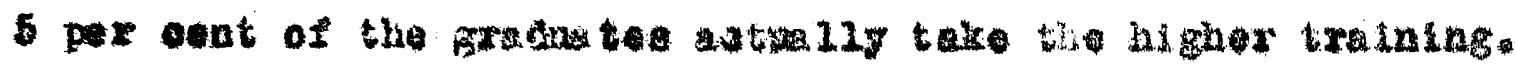
(soe cablo zaxit.)

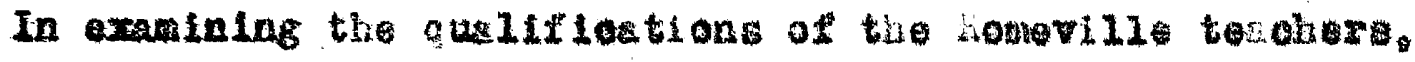

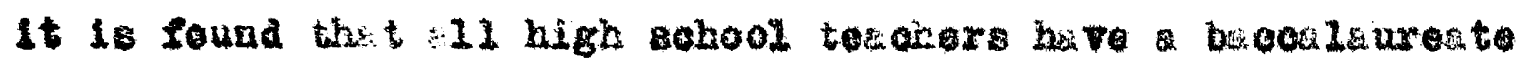

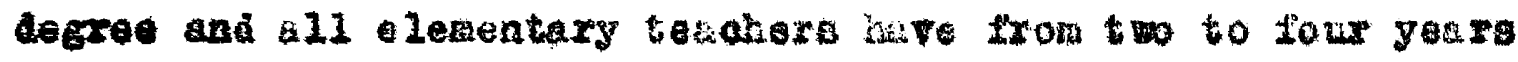

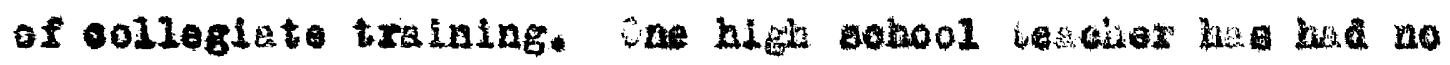

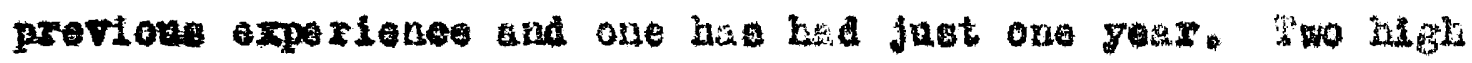

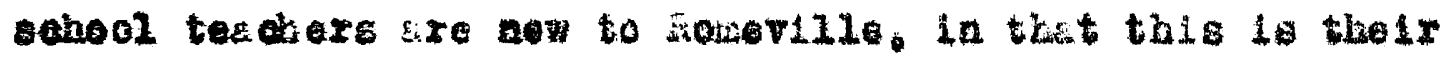
firet reor in this echool. 16 usual in the otate. the

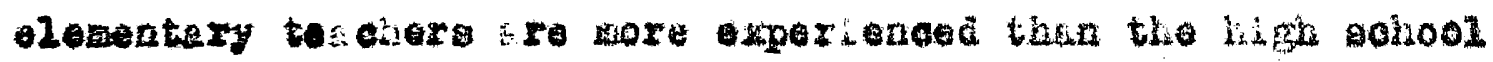

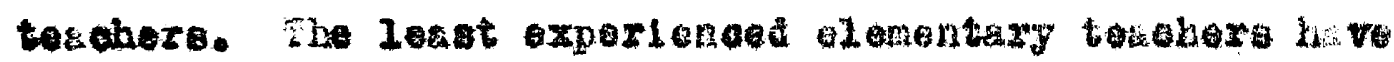

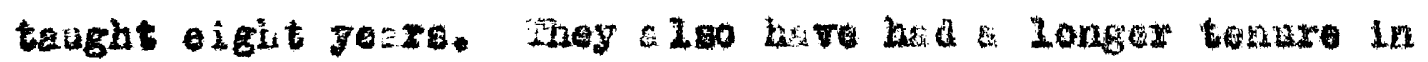

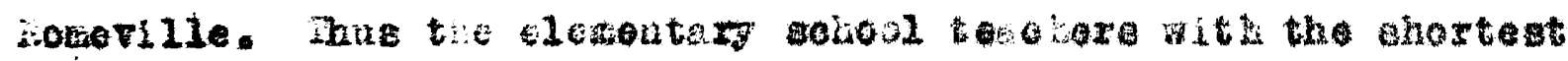

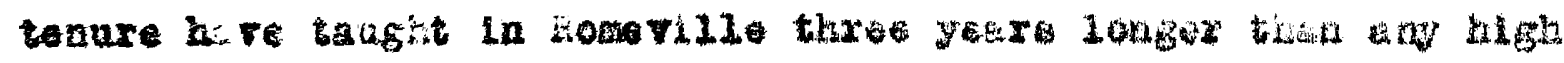

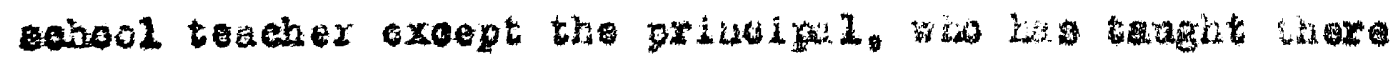

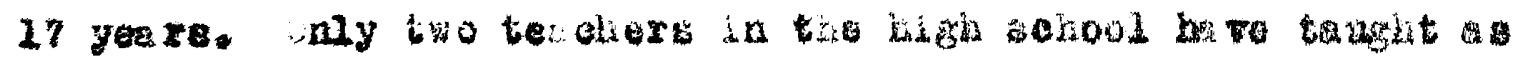
2one as three gears in fonerille, bat all of the lamentary

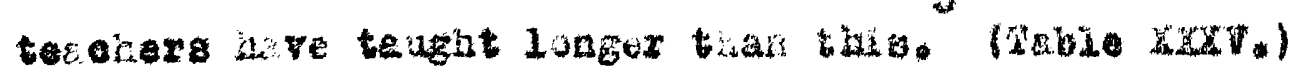

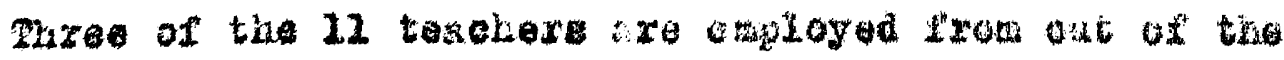

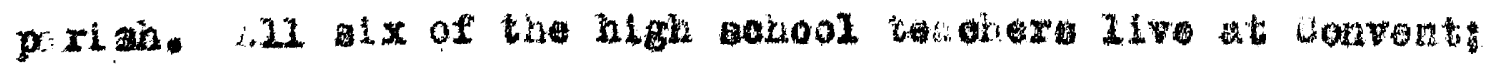

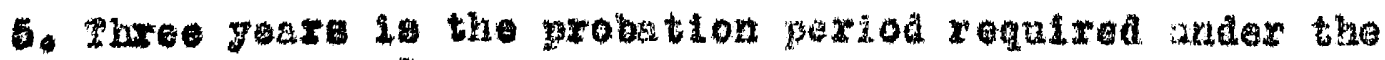

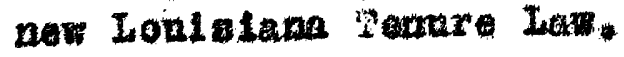


Table DadT

Subjeots Taken by Students of the Roneville High

Sohool

\begin{tabular}{|c|c|c|c|c|c|}
\hline subjeote & Bth & gth & 10 th & IIth & rotal \\
\hline $\begin{array}{l}\text { Oth Grade } \\
\text { Wathematios }\end{array}$ & 30 & - & - & - & 30 \\
\hline Inglish & 30 & 15 & 16 & 14 & 75 \\
\hline Blolog & 31. & 11 & - & - & 42 \\
\hline Fone Eoonont es & 20 & 11 & -- & - & 31 \\
\hline Astealture & 6 & - & - & - & 6 \\
\hline Hiatory & - & 4 & 16 & 14 & 34 \\
\hline estar & 6 & - & - & - & 6 \\
\hline Irwen & - & 4 & 16 & 13 & 33 \\
\hline Ispling & 17 & 3 & 14 & 1 & 35 \\
\hline Goomotixy & - & 15 & 14 & $\because$ & 29 \\
\hline Chendetry & - & $-\infty$ & 1 & 14 & 25 \\
\hline
\end{tabular}

Swmary

Subject Number Per Cent

Inglish

Toeatlonal Subjeots

Bome Econonics typling Agriculture

inthematice

Belence

Sociel solence

Foreign Language
75

72

31

35

6

59

57

40

33
100.0

06.0

41.3

46.7

8.0

78.7

76.0

53.3

44.0 
Table $\mathbf{x x v}$

Loadenito Trainlng and Tenore of Teachers in the

Romerille Sohool

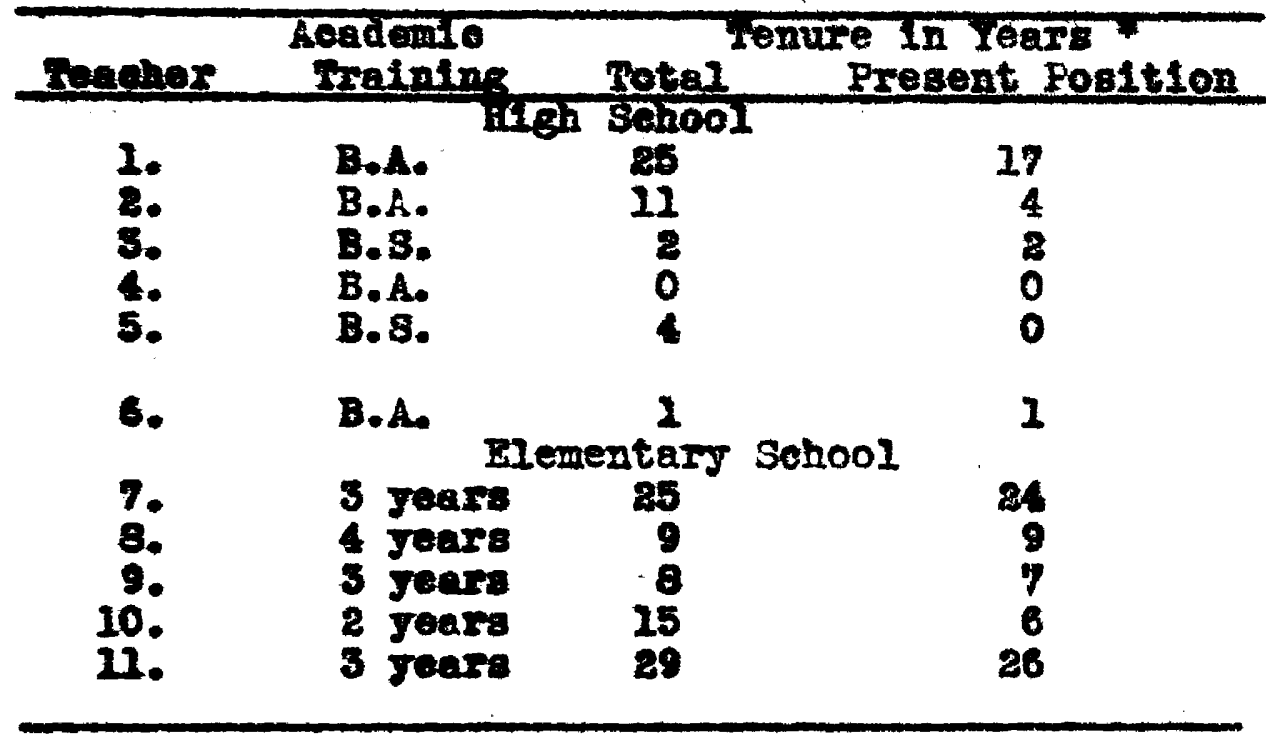

* Tenure is here uved in the same sense in which Foote uses 1t. Op. alt. p. 2 .

Years of asademio tralning means the number of rears of trainlug bejond secondary school. It is usuel that $" 2$ jeurs" means the complotion of the two year teachera' tralning couree in college. 


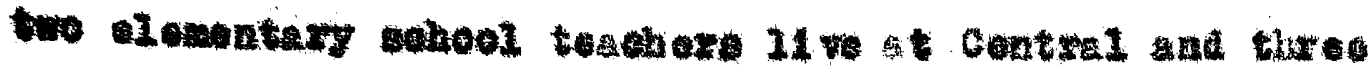

217e thentile

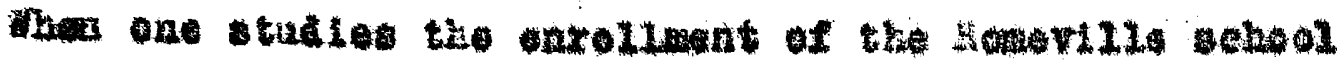

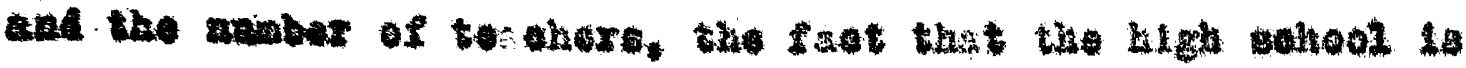

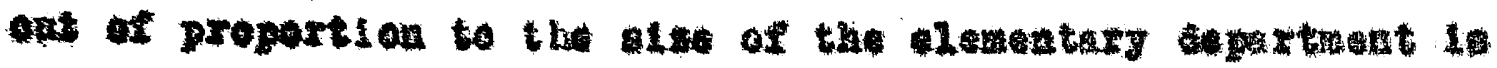

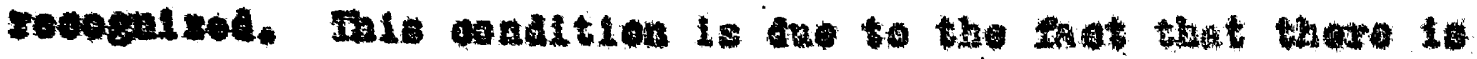

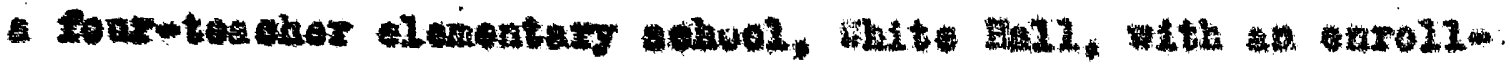

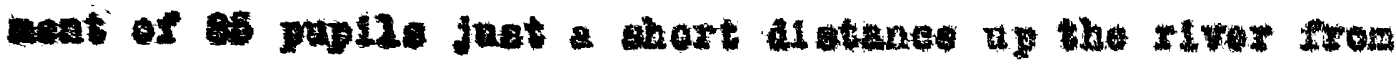

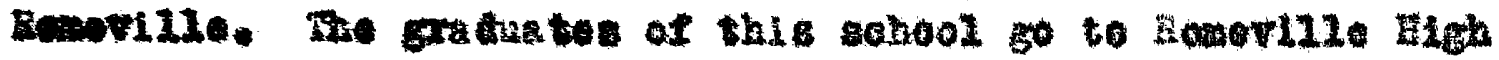

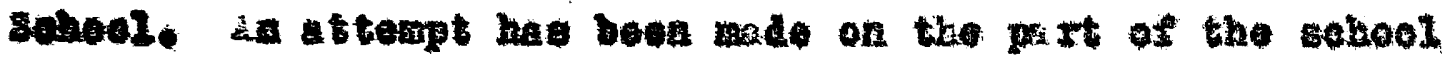
cathoritios to close tho eletentary aboul and to trangport the

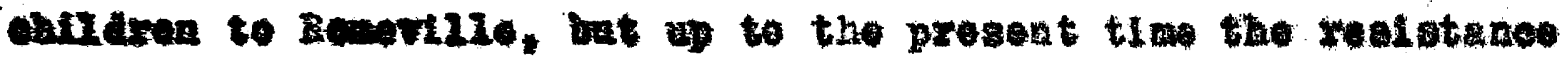

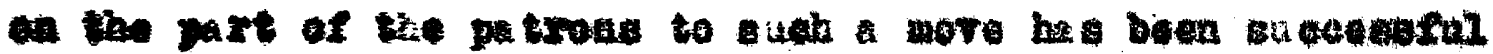
th proventing it.

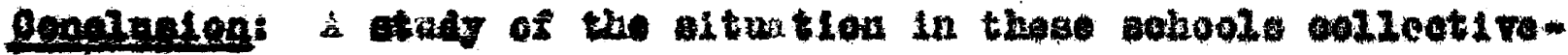
4 and as a comper te is now in orter. Cne of the conolnatione

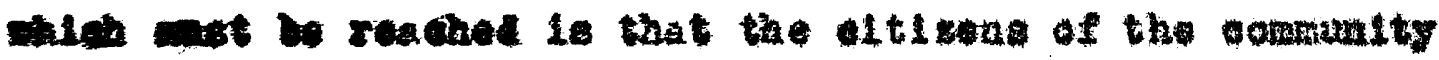
have dore well, thia tholr ans, by thelr gohools. At

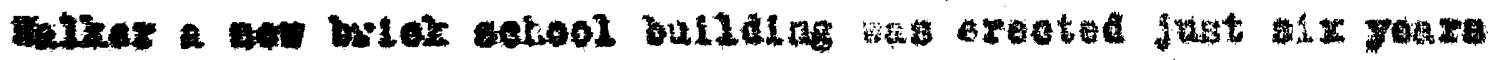

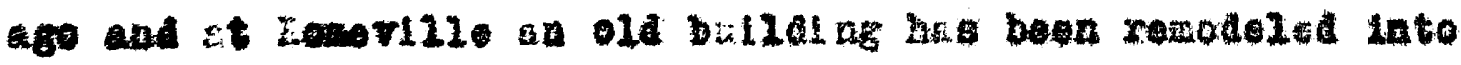

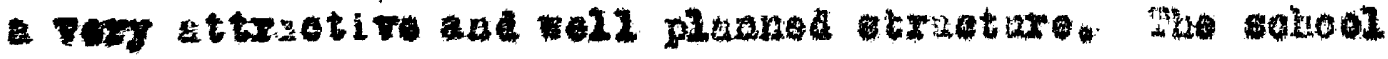

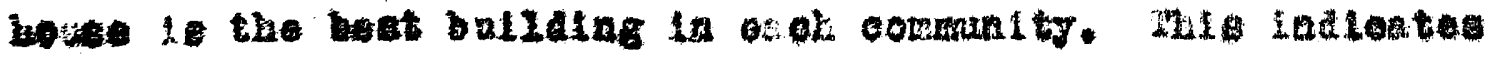

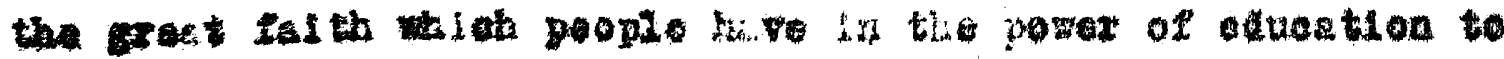

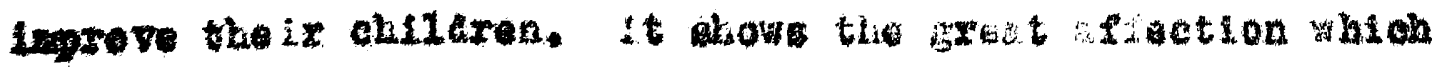

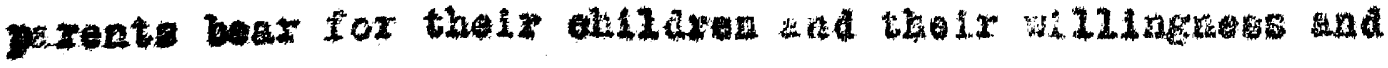

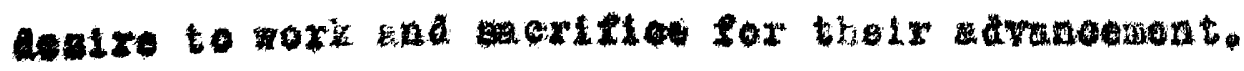




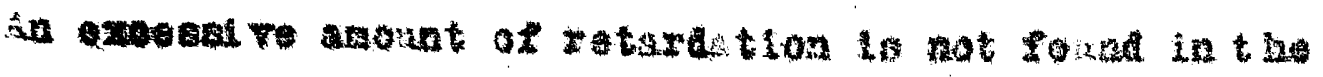

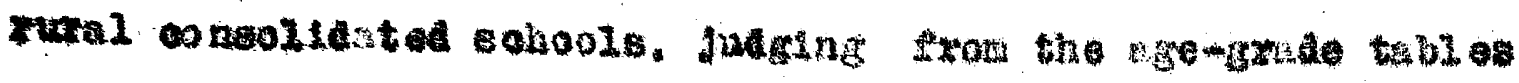

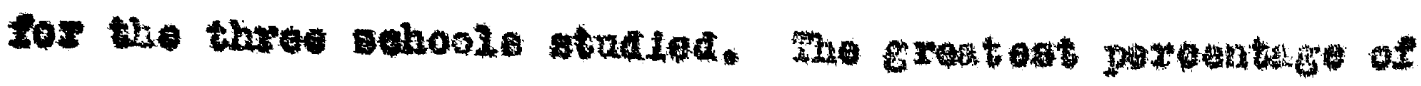

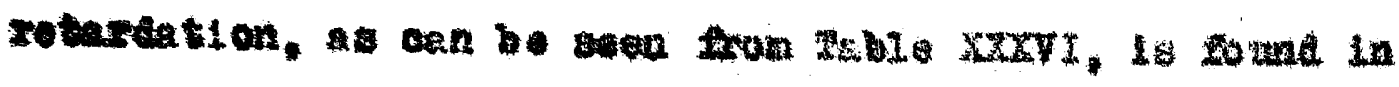

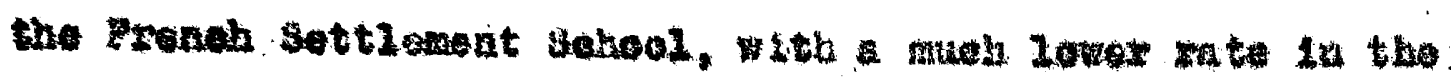

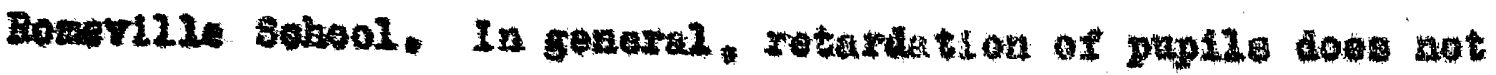

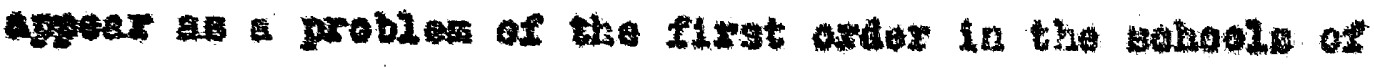
this alase.

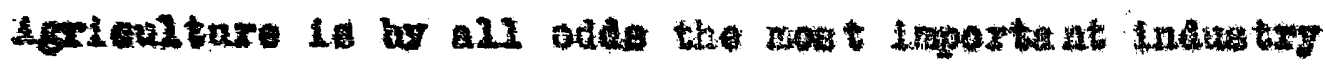

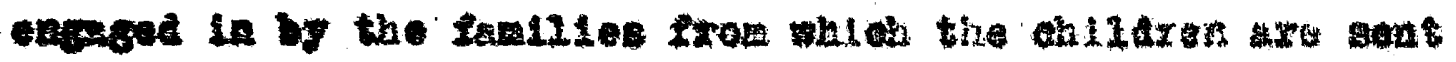
to the ramal abools of the state. To raopltalatel ia tho

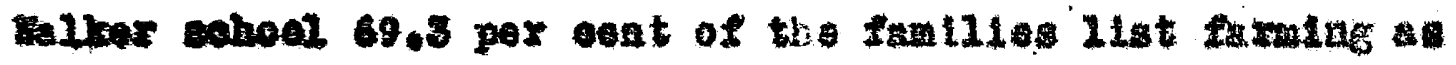

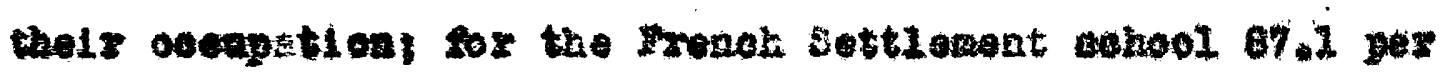

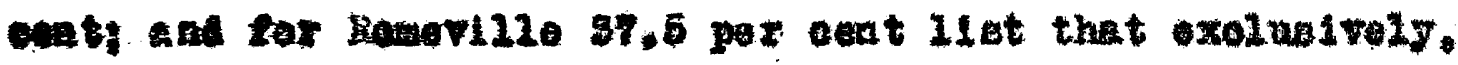

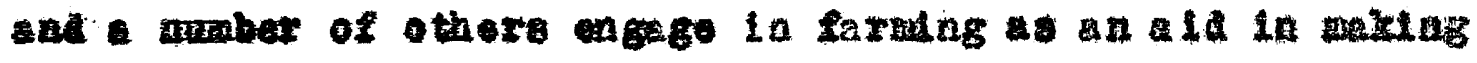

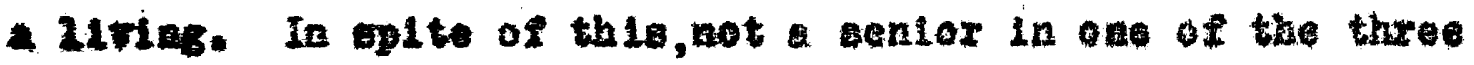

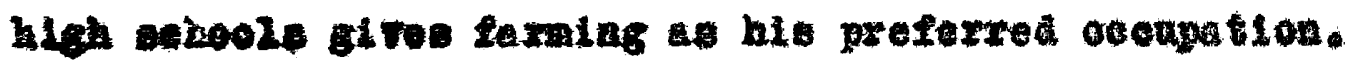

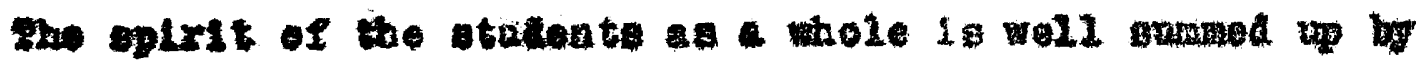

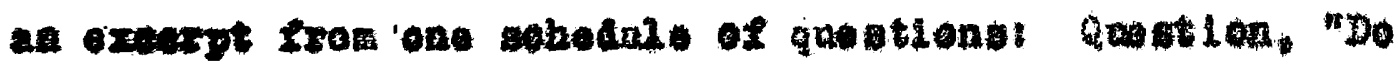

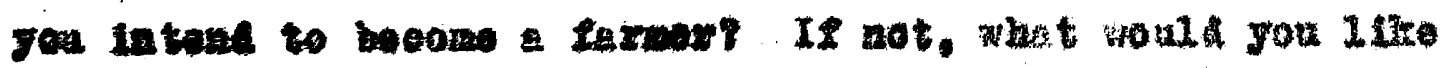

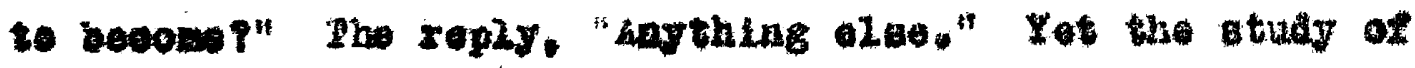

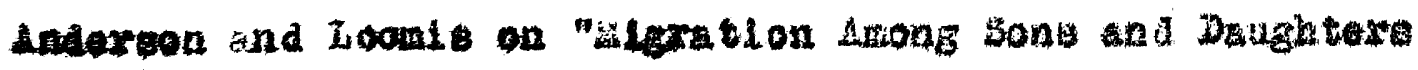

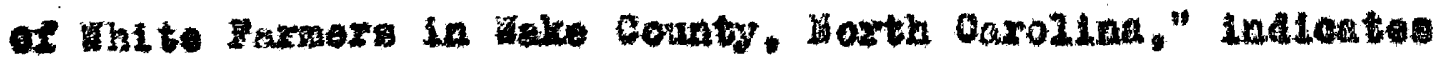

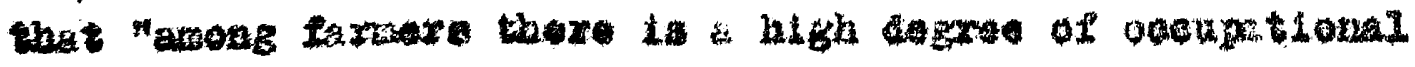
brandal a

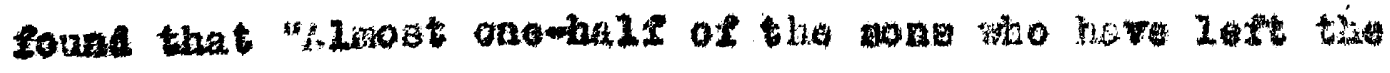

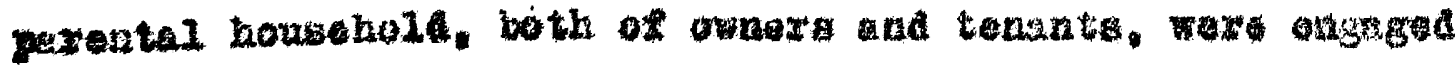


Table DexpI

Retardation in Three Loulaiena Rural Schools

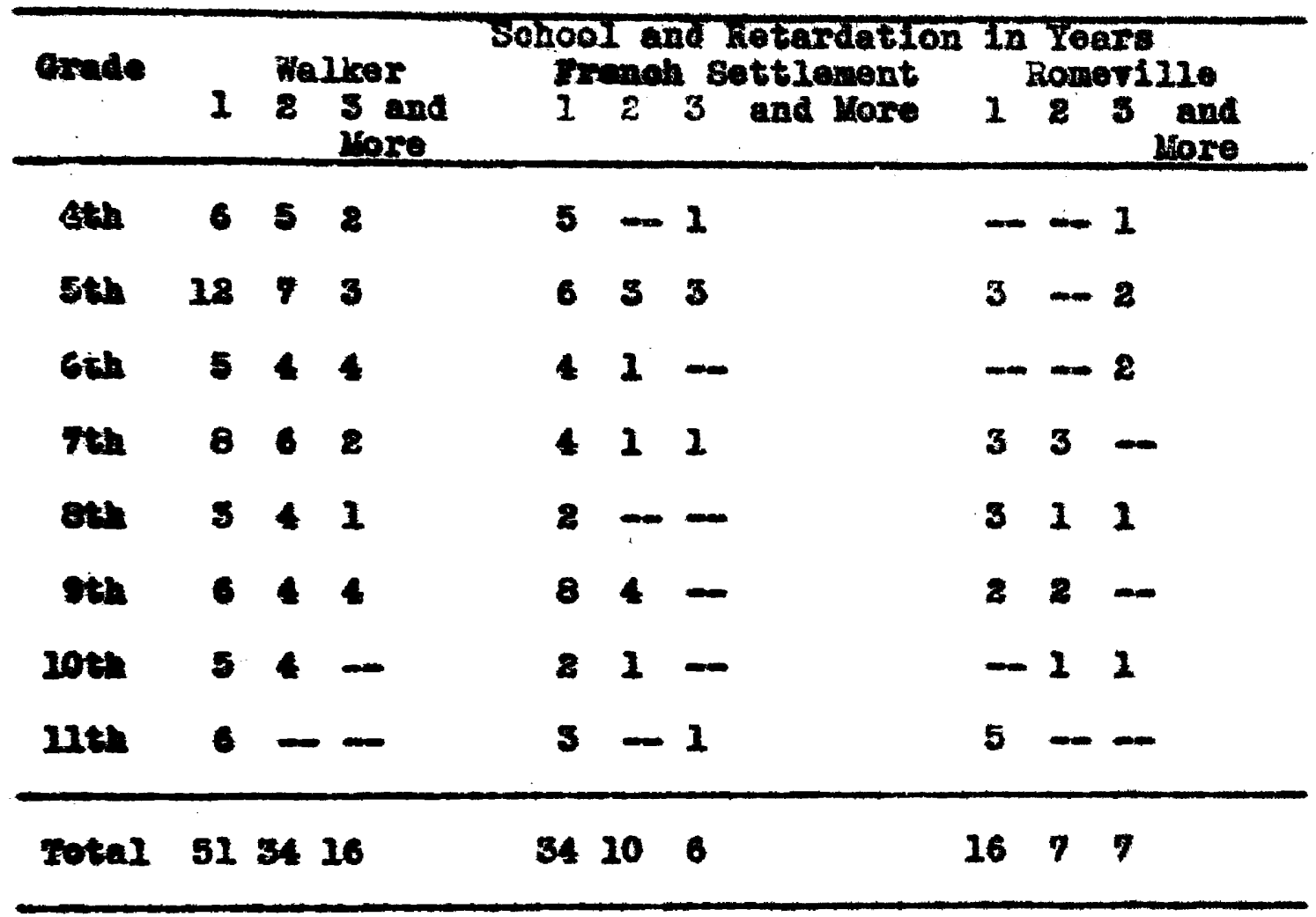

Potardation is flgured from the expocted grade in which child would bo if ho hed made regular advaneoment and had wegen sebeol at the age or alx yeara.

Pex Cent or Rotardation in Each Sohool

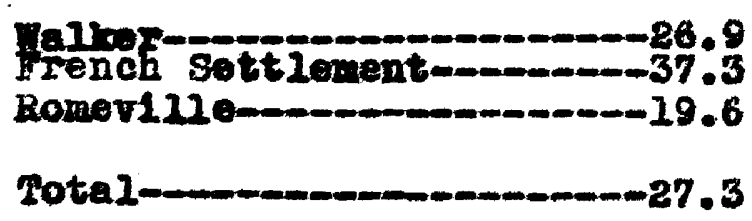




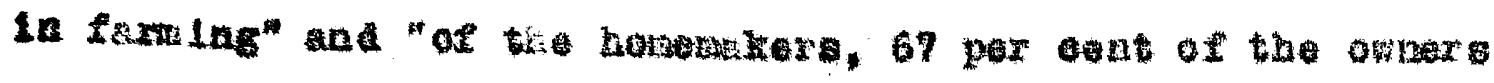

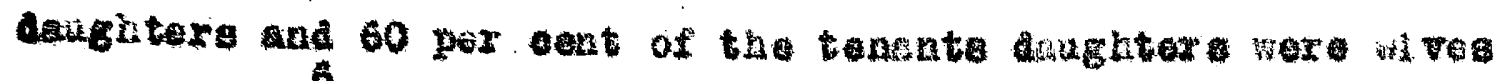

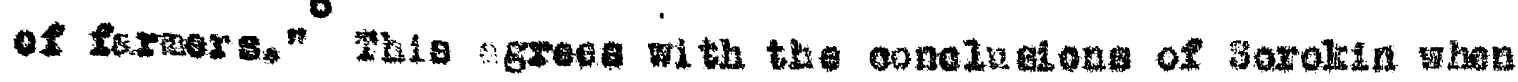

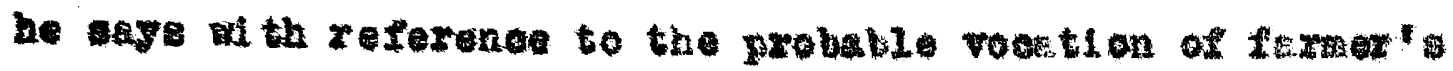

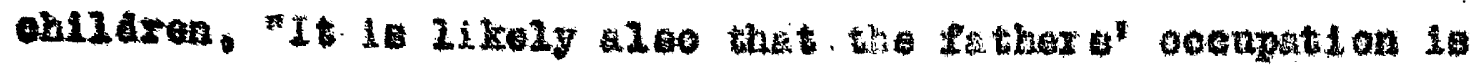
otill entered by the 11aren in a greater proportion than ary other."

It Io probably too woh to blame ox arodt lacoording

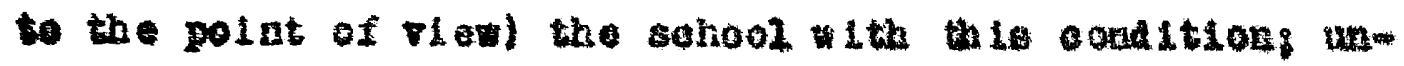

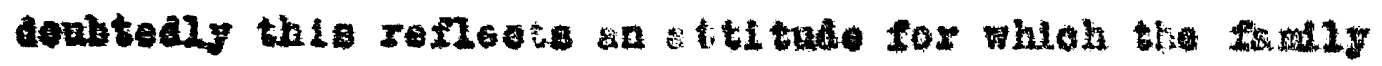

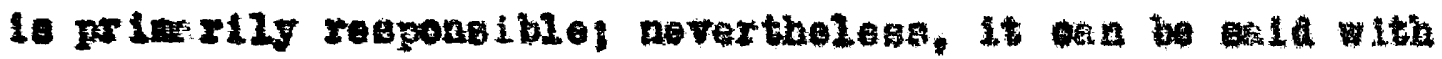
a degroe of foty, thet the cohoola are dolng 11ttle to counterict that foeling. The gehool. whoh f, axpported by

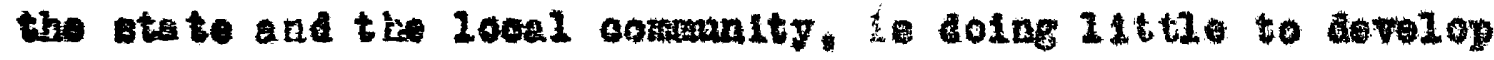
a epirit of appreatstion for the oostond and 2 ta basa oocuption in the soliool otudenta. It lo not fltting thesil

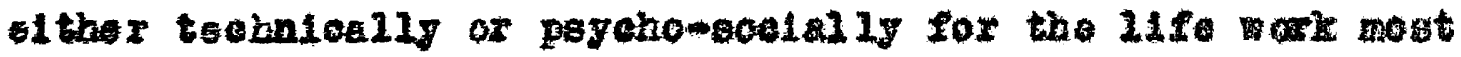

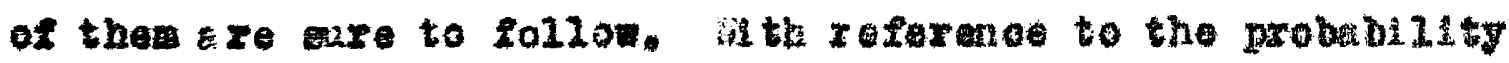

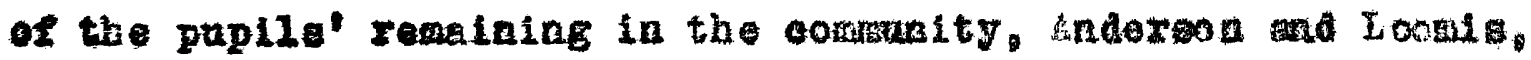

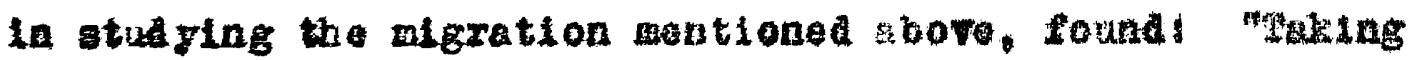
tho group a wole, 80 par ont of all the no and deughters ootzod with a rabla of 26 milos of the prental hone. while 20 per cent loogte orthin 10 miles of the pareatal howe

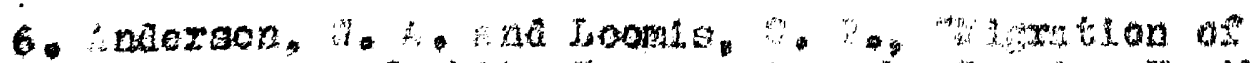

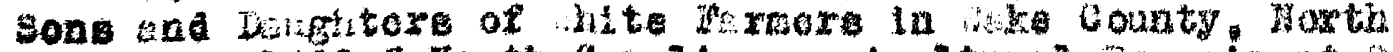

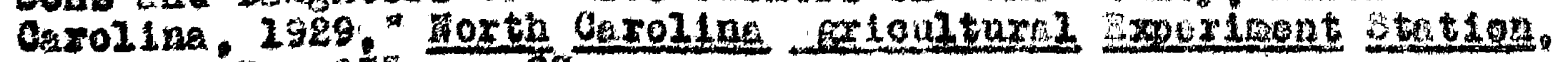
Eullotin $10.275,20$.

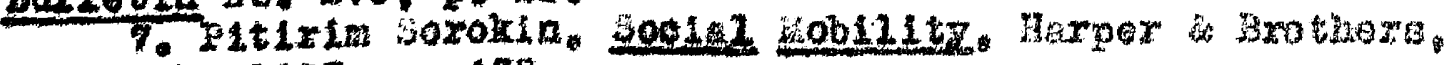
How Tork, $1927,18 * 485$

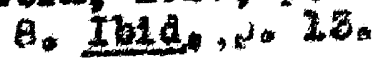




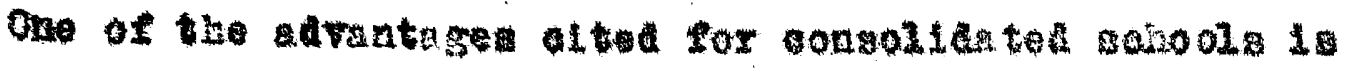

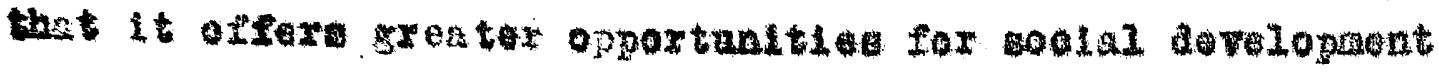

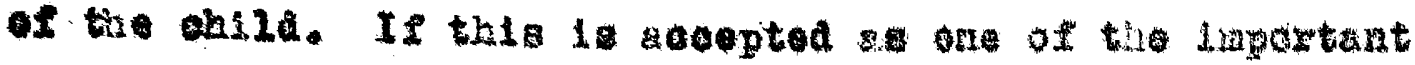

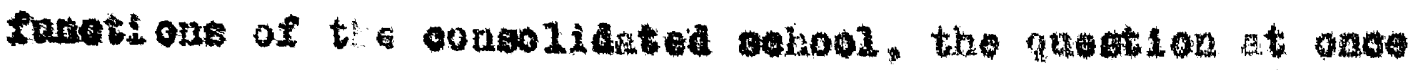

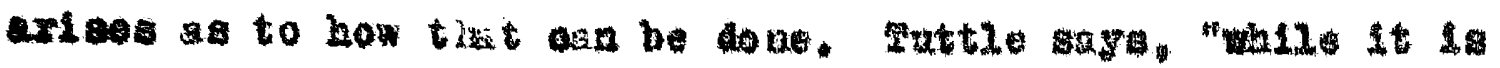

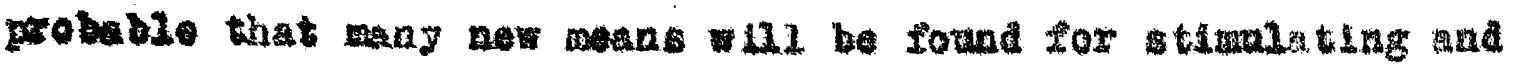

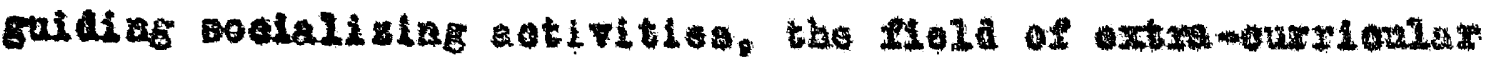

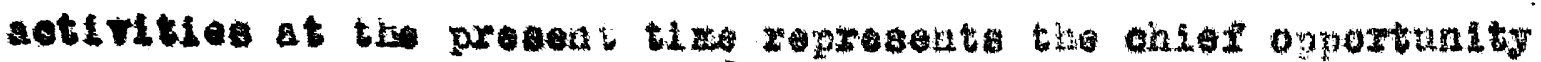

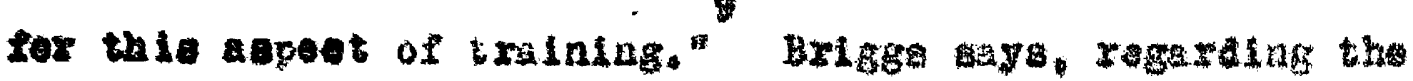
rirtuce of extra-eurrientar activitios.

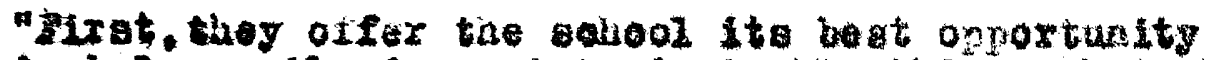
to bolp prpile ao certain deslrsble thinge that they

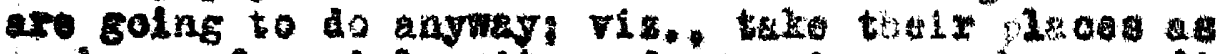

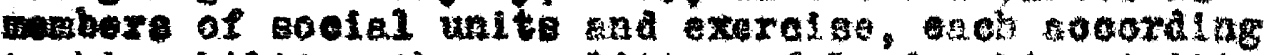

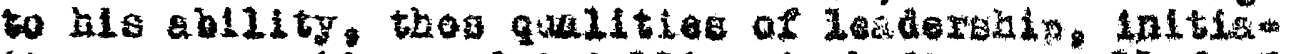

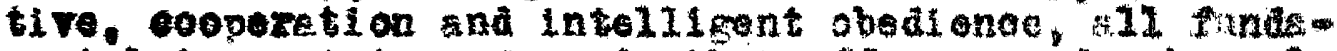

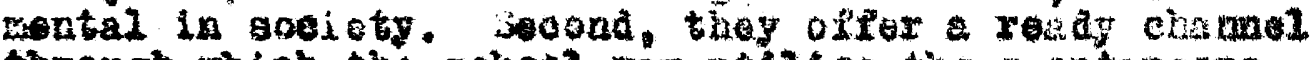

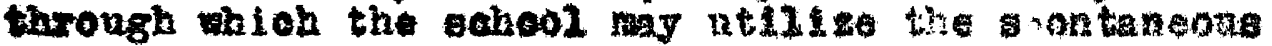
intereat sad activitiob of tine clolescent and through

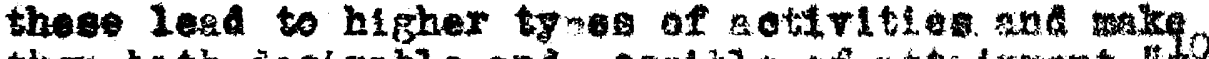
then bo th degirable and opos blo of at te livant."

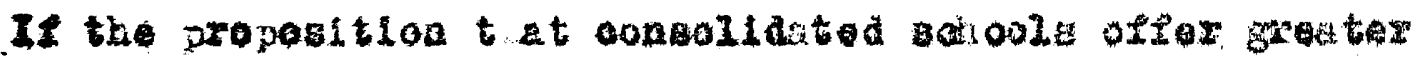

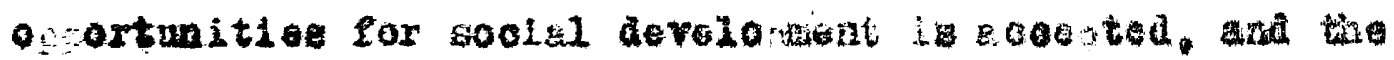

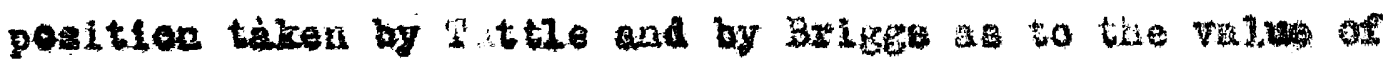

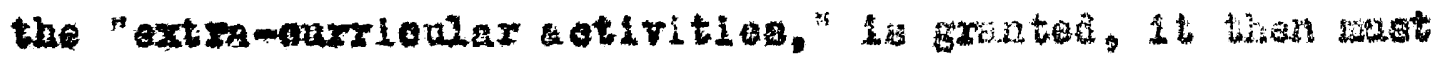

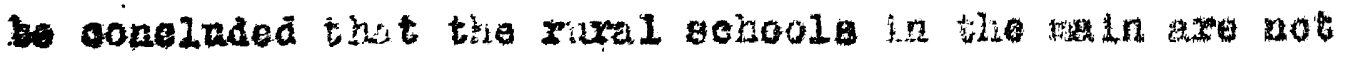

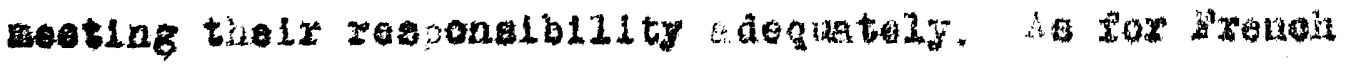

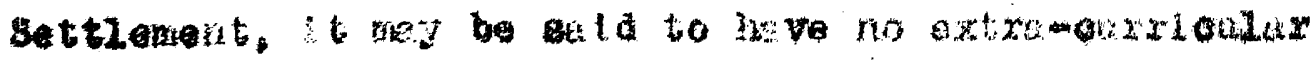

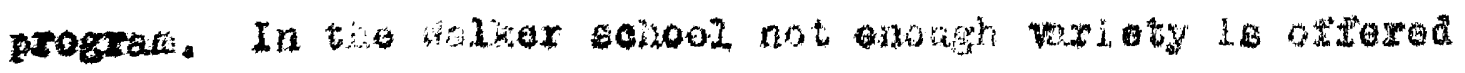

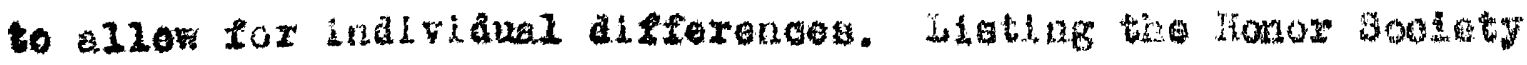

1. Put2o, ou. alt. D. 496.

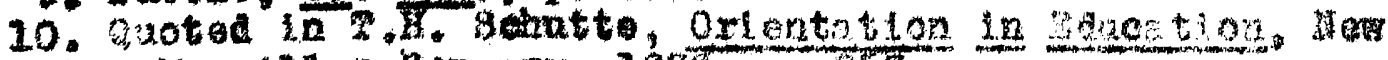

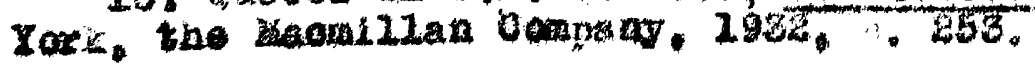


with ita six abers as antra-ourrloulir aotivity, whioh 1t realiy is not, but rather a duvloe for honoring butstanding students, a total of elght aetivities in which the students teke part is found. (See Table XVII.) In the romeville sohool a moh wider selection appears, with band and gloe elub, athletios, rocational, acedenio and reareatlinal activitios having place. Here there are 13 ectivities. (Tabio XxxI.)

Phe question arises as to just what would be a reasonable number of activities to be expected in a sohool. Forhaps the beat answer to the queation would be to see what other choole in afferent parts of the country are dolag. In this regerd it 18 of interest to note some reports made by Sulth of studies of suoh a nature as this.
"In 1917 8. H. Wilds ade atudy wich lnoluded sixty- three sohools, both large and smell, gelected by rendom eapling throughout the nation. Thls revealed a median nuber of 14.2 eotivities per sohool, the median for the larger sohools belug 25.7 per cent, and for the lier schools 13.5 per cent. A study reported in the Nay, 1920 , number of the Amerloan Edueational Digeat Ineluded 1071 large, mediura and see 21 sohools, proa forty-three states. Thls study showed 287 distinct types of extra-ourrioular ao- tivities, not licluding the feneral asserably and clase meeting aetivitles. The grerage number of aotiritles per sohool was 15, 11

alnee I025 the novenent for oxtre-ourpioular activitieg has increased in norentun, and jet oniy one of tine sohools studied approeabes the mediai for sell sobools, according to the etudy of 1917. It seens alsn that in those sohools where the greatest noed apeurs thore is the least whe in the 11ne of out-of-olass activitiog.

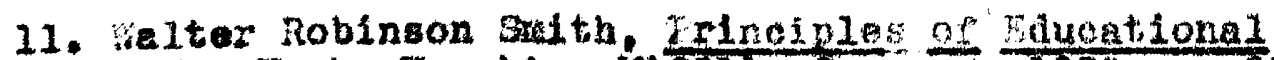
soclologr, hew York, Houghton itfrili Company, 1826, p.684. 


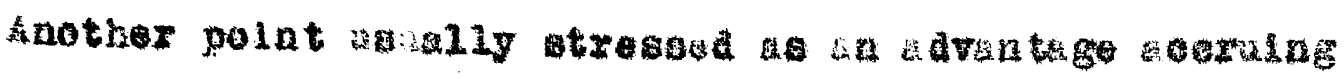

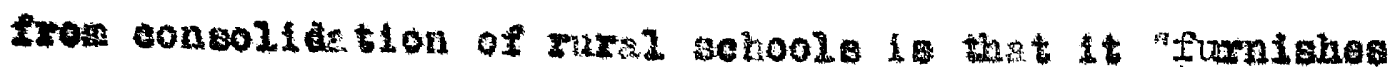

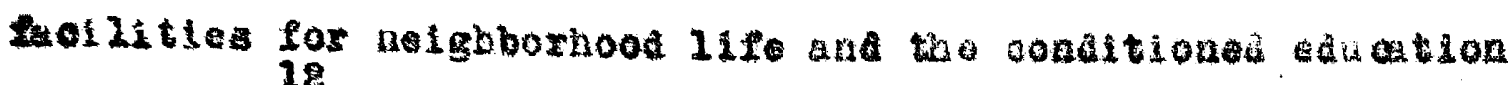

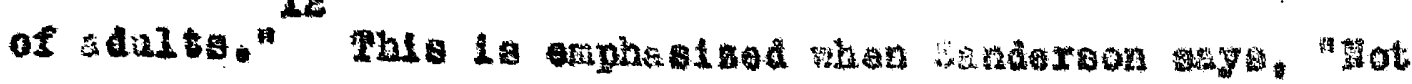

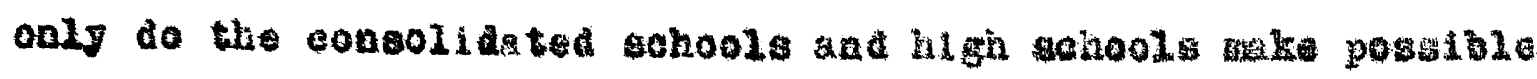

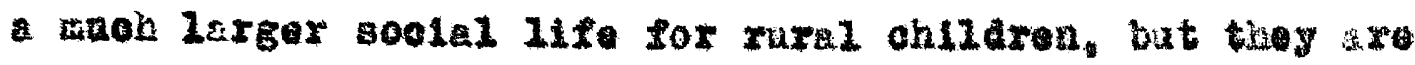

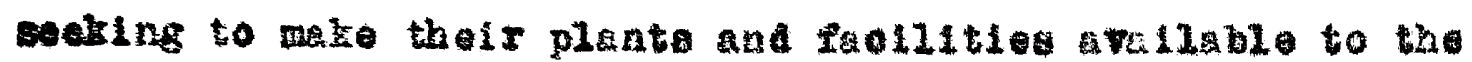
vhole popalation se soolal centere for eomminity $11 f_{0}$ " 13 If the consolideted raral sohosis fumloh fullitios for neighborhood 21fe, stoted above, then oortalnig tho

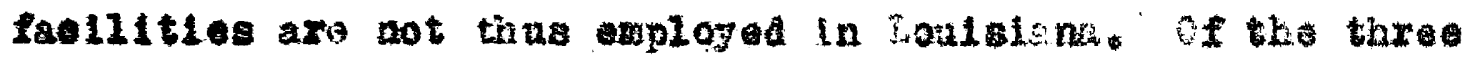

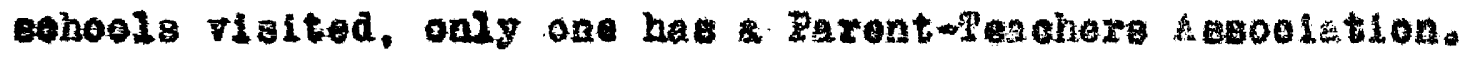
In that sebool, oz of 149 anewers,108 ate to the thelx parente do not belong to the Parent-Teabox issoolation; 40 that they do. onis one in thrae is merar. There is no

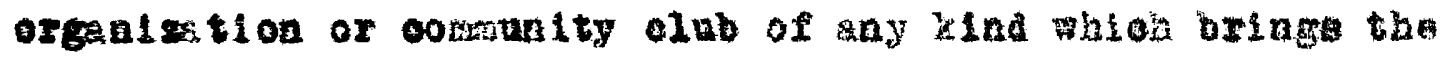
parents to the sehool. Fhere is notring oxoept the interest they have for thelr children ard what they re dolng for the

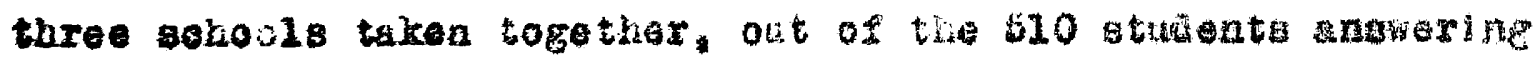
the qagtion, zaz otatod that their perenth hal not rialtod

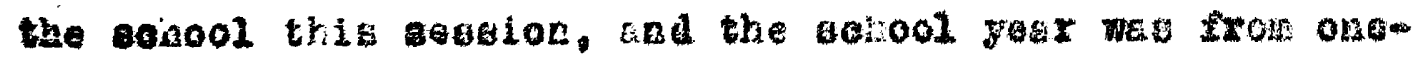

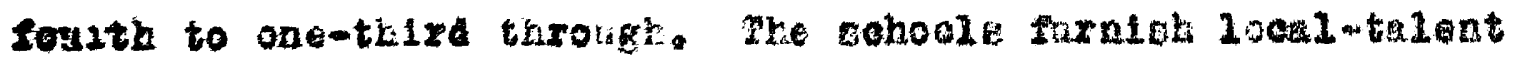
amagements for the oomonity from two to foux times a yos In

12. Glllette, op. alt, $p, 38$,

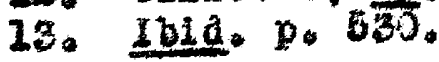




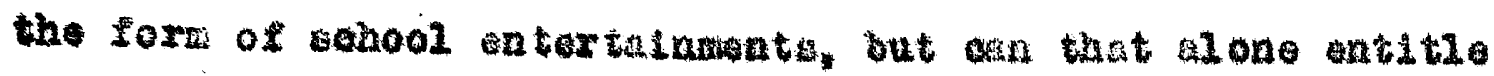

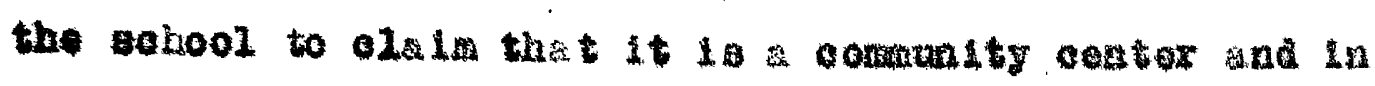
that way aerres a funotion that the one-rook settool of former dsy: dia not aerve?

It 10 ossentigl that partiender atention be pald to the subjecte whah the studente in these rumal sohools are

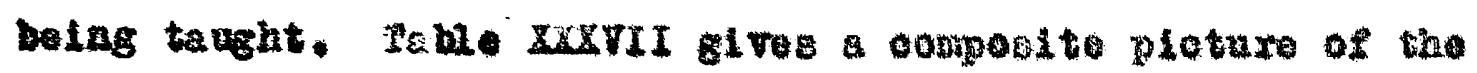
ptudies parswed by the high sehool students, ingligh, alace loar geare is requi red for high sobool gradnetlon, is the sabje ot taken by wost students, (284). Renting very alosezy

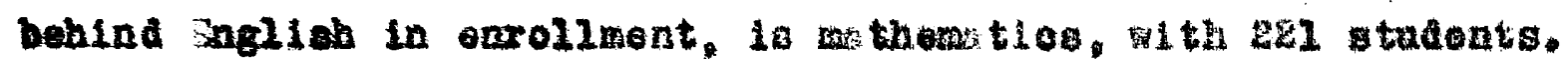

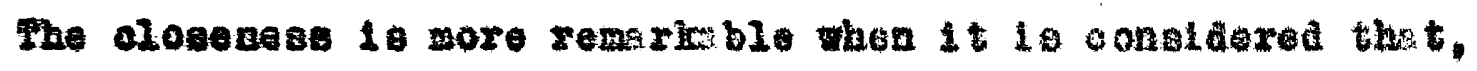
although foux gears of ingllah is roguirod for graduation fron high sohool, only one ant of thomblod lelonentary algobra) is required. In the fleld of coolal selonoe, 97 ogt of 148 parsue the traditlonil history cowa, one year

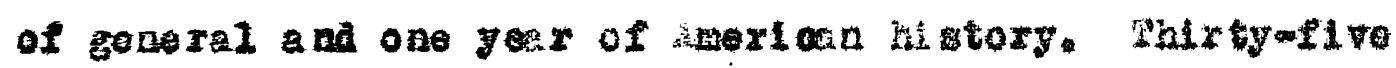

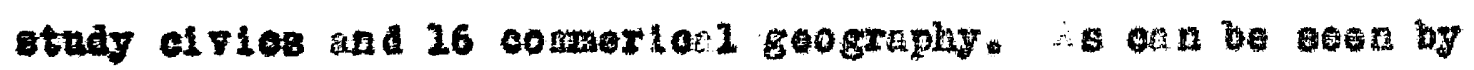

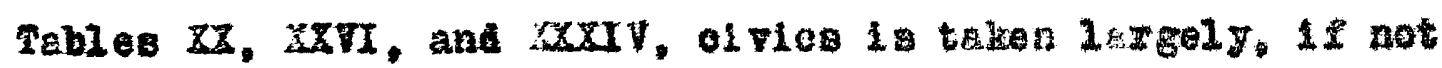
excluatrely. by those who do hot atza bous econonitos ox

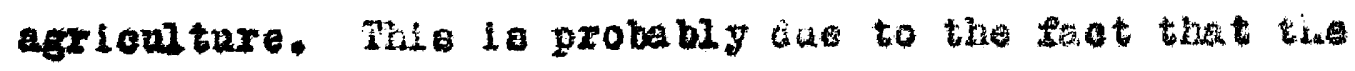

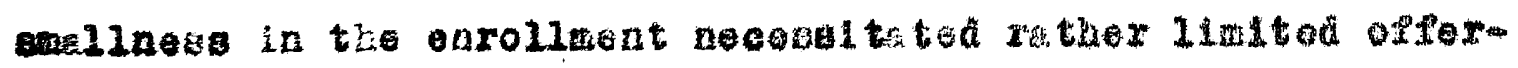

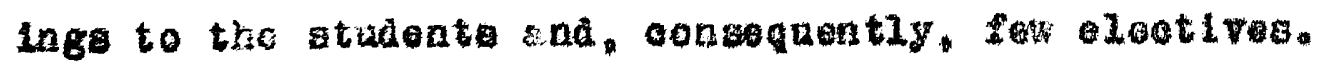
This is wet by allowing the stadente to oksose botweon home

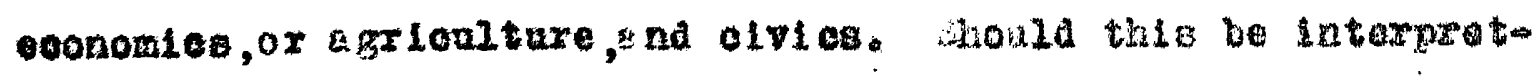
ed to nean that only the non-roestonal studente aed 


\section{Table XXIII}

High Sekool dubjeots studied by jtudents in throe

Lous atane steral Sohoolo

\begin{tabular}{|c|c|c|}
\hline Spbioets & $\begin{array}{l}\text { Stadont } \\
\text { unguer }\end{array}$ & $\begin{array}{l}\text { BEudytae } \\
\text { Ber goat }\end{array}$ \\
\hline Saglish & 234 & 200.0 \\
\hline 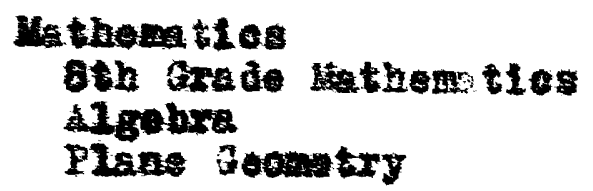 & $\begin{array}{r}291 \\
78 \\
79 \\
64\end{array}$ & $\begin{array}{l}94.4 \\
35.3 \\
32.8 \\
27.4\end{array}$ \\
\hline $\begin{array}{l}\text { Solenes } \\
\text { Ceneral selense } \\
\text { Blology } \\
\text { Physies } \\
\text { Obonistry }\end{array}$ & $\begin{array}{r}176 \\
36 \\
206 \\
21 \\
15\end{array}$ & $\begin{array}{r}75.2 \\
14.5 \\
45.0 \\
9.0 \\
6.4\end{array}$ \\
\hline 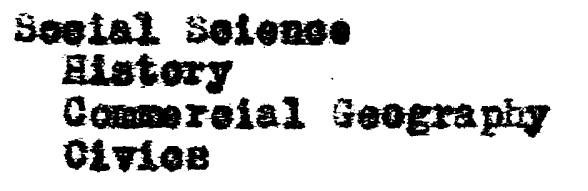 & $\begin{array}{r}146 \\
97 \\
16 \\
36\end{array}$ & $\begin{array}{r}63.2 \\
41.5 \\
6.8 \\
25.0\end{array}$ \\
\hline 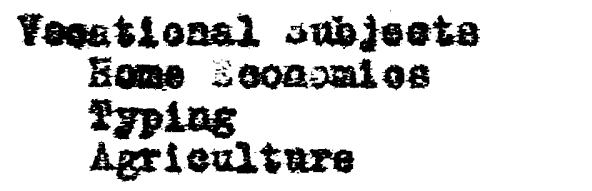 & $\begin{array}{r}163 \\
122 \\
86 \\
6\end{array}$ & $\begin{array}{r}69.7 \\
52.7 \\
25.0 \\
2.6\end{array}$ \\
\hline Farelgn Langoate & 65 & 27.8 \\
\hline
\end{tabular}

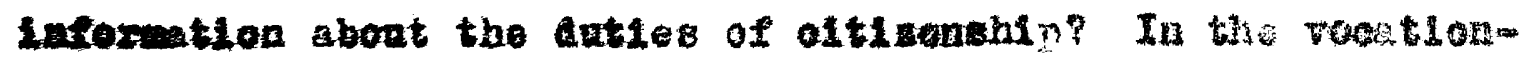

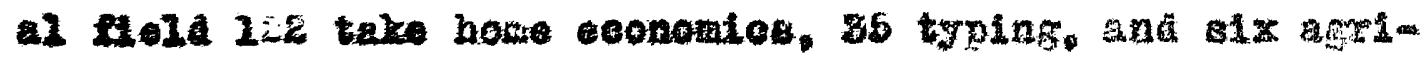
enture.

The olafw ba been rade that tho acheola are governd In their offeringe by the college-ontrunoe xaculrements

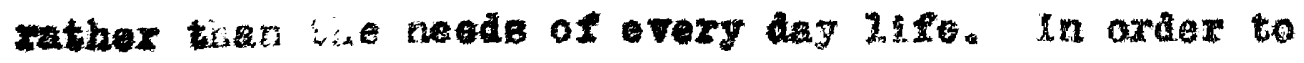

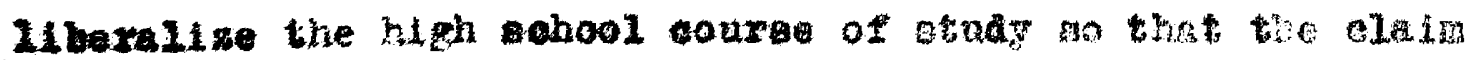

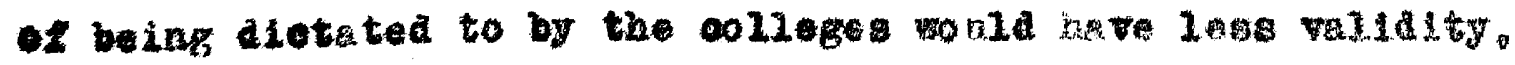


the State Boarl of adueation has made meny changes in the requirements for graduation from state-approved high schools. It is of laterest to follow thase for the pent decsde and a helf. Jxamining the state course of tuay for 1920, the following roquirements for graduct on fom a state-approved high sobool appoar:

English 3 units

Ha theme ti os 2 units

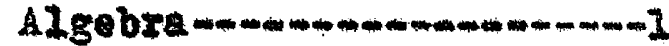

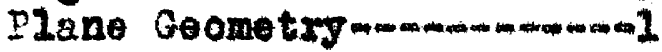

Soleneo-n-m-nom

Blologleal (botany. 200108y a na phyalolog / Physioal (ahemistry or physiog)

Elatory-

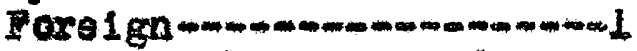
therles history and

civ160-10

A total of 9 unite was required, and a vide gelection os electiver paralo posolo.

In 1929 the approved oourge of atudy was allows:

Eng11 gh-

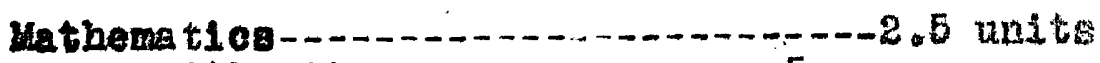
Aritrie tic-...............

Algebra

Plano Geometry-........-.

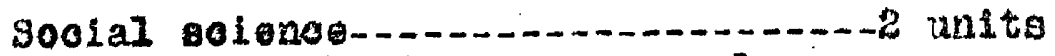
General hi etory-........-1 smeriean history-......-.-1

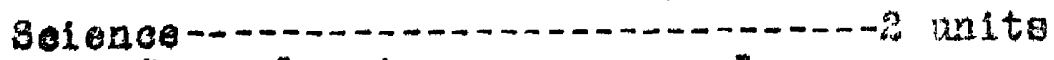
General solenoo-.......--1

Chemistry or physics--.--1

Forolgn langugo or rocatl onal subject-2 units

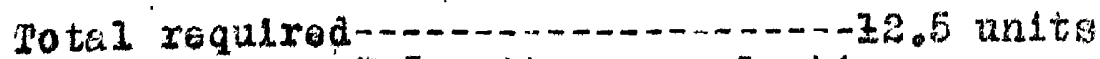
The renaining 3.5 units were eleotivo. 


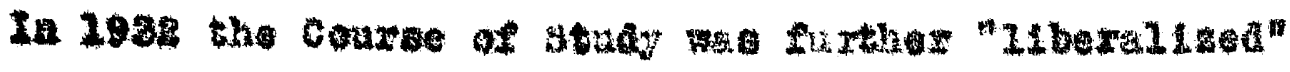

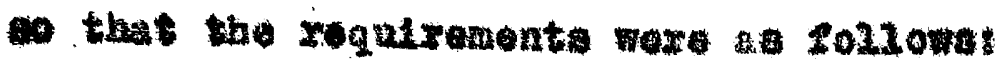

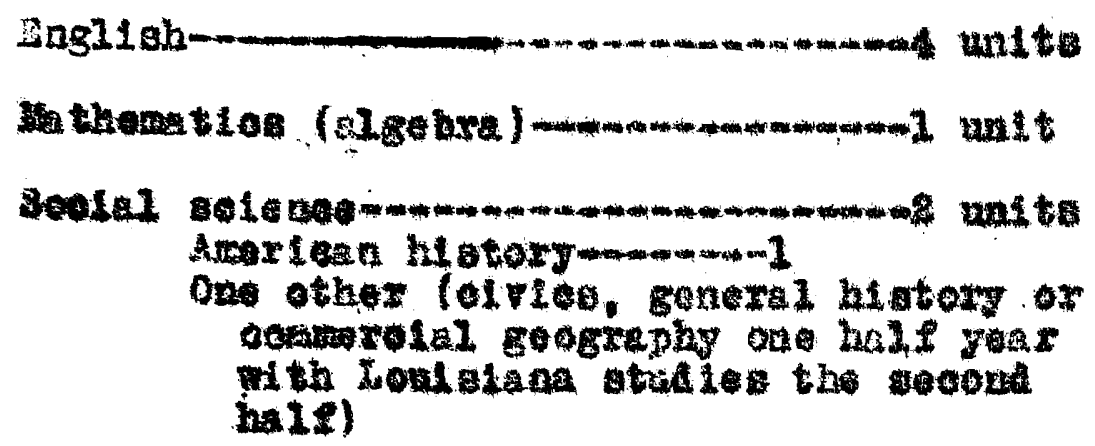

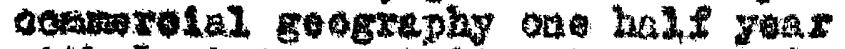

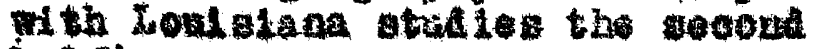
hale)

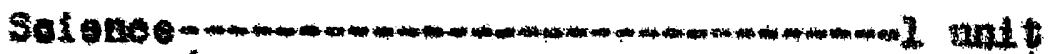 (sither blologe or generel botanee.)}

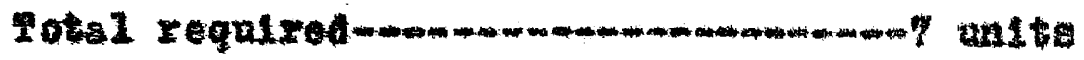

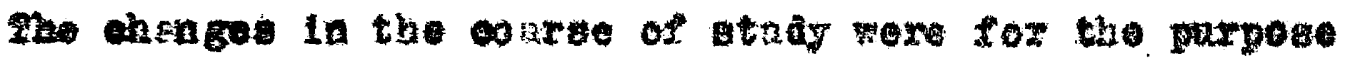
ol wing it posalble for high cohools to offer andocto other the those cealgnet for college ontrance, certaln tradtional

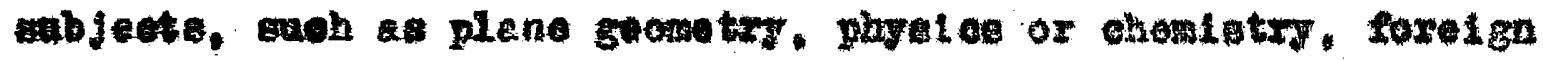

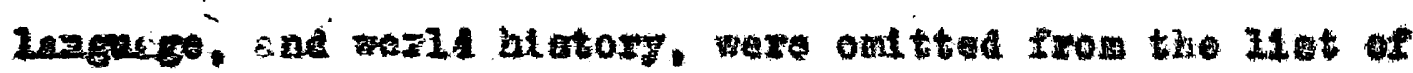

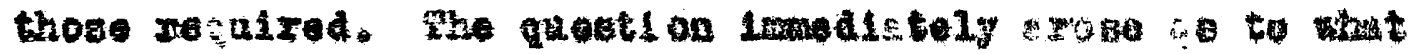

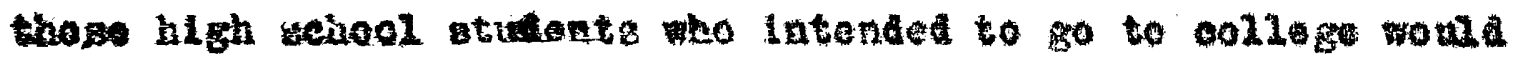
40. The grestion was aoon nettled in Loulstan by the

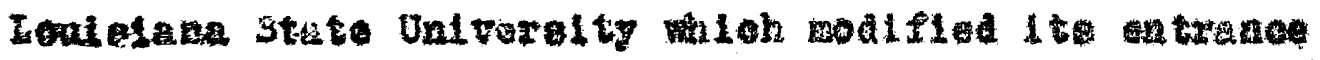

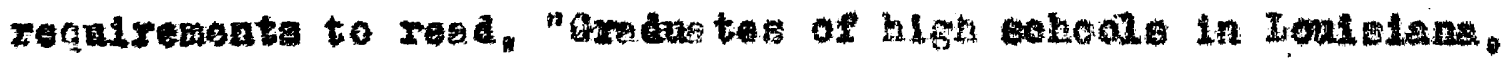

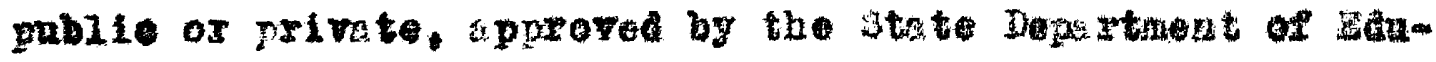

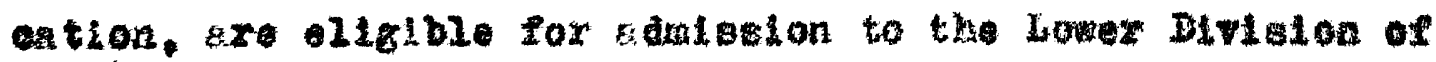
the Univeraity on preatutation of alplome of certiflente of

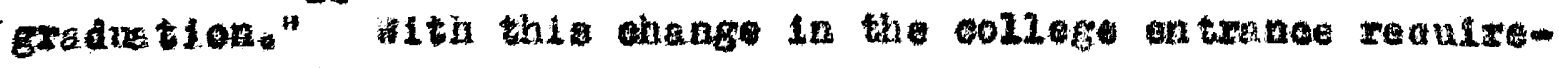

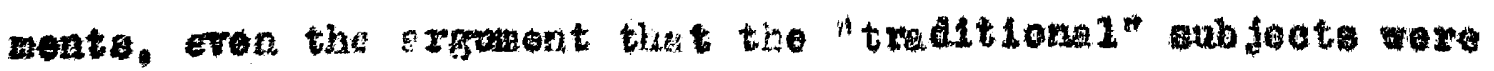
required for those bidente who intuded ho enter college

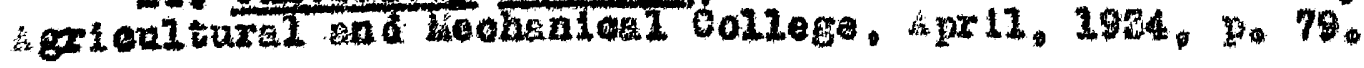




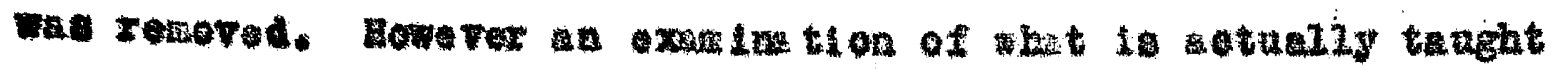

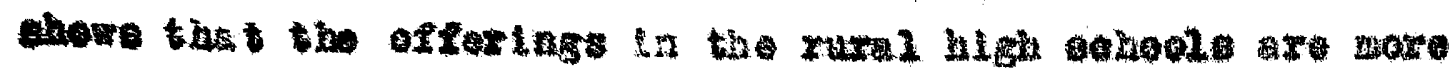

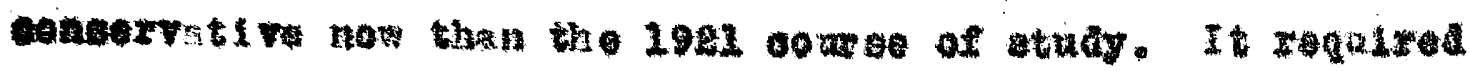

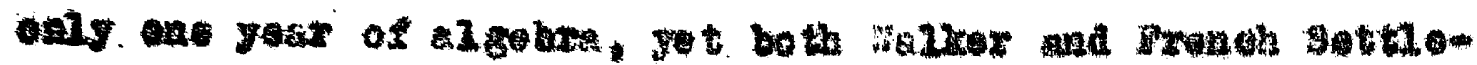
weat otudento take two jears; no forolga languge zegulned of the 1921 courge of atudy, bat avery one of the

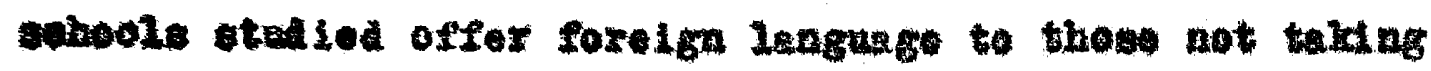
heme bencmi on.

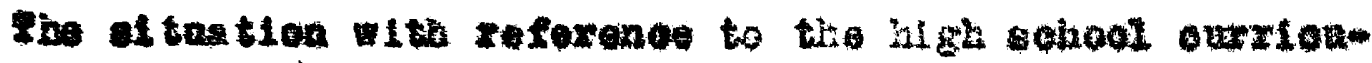

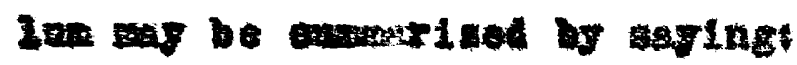

2. The practice in the asleotion of pubjoota to be taght

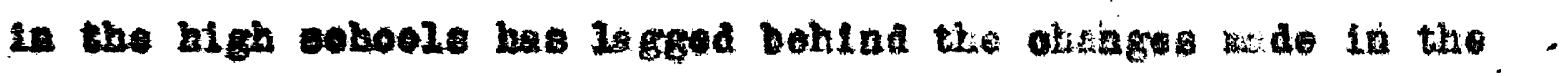
etate couree of otroly.

2. Holiftcation of the offerthes wo that necte of the

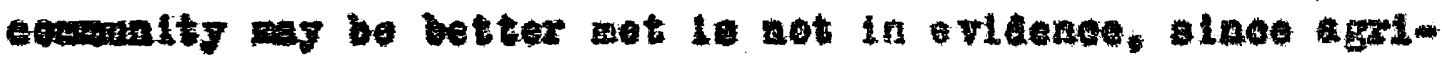

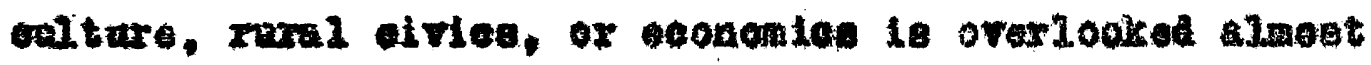
entirely.

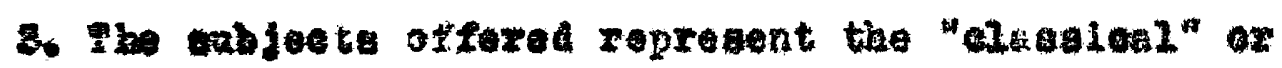

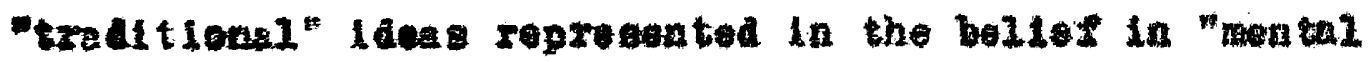
Alealplas" ox "inalreet relaes" ruther than the "practios" ex "alreet Yrines" beller.

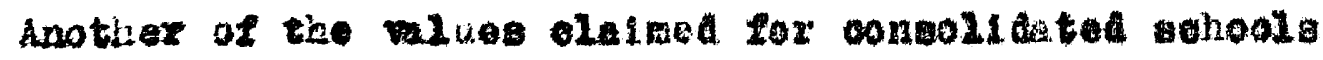

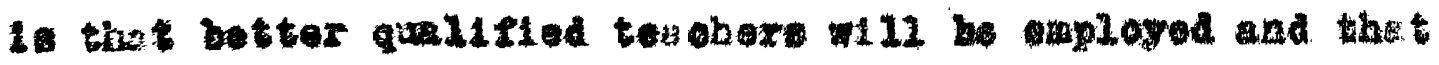

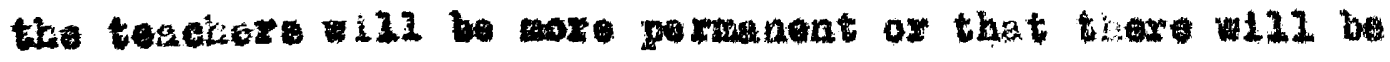

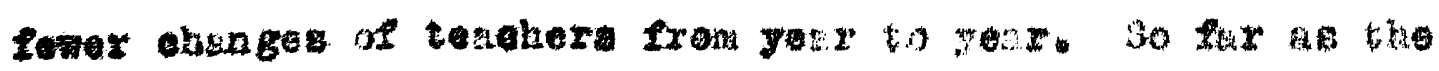

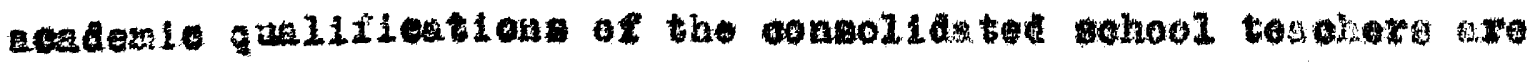

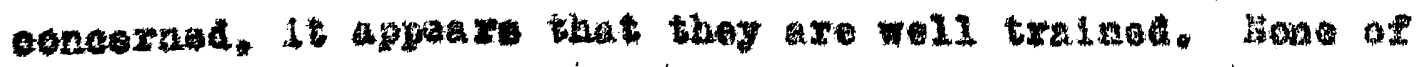

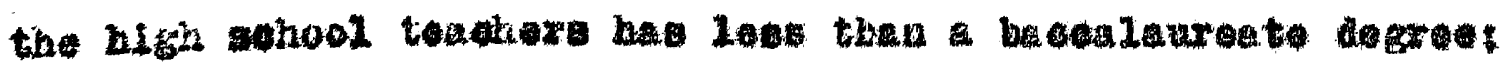




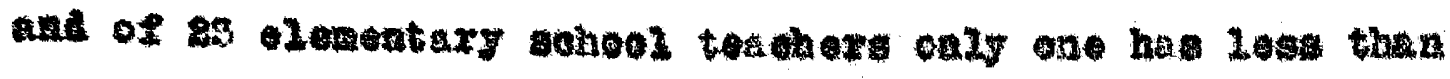
two years of oslage trelaing. bavoral hote thre and on

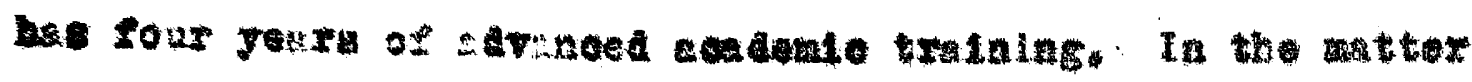

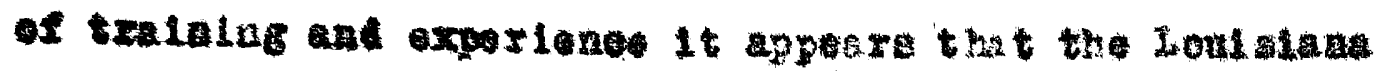
teachere sx not "untral nol and snexperloned."

Nthough the tecobero apper to be well trainod and to

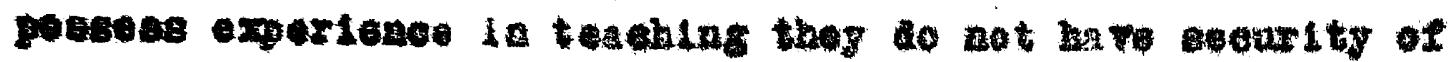

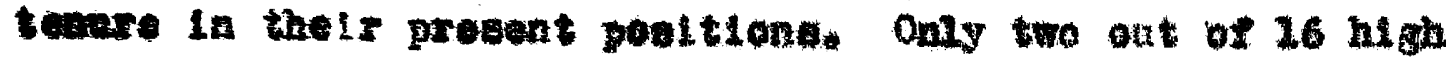

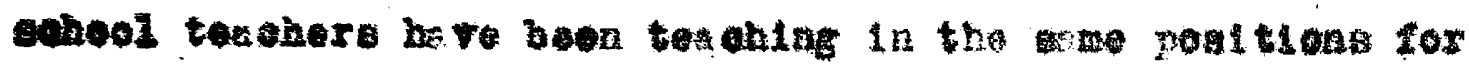
we thas fou gears, and 18 ta beo mployed thore leas tran

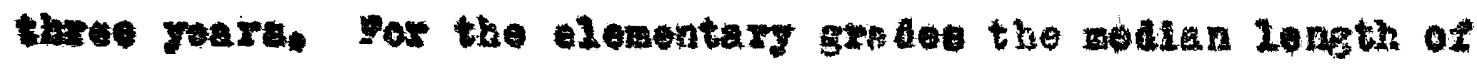

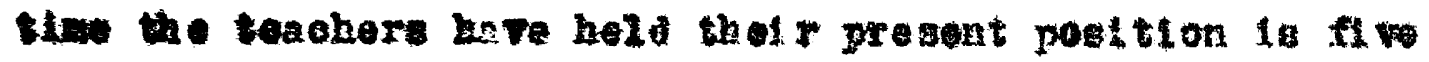

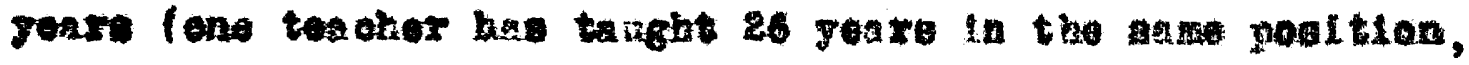

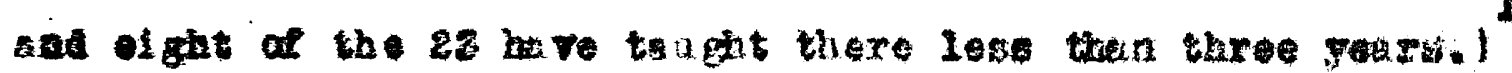

Interenting factere a selosed in study ing the

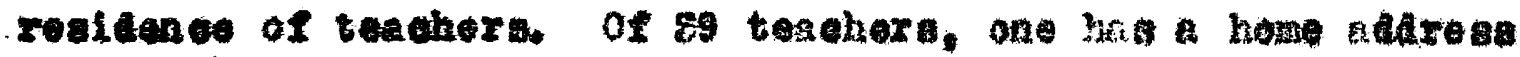

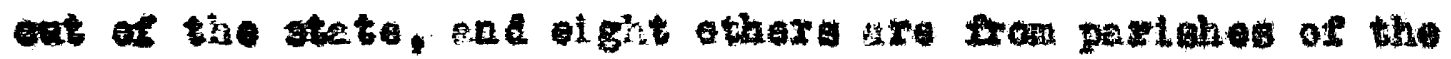
otate other than the oise in which thoy so teching. fbout

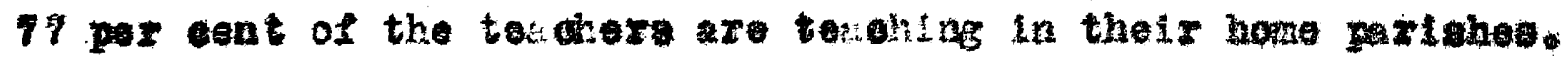

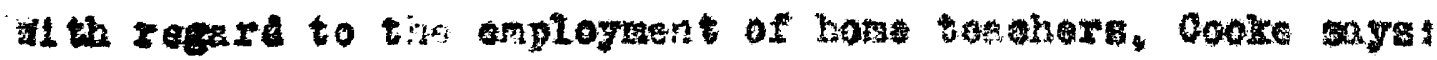

"here thare aro too any home-trlent tacthera th ingtruet fon beogies provinoial an loot I to the extent

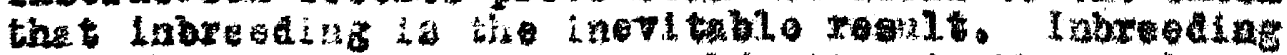

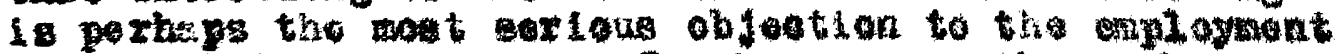

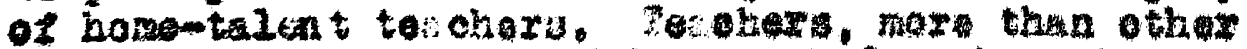

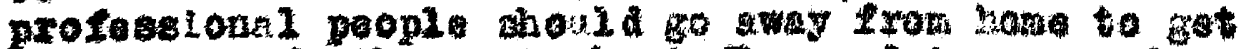
tho 1des of othigel to be inginanog in naw and aif ferent wayon "Is

15. Tha gastion of tenure is of latereat in Loulstana

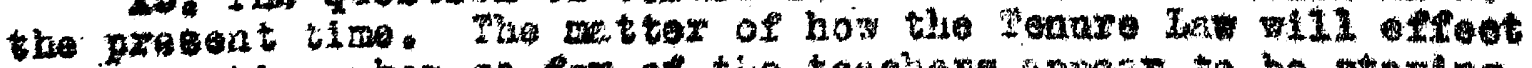

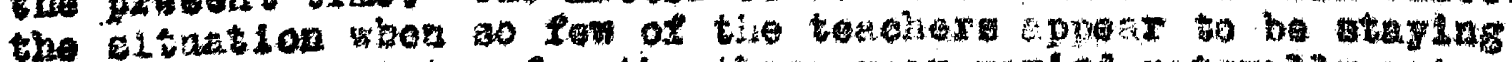

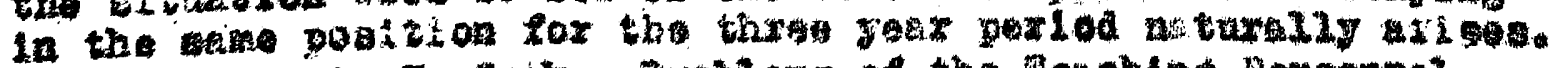

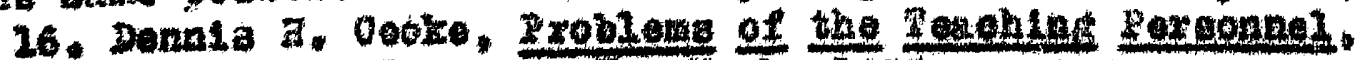

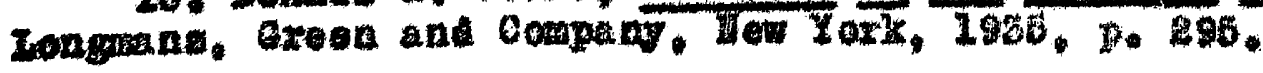




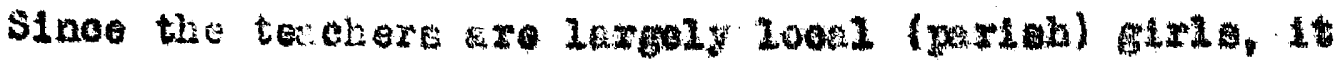

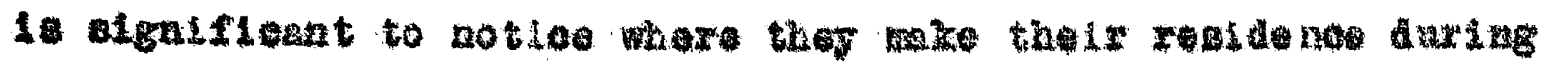

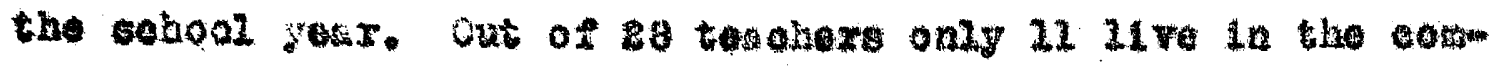

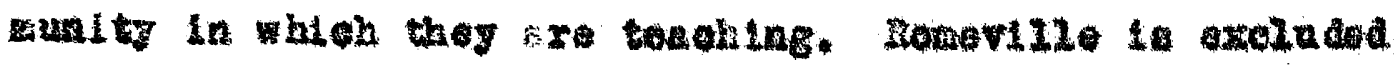

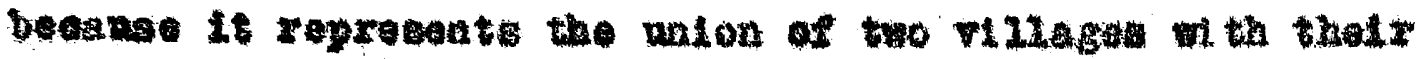

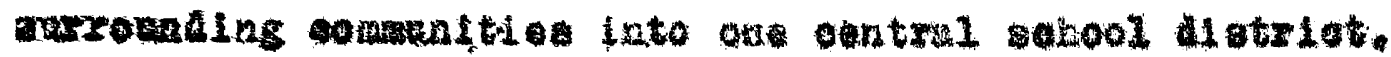

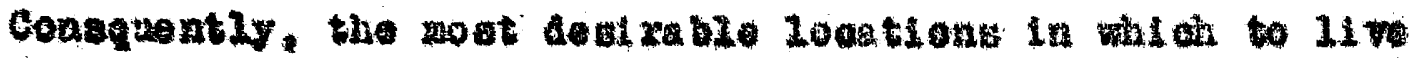

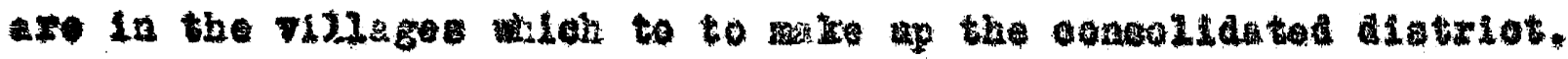

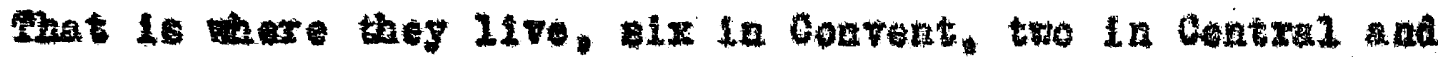

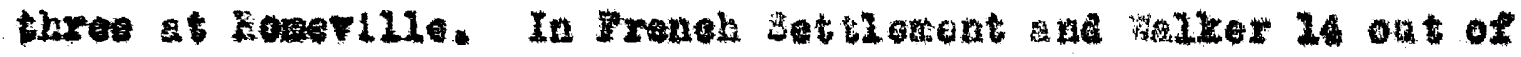

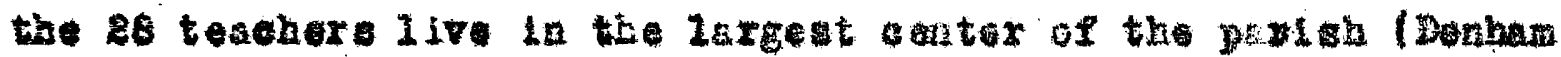

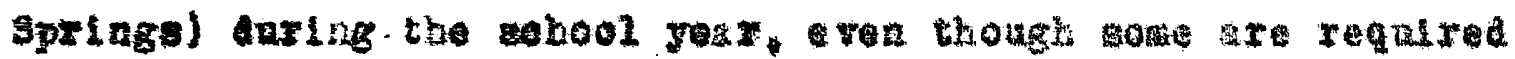

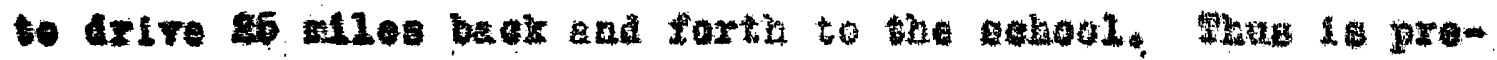

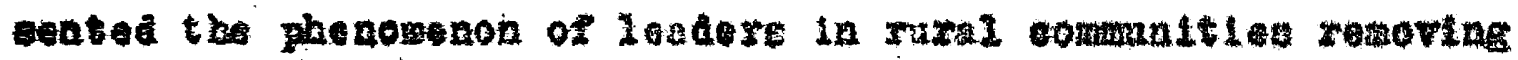

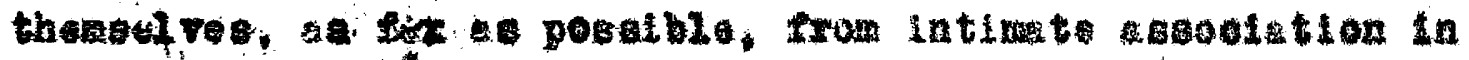

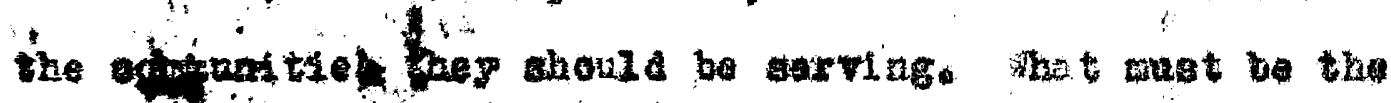

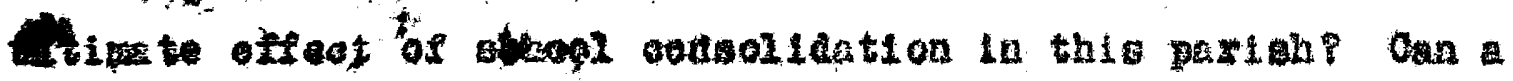

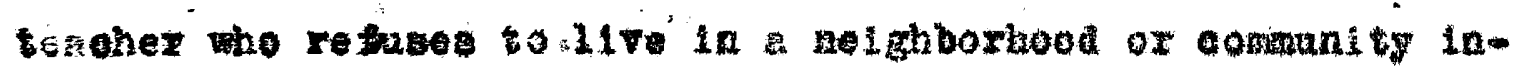
epire an steetson sud respet for that companity on the prot of the stidente? Here to

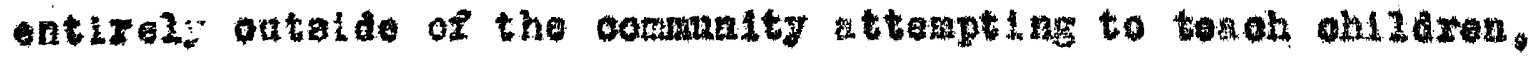

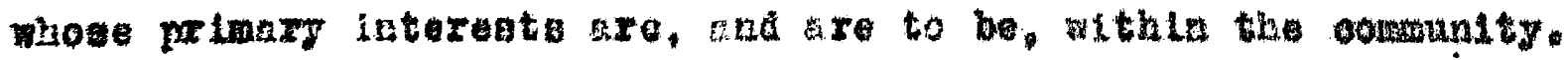

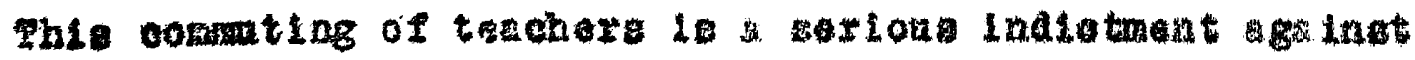
this tgoe of sobool oxgatiation. 
Section

The Sural Consolidated Blgh Sohool Loated in the V111age Centero

In this geotion the atudy is deroted to a conglder ation of the consolicted sohools which se looktod in village centere and serve the ahildren of the outlying alotrioto ar wl1 as those of tho village. For this parpose to sohools have been ohoeen as repregentative of tholr olags. They aro the Langhan High Sabool and the luteher Flgh Sehool.

The Hanghan Elsh Sohool: Hangham is a aroll inoorporated vilege In alehland Farigh in the porthet part of tho stato.

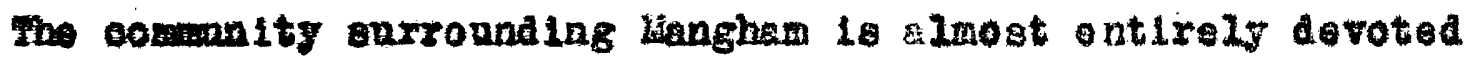
to agrionlture, with cotton constituting the prinolpal erop. The rillage is in the conter of a fortile agrioultural area

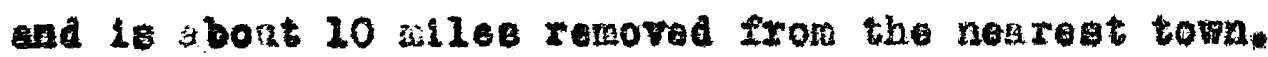

The sohool ha grown frow a one-room school, which was orgenisea in 1891. to an ibstitution housed in plant oooting nearly 550,000 as it stands todag. The bul101ngs, oonsioting

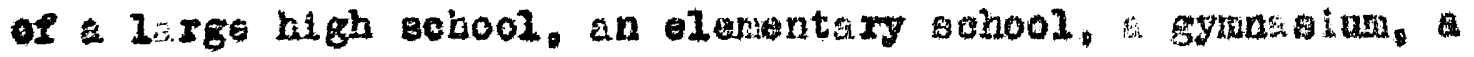

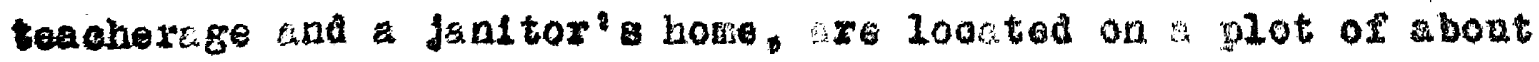

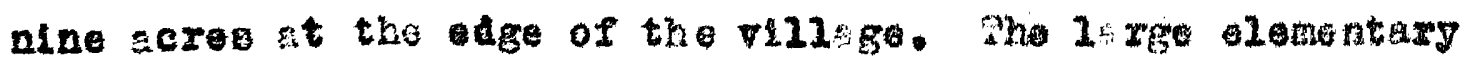
sohool bullding and the high sohool builang are conneoted with

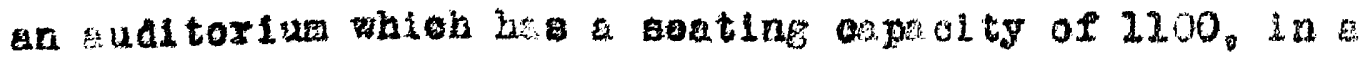
manner thet forme a large D. Baket-bell games are played

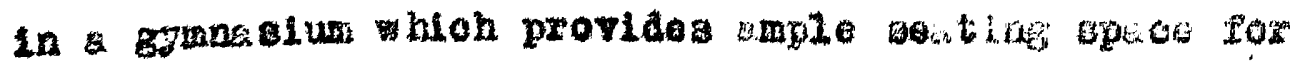


spootators, and in a seotion of the bulalas whoh.honges

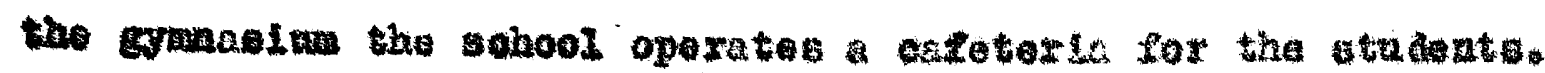

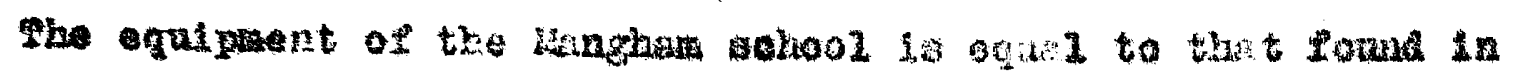
any othex sebook of 1 to site in Louishan.

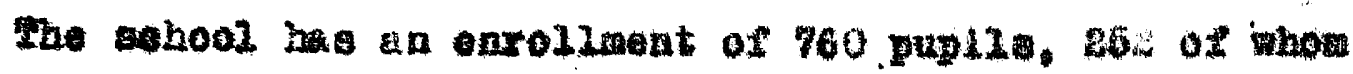

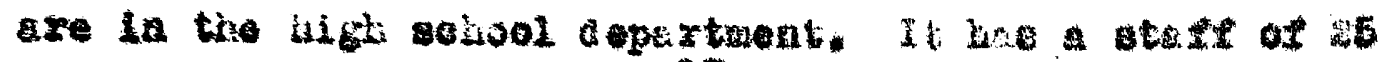
teschers sud to janitura. 17

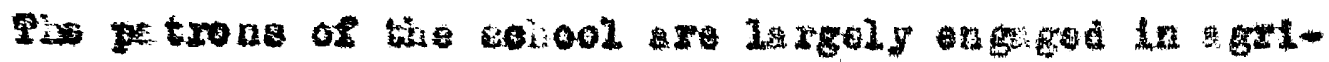

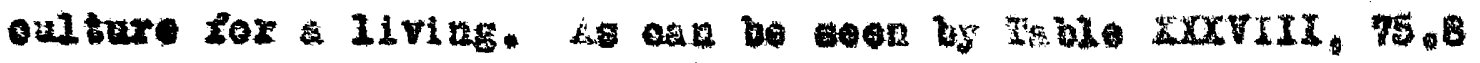
per cont of the stadents above the thira grado listod famiag

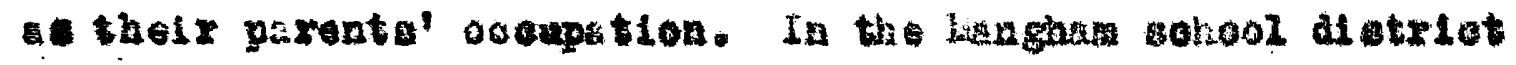

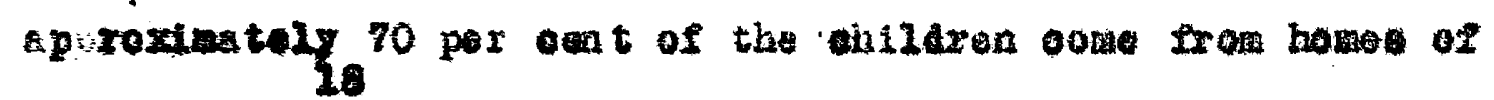

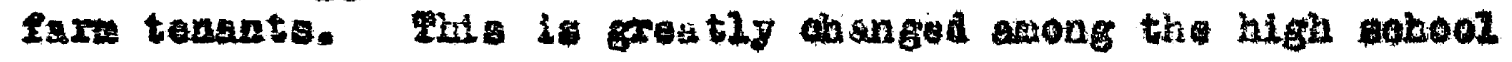

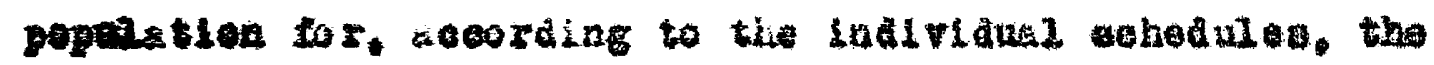

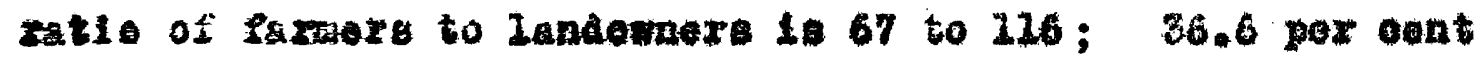

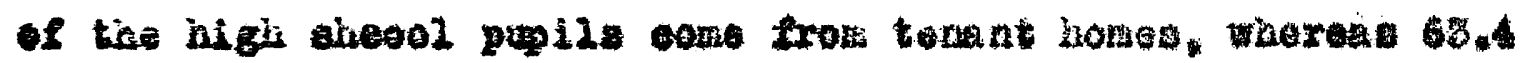

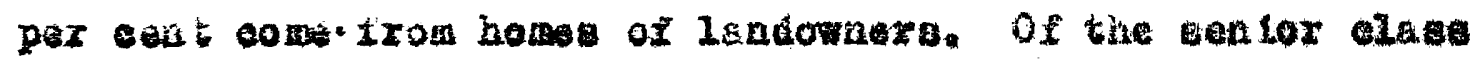
in ligh sohool. 32,4 per cont of the at wentes are ron the

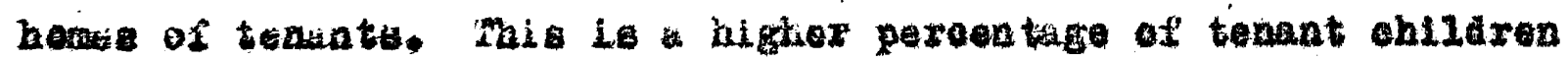

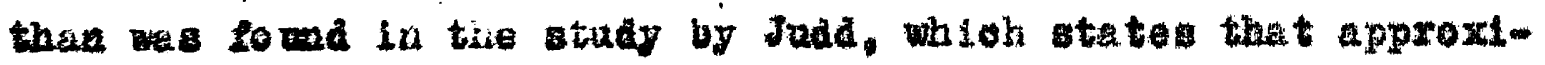

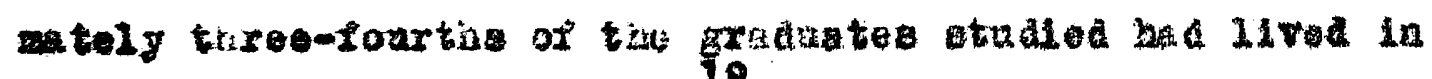

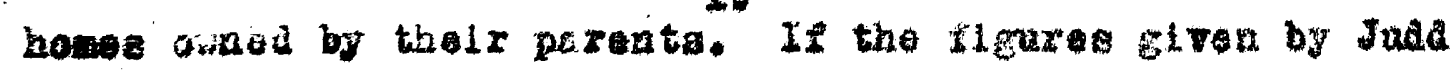

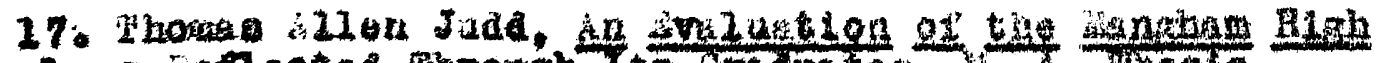

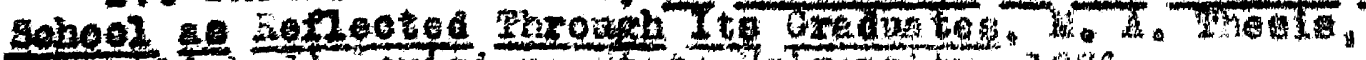

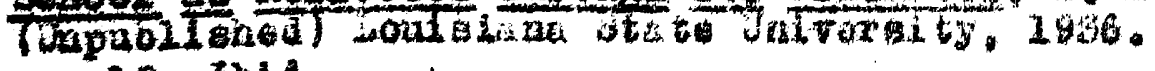

18. Ibld.

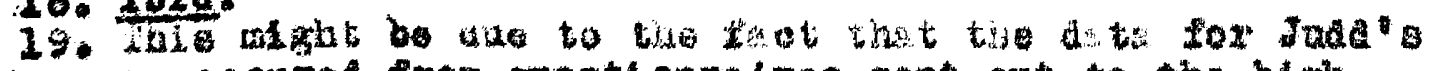

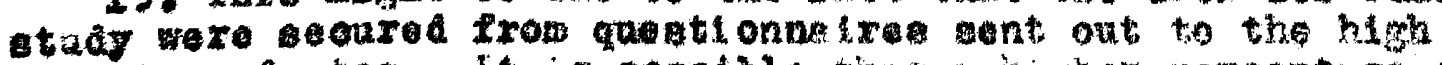

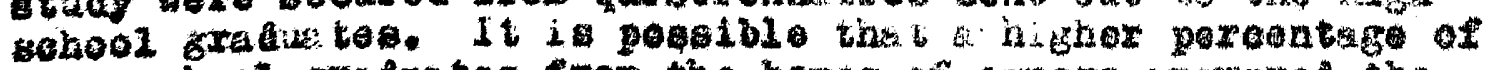

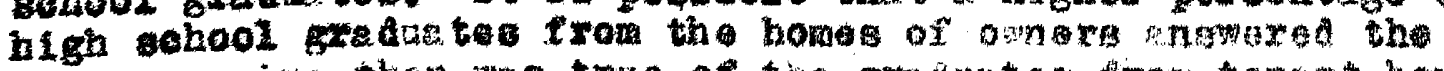

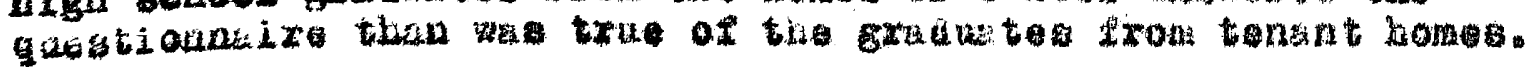


Table XXXYIII

Deoupetions of the Parents of Students of the Hanghem

Sebool

\begin{tabular}{|c|c|c|c|c|}
\hline Degureations & $\begin{array}{l}\text { inga } \\
\text { number }\end{array}$ & $\begin{array}{l}\text { Door } \\
\text { Por cent }\end{array}$ & $\begin{array}{l}\text { Elemen } \\
\text { Number }\end{array}$ & $\begin{array}{l}\text { IFy Sohool } \\
\text { Pers Cent }\end{array}$ \\
\hline $\begin{array}{l}\text { Farmax } \\
\text { Inborer } \\
\text { Perahant } \\
\text { Cas company Worker } \\
\text { Pablic Worker }\end{array}$ & $\begin{array}{r}171 \\
13 \\
9 \\
10 . \\
9\end{array}$ & $\begin{array}{r}70.1 \\
5.3 \\
3.7 \\
4.1 \\
3.7\end{array}$ & $\begin{array}{r}220 \\
8 \\
7 \\
4 \\
2\end{array}$ & $\begin{array}{r}82.7 \\
3.0 \\
2.6 \\
1.5 \\
0.8\end{array}$ \\
\hline $\begin{array}{l}\text { Hochande } \\
\text { Throreotant orfieer } \\
\text { Painter } \\
\text { reacher. } \\
\text { Clext }\end{array}$ & $\begin{array}{l}4 \\
4 \\
2 \\
2 \\
3\end{array}$ & $\begin{array}{l}1.6 \\
1.6 \\
0.8 \\
0.8 \\
1.2\end{array}$ & $\begin{array}{l}4 \\
2 \\
4 \\
3 \\
2\end{array}$ & $\begin{array}{l}1.5 \\
0.8 \\
1.5 \\
1.1 \\
0.8\end{array}$ \\
\hline 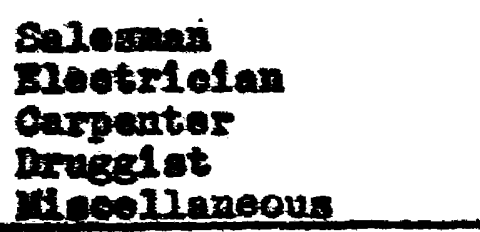 & $\begin{array}{l}2 \\
2 \\
2 \\
2 \\
9\end{array}$ & $\begin{array}{l}0.8 \\
0.8 \\
0.8 \\
0.8 \\
3.7\end{array}$ & $\begin{array}{l}\frac{2}{1} \\
\frac{1}{2} \\
\frac{2}{5} \\
\end{array}$ & $\begin{array}{l}0.8 \\
0.4 \\
0.4 \\
0.4 \\
1.8\end{array}$ \\
\hline Dotal & 244 & 100.0 & 266 & 100.0 \\
\hline
\end{tabular}

Tab2o $\operatorname{cocx}$

Oecupational Preferenee of the Students of the Manghem

Sehool

\begin{tabular}{|c|c|c|c|c|}
\hline Deoupations & \multicolumn{2}{|c|}{$\begin{array}{l}\text { High 39hool } \\
\text { Number Per Cent }\end{array}$} & \multicolumn{2}{|c|}{$\begin{array}{l}\text { Elementary SOhool } \\
\text { Number Per Cont }\end{array}$} \\
\hline $\begin{array}{l}\text { Turse } \\
\text { Teachor } \\
\text { Farwer } \\
\text { C1erk* } \\
\text { ATlator }\end{array}$ & $\begin{array}{l}10 \\
10 \\
37 \\
32 \\
15\end{array}$ & $\begin{array}{r}20.5 \\
9.7 \\
13.0 \\
16.4 \\
7.7\end{array}$ & $\begin{array}{l}40 \\
58 \\
34 \\
15 \\
16\end{array}$ & $\begin{array}{r}16.9 \\
24.5 \\
14.3 \\
6.3 \\
6.8\end{array}$ \\
\hline 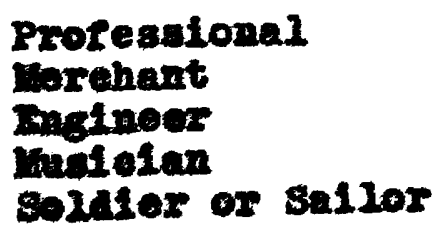 & $\begin{array}{r}14 \\
5 \\
14 \\
8 \\
6\end{array}$ & $\begin{array}{l}7.2 \\
2.6 \\
7.2 \\
4.1 \\
3.1\end{array}$ & $\begin{array}{r}12 \\
20 \\
8 \\
12 \\
6\end{array}$ & $\begin{array}{l}5.1 \\
8.4 \\
3.4 \\
5.1 \\
2.5\end{array}$ \\
\hline $\begin{array}{l}\text { Athlete } \\
\text { iliecelianeous }\end{array}$ & $\begin{array}{l}3 \\
2\end{array}$ & $\begin{array}{l}1.5 \\
1.0\end{array}$ & $\begin{array}{r}5 \\
11\end{array}$ & $\begin{array}{l}2.1 \\
4.6\end{array}$ \\
\hline 103aI & 195 & 100.0 & 237 & 100.0 \\
\hline
\end{tabular}


for the lienghen dietriat a re courn te end the statenente

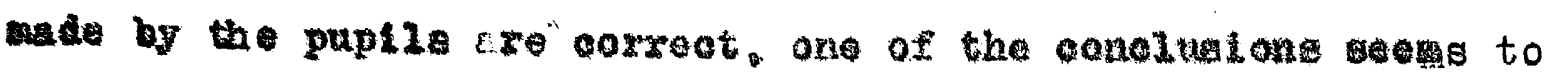
be justifled: (1) ather grater almination of pupla exom gohool bo tuken pl oe in tho lower graded or (2) that the perents of the chilaren from tenont homed ta group of younger peoplo than the pereats of the jortty of the hidh wehool paplie, and that their ohildren have not yet rosohed ingh sahool age. As it apperra now, 70 per ont of the hames furntsh just 36.6 pex cent of the high wehool population and only 62.4 per sent of the sentor alsae.

A study of whet the stadente of a sonool engase in as an cesuption after lecving sohool is laportant la orier to deternatne the courses which should be pargued in the odhool if 16 18 to propse those studente to "do bester the deariblo things

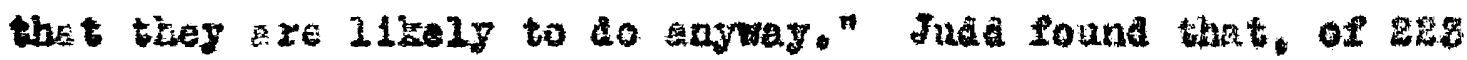

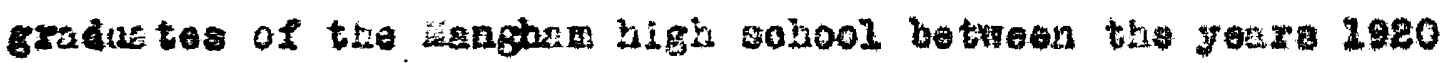
and 1985, 62 meze keping houre, 40 were students in other Latitutioas, 28 gere fareing, and 20 were teching. In ether words, 12.5 por oent were ferming and 27.8 per cent were

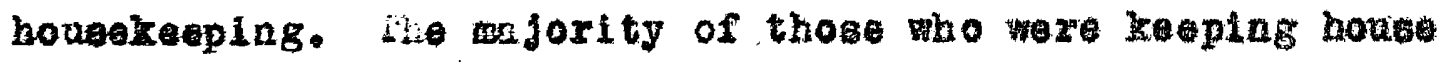

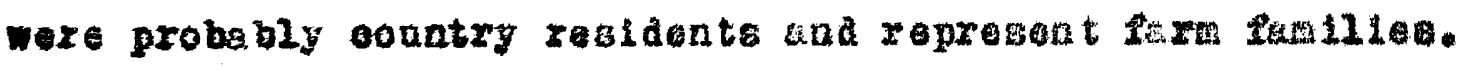
scoraing to the report givea by the high wohool students a to tre oocapation of tholr brothere find wistere who aro

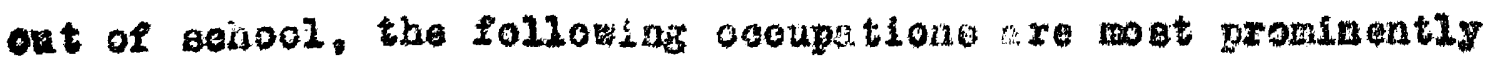

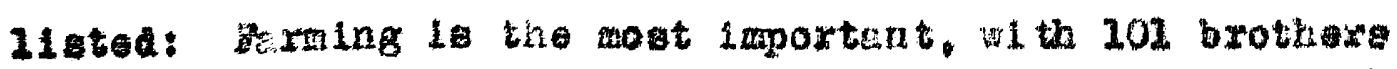

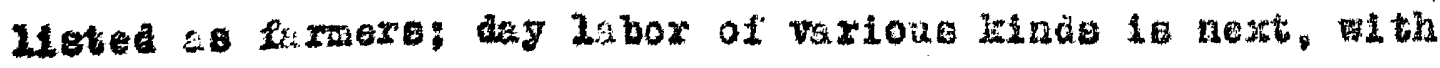
52: hougerife ia thixd, 1 th 29 . 


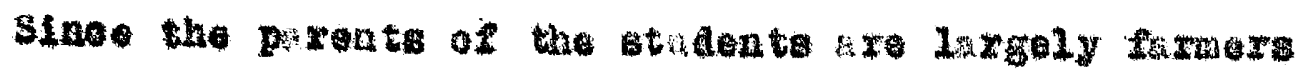
and ferwing rake as one of the nod laportant oocapetiono followe the high sohool grodu too slno 1920 and Is the ovouption engted in by sost of the brothera of those high wehool statents bow in sohool. It is latexesting to note

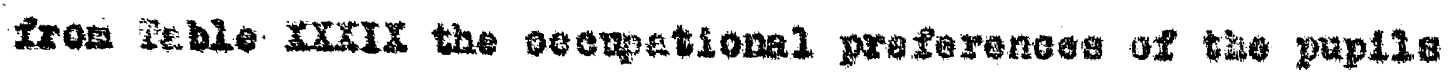

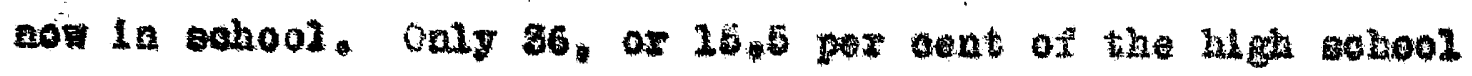

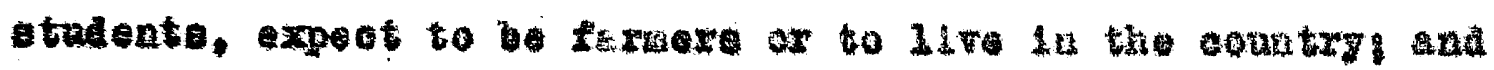
only 34, or 12.7 per eent of the tuente in the elemantsy grades. In other words, jugt 14 per oon of the aetool olildrea, 75 por oent of whos are depondent on garlow ture for thelr

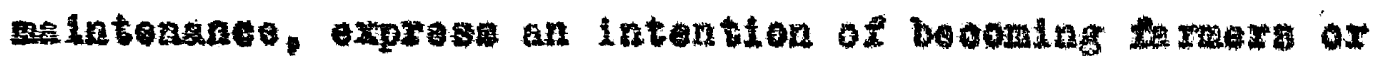
of 21viag in tho country. Iudd cound the 57.4 per oent of

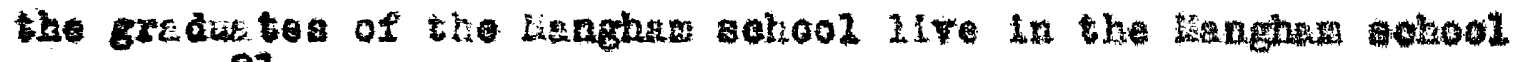
21

alatriot. If the proportion halde por those atsending

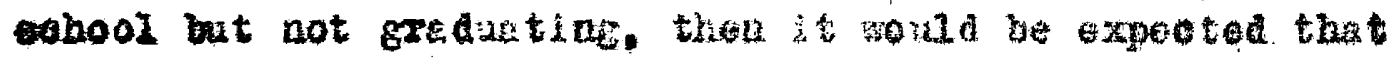

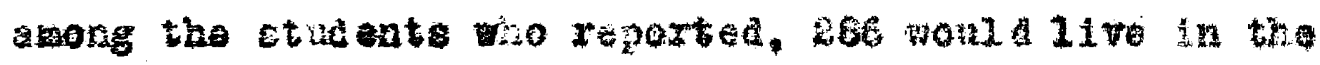

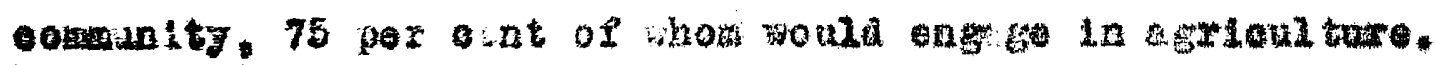

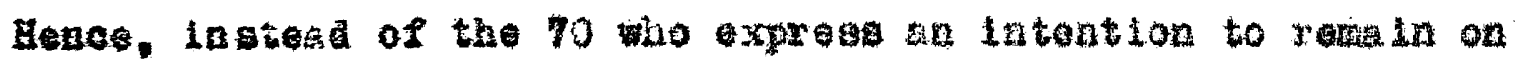

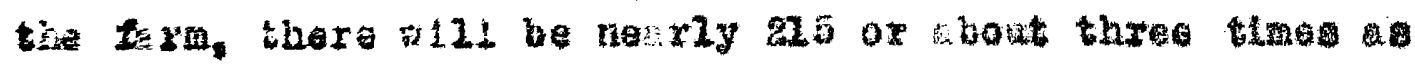

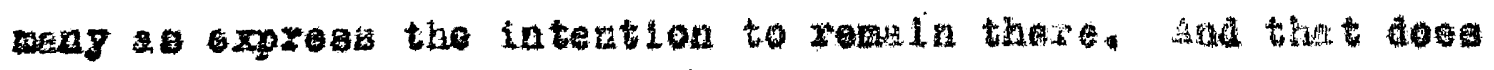

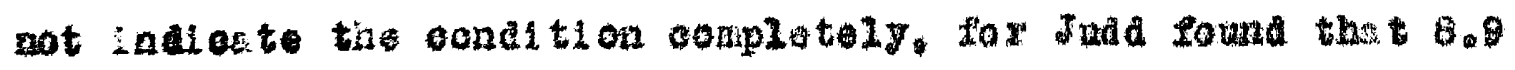

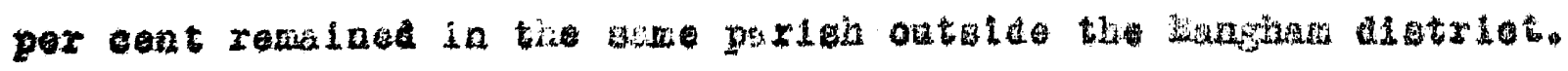

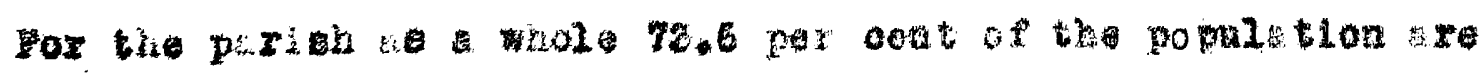

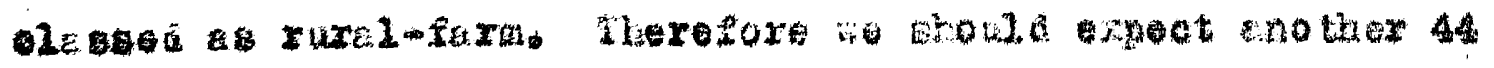

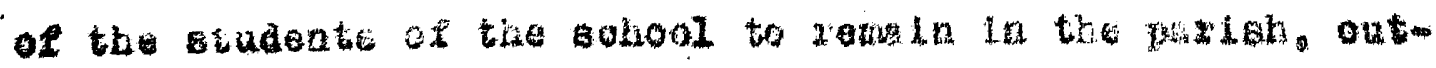

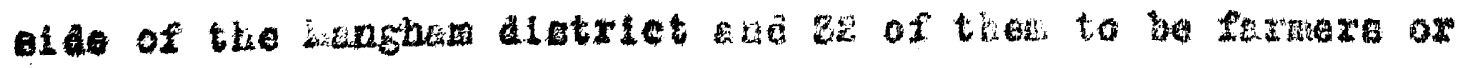




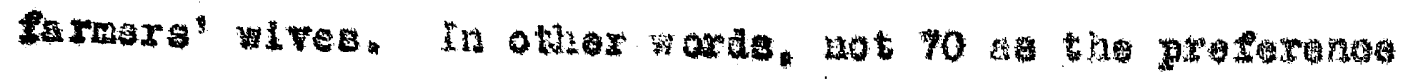

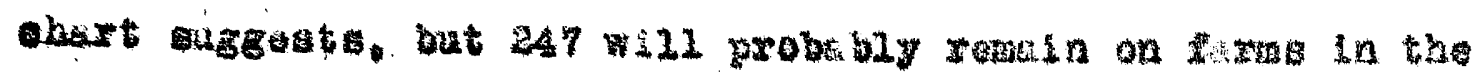
home pariah.

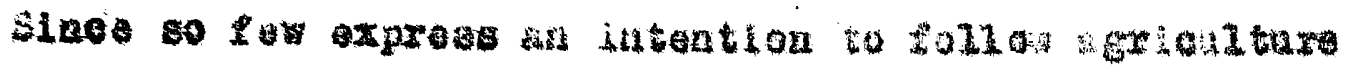

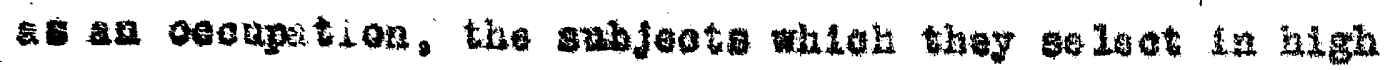

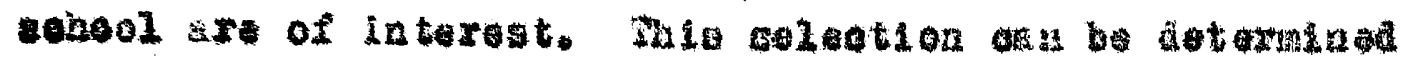

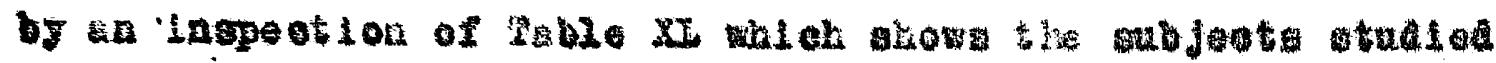
by high sehool studente, wa the nuber of students in the different grader parsulas them. plnoe an salyois bas ben asde of the indratries of the residents of the wisngham aletriot

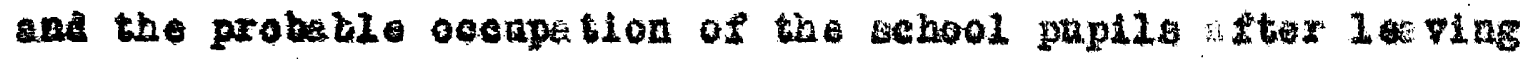

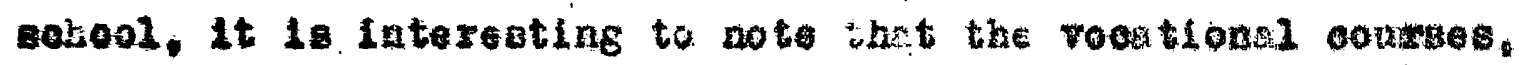

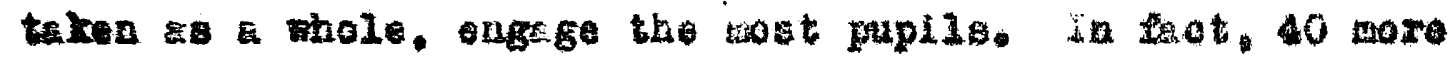
parave rodetlonel subjoots than study ngligh. Oz the 268 whe fopert a rootional subject, orar helf of them ohoose the

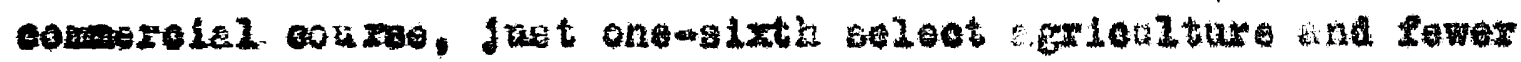

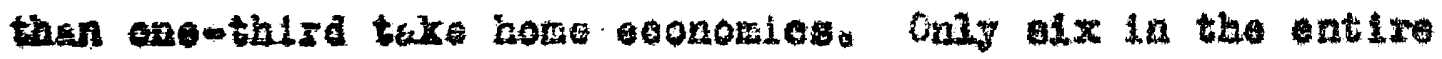

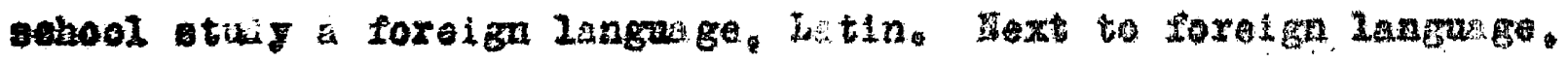

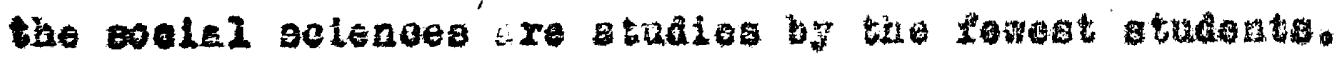

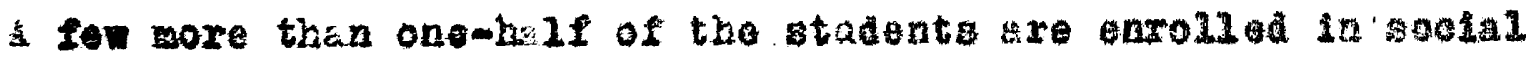

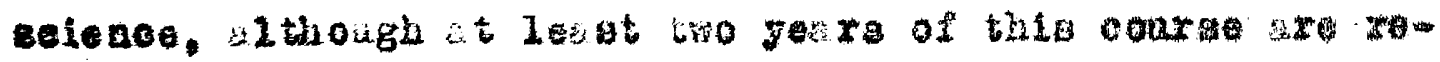

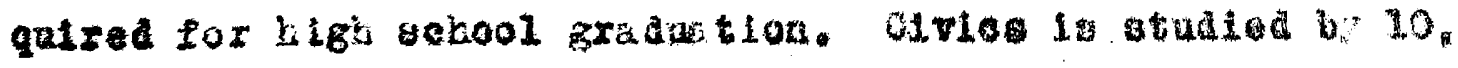
lese than one-iftic of the anth-erede enxoliment.

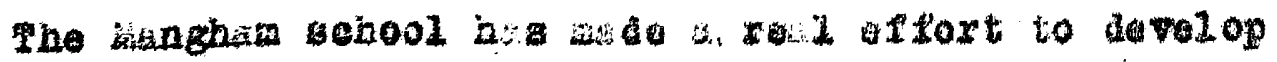

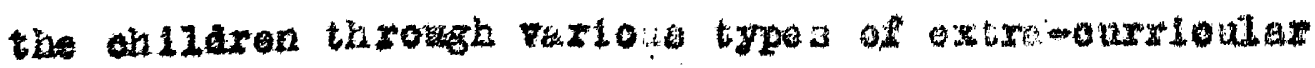

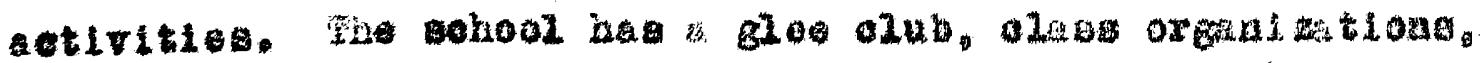

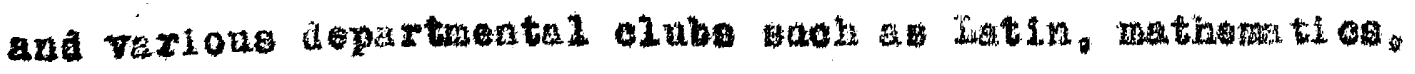

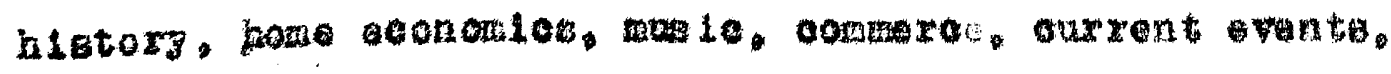


Tabie 2

Subjects Taken bJ the Students of the Mangham

High School

\begin{tabular}{|c|c|c|c|c|c|}
\hline Easleots & 8th & $9 t h$ & $\begin{array}{l}\text { Fer } \\
\text { loth }\end{array}$ & $\begin{array}{l}\text { Grade } \\
\text { Ilth }\end{array}$ & Total \\
\hline $\begin{array}{l}\text { Gth Grade } \\
\text { Mathosation }\end{array}$ & 65 & - & - & - & 65 \\
\hline Inglien & 67 & 56 & 59 & 40 & 222 \\
\hline Conoral Solence & 66 & - & - & - & 66 \\
\hline Eom Eeanctios & 36 & 25 & 13 & B & 88 \\
\hline Dlezess & 2 & 54 & - & - & 56 \\
\hline Algover & 8 & 56 & - & - & 58 \\
\hline Asmieulture & 28 & 19 & 15 & - & 45 \\
\hline Cowcrelal ceography & 17 & - & - & - & 17 \\
\hline aries & - & 10 & - & - & 10 \\
\hline Typins & - & 3 & 36 & 19 & 58 \\
\hline Filetory & - & 1 & 48 & 39 & 88 \\
\hline Geonetry & - & - & 39 & 3 & 48 \\
\hline Shorthand & - & - & 20 & 23 & 33 \\
\hline nookixeopins & - & - & 28 & 16 & 44 \\
\hline Iatin & - & $-\infty$ & 3 & 3 & 6 \\
\hline Cnedstar & $=$ & $=$ & $=$ & 22 & 22 \\
\hline Subjeots & \multicolumn{2}{|c|}{ Simmary } & Number & \multicolumn{2}{|c|}{ Per Cent } \\
\hline 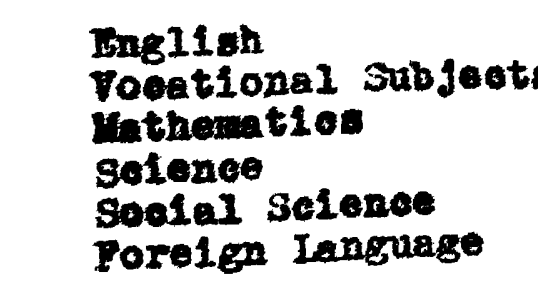 & & \multicolumn{2}{|c|}{$\begin{array}{r}222 \\
262 \\
165 \\
144 \\
115 \\
6\end{array}$} & \multicolumn{2}{|c|}{$\begin{array}{r}100.0 \\
118.0 \\
74.3 \\
64.8 \\
51.8 \\
2.7\end{array}$} \\
\hline
\end{tabular}




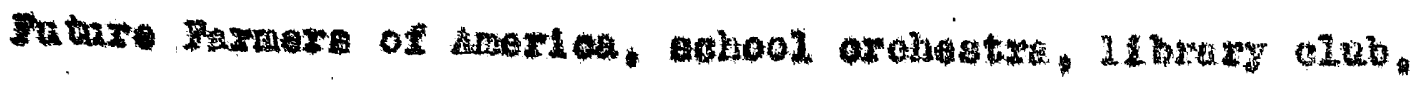

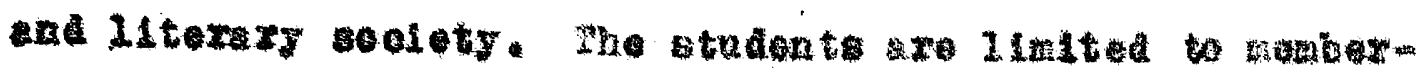
chip in two organtations. Weotlags are held a aring the

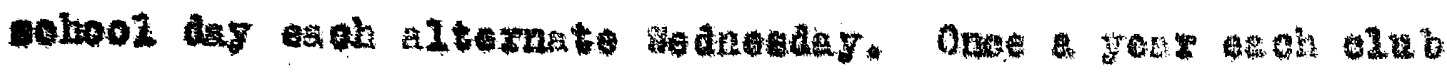

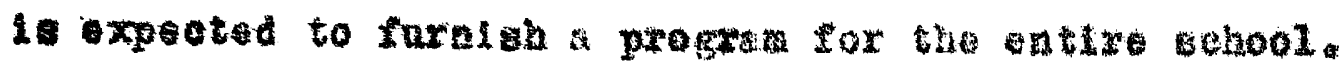

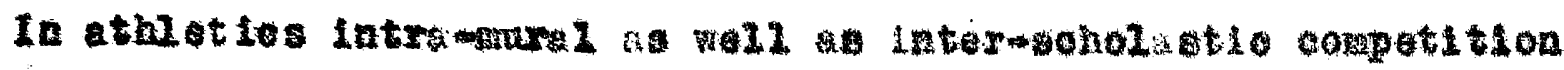

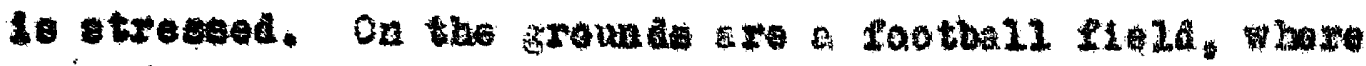

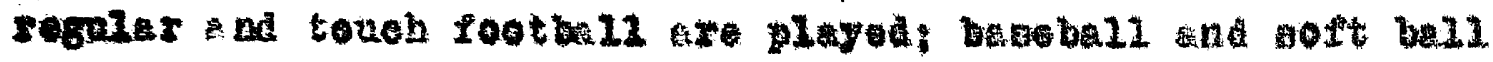

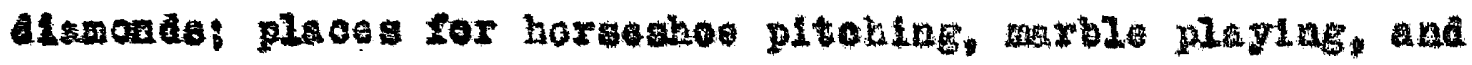
bexigg a rolley ball oourt and a ree trat. In the gyo

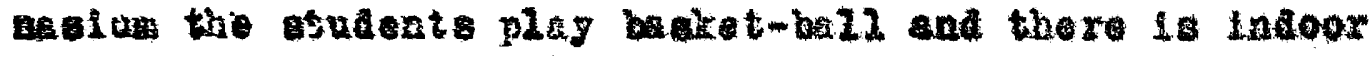

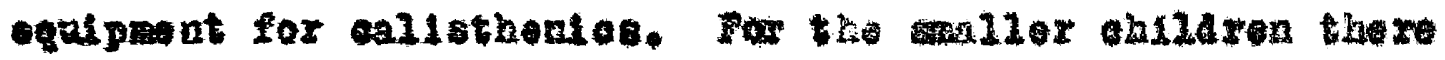

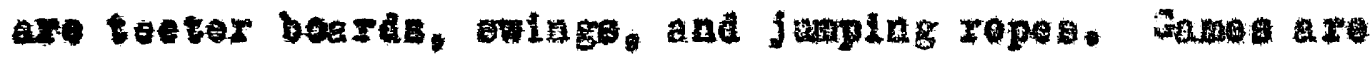

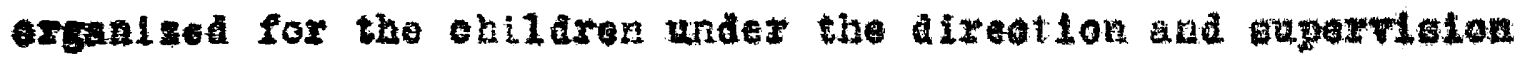

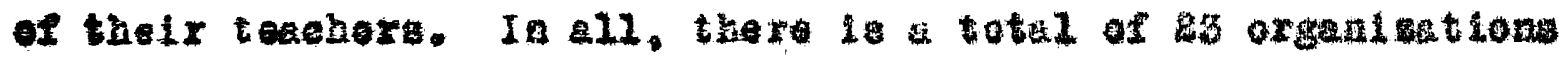

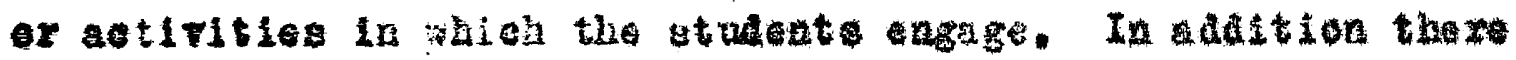

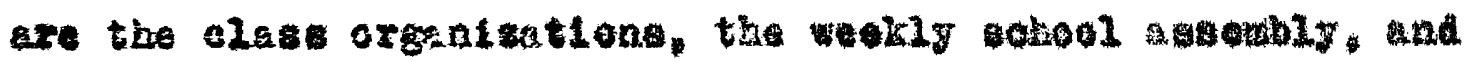

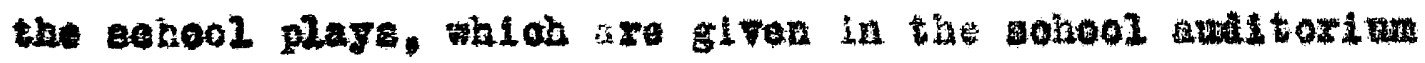
about three times res.

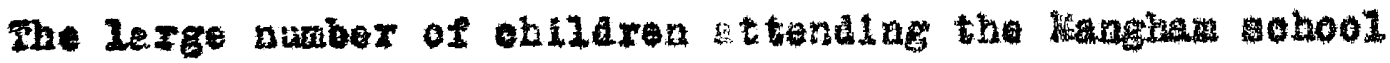

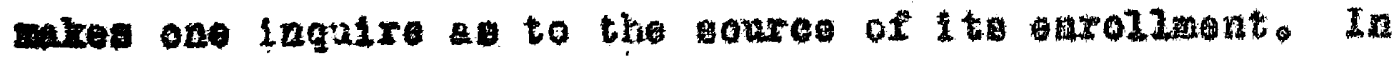

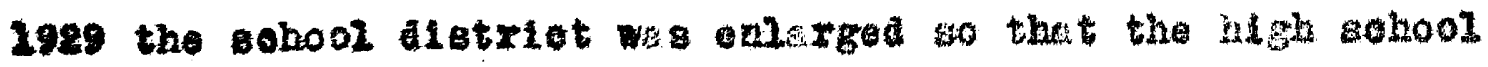
arev the oblidren from the ontire equthern ond of the parish.

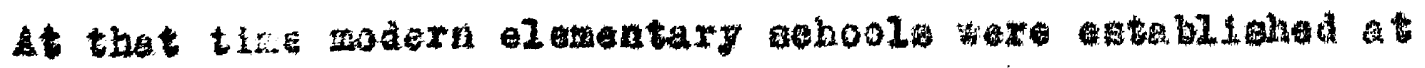

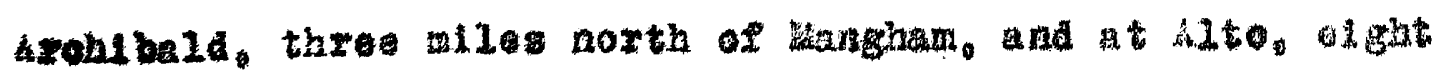

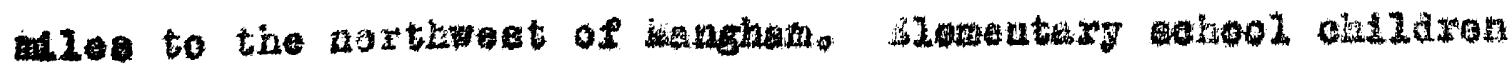

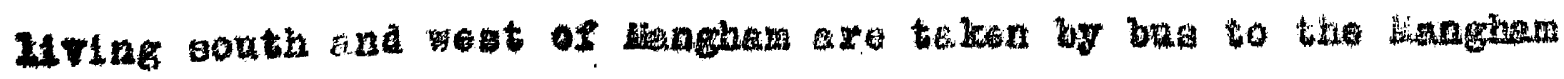
woon. 


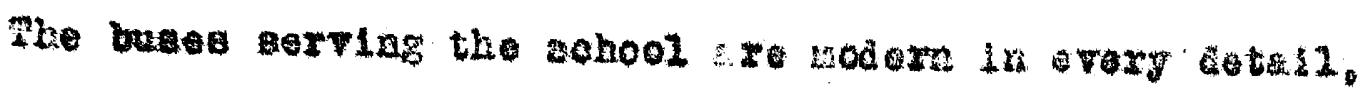

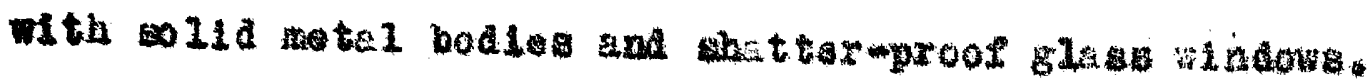

\section{Table xur}

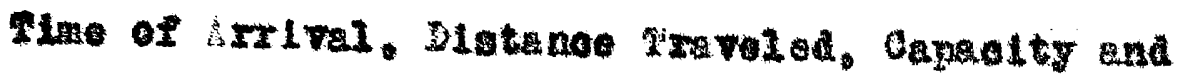

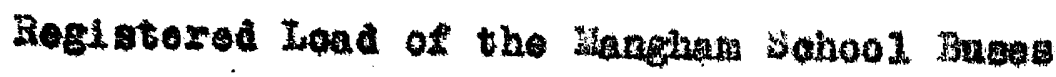

\begin{tabular}{|c|c|c|c|c|}
\hline $\operatorname{Eng}$ & 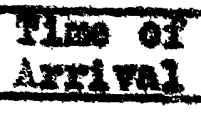 & $\begin{array}{l}\text { Jistanee } \\
\text { strareled }\end{array}$ & Gangot ty & $\begin{array}{c}\text { Krelstorad } \\
\text { Hoad }\end{array}$ \\
\hline 2. & $8: 00$ & 182 ates & 66 & 76 \\
\hline 2. & $8: 10$ & 11.4 w12es & 66 & 69 \\
\hline 8. & 8115 & $28.0 \mathrm{ml206}$ & 65 & 87 \\
\hline 4. & $7: 50$ & 12,6 alles & 70 & 81 \\
\hline 5. & $0: 05$ & $11.0 \mathrm{mt} 100$ & 65 & 68 \\
\hline 6. & 885 & $28.5 \mathrm{mL108}$ & 65 & 62 \\
\hline 7. & $7: 50$ & $7.5 \mathrm{~m} 11 \mathrm{ea}$ & 65 & 75 \\
\hline 8. & 8,00 & $28.5 \mathrm{miles}$ & 65 & 83 \\
\hline 9. & 8100 & $16.4 \mathrm{mils}$ & 65 & 60 \\
\hline
\end{tabular}

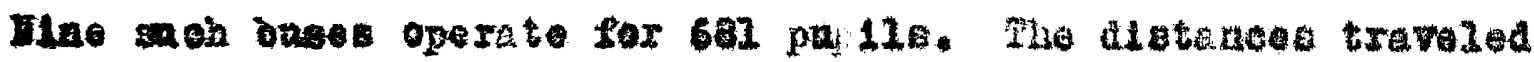

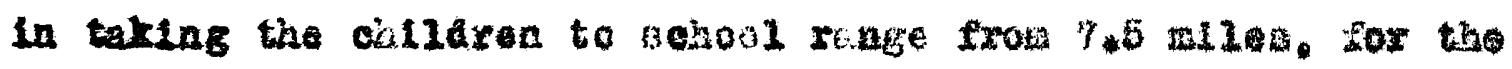

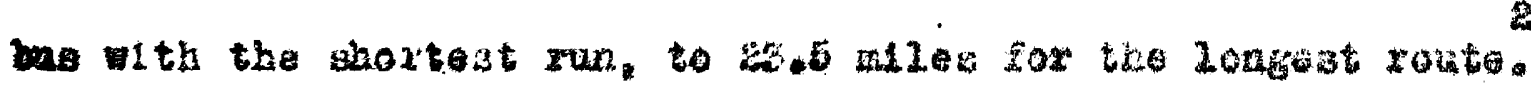

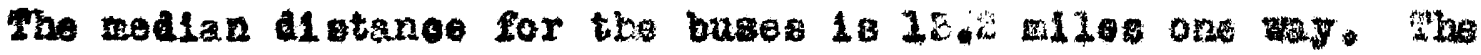

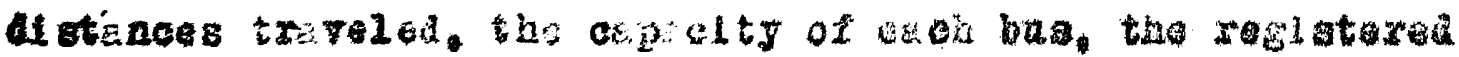

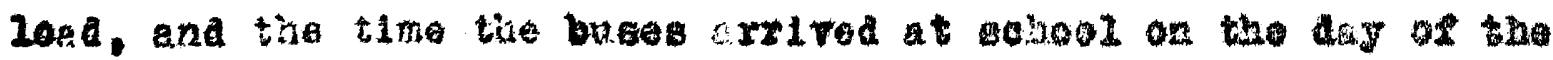

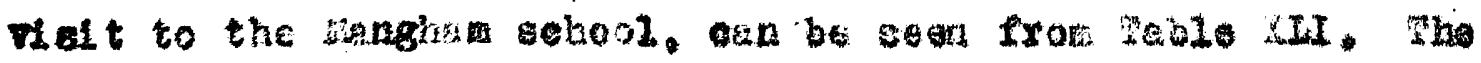

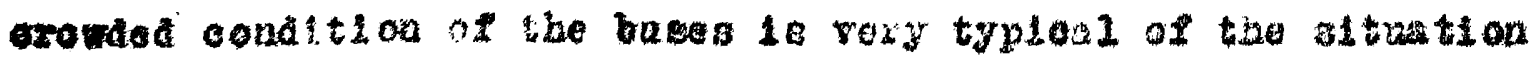

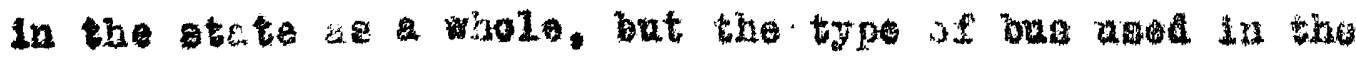

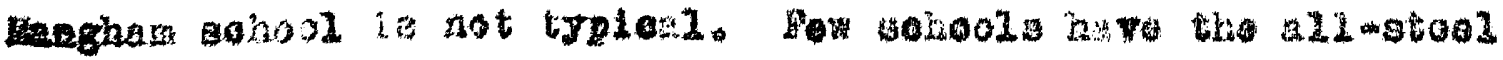




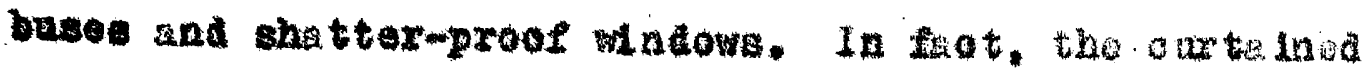

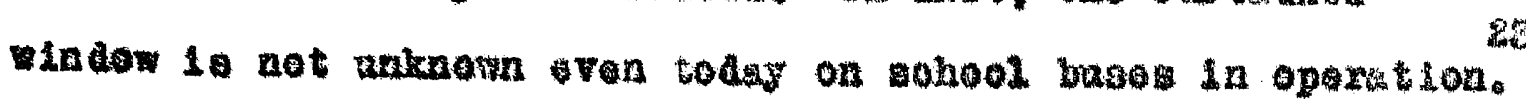
Al thoukh all of tho bigh school ptadonte of the datsict sre trensported to Mengham, whareas thero aro two other con-

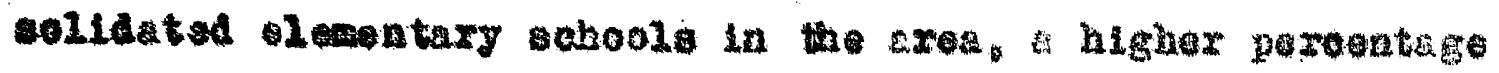
of. the elomentary ohileren thon of bigh sohool atudent are

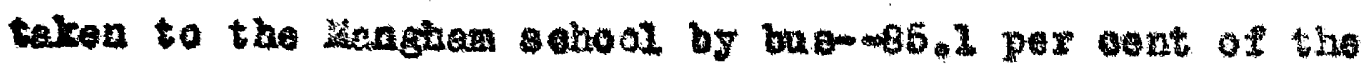
elementary whool group compsred with 60.3 per oent of the

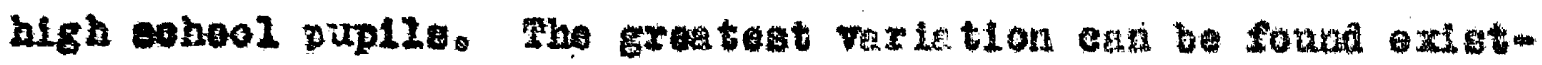
ing between the firat grade. Wh 90.7 per cont of its nubber trangerted, ind the high oohool senlors, of whon 70.1 pex oent ride the sonol bus.

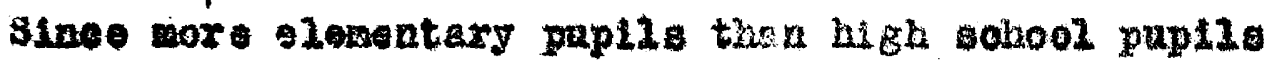
are trencopted to sohool. It is interosting to compare the detances treteled by the children Irow the alferent grodos.

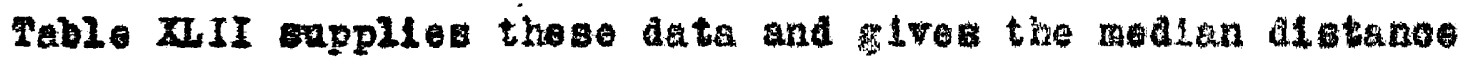
trereled by the gradeo. Dere gala the alewentery achool ehlldren tratel a longer datwnoe to wehool than the bigh

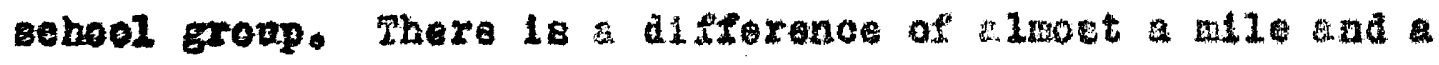
be11 in the wedita diotane traveled by the chilaron of the

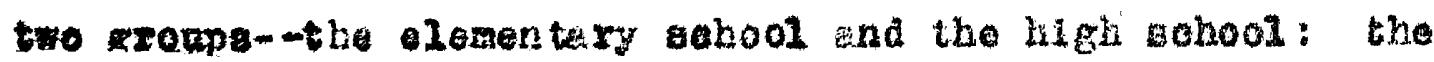

23. The the of axrival. Eres the time the school bus arrived et achool on the ang the vialt to the school we tas. It wa $\varepsilon$ rexy xelny doy so the rural attendanee pia no donot

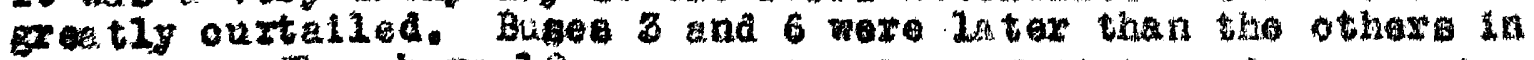

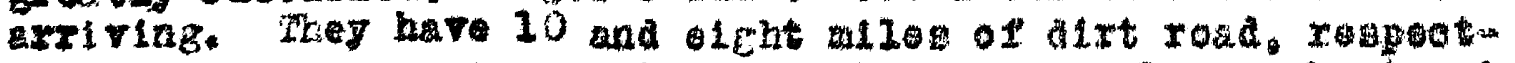
ively, on thelr routes. The time tho bas mut leavo the termo ane of the routo oan bo 4 guxed Irom tho dlotano traveled and the time of arrital. An average of about 10 to 12 nlles an hour

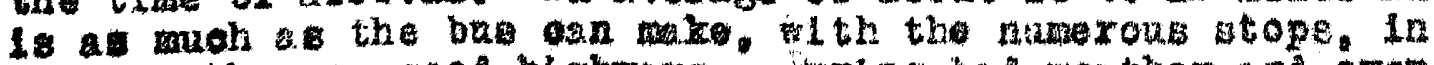

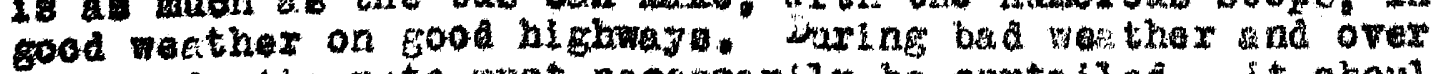

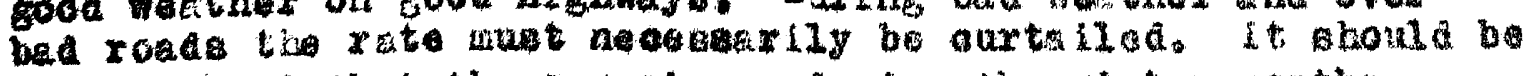
kope in malne tips the onn riaes, daring the lnter wontho. around seren o clock and ata ebout five o'alook in the erening 
Table $2 \pi x I$

Distances Traveled by Students in Reaching the Manghem Sohool

\begin{tabular}{|c|c|c|}
\hline Betare is Mines & Eloh Sohool & Elementary sohool \\
\hline $\begin{array}{l}\text { Togs than one } \\
1 \text { to } 1.99 \\
2 \text { to } 2.99 \\
5 \text { to } 3.99 \\
\text { t to } 4.99\end{array}$ & $\begin{array}{l}30 \\
15 \\
13 \\
23 \\
21\end{array}$ & $\begin{array}{l}28 \\
17 \\
19 \\
14 \\
13\end{array}$ \\
\hline $\begin{array}{l}5 \text { to } 5.99 \\
8 \text { to } 6.99 \\
7 \text { to } 7.99 \\
8 \text { to } 9.99 \\
9 \text { to } 9.90\end{array}$ & $\begin{array}{l}12 \\
18 \\
12 \\
15 \\
20\end{array}$ & $\begin{array}{r}19 \\
11 \\
27 \\
12 \\
6\end{array}$ \\
\hline $\begin{array}{l}10 \text { to } 10.99 \\
11 \text { to } 11.99 \\
18 \text { to } 19.99 \\
13 \text { to } 13.99 \\
14 \text { to } 14.99\end{array}$ & $\begin{array}{r}12 \\
8 \\
18 \\
3 \\
2\end{array}$ & $\begin{array}{r}18 \\
11 \\
19 \\
4 \\
2\end{array}$ \\
\hline $\begin{array}{l}25 \text { te } 15.90 \\
16 \text { to } 16.99 \\
17 \text { to } 19.99 \\
18 \text { to } 18.99 \\
19 \text { to } 19.99\end{array}$ & $\begin{array}{l}4 \\
0 \\
0 \\
5 \\
1\end{array}$ & $\begin{array}{l}9 \\
5 \\
4 \\
5 \\
1\end{array}$ \\
\hline $\begin{array}{l}20 \text { to } 20.99 \\
21 \text { to } 21.99 \\
28 \text { to } 22.99 \\
23 \text { to } 23.99 \\
24 \text { to } 24.99\end{array}$ & $\begin{array}{l}2 \\
1 \\
2 \\
0 \\
0\end{array}$ & $\begin{array}{l}7 \\
6 \\
4 \\
1 \\
0\end{array}$ \\
\hline $\begin{array}{l}25 \text { to } 25.99 \\
26 \text { to } 26.99\end{array}$ & $\begin{array}{l}0 \\
1\end{array}$ & $\begin{array}{l}9 \\
0\end{array}$ \\
\hline
\end{tabular}

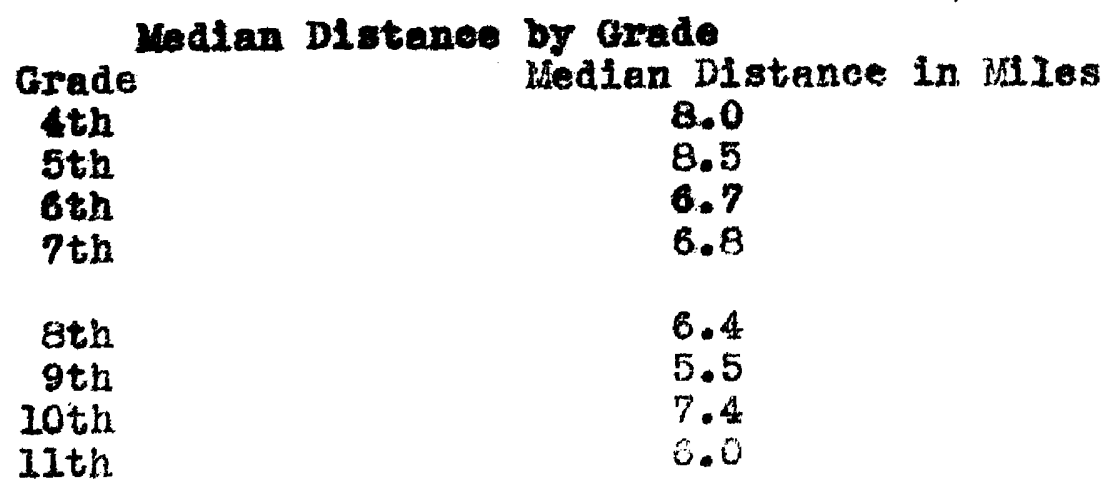




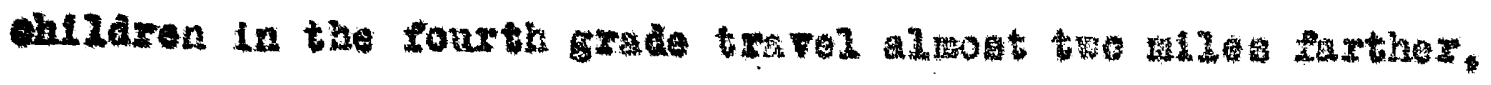

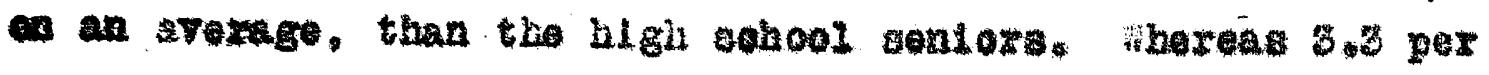
ont of tho lesentary ohilaxen bove the thira srade travel as suob as 25 millos to reach achool, Io se than ono $z$ cont of the high school atriente travel that ditanoe. Athongh 25.8 per cont of the grade sahool ahizaren go 10 mlles or more to

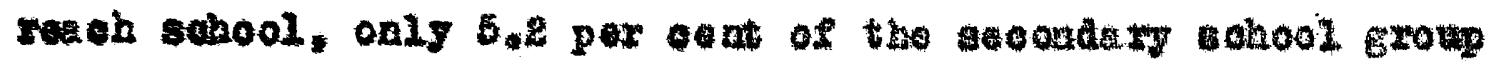
trevel that tar. smong those the travel 11 whlog of tarther thore are 32.1 per cent of tho elementary grade pupile and 27.7 per eat of the high sohool group. In contragt onth this,

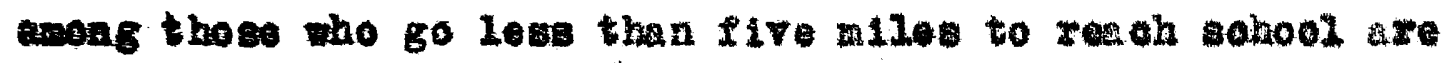
4.0 per eed of the algh school group and 38.6 per ee at of the elementary echool puptle. This ind loster that the olimination

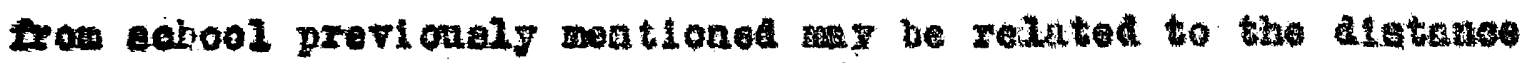
traveled by the etudente in resching whool.

The evianoe of eltaination from school ta the apper lovelo is farther otreagthenet by studying the retardition

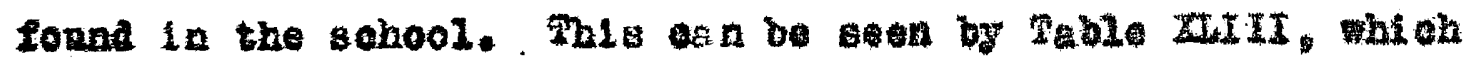
gives the ge-grade ditribution of the paptis. He range In ago la notioed in the grader, ea followe:

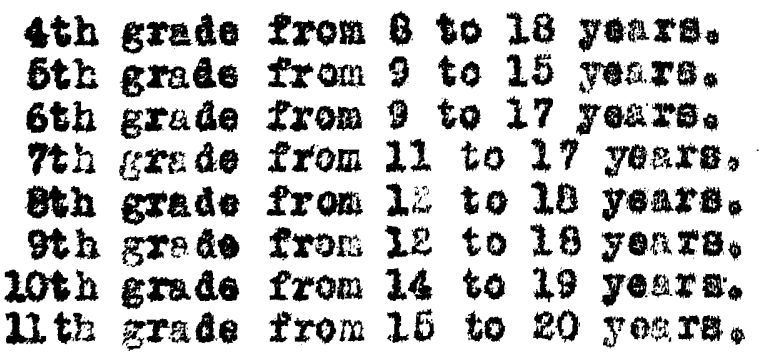

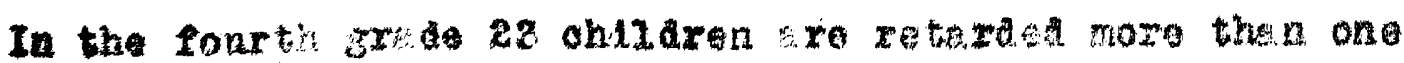

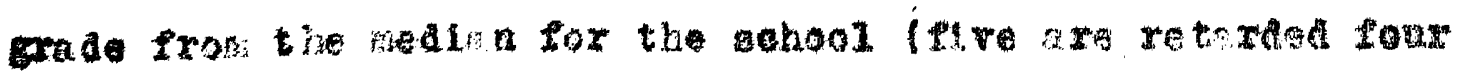

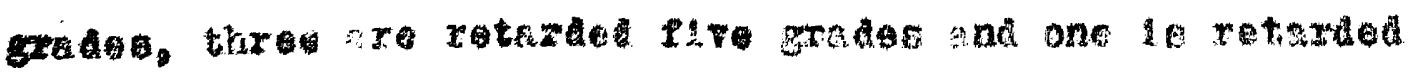


Table xaIII

Age-Orade Distribution of Students in the

Manghan Sohool

\begin{tabular}{|c|c|c|c|c|c|c|c|c|}
\hline$\Delta x$ & Ath & 5 th & 6th & Junhes & Ifizade & Oth & 10th & 11th \\
\hline - & 2 & 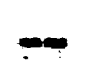 & - & $\cdots$ & - & - & - & - \\
\hline 9 & 28 & 3 & 1 & - & - & - & - & - \\
\hline 10 & 18 & 12 & 3 & - & - & - & - & - \\
\hline $\mathbf{x}$ & 21 & 18 & 17 & 2 & - & - & - & - \\
\hline 19 & 20 & 18 & 7 & 20 & 4 & 2 & - & - \\
\hline 13 & 4 & 7 & 20 & 12 & 27 & 5 & - & - \\
\hline 24 & 5 & 5 & 5 & 16 & 16 & 23 & 1 & - \\
\hline 15 & 8 & 3 & 6 & 11 & 6 & 18 & 16 & 4 \\
\hline 18 & - & - & 8 & 5 & 7 & 9 & 14 & 10 \\
\hline 17 & - & - & 2 & 1 & 8 & 6 & 14 & 14 \\
\hline 18 & 2 & - & - & - & 8 & 2 & 11 & 13 \\
\hline 19 & - & - & - & - & $\cdots$ & - & 3 & 3 \\
\hline 6 & - & - & - & - & - & - & - & 2 \\
\hline
\end{tabular}

* The muever inolosed in black lines represent the age medinns fox the exades in the Uanbham Sehool. Those inclosed in red ines represent the normal or expected age for the grade. 


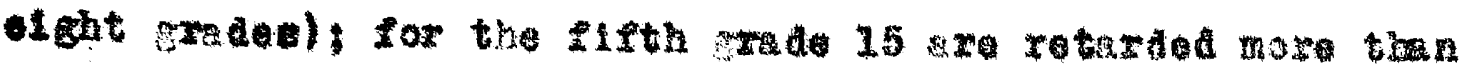

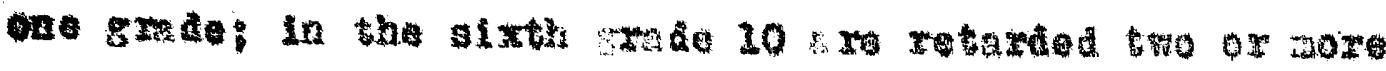

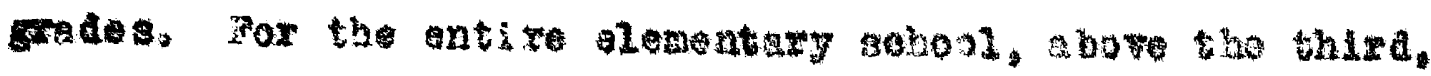

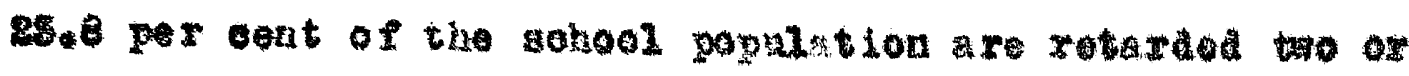
woro grades below. the cohool medien. Whe sohool median chows reterdation of about one grade from the expeted puptio rate - progress in the fifth ane sxth grades: all othex gradea chor a rate of progreas up to a ndard expeotatlons, If retardation is Iigared rom the expected progresa of the studeats, It is seen that 45.2 por out of the atudents enrolled aro retarded one or more graden. For the leasutary grade the retardation is 49.6 por cont of the onrollmont, wherous for the

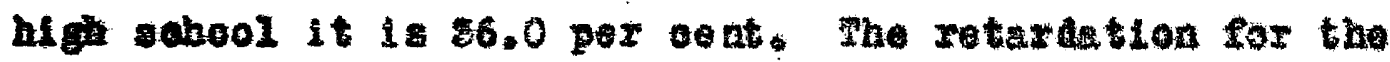
whool co a wole 18 coserhat greater than the median retardation

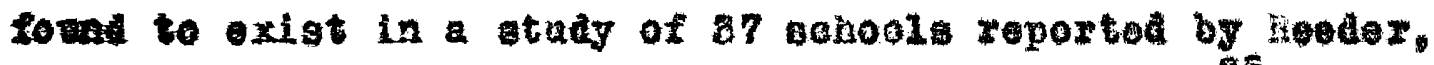
were 58.8 per ent of the studente pere rotarted. It aed obriong thet those studenta who are retarded two, three, ton or soro grades aro more 11301y to arop out of sehool than those who are progressing at the normel rate for the $2 x$ group.

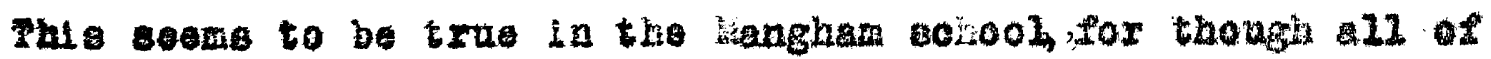
the ezomentary gredes and the ulghth grado bato pupla zotaried

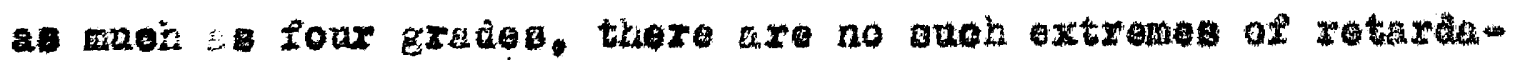
tion lo the apper lovele, Cartalny, ainoo it is virtadily

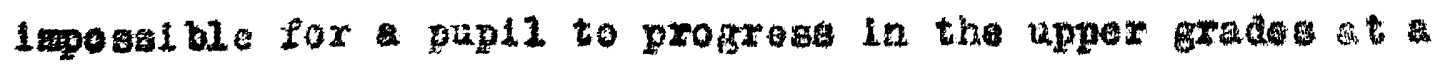

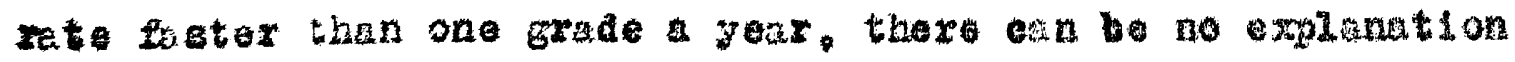

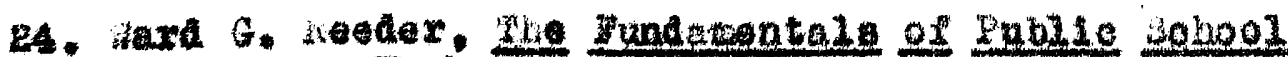

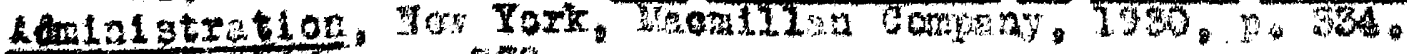
25. Ible. 0.030. 
for the ateforence in retardution in the internodicte the

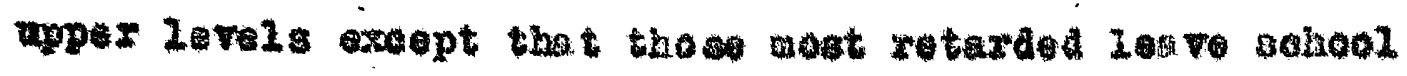
bero roahing the adringad grades.

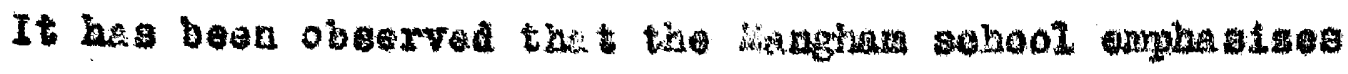

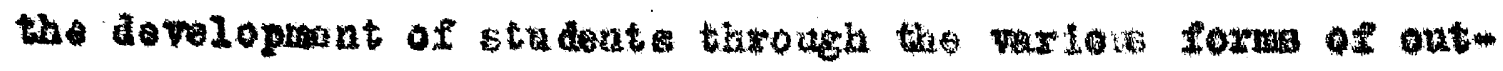
-ialas sotivitios. pert the chool playa in the commanty Ife if sot to be noted. Is the lianghan achool a commanity

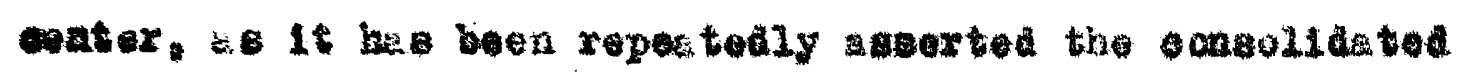
ahool would bo f I the firat proe not an oxpanzaton exiats

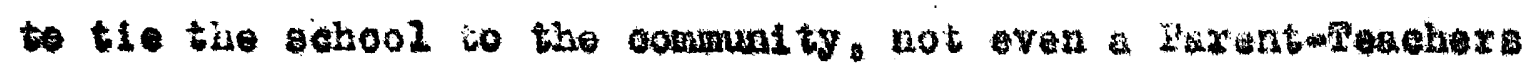

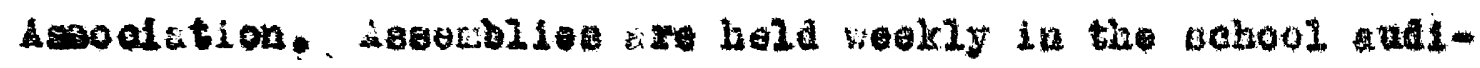

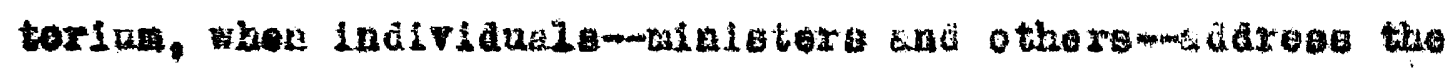

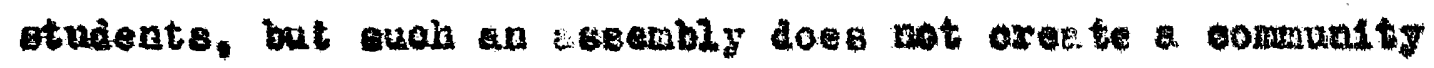
oonter. To laterest is not in the oommalty aring the metiags and dicussions, but in the students themedres. If the parente vialt tho anool, it io, so forind to be

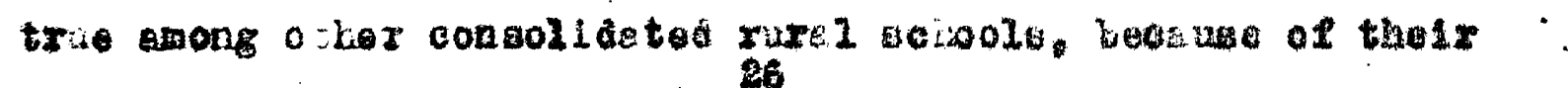
interest in the ir own oli2dren. Fbet interest coos not apes

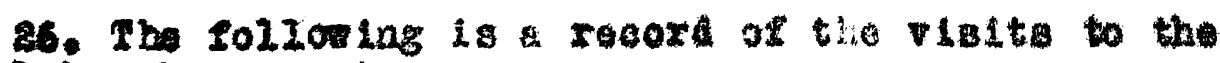
sellool by tive ytrant:
4th grade onlizren
78 raportad no vitto
3 Isport
5th grade ohlidren
52 roparted no visto,
¿ reported relts:
6tis orad oblldran
54 reporta no viatta
6 Terozed viette:
7th grade ohildren
57 raported no vialtw.

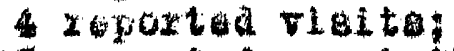
gth gre de ohllaren
46 roported no vialts.
i7 regertad Hits:
gth grade oh1zaren
46 roported no vidit.
b repoztod ialta:
lotk grado onlldxen
21th grade ohlzaren
I reported no vidita.
II repoxte visits
88 roported no vinfto

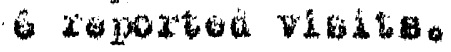




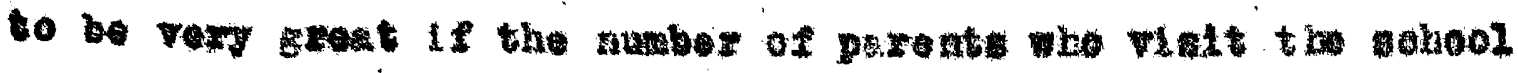
is any orterion, for 97,9 per cent of the ohlldren from the

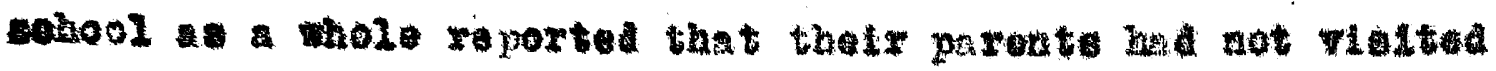

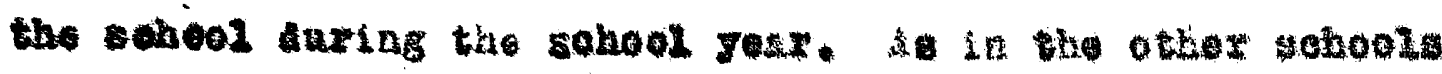

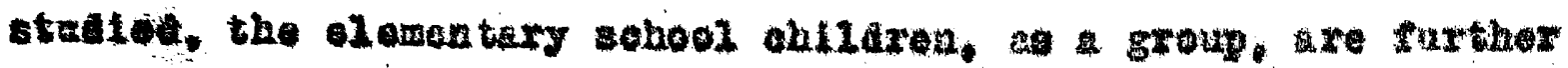

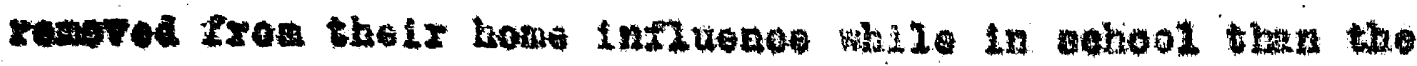
bigh sohool paplis: thus, although 19.7 por onet of the htgh

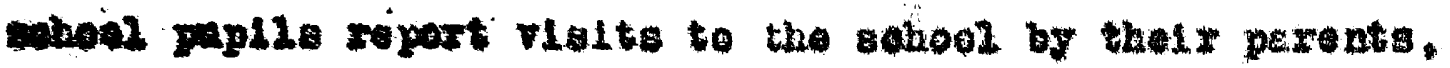
aly 6.9 yer oent of the alomentery school ohlidren roport

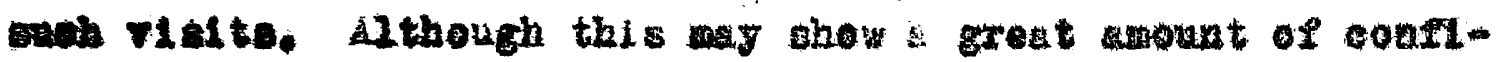

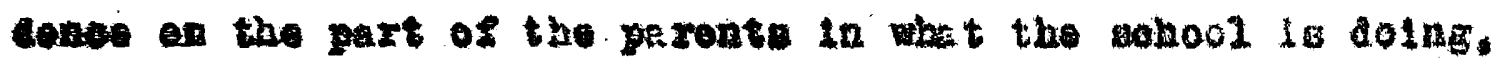

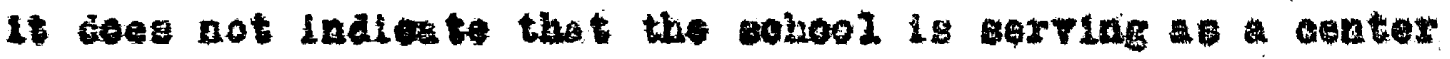
of comanit in interest.

It 18 observed (table XuIn) the the high sekool io

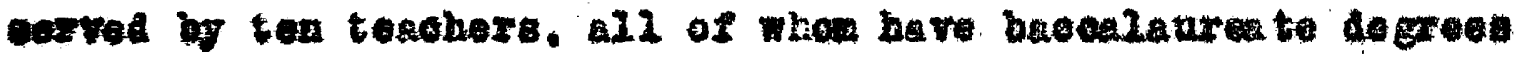

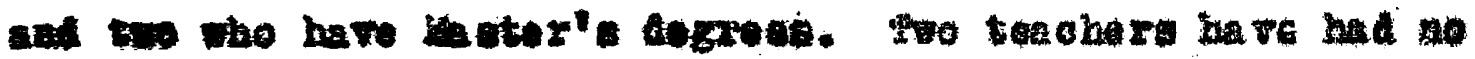

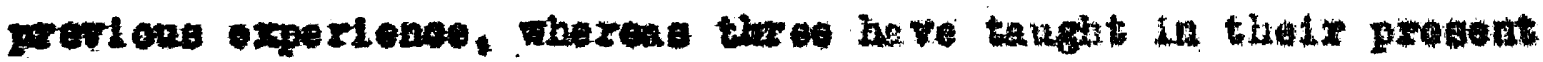

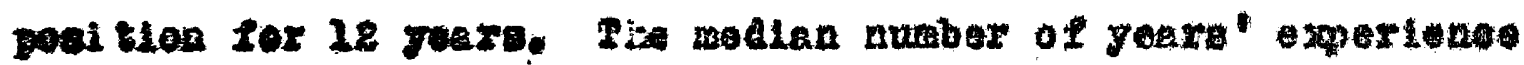

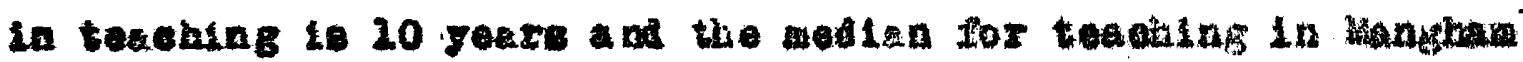

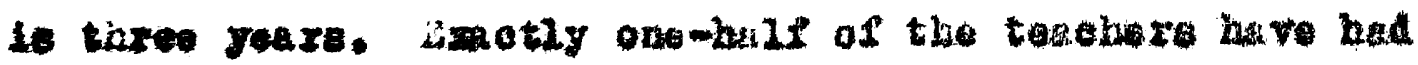

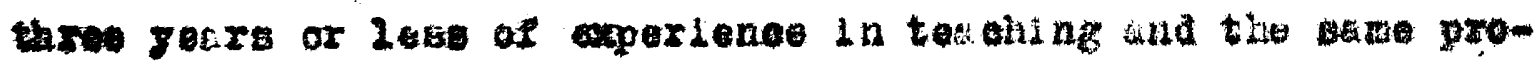

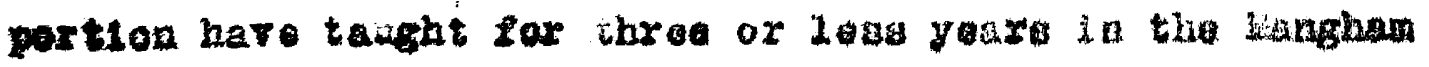

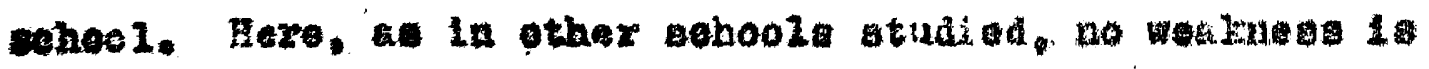

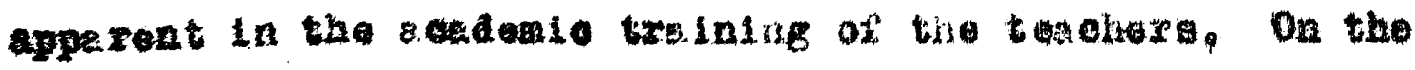
whe. they tre well gwalified exom the twapolat of oxperionee, as ondy Ifre of the 24 terahoro are

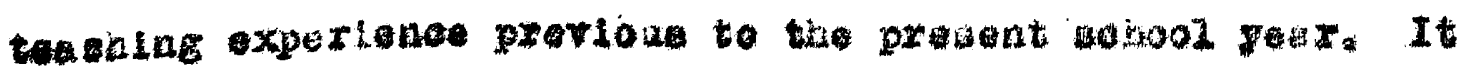


Table XIIV

Aoadenic Qualifications and Tenure of the

Kanghem Sohool Teaoherg

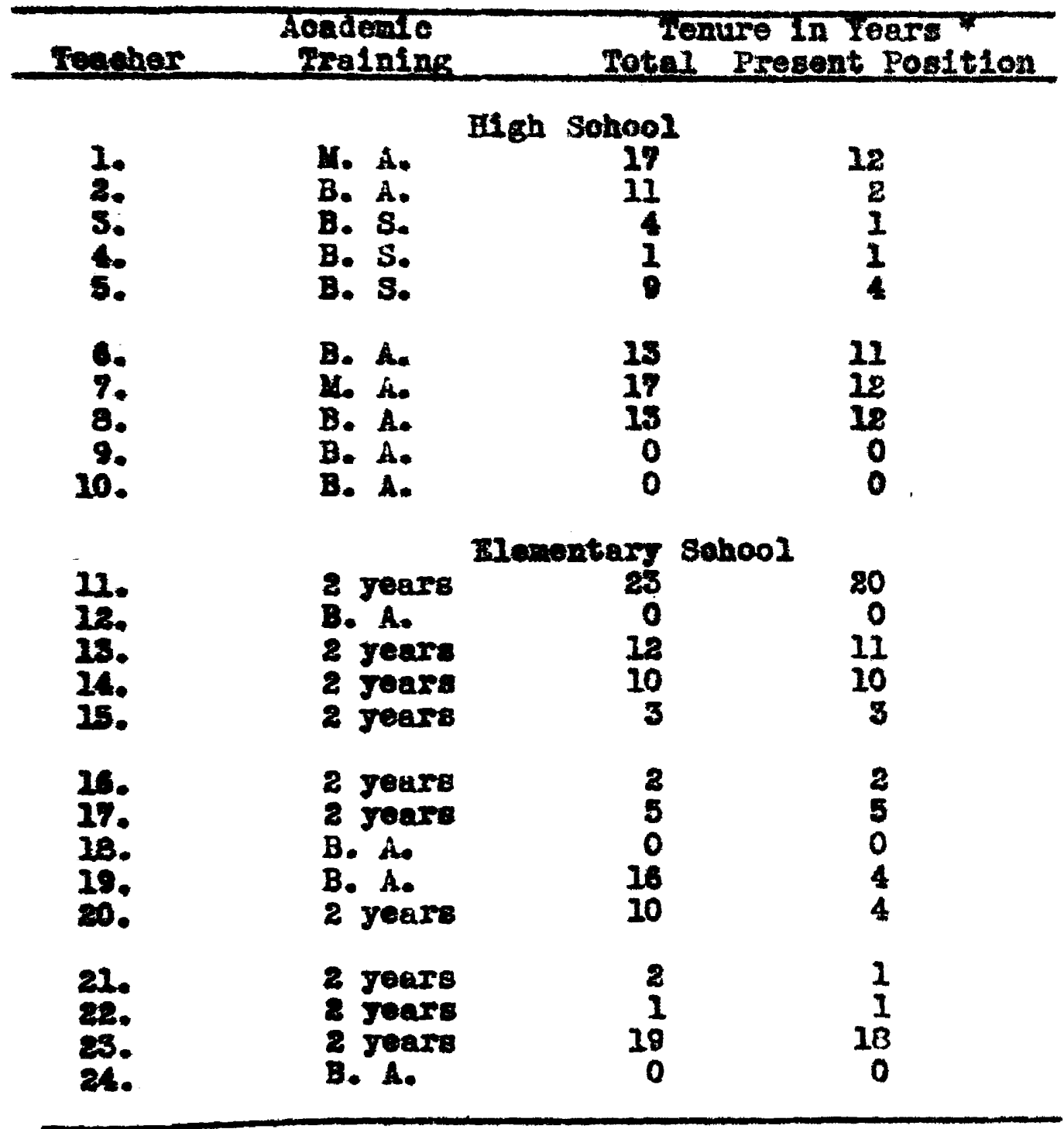

* The term "Tenure" 18 used in the sense in wioh Footo nees 1t. Op. it., p. 2 . 


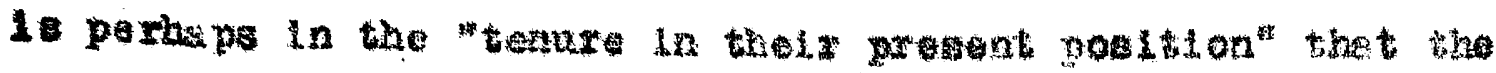

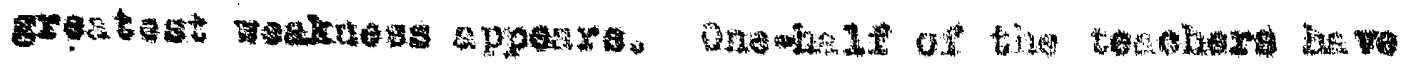

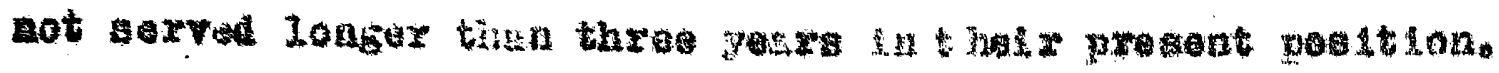

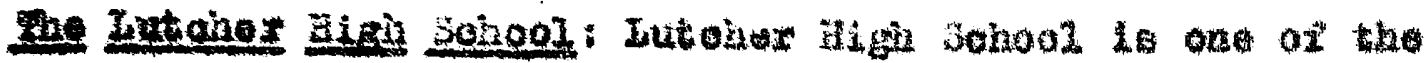

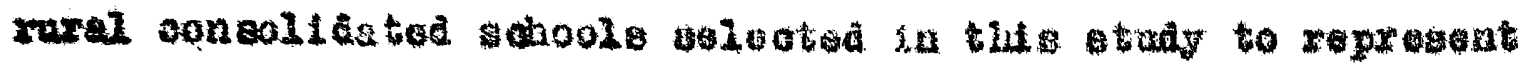

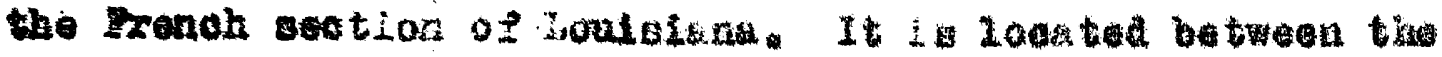

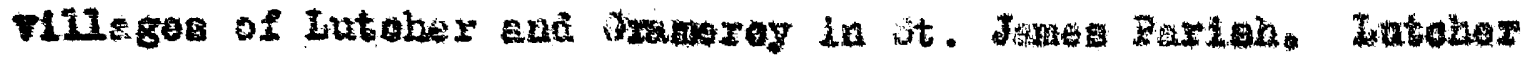
bad a population, scoording to the 2930 oendus, of 1,481 people. It is conitfol wivther there ase the wang there now

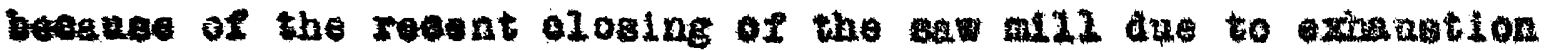

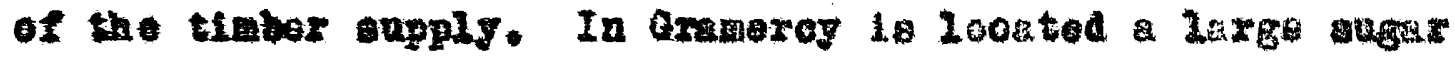
refinery. Bere is ogmanlty quite In rgely intereated in

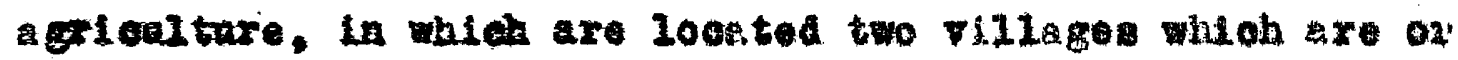

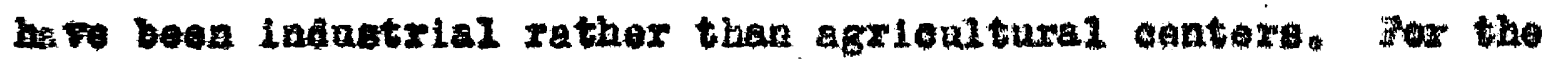
purieh as a wholo 82.2 per oent of the netive-whito nopulation sre olsead as rural-tarn people. The sgrioulture or this wootion

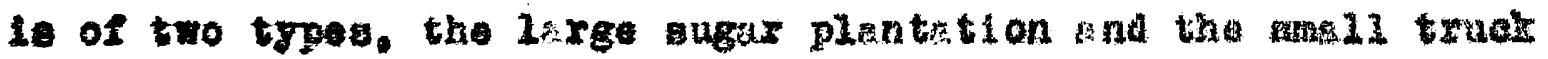

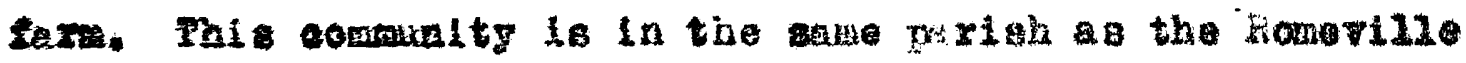
commity and; extept for the two villggea, ragmbles it. The hlgh sohool bullaing wa erectod in 1931 as a conallated

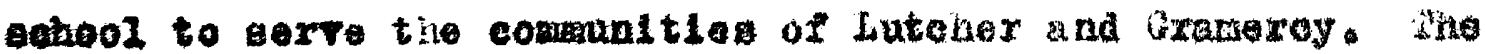

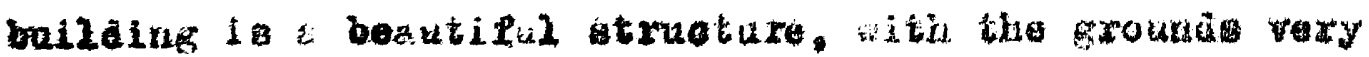

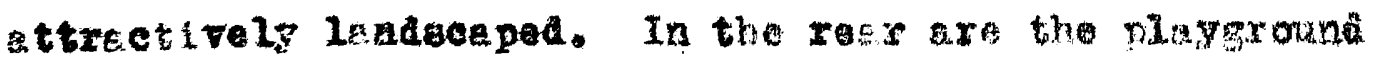

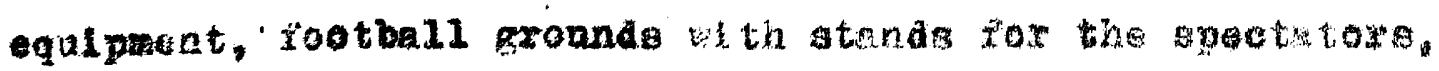

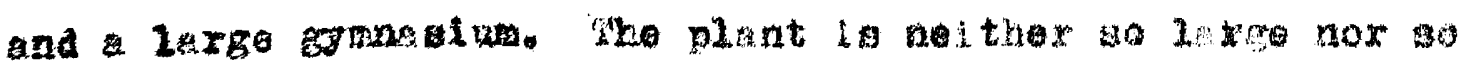

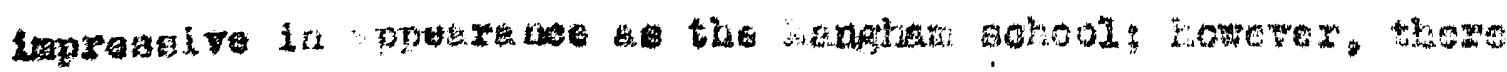




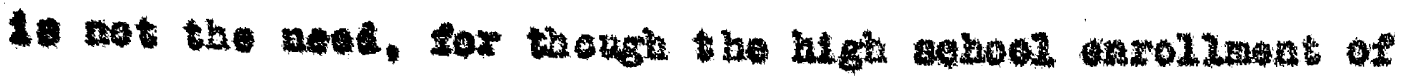

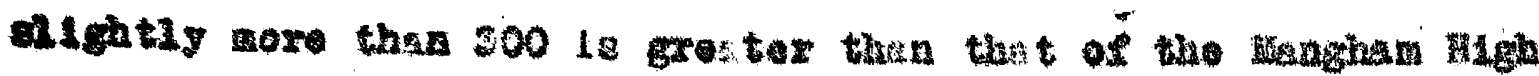

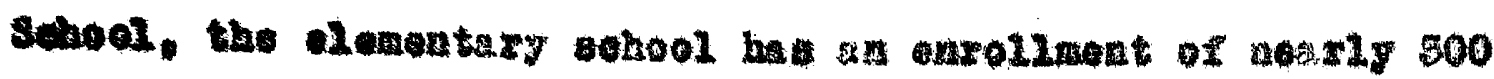

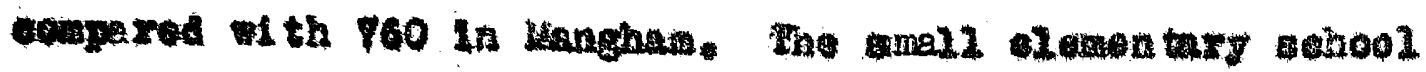
onrollinent in the Lutehex suhool to aleferent from that of aug

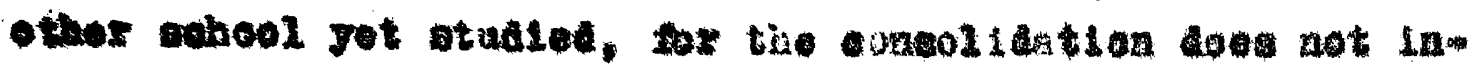

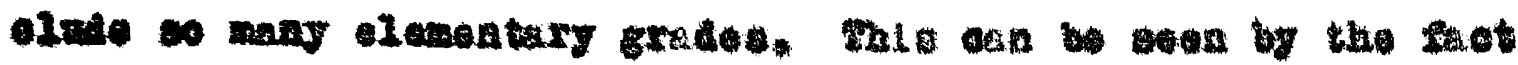
thet woag 24 tirst gradere, only fire rido tho sehool bast of 29 in the cooven grade, woven rice tho brel and of 29 in the

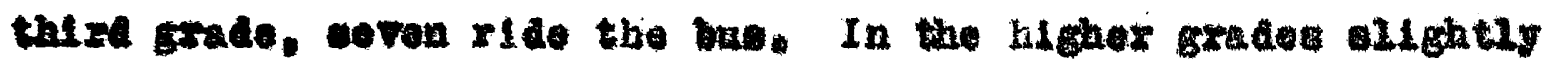

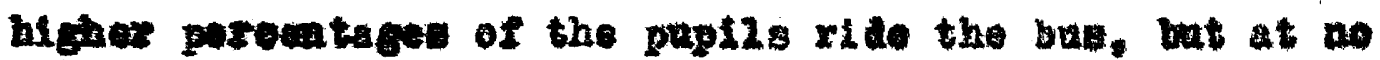

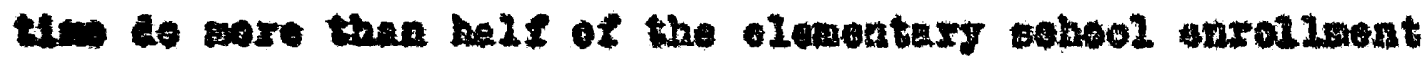

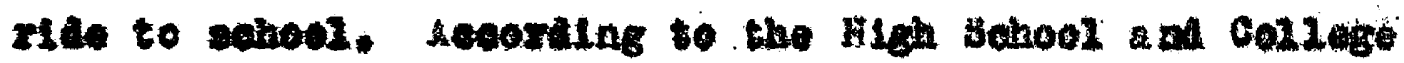

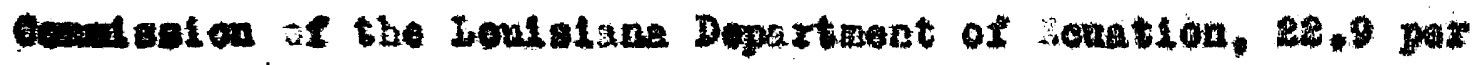

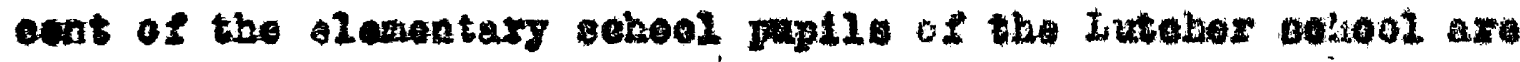

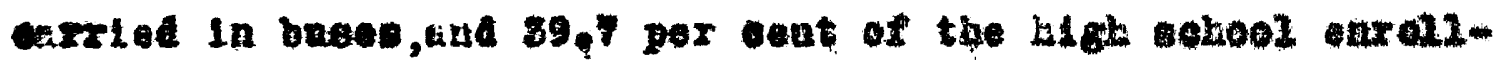

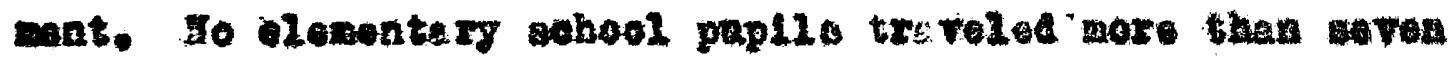
wloe to soch ochool, and ino longeot diotance travelod by

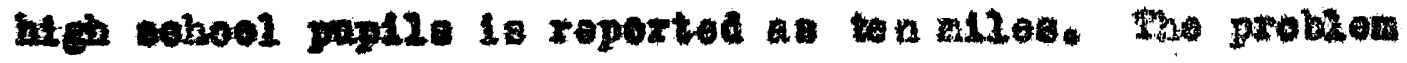

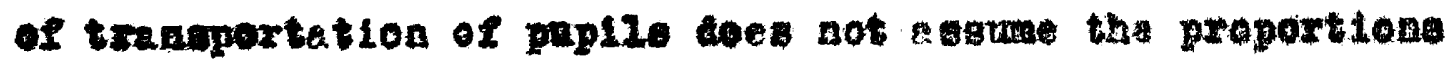

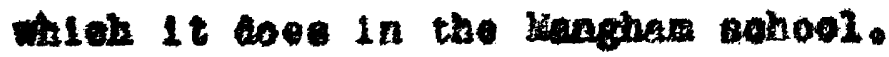

A zather bigh rst of rettritation obartod in tho

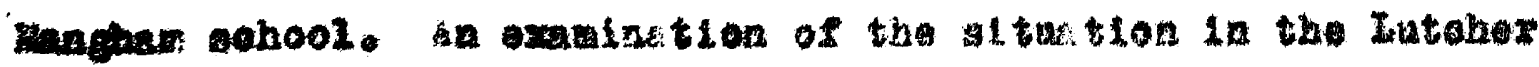

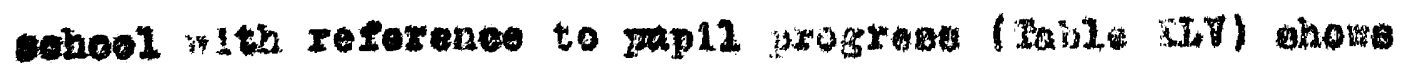
that the wian age tor erexy grede is the axpestad age tox

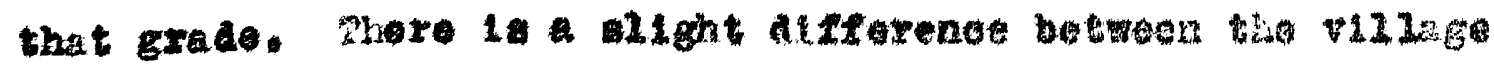

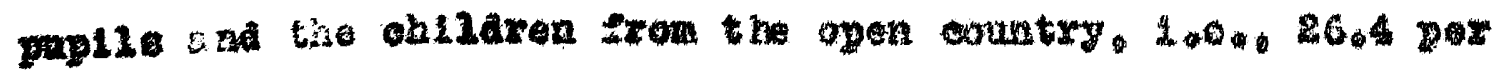


Table XIV

1ge-Grade Diatribution of Students in the Iutoher sobool

\begin{tabular}{|c|c|c|c|c|c|c|c|c|}
\hline$A D$ & ste & sth & 6th & $\begin{array}{l}\text { mer } \\
7 \text { th }\end{array}$ & $\begin{array}{l}\text { F Grade } \\
\text { gth }\end{array}$ & gth & 10 th & 21th \\
\hline$a$ & 1 & - & - & - & - & -- & - & - \\
\hline 0 & -18 & 7 & - & - & - & - & - & - \\
\hline 19 & & 28 & 7 & 3 & - & - & - & - \\
\hline $\mathbf{I}$ & 6 & 10 & 28 & 10 & 1 & - & - & - \\
\hline 21 & 8 & 7 & 14 & 26 & 15 & 2 & - & - \\
\hline 28 & 8 & - & 4 & 8 & 45 & 14 & - & - \\
\hline 14 & - & 2 & 6 & 7 & 22 & 25 & 16 & - \\
\hline 3 & - & 1 & 1 & 4 & 10 & 21 ; & 35 & 10 \\
\hline 16 & - & - & - & 4 & 4 & 5 & 13 & 24 \\
\hline 17 & - & - & - & - & 1 & 6 & 4 & 10 \\
\hline 18 & - & - & - & - & 1 & - & - & 7 \\
\hline 10 & - & - & - & - & - & 1 & - & 1 \\
\hline
\end{tabular}

De aubers inclosed in blaok lines represent the age mediens Fer the grades in the Iutoher sohool. Those Inolosed in red Iines represent the norwal or expected age for the grade. 


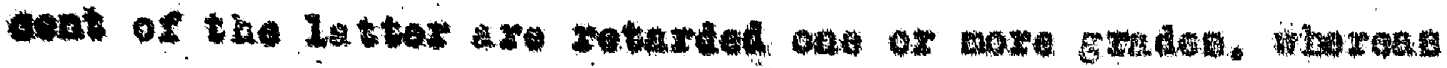

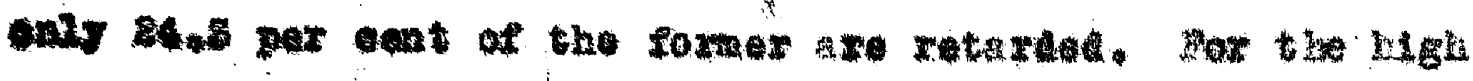

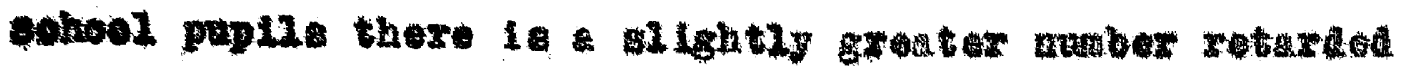

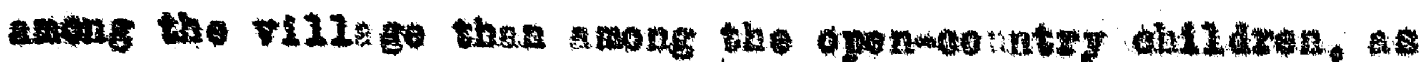

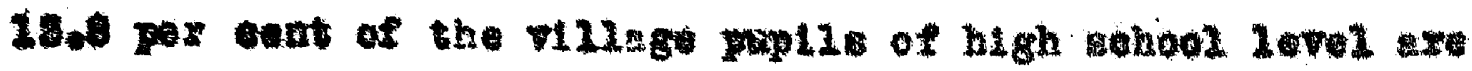

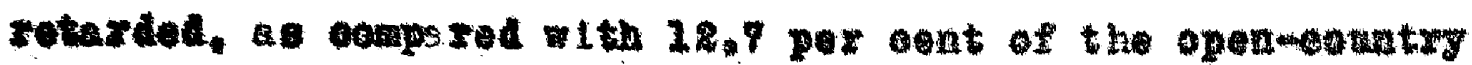

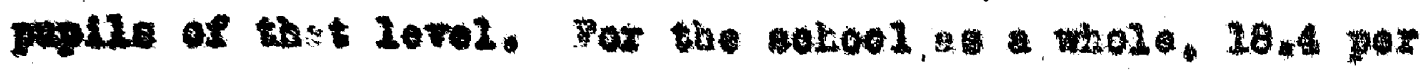

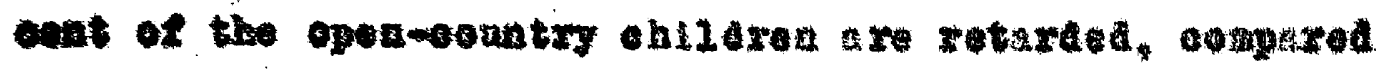
with 27.6 per coat of the vilidge children. The gretetet

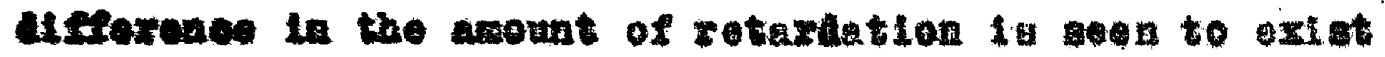
botween the oleseratery grates and the bigh ahool. In the grates the rate of retardation for the sebool it 25.1 per

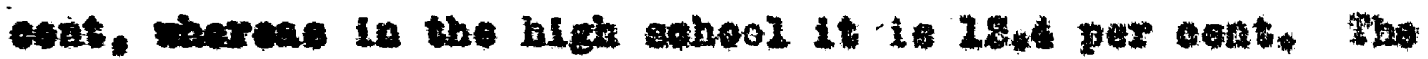
rte of retardstion for the sobool a o whol to 17.9 per coat.

The next toplo to be constderad is now thoodengation of the parate of the open-eountry elidren in relation to the expected ox proferred roontion of thes chlidren. It an be

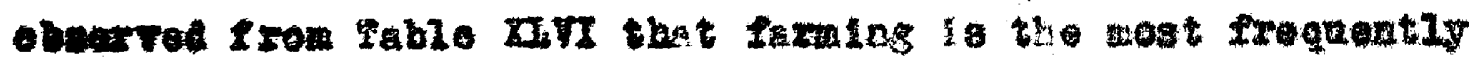

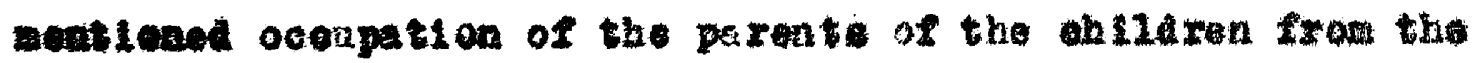

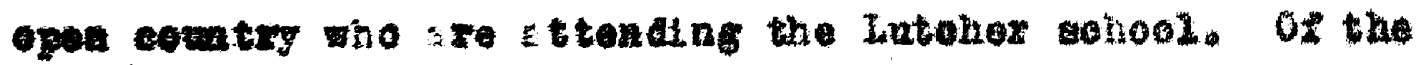

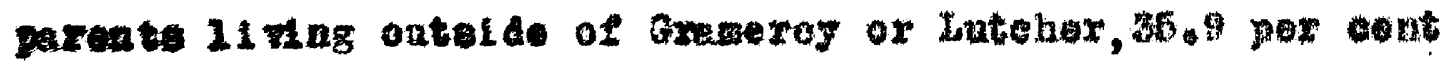

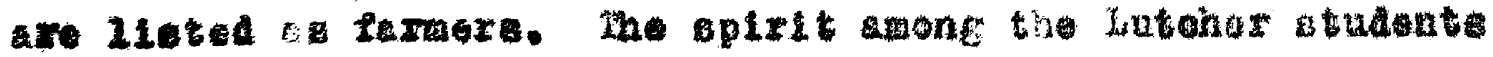

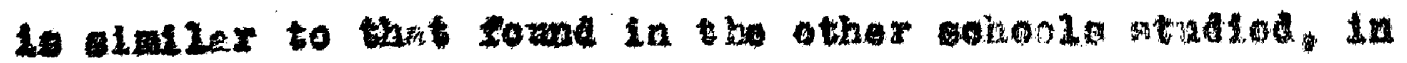
thet tew of the studenta exprese an oxpoctation of be ing

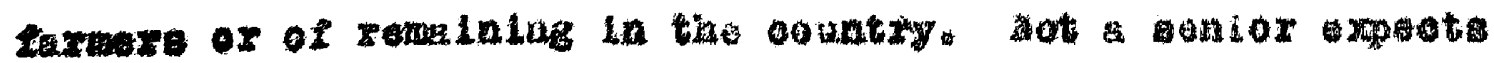

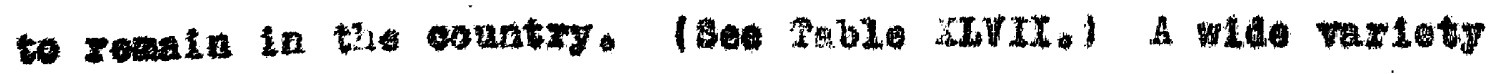


Table xVI

Cocupations of the Parents of Students of the

Iutohor Sehool

High sohool Elementary sohool number Per cont Number per cont

\begin{tabular}{|c|c|c|c|c|}
\hline 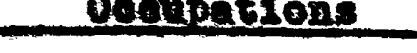 & slinos & Por cont & Number & Per cont \\
\hline 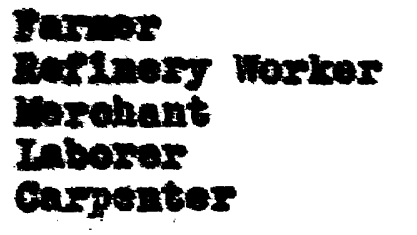 & $\begin{array}{l}32 \\
18 \\
11 \\
8 \\
5\end{array}$ & $\begin{array}{r}37.6 \\
14.1 \\
12.9 \\
9.4 \\
5.9\end{array}$ & $\begin{array}{r}31 \\
5 \\
9 \\
7 \\
2\end{array}$ & $\begin{array}{r}43.7 \\
7.0 \\
12.7 \\
9.9 \\
2.8\end{array}$ \\
\hline 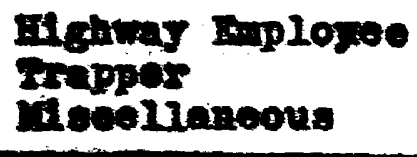 & $\begin{array}{r}2 \\
0 \\
15\end{array}$ & $\begin{array}{r}2.4 \\
0.0 \\
17.6\end{array}$ & $\begin{array}{r}2 \\
11\end{array}$ & $\begin{array}{r}2.8 \\
5.6 \\
15.5\end{array}$ \\
\hline Totel & 85 & 100.0 & 71 & 200.0 \\
\hline
\end{tabular}

Tabie XIVII

Coenpational Preferenoe of the students of the

Latoher Sobool

\begin{tabular}{|c|c|c|c|c|}
\hline Oopuat1ors & $\begin{array}{l}\text { Hegr } \\
\text { number }\end{array}$ & $\begin{array}{l}\text { School } \\
\text { Per Cent }\end{array}$ & $\begin{array}{l}\text { BIement } \\
\text { Number }\end{array}$ & $\begin{array}{l}\text { 80hool } \\
\text { Per Cont }\end{array}$ \\
\hline 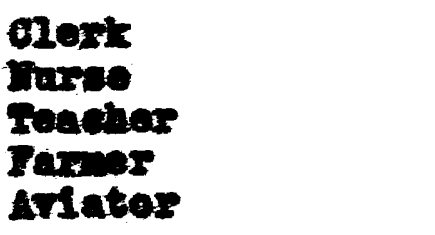 & $\begin{array}{l}56 \\
41 \\
17 \\
28 \\
17\end{array}$ & $\begin{array}{r}19.7 \\
24.7 \\
6.1 \\
10.0 \\
6.1\end{array}$ & $\begin{array}{l}11 \\
18 \\
42 \\
27 \\
19\end{array}$ & $\begin{array}{r}6.1 \\
10.5 \\
23.2 \\
14.9 \\
10.5\end{array}$ \\
\hline 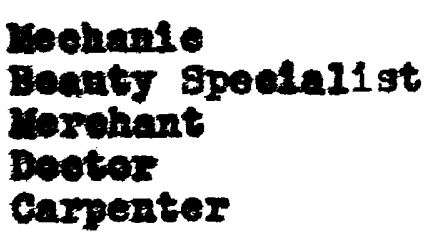 & $\begin{array}{r}19 \\
15 \\
9 \\
7 \\
4\end{array}$ & $\begin{array}{l}6.8 \\
5.4 \\
3.2 \\
2.5 \\
1.4\end{array}$ & $\begin{array}{l}3 \\
6 \\
8 \\
5 \\
8\end{array}$ & $\begin{array}{l}1.7 \\
3.5 \\
4.4 \\
2.8 \\
4.4\end{array}$ \\
\hline 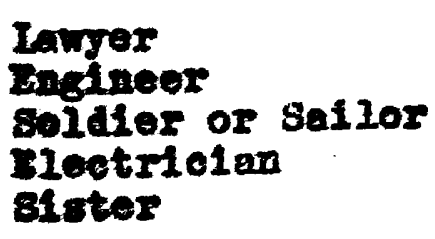 & $\begin{array}{l}4 \\
9 \\
2 \\
4 \\
2\end{array}$ & $\begin{array}{l}1.4 \\
3.2 \\
0.7 \\
1.4 \\
0.7\end{array}$ & $\begin{array}{l}5 \\
0 \\
5 \\
1 \\
2\end{array}$ & $\begin{array}{l}2.8 \\
0.0 \\
2.8 \\
0.8 \\
1.1\end{array}$ \\
\hline $\begin{array}{l}\text { Trapper } \\
\text { Hiscellaneous }\end{array}$ & 4 & $\begin{array}{r}0.4 \\
15.8 \\
\end{array}$ & $\begin{array}{r}3 \\
17 \\
\end{array}$ & $\begin{array}{l}1.7 \\
9.4 \\
\end{array}$ \\
\hline & 279. & 200.0 & 181 & 100.0 \\
\hline
\end{tabular}




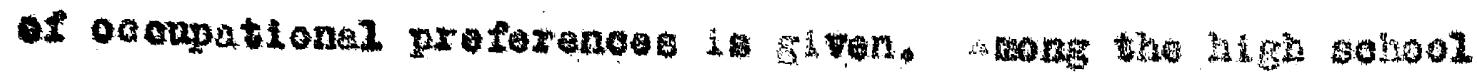

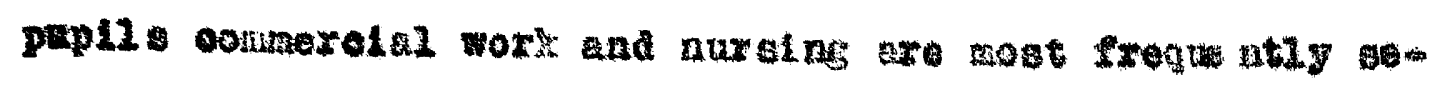

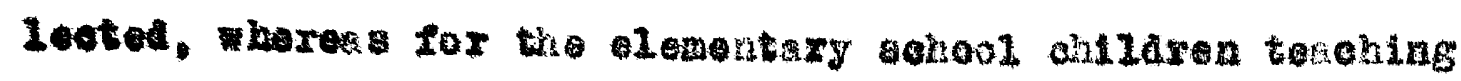
and farding are moat popular.

In the luteher achool, the la the liangham avood, th

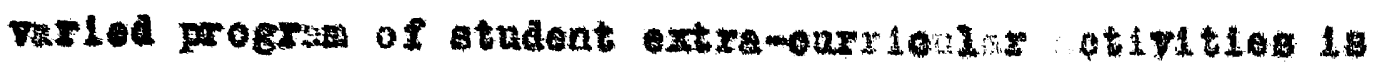

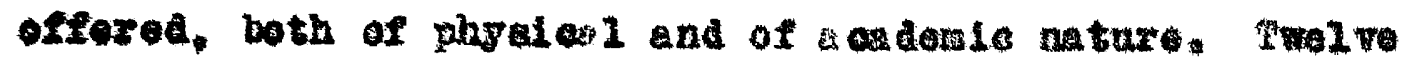

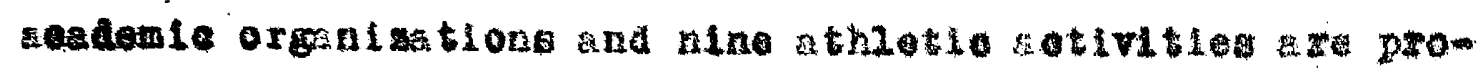

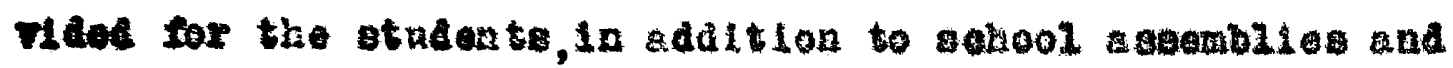
elese orgenisetione. I 360 Table ChVIII, whiob shows the aetivities, the orgenistlons, and the armber of stats onts who atod that they take part in thom, ) There coens to no Iint placel on the nuber of aotifities in which the atudent nay take pert. The olube, wads, gle olub, and other oxganisatigas met and prootice auriag the pehool hour at regriar periods provided most of the stidents can fo juged from the

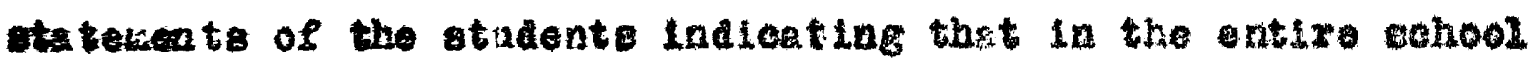

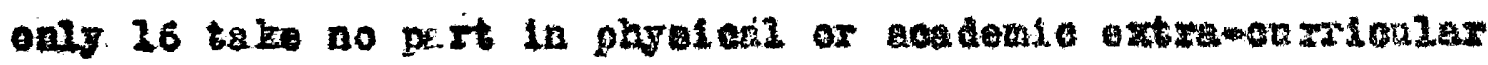
eativitieg,

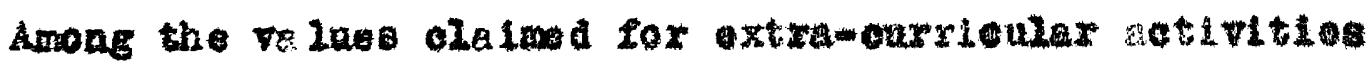
Is that of offering opportanition for areloplng gasiltion of Lederemip knong the studente. Durlng the vist to the Litoher

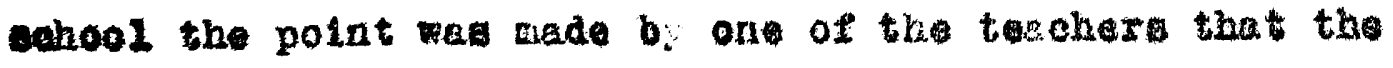
open-ountry snd v12lgge chllaren held themeelves apst and the they conetitute to groupg in the sohool. On vationg ocealono thlas ocntention ha been we to the anthor by 


\section{Tab2e XIVIII}

Particlpation in Student hotivities and Organizations in the Luteher High Sahool by Residenoe

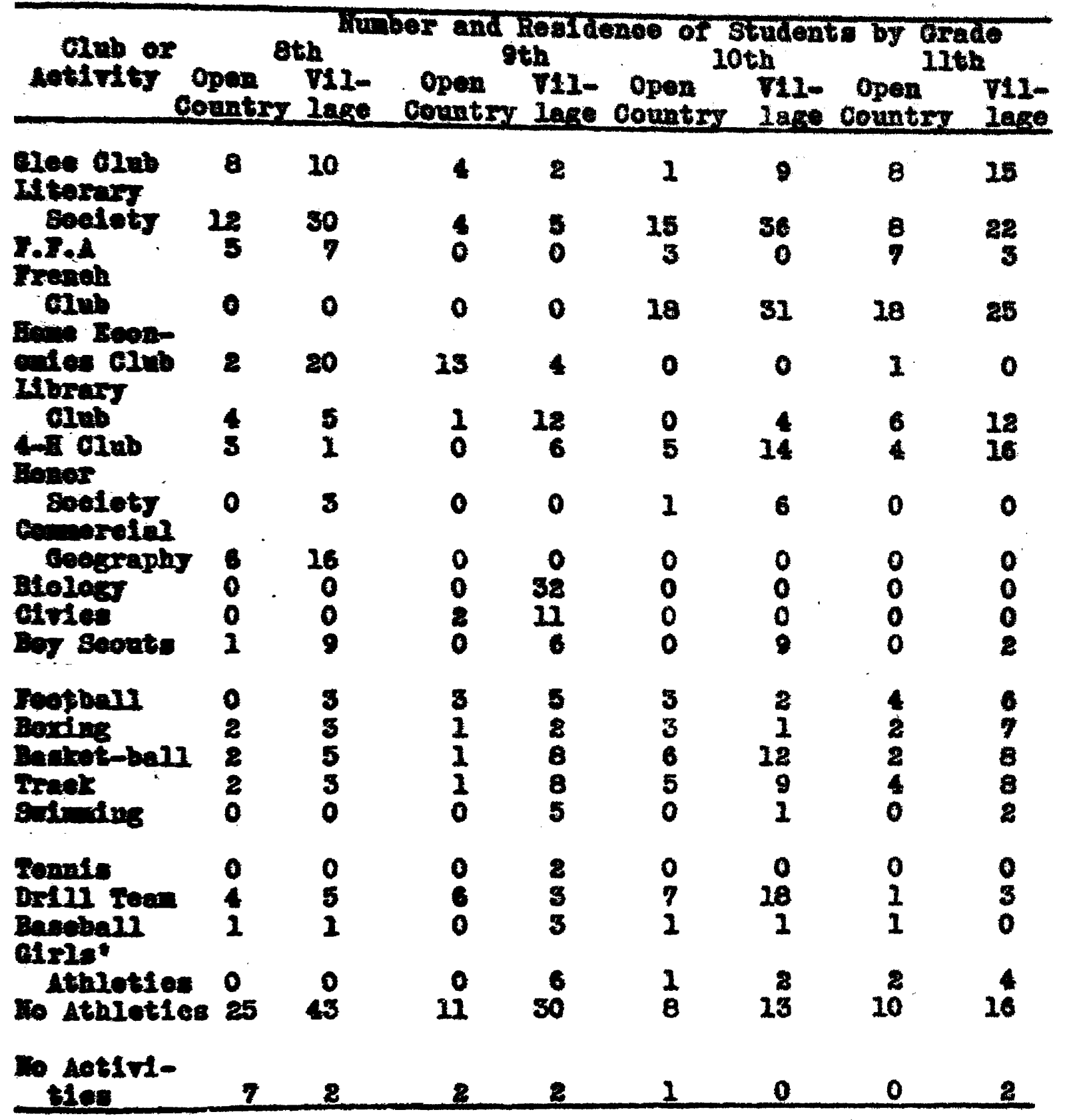

The school has two student bands not llated abore-- an A band ith 23 members and a band wth 35 members. 


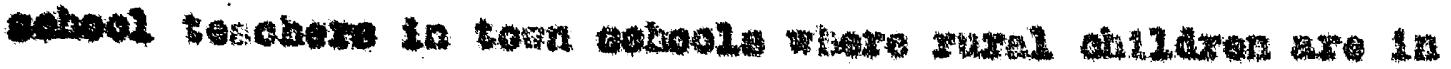

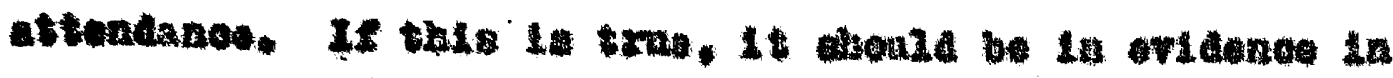

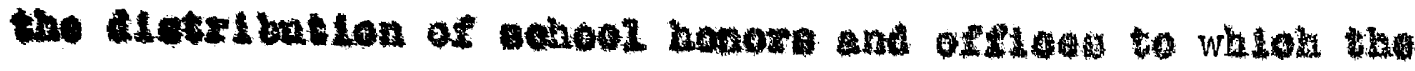

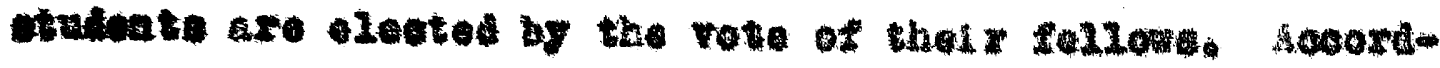

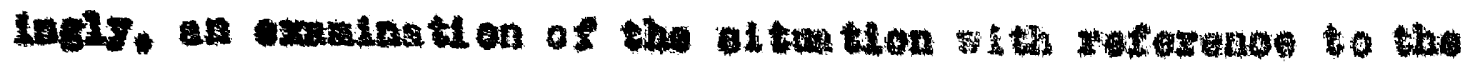

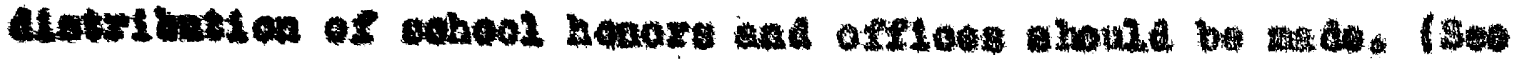

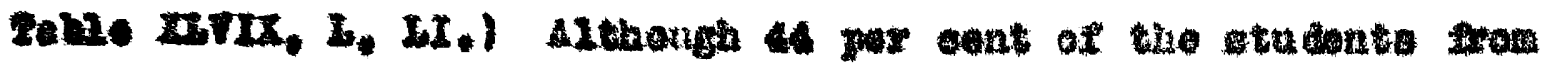

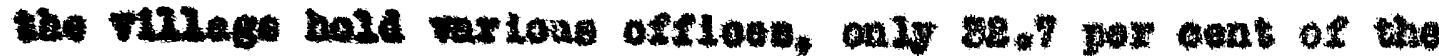

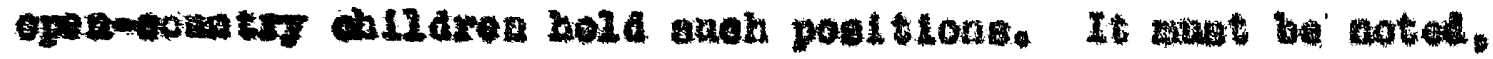

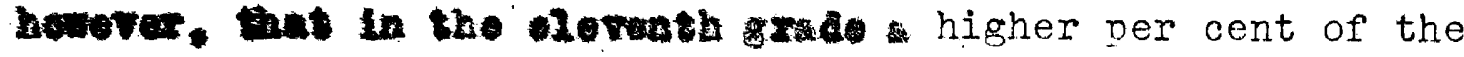
opan-onatsy otralonte hold achool of

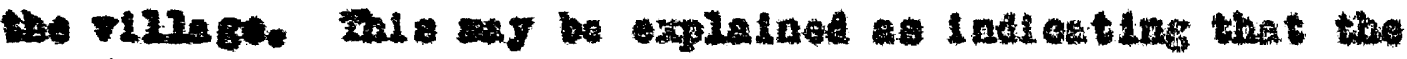

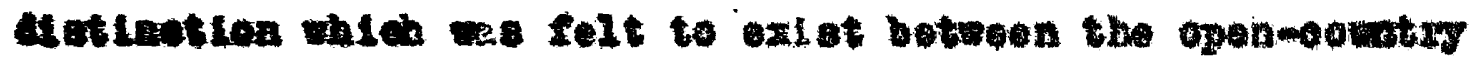

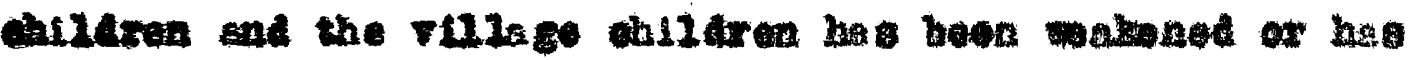

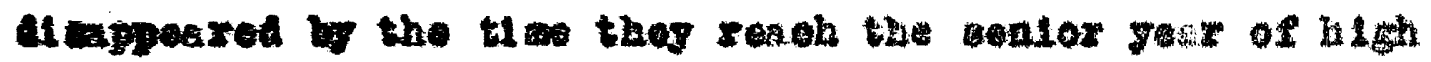
sobool.

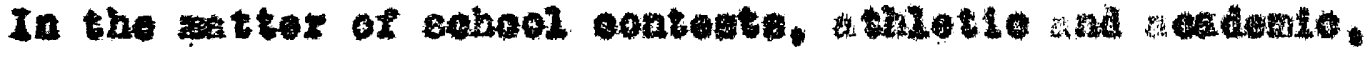
a more congletent alfferentiation botween the paplla frod the

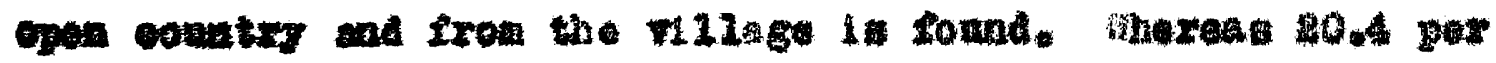

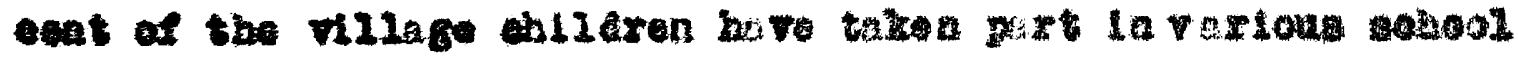

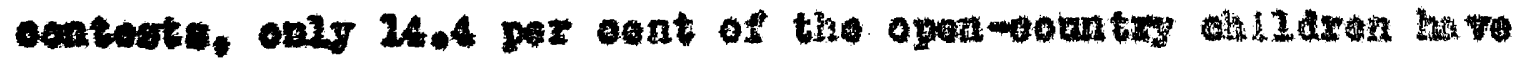

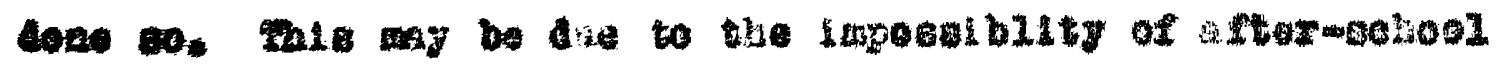

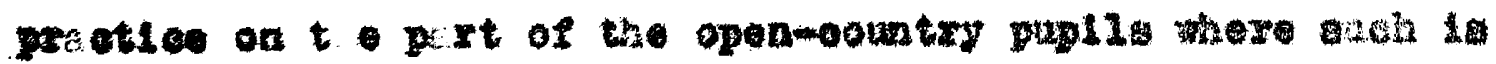

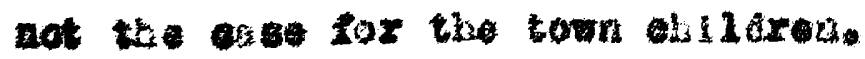

1t to now intereating to examino the rolo tho colnool

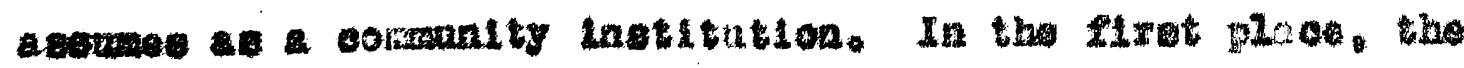

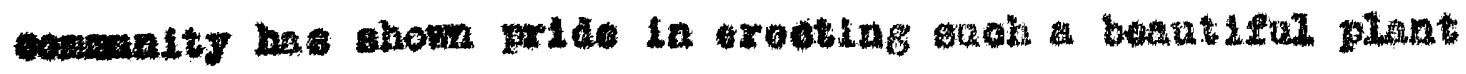


Table XIVIX

School or Olub Offices Held by Lutcher Students Acoording to Their Regldence

\begin{tabular}{lcc}
\hline Orfice & \multicolumn{3}{c}{ Residance } \\
\hline Ilo orfice & 74 & 116 \\
Presldent & 10 & 19 \\
Fice-Pregident & 4 & 19 \\
Preasurer & 8 & 6 \\
Secretary & 7 & 21 \\
Secretary-Treasurer & 0 & 5 \\
Critic & 0 & 1 \\
Mlscellanoous & 7 & 20 \\
\hline
\end{tabular}

Pable I

Contests in Which Students Have Represented the Iutoher Sohool According to Residence

\begin{tabular}{lcc}
\hline \multicolumn{1}{c}{ Contests } & \multicolumn{3}{c}{ Reglidence } \\
\hline Sehool Subjects & 5 & 5 \\
Debating & 0 & 4 \\
Vuslo & 0 & 2 \\
Suriming & 0 & 6 \\
Basicet-ball & 0 & 7 \\
Boxing & 0 & 5 \\
Track & 5 & 6 \\
Other Athleticg & 4 & 4 \\
\hline
\end{tabular}


Table II

comparison of Open-Country and Village students of the

Inteher High Sehool on the Basis of Sohool Honors and

Contests in which Students Have Represented the School

\begin{tabular}{|c|c|c|c|c|c|c|c|c|}
\hline \multirow{3}{*}{ arade } & \multicolumn{4}{|c|}{$\begin{array}{l}\text { Open-country } \text { Gtudents } \\
\text { orfices lone }\end{array}$} & \multicolumn{4}{|c|}{ VIriage students } \\
\hline & \multicolumn{2}{|c|}{$\begin{array}{l}\text { Orfices } \\
\text { Tumber Per } \\
\text { Cent }\end{array}$} & $\begin{array}{l}\text { Don } \\
\text { Rumber }\end{array}$ & $\begin{array}{l}\text { Per } \\
\text { Cent }\end{array}$ & \multicolumn{2}{|c|}{$\begin{array}{l}\text { Orfices } \\
\text { Number Fer } \\
\text { Cent }\end{array}$} & \multicolumn{2}{|c|}{$\begin{array}{l}\text { Nowe } \\
\text { Number Per } \\
\text { Cent. }\end{array}$} \\
\hline & $\mathbf{3}$ & 9.1 & 30 & 90.9 & 21 & 34.4 & 40 & 65.6 \\
\hline Oth & 8 & 30.8 & 18 & 69.8 & 15 & 29.4 & 34 & 70.6 \\
\hline Ioth & 10 & 36.5 & 16 & 61.5 & 28 & 56.0 & 22 & 44.0 \\
\hline 11th & 15 & 60.0 & 10 & 40.0 & 27 & 57.4 & 20 & 42.6 \\
\hline \multirow[t]{2}{*}{ Iotal } & 36 & 38.7 & 74 & 67.3 & 91 & 44.0 & 216 & 56.0 \\
\hline & $\cos$ & ateats & In thleh & Studer & ts Ileve & Repre & sented & Sohool \\
\hline oth & 0 & 0.0 & 32 & 100.0 & 3 & 6.0 & 47 & 94.0 \\
\hline oth & 1 & 4.8 & 21 & 95.2 & 7 & 16.3 & 36 & 83.7 \\
\hline $20 \mathrm{th}$ & 7 & 29.2 & 17 & 70.8 & 16 & 34.0 & 31 & 66.0 \\
\hline 21th & 6 & 32.6 & 13 & 68.4 & 13 & 32.5 & 27 & $67 / 5$ \\
\hline Total & 14 & 15.6 & 76 & 84.4 & 38 & 20.4 & 148 & 79.6 \\
\hline
\end{tabular}




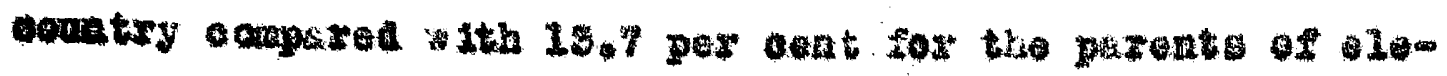

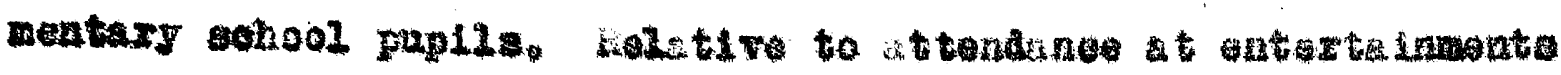

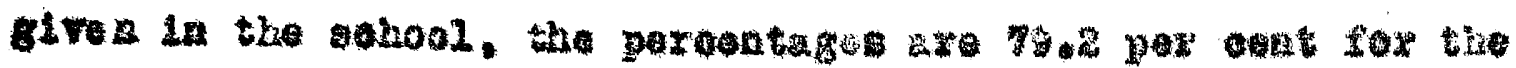
perenta of elewontary colool gaplis a 80.2 per ow tox

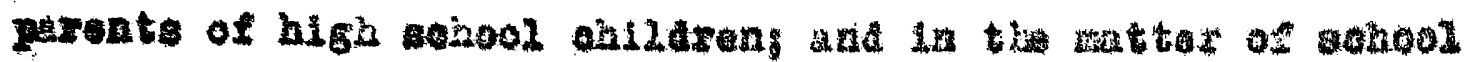

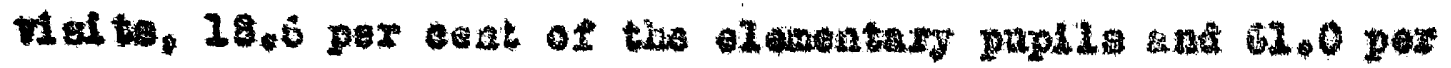

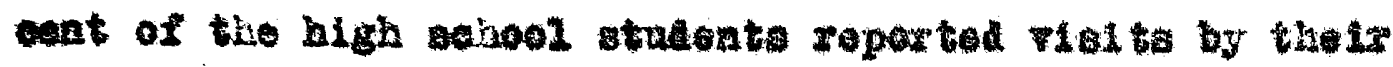
parente.

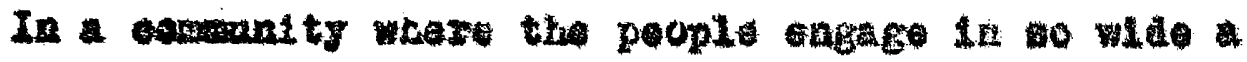

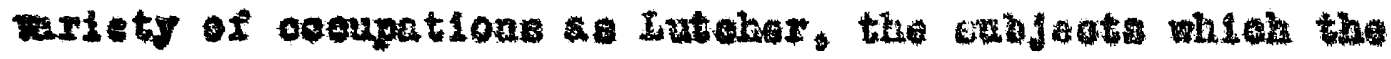

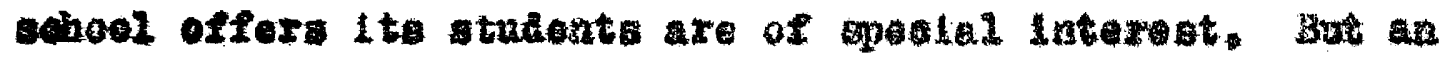

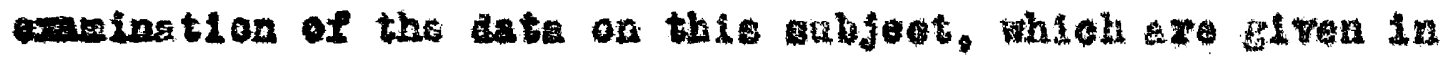

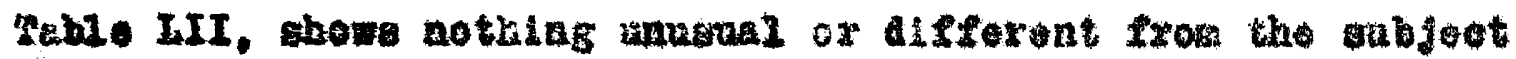

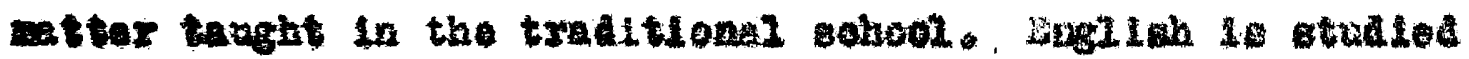
by the most otudente, th a totad of 260 taking the oulsect.

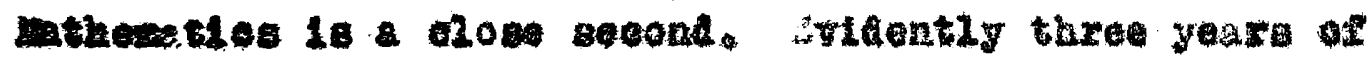

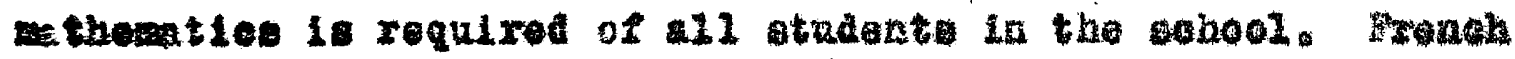

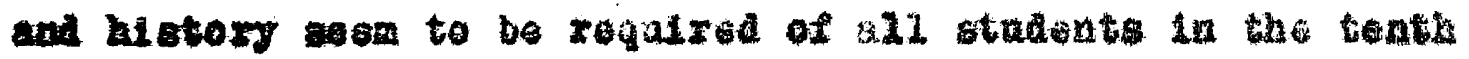

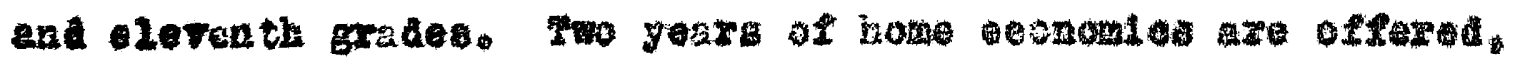

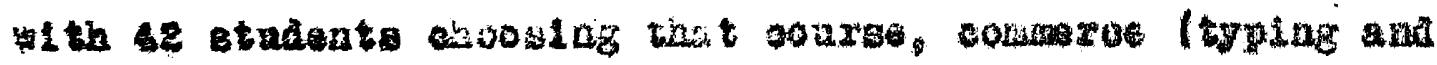

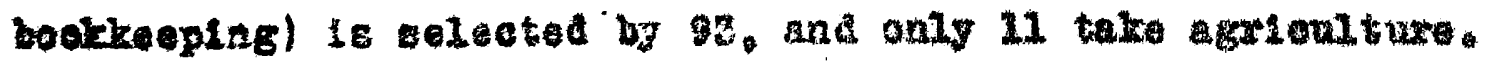

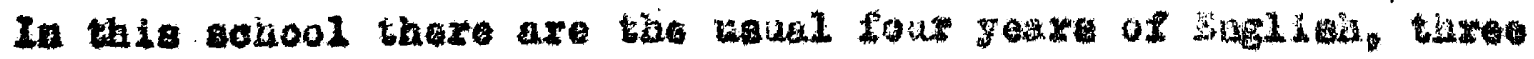

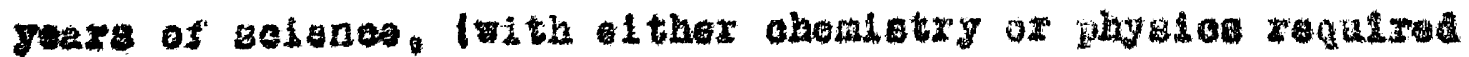

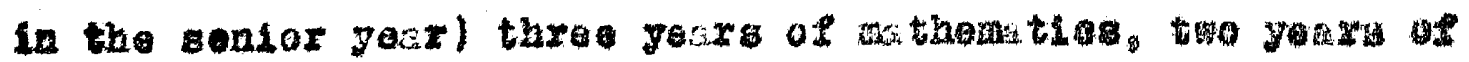

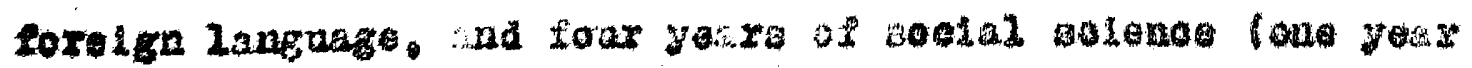

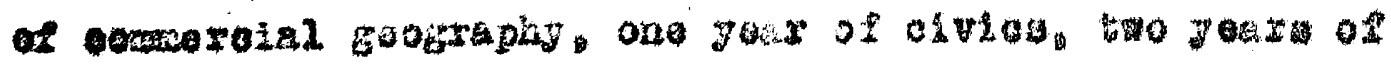
betory, forld and harian). The tradilond progran ia 
Table III

Subjeots Taken by the Students of the Intoher

High sohool

\begin{tabular}{|c|c|c|c|c|c|}
\hline subleet & Eth & Oth & 10th & 11th & rotal \\
\hline Hethesatios & 90 & $-\infty$ & - & - & 90 \\
\hline Dagling & 90 & 70 & 64 & 56 & 280 \\
\hline Genoral Selenoe & 89 & 2 & - & - & 92 \\
\hline Fow Beonomi os & 23 & 19 & - & - & 42 \\
\hline Blaloes & - & 52 & - & - & 58 \\
\hline Algown & 1 & 72 & - & - & 72 \\
\hline Afolenttore & 10 & - & - & 1 & 12 \\
\hline Gompratal & 30 & - & 1 & - & 32 \\
\hline atries & 1 & 49 & - & 2 & 58 \\
\hline 2yolns & 16 & 8 & 8 & 6 & 38 \\
\hline Iftory & - & - & 63 & 50 & 113 \\
\hline Ecountry & - & - & 64 & 5 & 69 \\
\hline Booliseopine & 28 & 82 & 2 & 3 & 55 \\
\hline Frouk & - & - & 62 & 51 & 113 \\
\hline Chealotry & - & - & 2 & 26 & 87 \\
\hline Purates & - & - & -- & 29 & 29 \\
\hline Engis & $=$ & 20 & 8 & 1 & 19 \\
\hline 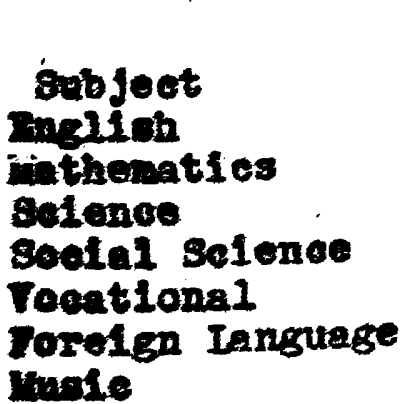 & \multicolumn{3}{|c|}{$\begin{array}{c}\text { Sumary } \\
\text { Number } \\
280 \\
231 \\
199 \\
198 \\
146 \\
113 \\
19\end{array}$} & \multicolumn{2}{|c|}{$\begin{array}{c}\text { Per Cent } \\
100.0 \\
82.5 \\
71.1 \\
70.0 \\
52.1 \\
40.4 \\
6.8\end{array}$} \\
\hline
\end{tabular}




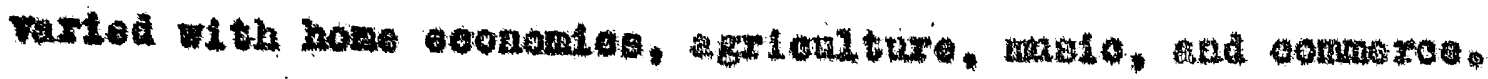

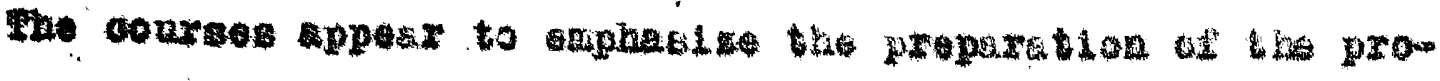
opective graduster for college rather than that of all the atudente

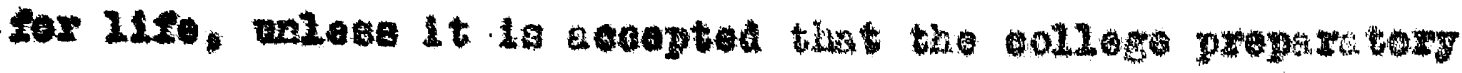

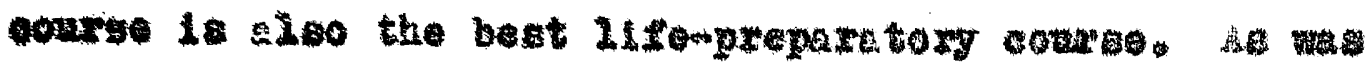

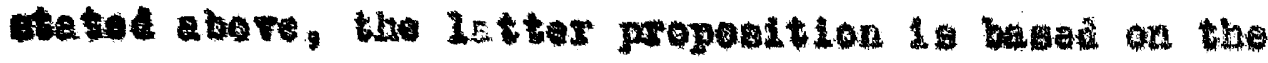

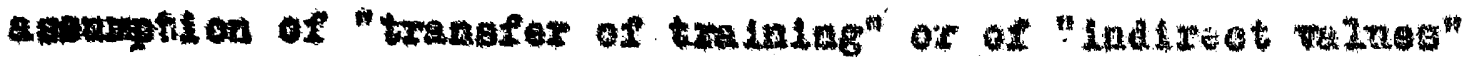
to berived from the eouroo pureued. Or 56 in the gran-

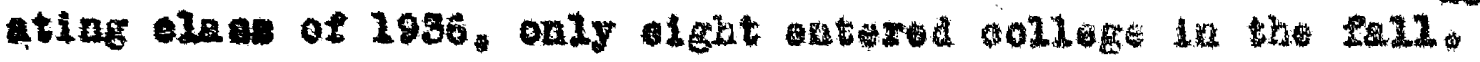

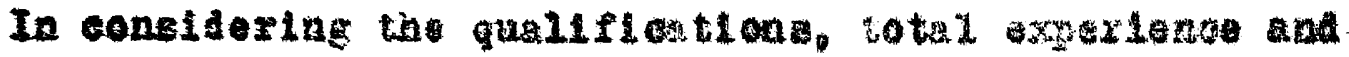

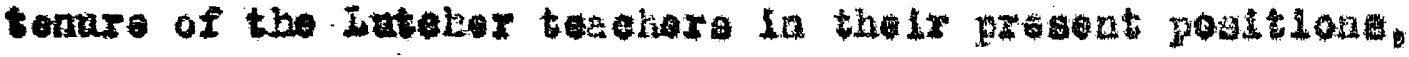

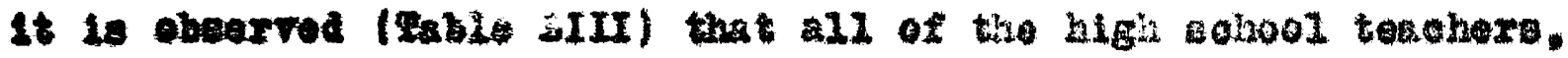

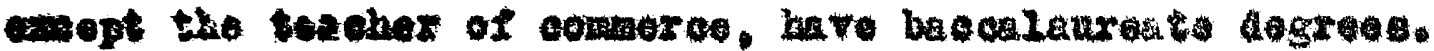

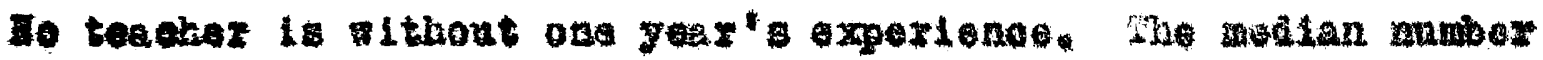

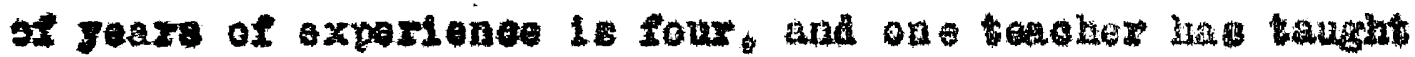

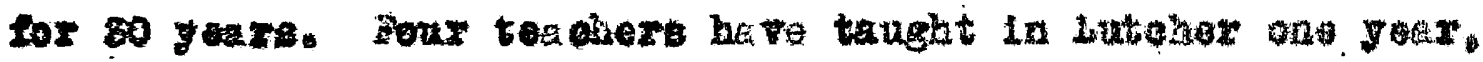

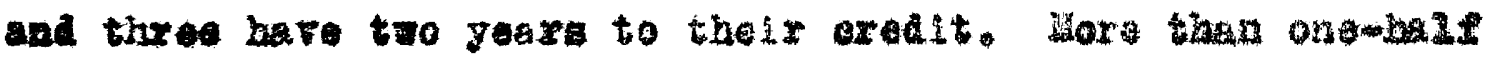

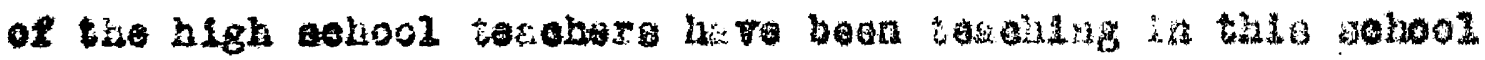

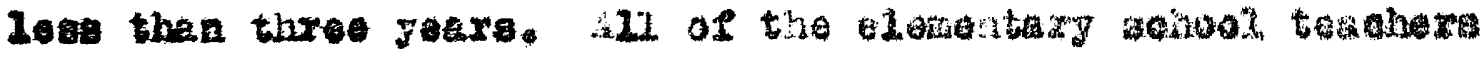

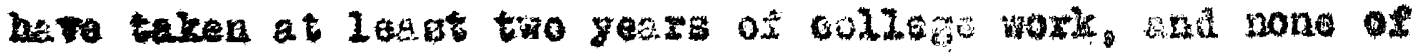

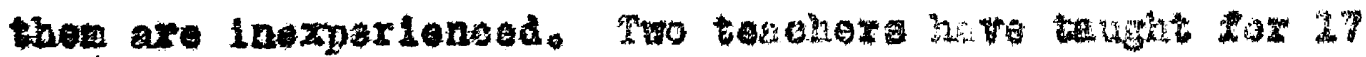

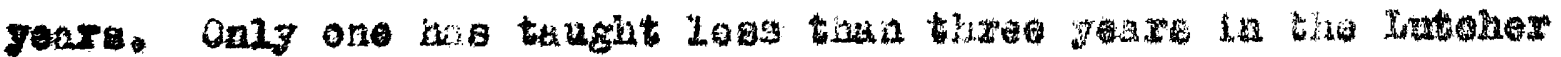

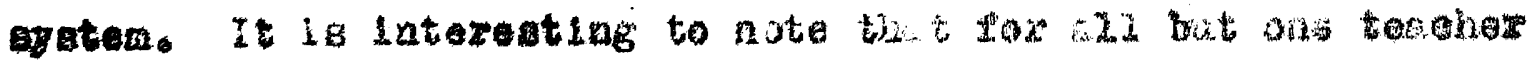

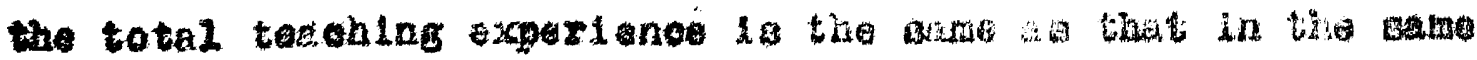

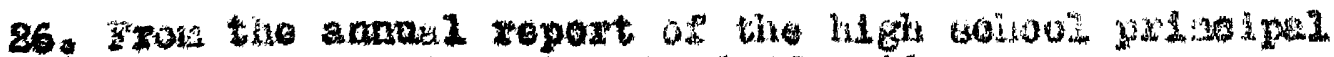

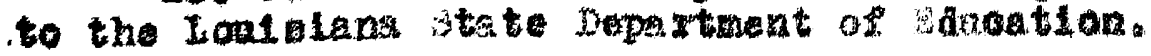


Table IrI

Acadenio Quallfieations and Tenure of the Iutoher

Sahool Teaohers

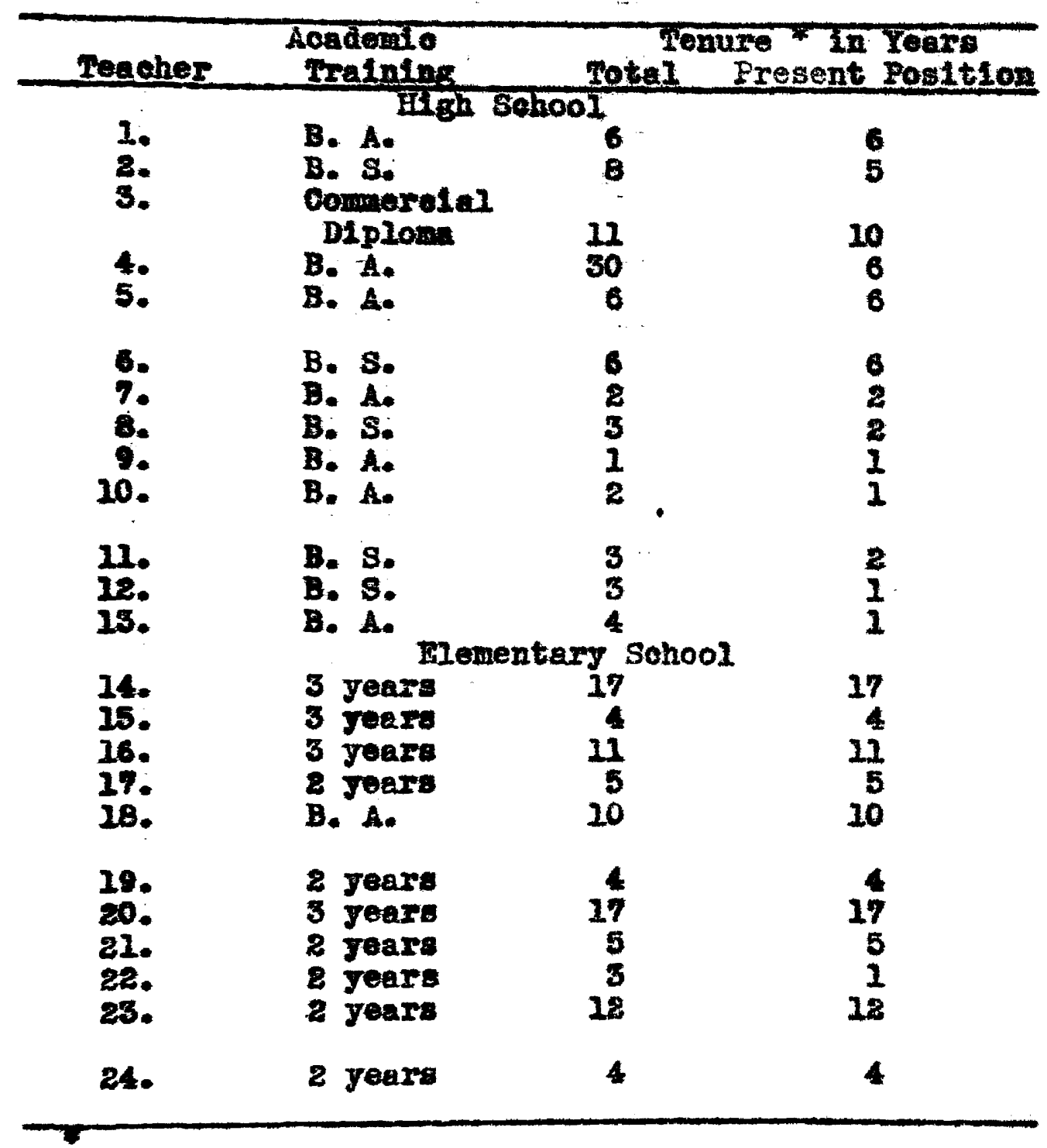

Tenure is here used in the same sense in which Foote user 1t. or-cit., p.2. 


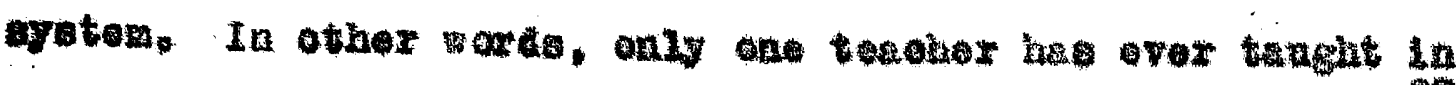

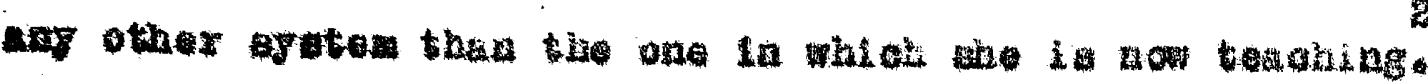
wiase the tow of Lutelder is the largest pleoe for

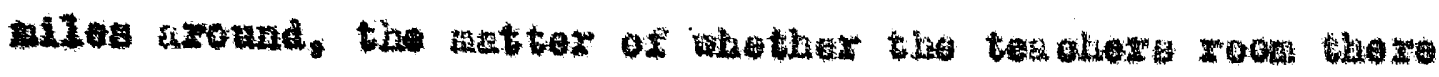

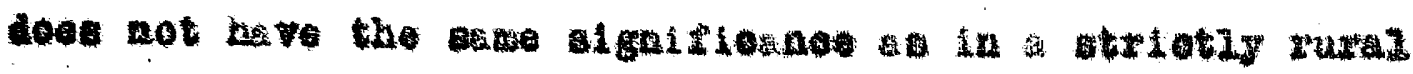

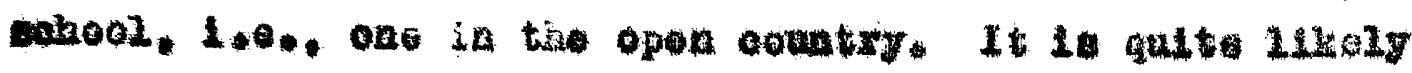

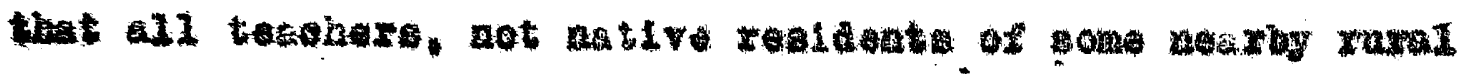

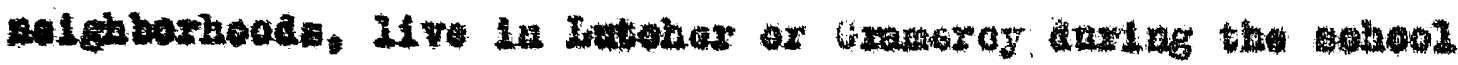

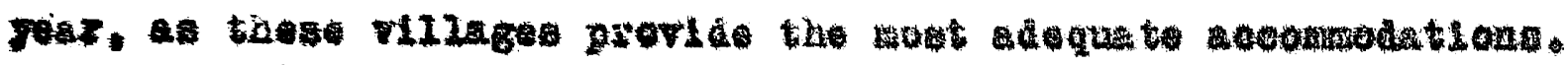

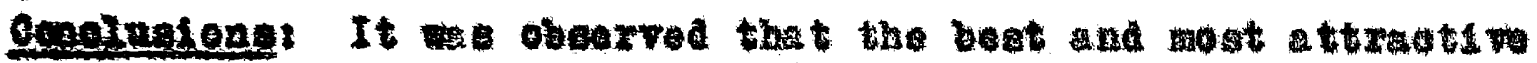

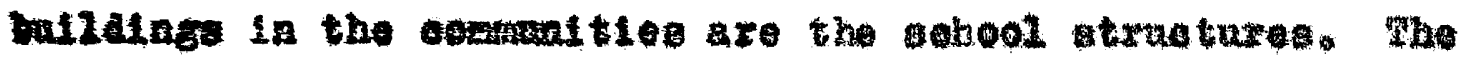

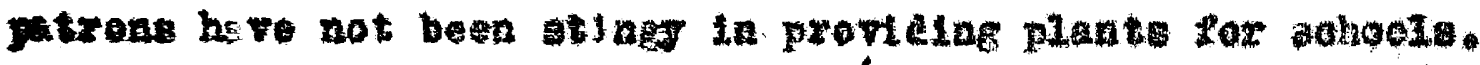
It might be pelated out the the conatzation of adounate

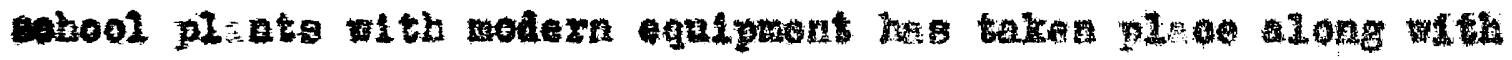

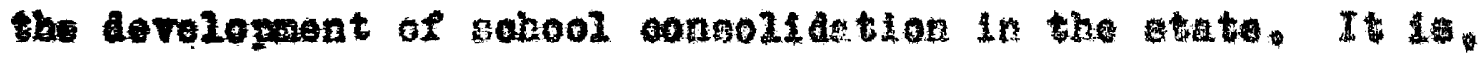

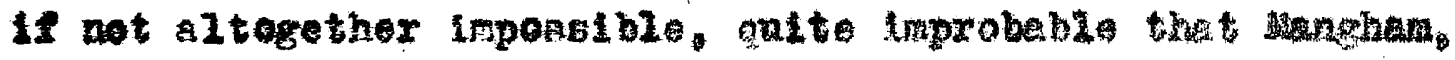

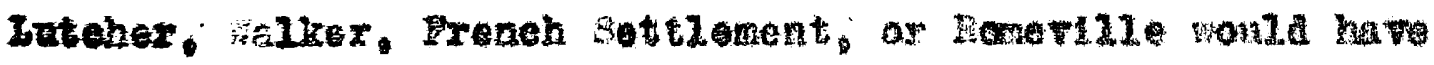

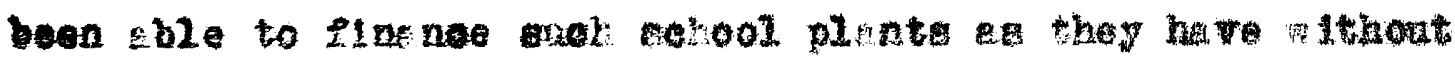

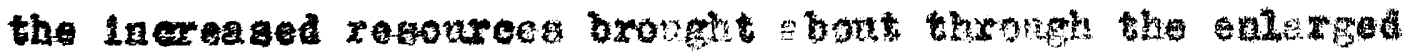

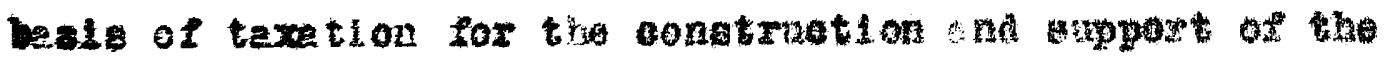

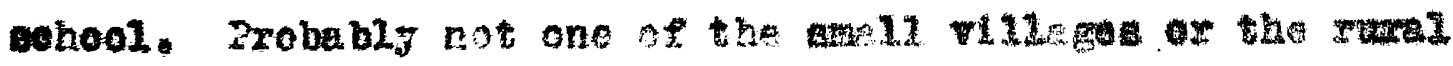

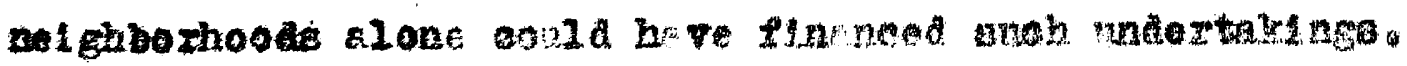

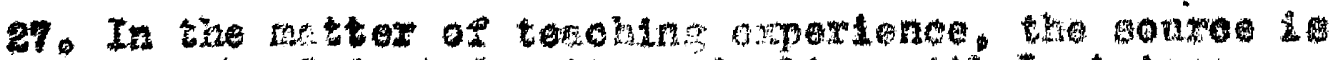

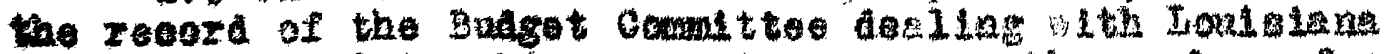

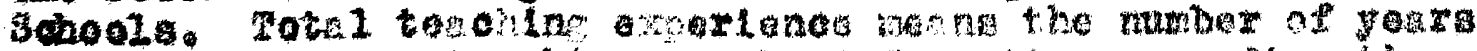

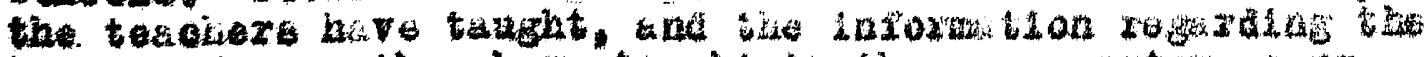

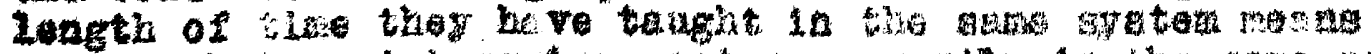

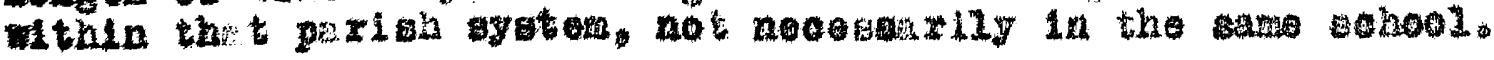




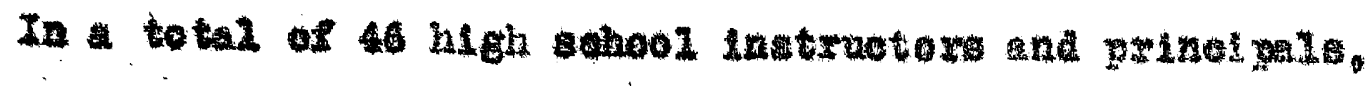

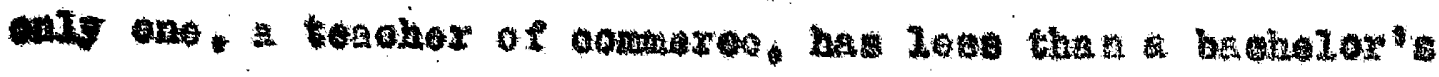

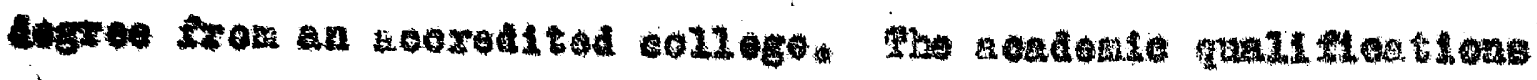

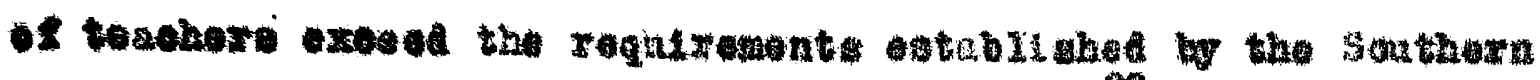

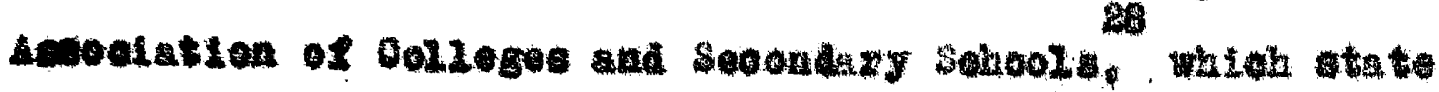

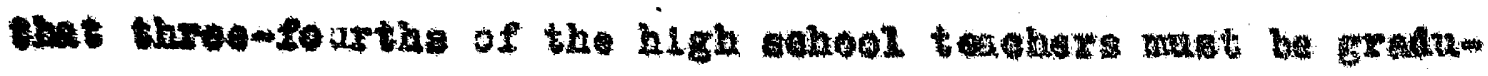

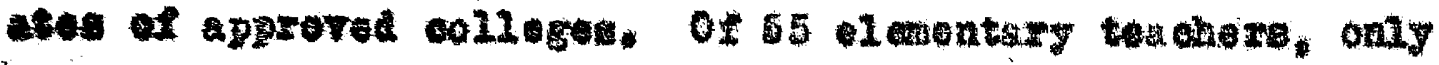

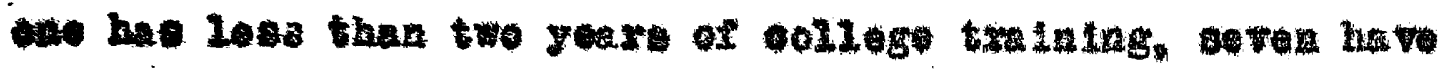
Brinelor's cogrees, and light have thre grare of oolloge woxtr

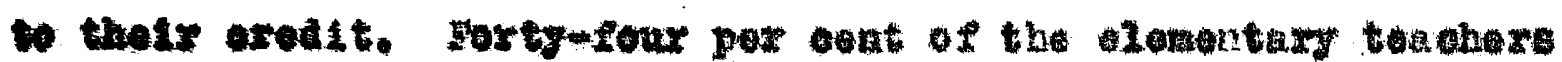
Mve reopited more than two jears of college prepartion.

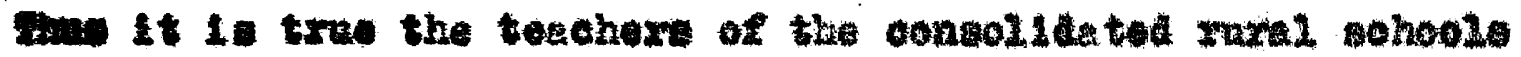

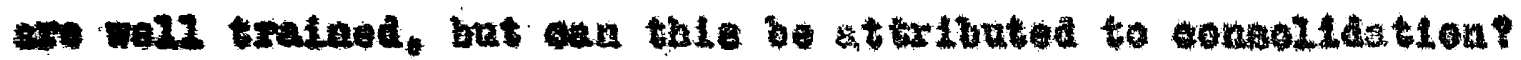

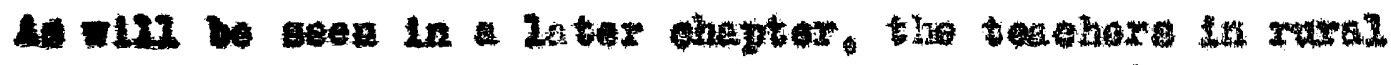

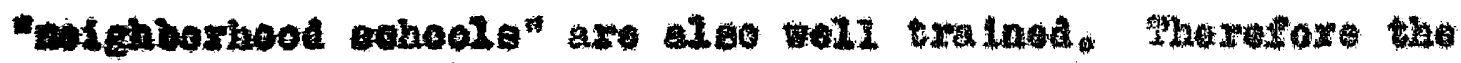

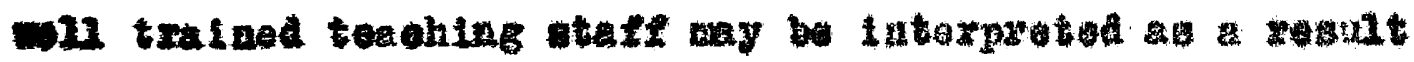

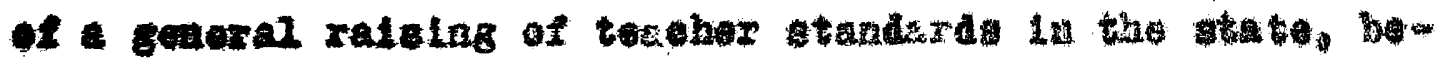

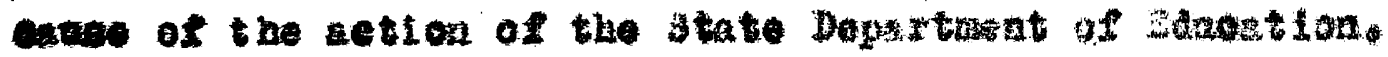

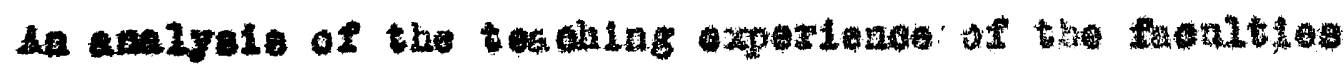

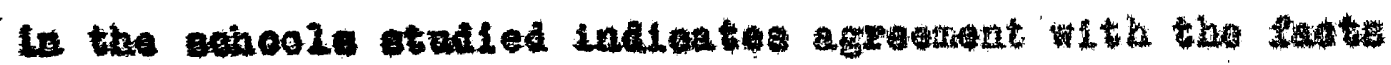

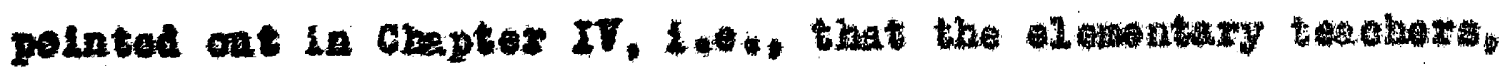

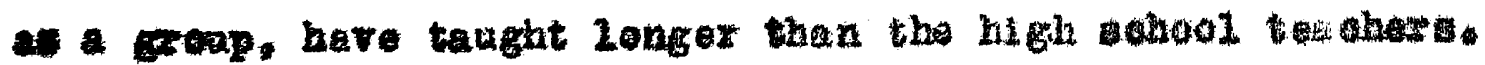

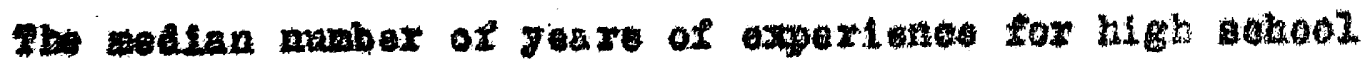

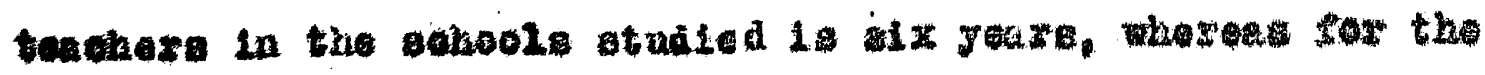
Lematary todohor: It 10 atre Jøars.

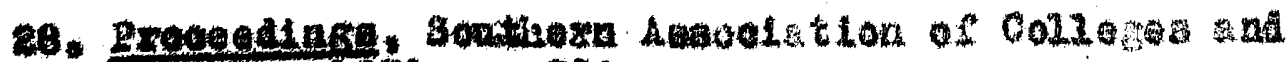

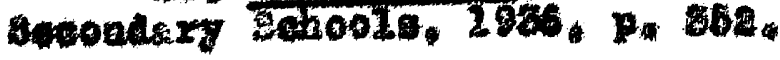


Tonure in the preaent posttion, too, 1s 20nger in the

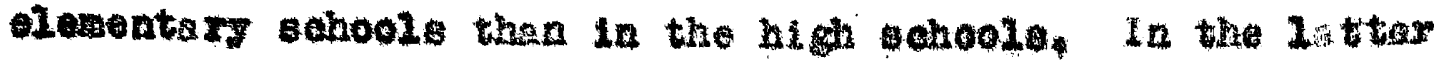
the sedica ferw of norvice in the present post tion $1 \mathrm{~s}$ two

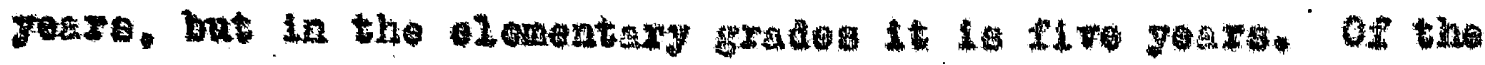
high sohool techers. 58.7 per cont have tauht lese than

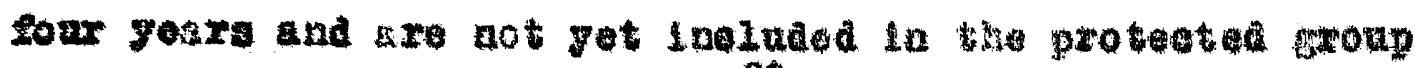

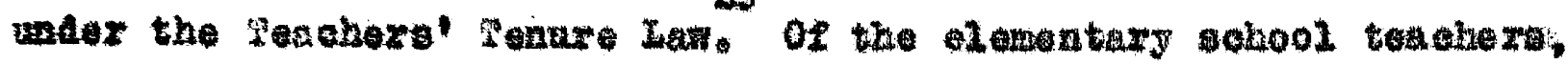
85.5 per cont he not comieted throe genrs of tosuling in their present position. She differenoe found bowen the lementary and high sehool teachers agread with the otaterent of cooke

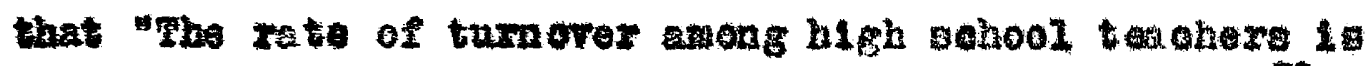

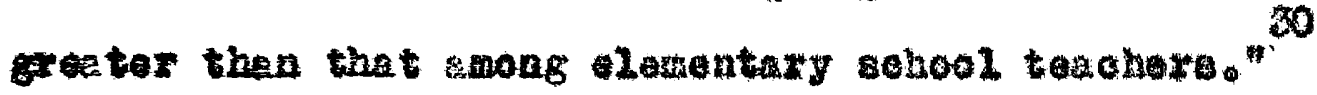

It me se conolnate that the towers ax mell tratned

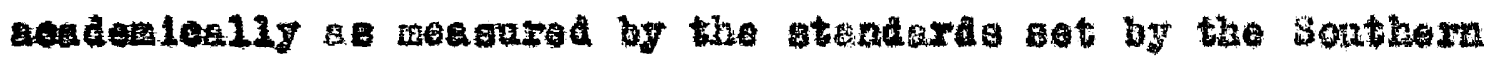

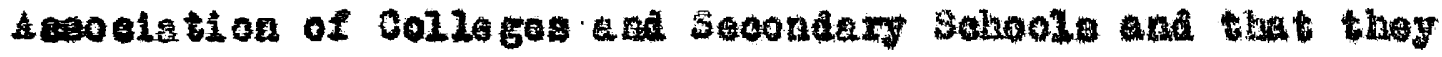
hare had a zeaconable amont of experience in tosohing: but.

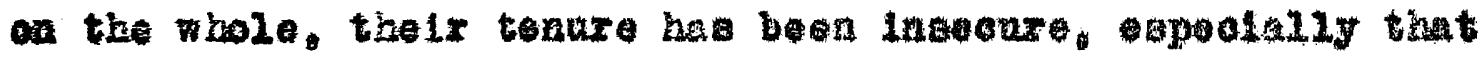
of the high serool teachera. It lo doubtral if tho "rentare

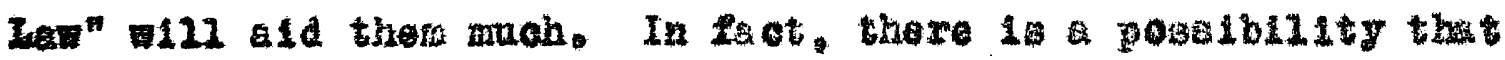

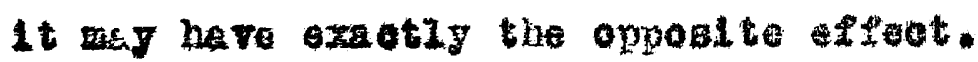

One neode ondy to potat out. In oonstatering the longth

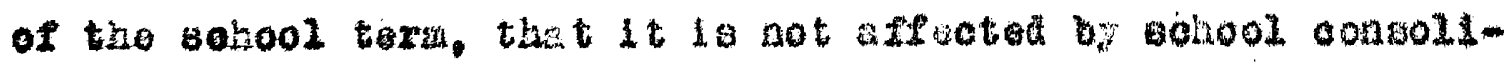

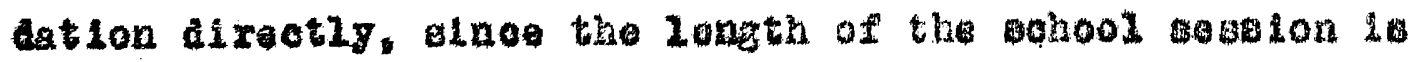

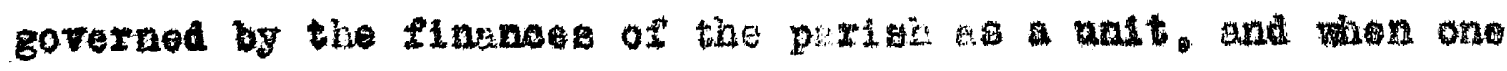

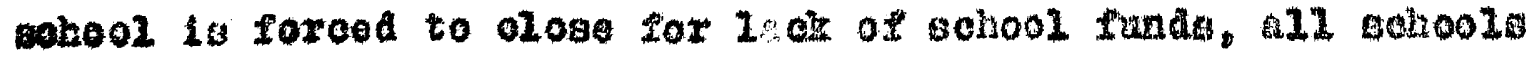




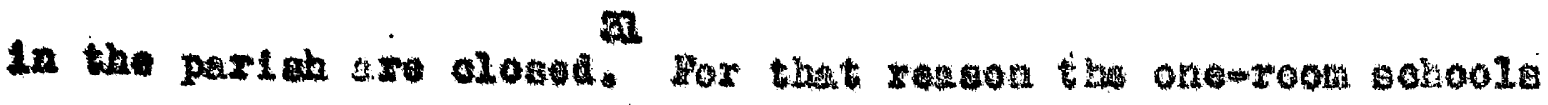
have a long a tero the largent oonsolluted sehool in the pariah.

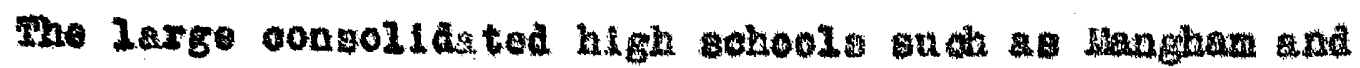

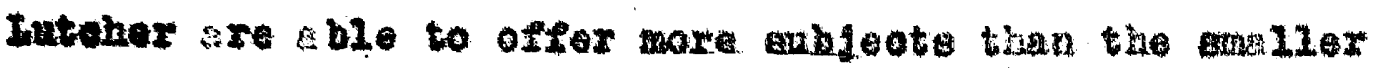

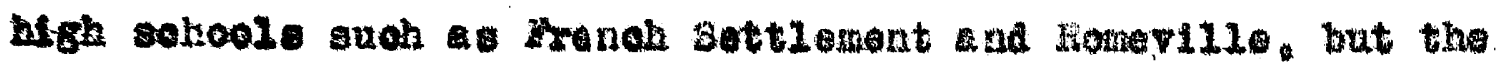

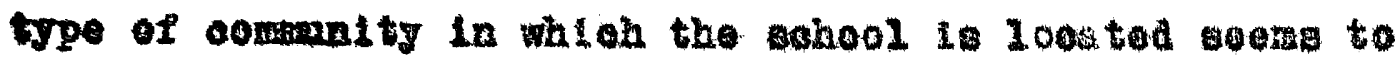

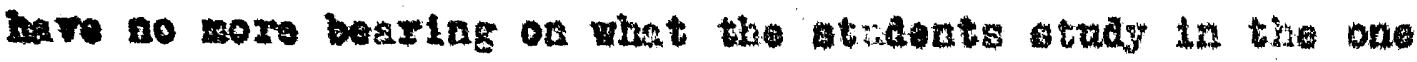
than in the other. i sost of mgion 2 power. mang. seoms to bettribated to odaction so the little regard is given to wat the stedont otudies so long a to la la school, being "otnested." Thee bellefo persibt il splte of the expirimenta of paychologiats such at woodworth and horndike, Deurborn, 84

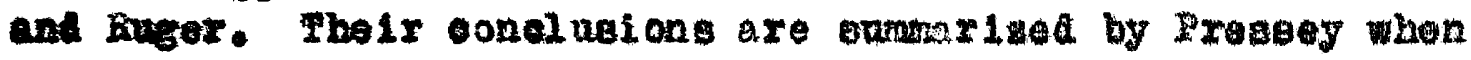
he age, "Oursicale wat, then, be congtructed with alroot rerexence to the objeotive to be obtalned; subjecta oan

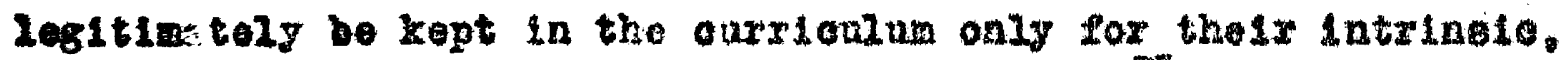
not for the diociplinary or inalreot, vilue " ${ }^{35}$ Eo furthex otetes, "atuentlonil progreas in the vorage bchool has lagged

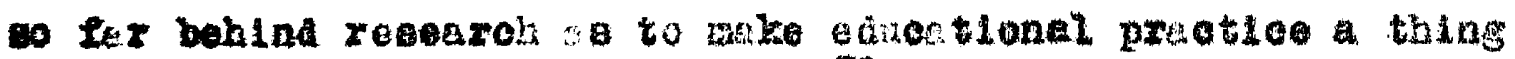
apart frow eduoatlonal knowlodge" "

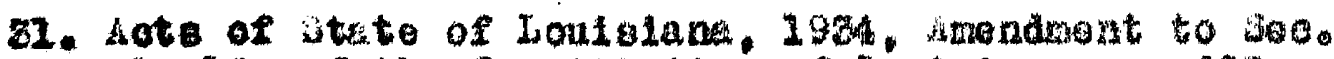
26 of artiole 12, of the Conetitution of louldiand, po G82.

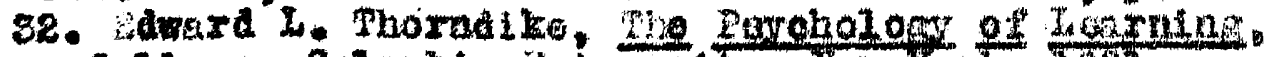

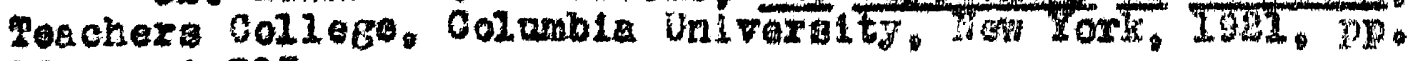
864. end 897 . z: Ibid, p. 876. 34. 1016. 408.

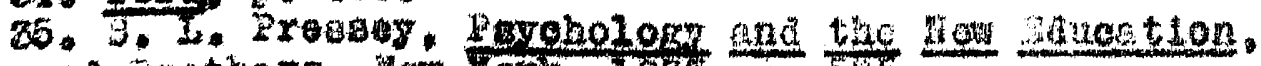

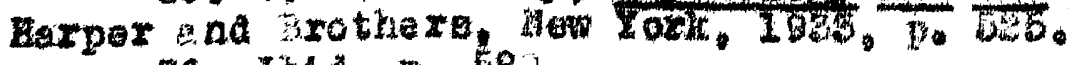
56. IbLdo. 58 . 


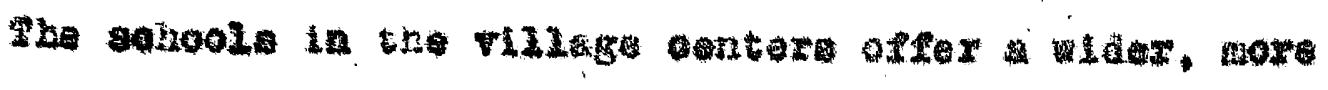

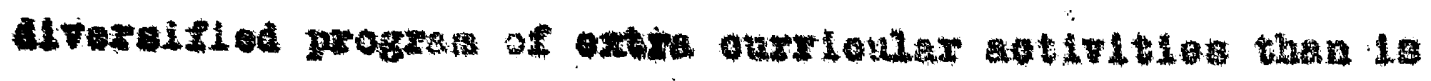

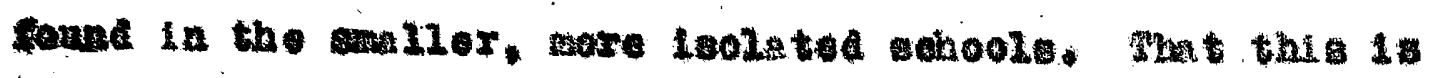

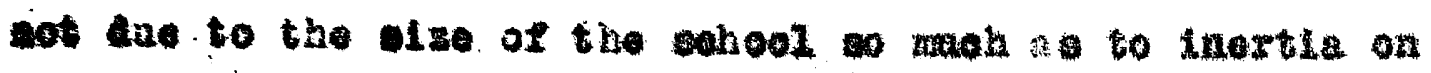
the paxt of the sohool dathortties on be cononotrated by

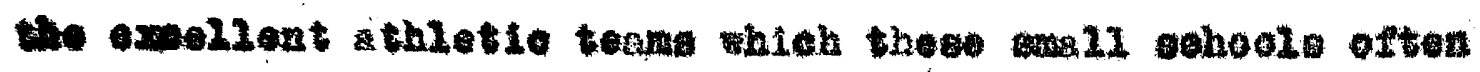
crvalop, It appears in most of the roheold that the develop-

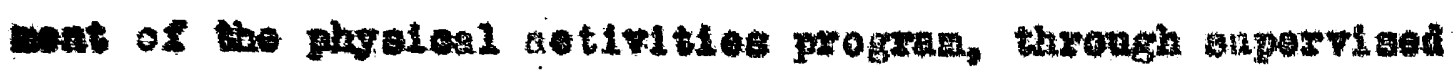

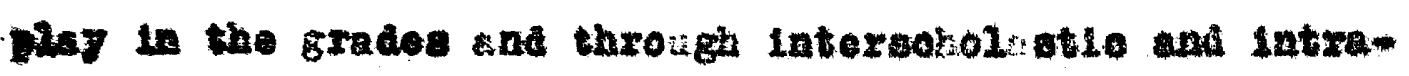
werl athleties in high sabool, has advaneod fuxther then the acaluale or 11 texaxy gotivities. Fox, whereas ta some abools,

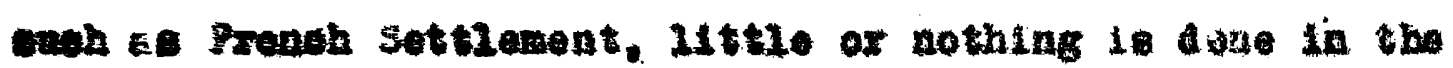

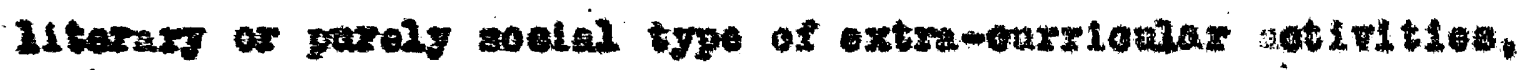

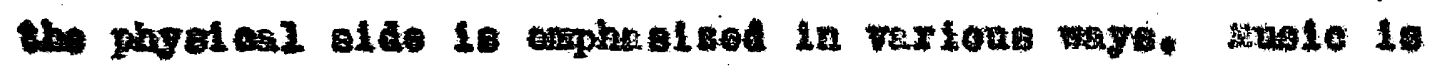

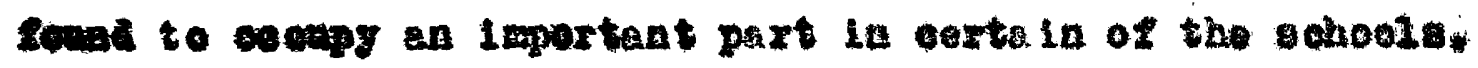
Thet tho coneolidated sohool offere greater opportunt

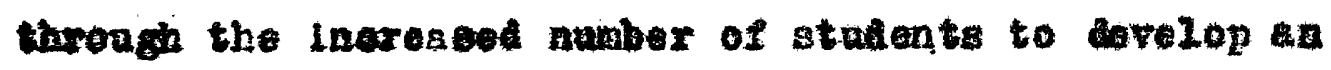
aetitity progres wide exorgh to mot tho deanda of the school

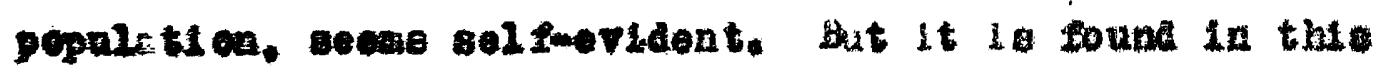

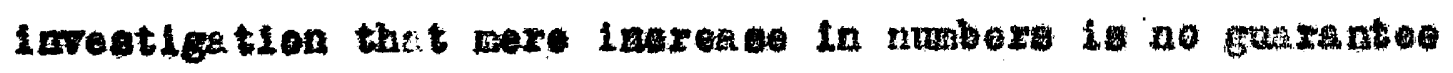

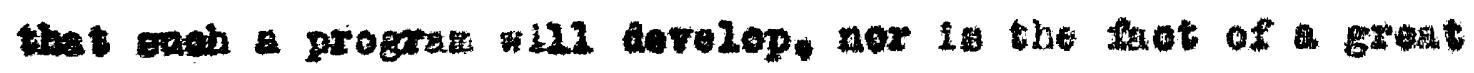

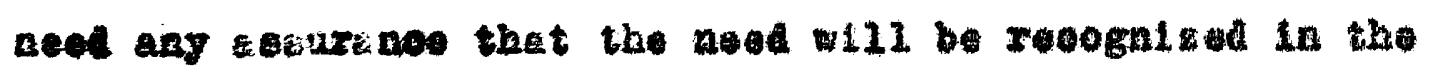
cencolideted sohool.

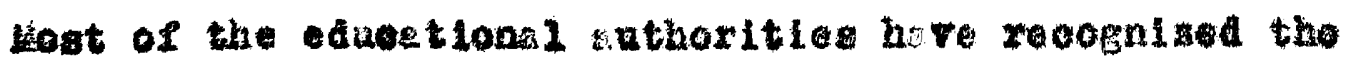

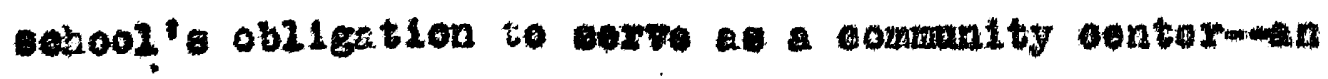

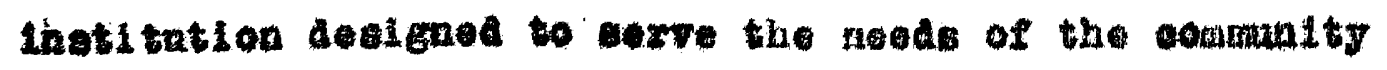

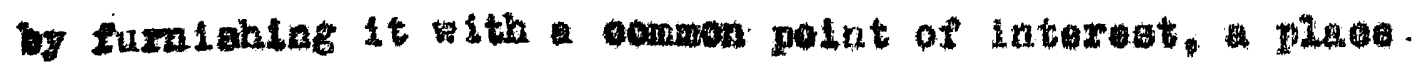

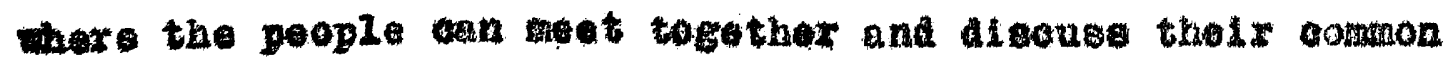




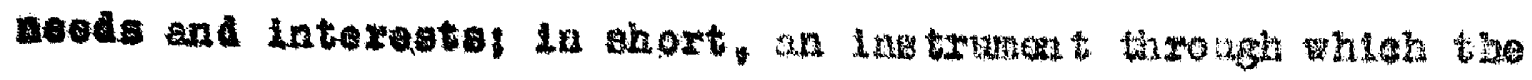

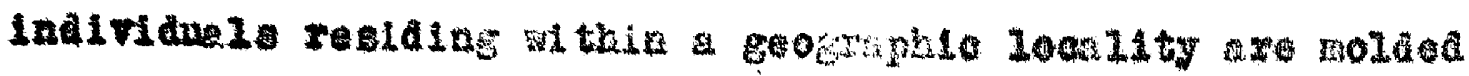

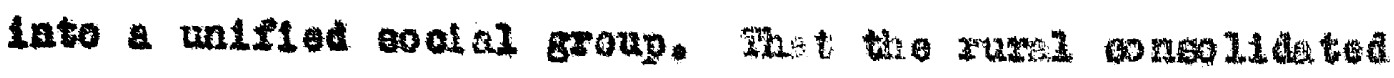

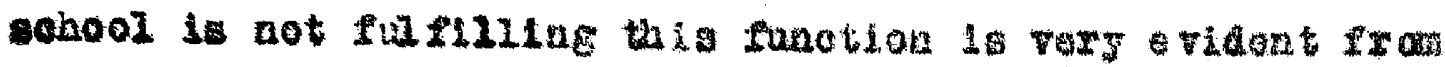
the staig of the alferent sohoole, congl dering the eleneatary and high sohool tudento together only 80.2 per cent of tho didron, 1990 than one third, reported the thatr parente bad been to tho achool during the wohool year. At the

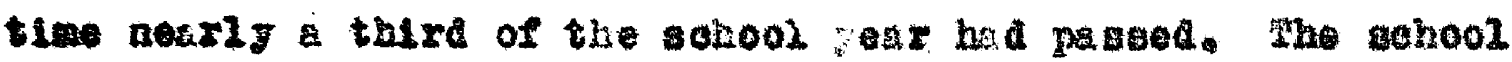
eerres evea 1088 as a pagnet to atract the por ren of the elementary ohilaren tien of the older high solool group. for. whereas 59,6 per oent of the high sohool otudents roported

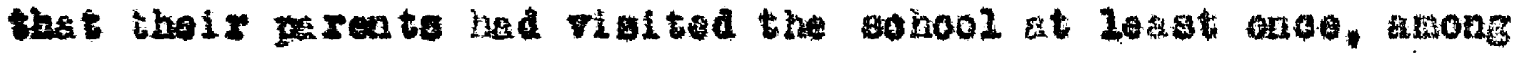
the erede sohool pupile only 20.8 per cent repted visits by their parentg. A180, uafing the tter of attendande at the

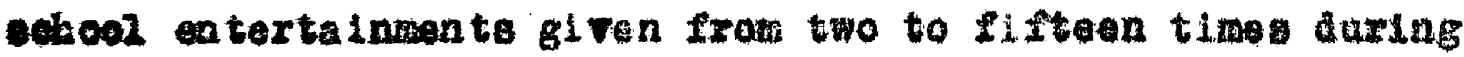

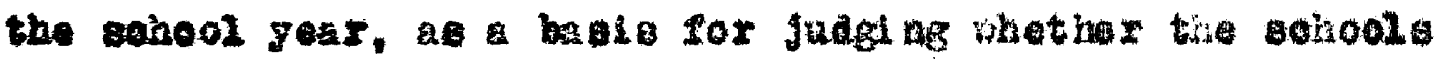

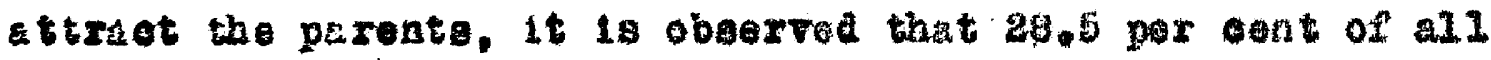
the perente do not attend tio achool ontertalnentio horo, a In the metter of soliovl vistation, the howe of the erado

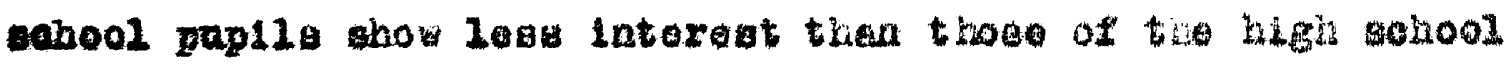

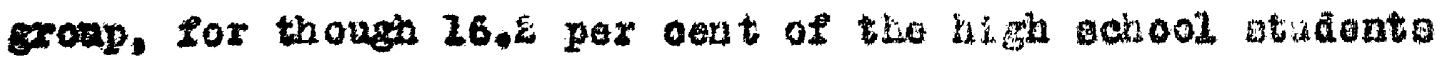

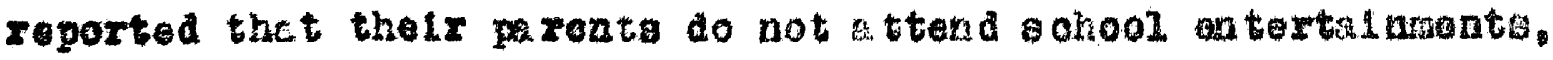
36.7 per cent of the elenentary nonool puplle gove the vame

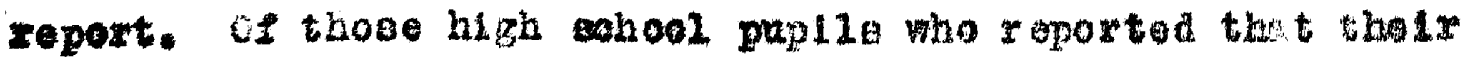

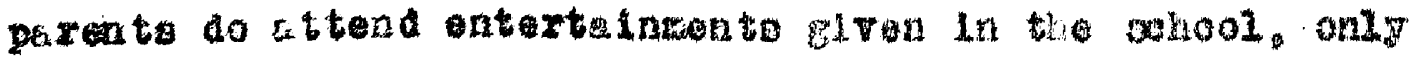

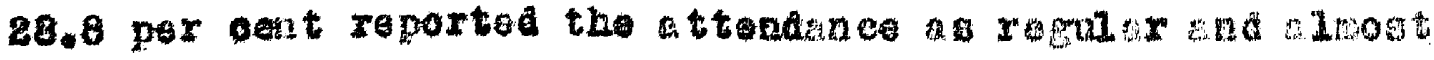

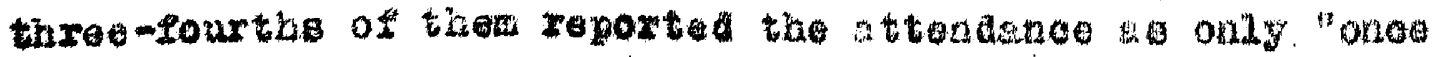




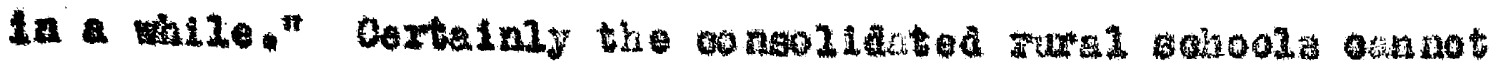
clalo to be fulfiling their mation a compunty conter. Are the consolidated olwols repponotve to the asedo of

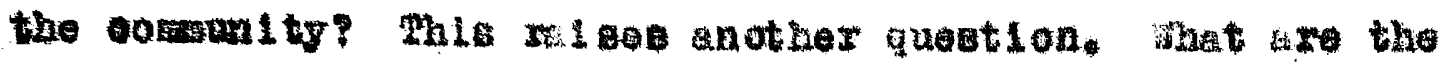

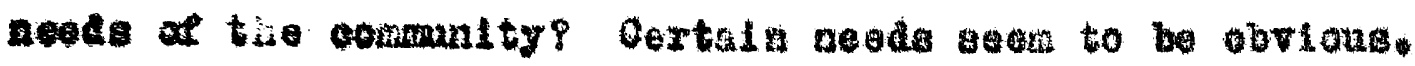
The firet noed is a papulation trainod to bo efietent la the sills upon whidh they depend for a I1valikood, It does not

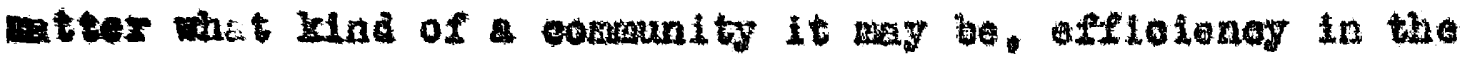
maie aconomie activitios of the mobor is indisponable. I second noed is for the people of the ommanty to fit lato thelr proper aiches in the cociti order of which they are a part. This seens especially trie of democratio cowntry. Qun a gorernment by ganation of the governad cont inne if the Wtisens do not underotend the part they ghould play in that corernment? It it not deglrable that the futaxe mabere of the group or the eamunity be taught gave of the principlea of the group end commalty rellions and lateractionf Shoula

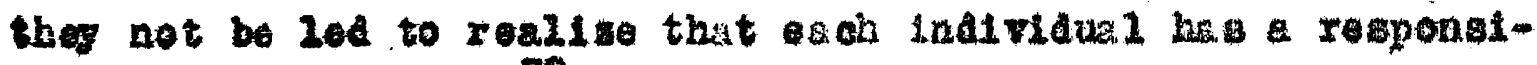
38

u11ty to thet group? A thira neod is a comanity of spirat eultivated through comon latereat and comon mating

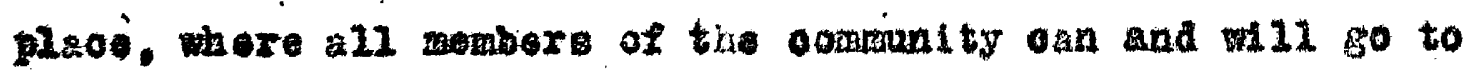

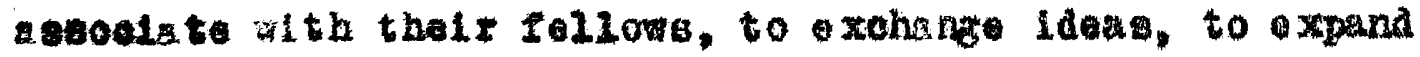

37. "rice aogulation of roontionel gikili and inforation

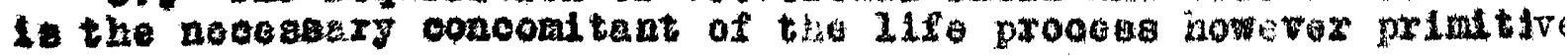
That for very aber of boolety rooational training la absolutez:

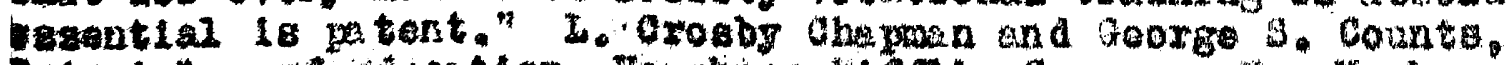

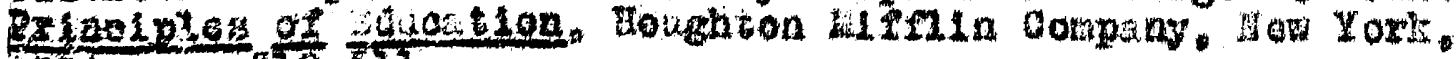
1.2.

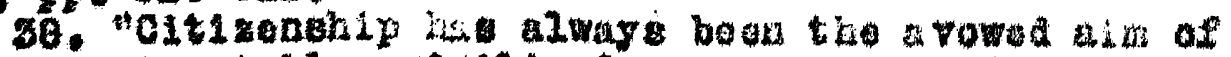

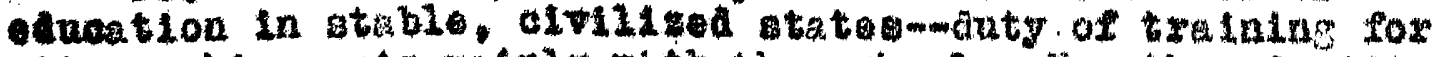

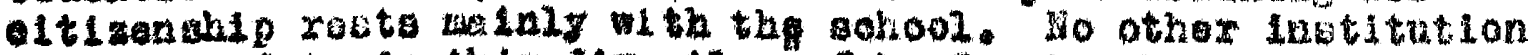

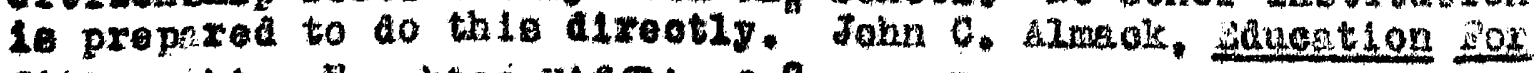

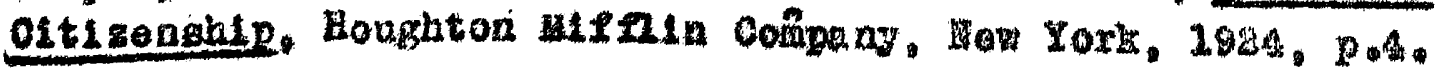




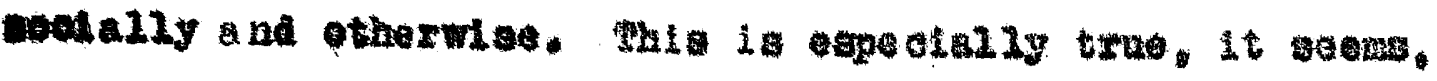

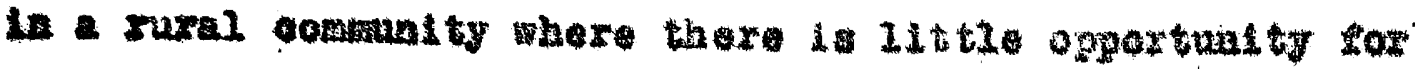

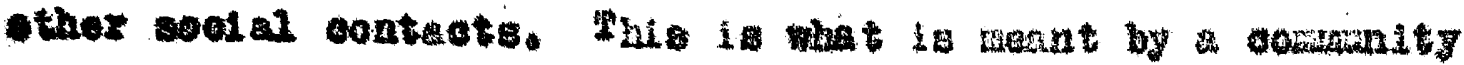

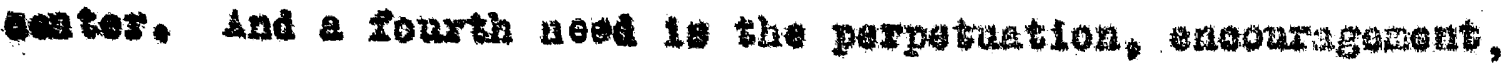

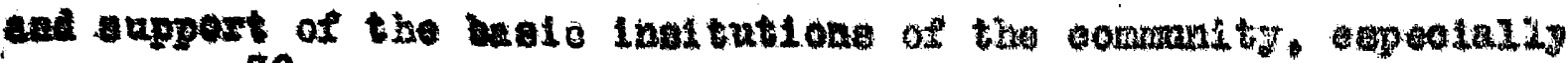
the ranily. 89

Theoe are but come of the rery apparen neads of

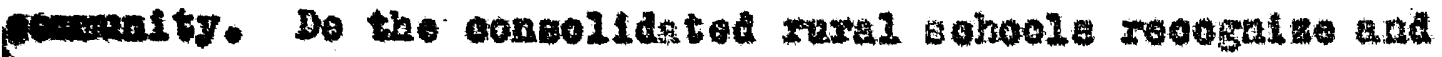

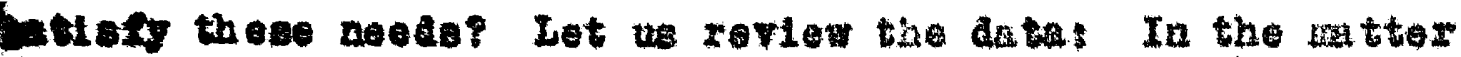

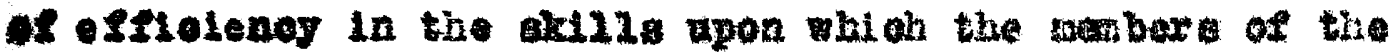

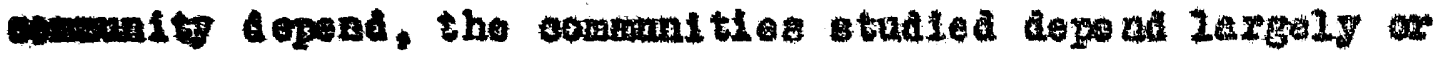

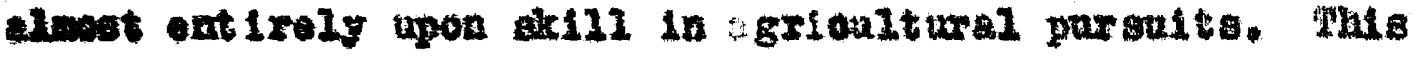

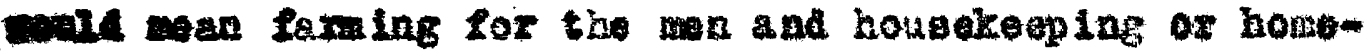
ane for the wonen. Tot in those ochools, shere 736 students otyly English, 62 ohoso the agrloultaral courbe and 246 wle ef how eonomieg, the two coursod preaund to proptre

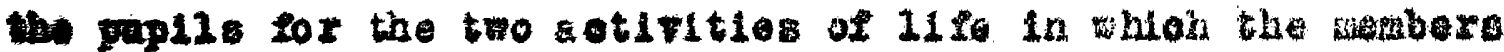

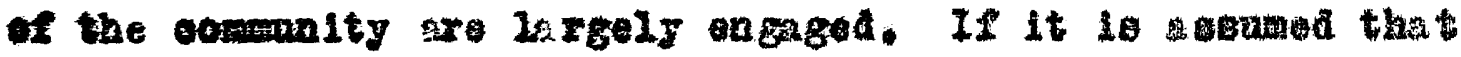
thexe is en oren alatribution of the thexes, the flowing

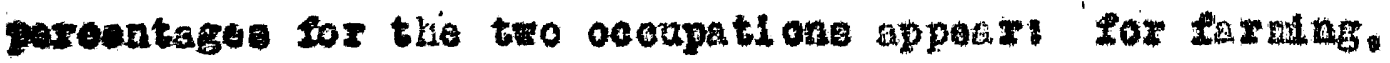
16.0 por cent; and for homenulng. 6.8 per oont; in othor wexte. Less than one-ifth of tho boge axo tra tad in the

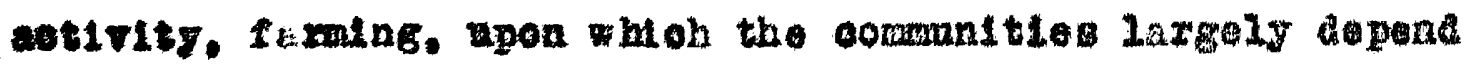
and only two-thirde of the firlo tele course in the

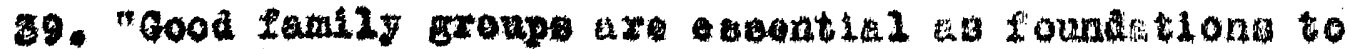

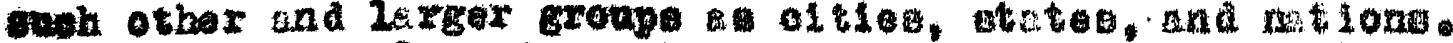

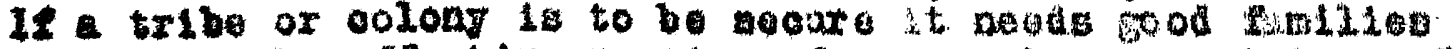

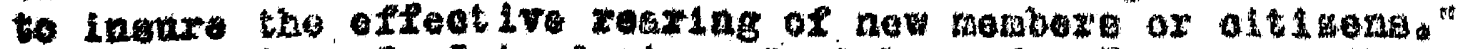

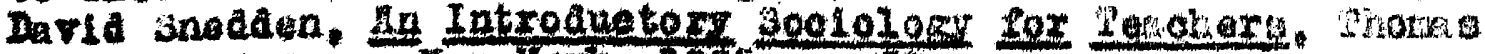

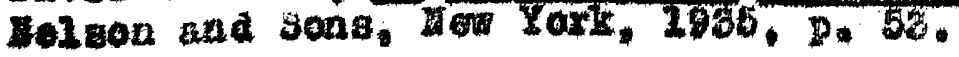




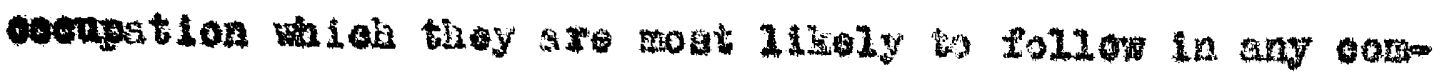

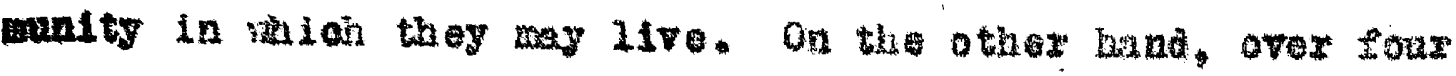

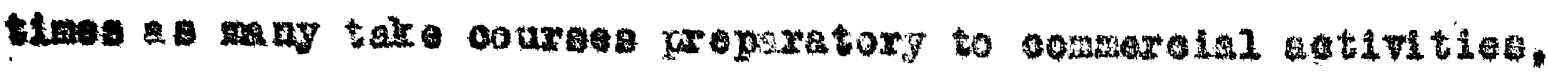

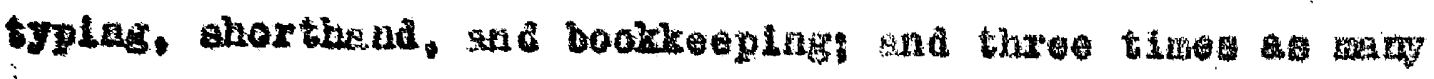

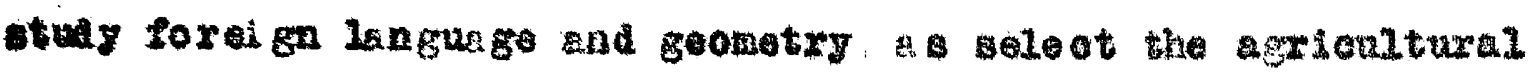

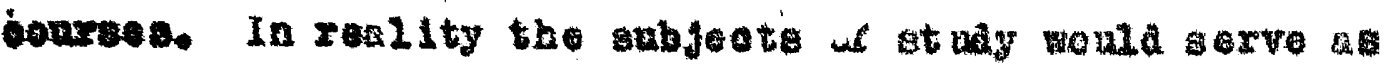
eppropictely, 12 not wi there apprent gastifiention, for otrlotly urben comemitles a those in whiob the goirools are Leented.

Do the rural consolidsted sohool oquip the atudents te It Into their plaeos in soolety, to assume the dutios of

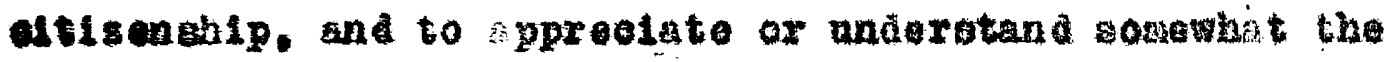

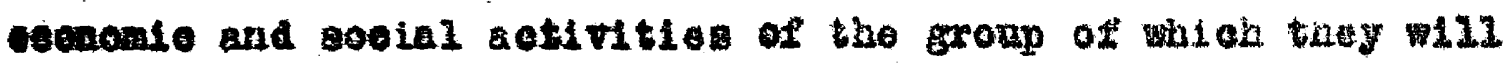
mepone a part? Certein vilues in these 11 mes mill no doubt cormo from the extre-ourrieular aotivitles, bat not all of the secoolo otudied heve a progras of otivities of that nature.

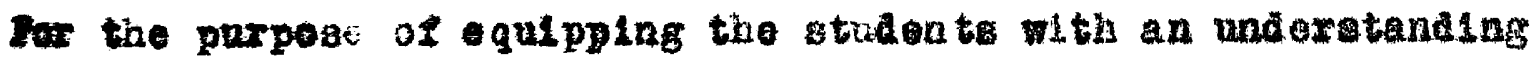
of their country's government, and thelr dut les of oltigen-

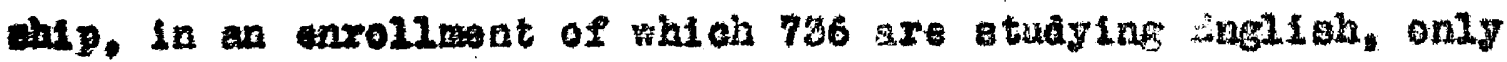
on ax atudylag divios, the oubject promod to farnish the Lafomation rogarding the ir government and the duties of cltizenchip. Is it to be regurdod a almoat eight timos to luportant

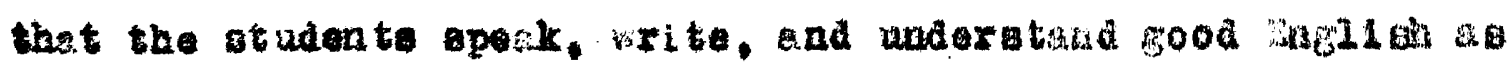
It le thet they waleratend the atios of eltisenghip which thoy

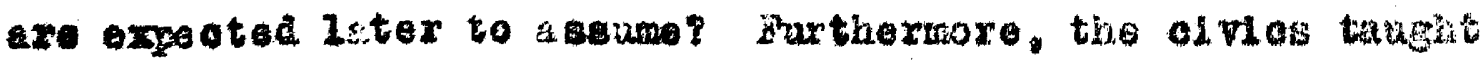
In the woet 2001 ted zaral oohool is the game at that taight

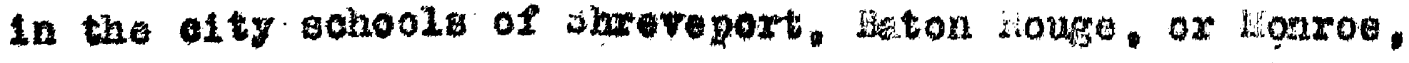




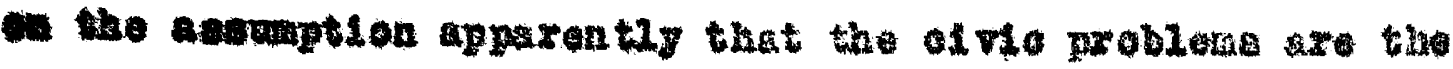

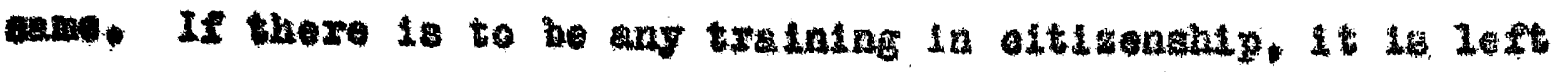

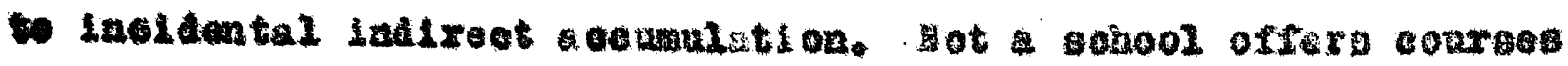

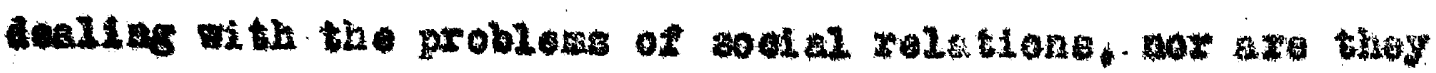

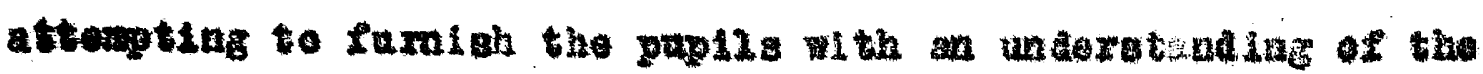
ceonenile cotivities whieb they will certalnig onoountex in their it is in the opmuntioy.

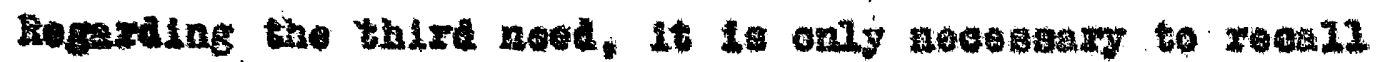
thet it is fond of anining the roperte of the atuleats that ariy s0.2 per cent of the parante of the sohool chtldren ho bean to the sahool during the getheol your which was at tho the the reperts were made eras fourth to a thira gon, and

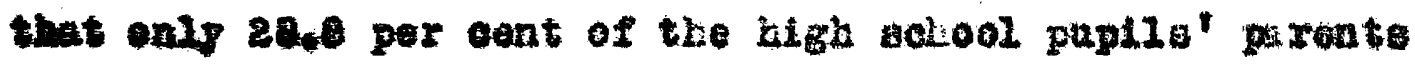

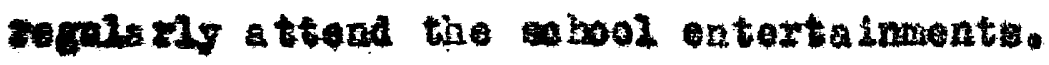

neforence bas bean ade to the noed tor gupporting and

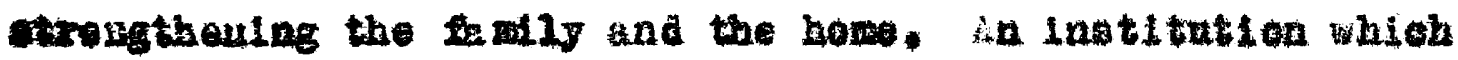

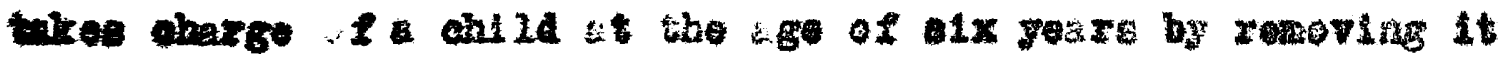

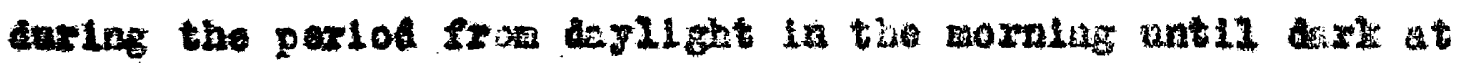

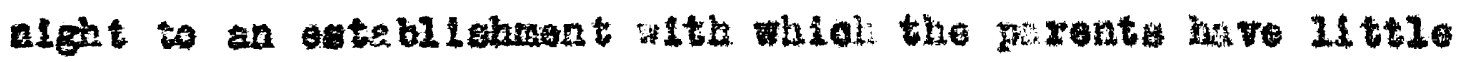
or ao alraet cortrot ocn hardy be considered an ggency ror

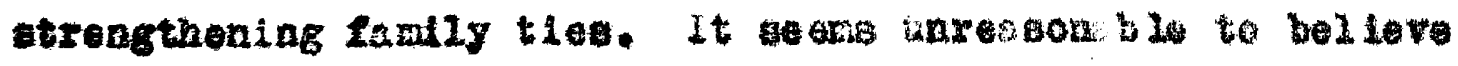

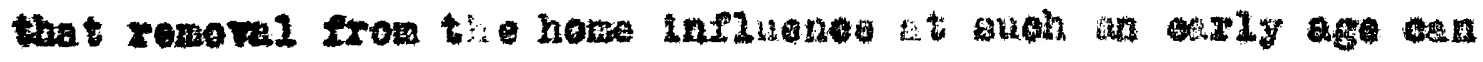

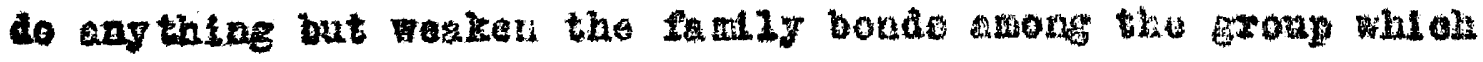

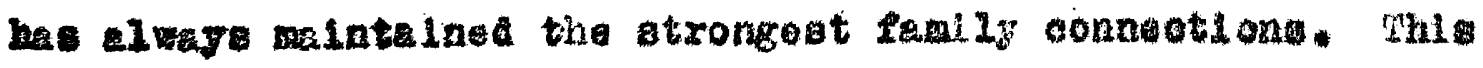

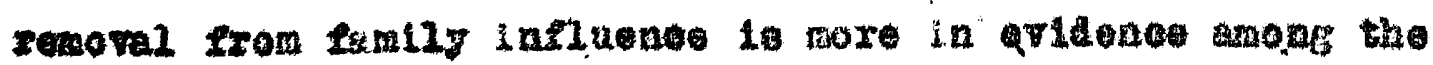
raxal chilaron sttending oonollat tod aotools than it is

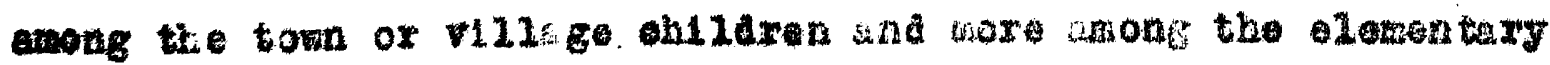
uhllaren than those of the high gohool. Tere le the pletere 


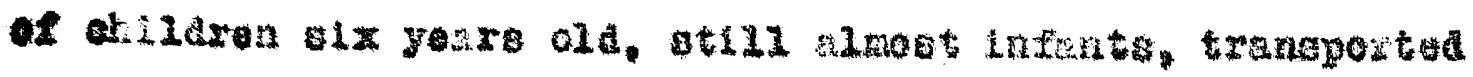

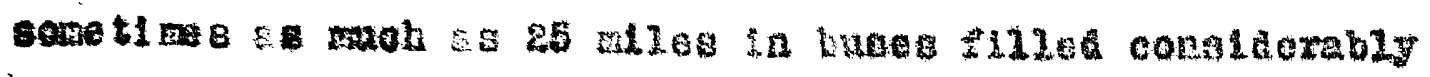

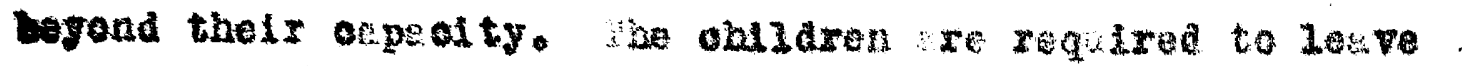

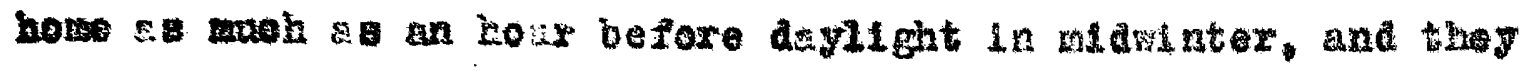
bot houe about an hour after dax for five dayo out of gever. Theg eome wader tro lastruction and guidsnce of ren and women wo do not zoos their parento and of whow tho prente know nothing exeopt through the reports brought to thow by their onlidron. Oertalny the conbolidsted rural high sehool on not be regerted

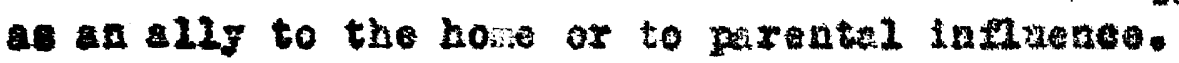

In fine: the cassolidated rural high bohool does not

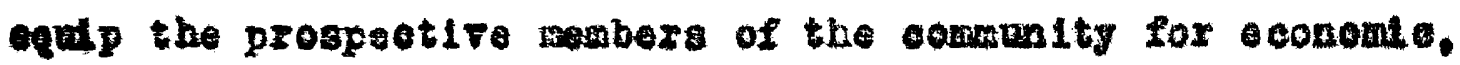
atrie, or cosial offlaienoy.

40. For a leasilon of the rural howe and the

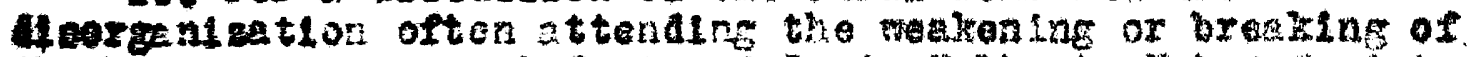

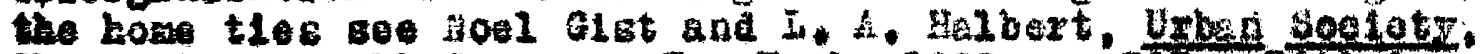

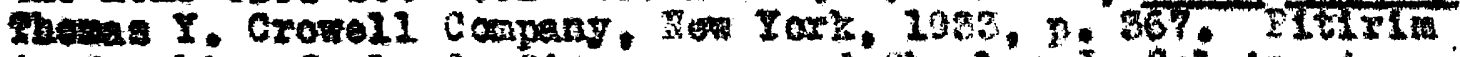

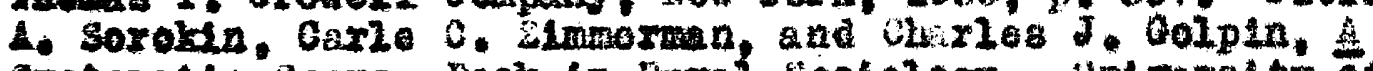

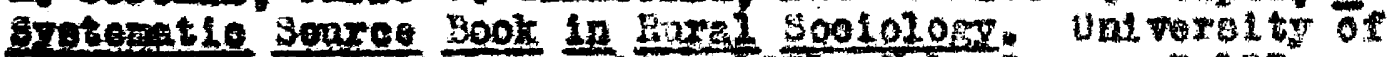

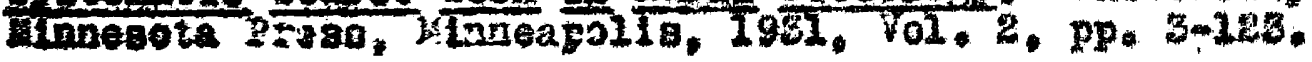




\section{CHAPTRR VI}

\section{COASOLIDATED HIGZ SCHOOLS LOCATID IN URBAN CHWTHRS}

Hot all rural chlleren are equeated in open-country or V11ago sahools. In faot, elmost all the large town and alty cehools In the state, outside of New Orleans, onroli a conelderable proportion of their atudento from the rural soetions. In this chapter an analysis is of the date coaling with a smell of ty high sohool and a large tom high cohool, In an ondeavor to determine, in so far as it is posalble, the effoets of merging rural sohools with schools loeated in urben eenters; to find to what oxtent the alvantages elained for consolldated schools hold for the rural chilaren tho attend these sohools; and to note how responsive these sahools are to the noeds of the rural neighborhoods contributiag to their enrolinent. For this study two represent17e sohools lockted in different seotions of the state have been selected: the Ouachita HIgh Bchool of Monroe, a and of ty of 26,028; and the Terrebonne High Sohool of Howna, town wh a population of 6,531 located in the Irenok bection of Loulatena.

Qugohlta Parlah Ilgh Sohool: Tho Ouachl ta Parish IIIgh Bchool bas orolved from plen derlsed in 2894. At that time a parish high school was to be erected on a plot of ground rronting the Ouachlta Fiver, donete by Don Juan'Piln1ol. The Polloe Jury gave $\$ 3,500$ for the ereotion of a publis high sohool bullaing 
on the oondition that for that jurpose. An awount alrost double the 2,000 was raleod and bullding was oxeoted at a cost of wh, $10 \ldots, 45$. cxelusive of furniture. The purpose of this sohool, as stated In the eatalogue of the Ouechita Parish High school for the reare 2003-1904, was: "to afford bright snd atbitious pupliza of the publ10 achools an opportunity to get all the advantages a high sohool training; and to thus bragen and axtond the pablle sohool syatede" In 1903 the buliding wha enlarged at an expenge of 46,500 . This building served as the parligh high sohoel unit, Ath the primary, intermodiate, sratemar and high sehool gredes in the sane strueture.

In 2026 a now plant wa ereated sorose the atreet from the ordesal buslasng at a oost of about $\$ 850,000$. Foday the old balating is used exolusirely for elementary onliaren, and tho aw plant houses the present enroliment of opproxinatisy 1,360 papila, about half of whom are brought to the school by buses. The Orachita IIgh 30 hool is one of the highest rating schools In the state, beoording to a record inite by 1 ti graduates whe 2 onter colloge. It conteotants always make favorable reoords In oontests suoh as school cobates and litarary rallios.

1. Ounohtta Parlion High Bohool, Catgiogue, 1003-1904, p. 6, (Uapubilshod.)

2. soooralng to the report of the southern Asuoalation of colleges and secondary Bohools for 1834-35, the freduetes of the Ouahltg Parloh H1gh Sohool falled in $10 . "$ per cent of the - 2 lege anmeater hours which they carried in thelr firat yeas in colloge. The avorage for the graduates fron all Southara Approved ligh Sohoola va 12.4 per cent, and the arrerage for the graduates of high sohouls of Loulalana was 3.3.3. por cent. Prodeedings of the Southern Association of colieges and Becondary Sohool. 1935. 
Aeaderteally the bohool ranks high.

Whon the sohool was ilist begu, ln lagk, no doubt it was et sowe alstaree from the center of the town ald the squaro bleck of ground would have been oundaetod anje playground tor the earollment whioh was antlapated. But Iow the now threentory builalng is only fow feot fron the aldewalk and ocouples the entire lot, epproxinately half of ta oity blook.

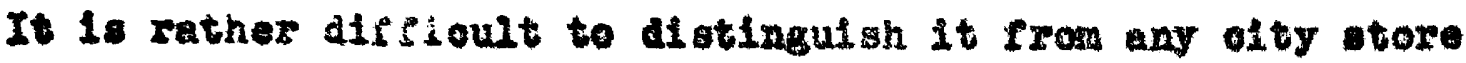
bullaing exeept for the type of whilows. fho bullaing reees Bouth Grand streat, one of the primalpal business atreets of the olty, and a orose streot whion separates it rrom the Lemeatary sohool. The elmentary sohool does not occupy the atire square, so thet the rear of the blook upon which it It altuated 1a ued as football prantioe fleld tor high cohool boys. There 18 no pleyground equipment whatever for the elementary school, and the high sohool hes no gymasiug. 11 athletie pratioe 19 done on the elesentary school grounds. Although approximately onemalf of the high thool enrolinent is brought in by buses, one can not fail to get

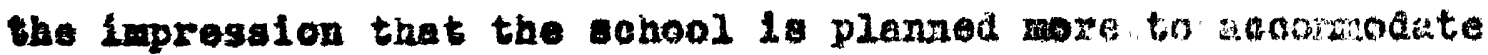

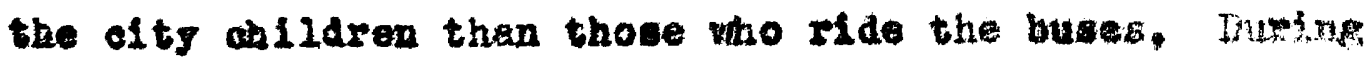
the noon hour the eity ohlldren go hora, but the rural ohlldren, after cating their Iunch in the caferoxta or in the Iunab soom acrose the Btreet, have no plaos yopared for

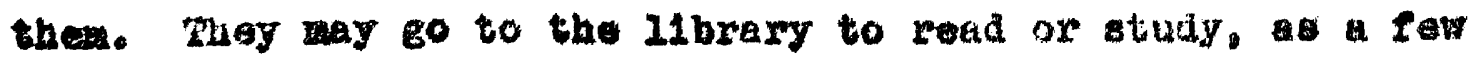

3. Acooralng to the report of the collegor and High Sonool conmettee, 51.3 per oent at the high school anrollment was trainjurted in 2934. 
do, or walk the alty streets unt1l one o'olook.

Although ohildren fron the noarby handet and viliges as woll as those living in the open oountry are transworted to the Ouachite Parish $\mathrm{HI}$ h School, the reports indioate that 42.9 per oent of the rural pup1ls eome frove farre homes and thet faraing is the most important ocoupation from the standpoint of the number of parents engaged thereln. (seo Table IIV.) maployent in the paper 121 looated in west Honroe ranks next to faming, and a rather vide varlety or oocupations is IIsted. This is to be expeoted in a region bordering a small alty in with there are found luaber and paper mil1s, gas and 011 incustries.

Sith so many of the parents engaged in agrloulture, it is interesting to note what the brothers and at aters who are away tron hose are dolng. (see Table LV.) Housekeeping occuiples tirat place in importance, th 48 liated in that ontegory, and farming 18 second, with 31 . of the 288 reprorted, 10.8 pex oent are farring and 16.7 per cent are houselveaping. There are no date avaliable for ascertalning the reroentage of those listed as housekeopers who are lifine on farms, but fror the studies elted before it 18 probable that most of them are $11 \mathrm{ving}$ in the open country.

By a study of Table LVI it is seen that farming Is seleoted by a relatively amell group of students as thelr most popular roogtion. Por the glrla, nursing ranks as the preferred rocetion, whereas varlous klnds of eneinearing ramk first for 
Table IIV

Oooupations of the Parents of Rural Children Attending the Outohita Parloh High Sohool

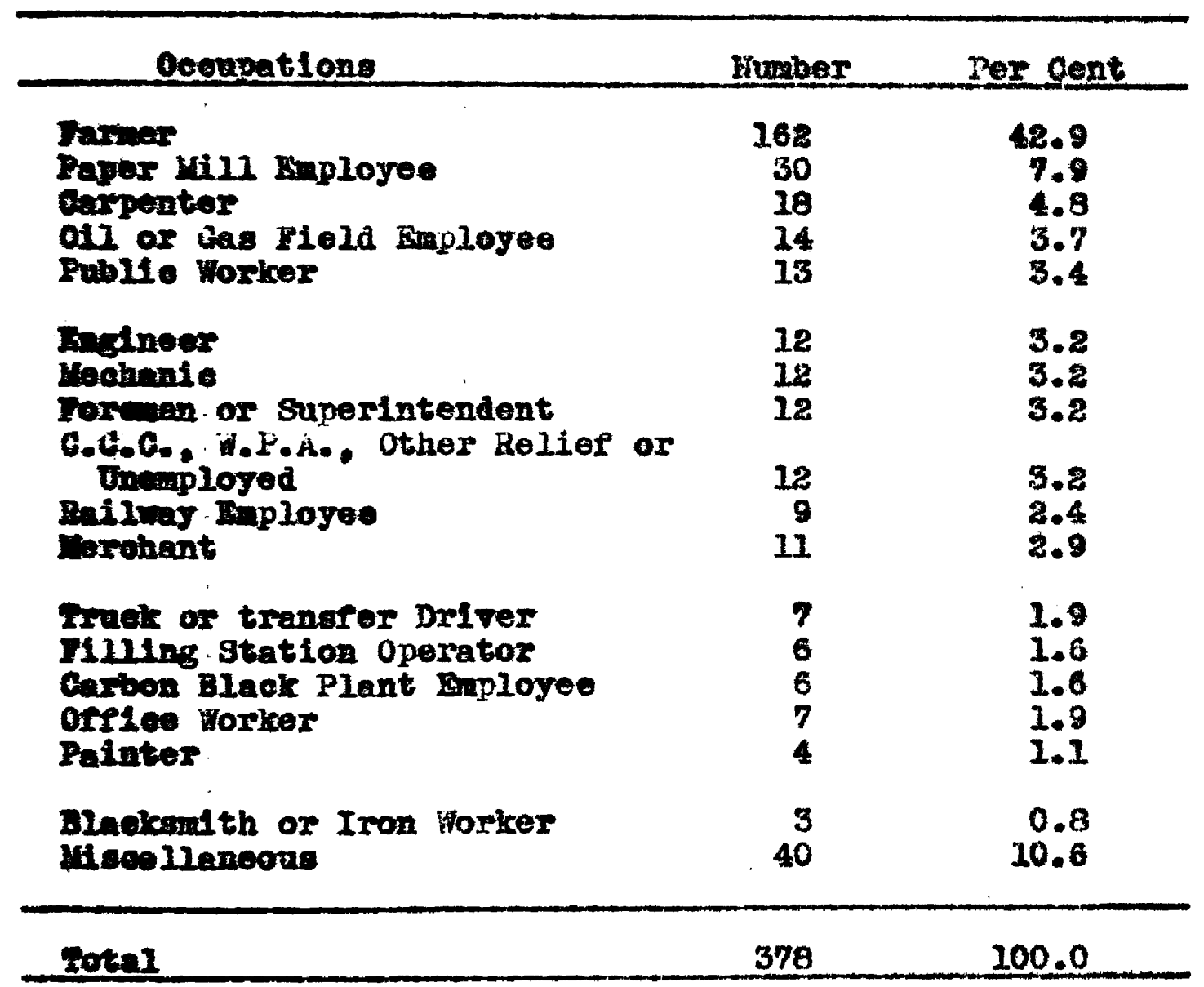


Table IV

Decupations of Brothers and Sisters of Rural students Attending the Ouachita Parish High Sohool

\begin{tabular}{|c|c|c|}
\hline Deoupations & Aumbex & Per Cent \\
\hline 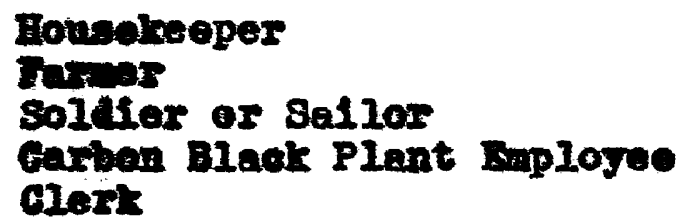 & $\begin{array}{l}48 \\
31 \\
18 \\
15 \\
21\end{array}$ & $\begin{array}{r}16.6 \\
10.7 \\
6.8 \\
5.8 \\
7.2\end{array}$ \\
\hline 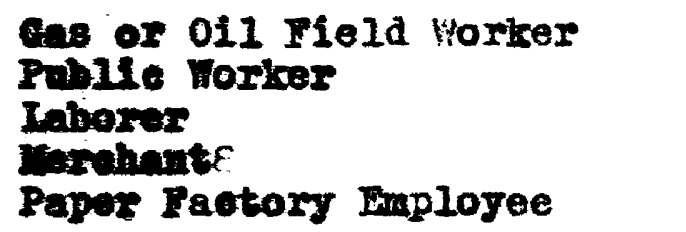 & $\begin{array}{l}14 \\
13 \\
11 \\
10 \\
10\end{array}$ & $\begin{array}{l}4.8 \\
4.5 \\
3.8 \\
3.4 \\
3.4\end{array}$ \\
\hline 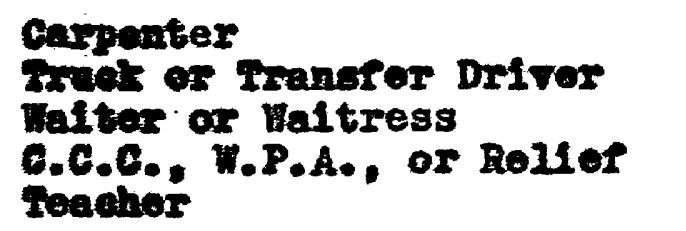 & $\begin{array}{l}9 \\
9 \\
8 \\
7 \\
6\end{array}$ & $\begin{array}{l}3.1 \\
3.1 \\
3.8 \\
2.4 \\
2.1\end{array}$ \\
\hline 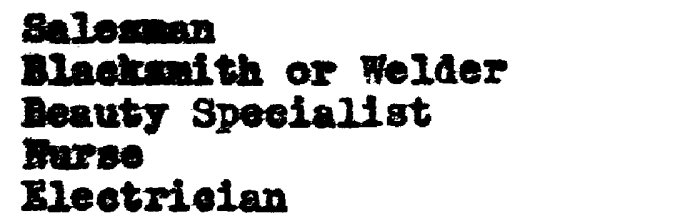 & $\begin{array}{l}7 \\
4 \\
4 \\
4 \\
2\end{array}$ & $\begin{array}{l}2.4 \\
1.4 \\
1.4 \\
1.4 \\
0.7\end{array}$ \\
\hline $\begin{array}{l}\text { Brimeyor } \\
\text { ineellanoous }\end{array}$ & $\begin{array}{r}2 \\
32\end{array}$ & $\begin{array}{r}0.7 \\
11.0\end{array}$ \\
\hline Xotel & 290 & 200.0 \\
\hline
\end{tabular}


Sable IVI

Oeoupetional Preference of the Rural students of the Ounchita Parlsh High Sohool

\begin{tabular}{|c|c|c|}
\hline Gequpations & Nomber & Per Cont \\
\hline 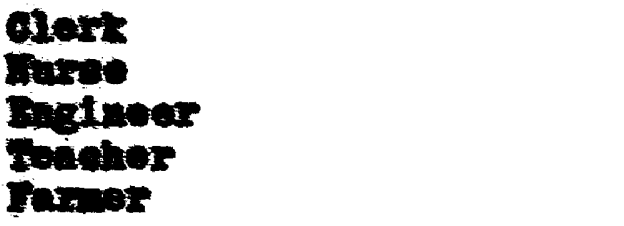 & $\begin{array}{l}69 \\
49 \\
47 \\
28 \\
27\end{array}$ & $\begin{array}{r}20.1 \\
14.3 \\
18.7 \\
8.2 \\
7.9\end{array}$ \\
\hline 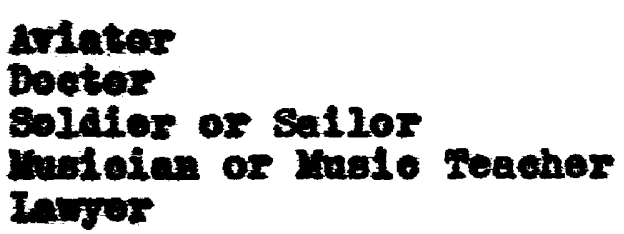 & $\begin{array}{l}18 \\
15 \\
117 \\
7 \\
7\end{array}$ & $\begin{array}{l}5.3 \\
4.4 \\
3.2 \\
2.0 \\
2.0\end{array}$ \\
\hline 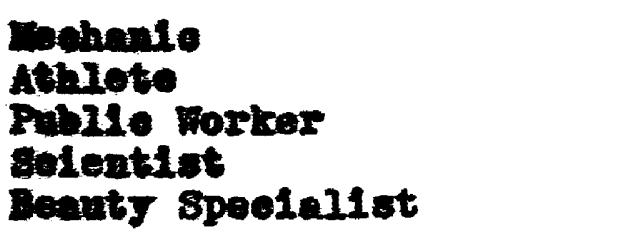 & $\begin{array}{l}5 \\
5 \\
5 \\
4 \\
4\end{array}$ & $\begin{array}{l}1.5 \\
1.5 \\
1.5 \\
1.2 \\
1.8\end{array}$ \\
\hline $\begin{array}{l}\text { Religious worker } \\
\text { irtiot } \\
\text { madio Worber } \\
\text { interior Decorator } \\
\text { Beteotive }\end{array}$ & $\begin{array}{l}4 \\
4 \\
3 \\
3 \\
2\end{array}$ & $\begin{array}{l}1.2 \\
1.2 \\
0.9 \\
0.9 \\
0.6\end{array}$ \\
\hline $\begin{array}{l}\text { Dorehant } \\
\text { Ealesinan } \\
\text { Hil weellaneous }\end{array}$ & $\begin{array}{r}2 \\
2 \\
22\end{array}$ & $\begin{array}{l}0.6 \\
0.6 \\
6.4\end{array}$ \\
\hline getal & 343 & 100.0 \\
\hline
\end{tabular}


the boys. Only 7.9 per oent expressed thal expectation of beling faraers.

sino the rural chllaren oome from farm homes to a large extent, it 28 signifloent to observe what they study in sohool to teach then, "To do better the dosirable things they are IIkely to do snyway." It 18 observod by rable IVII that Fugliab stands f1rst, w th 381 reporting coursss in that mbjeot; methratios is a close second, with 335 taking some courses in that branoh; agriculture is not orfered; a total or 205 etudents take commeroe; and 124 purgue some brenoh of home eoonomies. In brier, no one would be able to detect from the aubjeets ohosen by the rural students that they live in a rural nelghborhond and that faralng is the oosupation of their perents.

The Ouachlta Pariah High Sohool was designed as a parieh 5 high sohool, to whloh oblidren from all parts of the parish were to be brought; therefore it is interesting to note the distanoes traveled by these otudents. Table IVIII furnlshes this information. The alstenoes range from one to $25 \mathrm{miles}$. Wth the medan distance of 7.6 miles. As the parish sohools all operate under the same manegenent, it is noosssary to examine the plan under whioh the trangportation aystem operates. There are in the parish $1 \%$ glementary sohools beiddes those operated in conneotion wh the bin sahools. The busea in

5. At the present time there aro two rural hifh gohools in Ouachlte Parlsh, operated by the Taxish Sohool Boari, at Calhoun and 0kaloosa, in the extreme western giat of the parish, and a

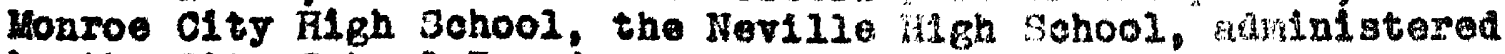
by the Clty Sohool Board. 
Table IVII

Enbjeote 2kiken by Rural Studenta Attending the Ourchita Parioh Algh Sohool

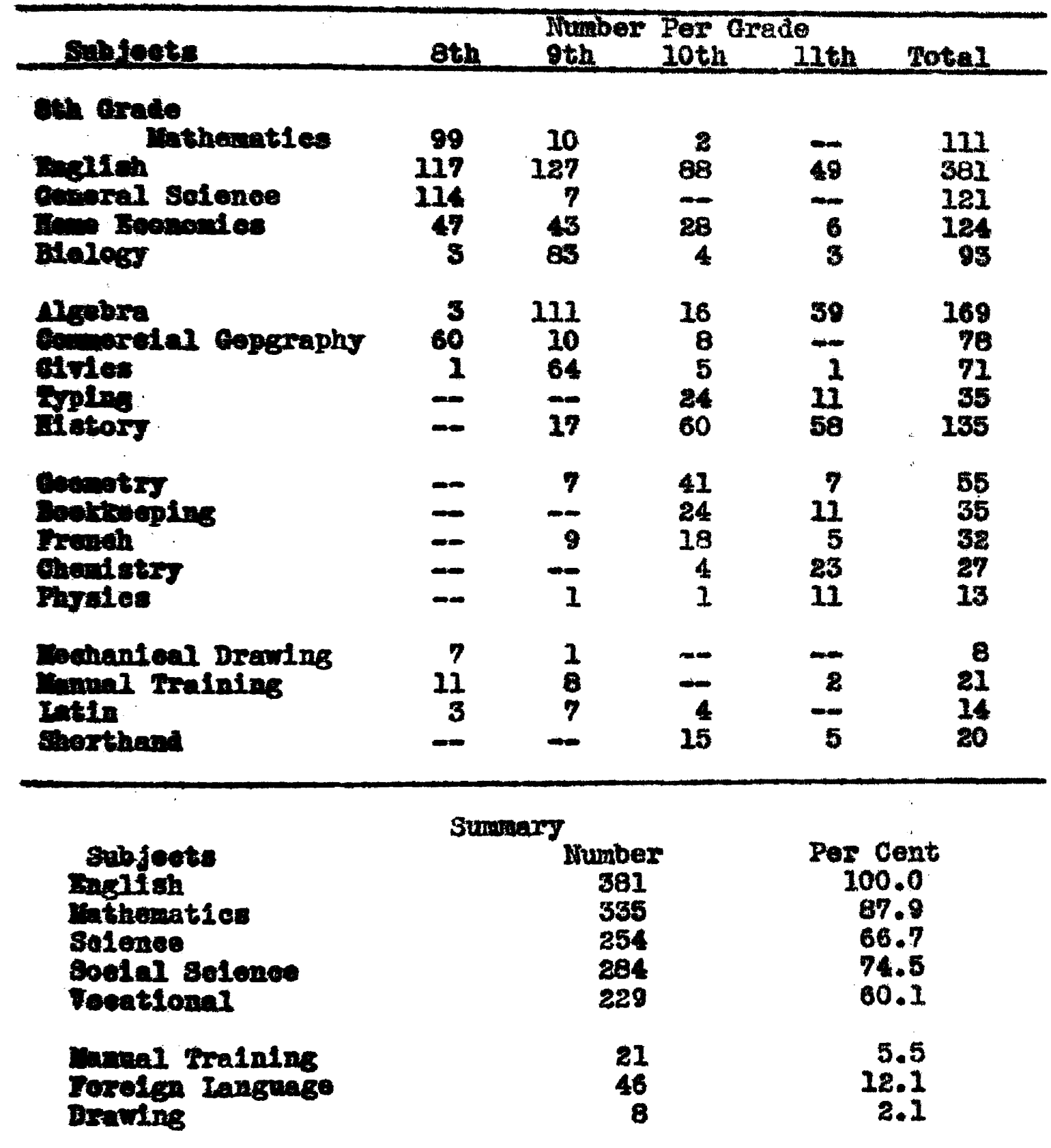


Table IMII

Dintanees Iraveled by Rural Onfldren to Reach the Ouachita Parlsh High School

\begin{tabular}{|c|c|c|}
\hline Elenoe is Mtles & Humber & Per Cent \\
\hline $\begin{array}{l}1001.9 \\
2108.9 \\
8103.9 \\
1 \text { to } 4.9 \\
5 \text { to } 5.9\end{array}$ & $\begin{array}{r}2 \\
19 \\
59 \\
36 \\
58\end{array}$ & $\begin{array}{r}0.5 \\
5.2 \\
10.6 \\
9.8 \\
15.8\end{array}$ \\
\hline $\begin{array}{l}90.9 \\
10\end{array}$ & $\begin{array}{l}19 \\
17 \\
20 \\
16 \\
17\end{array}$ & $\begin{array}{l}5.2 \\
4.6 \\
5.4 \\
4.4 \\
4.6\end{array}$ \\
\hline $\begin{array}{l}11 \text { to } 11.9 \\
18 \text { to } 18.9 \\
18 \text { to } 18.9 \\
14 \text { to } 14.9 \\
15 \text { to } 15.9\end{array}$ & $\begin{array}{l}7 \\
19 \\
16 \\
16 \\
26\end{array}$ & $\begin{array}{l}2.9 \\
5.2 \\
4.4 \\
4.4 \\
7.1\end{array}$ \\
\hline $\begin{array}{l}16 \text { to } 16.9 \\
17 \text { to } 17.9 \\
18 \text { to } 18.9 \\
19 \text { to } 19.9 \\
00 \text { to } 20.9\end{array}$ & $\begin{array}{r}6 \\
6 \\
10 \\
0 \\
8\end{array}$ & $\begin{array}{l}2.8 \\
1.6 \\
2.7 \\
0.0 \\
2.2\end{array}$ \\
\hline $\begin{array}{l}21 \text { to } 21.9 \\
22 \text { to } 22.9 \\
25 \text { to } 23.9 \\
24 \text { to } 24.9 \\
25 \text { to } 25.9\end{array}$ & $\begin{array}{l}2 \\
5 \\
0 \\
0 \\
1\end{array}$ & $\begin{array}{l}0.5 \\
1.4 \\
0.0 \\
0.0 \\
0.3\end{array}$ \\
\hline
\end{tabular}


the parlah are also used to carry high sohool and junlor eolloge students, even though the jority of thel $x$ pasuengers say be deslgned for some rural elementary school. The elomentary ahool serves as gathering point for the high sebool and Juntor college students who, after being assorabled there, are sent on to the oity. Those livine between the elenentary sohool and the ofty are transported directly to the High sohool from whioh the vollege students are taken on to the Hortheast Center of Loulsiane State Univeraity, wich Is loeated in the auburbs of Nonroe.

As the rural ohildren come from long distanoes to get to setool, the question natureliy arises as to the erfect this may have on their participation in extra-ourrioular notivities, Alla from the usual intersoholagtio atheties, there are aeademis olubs (French olubs, comeroe olubs, and the Ilke), forensic and dranet1o clubs, home-room organizations and class organizations, gloo clubs, librery clubs, and an orehestra. Fryoloal Inatations forbid intra-raral athletic aotivities. To sehool elube meot every two weeks at a regular cotivity period during the day. Then a comparison is made of the diatribution of offloes in the school eluba amone the elty and rurel ohildren,1t. is found that 74.7 per cent of the ertices go to those students olassed as urban and 25.3 per cent go to the rural, or the rural ohlidren who attend the cehool, 17.5 per cent hold sone school offloes; and, although the sahool lays stress on the district and the state rally conteate, only 8.3 per cent have taken part in any of the 
eantests. In Lutoher, where the open-country ohildren do not have to travel guoh lons algtances and there is not such atkreme differenoes in home envizonment between the Fillage and epen-eountry ohlldren, 30.9 per ont of the open-eountry chlldrea have held sohool offloes as compared with 4.13 per cant or those. from the village. Also, in tutoher 15.6 per oent or the ohilaren from the open country and 20.4 per cent of those res the village have represented thelr sohool in contests. If the number who filled in the sohedules represent the actial number of onlldren from rural hones attending the Deeehita Parioh IIgh Sohool, then 28.2 per cent of the sohool enrollabet, as recorded in the 1935-36 report of the southern Apeodetion of colleges and Sesondary Sohools, are rural entlaren. Theae hold 25.3 per cent of the sahool offioes. Thus there seess to be no signiflcent erldence of distinction between efty and rural ohslaren in their eleotion to achoel offlees. There 1s, however, a rather marked difference in tho opportunity prorided by the Ouachita Parish High Sohool for this reinable treining when it is compared with village wohool suoh as Lutoher which also stresses extra-ourrioular aetivities.

How well does the Ouoh1ta Farish High Sohool fulf1II the Nital funetion of comunity oenter? It sems obvious that no

6. The inforsation regerding the olub and organization orflees was furnished in detall by Mr. Jack Hayes, Frinolpal or the Ouachita Parish MIgh Sohool.

7. It wal stated before that approximately one-half of the igh sohool enrollnent is brought in by bus. The disorepanoy between the percentages given above ks rural chilaren and those brought in by bus is explained by the fact that children are brought to school by bus from heat ilonroe. 
Lty sohool can serve as a comunty center for rural peoplo Alstributed in widely dispersed neighborhoods, 20 to 25 falies frow the sehool. The truth of this statement can be rerified by the reports of the rural students. Only 11.7 per eent of the students reported that their parents had visited the school this jear. Only 10.2 per obnt of the rural parents are nembers of the sehool's Parent-Teachers' Assooiation, and but 25.0 per cent reported that their parents attend sohool entertalmenta. As was true of the other Bohools studied, Ouachita Parish Etgh Sohool has a faculty well prepared acadentealiy for the tank of toaching. Of 55 teachers only one, the football coach, bas $20 a 8$ thun a bacolaureate degree. Eleven have master's dogxeos. Feaching experlenoe ranges from one year to wore thin so rears, with a median of aight years of aotul teashing. The Iength of gervice in the Ouahita Parish High School also rages frow less than one jear to more than 30 yours, with sodian of four rears. Thirteen of the 55 tedohers are taeching for their firet year in Ouachita rarish High Sohool. and 23, or 41.8 per oont, have not taught there long, enough to have served their perlod of apprenticeshlp as established by the penus Ifw.

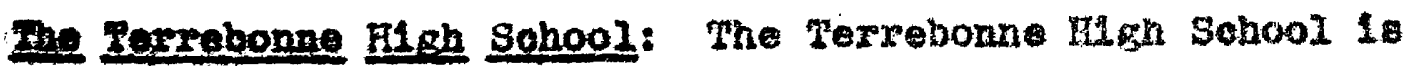
lookted at Hown in the Frenoh gootion of the state. This wehool has been a state-approved high school alnce the session $B$ 1910-11. It is also approved by the bouthern issociation of

8. State Department of Education of Loulsiana, mducetional Blrectory," pulletin Ho. 304, 1935, p. 16. 
Collegen and Becondary Sehools, wh thit th has a very high ctanding. It operatos as a parish high ohool, in that there wo no other publio statomaproved high sohools in the area. There are, hewever, two statemapproved cathollo high sohools Iooated in Howne.

The pariah hes a whte population of 7,294 between the agea of six and alghteen, inolualve, of wom 2,976 are of sevendary sahool age, 13 to 18 1nelusive. To accomodate thie wite population 21 elepantary cohools, having a total engariment of 415s, are maintained. The high school enroliment in the rerrobonne Figh School, in addition to those taking high goheel sourses in some of the elementery sohools, fo 7al.

The parish has one of the highest ililteragy rates found In the otute: 28.0 yer cent of 14 a native witse population. of those 14 and 15 years of age, 56.4 per ont are attending sehool; and of those 16 to 17 yeara of age, $28_{4}$ ? per cent are 18 aehool. If compartson is pade or these figureg with

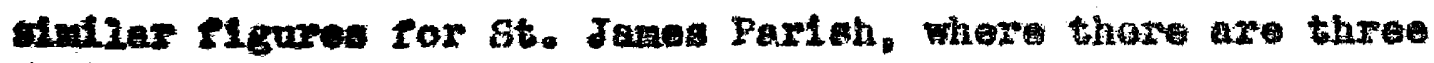
otite-approved hlgh sohoels and 10 elementary soheols to servo an are about ono-beventh of that of Terrebonin Perish, ${ }^{12}$ and,

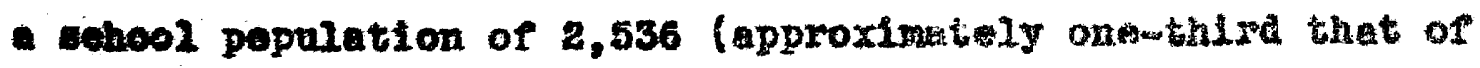

9. Op. att. Accoralng to the 1935 report the graduate of the rerrobonne High sehool who ontered collegs falied in 4.5 per cent of thalr college ooursea. This is considerably below tho average for the atate which if 13.1 per cent. 10. State Departient of Fouoetion of Loulsiane, mfighty-

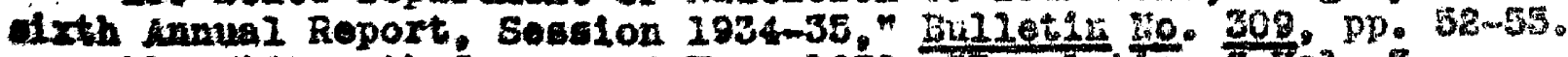
Part 1 .

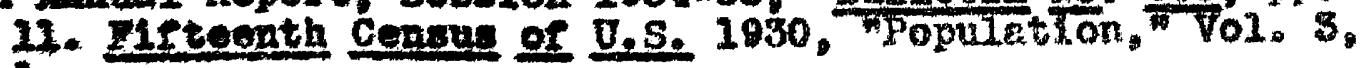

18. The arens are as rollows: 5t. James, 162,560 aores, Texrebenne Ferloh, $1,225,840$ aores. 
Tarrobonne Perlah) 72.6 per cent of those 14 and 15 yenrs of ige and 40.9 per cent of those 16 and 17 yeara of age are found to be in aohool. 13

It Is interesting to exanine some of the industrial characteristlos of the parlah. Terrebonne Partah lesds the -tate in the produotion of furs. It has important fisheries, and produeos and oans great quantitios and many varieties or cea rood. It ranks third among the 64 parlshes of the state In the production of sugar, and is an important comenercial produeer or garden vegetables and rice. It has a rural poprateston of 23,285 , of whom 8,633 , or 37 per ent, are classed os raral-farm, whereas 14,663, or 63 per cent, are olassed as rural-nomerara. Houna, 1ts only urban center, has a population ot 6,581.

of the rural students attendine the Terrebonne High School, 19.6 per eent gave farming as the ocoupation of thelr peronts. (8ee Fable IVIX.) Tife Indicates that the proportion of those elesed as rural-rarm who send their chlldren to high sohool Is higher than those elassed as rural-nonferm, sinee 63 per cent of the rural population aupply only 51.4 per cent of those colng to high school.

Howeckeping and farming are the rost important occupations of the brothers and alsters who are awey fron home, wh 30.5 per oent 11 sted as hougekeepers and 10.3 par cent ilsted as

13. 3t. James Pariah 18 mentioned beenuse it is the parish In wioh the Lutcher and Romerilio high schools ate locnted, end Its educational characteristios heve been already exanined. 14. Ioulstana 1922-1923, Departnent of fgrloulture and Inderet1on, Baton Rouge, pD. 184-185. 


\section{Table IVIX}

Oeenpations of the Parente of Rural Chllaren Attending the Terrohowne High Sehool

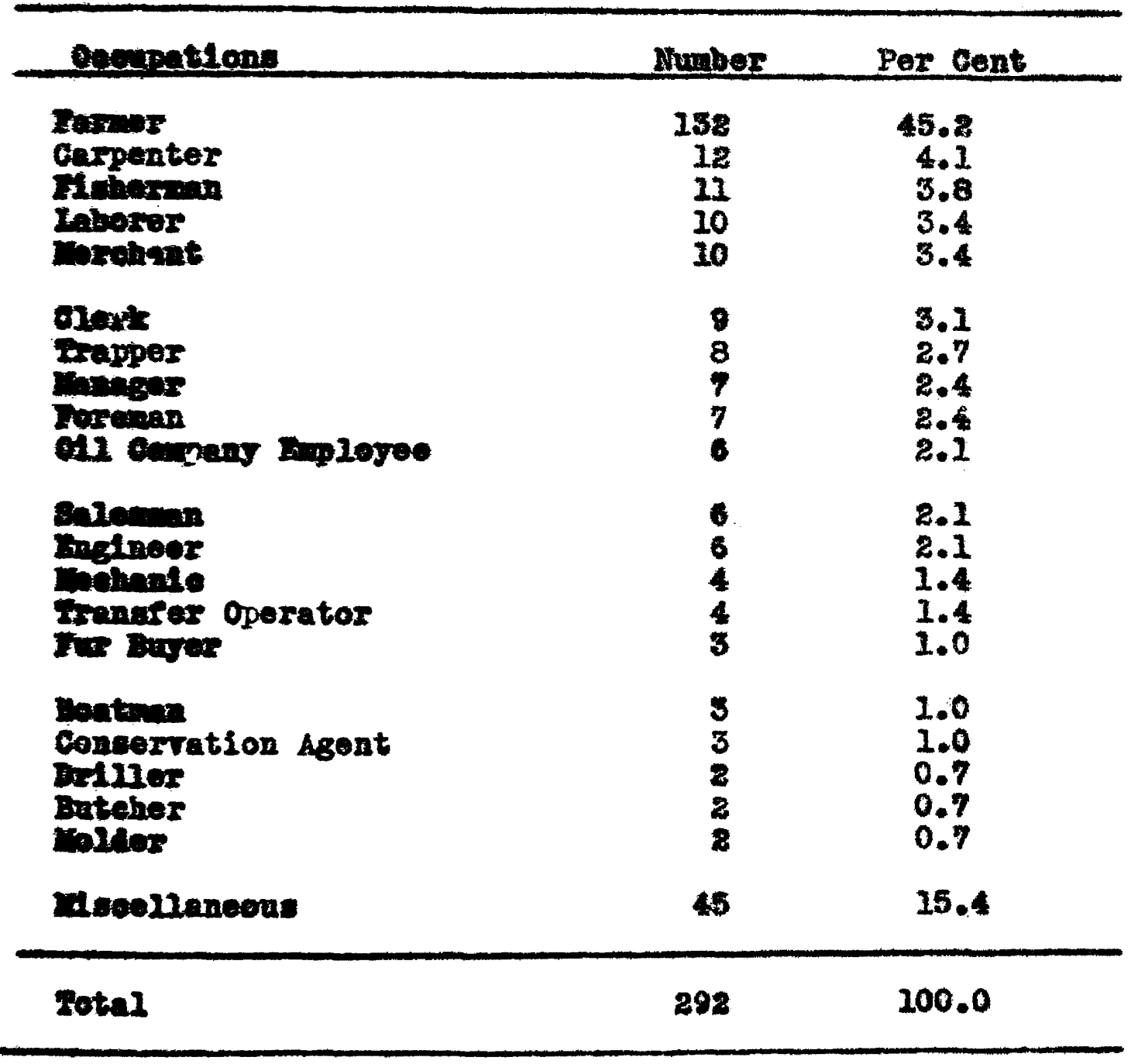


farmers. Sulghtly more then 40 per cont are enteged in frraing and in housekeeping. (Table L..)

It is interesting to note whet the students desire to do. Pabie LXI shows that nursing renks first for the firlo, and engligearing flrst for the boys. Lare expect to angrge in aurelng, teaching, entineering, aviation, bookkeeping, and atenography than in faraing. Thereas 18.4 per cent wh to be nurses, 23.8 per cent to teach, and 10.6 per oent to be engineers, ealy $\mathbf{3 . 9}$ per cent expect to be farmers or to Ifve in the country.

An examination of the courgea offered by the school should now be wade. In the first place, home econonites is not offered. mable IXI (which gives the subjects studled by the rerrebonne \#igh Sohool students) indicates peculiar differenoes in the abjecte selected by the rural and tom puplis. Social seience ranks next to Fnglish in popularity with both groups, but whereas 89.8 per eent of the tow pupils study thet subjeot, only 76.8 per oent of the rural students eloct 1t. Although 89.8 per eent of the town pupils study mathematics, oniy 55.3 per cent of those from the rural distrlots choose that riold of activity. One observes that 55.9 per cent of the town pupils and 68.3 per cent of the rural ohildren seloot the rocational courses is howerer, only 11.7 per cent or the rural pup1ls take agriculturs. jore rural

15. Sorse of the rural students were Induced to take agrioulture by the argurent that there would be as great educational Felue in the study of agrioulture as in sny of the other subjeota. The princlpel stated that although he and the agrioultural tesohor had teken time to urge atudents to enroll in agrioulture, even Golng to the differont elenentar $\mathrm{y}$ schools in the yar1sh to speak It th prospective students, only a few were fndused to onroli in the agroultural classes, on the othor hand, at was neoefsery to Iint the number that oould enroll in the rrench and gpanish elasees. 
Table IX

coespations of Brothore and Siaters of Rural students Attending the Terrobonne High sehool

\begin{tabular}{|c|c|c|}
\hline opuntion & Duber & Per Cont \\
\hline 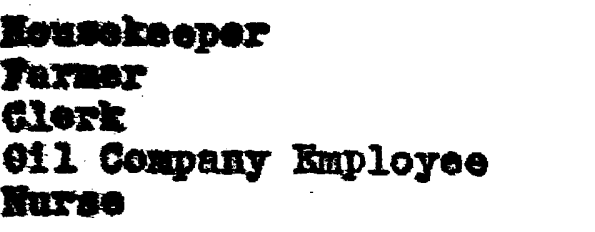 & $\begin{array}{l}88 \\
29 \\
24 \\
18 \\
14\end{array}$ & $\begin{array}{r}30.5 \\
10.8 \\
8.5 \\
6.4 \\
5.0\end{array}$ \\
\hline 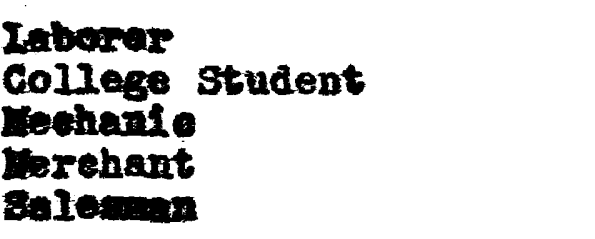 & $\begin{array}{l}11 \\
8 \\
7 \\
5 \\
5\end{array}$ & $\begin{array}{l}3.9 \\
2.8 \\
3.5 \\
1.8 \\
1.6\end{array}$ \\
\hline 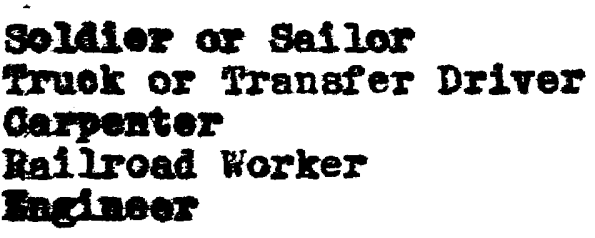 & $\begin{array}{l}5 \\
4 \\
4 \\
4 \\
4\end{array}$ & $\begin{array}{l}1.8 \\
1.4 \\
1 \cdot 4 \\
1 \cdot 4 \\
1.4\end{array}$ \\
\hline 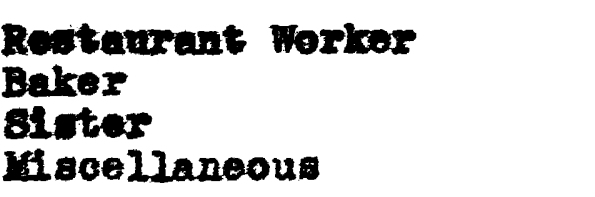 & $\begin{array}{r}3 \\
3 \\
2 \\
46\end{array}$ & $\begin{array}{r}1.1 \\
2.1 \\
0.7 \\
16.3\end{array}$ \\
\hline Total & 288 & 100.0 \\
\hline
\end{tabular}


Teb1e IXI

Oeoupational Preference of Mural students of the Terrobonze High Sohool

\begin{tabular}{|c|c|c|}
\hline - Pexpat lons & Number & Per cent \\
\hline 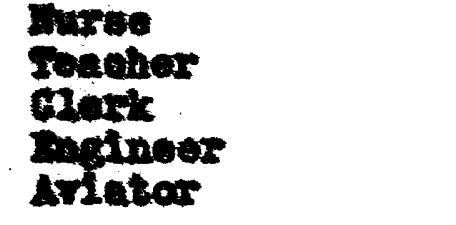 & $\begin{array}{l}47 \\
45 \\
44 \\
27 \\
16\end{array}$ & $\begin{array}{r}18.4 \\
17.6 \\
17.3 \\
10.6 \\
6.3\end{array}$ \\
\hline 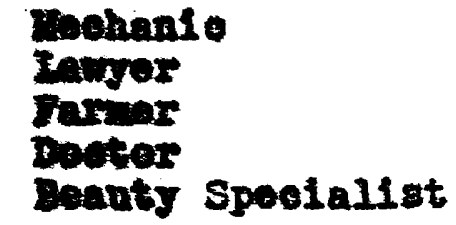 & $\begin{array}{r}10 \\
10 \\
10 \\
7 \\
2\end{array}$ & $\begin{array}{l}3.9 \\
3.9 \\
3.9 \\
2.7 \\
0.8\end{array}$ \\
\hline Isoe Llaneous & 37 & 14.5 \\
\hline $\operatorname{tata} 2$ & 255 & 200.0 \\
\hline
\end{tabular}

thas sem pupila, both actually and relatively, ohoose oourges In eximarea.

Whan one leams that of the last year"s graduating olase of $8 \mathrm{enly} 16$ entered college, and that only aix of the 16 were from raxal howe, he wast reallze that for yore than $B 5$ per eont of the rural pupils and about $75 \mathrm{per}$ oent of the town paplis. high sehool graduation marks the apex of their ectuontion2 achereneat. For the zaral ohilaren espealally, should one reogence the ract that,for the great majority, high sohool Ia the eulnination of their formal or inetitutionalized eduoation. That may explain in part tho differences found between the sural and the town groups in the aubjocts studiod. There serms to be a greater desire on the part of the rural roldents to 
Table $\mathbf{E x T}$

Subjects Studied by Studente of the Terrebonne High

Sahool

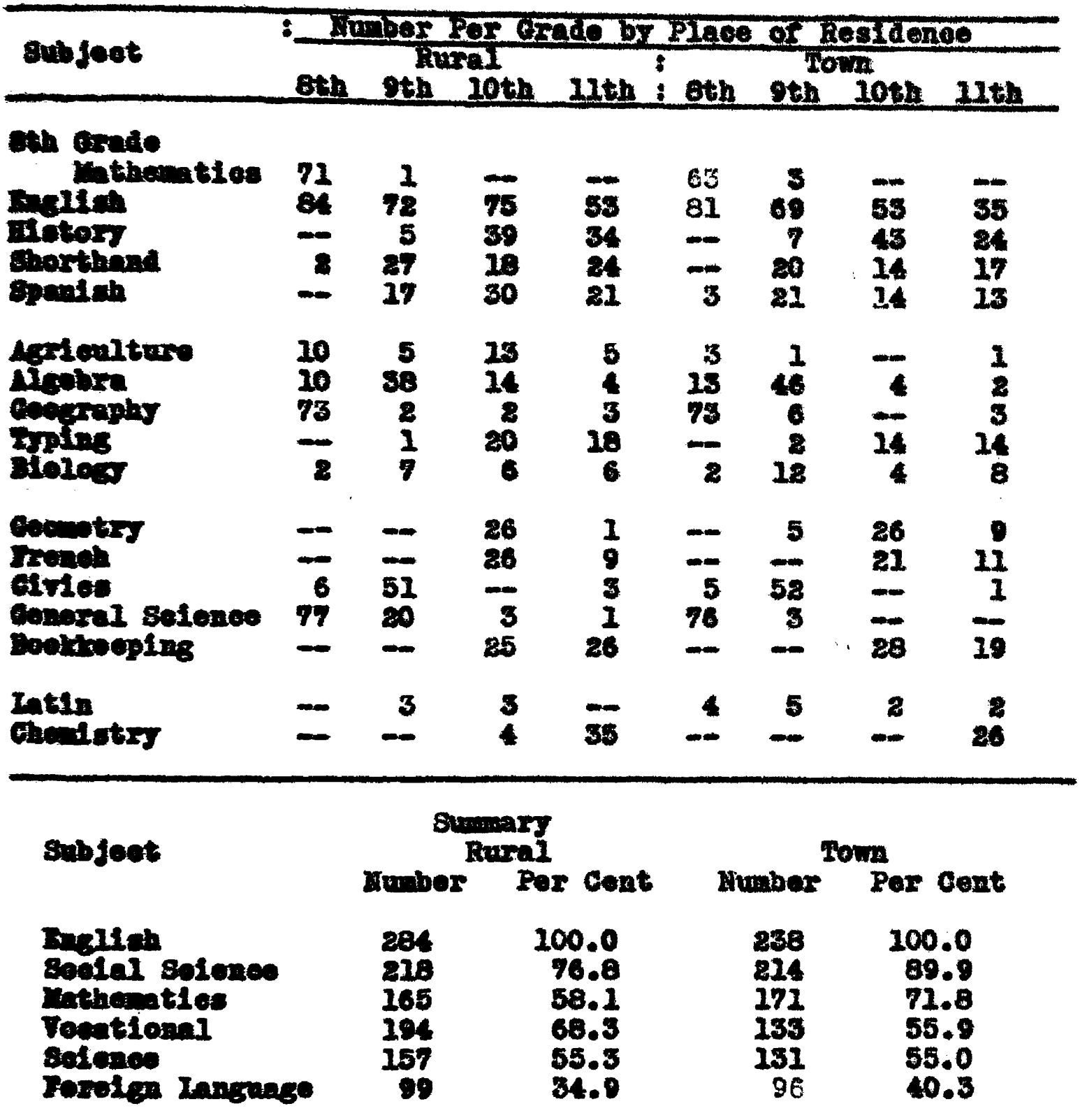


prepare themelves for the oceupations of iffe, fudging fros the percentage found taking roontional work, than 1 g true of the town residents. It should also be noted that the reeation whlah they prefer are urban rather than rural. The purauits they desire to follow are not connected wh the life they have been Ilving.

since the Terrebonne High sohool is a pargh high sohool and preavabily serves all the population in the largeat parish In the state, one would expect to find the students prom the raral distets transported for long af atances. That this is true can be seen from Table IXIII. Almost 55 per cont of the arollment of the Terrebonne High Bohool are taken to sohool oy baes, the distances traveled ranging from one to nore than 25 niles. One girl it years old, a sentor in high school, reported that she traveled 33 miles to school. The modian Astanoe traveled is 9.6 miles, more than that traveled by the studente from either the Ouachita Farlah Hgh Sohool or the Manghus sehool. Twenty-two pup1la, or 8.2 per oent, travel nore then 20 alles to achool. School bezins at 8:40 in the morning and loves at 4:00 in the afternoon. Those IIving as far as 20 Wled from the school anst satoh the bus about daylight. If theg do not I1re on the bus Iino, theg rust walk the intervening Astanes before deylight; on the return trir they probubly reach howe after dark. As 13 pointed out in the disousaton of the Ouechlta Parlish High Sohool and in the disgussion of the Fondale Bohool (Chaptis VI), tho parish trangportation ayat era operates as anlfled machine, so that the buses mugt of necessity pick up the elementary ohlldren who are transported 


\section{Table LaII}

Distances Fraveled by Rural Students to Reach tho

Torrebonne High Sohool

\begin{tabular}{|c|c|c|}
\hline Al tence is lizes & Inopas & Per cont \\
\hline 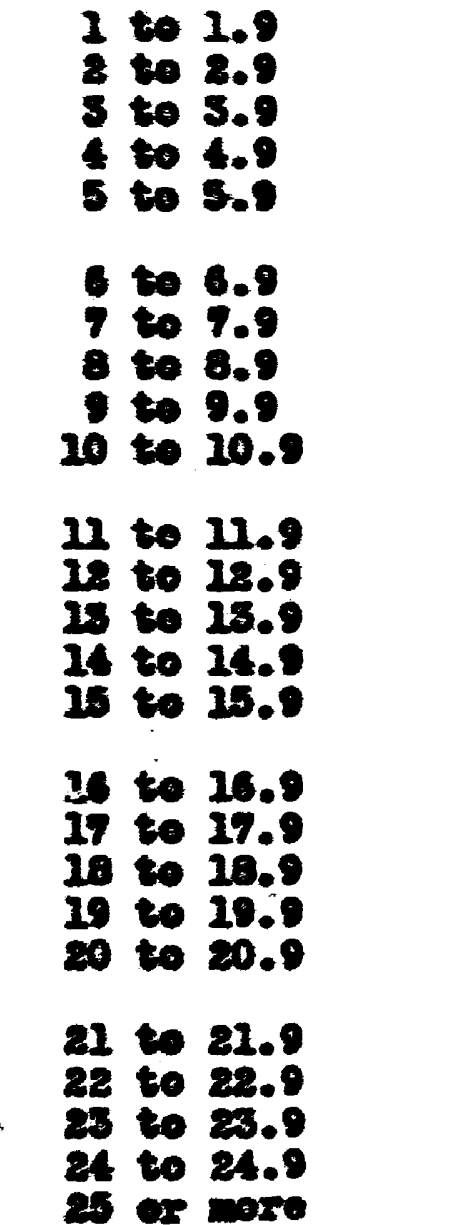 & $\begin{array}{r}17 \\
86 \\
10 \\
18 \\
8 \\
14 \\
5 \\
82 \\
31 \\
18 \\
5 \\
28 \\
4 \\
9 \\
8 \\
17 \\
8 \\
12 \\
3 \\
7 \\
5 \\
5 \\
1 \\
0 \\
2\end{array}$ & $\begin{array}{r}6.4 \\
9.7 \\
3 / 7 \\
4.5 \\
3.0 \\
5.8 \\
1.9 \\
8.2 \\
11.6 \\
4.9 \\
1.9 \\
8.9 \\
1.5 \\
3.4 \\
3.0 \\
6.4 \\
3.0 \\
4.5 \\
1.1 \\
1.6 \\
1.9 \\
1.9 \\
0.4 \\
0 / 0 \\
0.7\end{array}$ \\
\hline
\end{tabular}


to the conoolidated elenentary sohool distributed in eontrallzed points. Ithis means thet the elementary on ldren mot elso leave home berore deylight and get home after dark, oren shough they are not tranaported suoh ione disternees as we round to be true of the tenghan sobool ohjlaren.

A study of the part the school is taing to develoy the student soclally and physloaliy through the mediun of extreomrioular aotiritios indicates much similiarity in the phyateal situation in the ouachite parish and the rerrebonne Elen sobools. Both are locatod in the heart of urban centers vith inadequat apace for playground or physical aetivities. me rorrobonne High Sehool is looted on the block adjoinings the court house square, Just one blook from the matn street of the town. The sohool is so congeated that frage bullding has bean butlt next to the briek struoture to take eare of the curplus. There is no room on the school gromis for playgrourd equipment of eny kind. In order to practice for athletie chatente the eoutestants must go a rile fron the school to find opes. An at tine Onachita Parish High School, the rural ohilawen bare no place to 80 during the noon howr; so many of them walk wa dow the tom atreets. No intra-inural atkletie progran is posalbie with suoh a stuation.

the prinelpal of the sohool has atterpted to devalop an acadomic activity progrem. A forn of student government is in operation; departmental olubs, gchool paper, band, a Aramatic club, class organtzations, and the 11 ks are found In eperation. All cetivities are sohoduled for a regular gotivity perlod curing the day. Wo hours are devoted to ethletio 
practioe so that rural studentg oan ongage in athletics fust as the town pup11s do. A corparison of the students part in the activities of the school. shows that 32 of the aluh or class offlces for the ourrent year were held by the students wo live in rural distriots, and 24 were held by the tow students. of the group representing the town population, 211. or 67.6 per cent, reported they had held no of lles, whereas 245, or 86.9 per oent, of the rurel ohilaren so roported. Thus there seems to be slo warked eridones to support the contention, somatines wade, that rural oblidron to not raelve theis share of the sohool honors of offlces. Tho seme is true in regard to representation of the sohool in contesta of varlous kinds. In fact, it amenears thrs the ohllaren from the rural distriots who attend the Mexrobnone El shehool may reneive oven more than thels ahare of rocosnltion.

Cortalnis the Terrebonne Fligh sohoog can rake lltkle

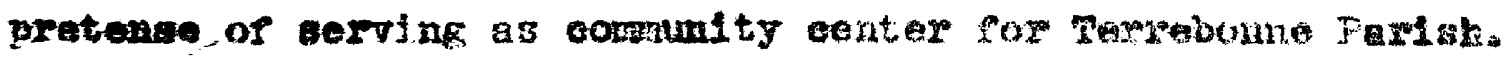

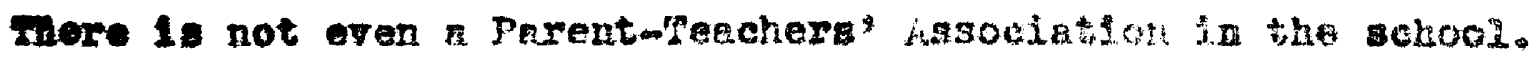
ondy 26.1 per oent of the ruzal students rejorted thet sheir parents had risted the sohood this year. anti the sehool spents but little more renoved from tho rural parents in go fax as school Fiafts axe ooncemed than rrop those of the tom, for only 17.1 per oent of the town puphis reported thet the parente had visited the mohool. Onit 52.9 par ent of the rural ohlidren reported that their parents gttend school entertainments, whereas 63.2 per cent. of the town paphls

16. The data on the alub orfleers for tice acrent yeax were applied in detall by Mr. F.S. Talbot, Princlind of the Rexrobonne Figh Bobool. 
reported attendanoe.

As in all of the sobools atudied, the teachers in the

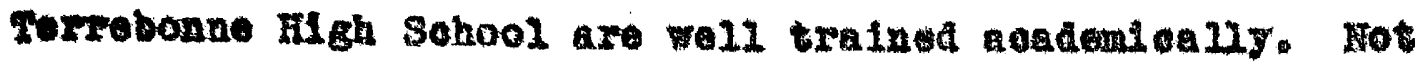
a tencher has less than a beholor's degree, and three of the 20 have mater's Aegrese. Only two teachers have not seught previousiy to this year. The modian torm of teaching experienee for the teachers is aeven years. Thre todohers are seaching in their present positions for the flrot time. onif six toacherg have not taught long anough in their prosent positions to hare passed the period of probation. De-third of the teachere have taught in no other whool grater than that of Terrobonne Parish.

Gepelustan: As has been found in all of the sahools, the condento training of teechera in the urben institutions in wich rural chlldren are trained is considerably above the requiremente of the southern Assootation of 00110gen and

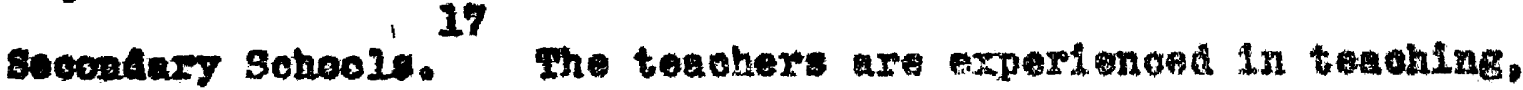
lowly 24 hare lese than three years' teachine oxpertenoe out of total of 76 teachere), but thel $x$ tenurs in the sone podtion is not secure; 89 or 38.1 per oent hare not taught In the sane position long enough to be protected by the Zeachers' Terure Law.

Both sohoels are located in the heart of the olty of town with no raclities for playground or phystond activities. Both whoole are vezy much orererowded. Despltine the fat that about 50 per cent of the onliaren are brought to the achool by buses. 
no provision is rade, outside of the regular sohool routine, to provide for the comport and leisure tine of these atudents. From a study of these sohools, one is led to conclude that the neede of the rural ohlidren are not taken into consideration. for there are no facilities for their physleal recreation and no provisions made for leisure time sotivities. These two sehools, Jooated as they are in such congested sections, are not suitably placed oven for city sohools, and they oertalmiy are not adapted to the needs of the rural ohlidren.

There appears to be 11 ttle connection between the place or residence and the type of subjects atudied by the pupils. If the situation in the Terrebonne Iligh School is typieal, a hlgher percentage of rural students are preparing themselvos for elerieal pursult by taking courses in commerce then is true of the tow pup1la. This seens to strengthen the obervation previously made, that rural studeats do not desire to 21 re in the country or to engage in africulture as a voeation. Although one osn not clain that the sohools aro eolely responsible for this condition, it appers that the cendtion growe with school progress or advanoonent. This on be seen by conaldering the combined data for all the high sohools and all of the elementary schools whloh are studied. atrong all the elerantary sohool jupils attending tow schools or rural oonsollated schools, 19.6 per cont stated that they expeoted to renaln in the country; among those who have reached high chool lovel the peroontage has fallen to 1014 per cent; and anong those who have reached the senior year of high school this has been further rebued to 6.0 per cent. It sesias thet 
there can be but one of tiro explanations for this phenomenon. Hther the pupils who desire to remein in the country do not continue in school; or as they continue to climb the educational ladder, their desire to remein in the oountry is changed to an Intention to pursue urban I1fe and oocupations. 18

One can bardly fail to be impressed by the fact that the whool acts as an agent for removing the differences which way have exlsted between the rural ohildren and the town ohlldren. But it should be stressed that this unifying Influence is not of such a nature as to fit the students of weth groups to have a mutual understending of each other's problems. Rather it unifies the divergent groups by making raral onlldren familiar with urban life. The urban students do not become familiar with rural ways. The rural students are taken into a school located near the geographio eenter of the town or ofty. They come into contact each day with elty life, the subjeots they study are those which have been deened proper for the college preparatory courses or for courses in comnerce, an urban occupation. They have few sehool courses designed to fit then for life in rural comanities. Is it any wonder, then, that after years of life spent in this urben onviroment, studylng aubjeots thought to be suitable for the proper development of sons and daughters of the "social elite" that they come to the almost unaninous decision by the time they

18. In maklng this comparlaon only those pupils who live in rural homes are considered. For the elenentary grades we Find of 962 pup\$1s in the fourth through the sevohth grades, 189 express an intention to remain in the oountry; amone 1, 281 pup11s, 133 express an intention to remain in the country: and of 232 high school seniors, only 14 express such degire. 
are senlors that they do not want to becone forners or to IIre in the country?

The sohools are tryins to weet the nevds of the pupils In the matter of soolal develoment throngh the medius of abool aotivitied, within the linits of thelr physical oquipaent. soaderaio, musloal, and social aotivitiea are araliable to the students; and by sons or the setivity perlod, soheduled as a part of tho sohool day, rural ohilaren are Cren opportunity for this kind of development. The olalns arten made that town and ofty oh11Gran monopollze the sohool henors and that there is a form of soolal dfferentiation votween the pup1le from the rural sections and those of the tow which excludes rurel children from thelr shere of representation in sahool aotivities, does not saen to be mbstantiated to any marked degreo.

Little erldence exists to support the oontention unde by Mueational theorlats that the consolldated school aerves as - oomanity conter, especially when the consolidated sehool bolongs to the olass under discussion. The parents or nore than three-fourthe of the rural puplis had not ylatted the sobool during tho sohool year, and not more than ond wall reported that their parents so to the chool por entertalnsents. This is ensily underatood wen one conblders the distances whioh the onllaren trevel to reach the school. No lisatitution can sorve to attract the patrons when it is so latrioult to reach becauge of ditance.

The school 20 removed srow the rural poonle oan not aot 
es a comanity center; on the other hand, it seems that such an institution must Inevitgbly weaken the influenoe of the home and the nelghborhood. It is hardiy posalble that atudents in the adolescent pertod of life can be retained for Are days each woek for the greater part of the waklng day in an eaviroment ontirely allen to the home, required to study subjects doaling with aspects of life or activities unfamiliar to their parents and to their mode of 11 ving penoved fron Areat observation or influenee of their parents for a large part of their tiac, whout loatas that close understanding and intimate relationship obaraoteristio of prinary-group ascolation. This is another ovidence of the urbanizing Ineluenoe of the consolidated urban school fin whloh rural chiseren are trained. It is ohareoteriatio of urbanisa that the fantly ties are meakened.

19. See cist and Halbert, ov. eft, , p. 259. Hiles gapenter, The Socloloky of C1 ty Iife, Longwans, Green and Coupeny, Hew Yorik, 1932, pp. 230-24e. Jitirim 3orokjin and garle C. Zlemerman, ErInelples of Rural-Urban Soololody,

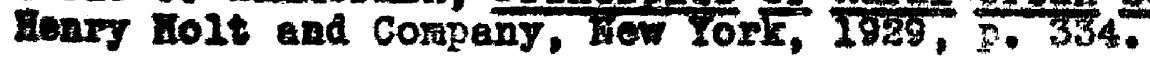


There 1s no page 100. 
QBRPGin VII

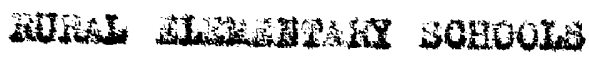

Wo study of the rural bohoola of a state would be complote Athert wowe roferenoe to those bato ingtifutions, the rural

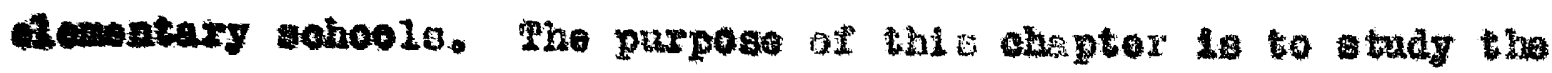
matal shoole in which only the elewentaxy grtade of work is

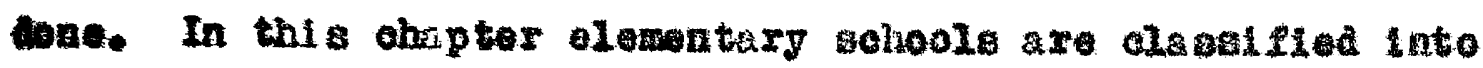

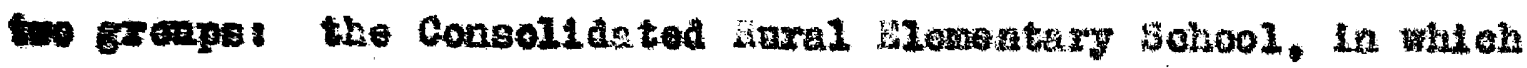

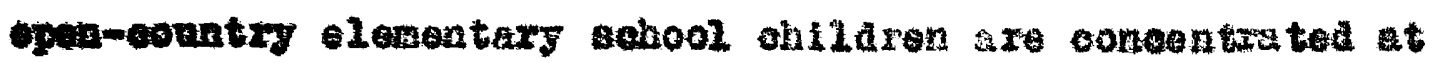

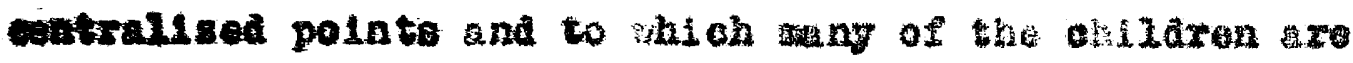

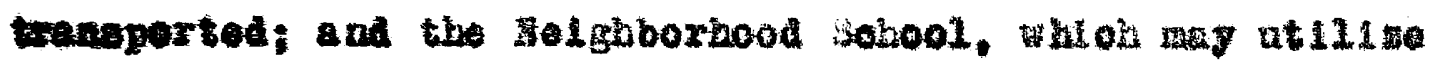
the servioes of one techer or mox las the numbr of ahildren

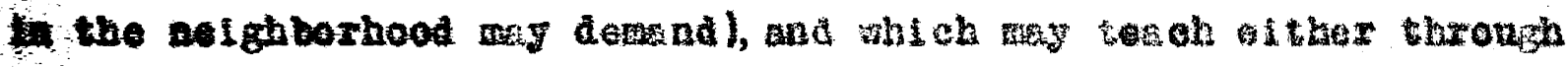

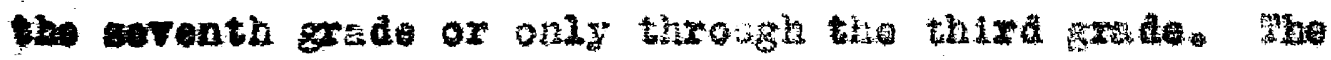

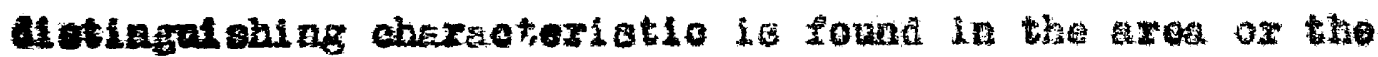
leadity atrred. I gohool servirig tao or nore nelghborbood.

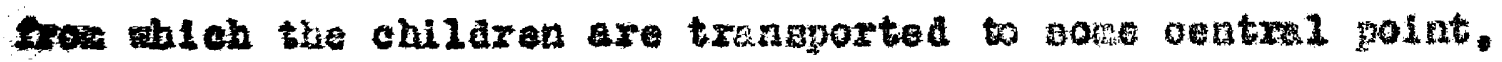

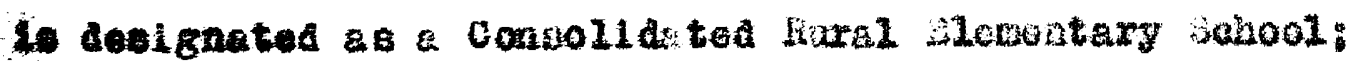

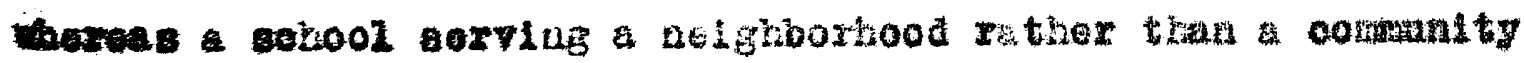

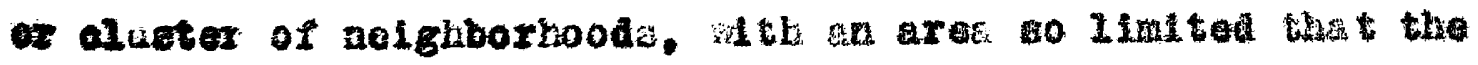

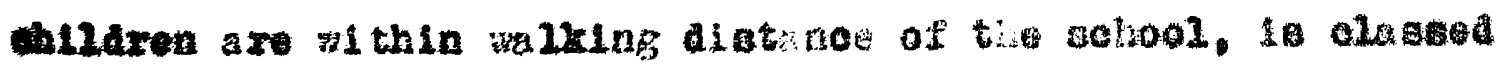
a. a Beighborhood Sohool.

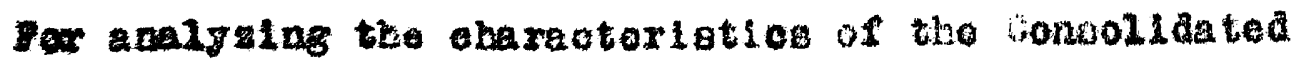

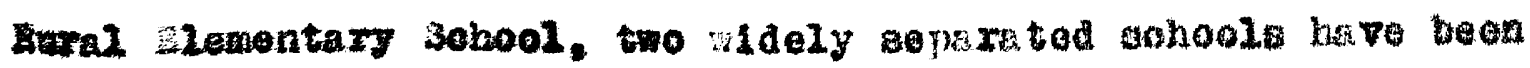

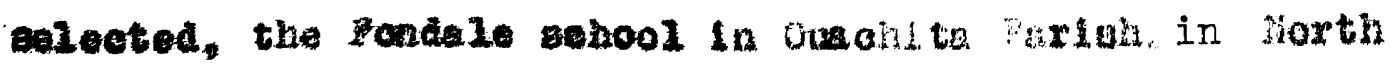


Iousiana and the Samstom sohool in Ibervili parish in the coutherm part of the state. A representative of the Ietghborhood Sohool, three neighborhoods have been gelected; the Mxon nelghborhood, and the Midwy nelghborhood, both of wioh are in Frankiln Parish in North Loutstang, and the Delmont neighborhood in St. James Parish, in the French seotion of the atate. The sohools tharaelves in the Belnont and the Warey nelghborhoods are examined, tut in the Nixon settlenent there 10 no sohool, and so the nelghborhood 1twelf is the begect of the investigation.

\section{Soetion A}

The Consolldeted Rural Blementary Sohool

\section{In Foncale Sohogl: The Fondale sohool is loonted fu Ward}

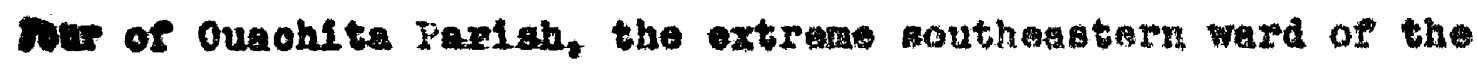
gurieh. Its northern boundary is about four wiles fron the center of konroe. The ward is bordered by the ouachlta giver on the went, Caldwell Parlsh on the south, and Rdehland Farish on tho cast. Phis is a atriotly agrioultural oomantty, having no Incorporated tom and only one hamlet, Bosbo, which has two storos, a gasoline filling station, a post offloe, a railway utat1on, a poolhall, and s1x homed. The grouter pert of the ware conalate of a rather low-1ging country, and acuthasatern part 1. a large unsettled swanp. The residents of the ward IIte along the banks of the Ouachlta Rfver, expept in the northeatern part, where there are a nutber of smal. Landowners. on the mole, the agrioulture of the ward is oarklud on by 
large plenters undor the oropper ogster. In the eystem both white and regro semilles are oployed. Cotton 10 the prinelpal orop, though sowe corn, Irlah potatoes, swet potatoes, cow peas, and garden vegetables aro rajood. A pared highaty rua through the entire length of the ward, and gravel soade aerve as tributaries to the pared hlghway.

The population of the ward was 1,742 in 1930, which reprosented an Inexease of 25 per oent ovor the number reported In the provioue census. The corresponding rate of inerease for the parish as a wole wat 78 por eont. of the 1,742 people IIring in Ward Four, 700 wore wh1te and 1,048 Hogro, of the wlted, 690 wore natiro-born and only ten were forelga-borm. Aomarding to the wohool centus trken in 203n, there wore 132 hove and 120 girls wong the whtes and 294 boyr and 168 glr2s wone the Hegroes who were or school ego, roprenenting 108 inlte randilen and 174 Hogro fanilles. In 1938 the shool ennour showed 11 thite bogs and 102 whtte girls of cohool age fren 138 whte fand11es, and 175 Nogro boys, fron 169 Nogro Itenizios.

grlor to 1031 there were three one-room sohools loeated at Her in the prairle of the northeast part of the wardi at Logtom, a canlll commulty lookted on the Ouachlta River in the soath centrel part of the ward; nd at Boseo, In the atrwa southern pert of the parlsh. The bulldings were trame otruotures of the type unually plotured by sohool max in their prograse of propaganas for ocmsolldation of sohoola. The 


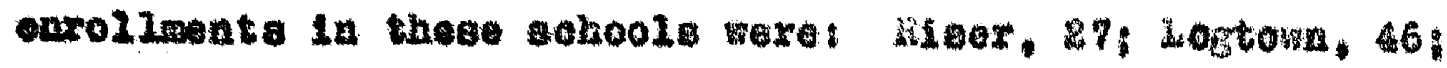

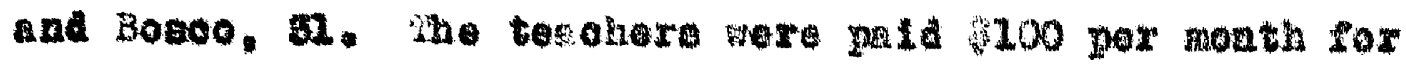
aine menthe. They lived in the oomant ty they gerved as fenitors a vell s instrictors. The ine illental axpenses of operating tho sohools were obout 200 pex you entse cost anounted to about 32,000 per yeat.

In 1980 a consolldution progret pat into effoct in thra fonr. The consolldated obool loout to Fondalo ear Iogtown. The new ballding, a briok btruetare, and tho

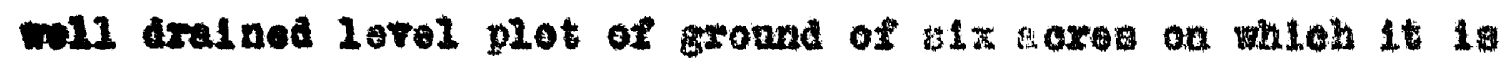

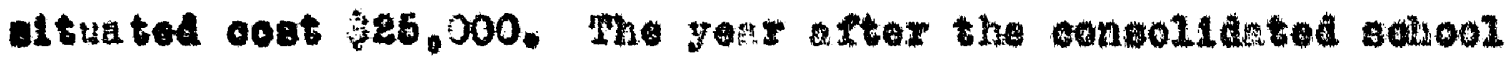

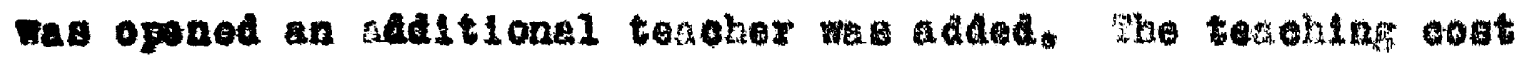

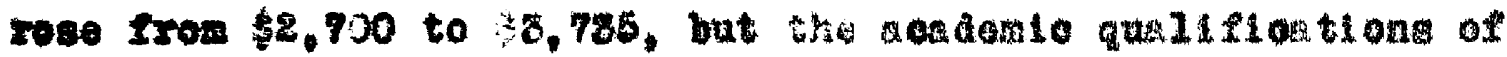
the techers were not laproved. In adation there were other expeneos, Inolnding the fanltor's wary, which wa the total coet, not counting tho cost of tho bused, anount to b4,600 a gear.

Three trangfore aro opernted to ory the andaren to the

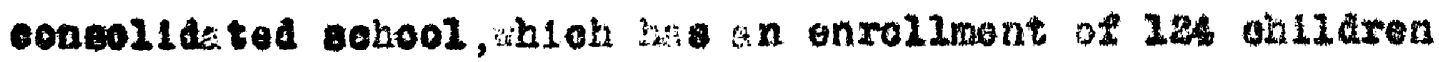
In 1985-36, al etributed as Pollowas:

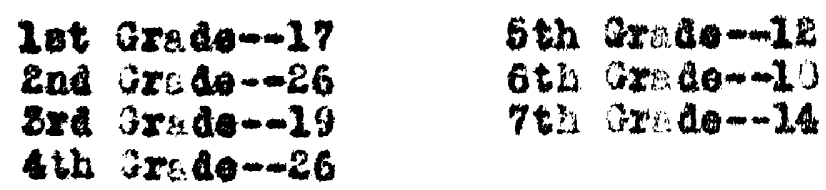

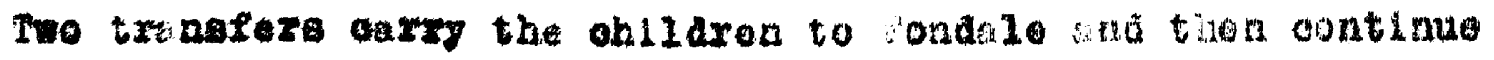

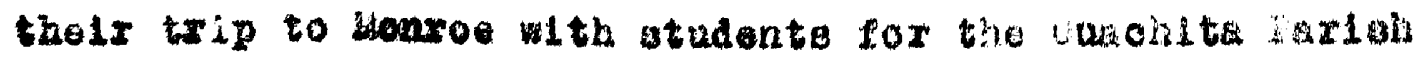

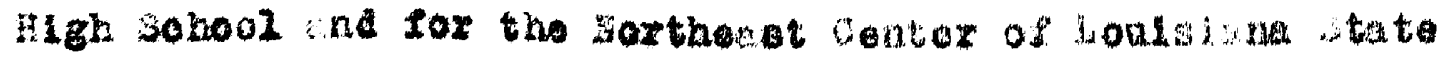

2. The porish owne ite own tranglers and hires drivers to operato trok. 
Oniveraity, One trunster oarries ahllaren from Bosco to Fondele and goes no farthor. of the ontire enxollment of 184. only 15 onilaren walk to sohool.

The Fondele sohool is wired for eloutrlafty, but at tho Hive of the rist had not boen oonucoted with the Loulatane

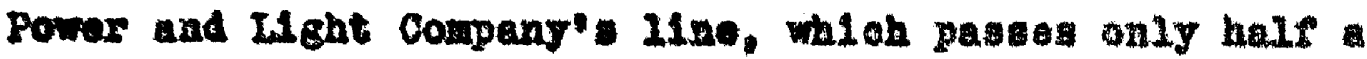
alle tron the sohool. The bullalng has ranalng water and is equippod with moders tollet facliltios. There $1 \mathrm{~s}$ no anditorive or asserbly hall in the buliding, and so when gatherings are plren, a class roon 1 s used as an asseably hall. Obrloualy whon the roome are made to cosenuodate andmen of rerty pupile, the ent1re student body, to say nothing of thelr parents, an not be soated in the room. The sohool wrally has three gatherings during the roar, one for gradution, one at Christmas, and one other. When these ontertalnments are glren, tho sehool buses are used to transport the parents. If the weather is oleax, the people gather on the sohool gromds, and the progran is given from the front stops of the buildsing.

When tho classes are not in session, the chlidren play rolleg ball and Indoor basuball on the groulds; and the younger onliaren joln the teachere in suob gaves as drop the hanakerchief and farmer in the dell and in Bimliar groug games. These ancezente are alrected by the tenohere under plans lald down by the state Bupervisor of Physloal raueation. There is no plageround equipment. Hoat of tho chiliren arrive at the wohool at 7:45 A.M. we that the buees oan coutinue thelx trip to the ofty and get there tor the opening of the high school 


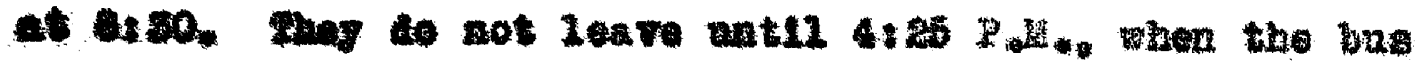

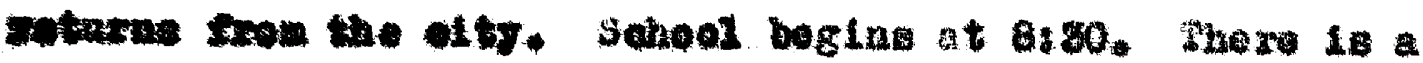

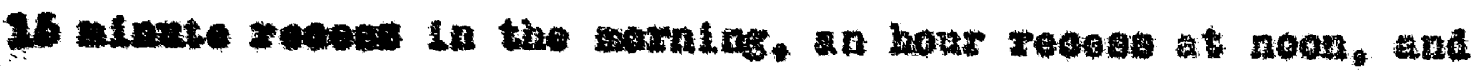

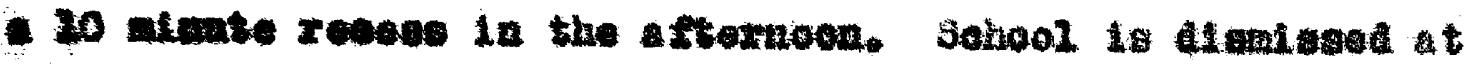

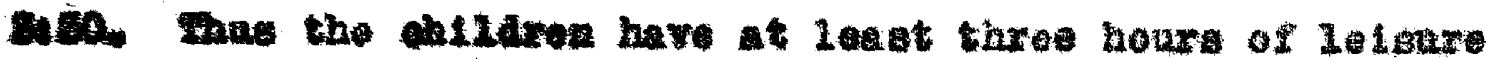
why cat, whid they opond on the wohool grounds.

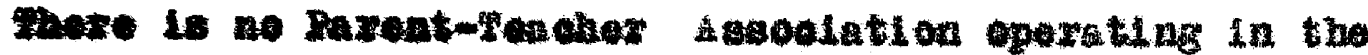
mon. It are statod the extorte had beon made to oxgaize a -14. lut the pareate conle not got to the sohool for beetings.

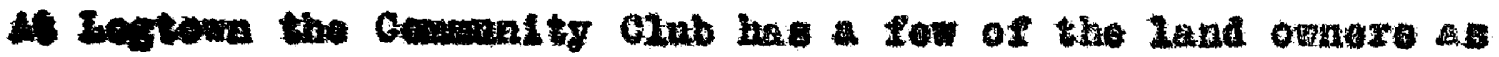
nabre, bat they hare atendesting rofuged to take in any

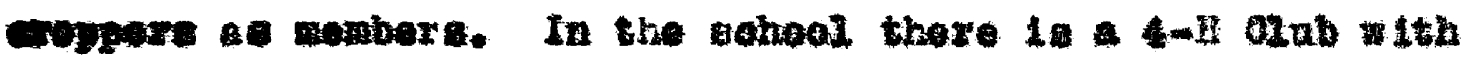

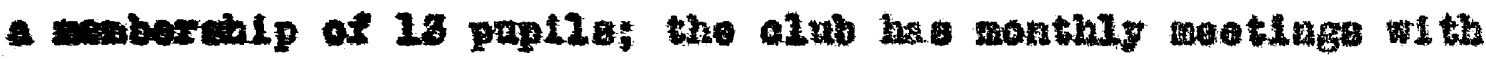

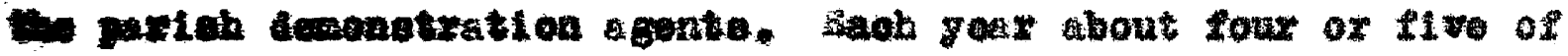

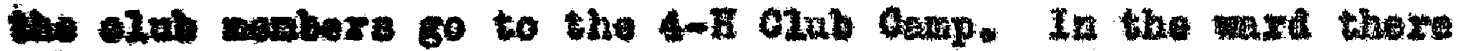

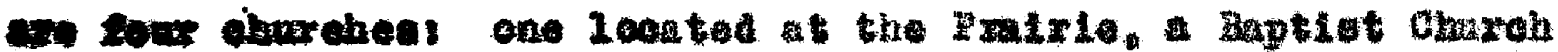

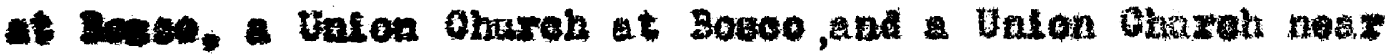
1egtown. Hene of the churohes seet cotive or well sttended.

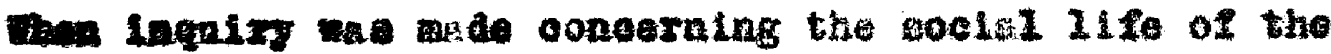

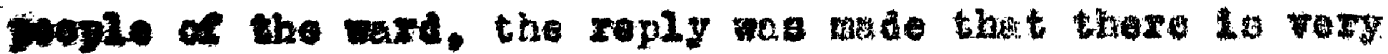
14the. The young peoplo of the Isndmowners 60 to the retion

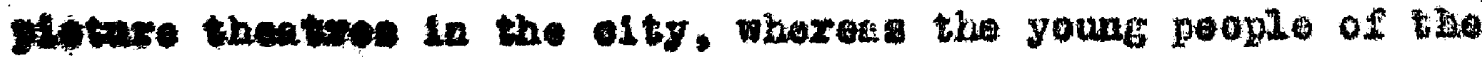

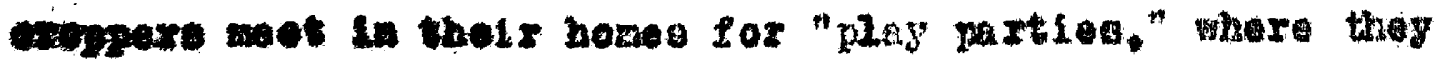

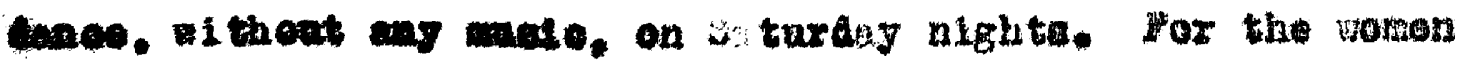

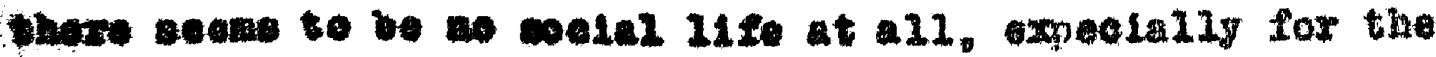

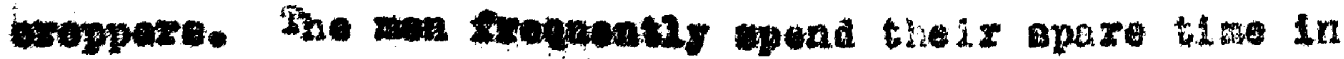

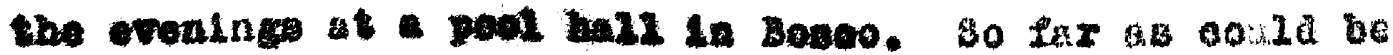


Learzed, this is the onis Inetitution for reoreation in the mard. The younger ohlldren, espeolally the boys, hunt and Hoh for amusersent, and when a group of them get together, thoy play baseball, not as organl zad teams, but eaph youngstex for hlmself in a game oulled work Dp."

Host of the nare has rural free dellvery mall aervioe. The land ormers take the dally Monroe paper, but tew, if any, of the oroppers aubserlbe for this, although sone taike farm

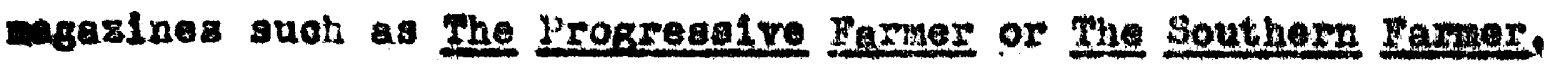
ande from these they have no realine water other than the sobool toxts which are rurnished to the children.

The situation can be more elearly portreyed by desoriblag - Iew cases. One fanily of the better type oropper class Urea about elght alles frora the Fondale sohool. There are tour ohllaren in the fally; two are in sohool, a boy of Pourteer in the sixth grade, and another boy twelve years old In the pourth grade. They live at the ond of the bus 1ine. The ohllaxen take the bus for school at seven o'clook in the morning and get home after fire o'clock in the orening. This fanily has one cow, some ohlokeng, and good garden. The ranere worke about twenty acres of land, which are plasted In cotton, corn, and potatoes. The family does not take dally peper. but does aubsoribe tir The Erogressive Farmer. The house contalns no books excopt the school text bosks whiak aro provided by the sebool. The boys had not been to ploture show in two jeara. About two months before this Inquiry was made the boys bad made a trip to wonroo. 


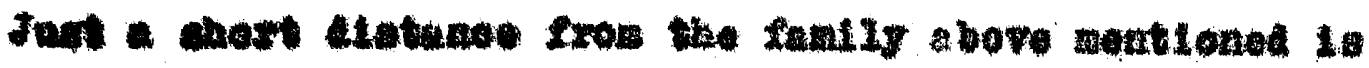

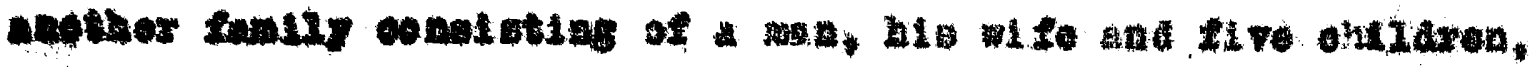

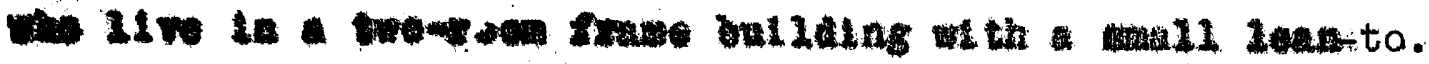

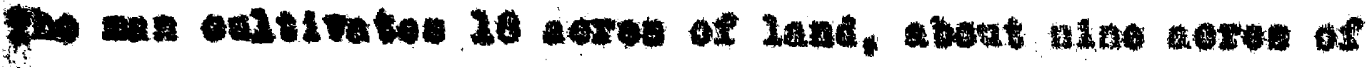

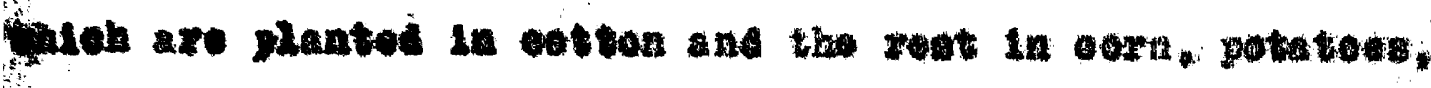

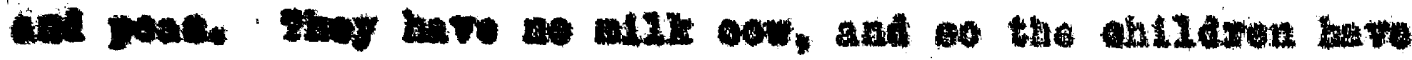

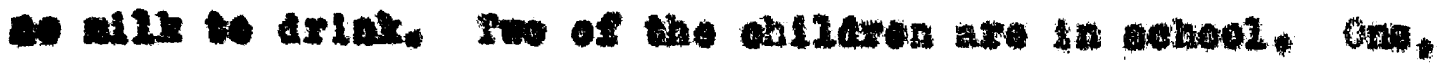

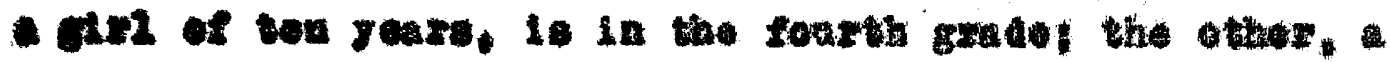

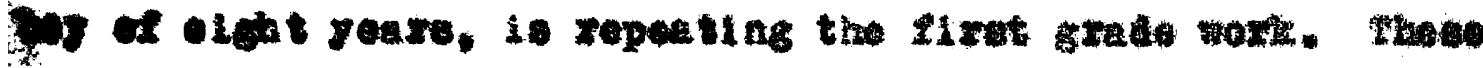

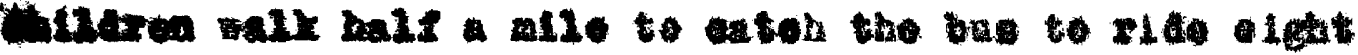
Ane to sobool. Laet winter the youngest wild, baby, had

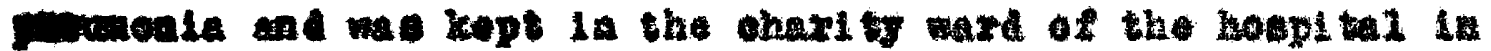

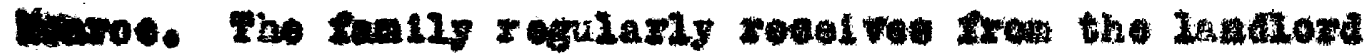

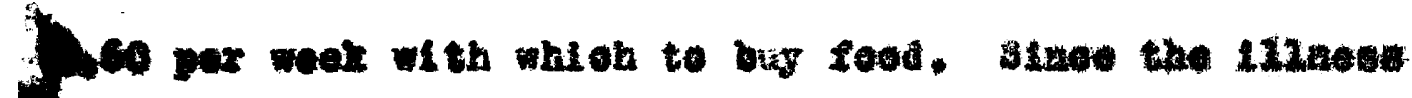

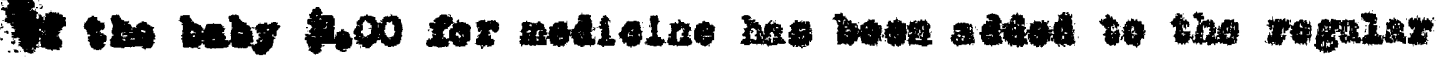

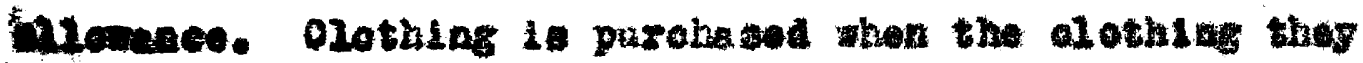

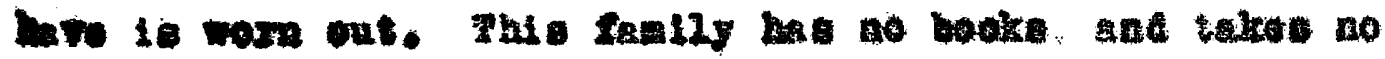

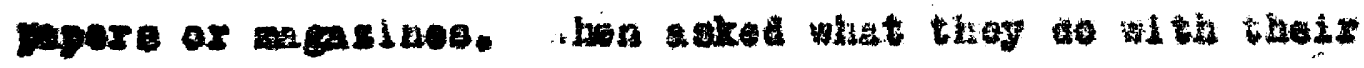

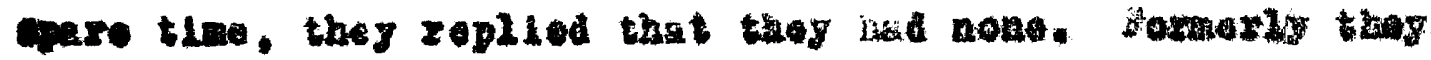

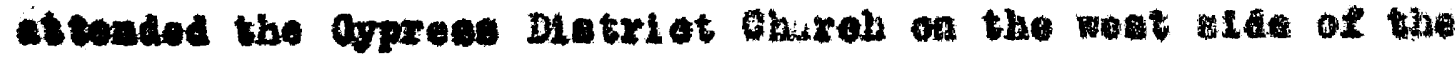
Aver. bat thoy have not boen thore for the pot two or threo raxe. The pareate take no part in the pehool aotifities meaned they beve ne way of getting to the ochool.

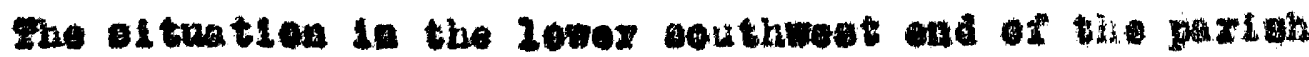
it wath noting. Boxe the river makeo a grest bend, and gravel

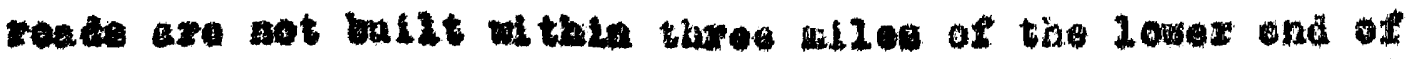

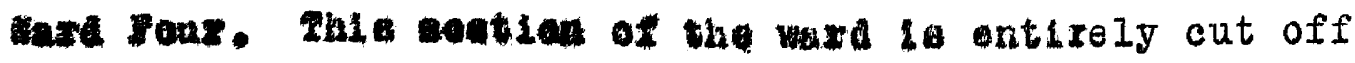




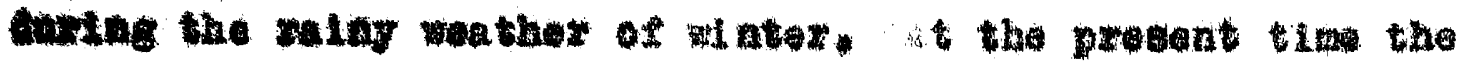

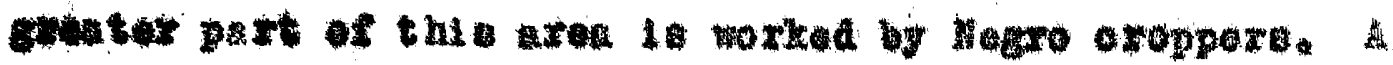

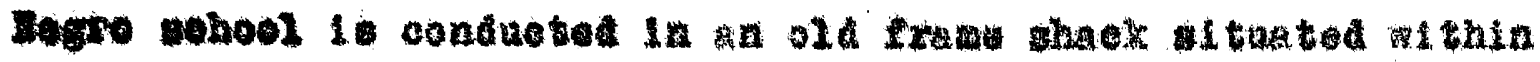

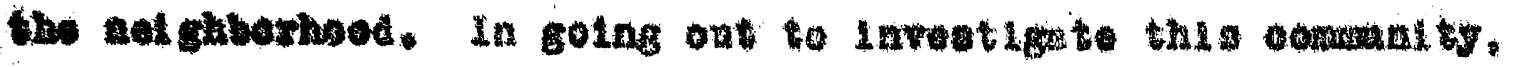

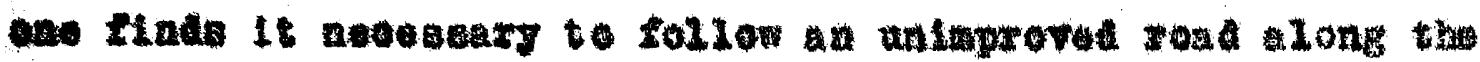

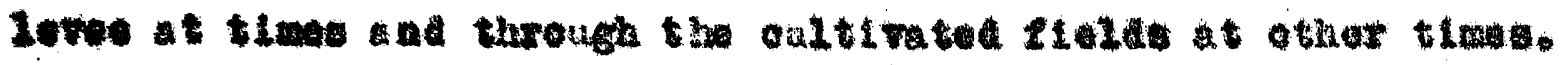

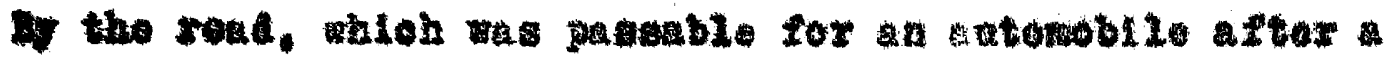

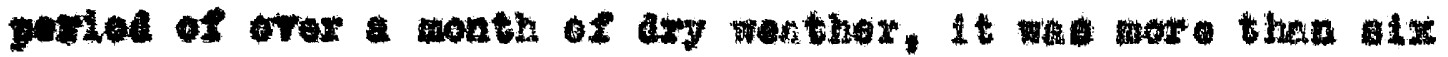

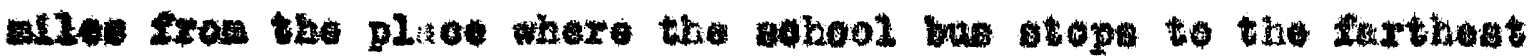

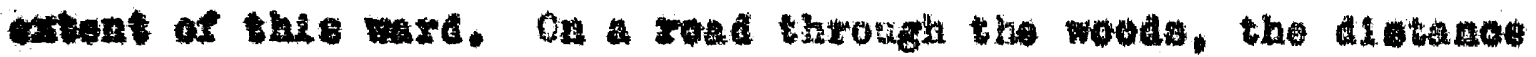

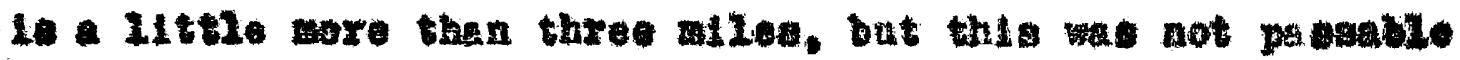

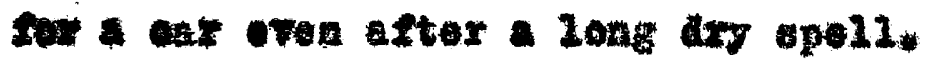

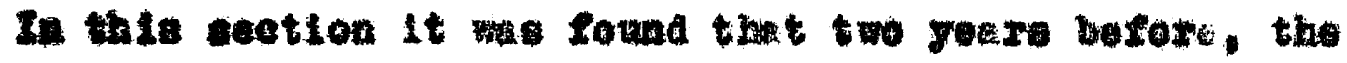

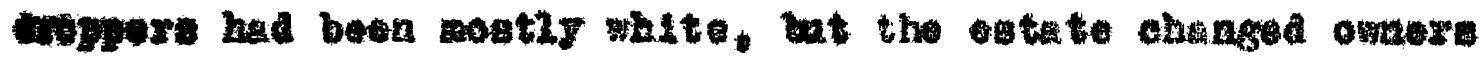

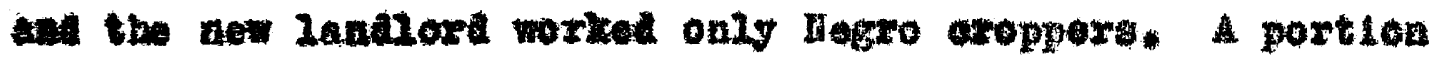

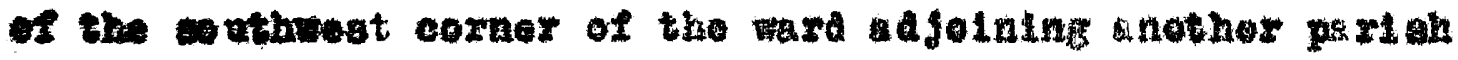

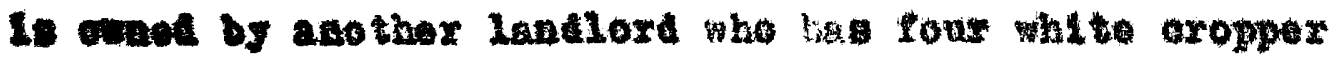

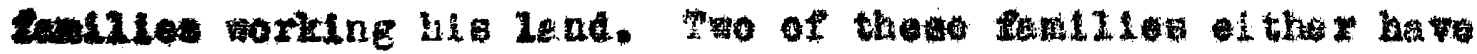

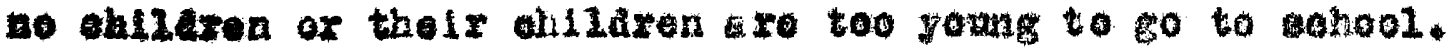

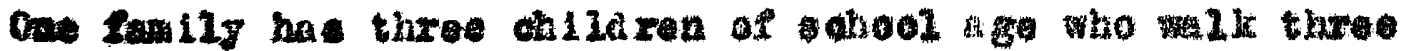

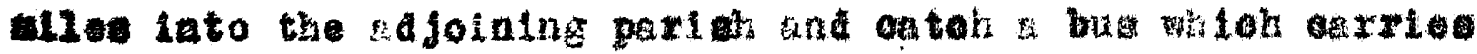

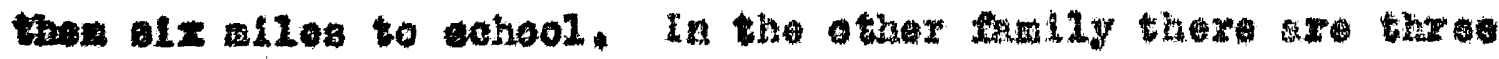

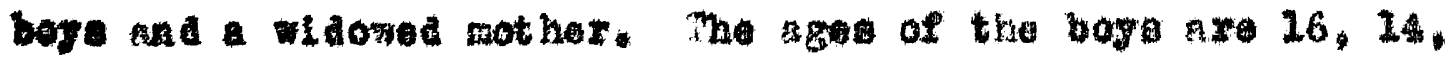

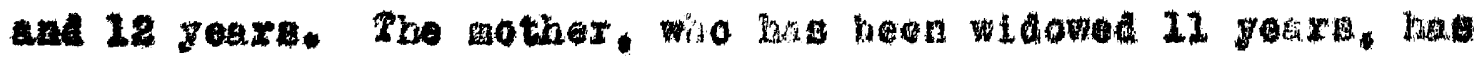

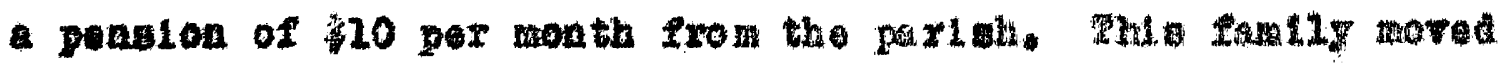

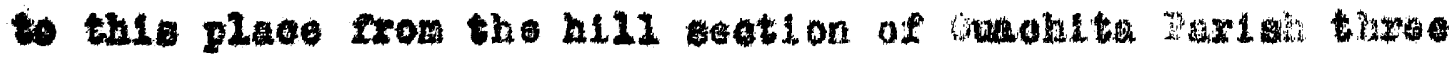

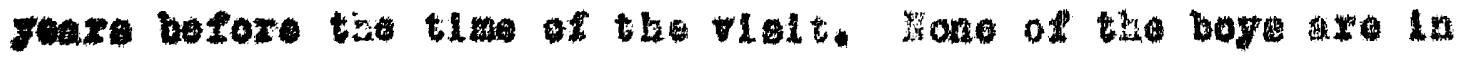




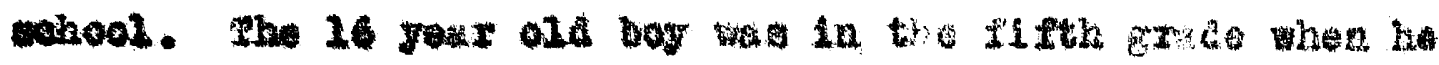

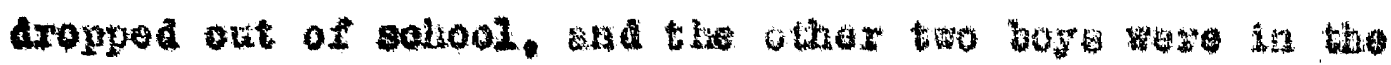
fourth grado. Jor two geare the boy stampted to go to

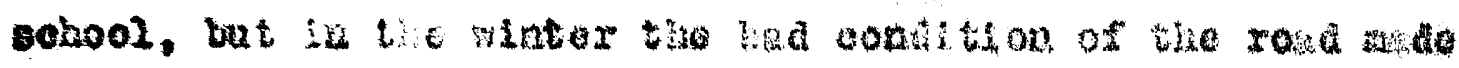

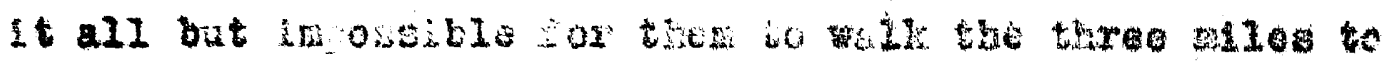

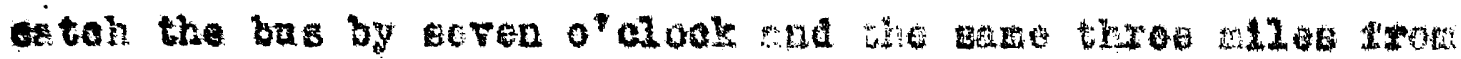

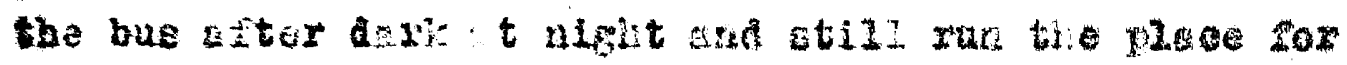

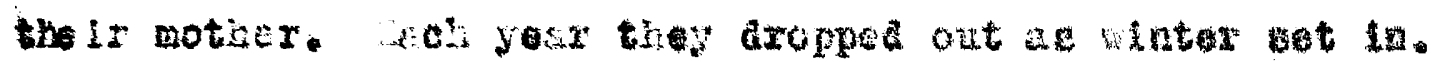

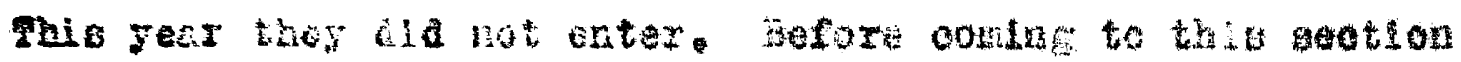

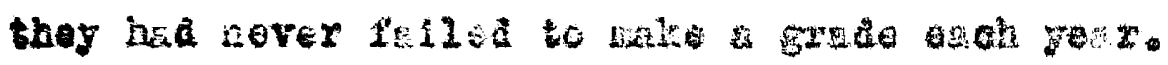

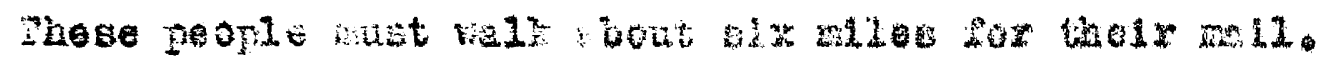

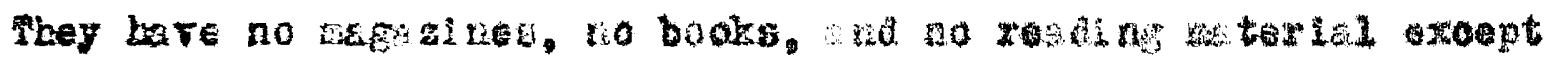

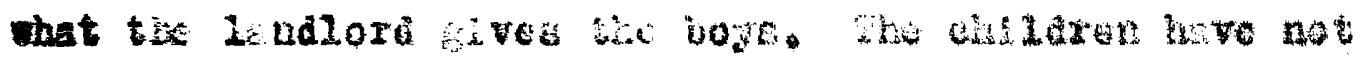

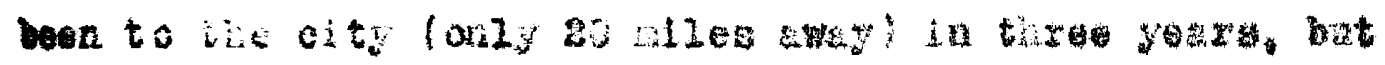

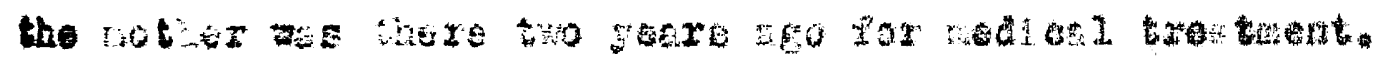

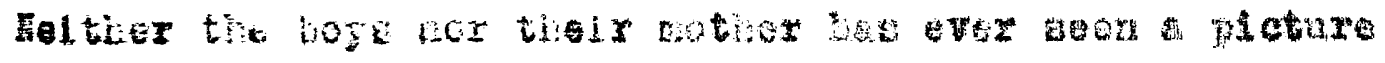

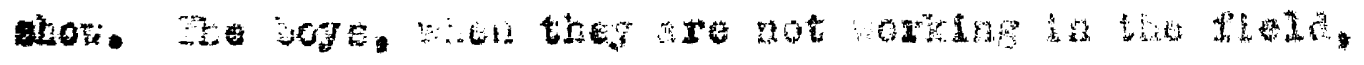

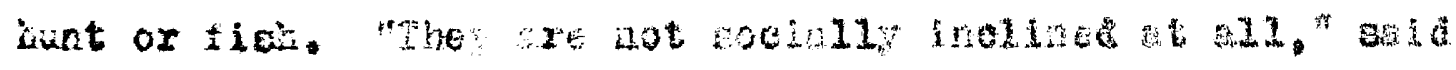

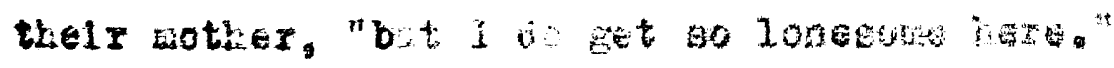

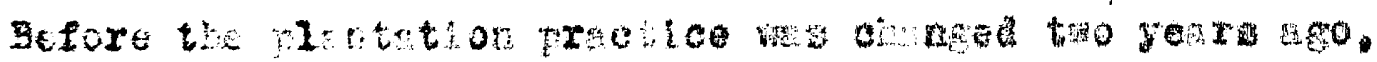

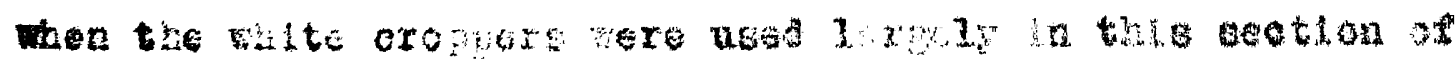

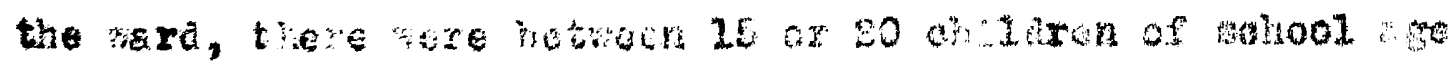

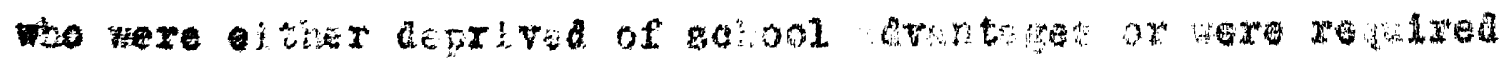

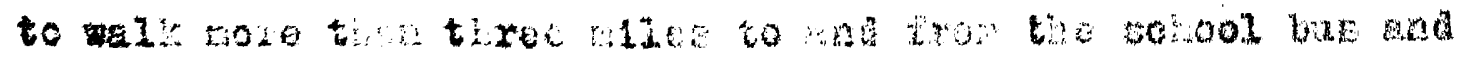

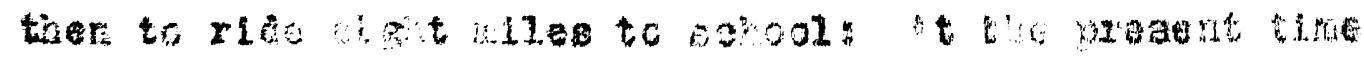

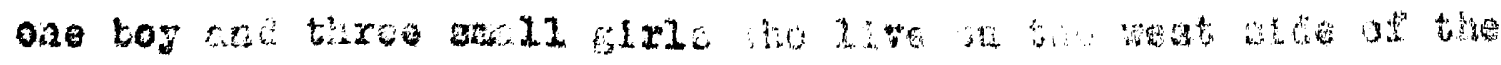

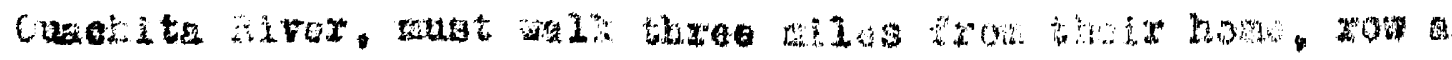




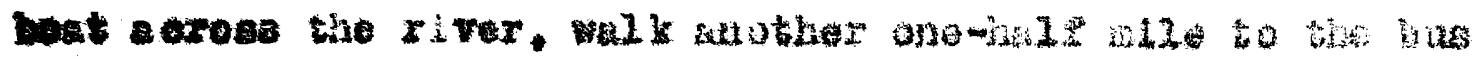

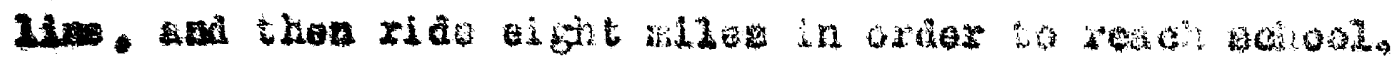

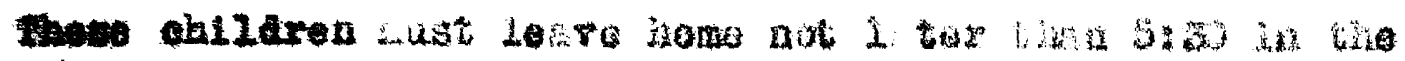

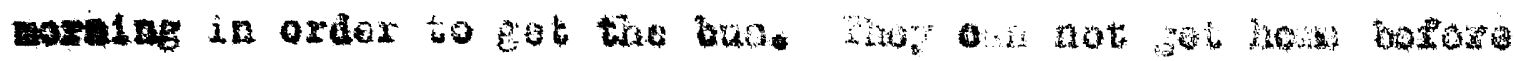

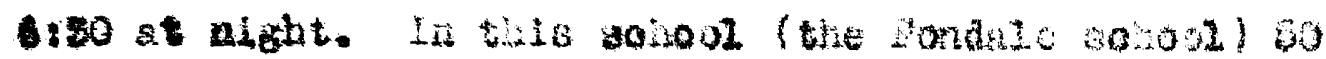

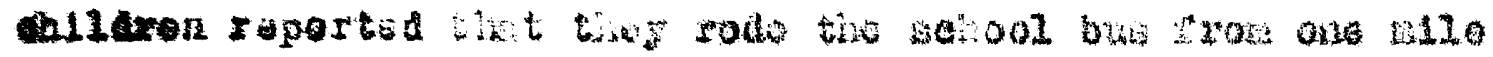

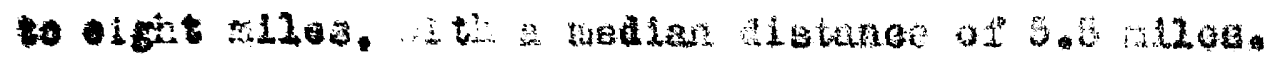

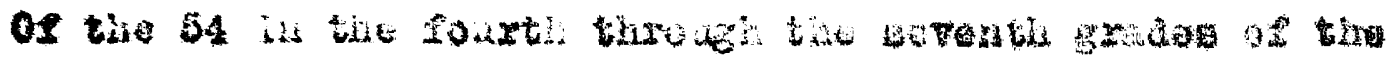

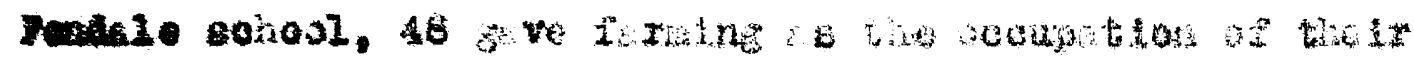

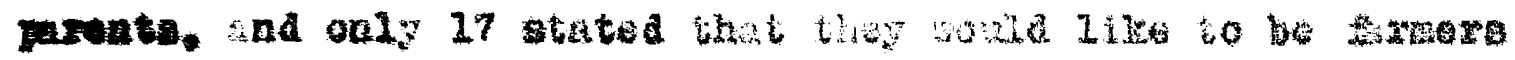
a to 11 ve in the country.

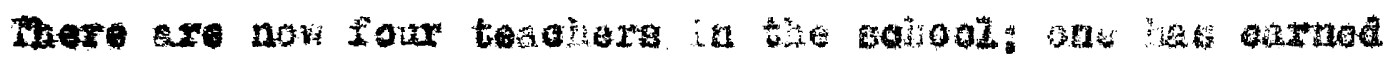

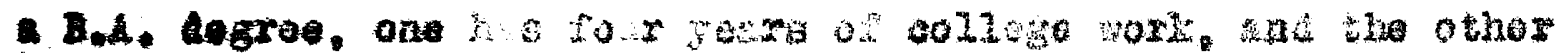

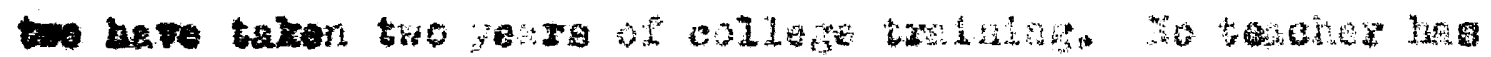

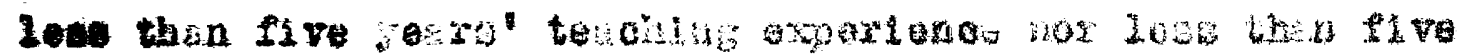

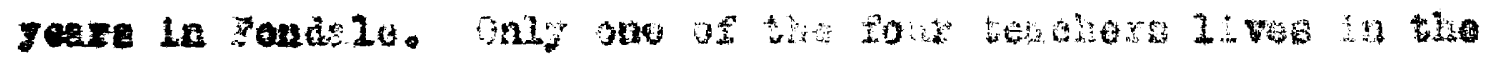

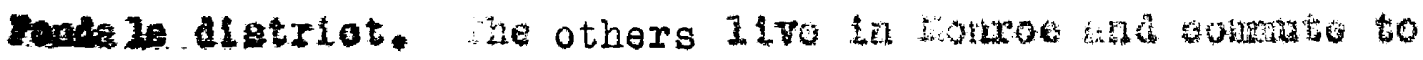

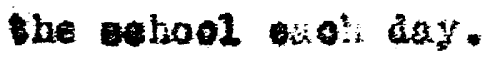

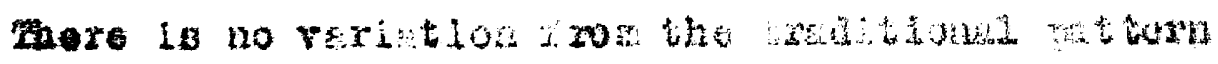

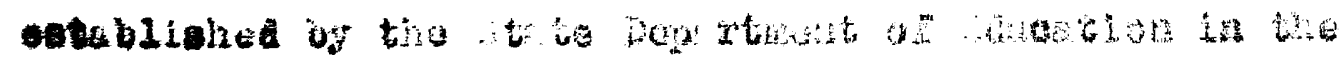
eubjects te

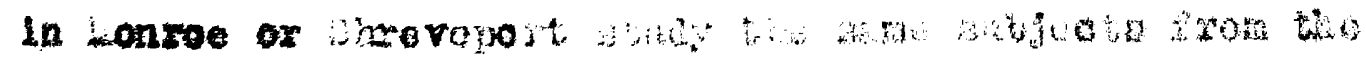

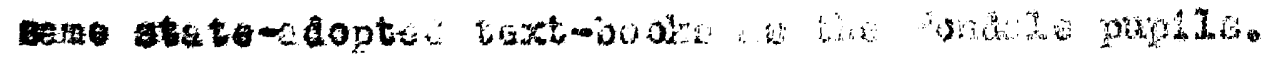

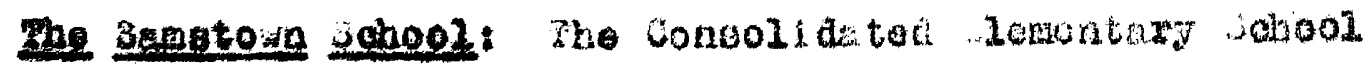

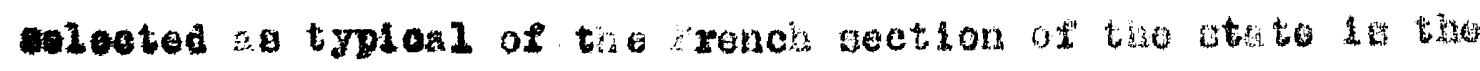

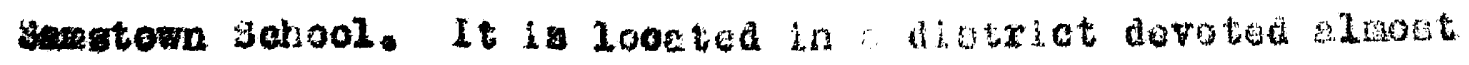




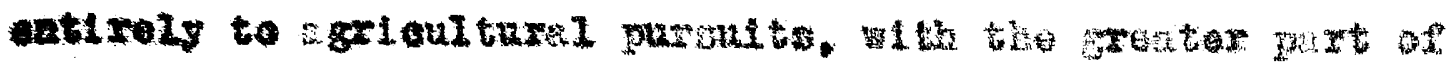

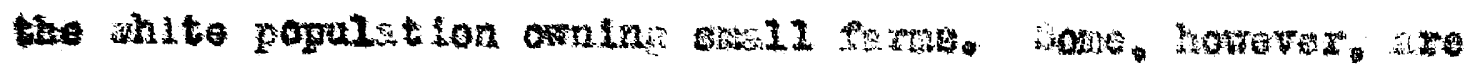

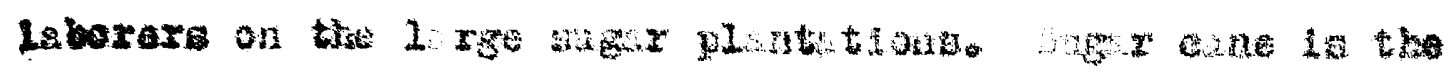

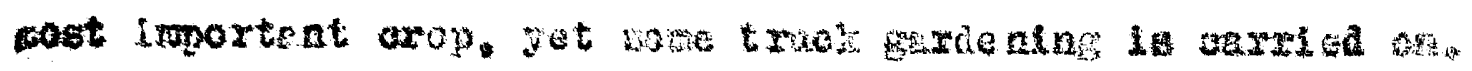

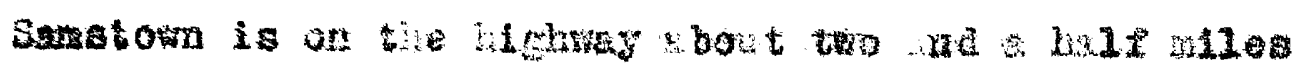

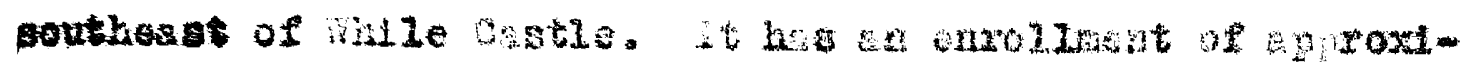

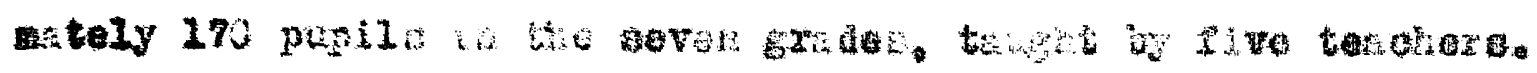

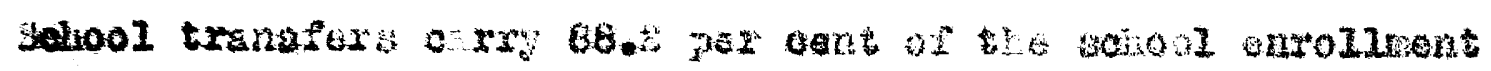

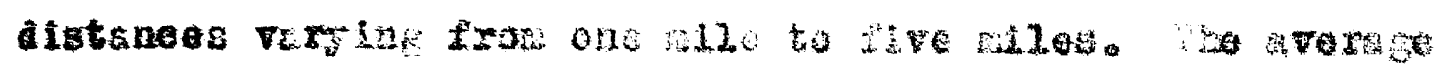

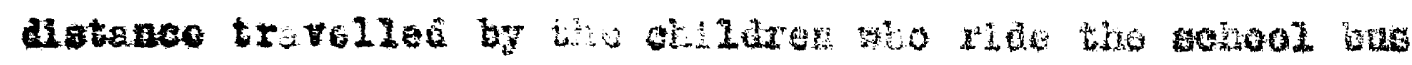

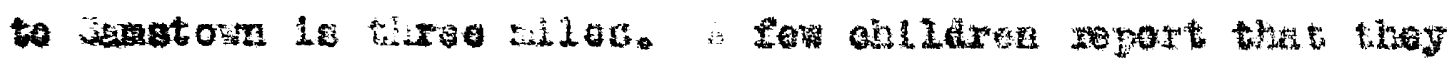

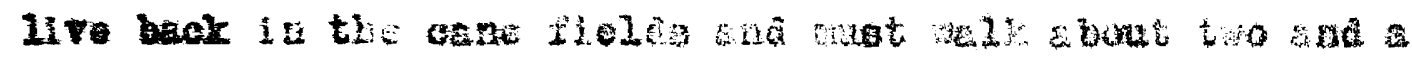

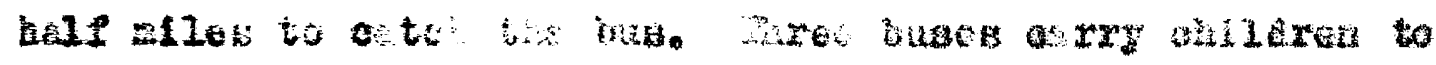

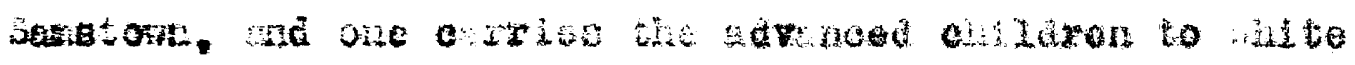

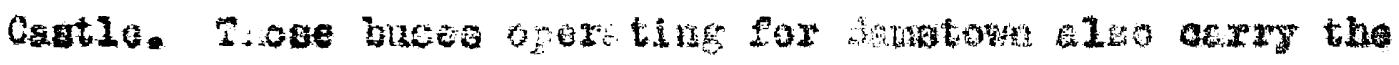

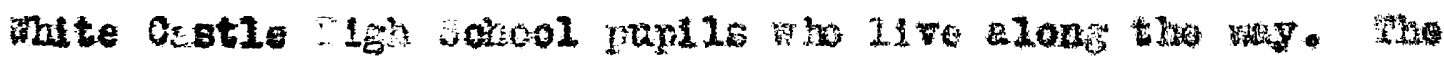
mite Cestio sehool opene at 8:45. Mra luses artive the re

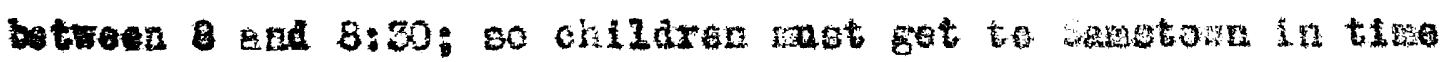
sor the bue to continue ta ints action or oourse, the

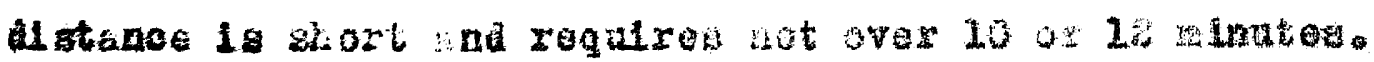

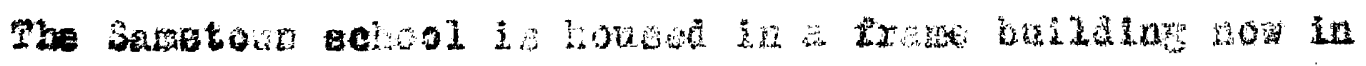

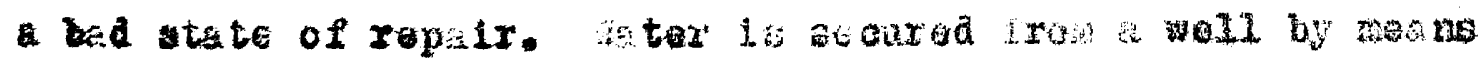

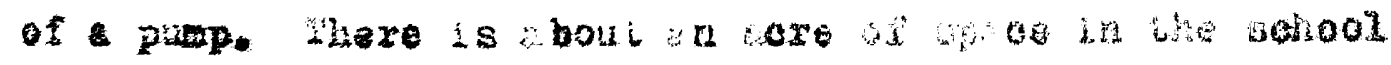

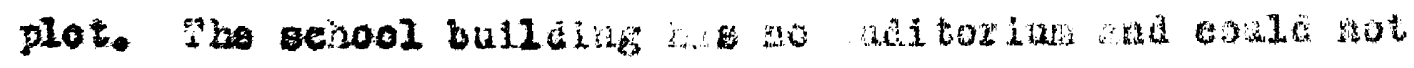

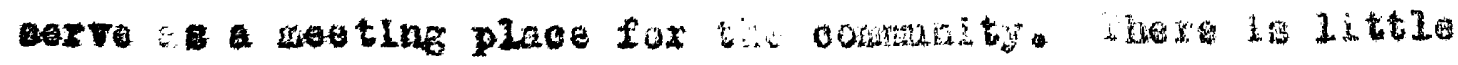

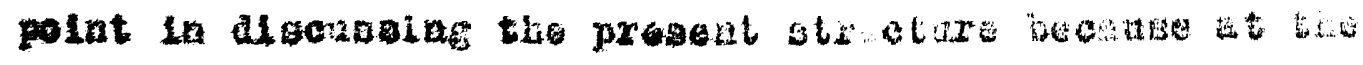

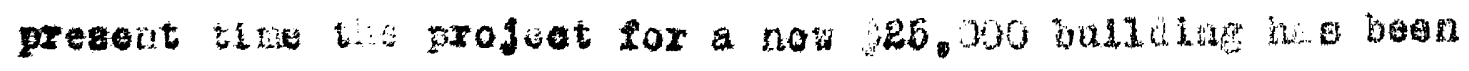

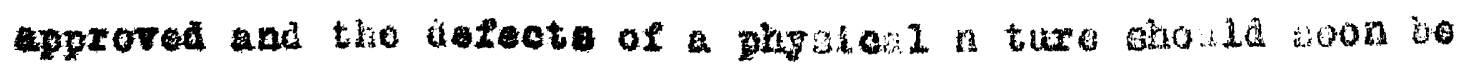
comroted. 


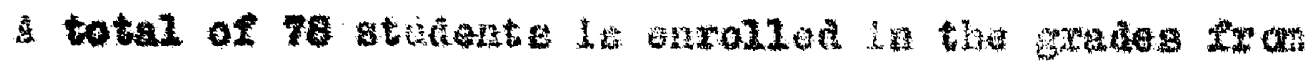

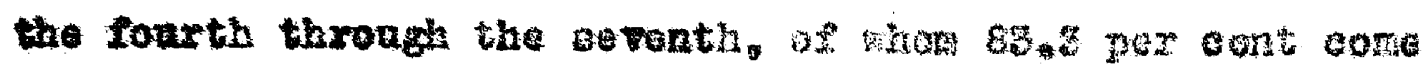

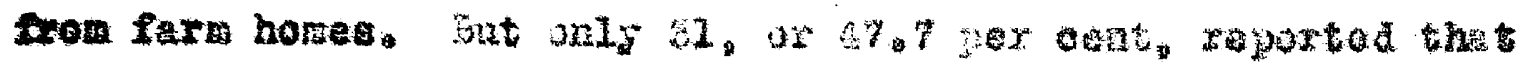

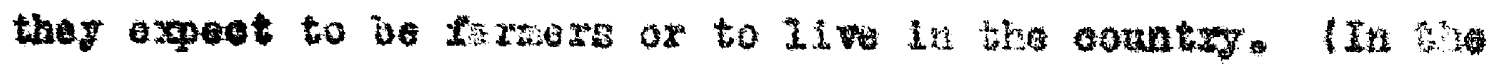

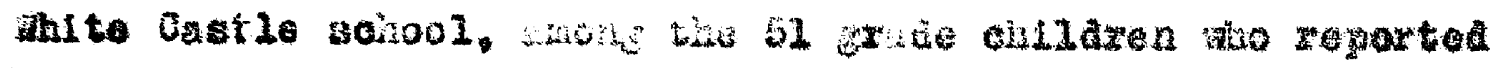
the farming ic toolr prant pocuption. 23. or 4t. 1 por

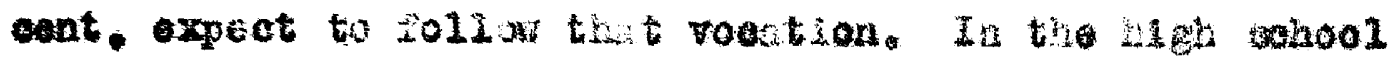

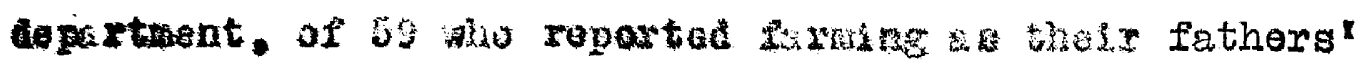

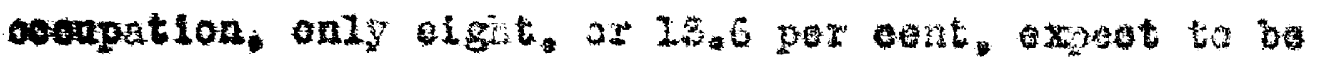
(n)were)

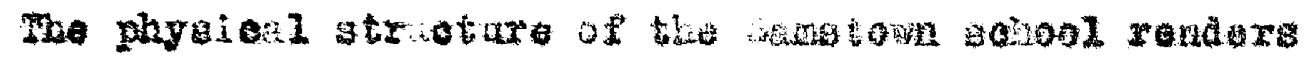

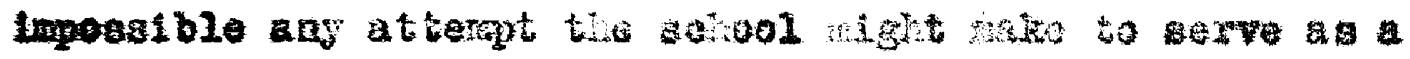

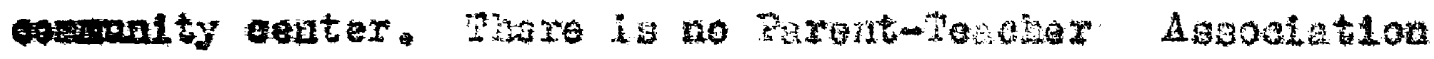

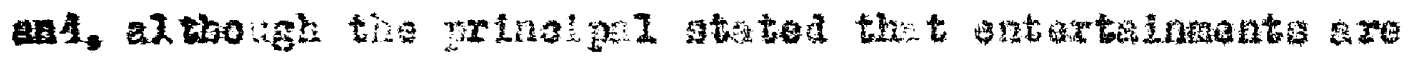

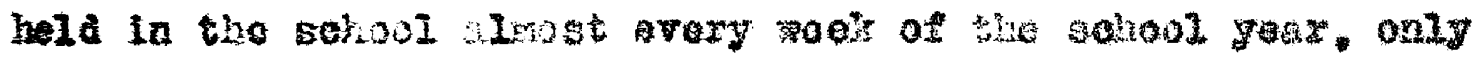
three out of 78 pupilis reported the thalr pronta had Inted the sohon this Fot. In reply to the quation regarains stend noo at sohool catertelnouts on the pert of

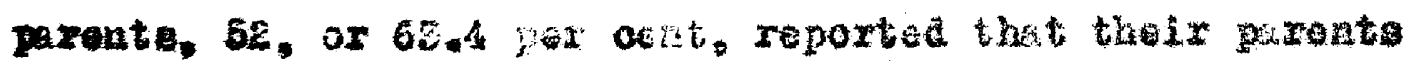

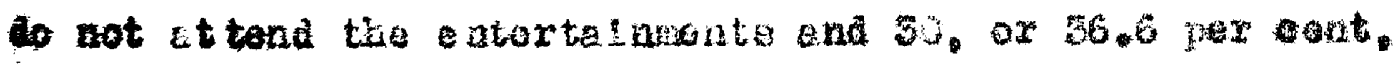
reportea st terésnoe.

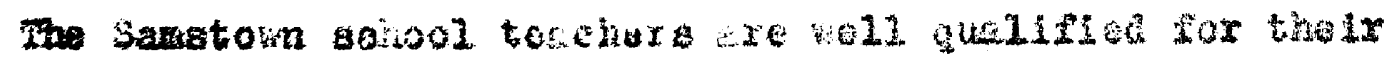

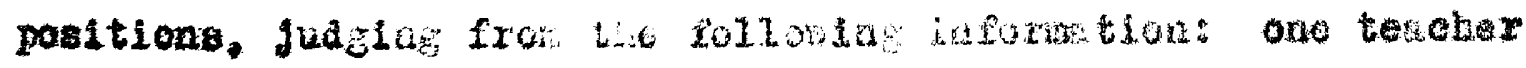

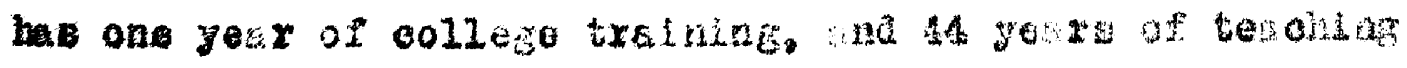
oxperiener. 17 of which have boon in the Samstow School; throe

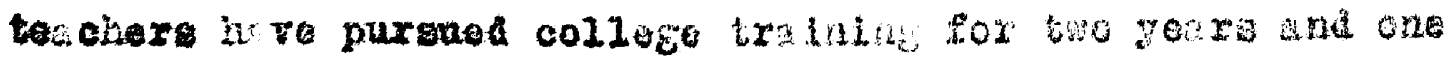




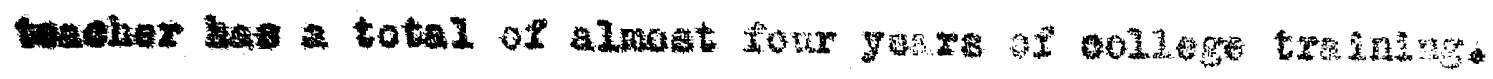

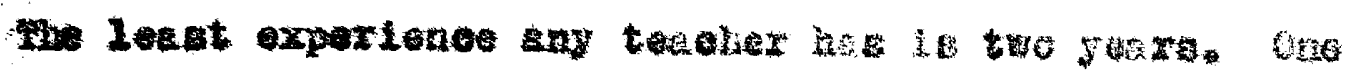

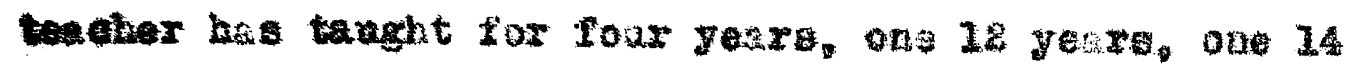

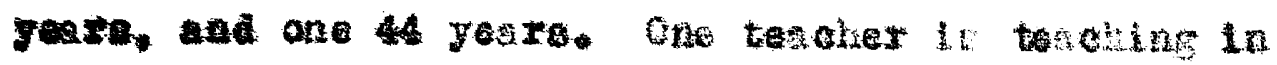

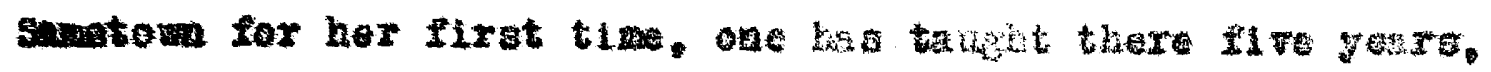

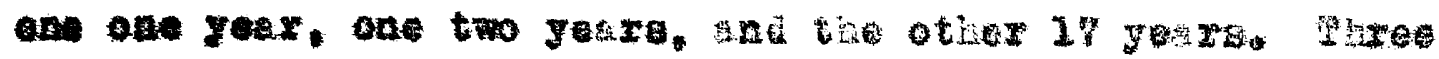

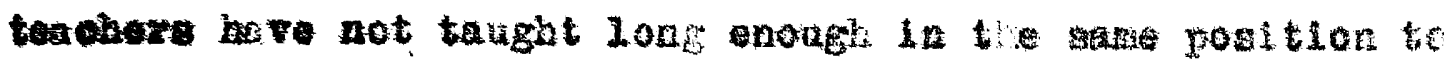

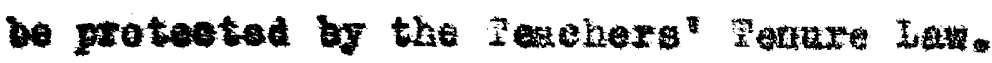

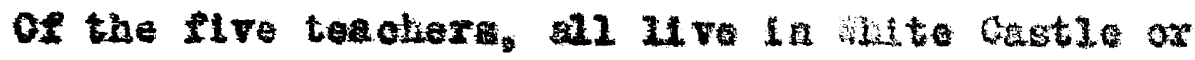

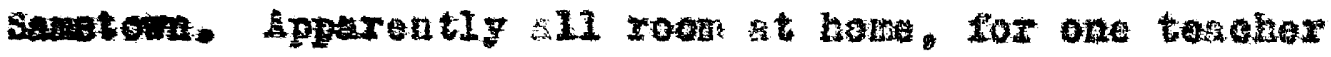

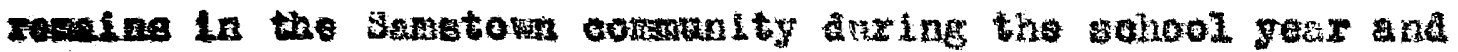
lour atay in waite Csotile.

Section $B$

Felghborhood selools

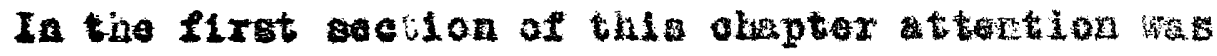

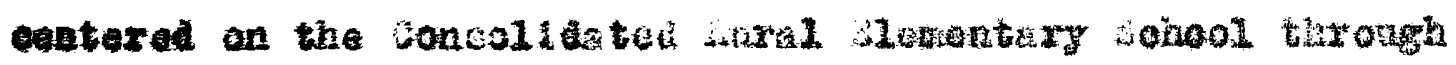

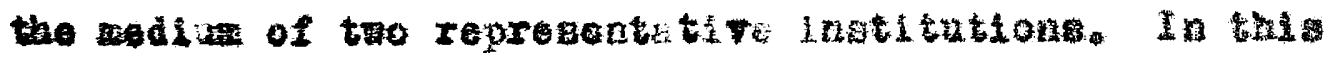

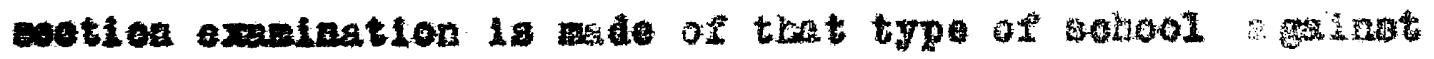

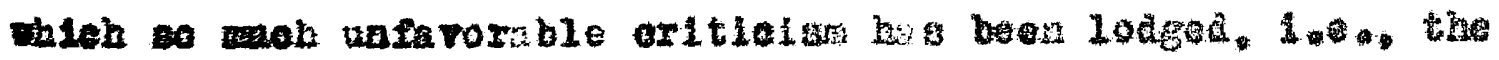

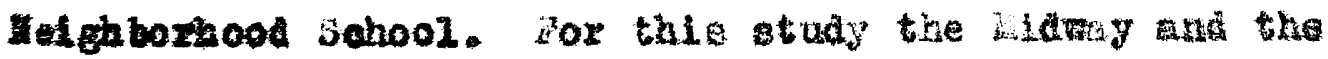

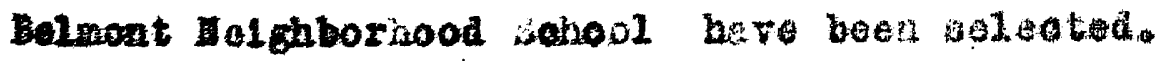

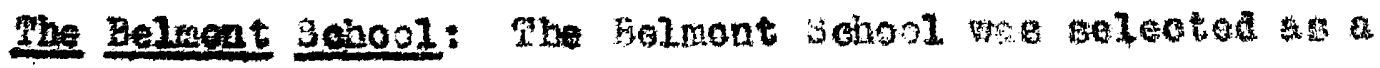

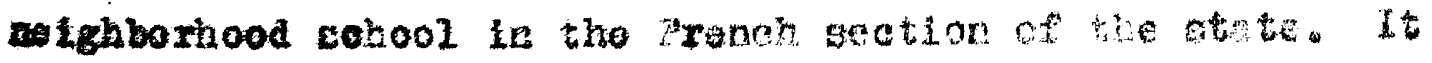

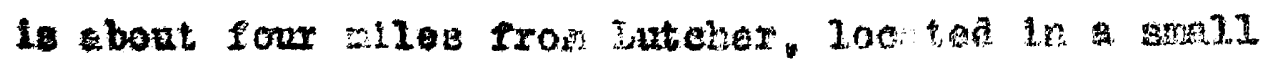




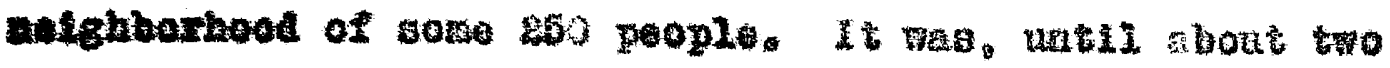

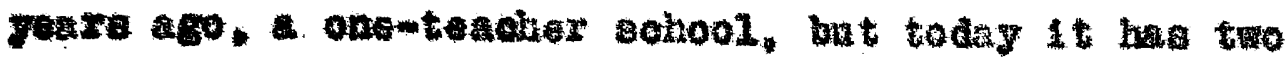

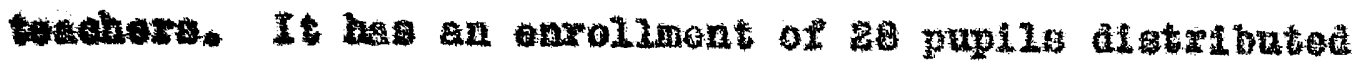

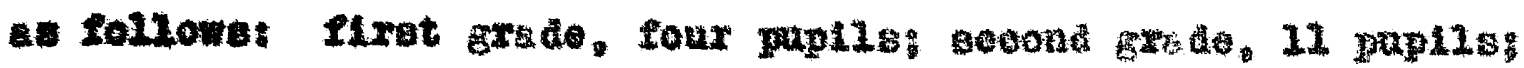

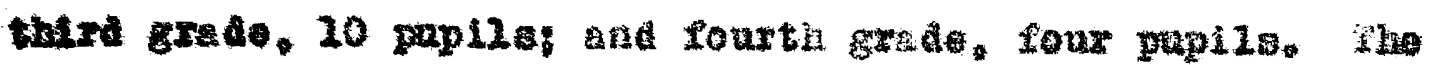

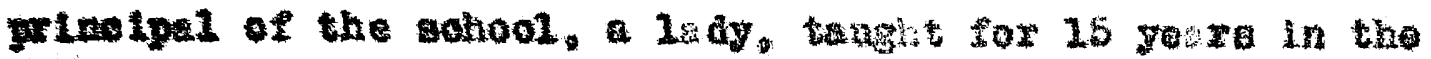

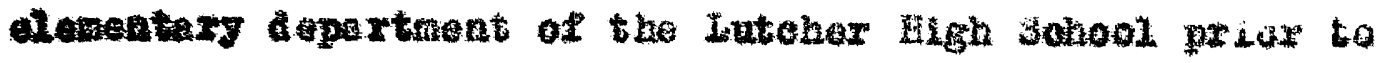

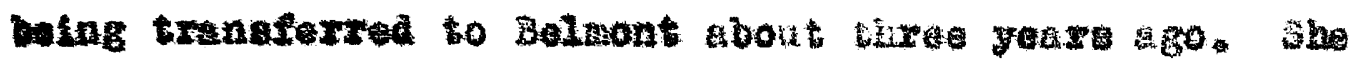

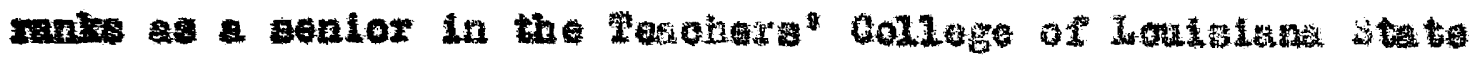

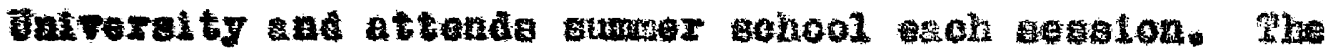

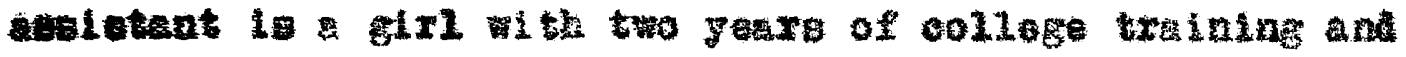

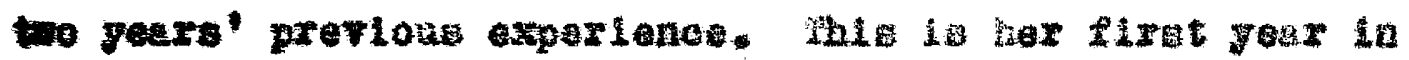
Balnans:

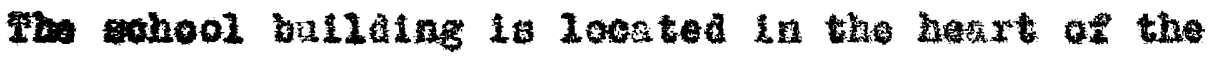

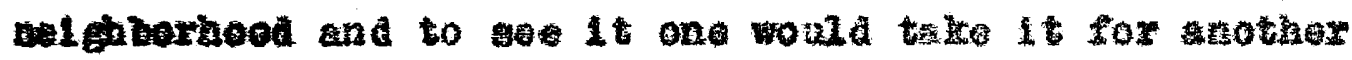

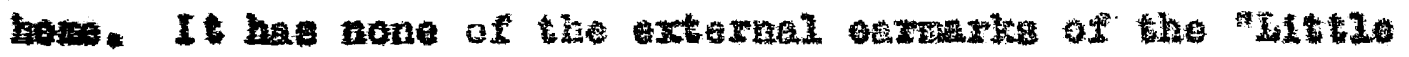

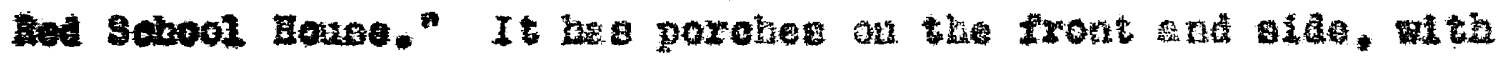

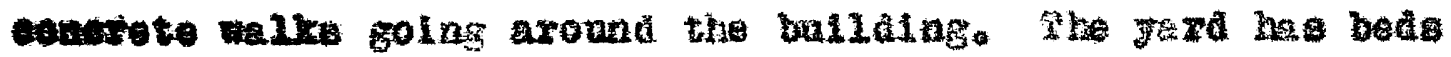

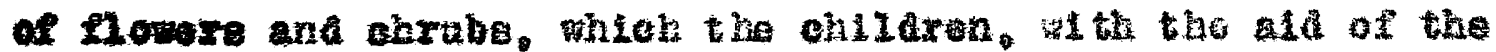

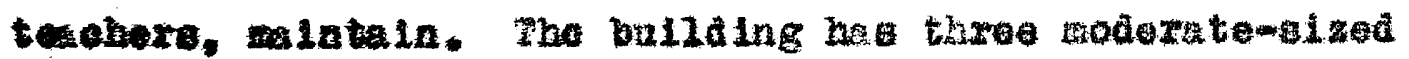

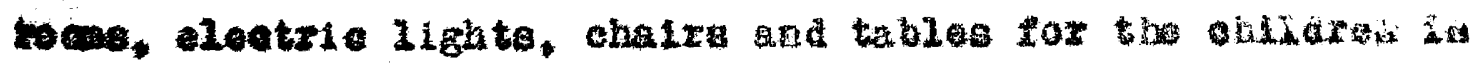

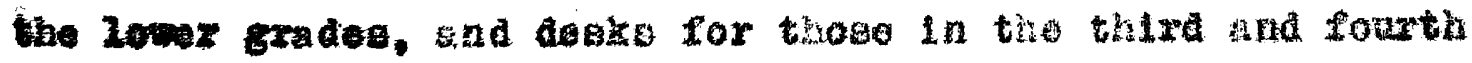

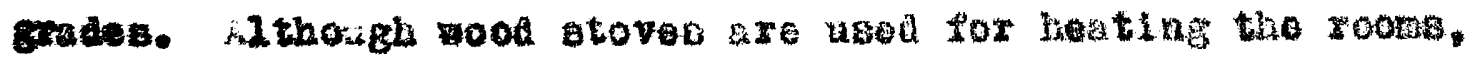

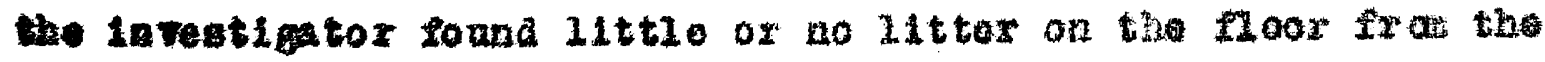

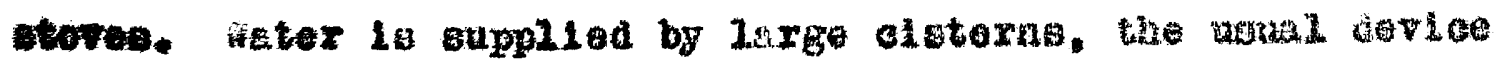

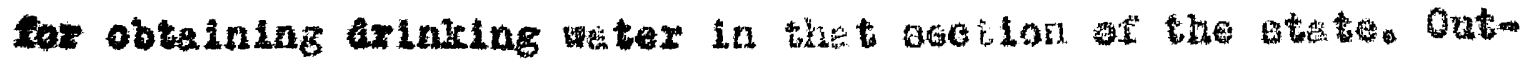

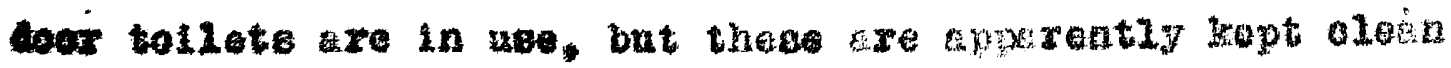


ant nattar.

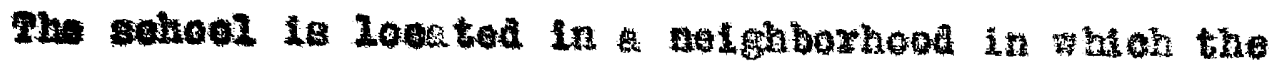

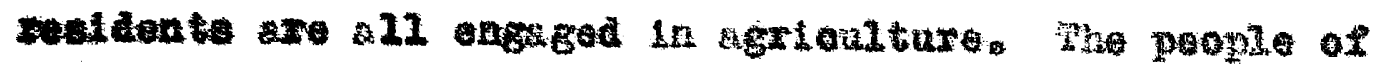

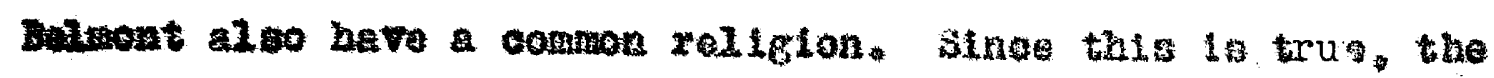

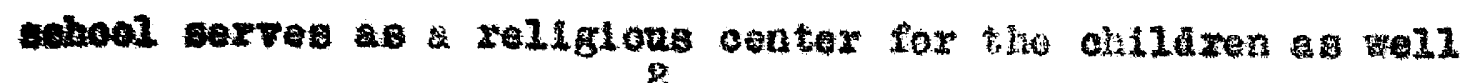
se eanter tox educat lon.

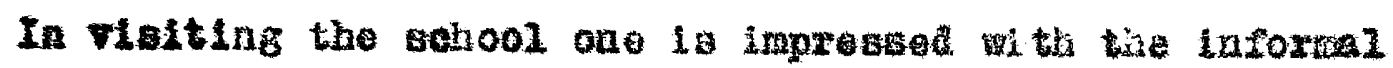
als atoting thore. It his tore the twoghere of a hore then af ablic inatitution.

The achool gechs to ware a real neighborhood canter.

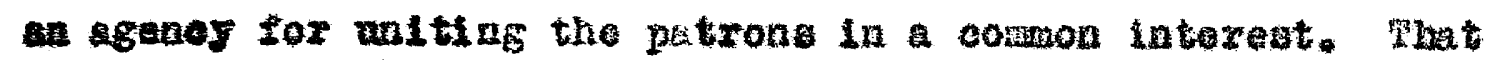

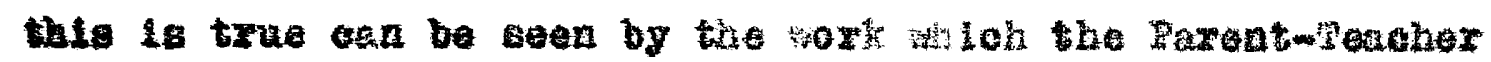

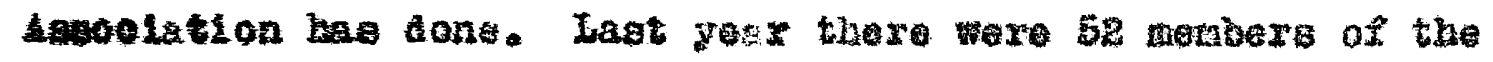

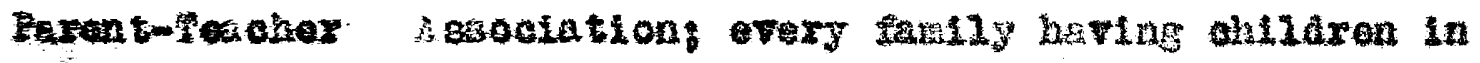

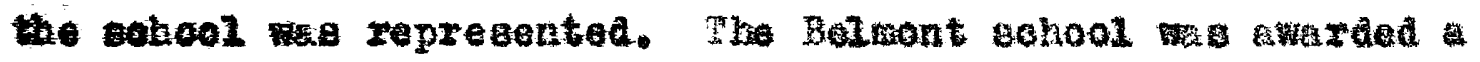

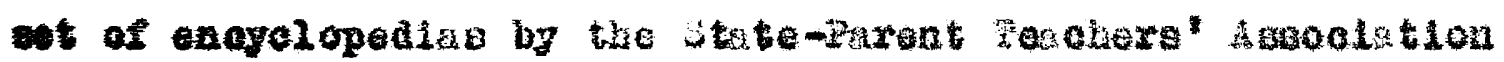

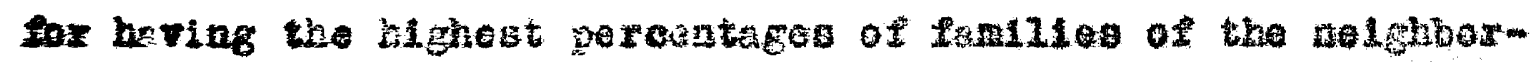

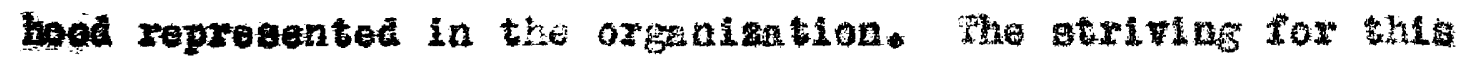
mete served to araw the sothol prond together.

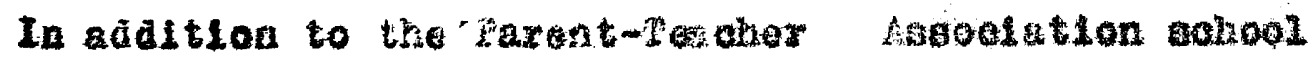

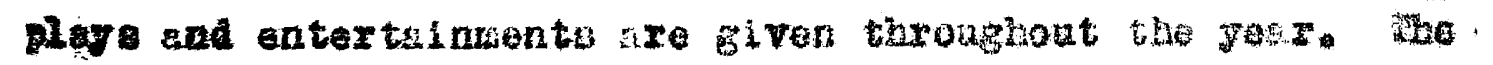

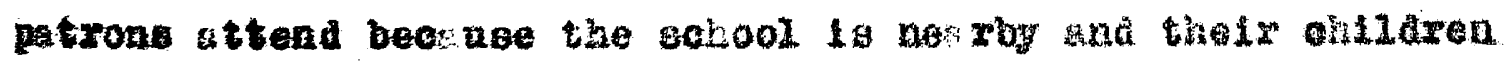
tare part. uther activitieg centering in the wolool tro

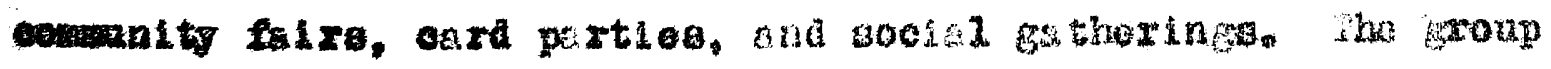

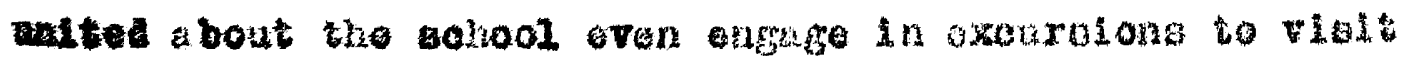

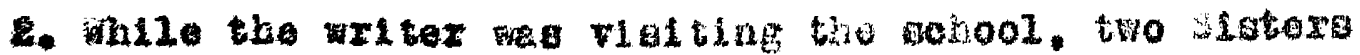

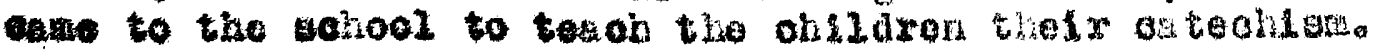




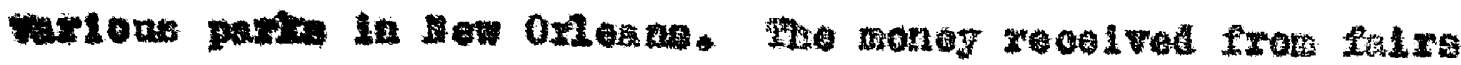
and other eatertalnuente. Glven at the sohool ha been agot to

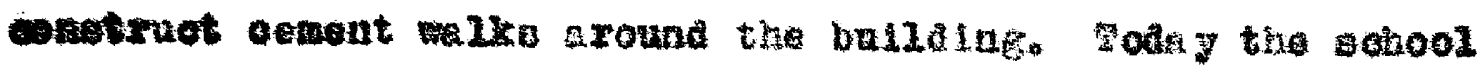

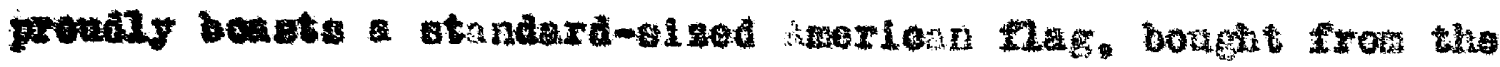
peweeds of a party given at the grohool.

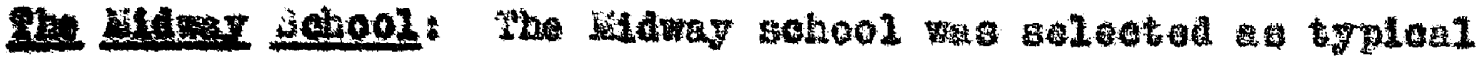
20: the Trankilo Pariah in horth Loulgiana in strictly ruxal

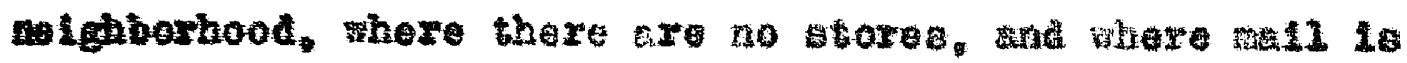

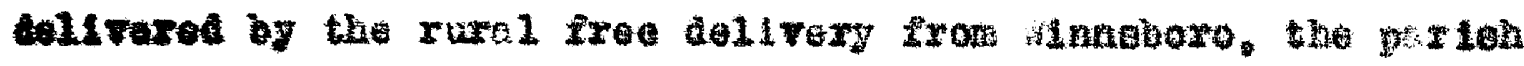
beat. Satarally the poonhe of the nel ghborhood axe bound to tinnsboro by soonorio neceasity.

The sobool is a three-torcher sohool, with a arage

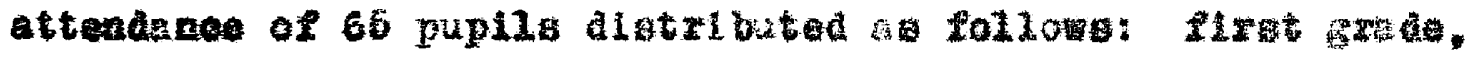
nive; thera grade, geven; fourth prode, 23; fifth grode. 12 ; axth grade, 10; nd serenth gride, ofx. ill tho ohlidrun

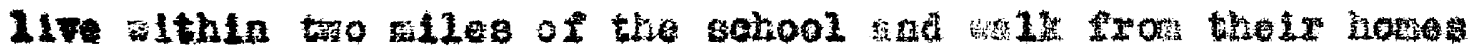
to vechol.

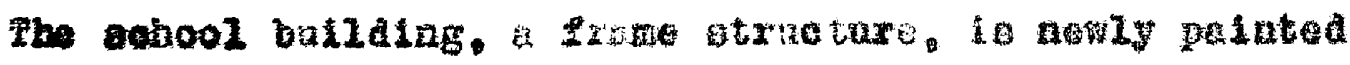

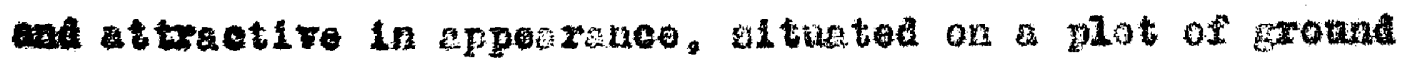

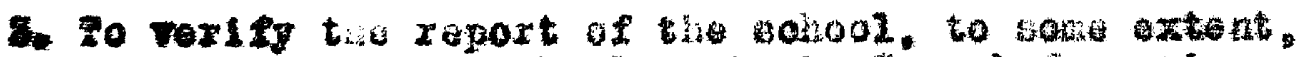

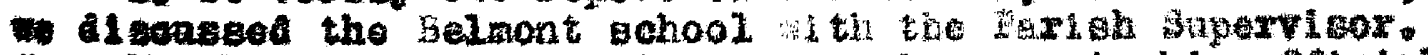

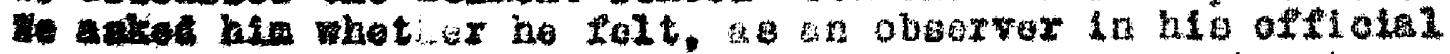

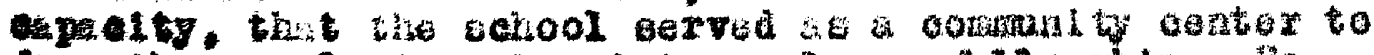

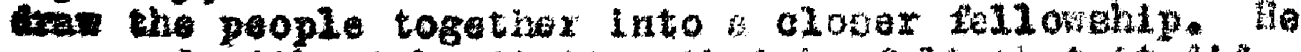

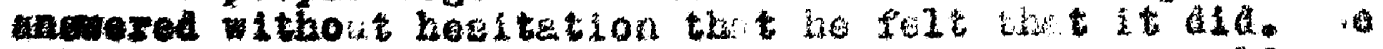

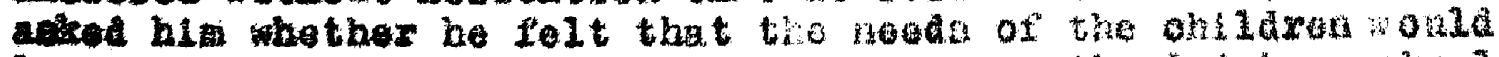

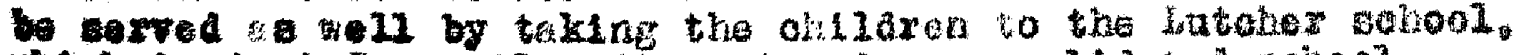

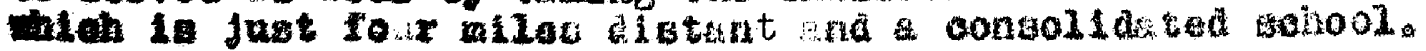

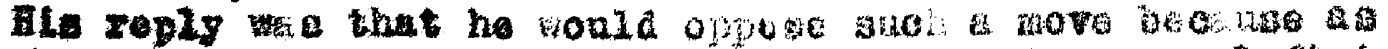

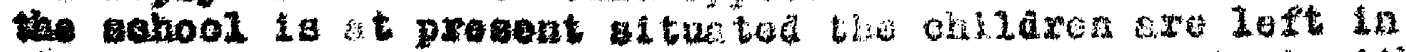

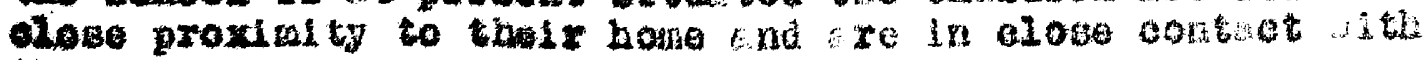
thele pirentw. 


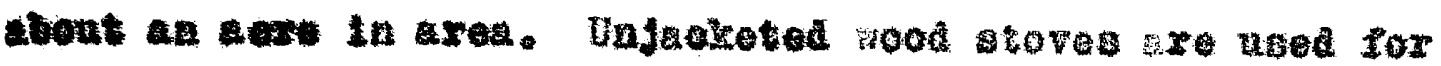

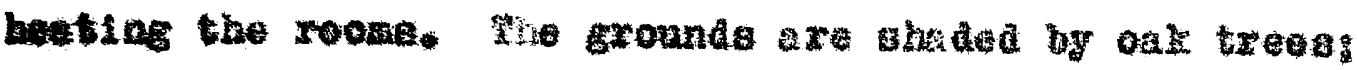

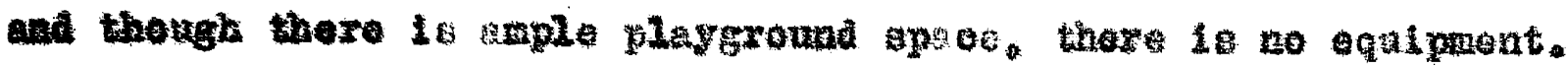

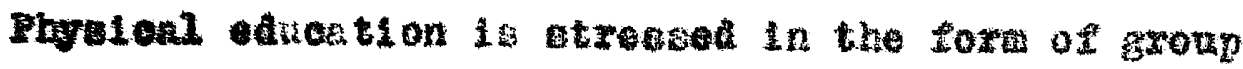

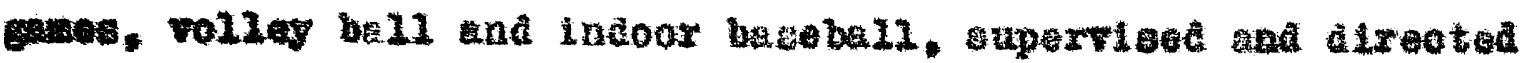

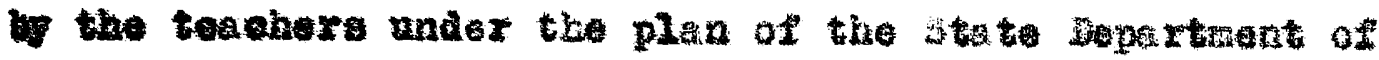
rtanean.

The ocenption of the prente of 44 out of 46 of the

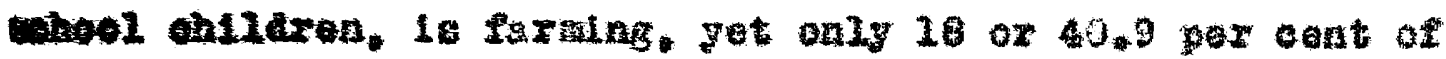

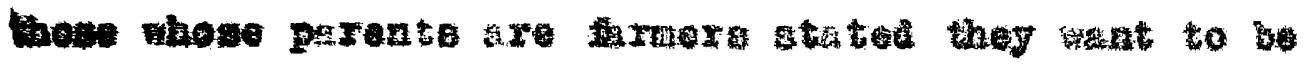

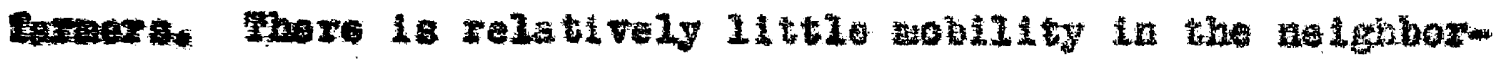
bode oniy 28 of the 46 ahliarea reported that they had over attanded ang otior Bohool.

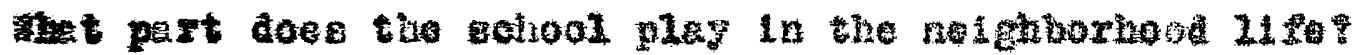

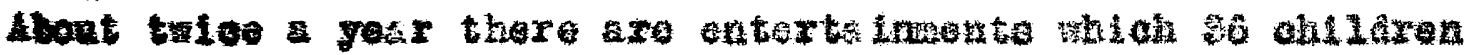
oteted thoir parents satend, and rine roported the the

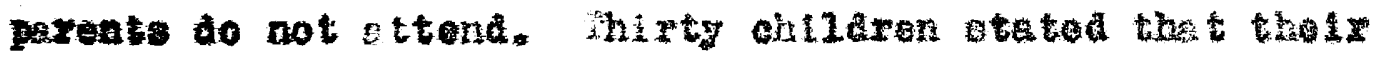

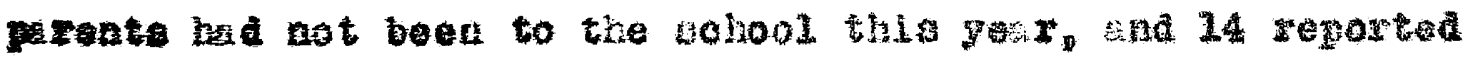

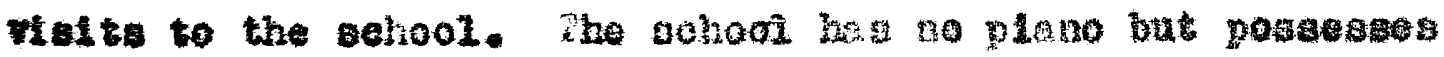

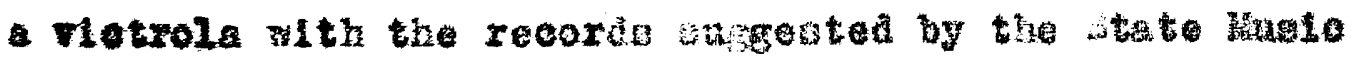

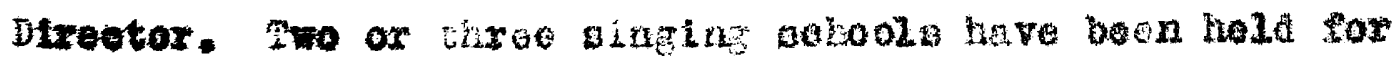

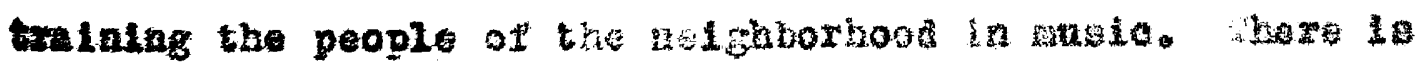

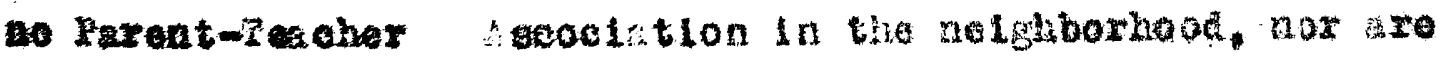

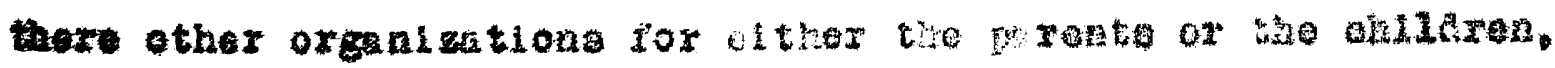
In which the arool batay ptort. coording to the gehool

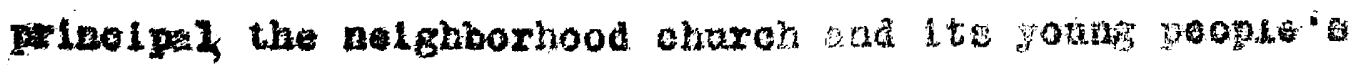

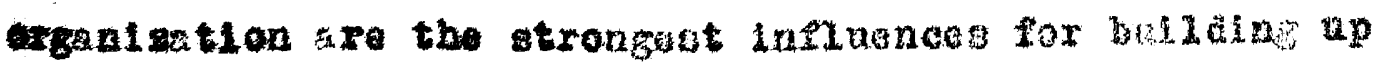

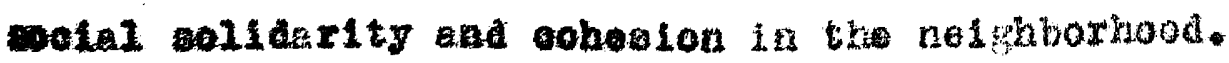


A studs of the gualinertions of the terohars phowed

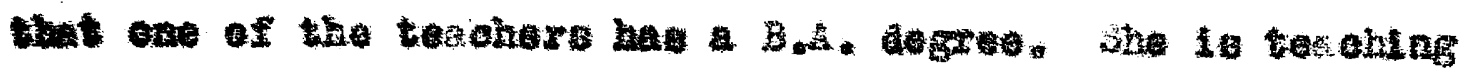

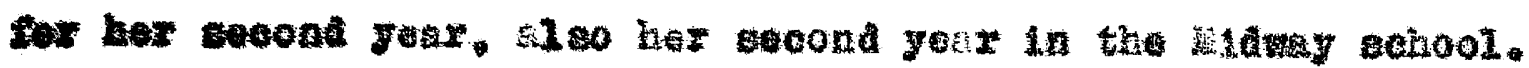

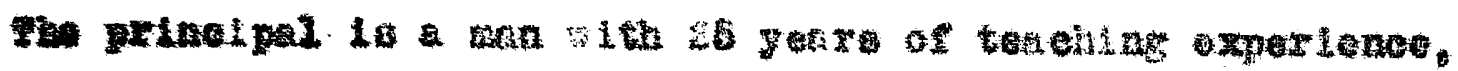

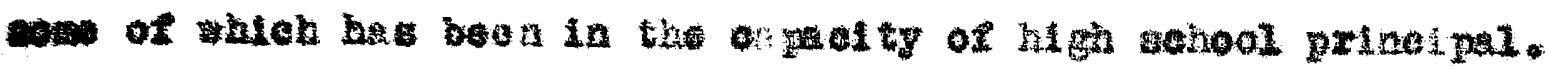

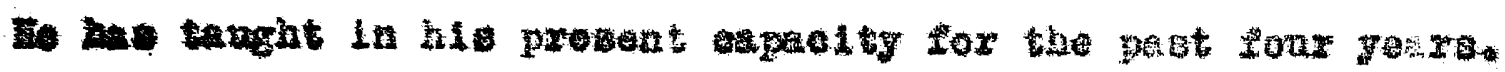

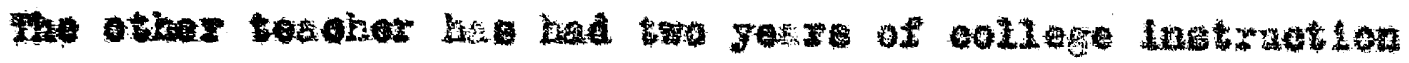

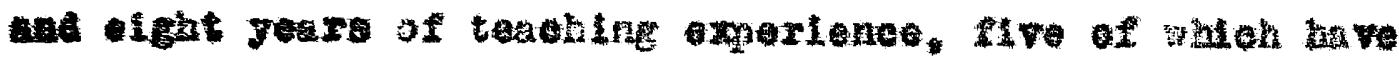

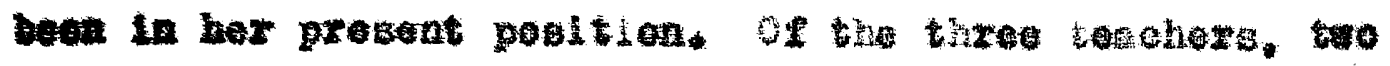

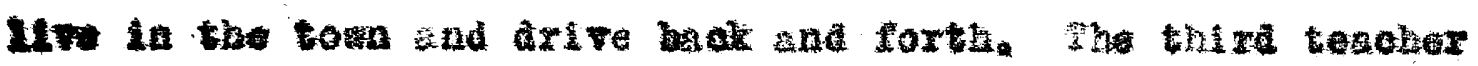

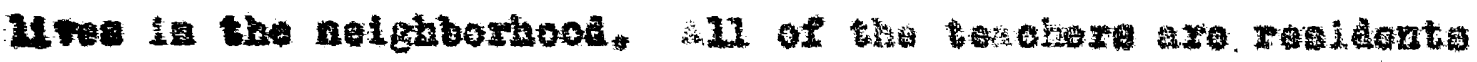
of the pariab in whteh thay re omployed.

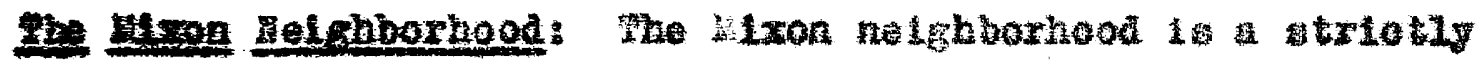

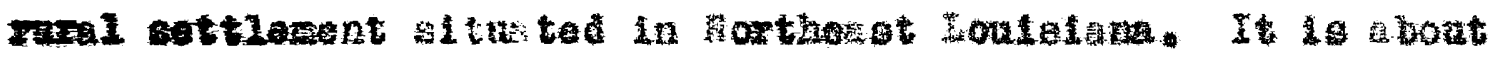

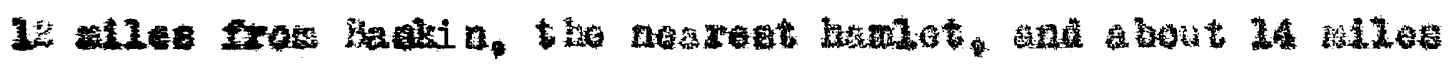
toner.

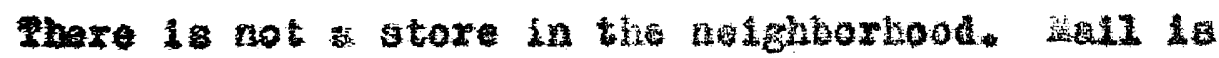

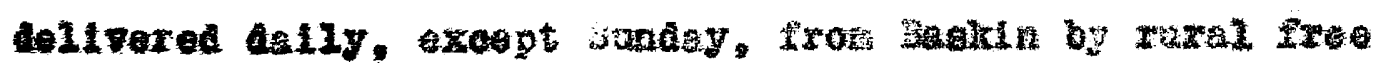

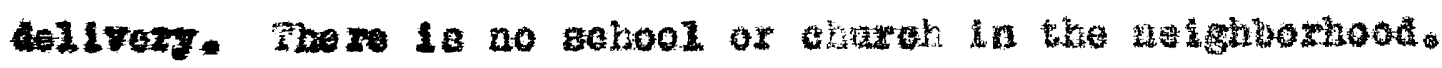

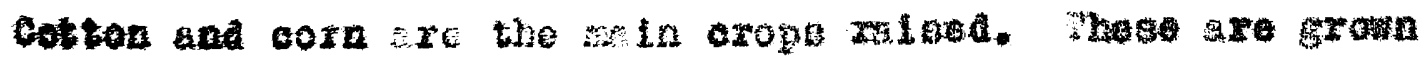
by farer of tise finte croppor or tenent olsae.

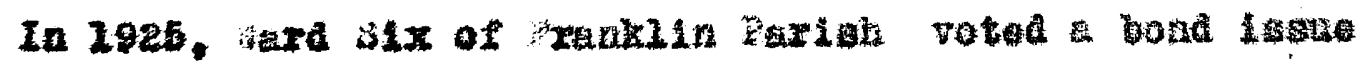

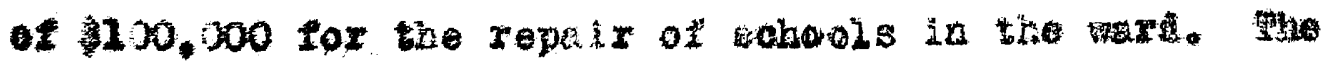

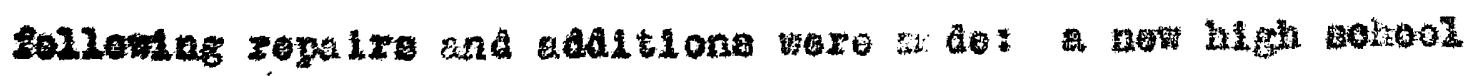
batlding controtod at akin, and the eld bulldag as

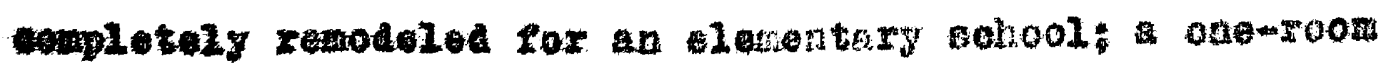
chool was balt at chrell, north of Beakin; another one-room 


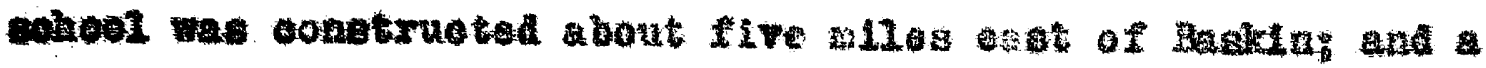

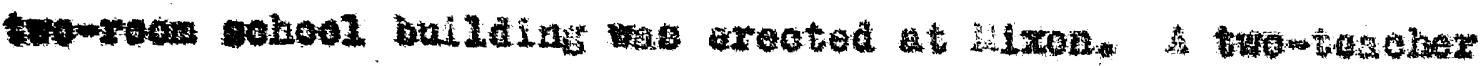

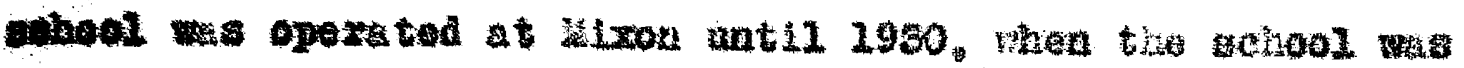
areed and the ohildren transported by bus the 12 miles to the

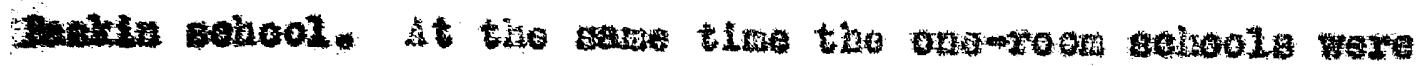
Gead and the chllaren trangportod to Bakin.

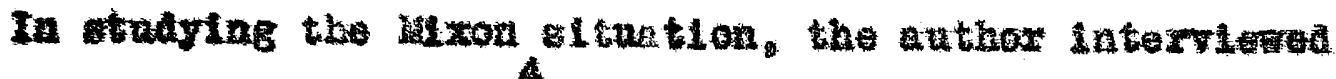
De perien suporintendent. Fe la the prior to the con-

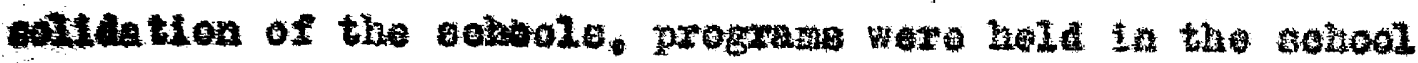

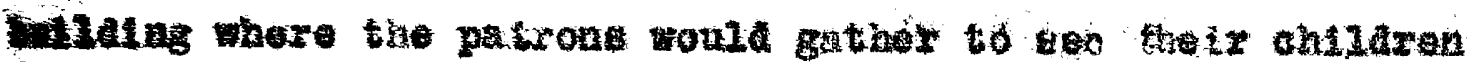

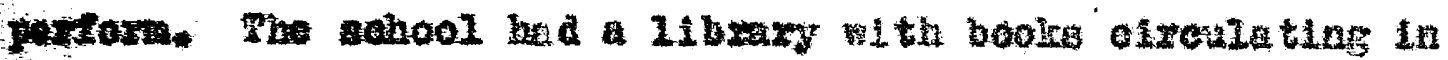

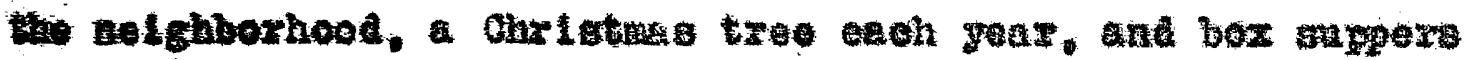

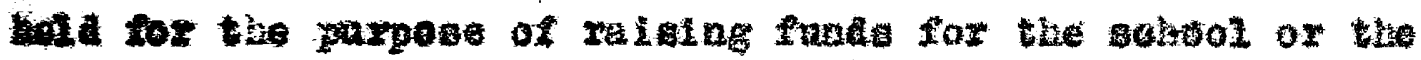

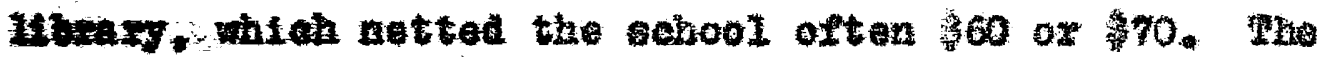

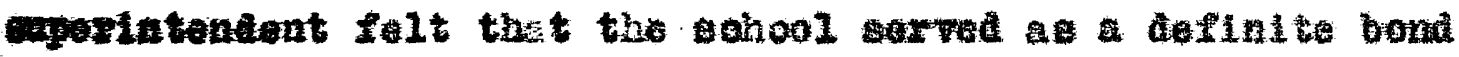
to bin the peogl of the nelghborkood together.

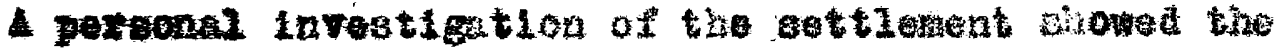

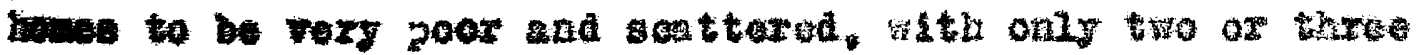

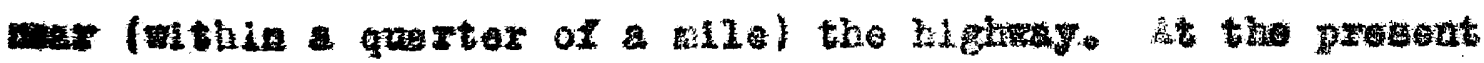

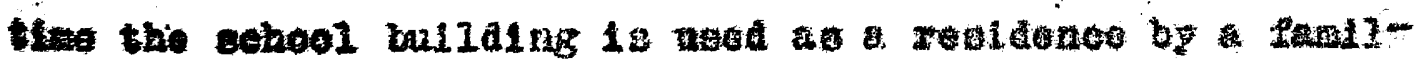

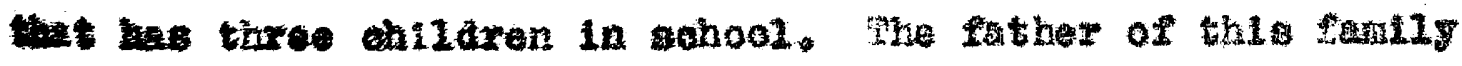

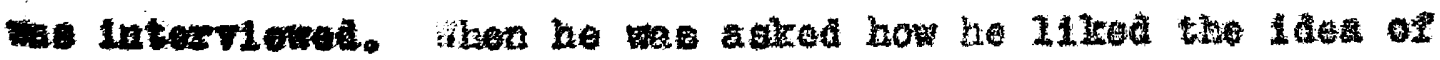

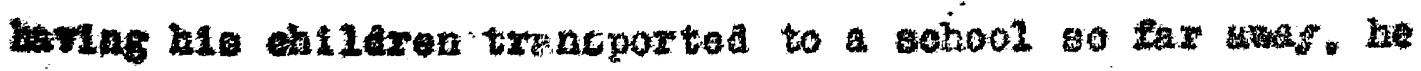
wie that he thought it was all right. thic stan had noved

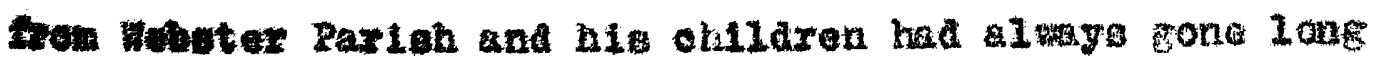

4. The prebent enporintendant is the wat who, serving 1

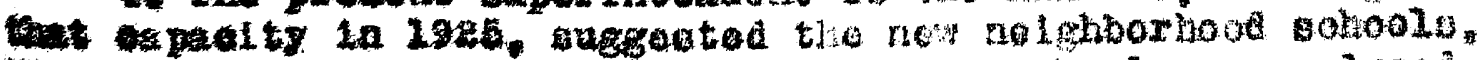

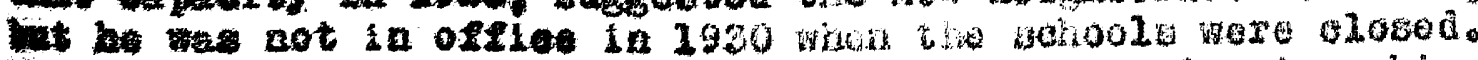

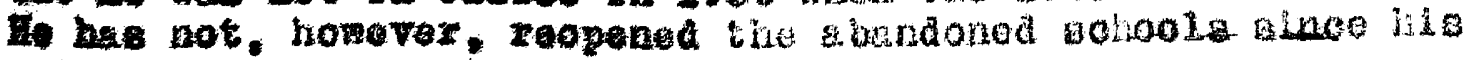
rotiars to tivo superintendenoy. 


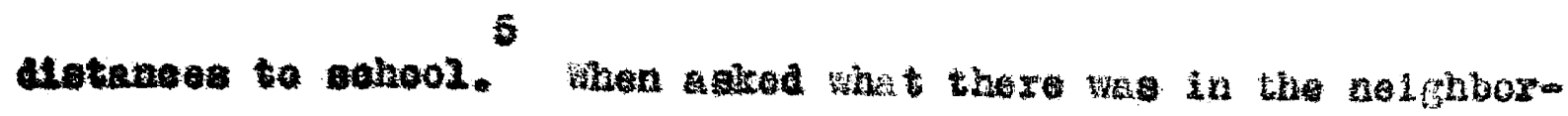

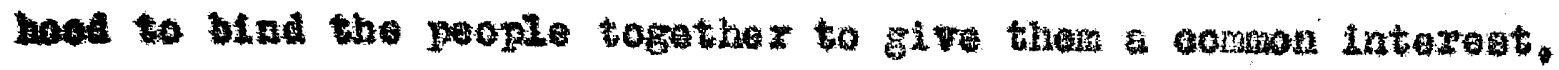

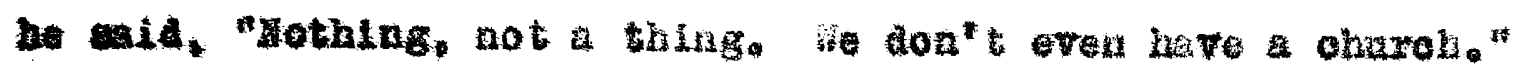

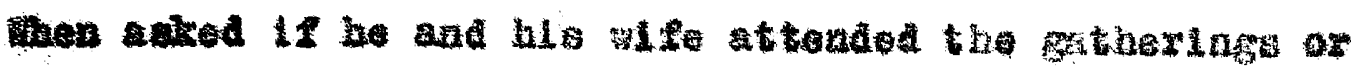

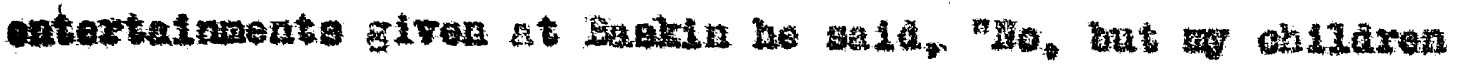
40."

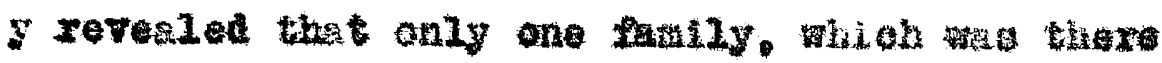

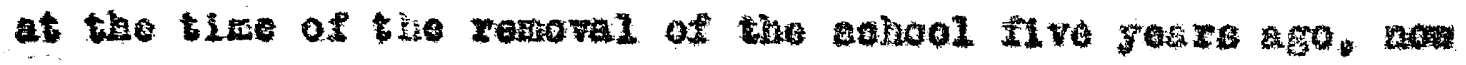
Irve in the nesghoorhood.

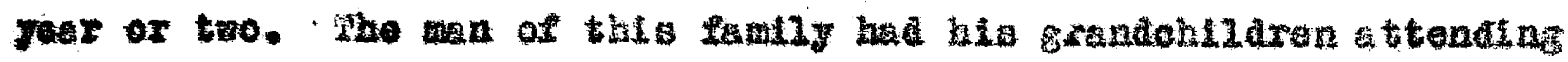

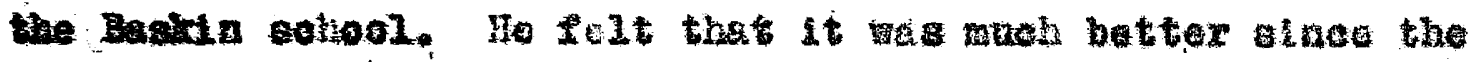
quanlastion than befora, becaus before when tho chllaren

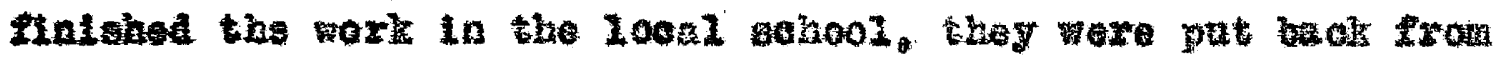

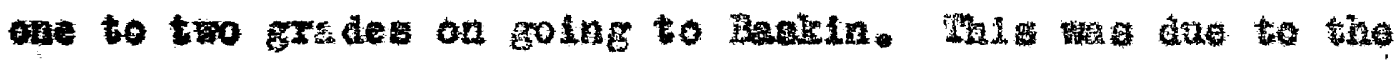

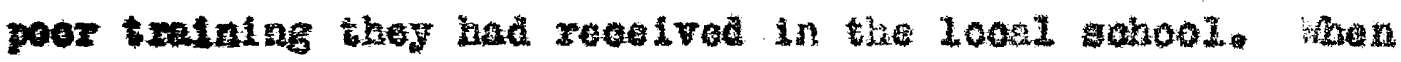

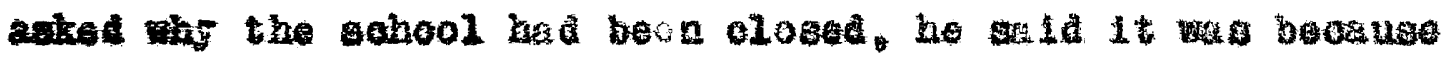

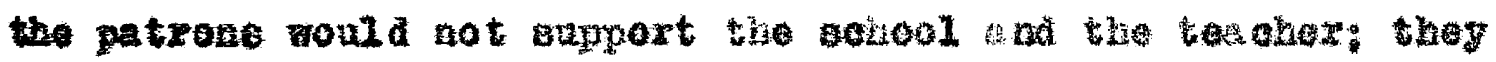

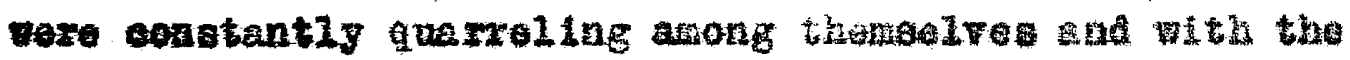

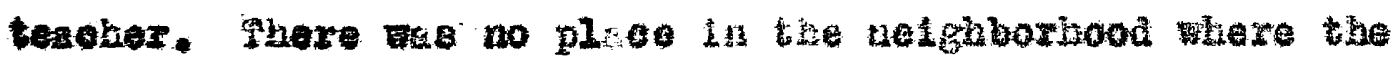

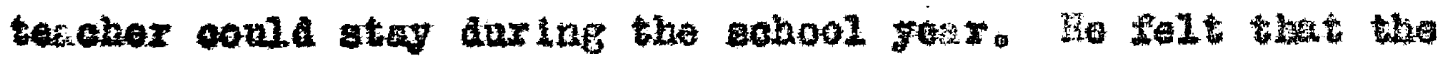
patrone gonarally aproted the oondolld ton.

In orbex to get to the sebool, the chidron rom tha

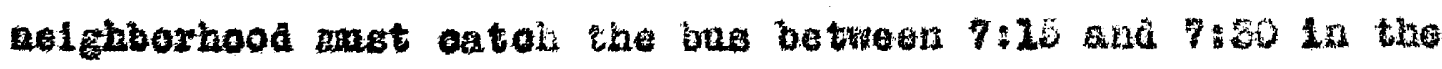

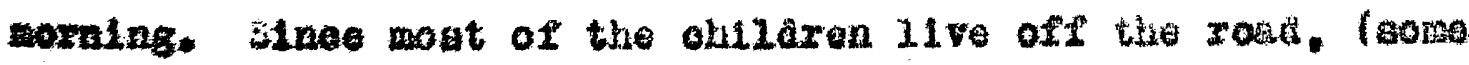

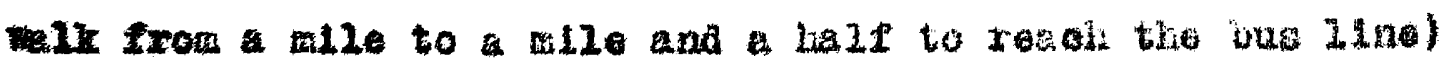

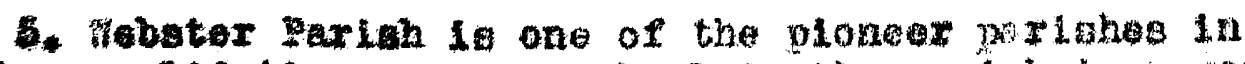

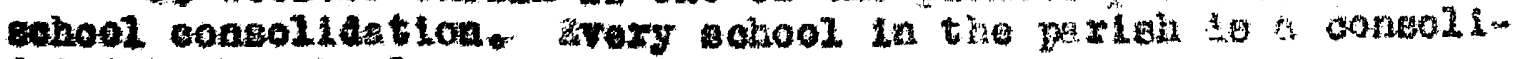
ctued high sehool. 
In the vinter thoy wet letse howe before daylight and do

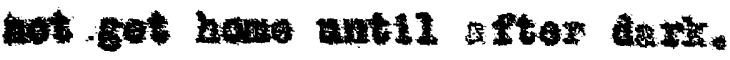

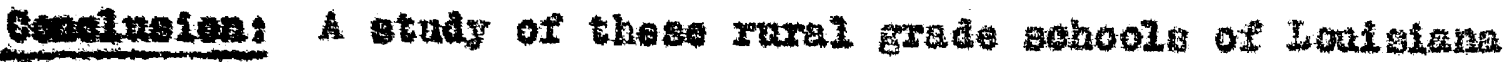

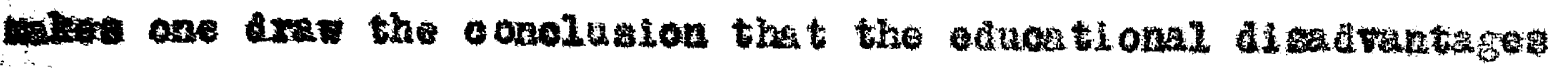

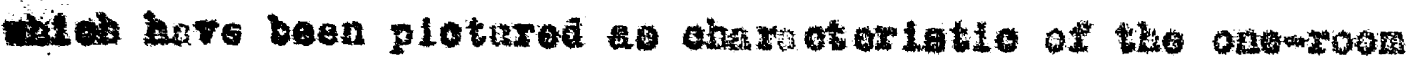

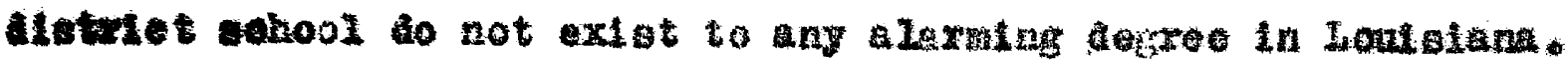

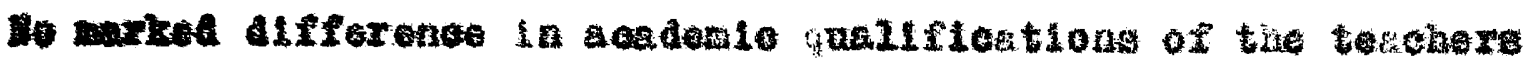

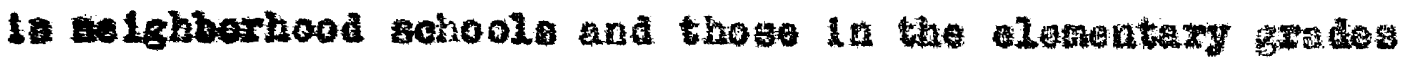

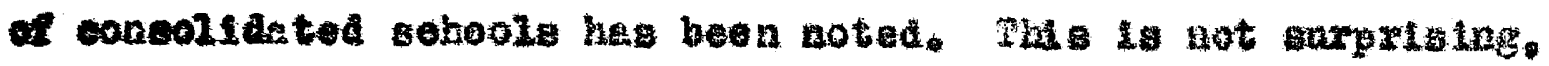

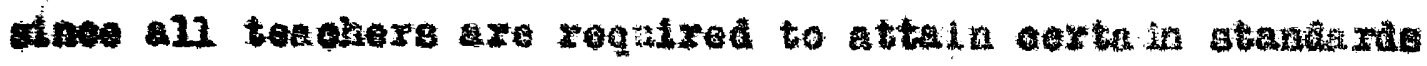

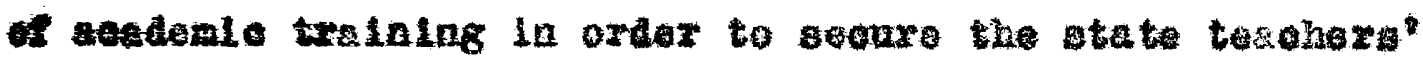

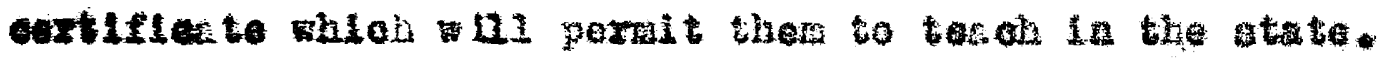
For aro the rumi grede tezchers inezperienead. In tret,

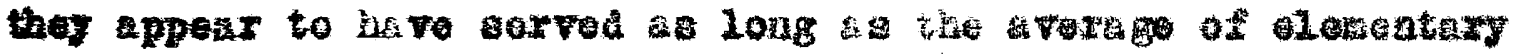

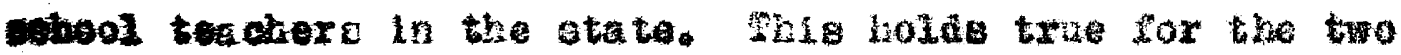

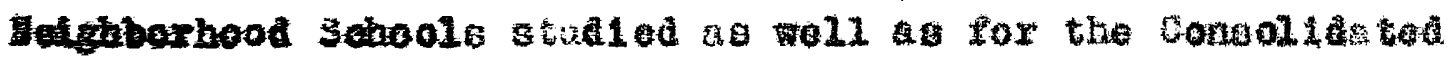

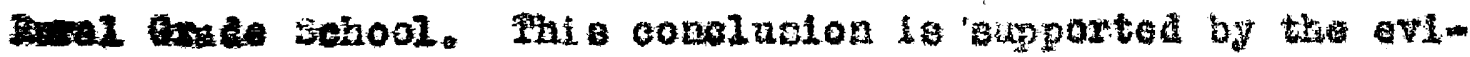

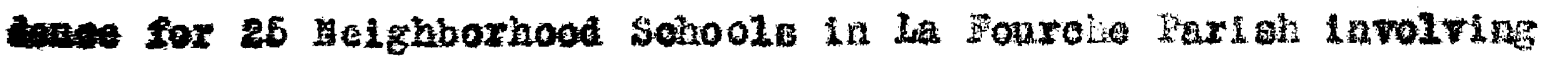

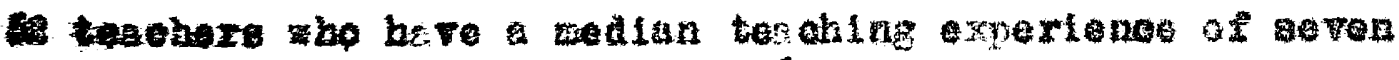
6 reare prior to the etrrent year.

It has also ben contended that the teucher tonure ls

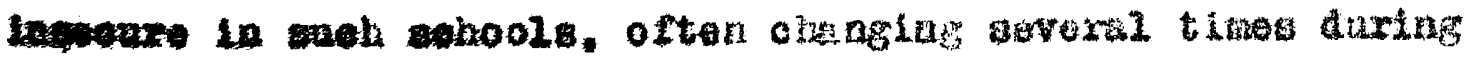

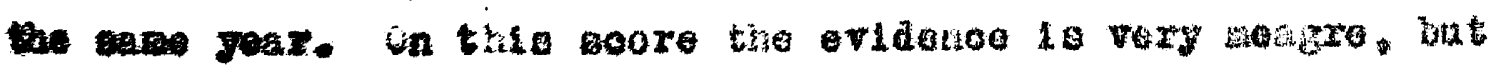

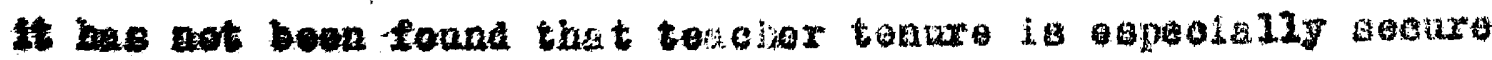

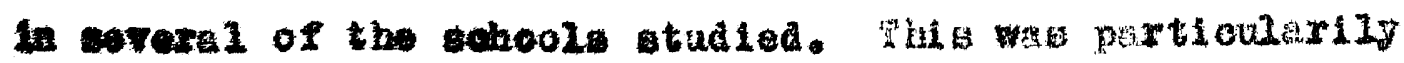

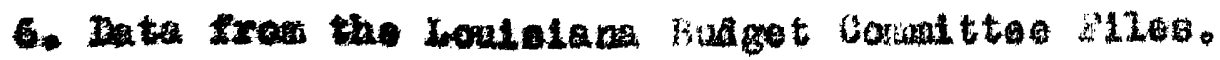




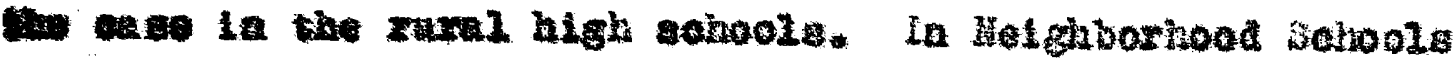

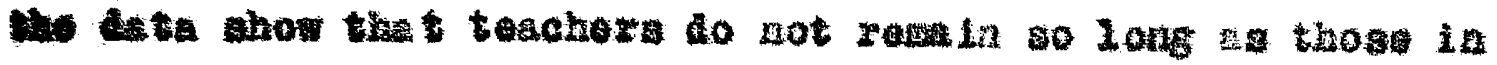

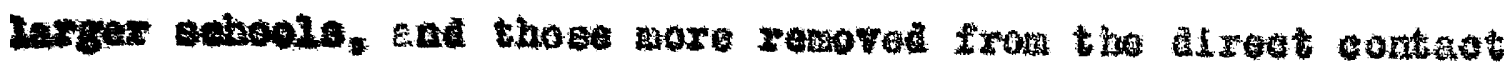

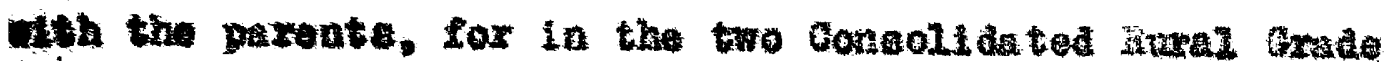

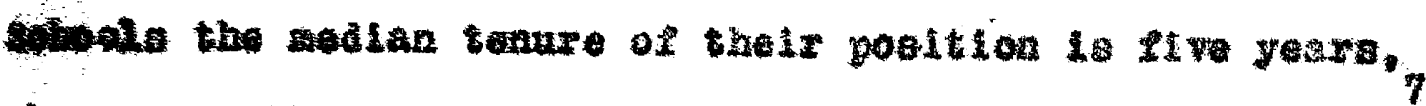

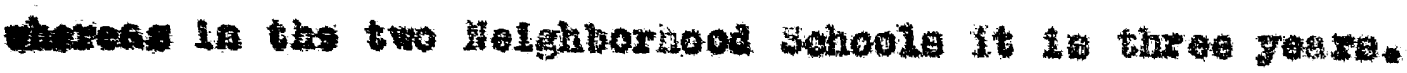

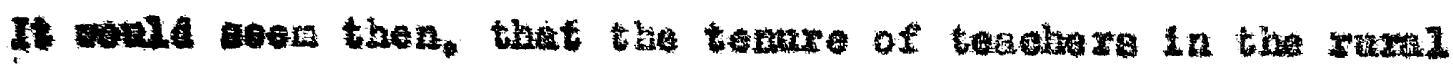

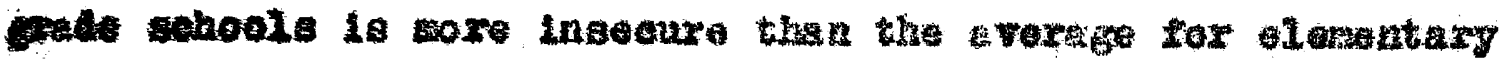

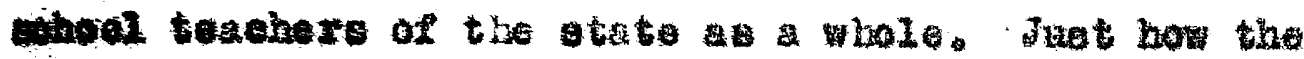

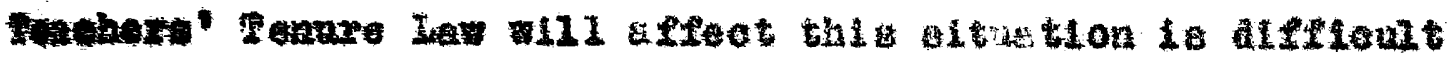

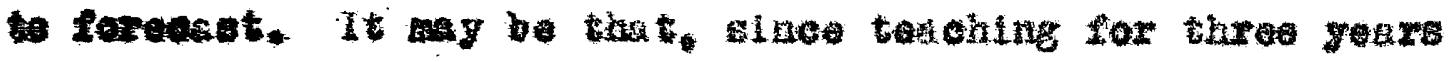

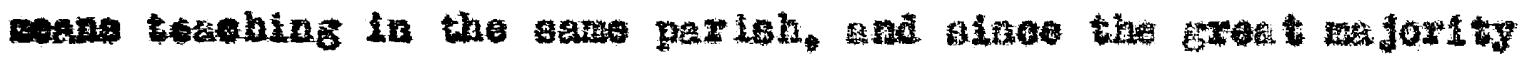

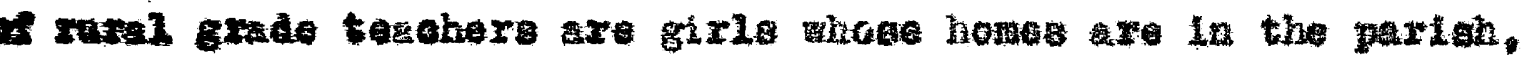

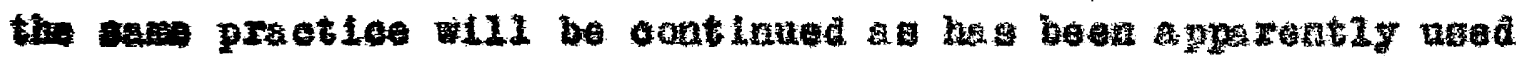

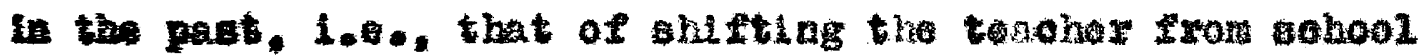

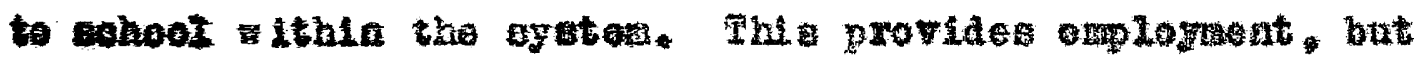

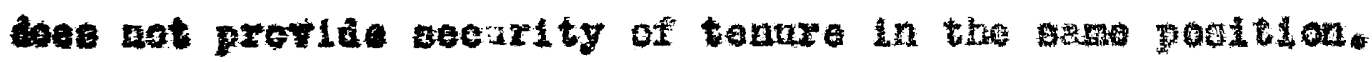

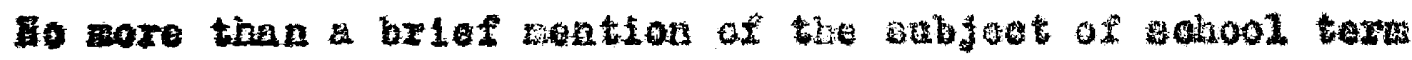

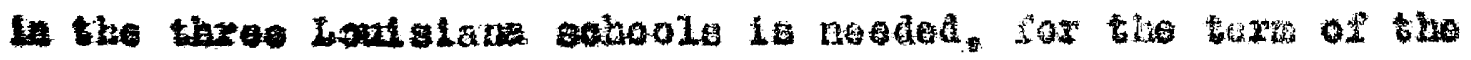

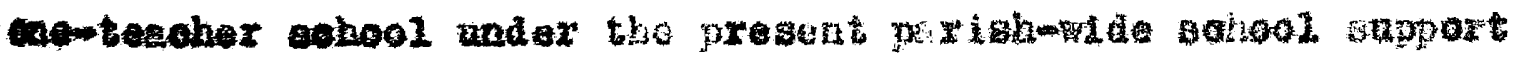

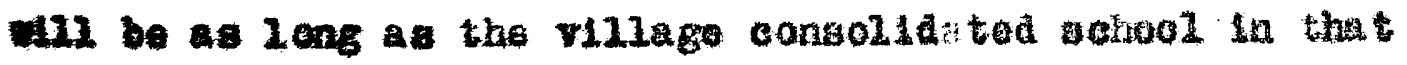
Natioh.

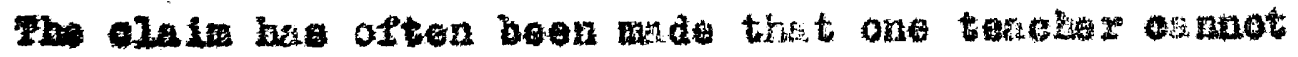

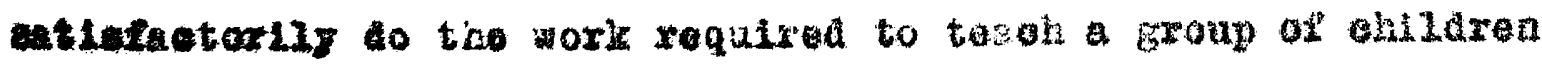

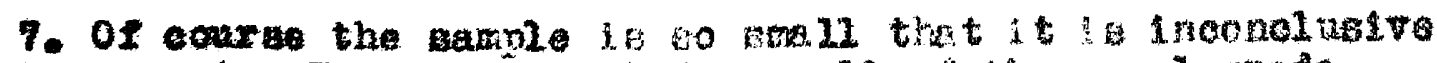

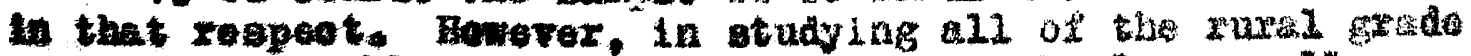

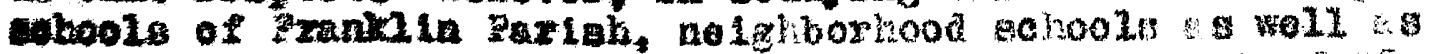

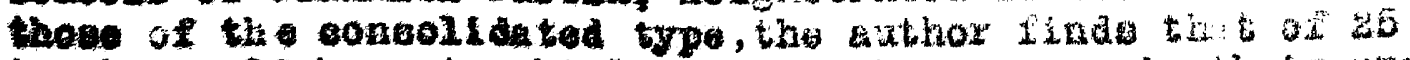

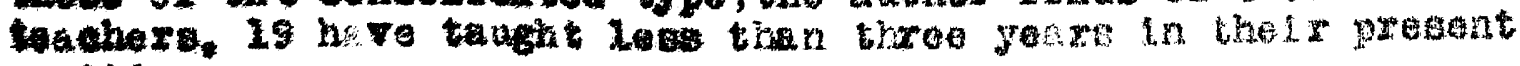
Dattion. 


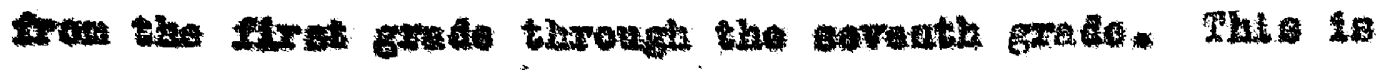

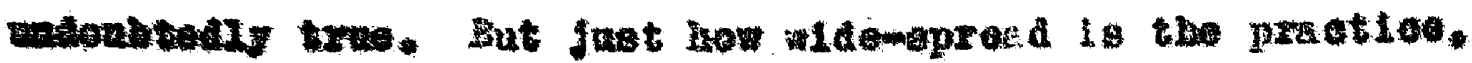

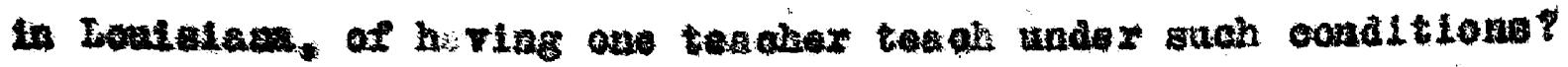

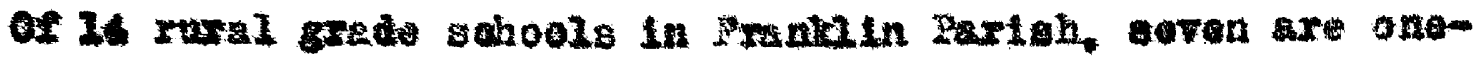

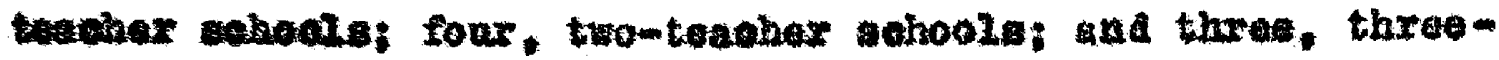

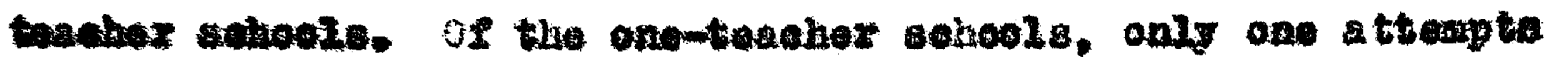

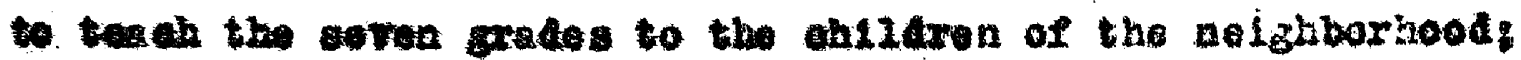
gnethex torohes through tive third grade: three ter on through the fourth grade; and two te:oh through the fifth grode.

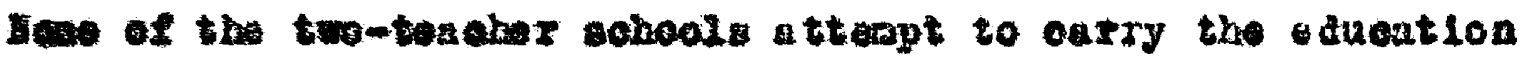
of the papile begond the shxth grade, and two of the foux whoole tale then only through the fifth grade. 21 of tho three-teader sehwels offor geven gxades of elemataxy training. siseo It I often cuatomary for temehere in the lower grades

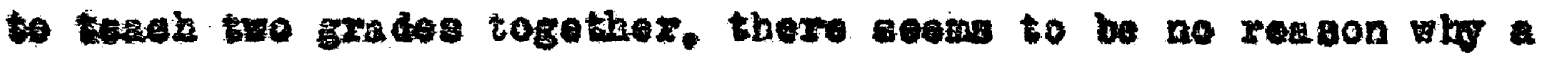

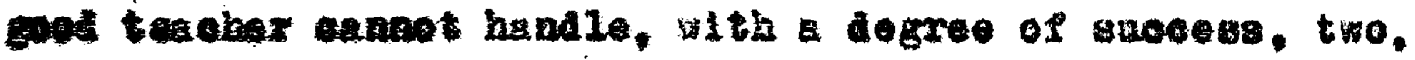

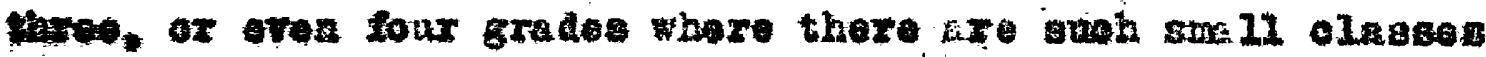

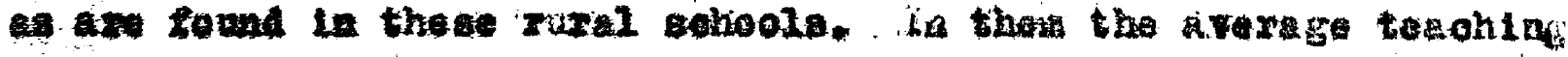
leat is not orer 22 papils.

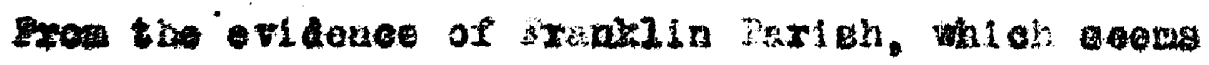

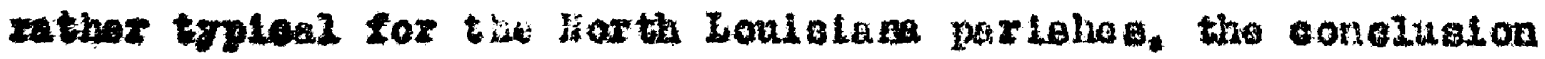

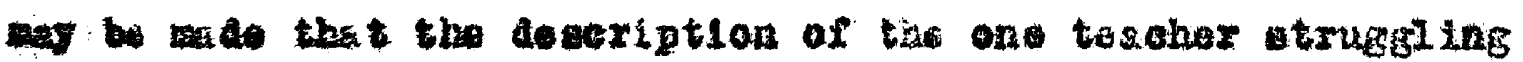

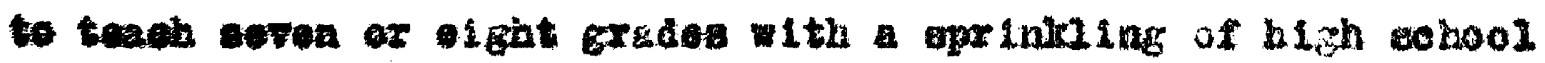

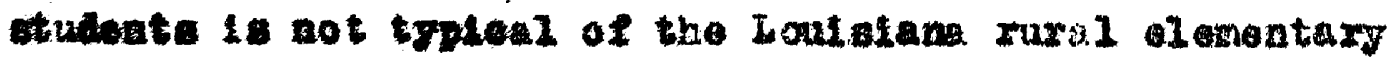
shools. Of an average eally attendeno of 634 children in

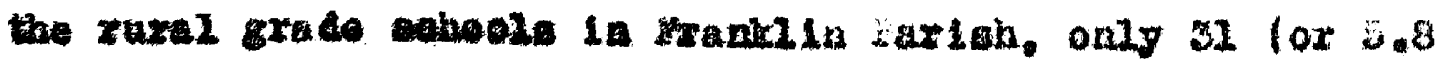

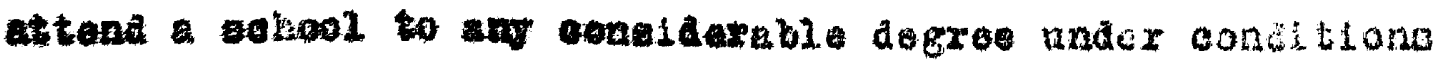
Iixe these deexibed above. 
8

In the atudy of Gaumitiz, it was found that many of the rurad sahoola were to amell to be able to do effective work. There is not sohool in rrankiln jarish with an average daliy attendance of lese then 19 pupils. In the entire state for the session 1934-35, the arerage da113 attellanoe for the one-teacher sohools was 20 , Wh the ref attendanee of 10 to 30 puplis. Only 53 out of 1,210 sohools had tewer then 20 pup1ls enrolied. Where there are approximately Dopils with one teacher to supervise the work of throe, four, or c1re grades, the arguaent of ingurflolent sooial contact for the small chllaren does not seom to apply. If Pressey's conelusion is accepted that chilaren of the Hadale ohllahood" ages (7-11) typloally play in groupa composed of alx or eight of 20 ohlldren, ${ }^{10}$ it evident that the average achool will supply Brouys of that alze. An examination of the olaims put forth in behalf of coneolsdated sebools is now timely in order to sat inate the benerits to the puplis aocruing from consolldatisn. one of the elalus is that the Increased size of tho sohool wild allow anrlohed offerings in subjeot matter, enourage eatabliament of high sohoole, nid provide for greater soelal participation on the pnrt of the students. If the sohools studied, Pondale, Samstom, Widway, and Belnont are

B. Caunits, op. 21t.

- State Department of Education of Louisiana, "Wighty sixth Annual Report," Bul lot in Ho. 309, 1935.

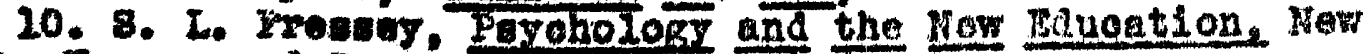
rork, harpar and Brothers, 1935, p. I24. 


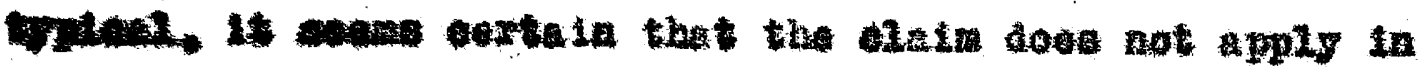

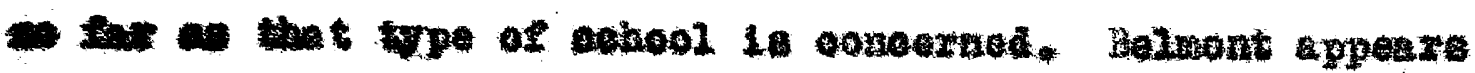

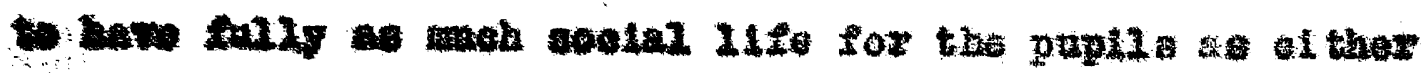

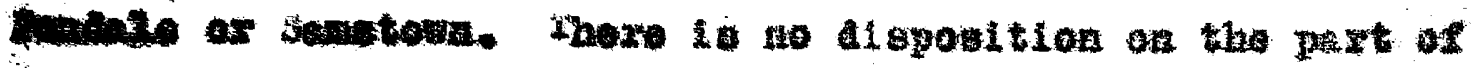

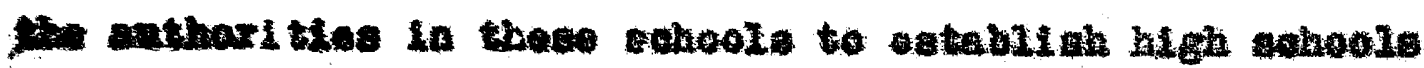

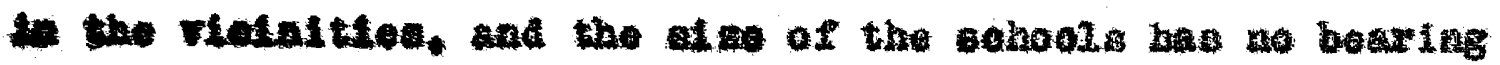

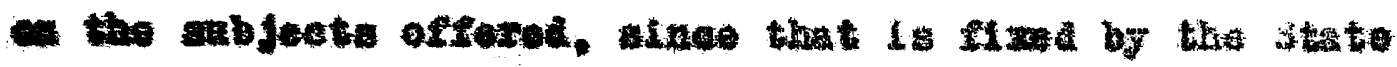

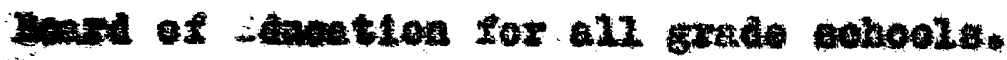

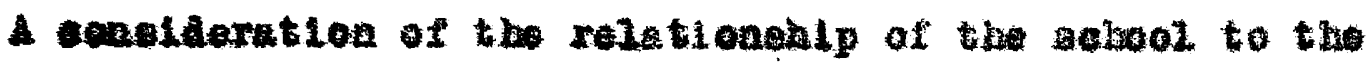

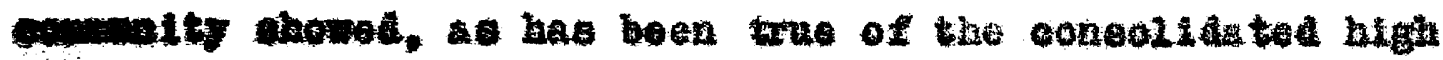

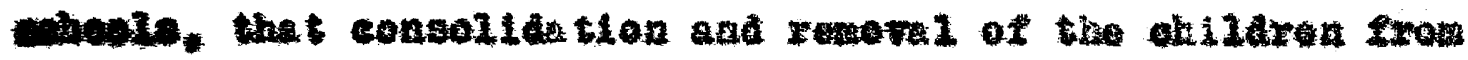
han abd ackgborhood laflweno go hand and head. It may

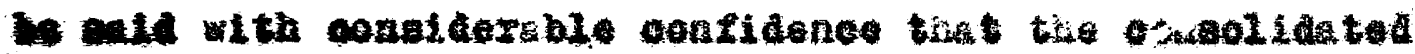

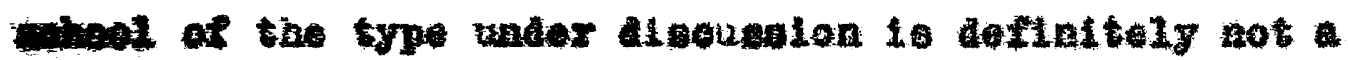

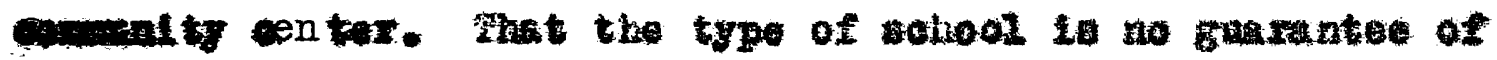

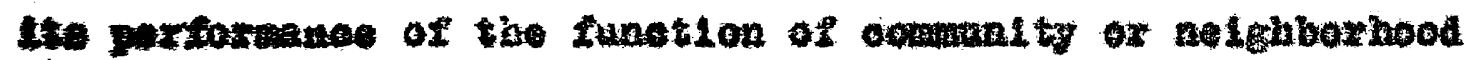

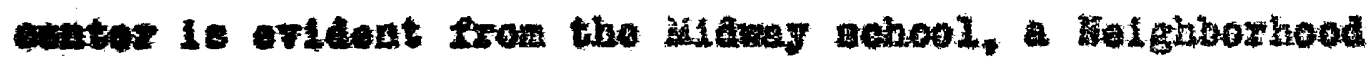

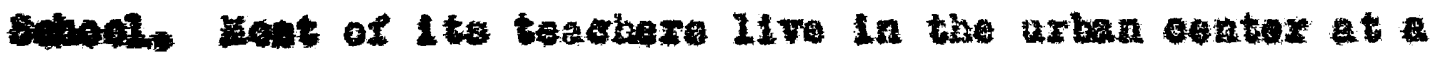

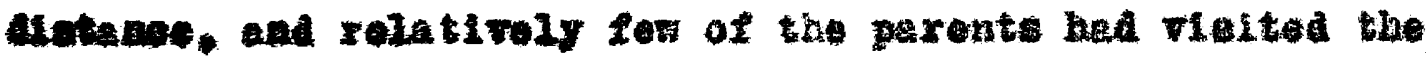

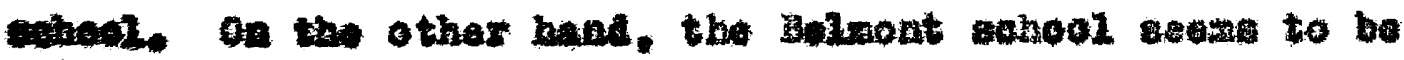

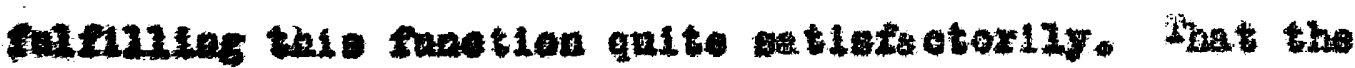

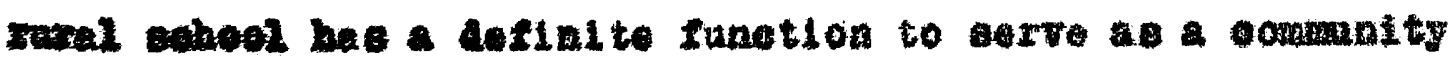

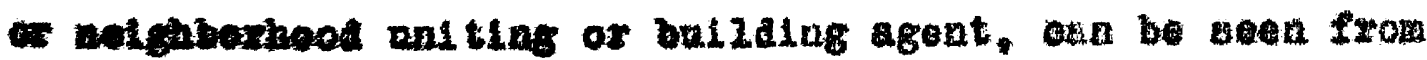

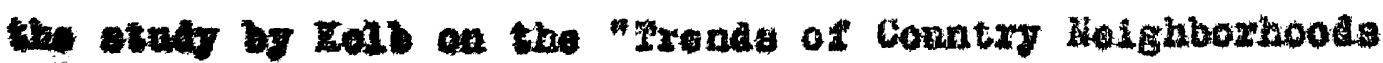

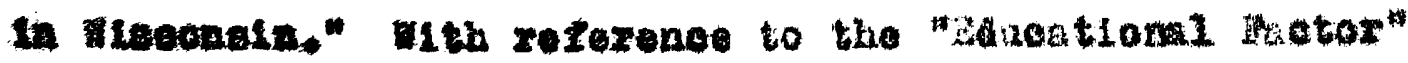

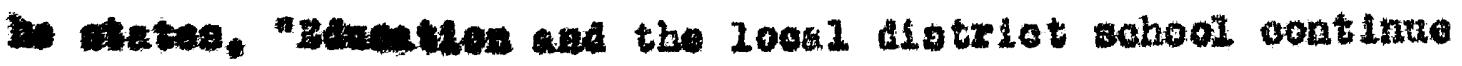


to plar a leading role in the iffe of rural nelghborhood." 11 Fron the study it seens that the attention of the school authoritles has been focused almost entirely on the actdemic development of the inatidiral puplis. The emphasts has been on selecting teachers that well trained in the art of tranemitting knowledge in academic subfeots to the puptls. on the wolo, the teachers have had amp 1 experlence in teaching. At the present time the fority of the narishes have parish superv1sors to gee thet approved methods of instruction are sollowed. An attempt to guarantee the teachers' position has been made by meang of a Teacher's Tenure Law. Teacher Retirement has been provided for a guarenteo of the future security of the teachers. Free sohool bnoks and sohool supplies are rurnished the children who attend school. In the sain, the buldaings are attrective and sanitary. so bas been prevlously shown, 44.6 per cent of the elenentary ohildren of the state faside from chose attending the city sehools in New Orleans, sonroe, Inke Charles, and Bogalusa) are trensported to sohool. Approximately 75 por cent of those are transported to the rural sohools. Howerer, a study of the schools and thelr operations makes ore belleve their ain 1s pedantic rather than prautioal. The exphosis seems to be more on the traininf of the individual child in subject matter which oill qualify him to do the higher acsdenide work

11. Agrioultural Experiment Station of the Univeralty of wisoonsin," Trends of Country Nel shborhoods," hesearoh Bujzetin 120, 1933. 
then to develop in him an spreciction an andergtcading

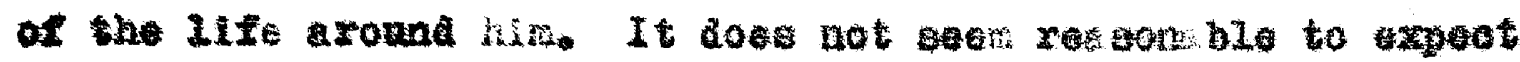

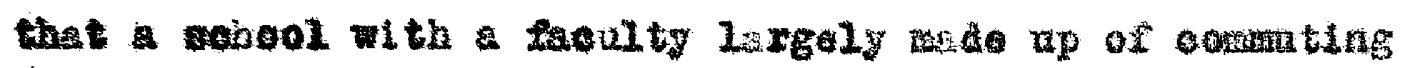

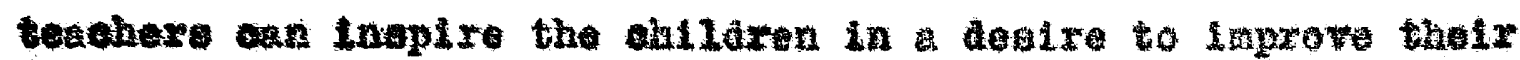
raral nolghboxhood fhloh anmot attract the biret axplagoes of the nelghborhood to 11ve there. Fetere. In Getalug the

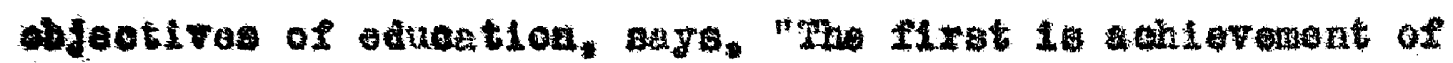
a high dogree of solldarit. athin the group. The mera

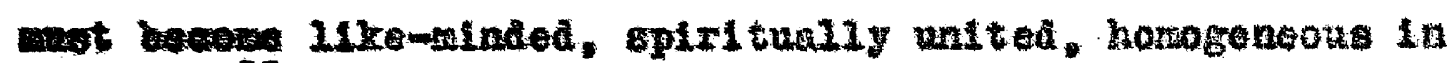

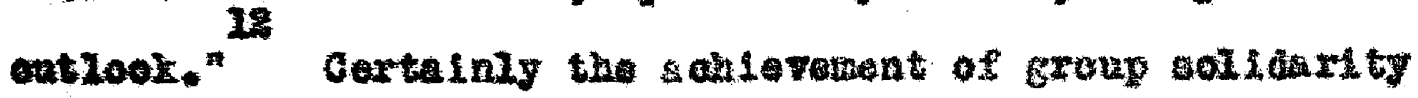

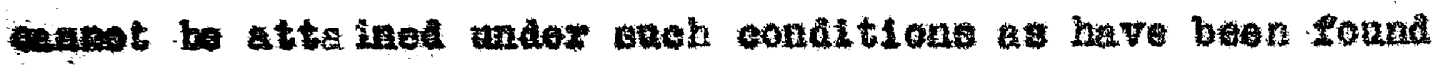
In the Bural consolidetal Zlementary sehools.

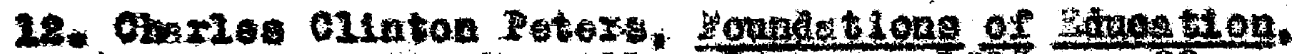

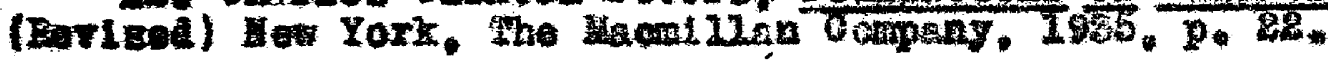


CEAPTER VIII

GHARAL CONOLUSI OR

The data for this study lead to some vary interesting oenelualons with reference to rural sohoola in Loulsiana. llach obapter has been sumearlzed and concluslons arawn from the date. For that reason, in this the coneluding chapter, the conelusions will be sumarized under a few general toplos. 1. The gualifiogtion and Tenure ot the Pural Sehool Teechers: The acedente qualfications of the Louistans tenohers are high. The teachers in the mall haniet or open-country consolldated high sehools untformy axe postessed of higher goadento training than is required by the Southern Assodition or Colleger and Secondary Schools of 1 ts gocredted ligh sohools. The training of teqohers in the small neighborhood sohools is also high. In faet, there is no apparent differenoe in the legae of academlo preparation among the gnell rurul grade sehool tecobers and the Inatructors of the large oonsolidated eleneatary sohoole of the open country, village, or town. Ifkewse, the Loulsiana temohers are not, as clasa, inexporienoed in teaching. The high sohool instmuotors do not have so mach exponience as is oharacterlatio of the grade school teachers, but they do have a modien of nore then pour years of teaching experiance. Although there may be more Inoxperienood teachers in the nelahborkogd sohools and in the 
anall rural consolldated elemantary schools than in the

lerger consolldated schools, one lo not wanted in oharacter1xlng the rural grade cohool tectahera as "Inexperienced."

The Loulsiana tenchers do not possess security of tenure In their positions. This is true in the rural aelghborthood school and in the rural oonsolldated high sohool, where frequently more than 50 per cent of the teaching bo dy have not corred in tho same position for more than three yoarg, and it 18 also true in the urban sohools in whioh rural ohildren are trained, for more than 35 per cont of the teachers in these urban schools have not oerved the three year "probation" perlod. 2. The charaoter of the Bural Sohool liants ond Thesr Iurnlahlnge: On the shole, the bullaings in which the rural shools ere housed are ettractive in appearance, sanitary, and well furnished. This has often been wade posalble through the consolidation of Bohools.

3. The Slze of the Kurel Sohools: The mall Loulslans schools do not appoar too small to provide ample soclal aotivity for young ohildron. The weaknes in the site of the Loulsiana cohools sems to be in the orowdine together of sure ohildren In one buliding than oan be edequately provided for. This orexorowding 18 especially true in the large urban schools in whloh rural ohlidren are trained. 4. The course of study in gural Sohoolg: The rural schools fall to recognize themselres as rural in so rar as thelr course of atudy is concerned. The same urbaq oommerolk1, or oultural subjeot mattor found in urban high sohools is 
charaoteristio of the arall rural high sehool. The ohter aifferenoe lios in the fact that the size of the lnstitution prevents It from offering the wide selection of this type of materlal. The provaling ldea in so far as the course of study Is ooncerned appears to be pedantio rather than utilltarian or practloal.

5. The Adaptation of the course of thudy to the Needs of the Cormanitr or No1 ghborhood in Haloh the School is Loouted: sino the course of study in these rurbl sohouls is that selented for urban rather than rural schools, there oan be but 11ttle or inoldental adaptation to the actual negds of the oomennity or neighborhood.

6. The Rate of Fupli progress in Rurel Sohoole: The degrso of retardation in the rural sohools. Is not exoptionaly high. The rate is considerably higher in the olementary grades than in hiph school. The strietly rural sehools do not have a higher rate of retardation than the schools looated In larger conters. In sact, the highest rate of retardstion found in any school was in the urban Ouah1ta Parish Hsh Sohool.

7. The Extent of Consolidetion of Sohools as Indented by the Mrensportation of Pup11日 to Sohool: Consolldation or sohools han reached the point in Loulglang there 42.5 per oent of the high oohool and 44.6 per oent of the enentary achool pupils are transported to school. This Indioatios ol ther somewhat higher denree of consullation amonts the lementaxy grades than among the high achools, or a ragher large amount of 
-limination from ahool in the upper levels. The elenentary sohool ohllaren travel somewhat farther to reach their rural consolldated sohoola than do tho ohlidren of secondary sohool level attending the same school. The fact that a higher pereentage of elementary than of high sohool pupils is transported to sohool, and that the elementary ohildren travel fartior in reaching sohool leads one to conclude that areat deal of elinination of pupils trom sohool takes place before the students reach high school and that this dropping out is related dirootly to the distanoe the puplis have to travel to reach sohool.

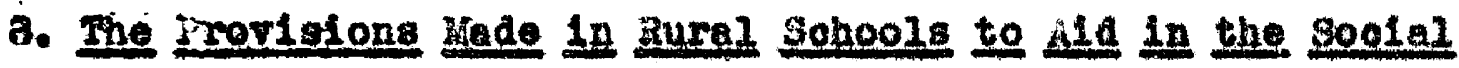
Derelopment of the chlidren: There seens to bo no uniform prectioe in extra-ourrioular activities for the sociel derelopment of the chlldren. The rural sohools located in 11lage centers appear to have a more balanced progran of physicel and aodemio aotivities than ol ther the urban high sohools or the anell hanzet or the open-country high sohools. In the open-country high ochools, physical developrest in the Pom of Interacholastio competition is stressed almost to the oxclusion of cosdemic notivities or physioal aotivitios asldo from the competitive sports. Also, the competitive activities aro usualig limited to basket-ball. In the urban high sahools the physioal derelopment ia alnost completely neglected because of the laok of spaoe and teolitios for oarying on such program.

9. The Reoognition on the Part of the 3ohool of Its Obligation 
to the compunity: Thero is very little ovidenoe to support the 1dea that the mural sohool, as an esteblished institution, sools any reaponalbility to the comranity in whioh it is 100ated. The oourse of study in the rural sohools does not rumlsh eridenos of any recognition of compuntty responslbility. Wot a high sohool raports any form of community activity funotioning in the sohool except the yarent-Fenohers' Assootation, which, in the main, 1 a sohool device for socuring eid for the sohool from the patrons, not a sohede whoreby the sohool oan act to ald the community. That the sohool is not regaried as a commity institution wh thy other function that that of training the youth in ocaderalo IInes 18 eridenced by the faot that onjy a small proportion of the parents of sohool ohilaren had viaited the sobool during the yoar.

20. Poasible Inadeguacies or Heaknosses in the System of Gonsolldated Rural Sohools: It appears that a new forn of "absenteelem" has developed wh the growth of rural consolidated ahools. It is "absentee" aduoational direotion. The ohildren of the nelghborhoods are removed from their home enviroment. They are trangported to another district, in some oeses to on environment entirely unlike that of their home surrounaings. 1 They are taught subject unrolited to the 11fe they live at hone and uncemiliar to thelr parents. They

1. In the annual report of one Loulslan Rural Consolidated High School, the prinolpel reported that some of the onlidren wo sat 81 de by side in the olassroom 11 ved as far as 50 miles apart. 
are taught in sohools which are renoved from the influenoe of thetr parnets and which have no interest in their parents. They are taught by teachers who in many oases are not "birds of passage" but are ocamuters, traveline from som urben or village conter to the rural school each day that sohool dutlos make such oomating neoessery.

The extent to which consolldation has ben oarried in some cases is certainiy a defeot. Some children sasat spend from three to four hourg eah day on the bus traveling to and from sohool. Thin necessitates their lenting home before day21ght in the morning and arriving hone artor dark at night. The buses in whioh these ehlidren are transported are frequently overorowled.

The consolldated rural sohool provides very strong urbanizing 1nfluence in a rural comentity. 2

The peycho-soofal orfects attending a continuation of the urbanlzing lafluenoe of the chools on the rural youth, together with the development of an unfriendly attitude toward rural life in general and farming in partioular among the Fural sohool children, oan not be farorable to the cuture well-belng of elther the comnunities or the rurel sohool pouths Who ahall remain, through fora of clrcumastancas, in the partloular comennty and engage in agrioulture as an ocouration. If the peycho-social or soolosecononic sttuation in rural seotions is unsetiafactory at the present t1me, w111 it be bettered by the type of educationad institution now operating

2. For a disoussion of uxban characteristios soo dist and Halbert, OD. C1t., DP. 261-391. 
thereln? In short, will the rural youths who reand in maral "de better the dealrable things that they are $11 \mathrm{kely}$ to do anyay" beouse of having attended and completed the course In a rural consolldated high sohool?

Anotber serious reakness of rural consolideted schools 10 the preotice of consolldating the rural grede sohools to weh an extent that onlidren at a tender age (sfx to 10 . years) are taken away from thelr home influence and transported, in some eases, wany miles from homo. This seems nethor ceslreble nor neossary. There can bo but slight question as to whioh is the better situation for young enilaren, that of the Pondale sehool of that of the Belmont sohool. In conclusion, it appears that: The consolldated sohool woes not solve the edueationsl problems in rural distriots. The rural achool and the rural comaunity need to be brought oloser together in o common bond of understanding. There eppears to be need for the small neighborhood whool for the ohlldren of the lower grades in maral seotlons. 
Appenaix A

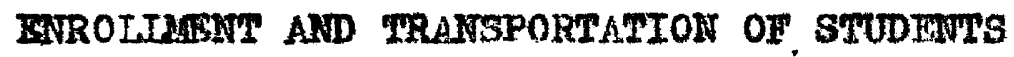

IN TIE PUBIIC SCROOLS OF IOUISTANA 
Table I

Sohoel Brollmont and Irameportation in tho Publlo

Sobools*

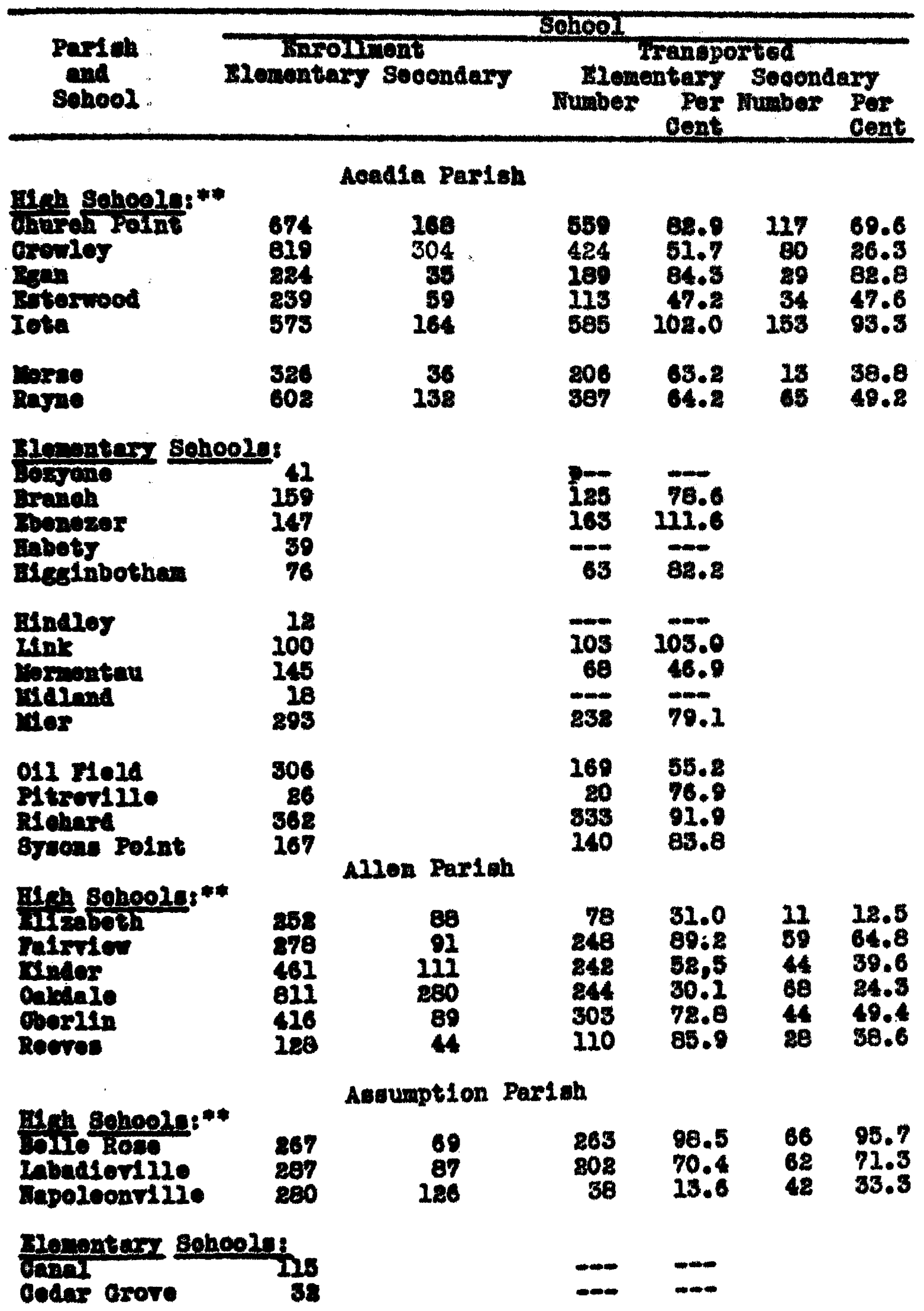


Table I (oontinued)

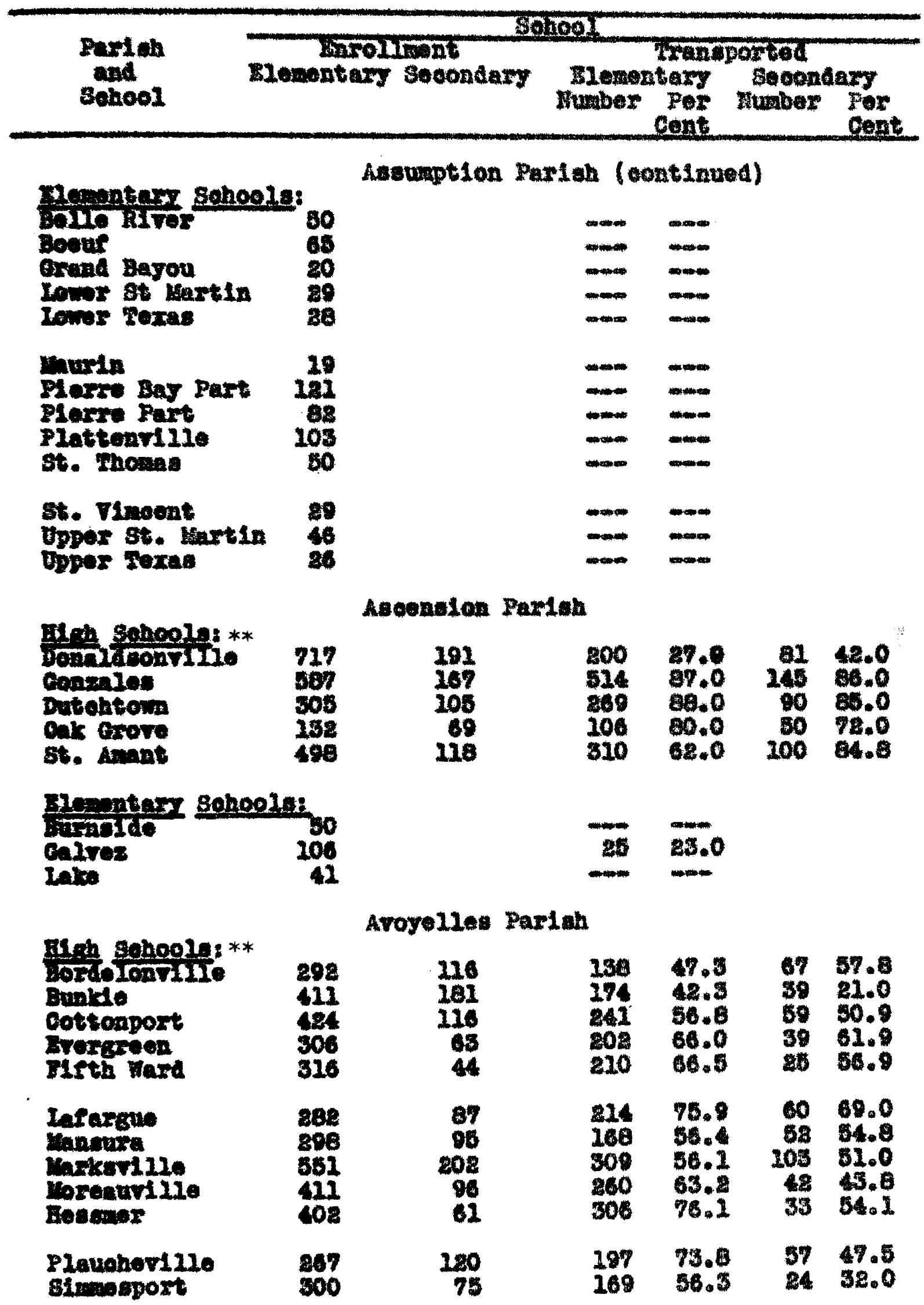


Table I (eontinued)

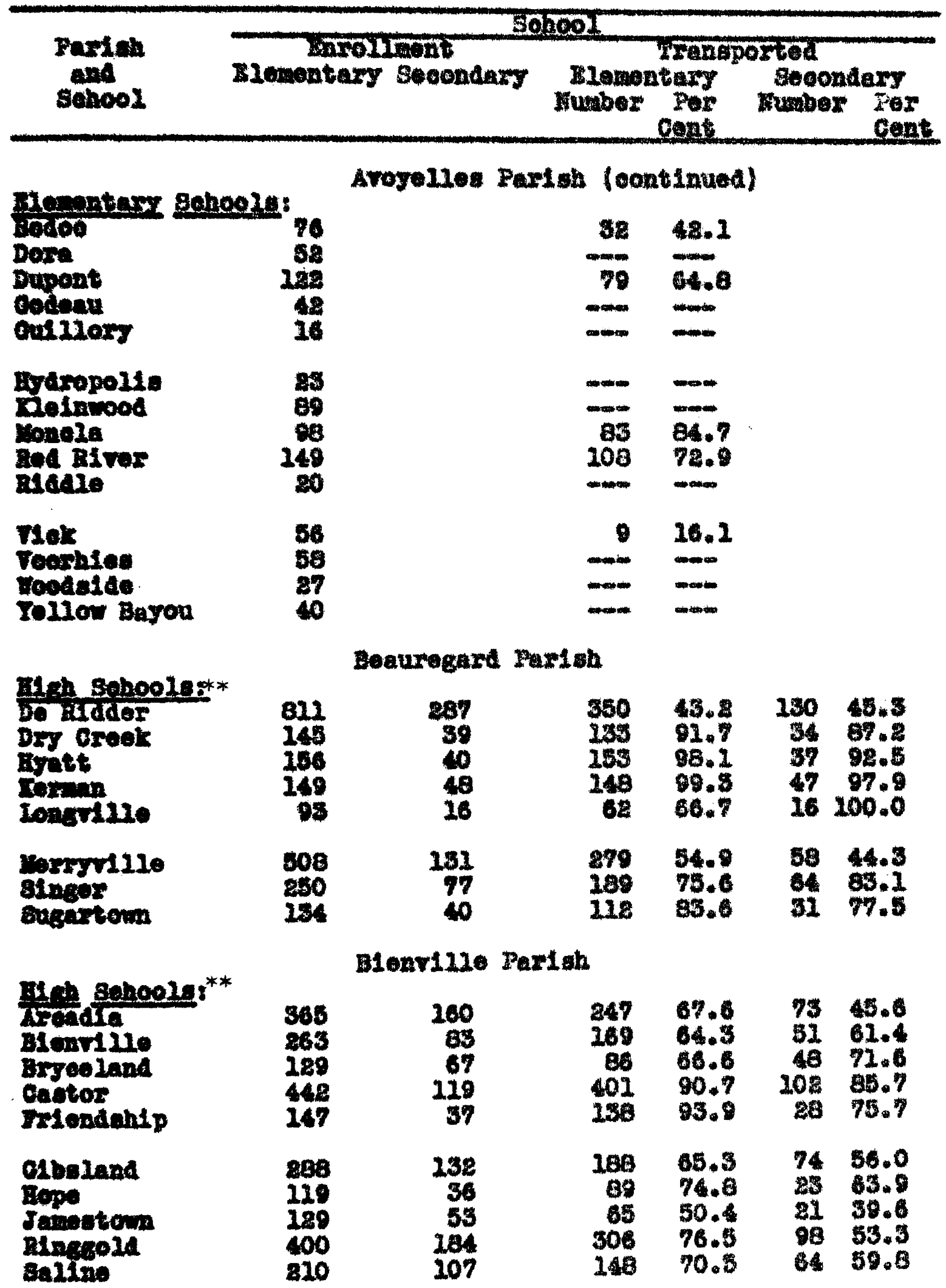


Table I (oontinued)

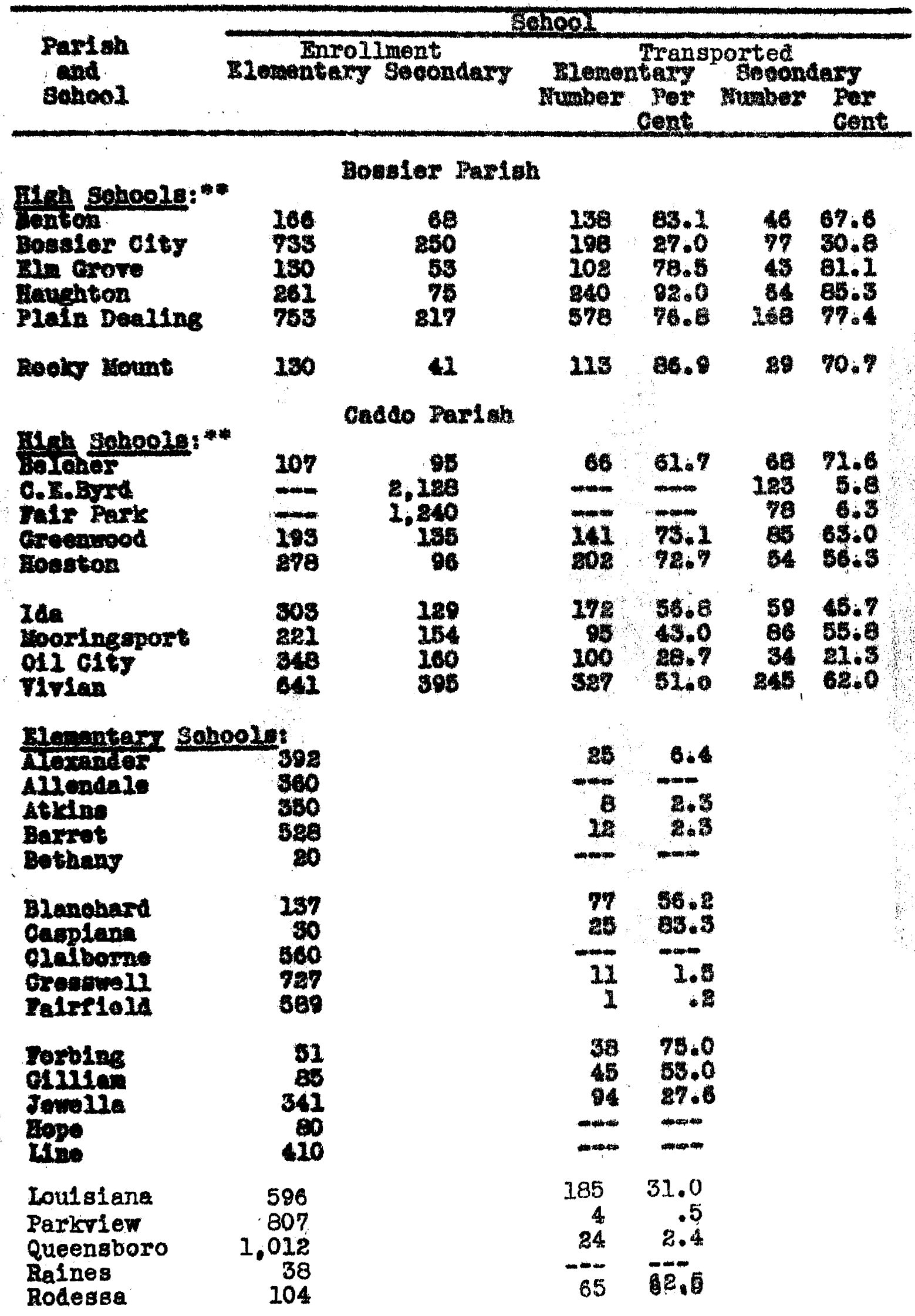


Table I (continued)

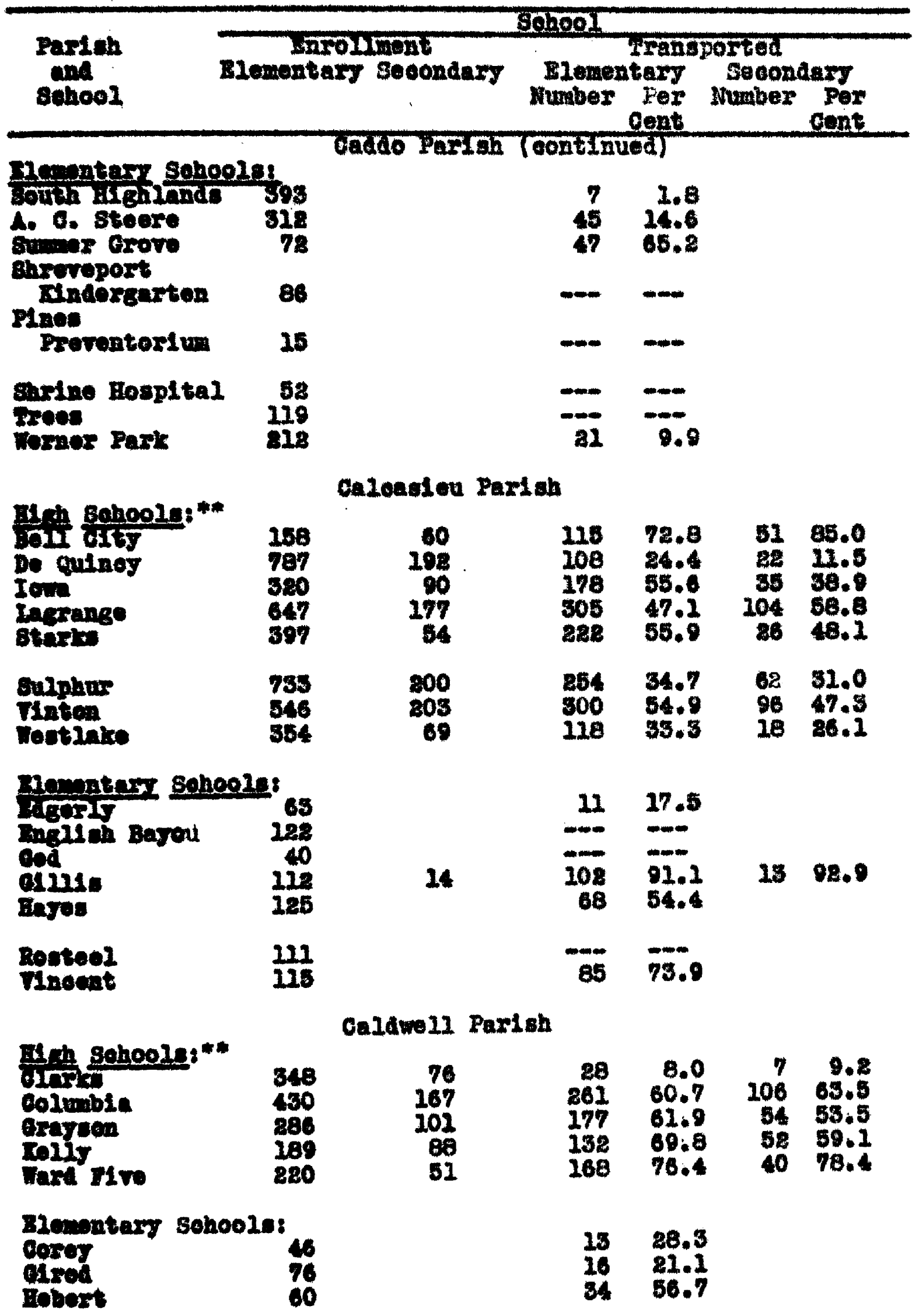


Tabio I (oontinued)

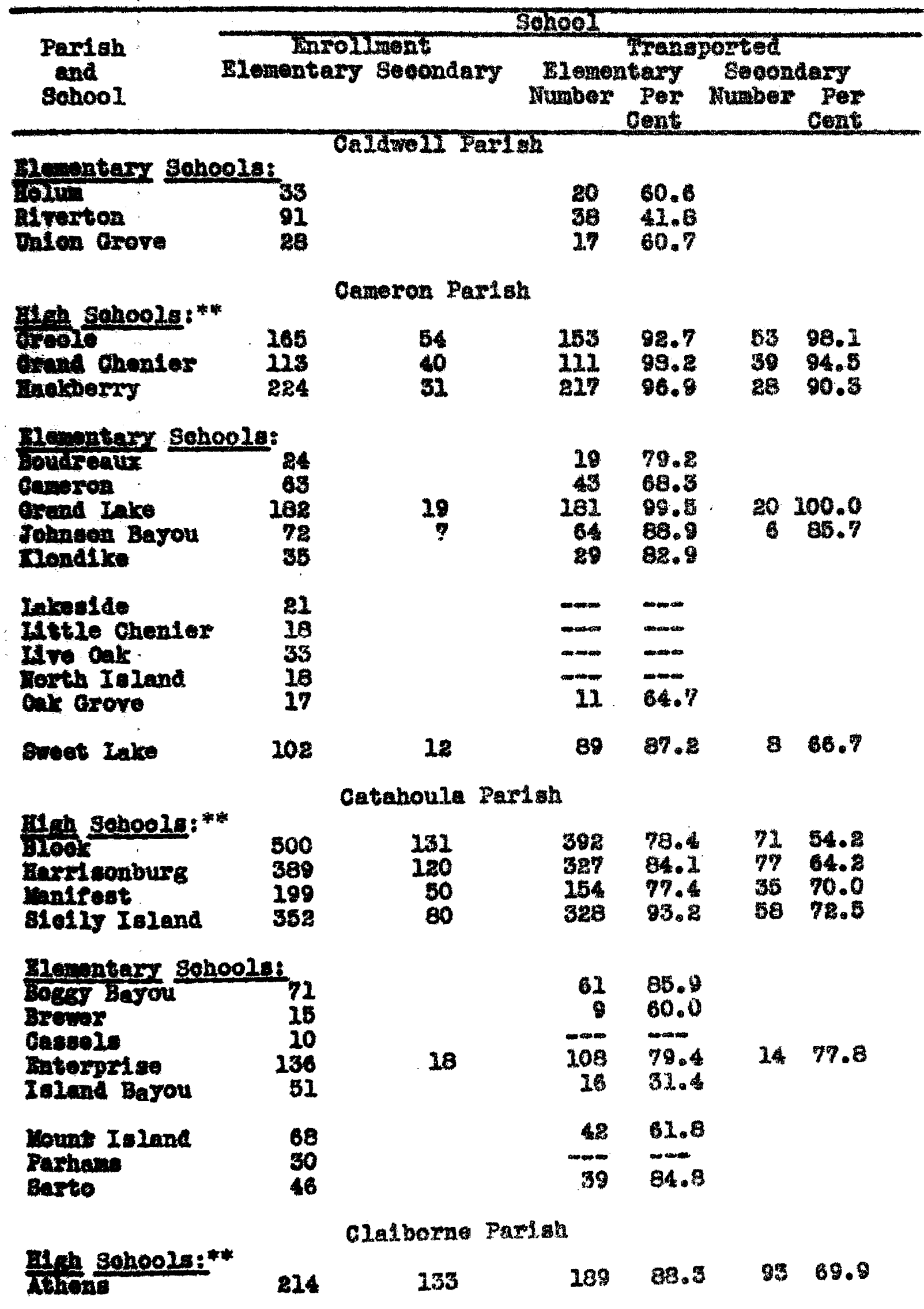


Table I (eont1nued)

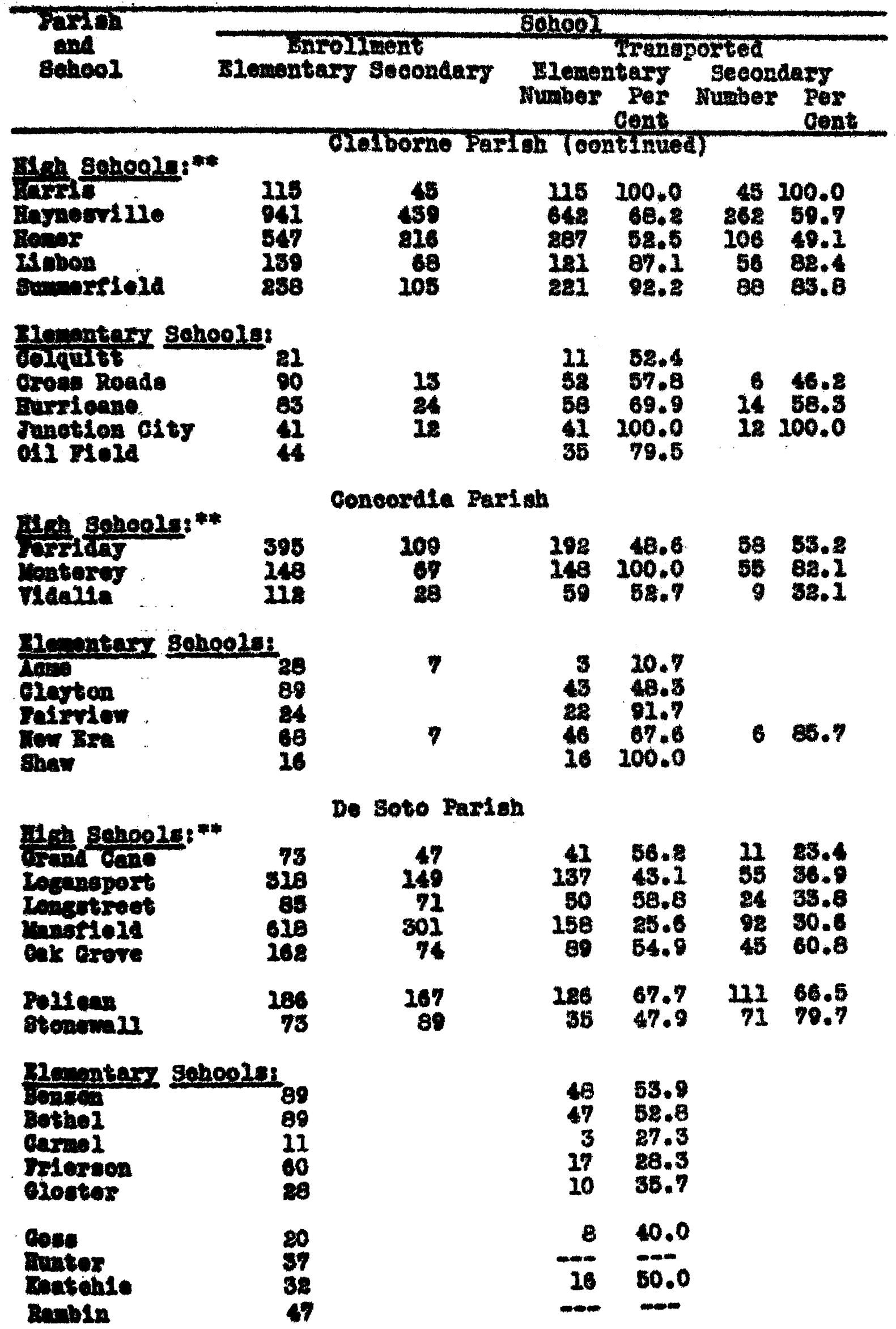


Table I (oontinued)

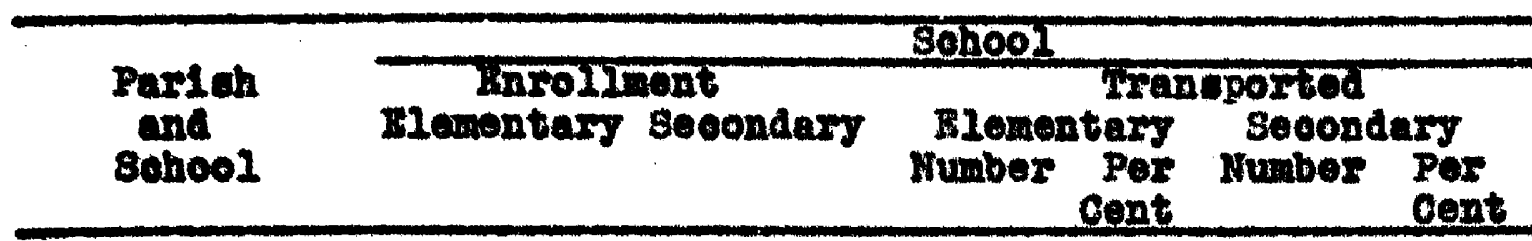

Domenter sohoolst min

Enoprton

shlioh

nalines

wouplo

Ent gohoele:"*

Laro.

Baton Rouge

Tunlor Bleh

salor Bleh

Botrant Forrace

Goxtral

Iotrovina

Berde

Bovonth Hexd

zechary

zeoment Bohoole:

ine

Boauregard

convention

Duexoeg

Iatrielao

Bighlande

BoLlinwoed

Bowill

remolsa

Lonto Sano

Iloholson

Elnth Ward

Eorth Blghiands

wrondotto

Hech 8ohoole: ** ano Retronos ront100120

\section{4 \\ 21 \\ 38 \\ 69 \\ 10}

Bast Baton Rouge Parleh

237

360

$-\infty$

803

340

586

100

188

177

289

309

287

578

217

288

287

45

340

130

488

161

345

891

Iaot Garroll Pariah

131

315

880

34

217

$2 a 5$

384

345

74

74

101

55

103

124

68

64 133

81
De 3oto Parlon (continued)

$\begin{array}{rl}60 & 81.8 \\ 89 & 55.6 \\ 41 & 50.4 \\ - & --.\end{array}$

84.7

$-\infty \quad-\infty$

41.3

95.5

5

6.4

32.4

93.2

$-\infty$

108

18.0

21.0

62

83.8

70.1

62

78.0

67.5

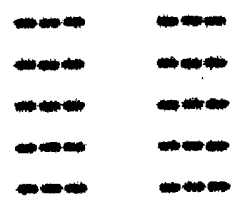

$158 \quad 84.0$

$\begin{array}{llll}32 & 11.1 & 18 & 29.0\end{array}$

$-\infty \quad-\infty$

$=$

$\cdots$

13287.4

$48 \quad 13.9$

$28 \quad 34.4$

$\begin{array}{llll}x & x & x & x\end{array}$


Table I (oontInued)

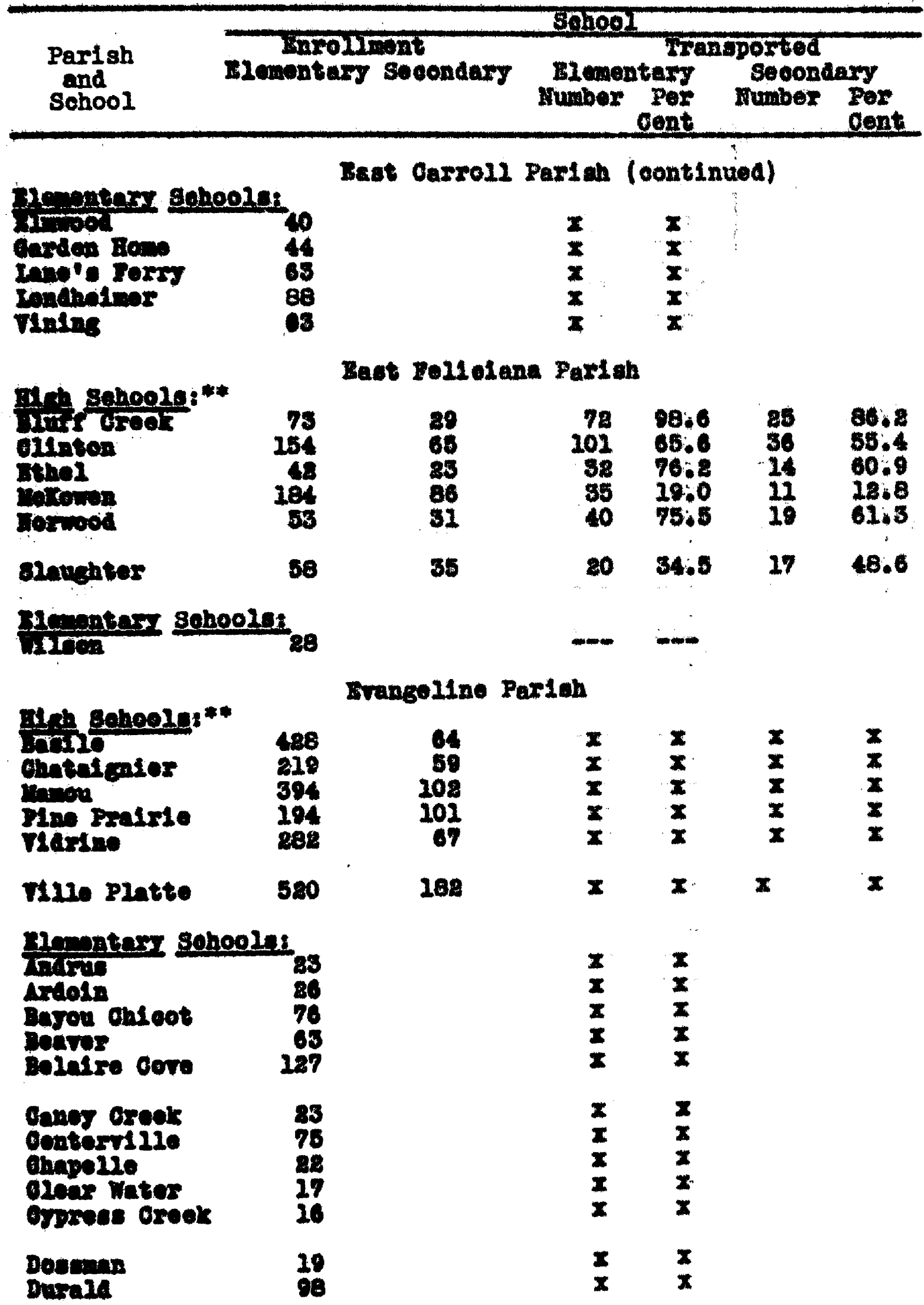


Table (eontinued)

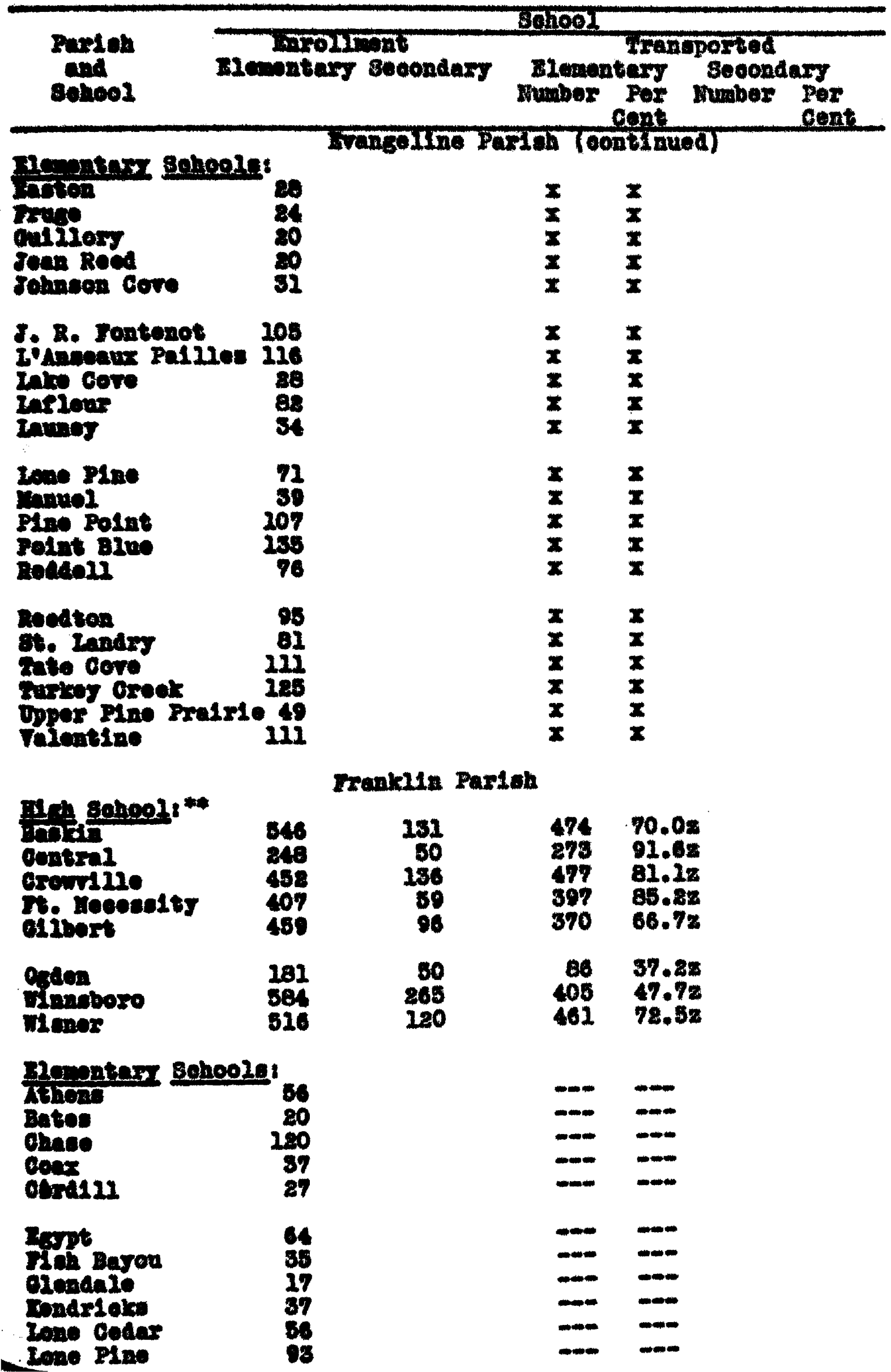


Table I (oontinued)

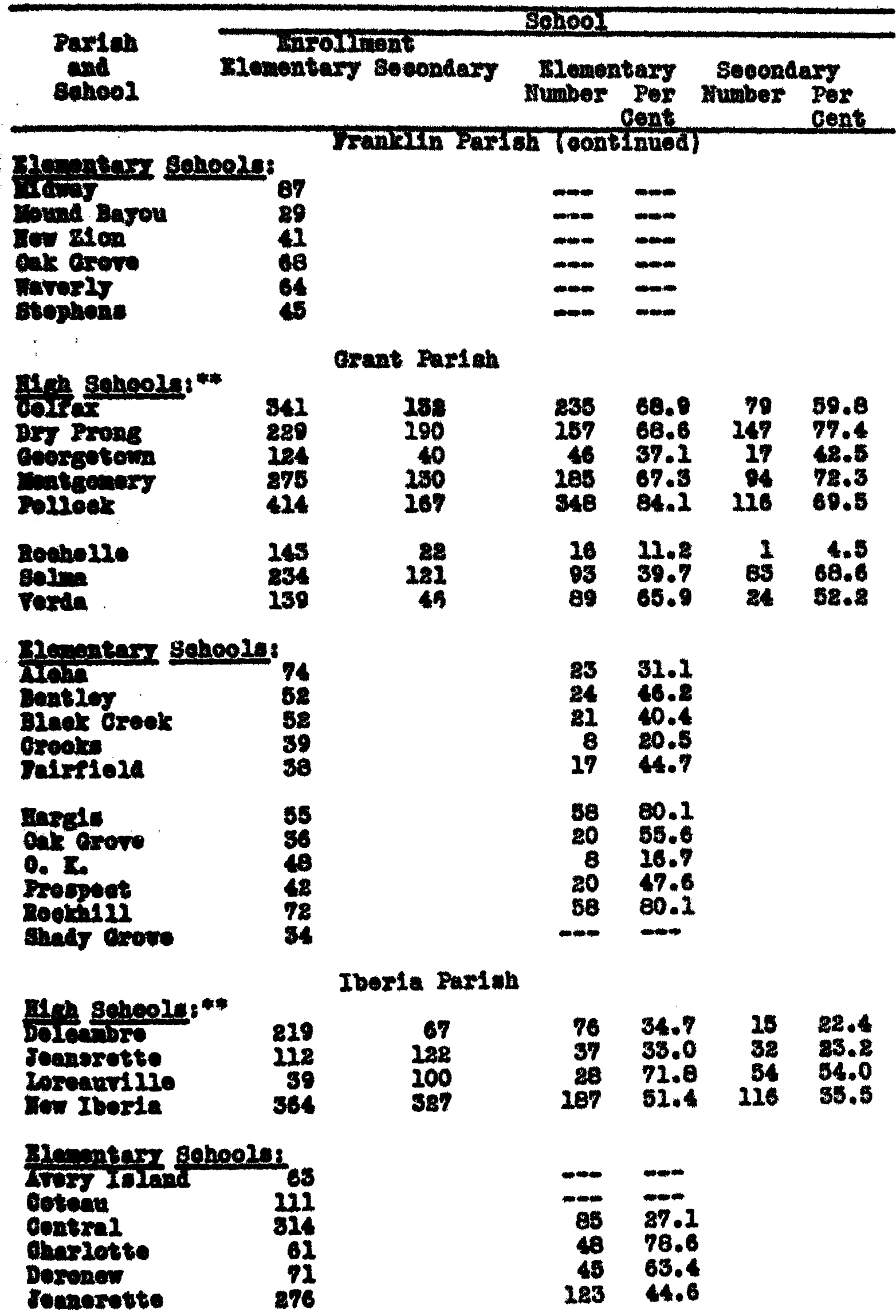


sable I (oontinued)

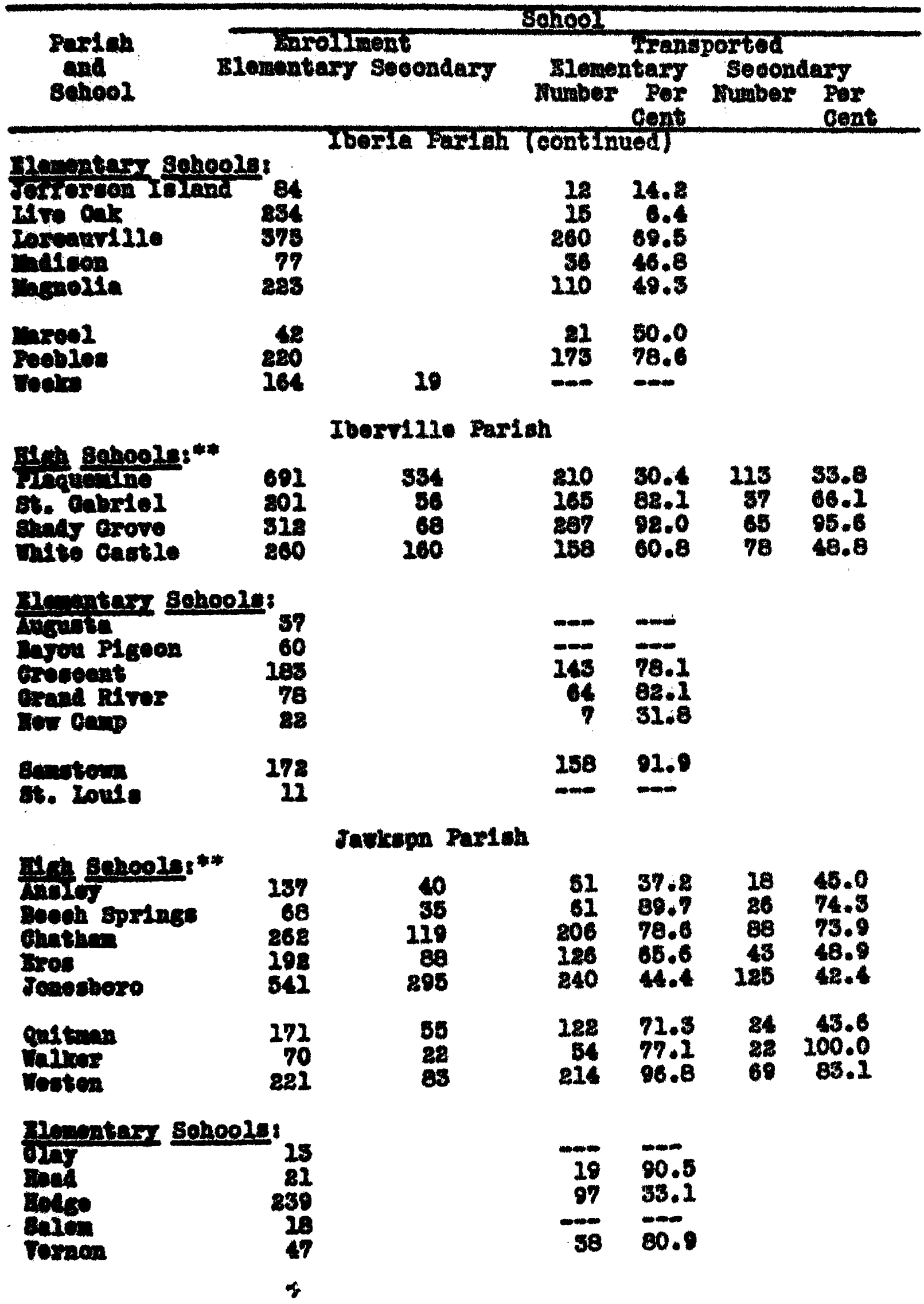


Table I (oontinued)

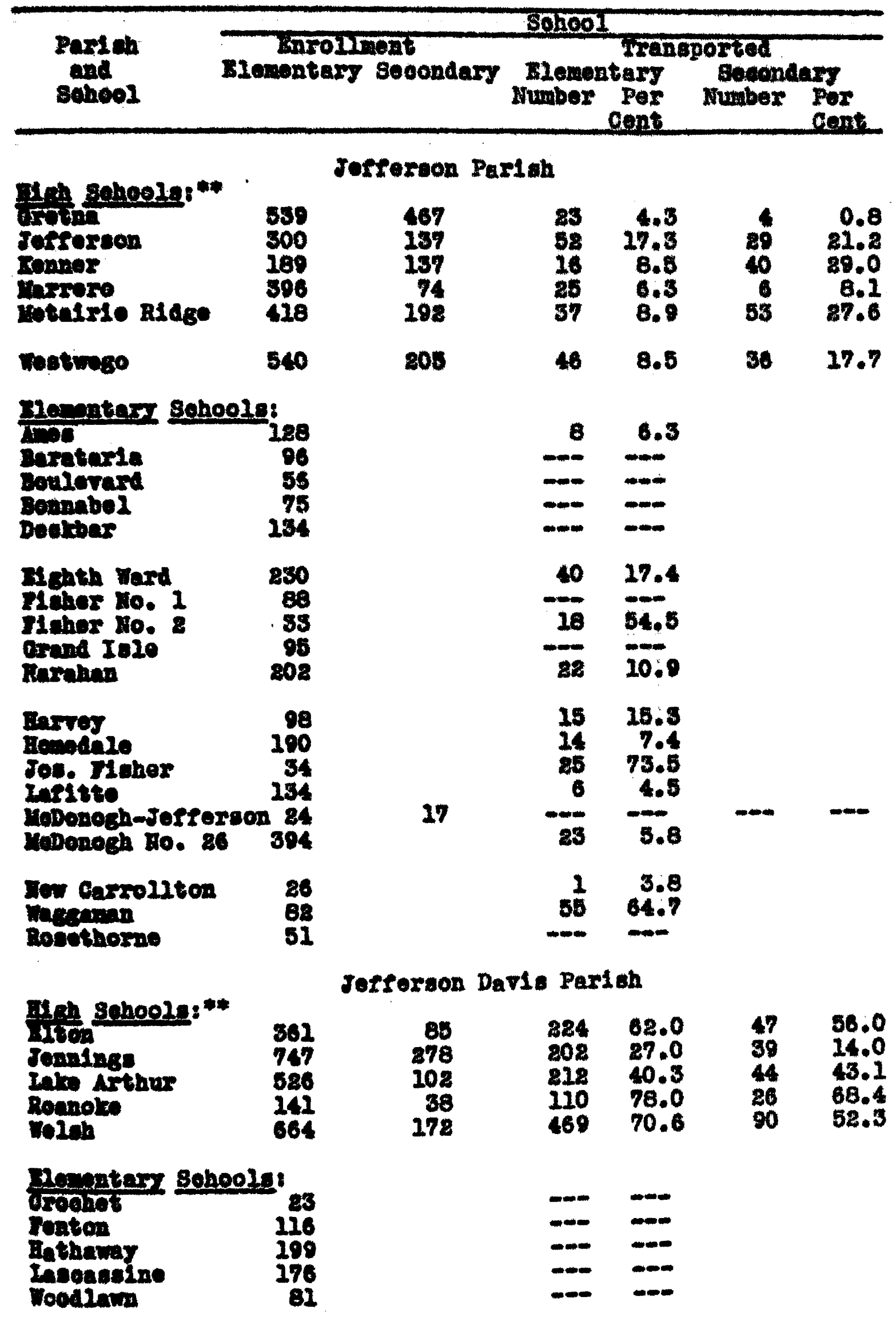


Table I (continued)

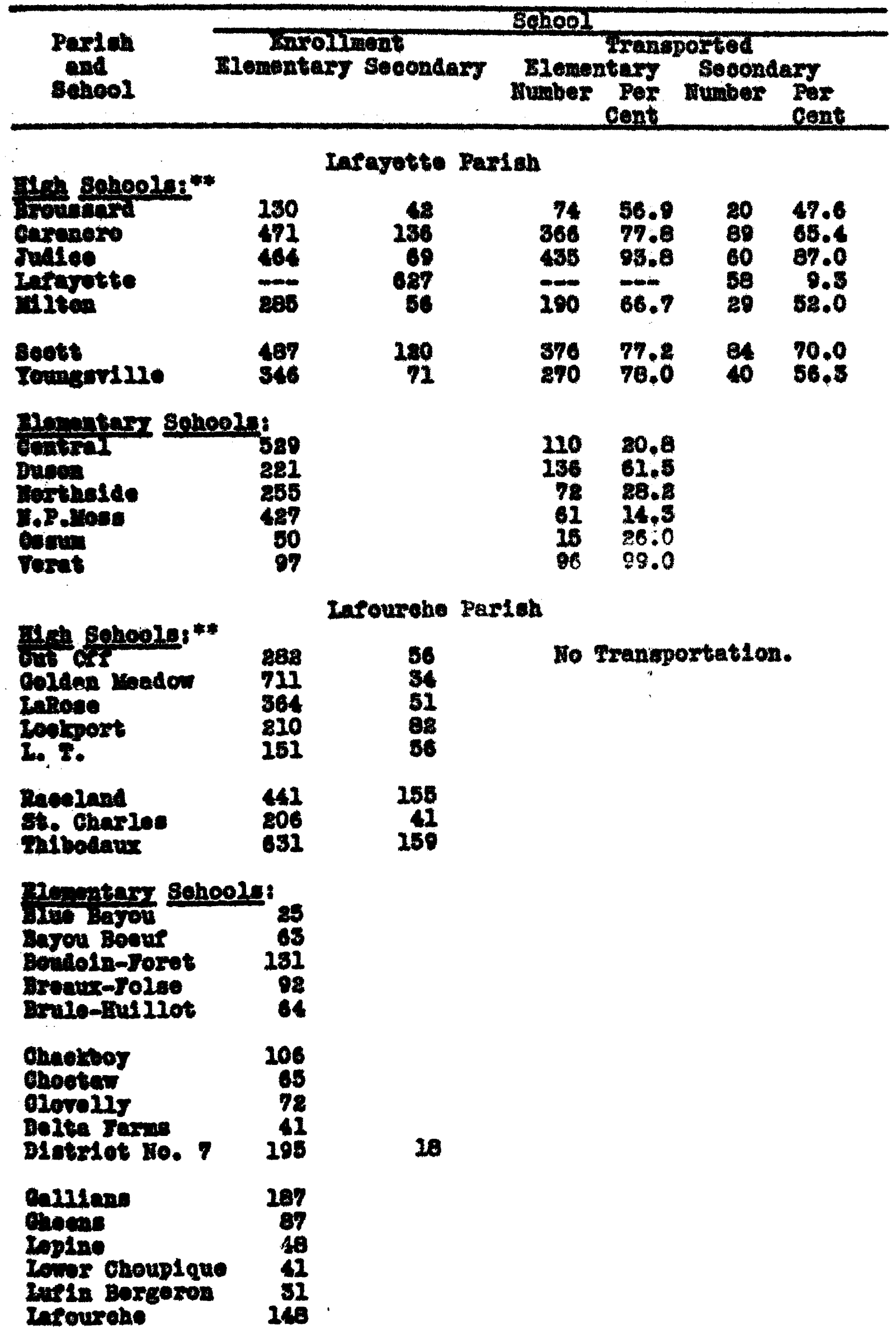


Table I (continued)

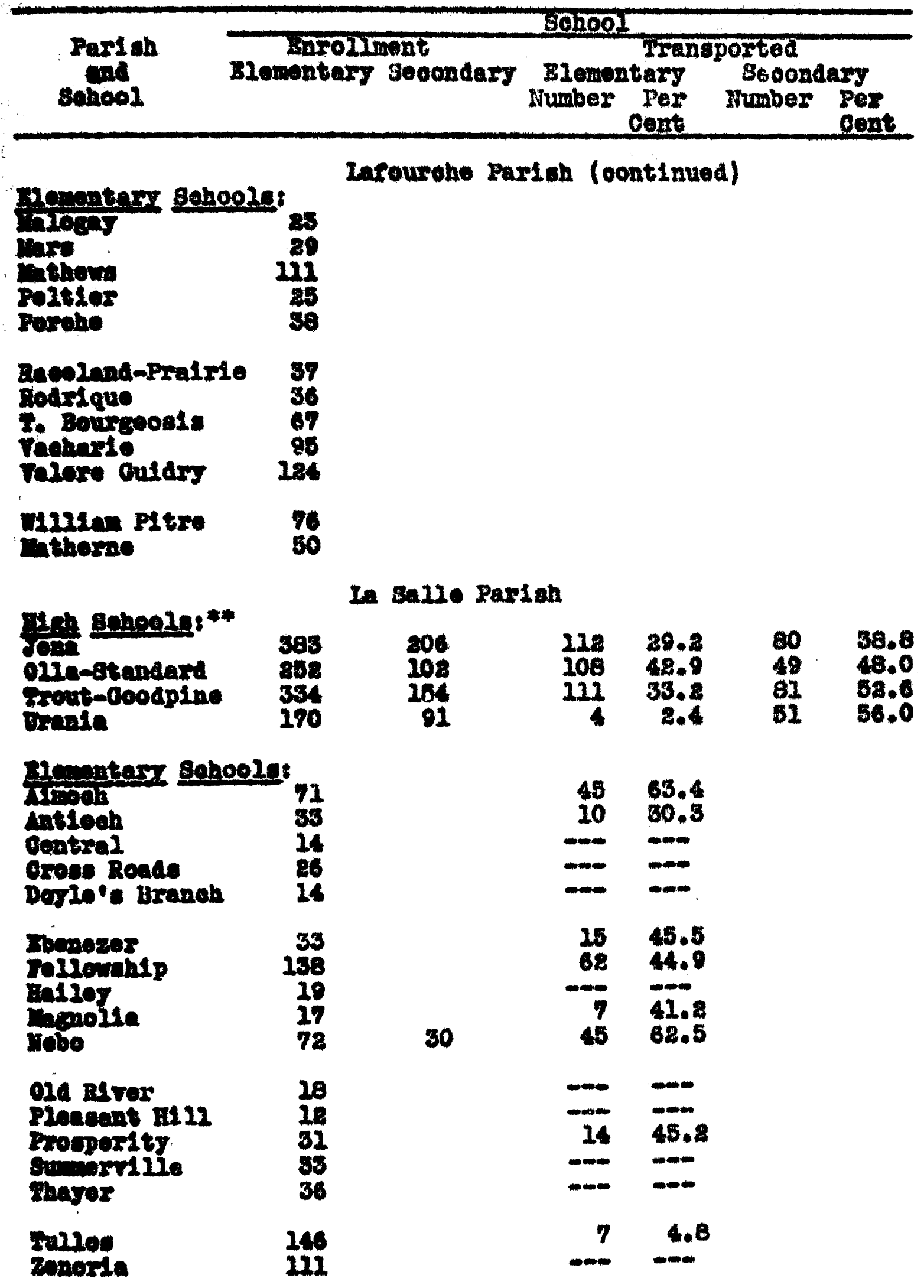


Fablo I (oontlnued)

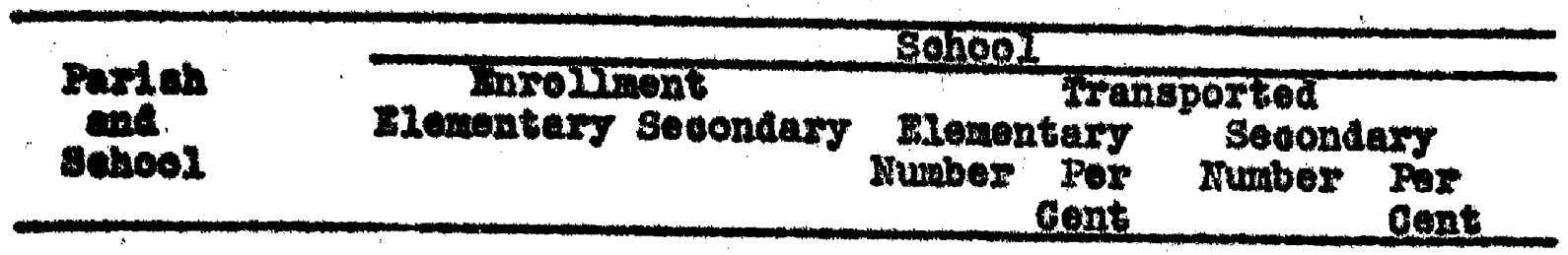

Ant Senoole;

thontrons

Bubad

7100

Euntea

Straboro

\section{Inooln Par1eh}

84

298

160

$-\infty$

388 40

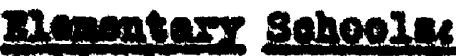
Ditros

Buriots spring:

Grove Rouds

cuibortom

noting

86

17

312

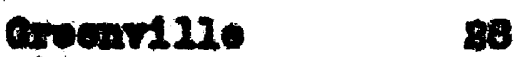

Bszareot 280

Dist

mopunde

xest

Yopral springe 35

ron-Eopo-bcrias

Robres

abios

Entar anoro

Thenn

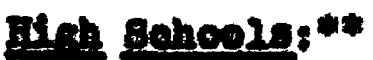

Dowing spetses

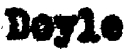

Feneh sott2uent

Folaen

In onk

Exropas

Evelngetela

Eaver

174
184
65
189

60

189

$\begin{array}{rrrr}330 & 90.6 & 144 & 82.8 \\ 168 & 59.5 & 108 & 88.3 \\ 155 & 96.9 & 68 & 98.4 \\ 869 & 88.0 & 889 & 66.6\end{array}$

$15 \quad 37.5$

844.4

1148.3

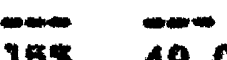

18549.0

75.0

$91 \quad 39.6$

$14 \quad 56.0$

1038.2

3566.0

$\begin{array}{ll}9 & 25.7 \\ 28 & 91.1 \\ 51 & 77.3 \\ 35 & 68.0 \\ 54 & 90.6\end{array}$

MTlngton Partah
809

485

258

198

167

241

804

274

388

116
814
58
58
64

69

45

188

182 doe $71.9 \%$

541 BE. $9 \mathrm{z}$

$231 \quad 74.52$

15863.72

$03 \quad 0.82$

$214 \quad 71.82$

$878 \quad 79.92$

26470.02

57676.82

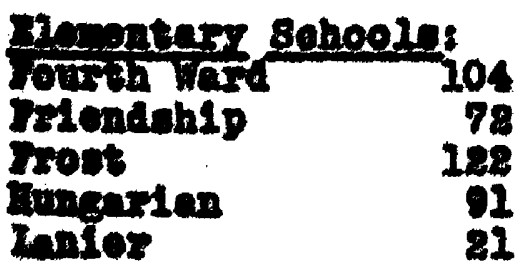

$\begin{aligned}-\infty & -\infty \\ -\infty & 63.0 \\ -\infty & -\infty\end{aligned}$


Tablo I (oontinued)

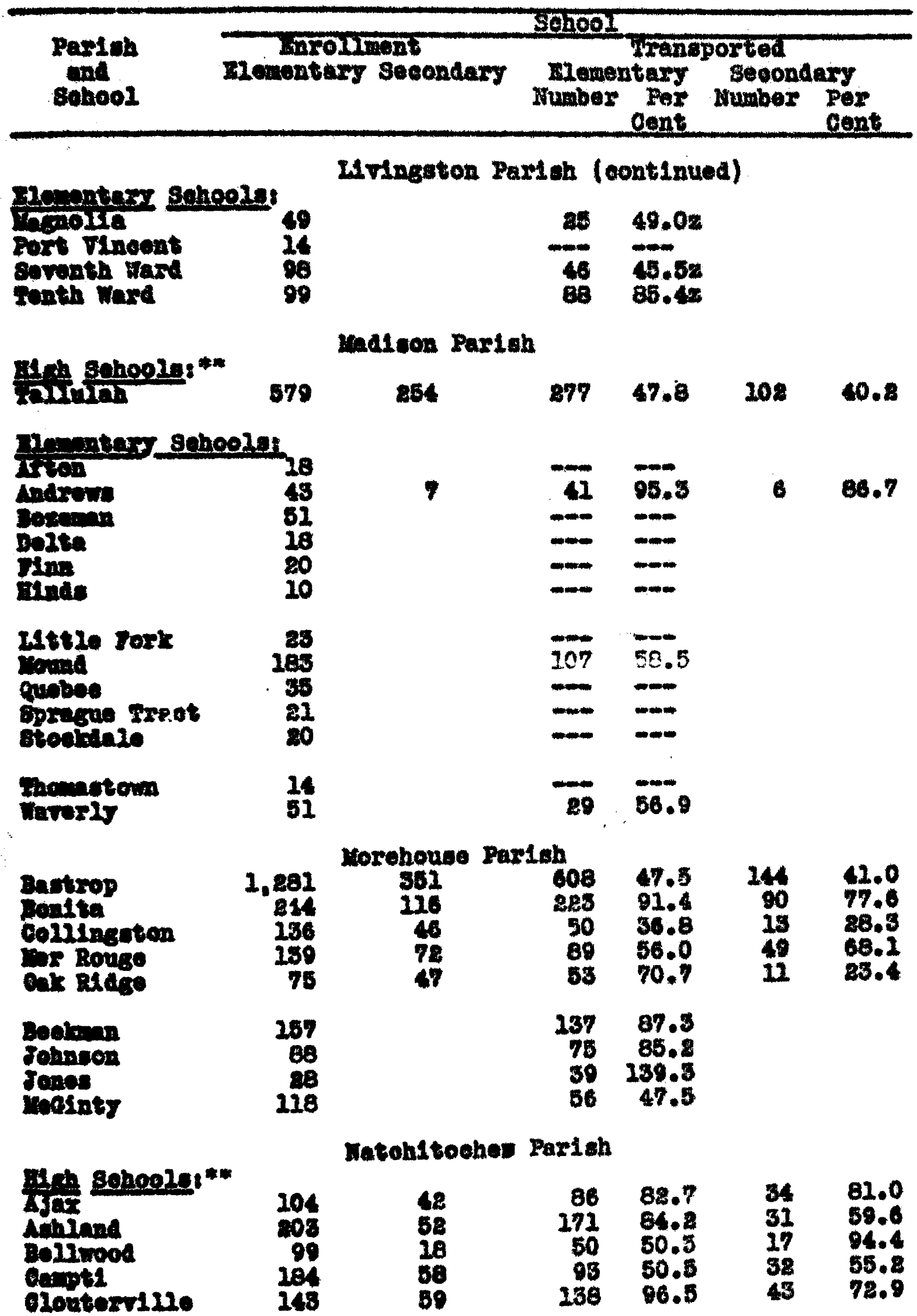


Table I (oontinued)

\begin{tabular}{|c|c|c|c|c|c|c|}
\hline \multirow[b]{2}{*}{$\begin{array}{l}\text { Partioh } \\
\text { and } \\
\text { Sohool }\end{array}$} & \multicolumn{6}{|c|}{ knrolument } \\
\hline & \multicolumn{2}{|c|}{$\begin{array}{l}\text { Knrol } \\
\text { Mloment }\end{array}$} & \multicolumn{2}{|c|}{$\begin{array}{c}\text { mimengr } \\
\text { Number Per } \\
\text { Cent } \\
\end{array}$} & $\begin{array}{l}\text { ported } \\
\text { second } \\
\text { number }\end{array}$ & $\begin{array}{l}\text { ary } \\
\text { Pex } \\
\text { Cont }\end{array}$ \\
\hline & & Natohitoohea & \multicolumn{3}{|c|}{ Parish (oontinued) } & \\
\hline $\begin{array}{l}\text { Diom-Alphe } \\
\operatorname{ang}\end{array}$ & $\begin{array}{l}217 \\
104 \\
158 \\
188 \\
247\end{array}$ & $\begin{array}{l}74 \\
38 \\
58 \\
58 \\
48\end{array}$ & $\begin{array}{r}198 \\
90 \\
188 \\
128 \\
118\end{array}$ & $\begin{array}{l}91.7 \\
68.5 \\
77.4 \\
65.5 \\
80.5\end{array}$ & $\begin{array}{l}57 \\
32 \\
45 \\
32 \\
38\end{array}$ & $\begin{array}{l}79.0 \\
01.4 \\
81.8 \\
50.4 \\
82.6\end{array}$ \\
\hline $\begin{array}{l}10 \\
1110 \\
\text { ookes } \\
\text { al } \\
x\end{array}$ & $\begin{array}{l}218 \\
274 \\
150 \\
154\end{array}$ & $\begin{array}{r}100 \\
304 \\
116 \\
60\end{array}$ & 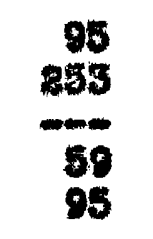 & $\begin{array}{l}84.8 \\
92.3 \\
39.3 \\
61.7\end{array}$ & $\begin{array}{r}38 \\
69 \\
136 \\
81 \\
28\end{array}$ & $\begin{array}{l}89.7 \\
65.7 \\
43.5 \\
69.8 \\
46.7\end{array}$ \\
\hline Dobeline & 238 & 61 & 201 & 86.6 & 47 & 77.0 \\
\hline \multicolumn{3}{|c|}{ 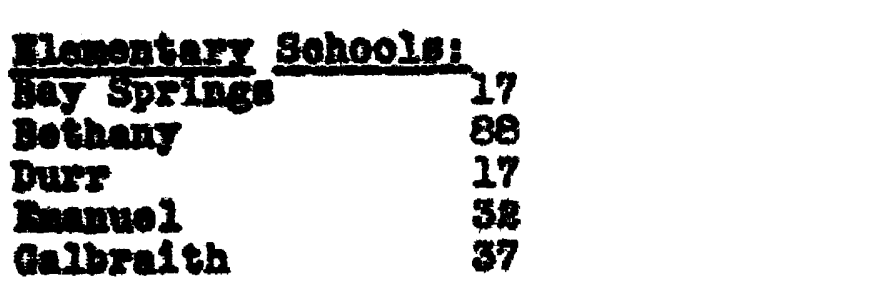 } & $-\frac{-\infty}{-17}$ & $\frac{11.8}{18.9}$ & & \\
\hline $\ln \operatorname{lng} 8$ & $\begin{array}{r}28 \\
686 \\
79 \\
48 \\
87\end{array}$ & & $\begin{array}{r}569 \\
58 \\
48 \\
--\end{array}$ & $\begin{array}{r}68.8 \\
67.1 \\
100.0 \\
-\infty\end{array}$ & & \\
\hline 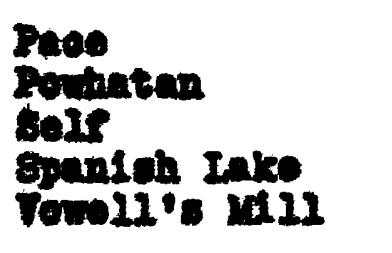 & $\begin{array}{r}54 \\
236 \\
24 \\
68 \\
70\end{array}$ & & $\frac{57}{92}$ & $\begin{array}{l}66.5 \\
67.6 \\
-5 \\
94.3\end{array}$ & & \\
\hline \multicolumn{7}{|c|}{ Ounohith Parlsh } \\
\hline 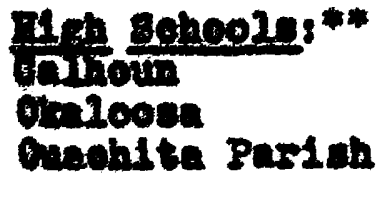 & $\begin{array}{l}830 \\
194 \\
605\end{array}$ & $\begin{array}{r}108 \\
.67 \\
1,480\end{array}$ & $\begin{array}{l}198 \\
185 \\
155\end{array}$ & $\begin{array}{l}92.6 \\
93.9 \\
25.6\end{array}$ & $\begin{array}{r}72 \\
67 \\
729\end{array}$ & $\begin{array}{r}90.0 \\
100.0 \\
51.3\end{array}$ \\
\hline 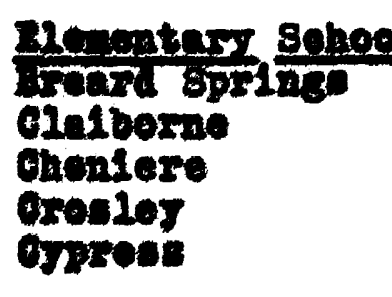 & $\begin{array}{r}188 \\
101 \\
101 \\
84 \\
1,027 \\
88\end{array}$ & & $\begin{array}{r}34 \\
21 \\
148 \\
74\end{array}$ & $\begin{array}{l}33.7 \\
25.0 \\
14.6 \\
89.8\end{array}$ & & \\
\hline Dren & 211 & 88 & 53 & 47.7 & 17 & 73.8 \\
\hline
\end{tabular}


Tab1e I (cont1nued)

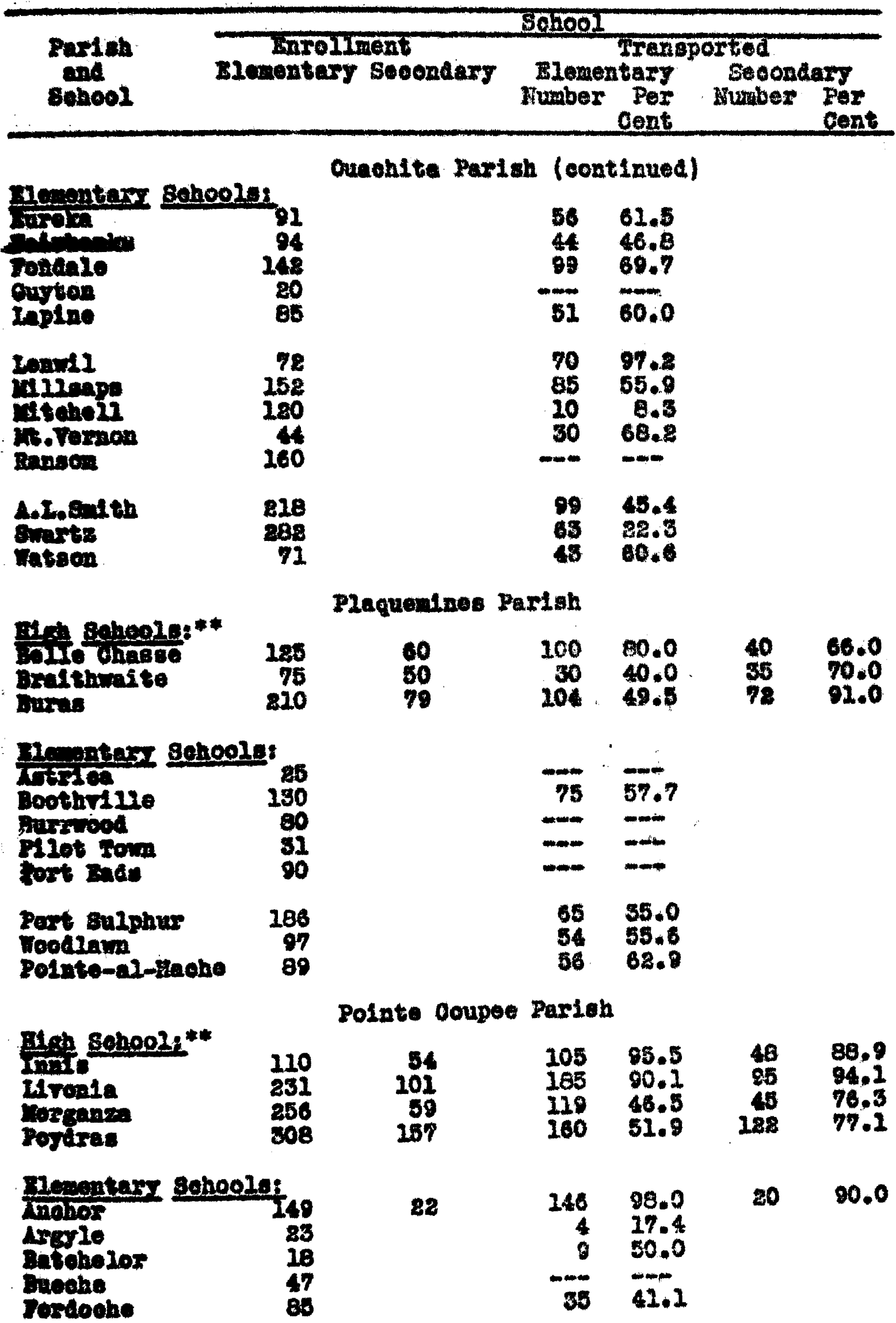


Table I (oontinued)

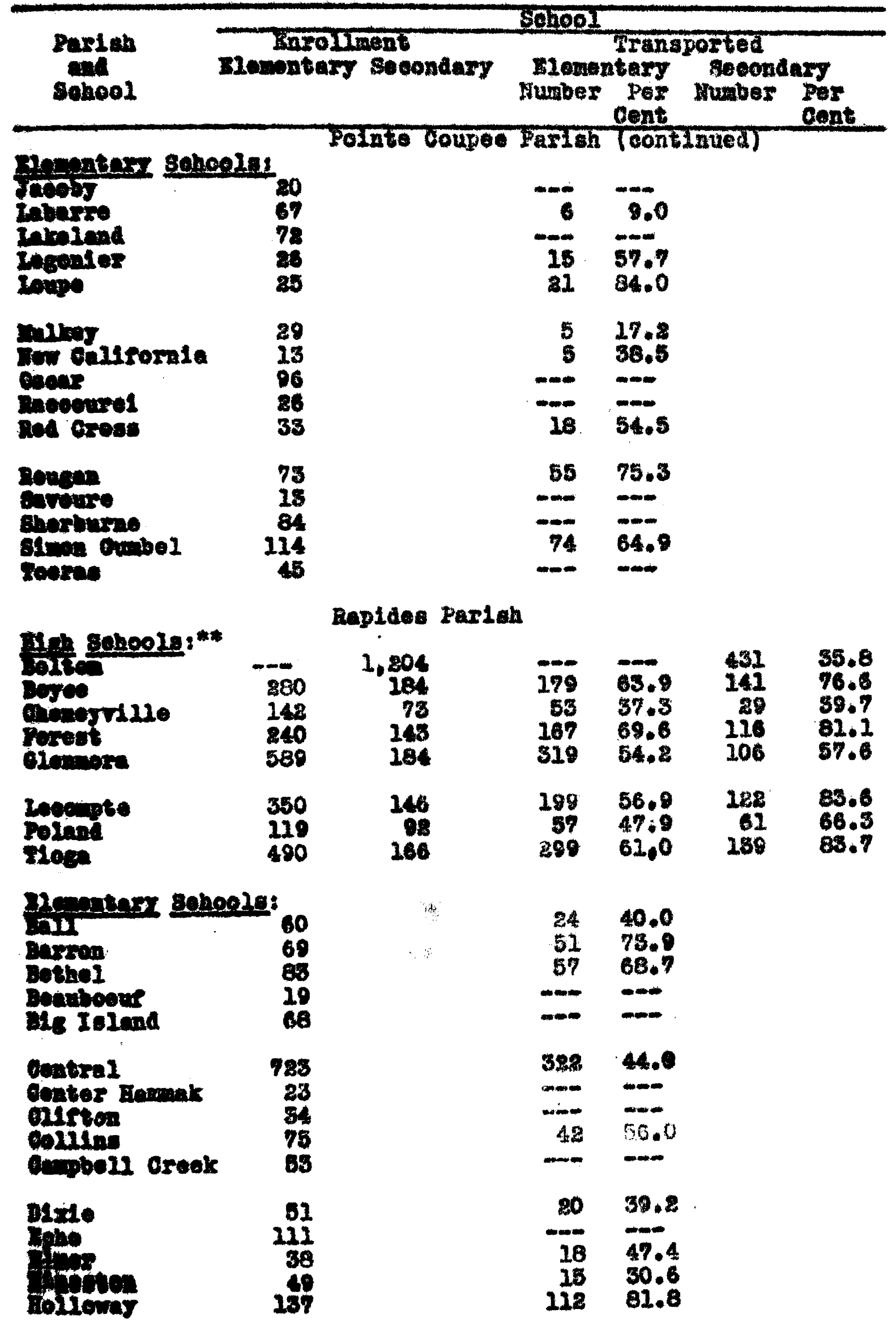


TableI (oontinued)

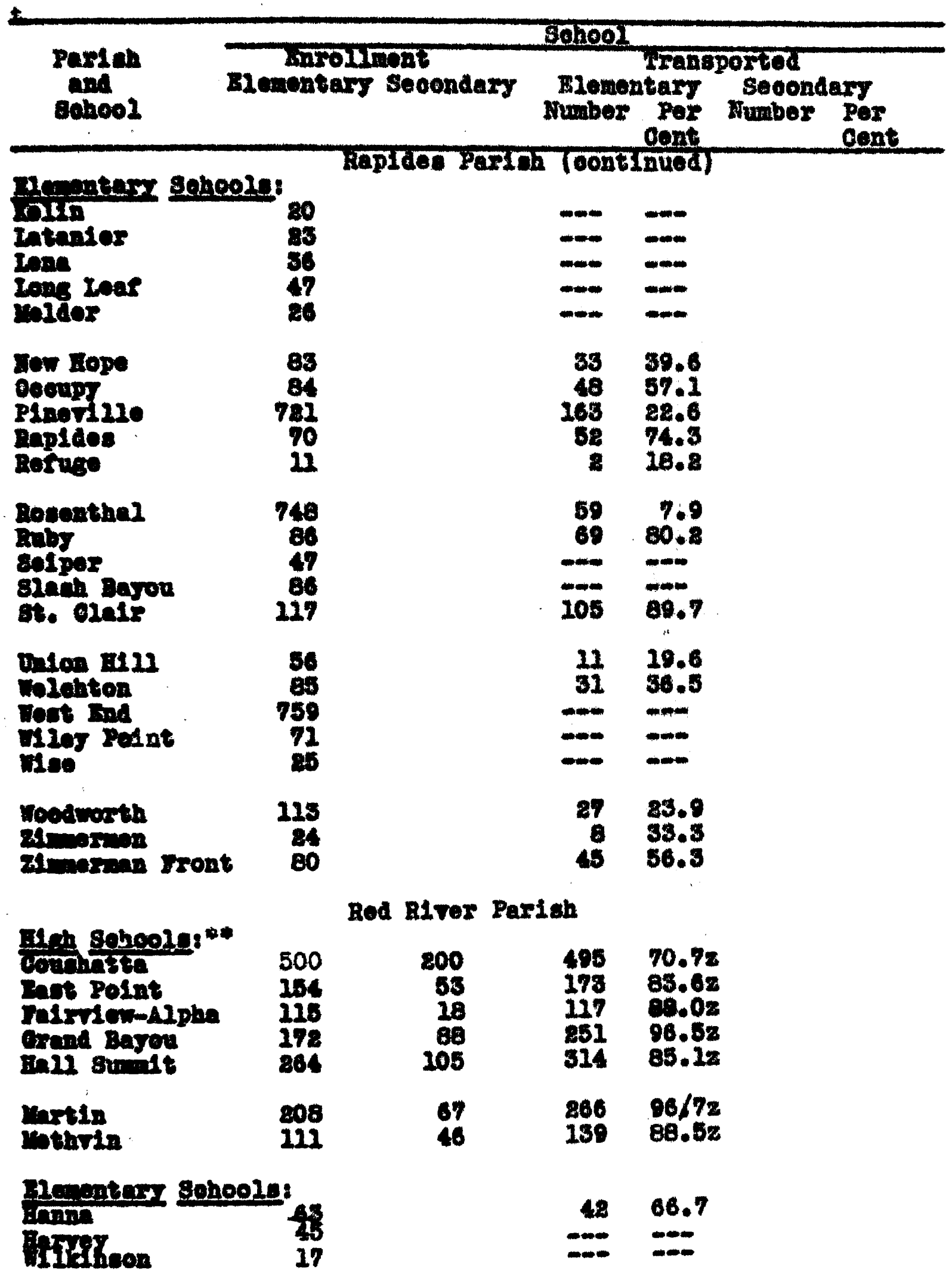


Table I (eontinued)

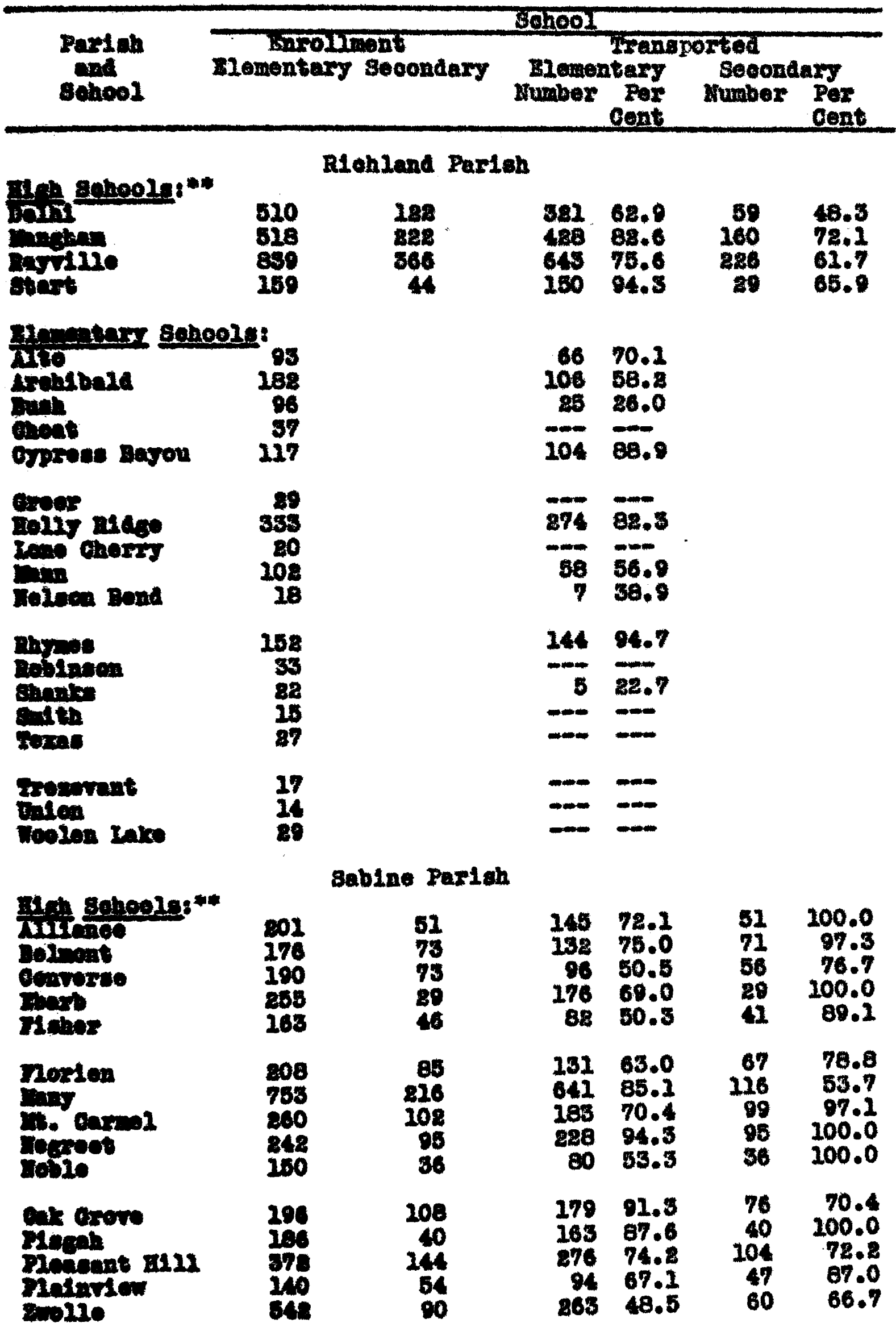


Table I (oontinued)

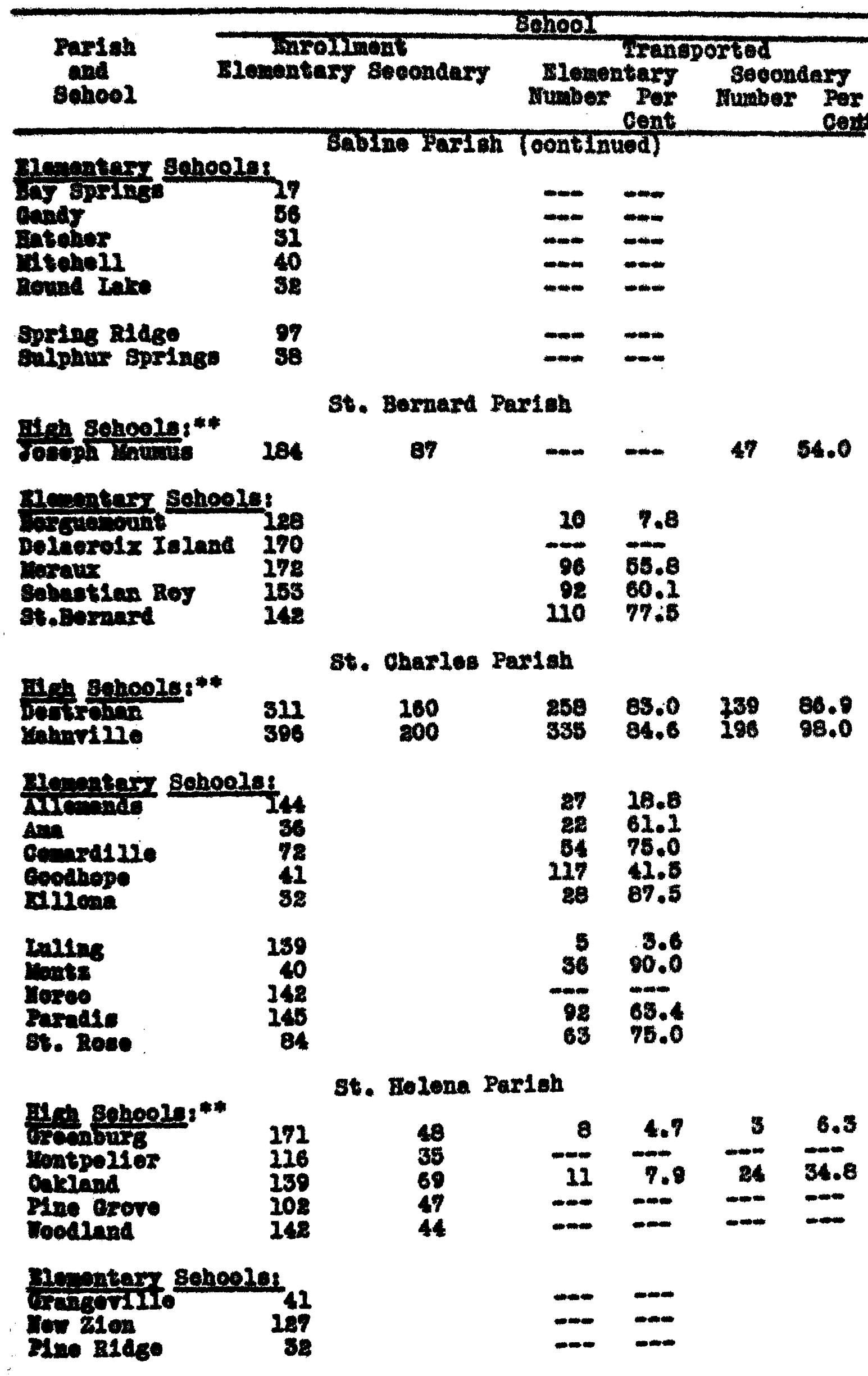


Tablo I (oontinued)

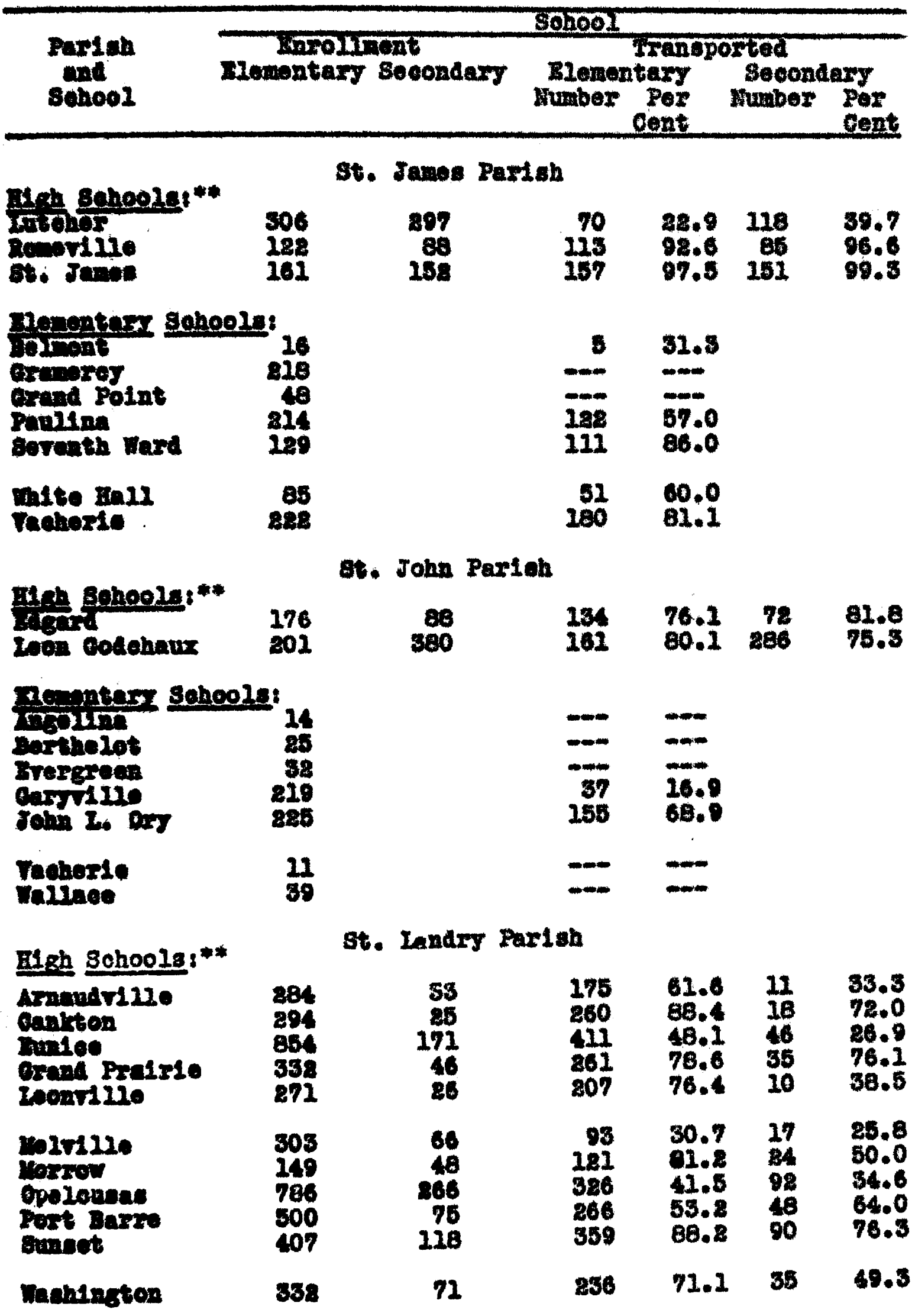


Table I (continued)

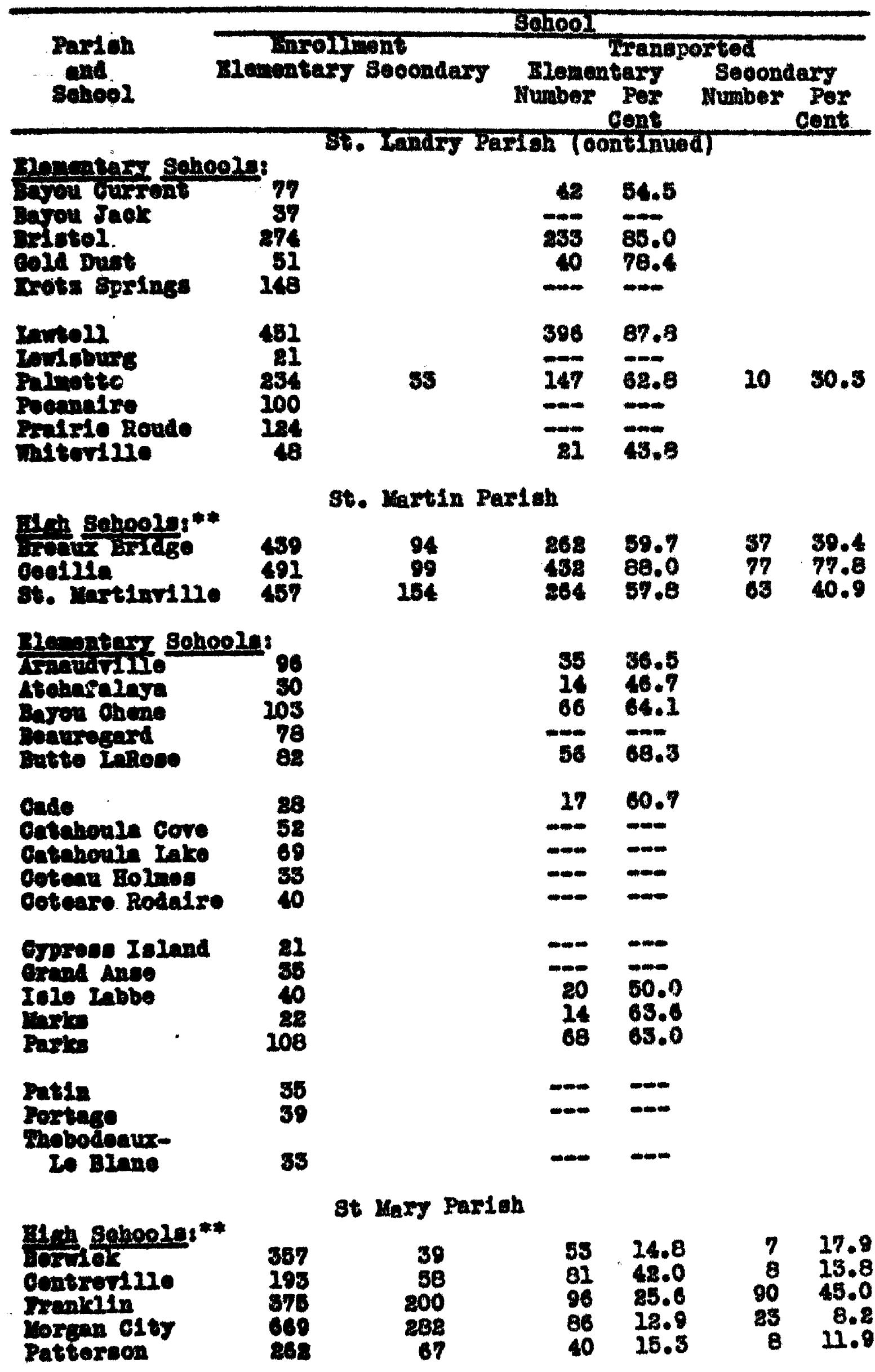


Table I (oontinued)

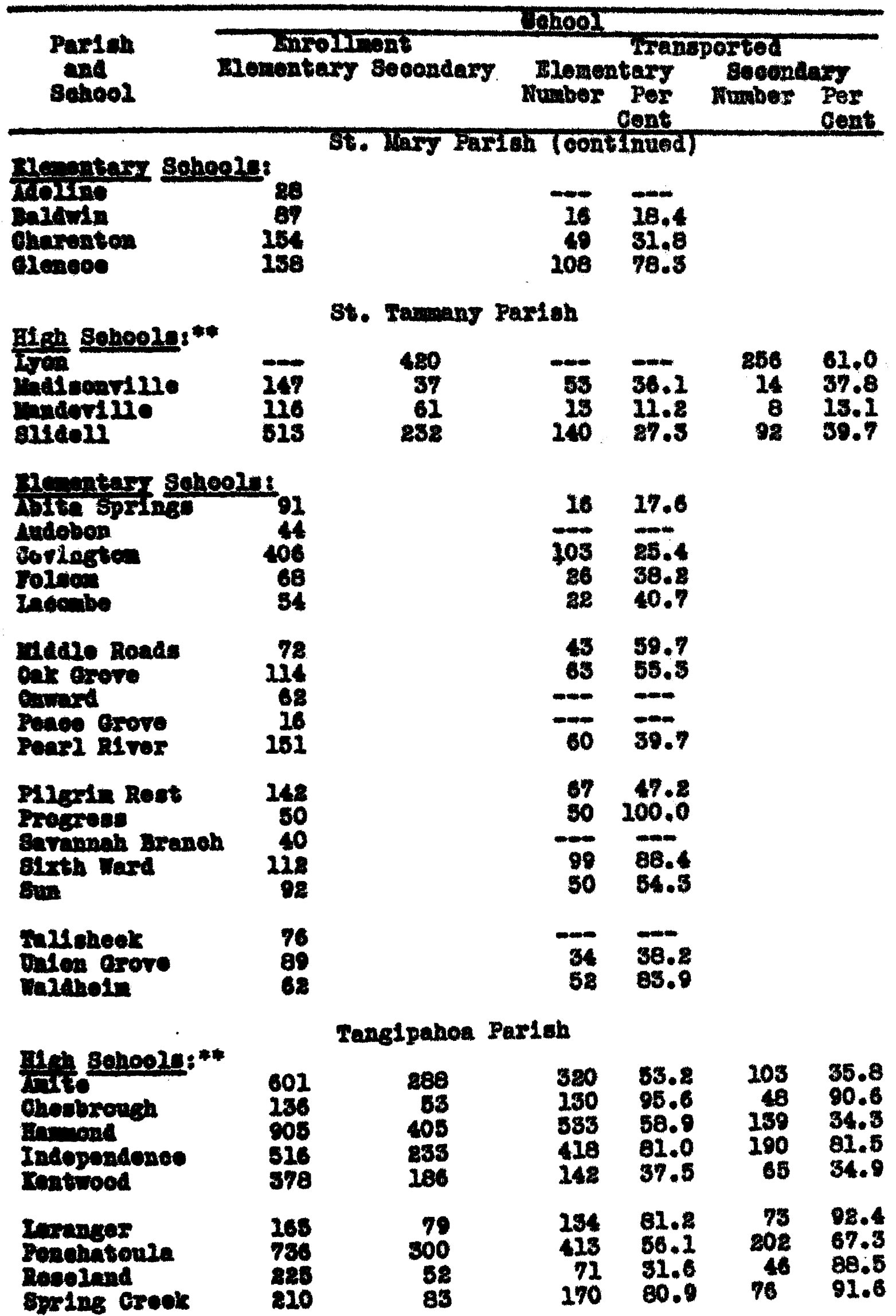


Table I (oont1nued)

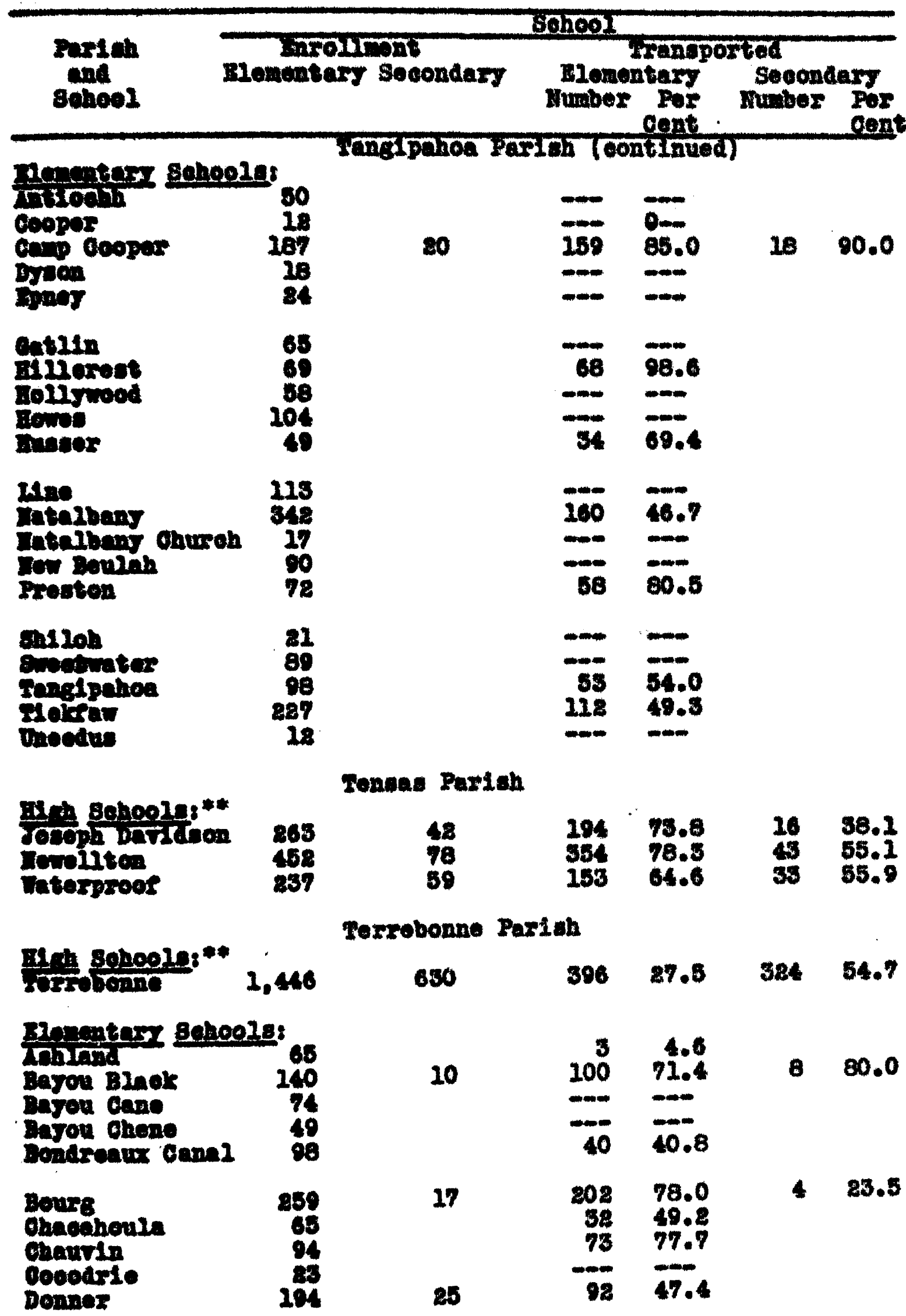


Table I (continued)

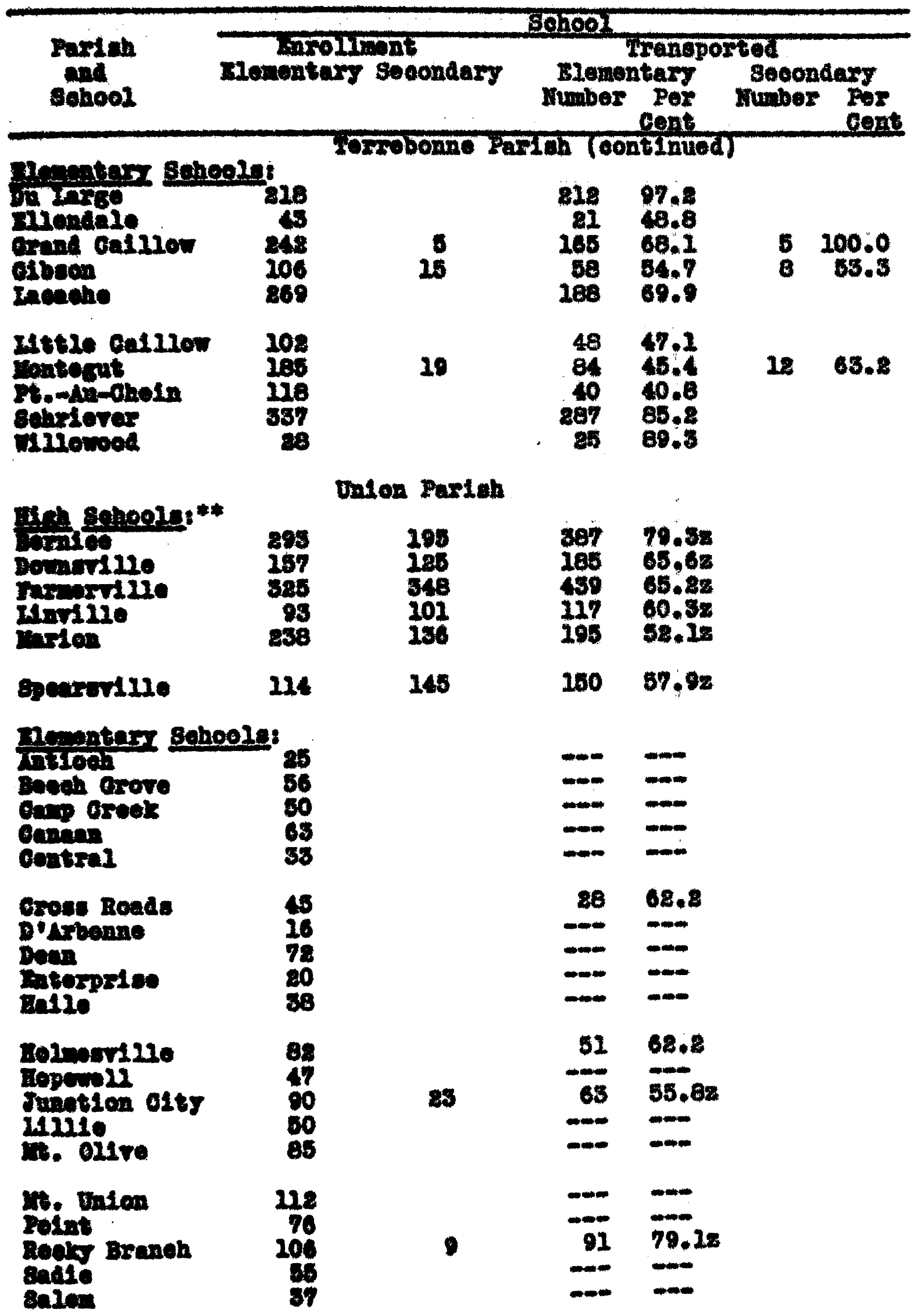


Table I (continuod)

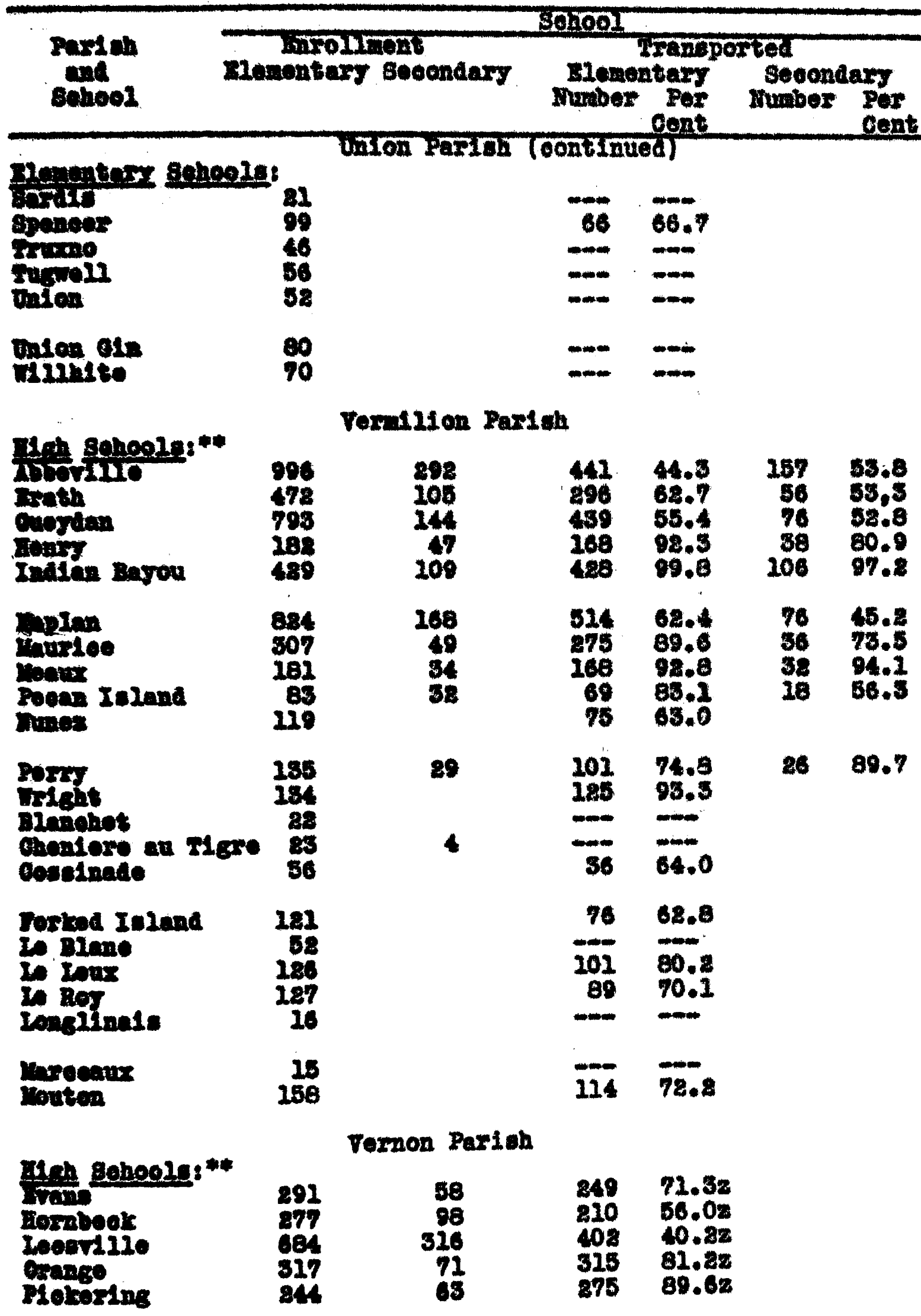


Fable I (eontinued)

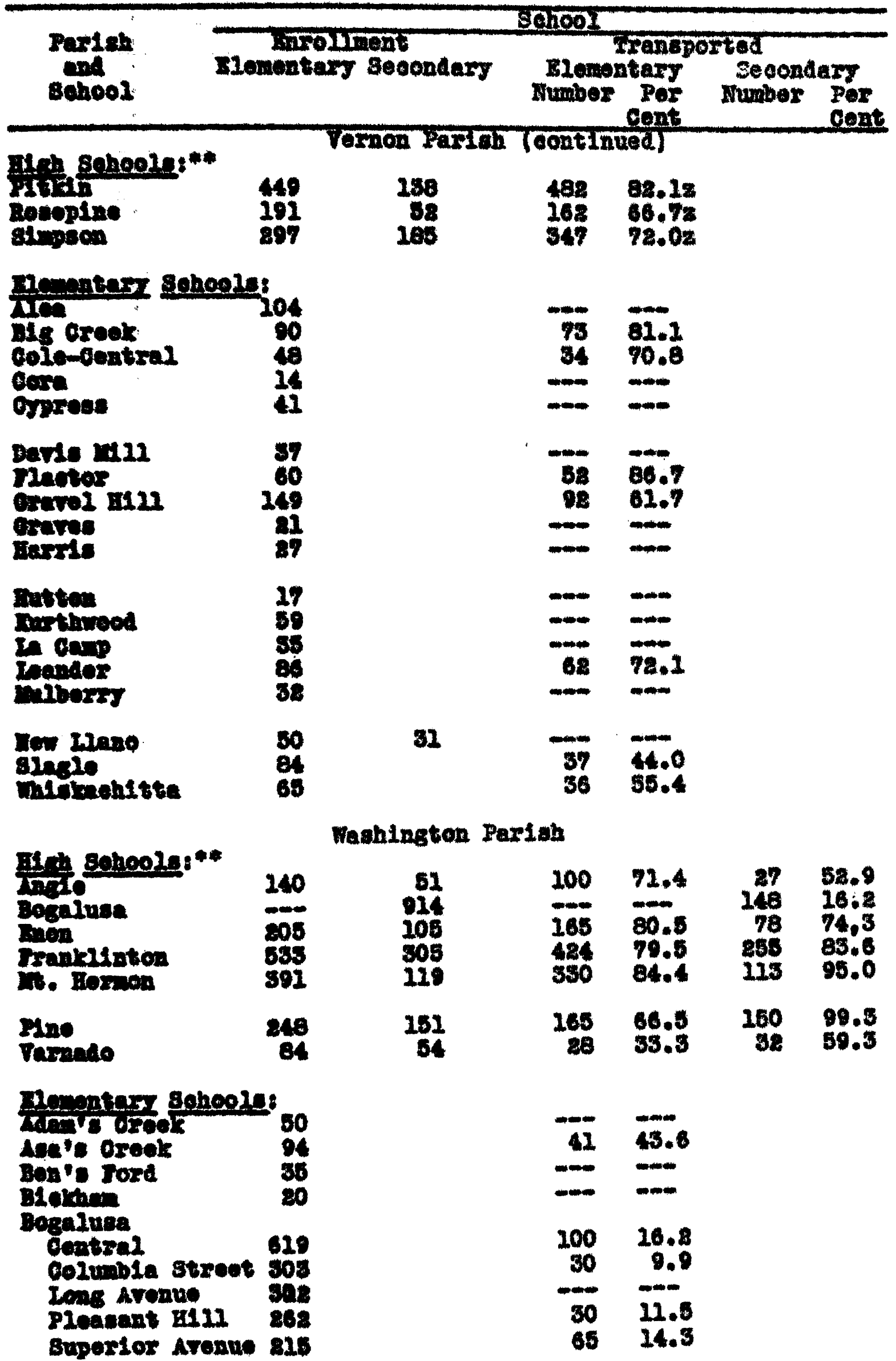


Tabie I (eontinusd)

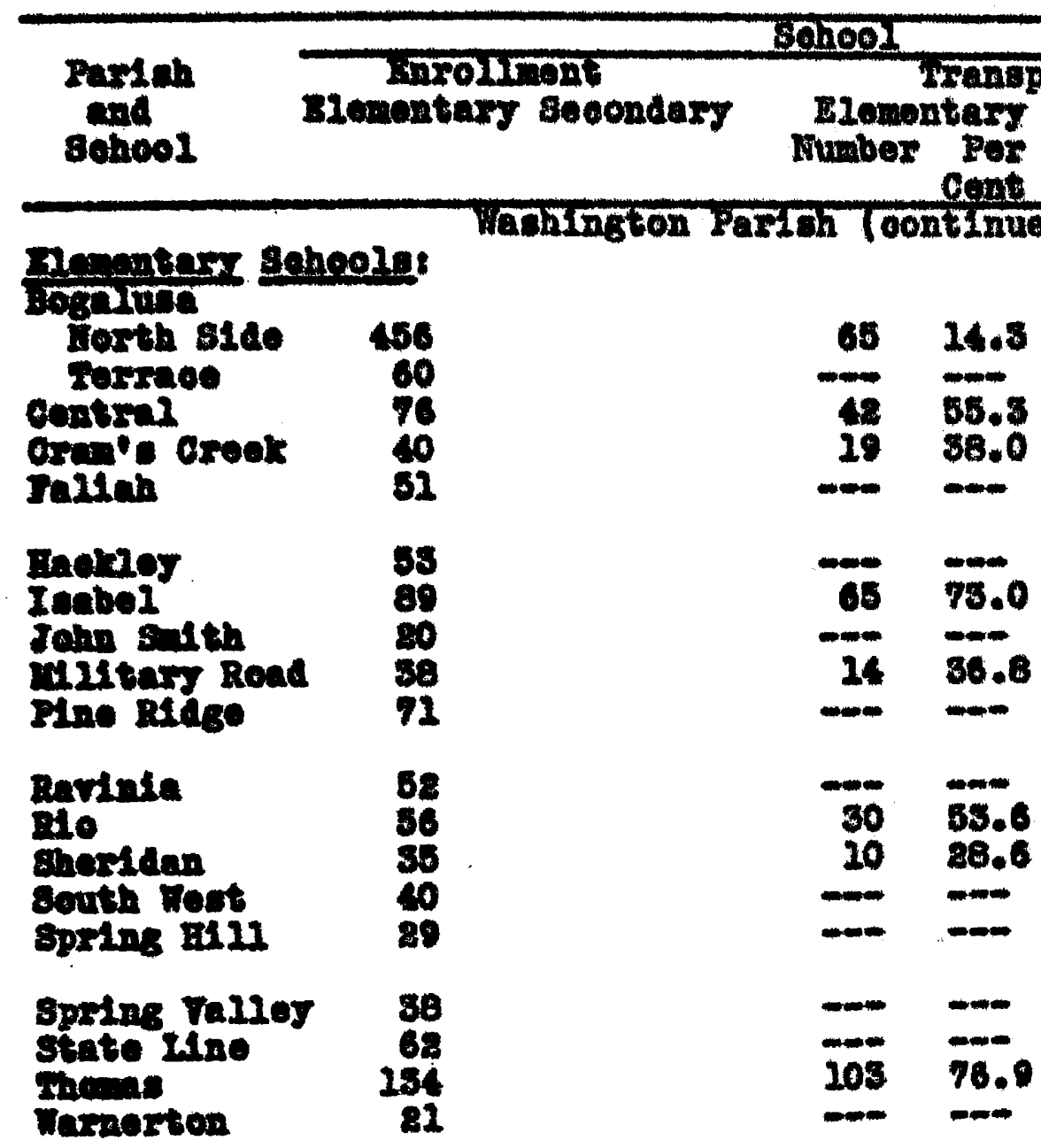

\section{Bish shooly** cexton ralloy Deriline Debborit Droxgeen Earin tinasen. \\ saropta \\ Buengaloo \\ 810205 \\ Eprins $\mathrm{EI} 21$}

Wobstor Paxleh

311
211
110
184
180
878

198

813

207

471

\begin{tabular}{|c|c|c|c|}
\hline $\begin{array}{r}105 \\
57 \\
56 \\
49 \\
48 \\
889\end{array}$ & $\begin{array}{l}\frac{x}{x} \\
z \\
x \\
x\end{array}$ & $\begin{array}{l}x \\
x \\
x \\
x \\
x\end{array}$ & $\begin{array}{l}x \\
x \\
x \\
x \\
x\end{array}$ \\
\hline $\begin{array}{r}70 \\
70 \\
63 \\
100\end{array}$ & $\begin{array}{l}x \\
x \\
x\end{array}$ & $\begin{array}{l}x \\
x \\
x\end{array}$ & $\begin{array}{l}\mathbf{x} \\
\mathbf{x} \\
\mathbf{x}\end{array}$ \\
\hline
\end{tabular}

Wost Baton Rowge Parish

\begin{tabular}{|c|c|c|c|}
\hline $\begin{array}{l}124 \\
116\end{array}$ & $\begin{array}{r}86 \\
106\end{array}$ & $\begin{array}{l}56.6 \\
35.1\end{array}$ & $\begin{array}{l}80 \\
54\end{array}$ \\
\hline 28 & 62 & 65.8 & 11 \\
\hline
\end{tabular}


Table I (oontinued)

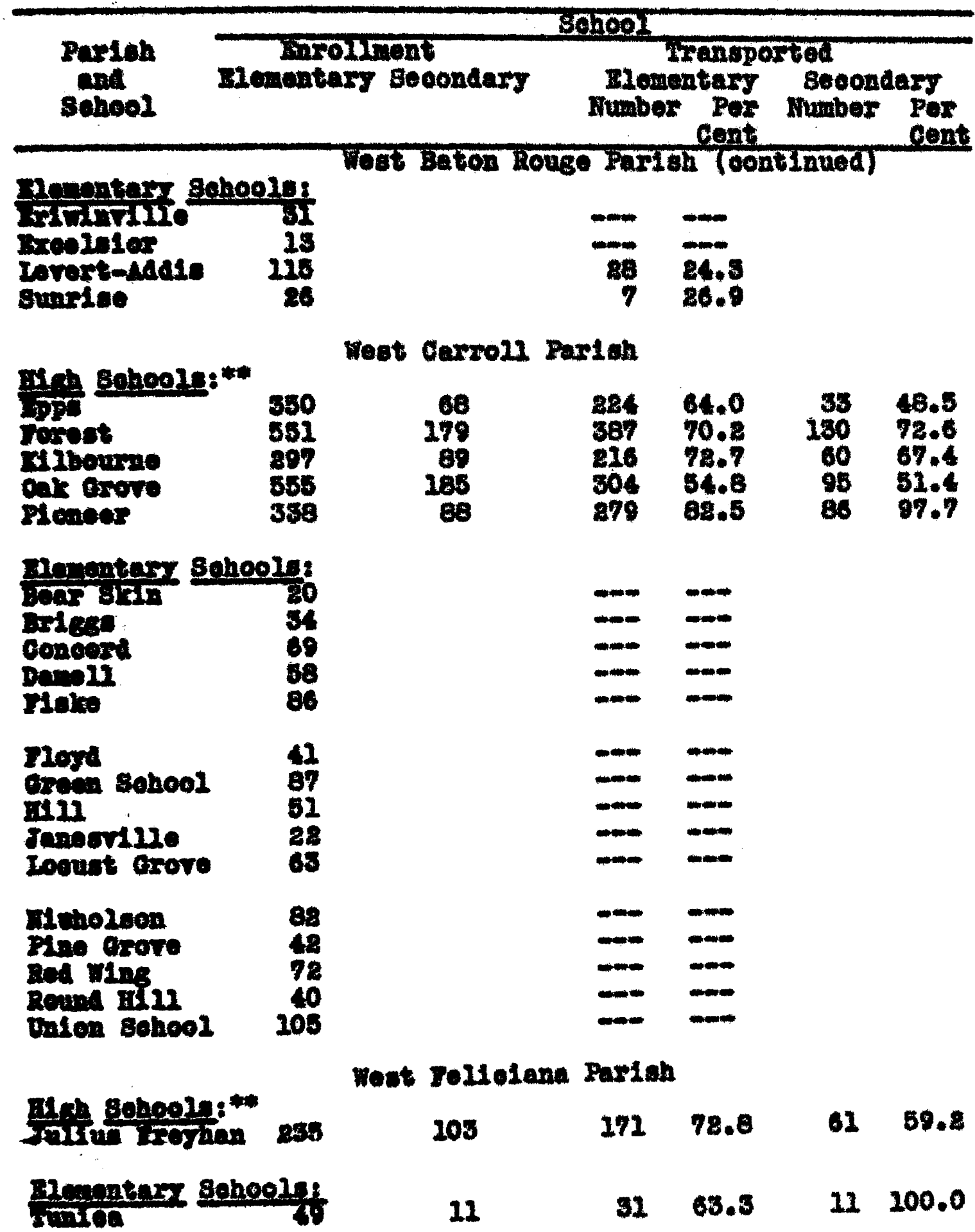


Gable I (eontinued)

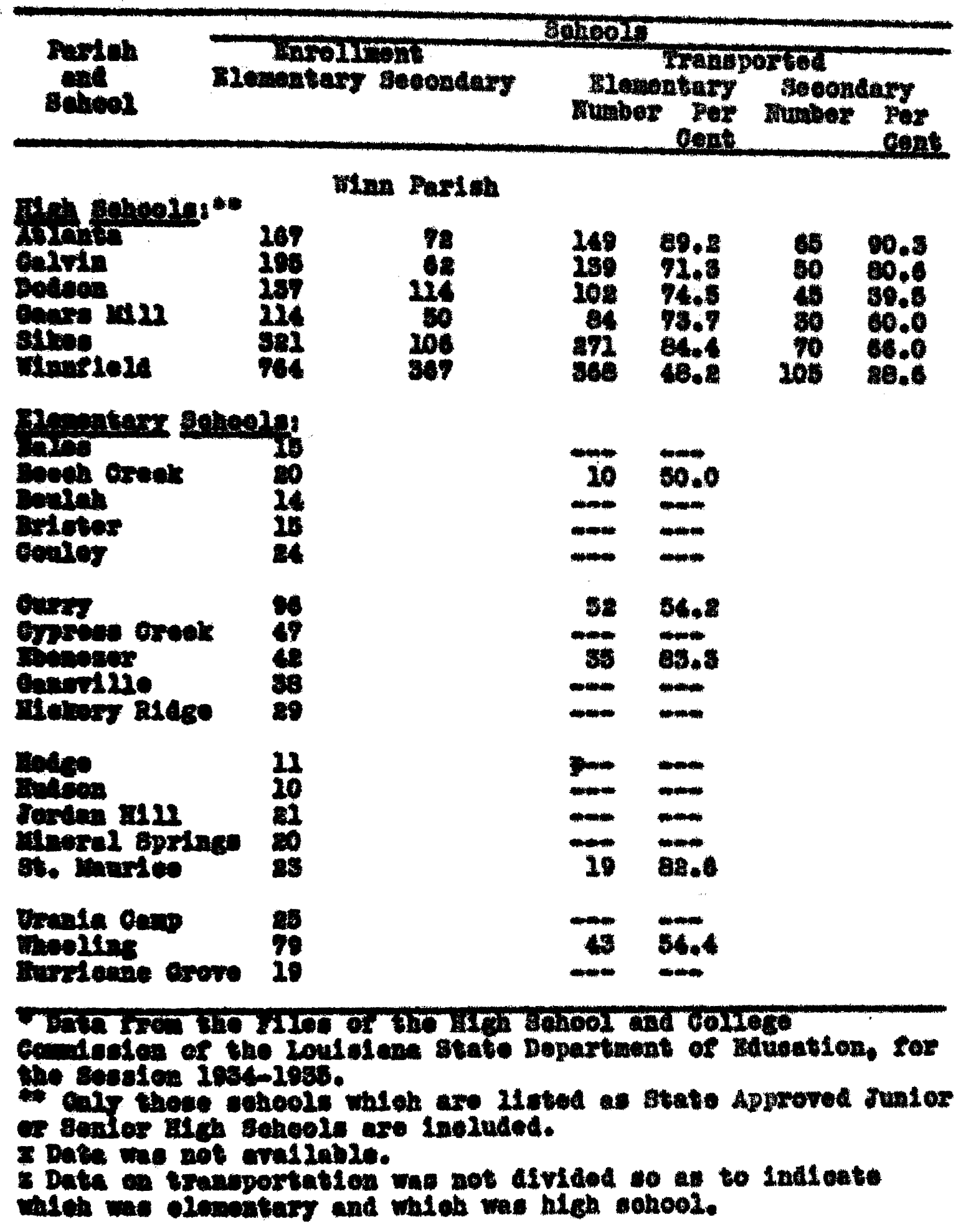




\section{Teble II}

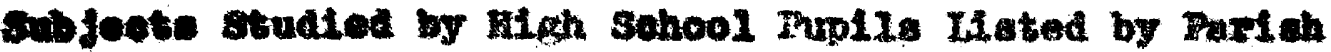
and Sobool

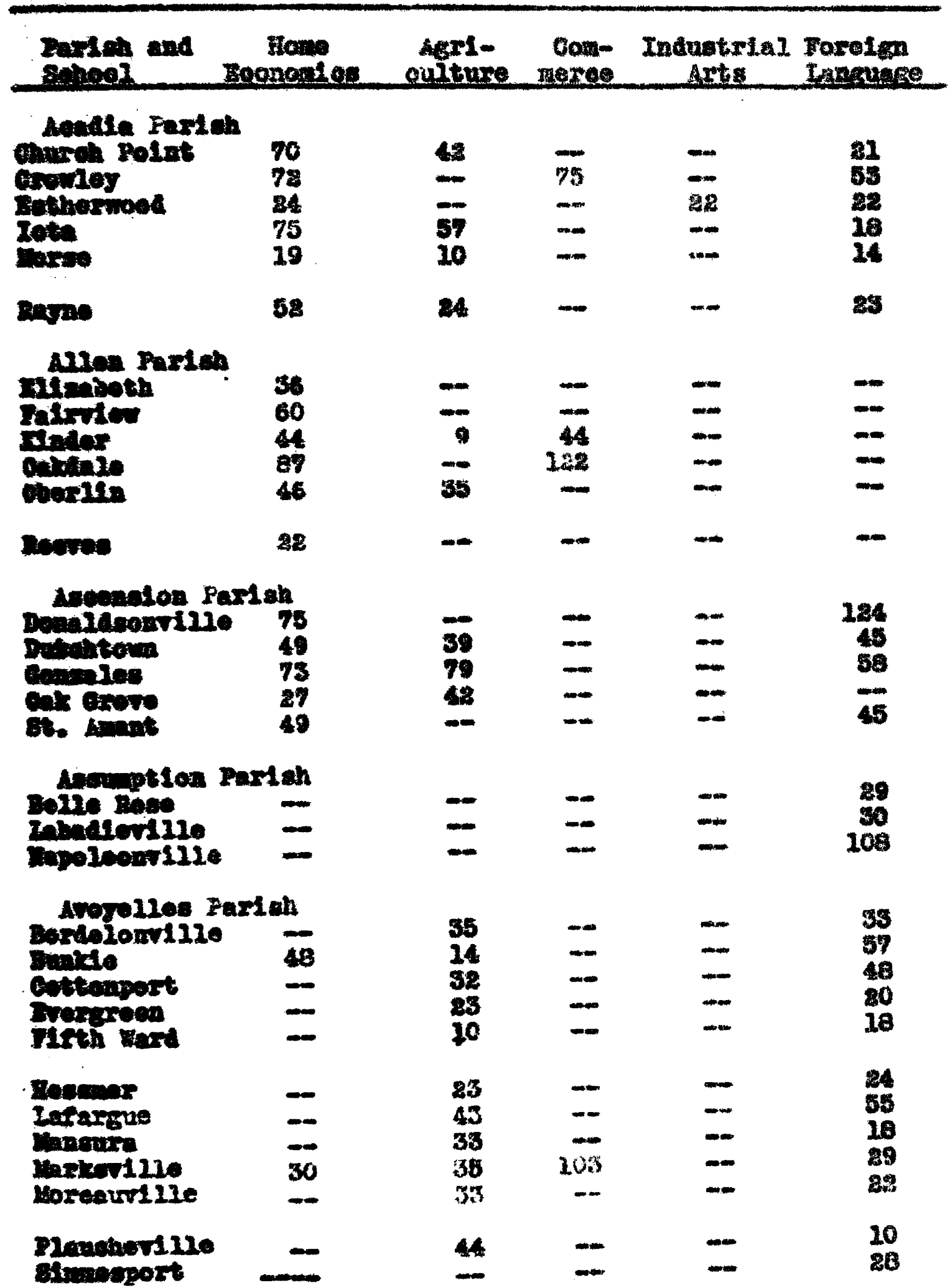


Tab10 II (oontinued)

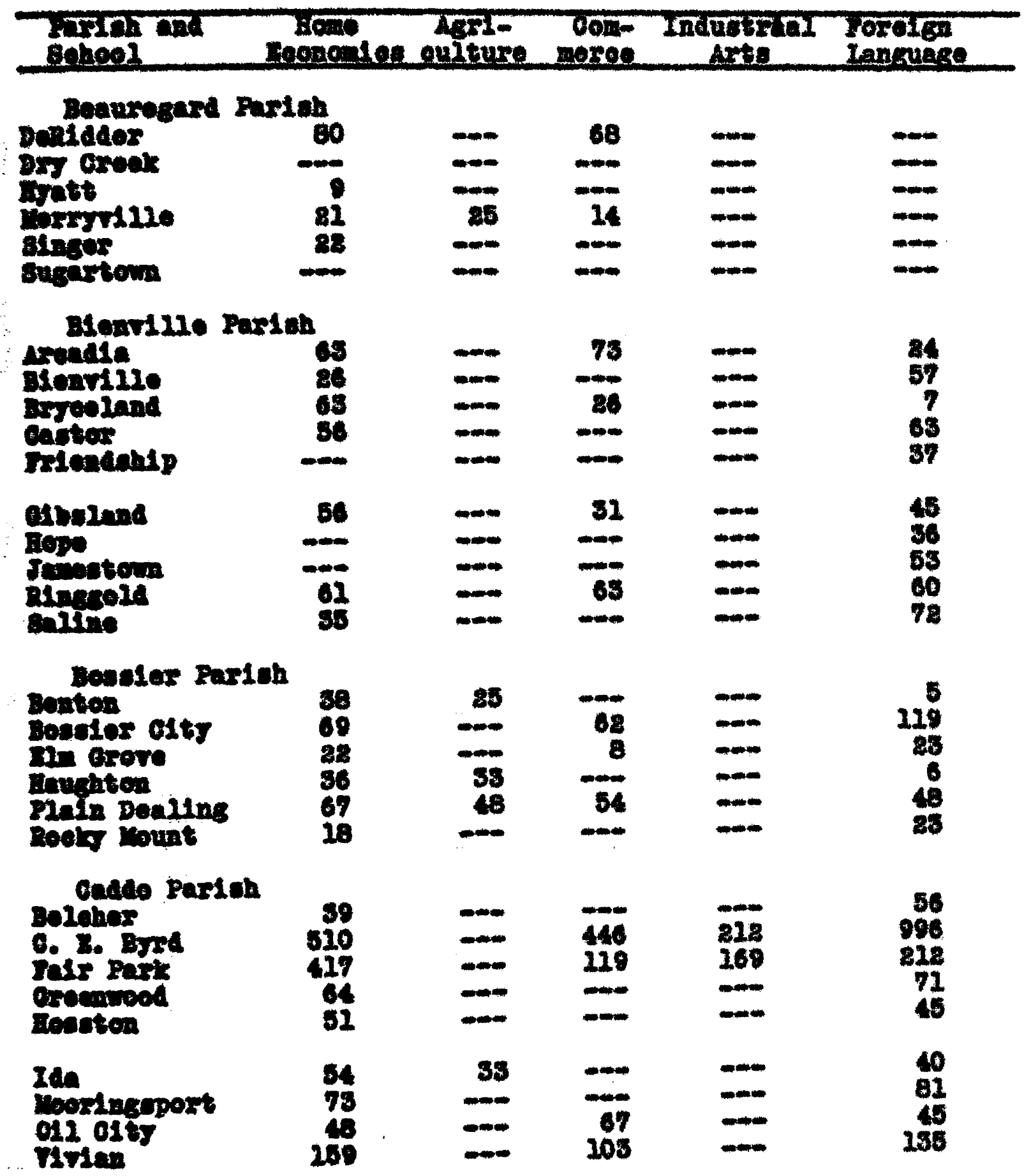


Table II (cont Inued)

\begin{tabular}{|c|c|c|c|c|c|}
\hline $\begin{array}{l}\text { ingon and } \\
\text { sohoel }\end{array}$ & $\begin{array}{l}\text { Hono } \\
\text { Iropontos }\end{array}$ & $\begin{array}{l}\text { Agri- } \\
\text { outure }\end{array}$ & $\begin{array}{l}\text { Com- } \\
\text { merce }\end{array}$ & $\begin{array}{c}\text { Industriar } \\
\text { Arts }\end{array}$ & $\begin{array}{l}\text { Toreige } \\
\text { Languase }\end{array}$ \\
\hline 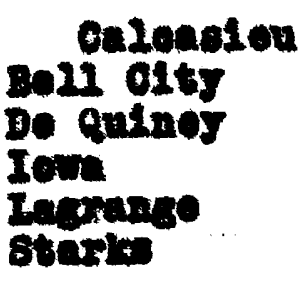 & $\begin{array}{r}\text { ardah } \\
69 \\
67 \\
49 \\
70 \\
87\end{array}$ & $=$ & $-\frac{98}{68}$ & $=$ & $\begin{array}{l}11 \\
15 \\
19 \\
42 \\
8\end{array}$ \\
\hline $\begin{array}{l}\text { Saphar } \\
\text { Tinbea } \\
\text { Dontink }\end{array}$ & $\begin{array}{l}78 \\
49 \\
31\end{array}$ & $=$ & $\begin{array}{r}86 \\
79 \\
-\end{array}$ & $=$ & $\begin{array}{l}12 \\
75 \\
30\end{array}$ \\
\hline 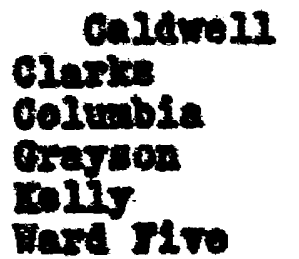 & $\begin{array}{r}\text { Widh } \\
68 \\
60 \\
50 \\
50\end{array}$ & $\frac{-\infty}{35}$ & $-\infty$ & $\begin{array}{r}58 \\
35 \\
36 \\
-\end{array}$ & $\begin{array}{r}20 \\
28 \\
-\infty \\
-\infty\end{array}$ \\
\hline
\end{tabular}

comoraa Partab oreole Data not avallable Orane Ohoniar Enolaterry

Catahoula Parish

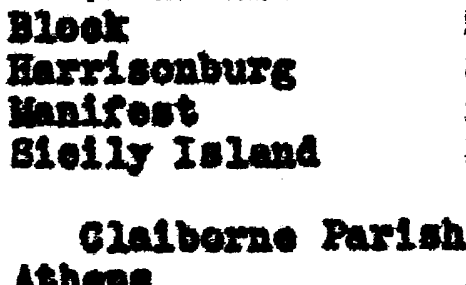

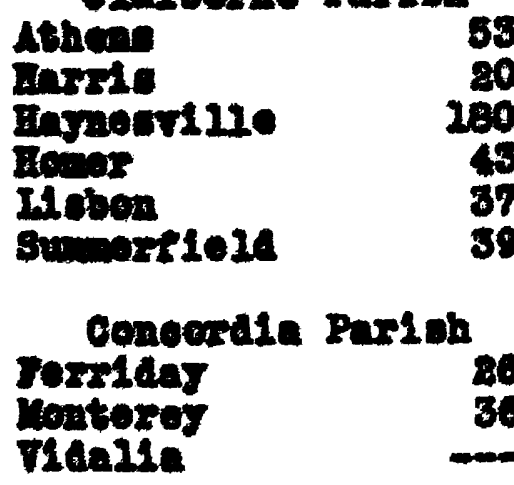

58

50

28

36

$=$

$-\infty$

$-\infty$

$-$

$-$

73

38

11

13

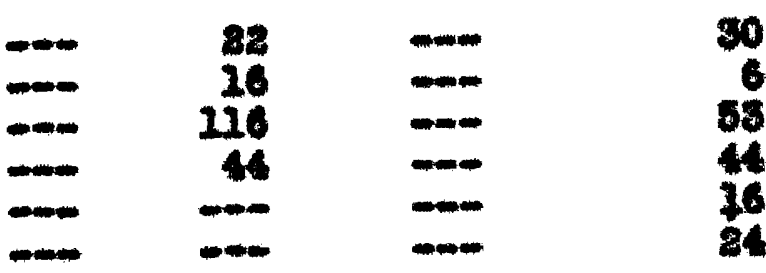

$\begin{array}{lll}31 & 37\end{array}$

$-\frac{18}{28}$ 
Table II (eontined)

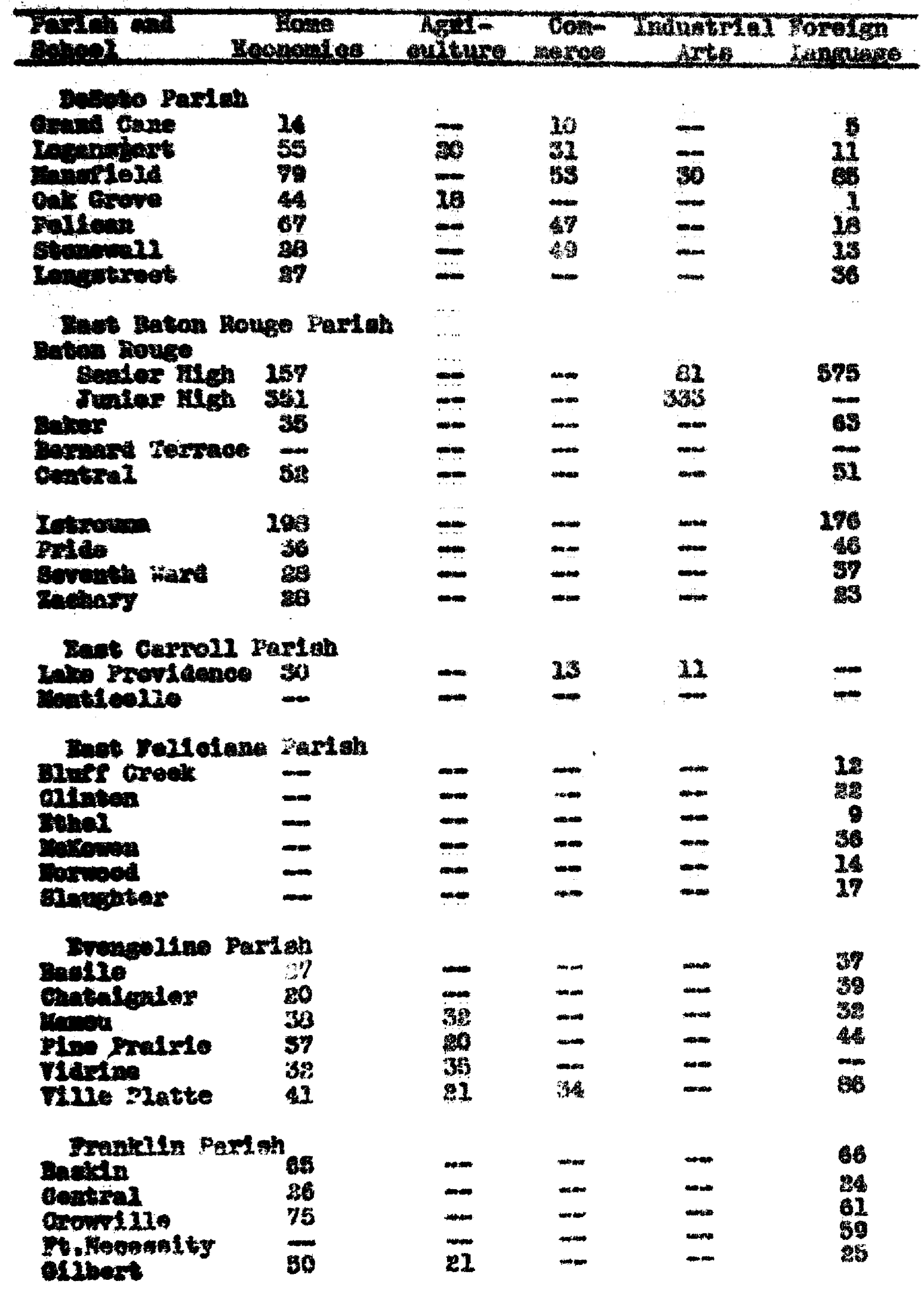


Table II (oontinuea)

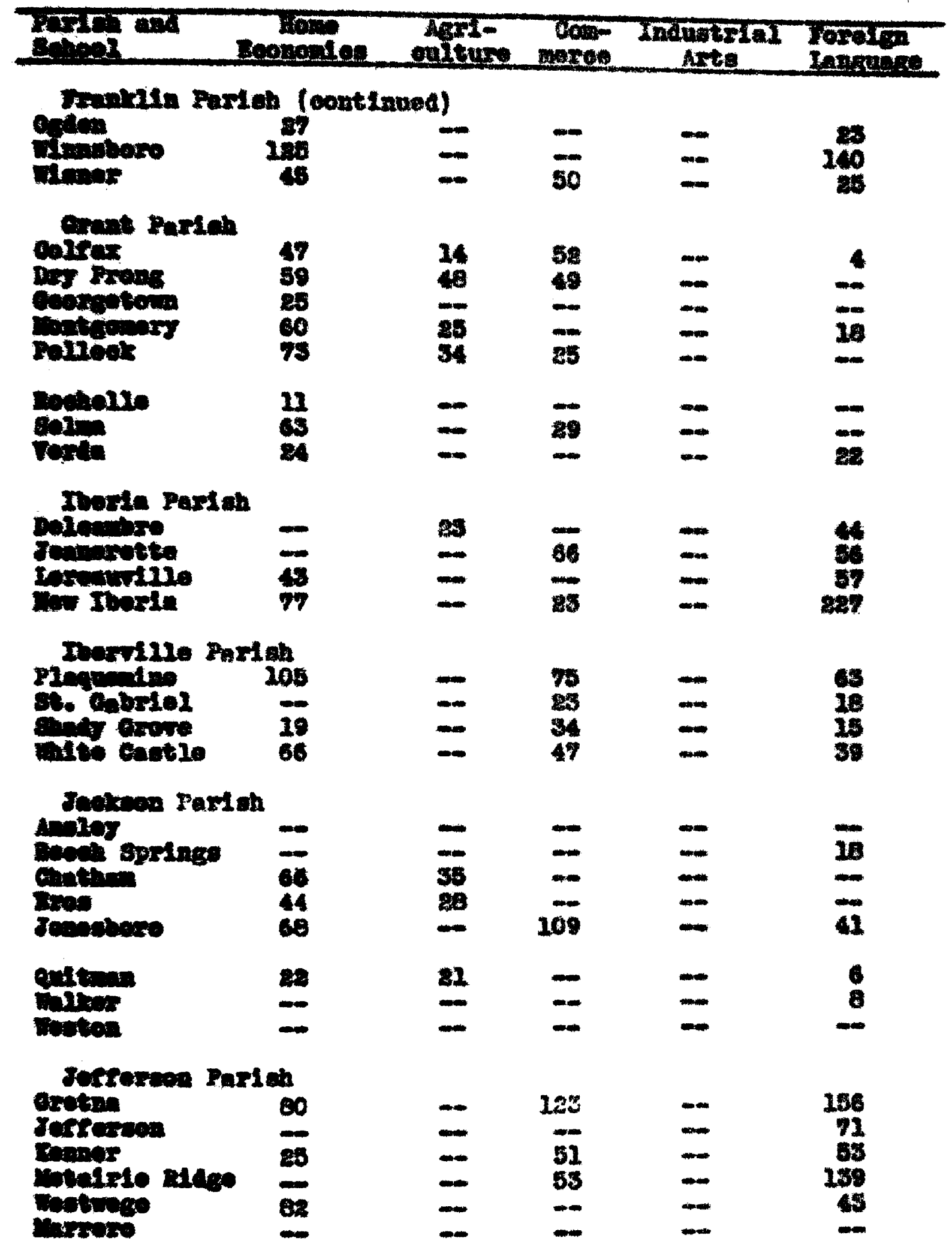


Pable II (eontinued)

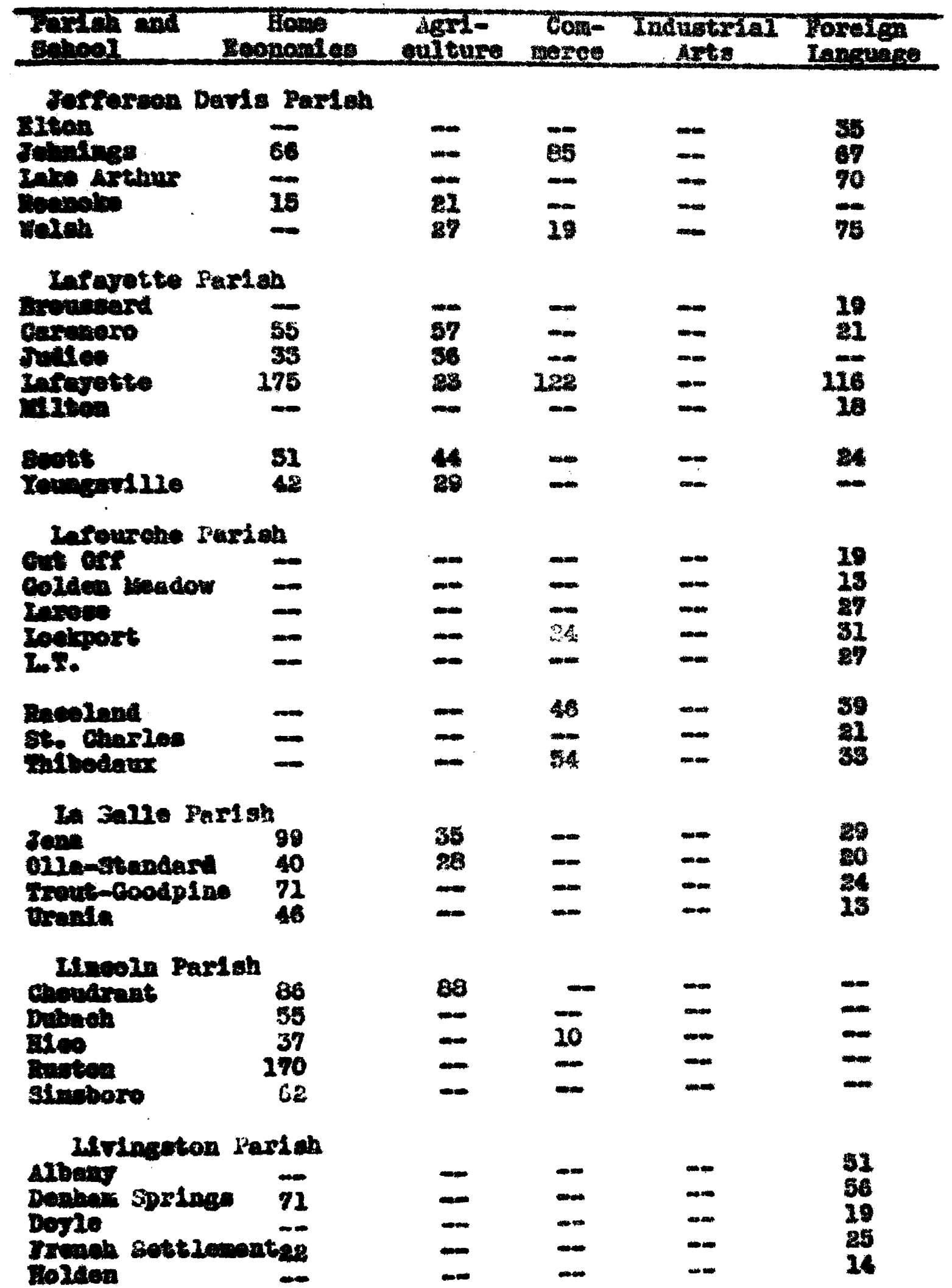


Tablo II (continual)

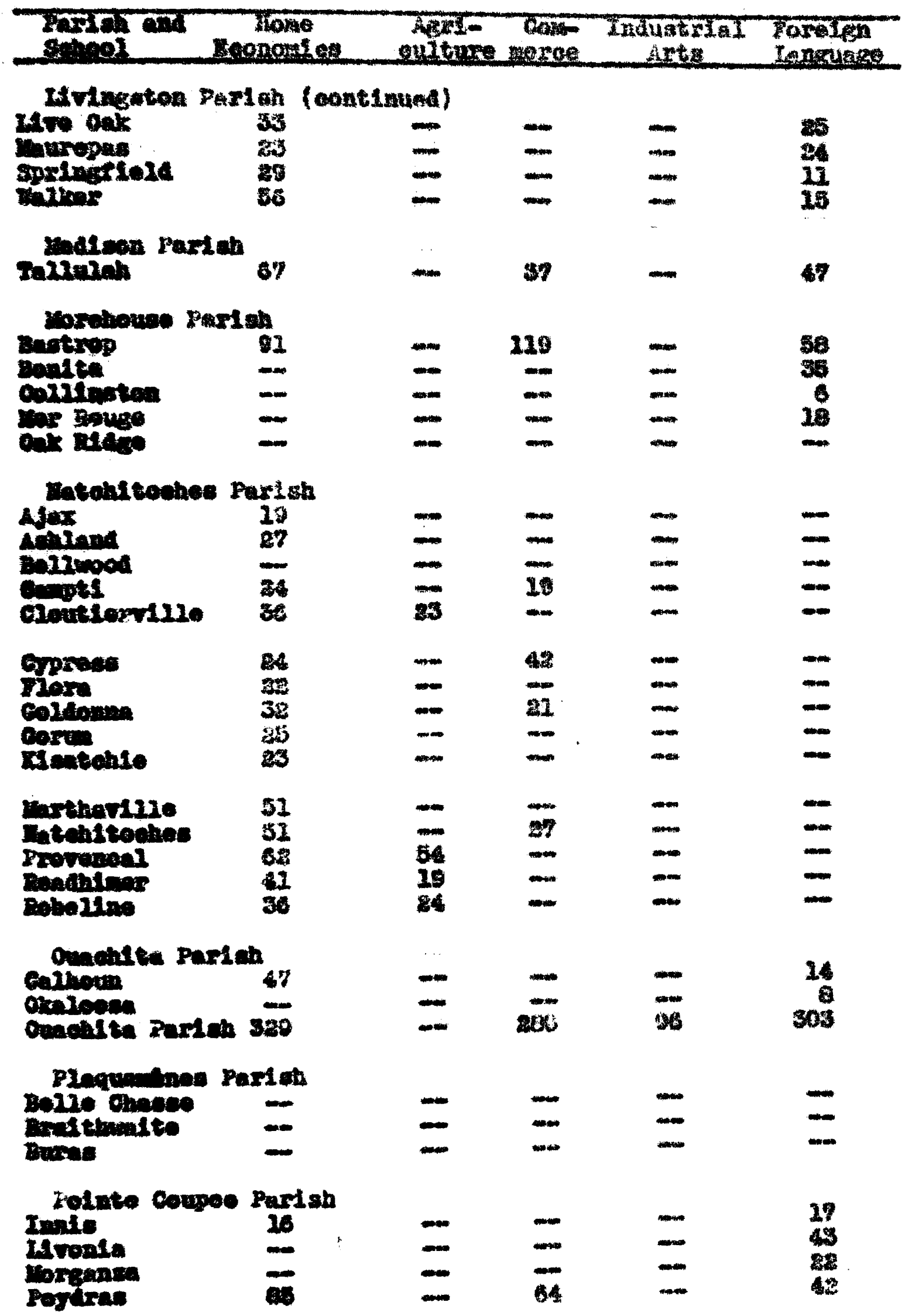


Trbie II (comtLated)

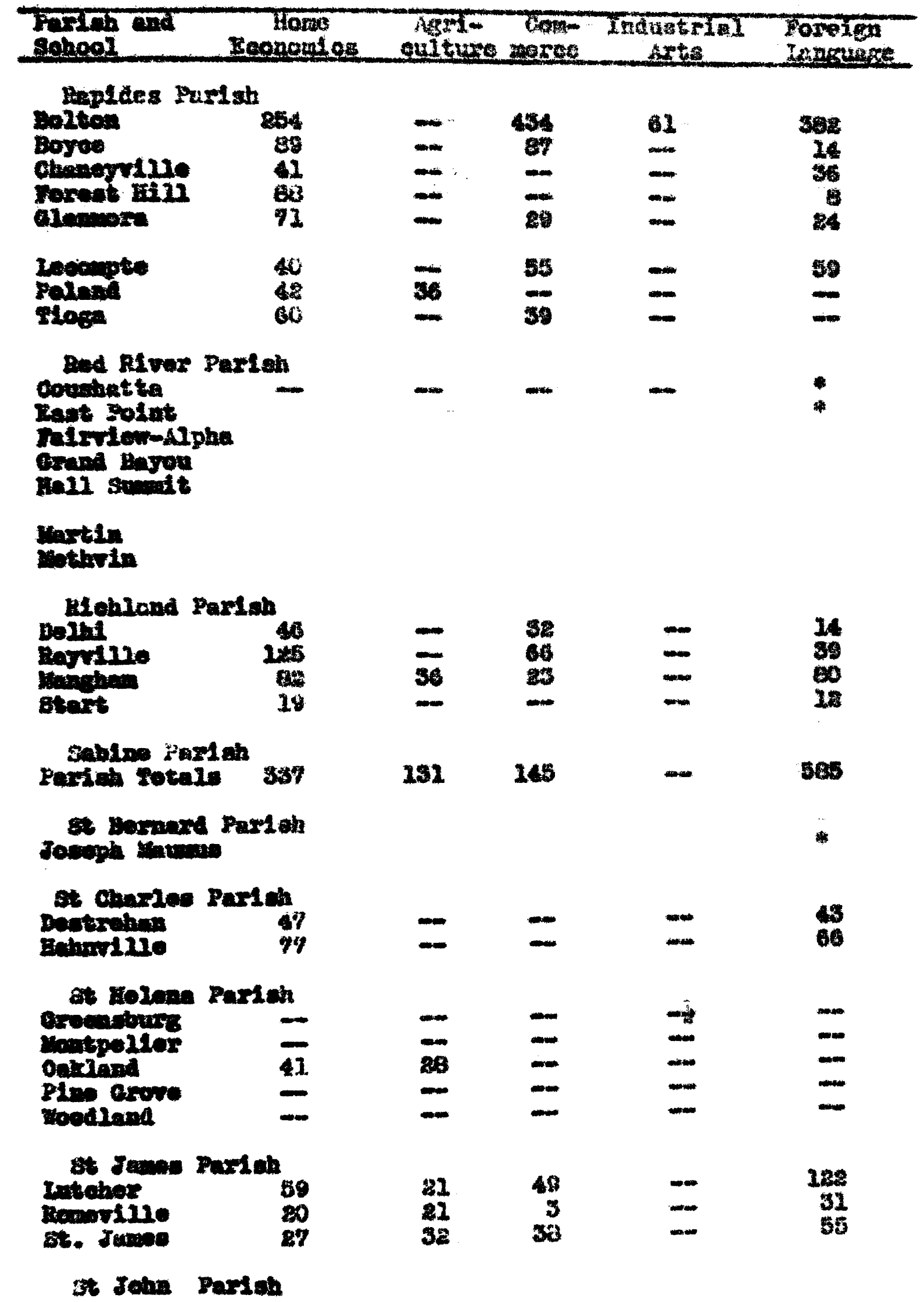


Tub10 II (oontioned)

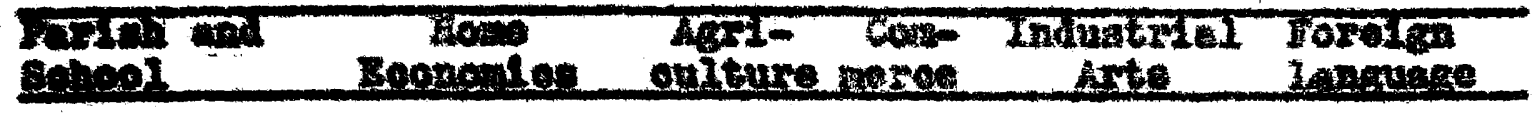

so Tohn Paxila

Begared -

Iros Codahaux -

st Inndxy faxish

Amonerilie

enation

Inten

ornd rratrie 2

Ieond 110

Eatri1s

roser

Opaleame

Pont Darre

sonect

wintington

Evertin Dariah

Deater Bridgo

ceallia

5. Hetimine 40

Bt Maxy Partsh

Barider

canseril10

rinatiln

torgen CIty

Pestermen

24

29

48

65

21

6. Tomany parteh

E) B. Ifon 107

walloonilie -

traneriso

gxeat

$-$

81

Tangl pato Perith

ante.

Grobrough

Etrond

Inapendonos

rontipot

Loranger

Randratoura

Roseland

spring creok
18

38

7?

$-$

$-$

26

66

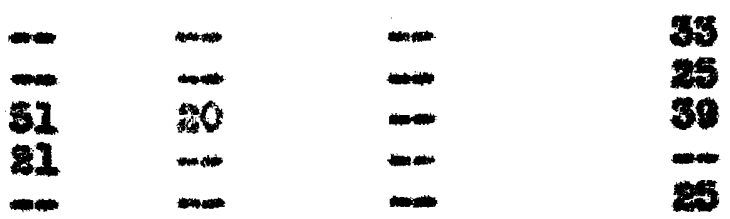

$-\infty$

$-$

18

$-55$

$-$

108

-

-

$\overline{-}$

4

$-$

48

$-$

$-$

11

$=-$

$=$

38

$-$

$-$

55

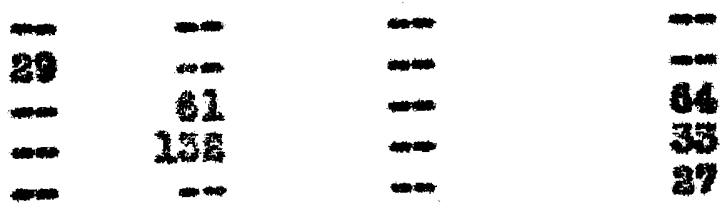

$-38$

-

14

$-31$

$=$

21

$\overline{36}$

105

$-\quad 210$

$-$

10

$-\quad-$

$-\quad 254$

- 86

45

$=$

$-$

$-$

$-$

16

98

58

4

$31=00$

$-58 \quad-200$

$=\quad-\quad=\quad 28$ 
Teble II (oontinued)

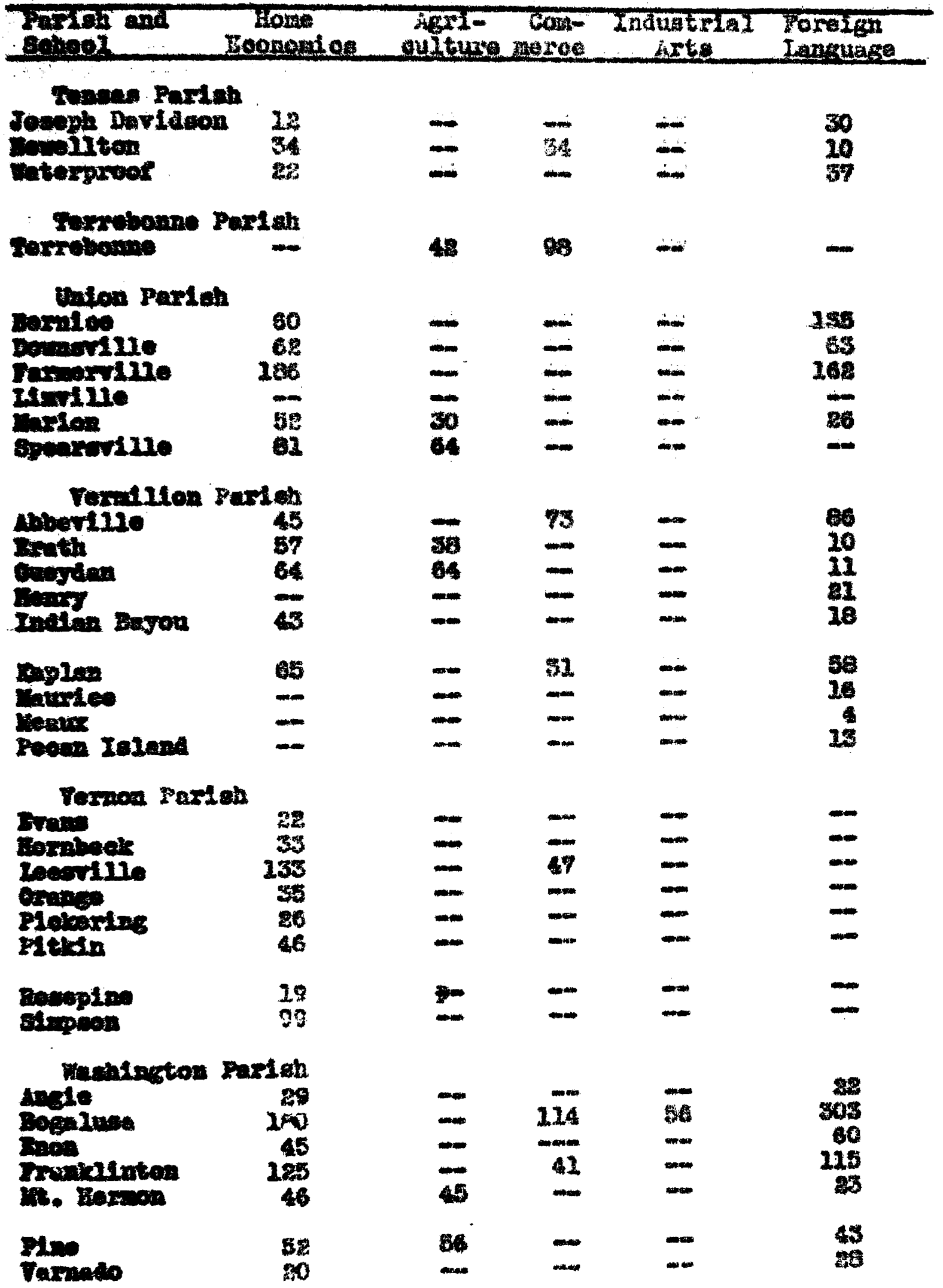


sable II (eontimed)

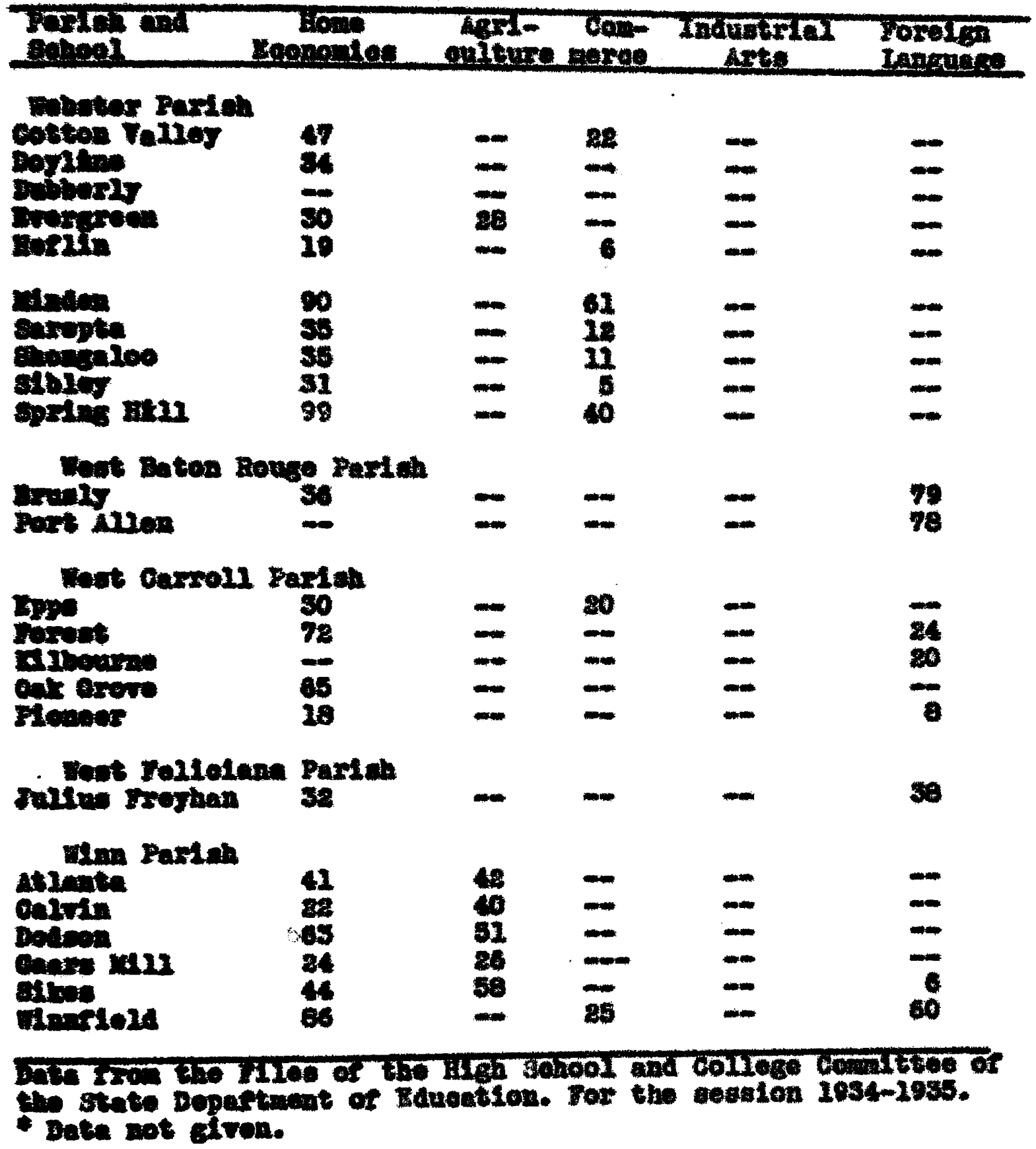


Appondix $\mathrm{B}$

Sohodulen Veod in studylug the

Loutelena Rural Bohoole 
Tule $\mathrm{I}$

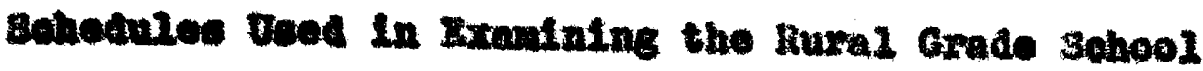
ontiarm

Tatis Rim Age Orate

Eature Nan HI O Oempation

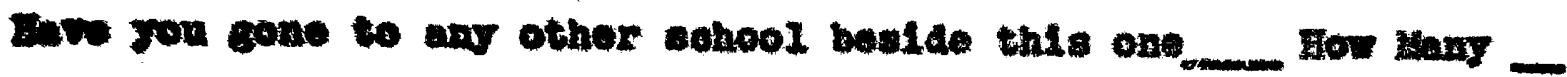

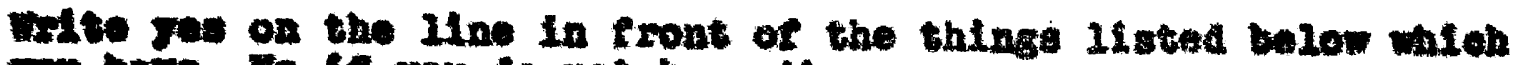
Jon knve, is if you co not have thome

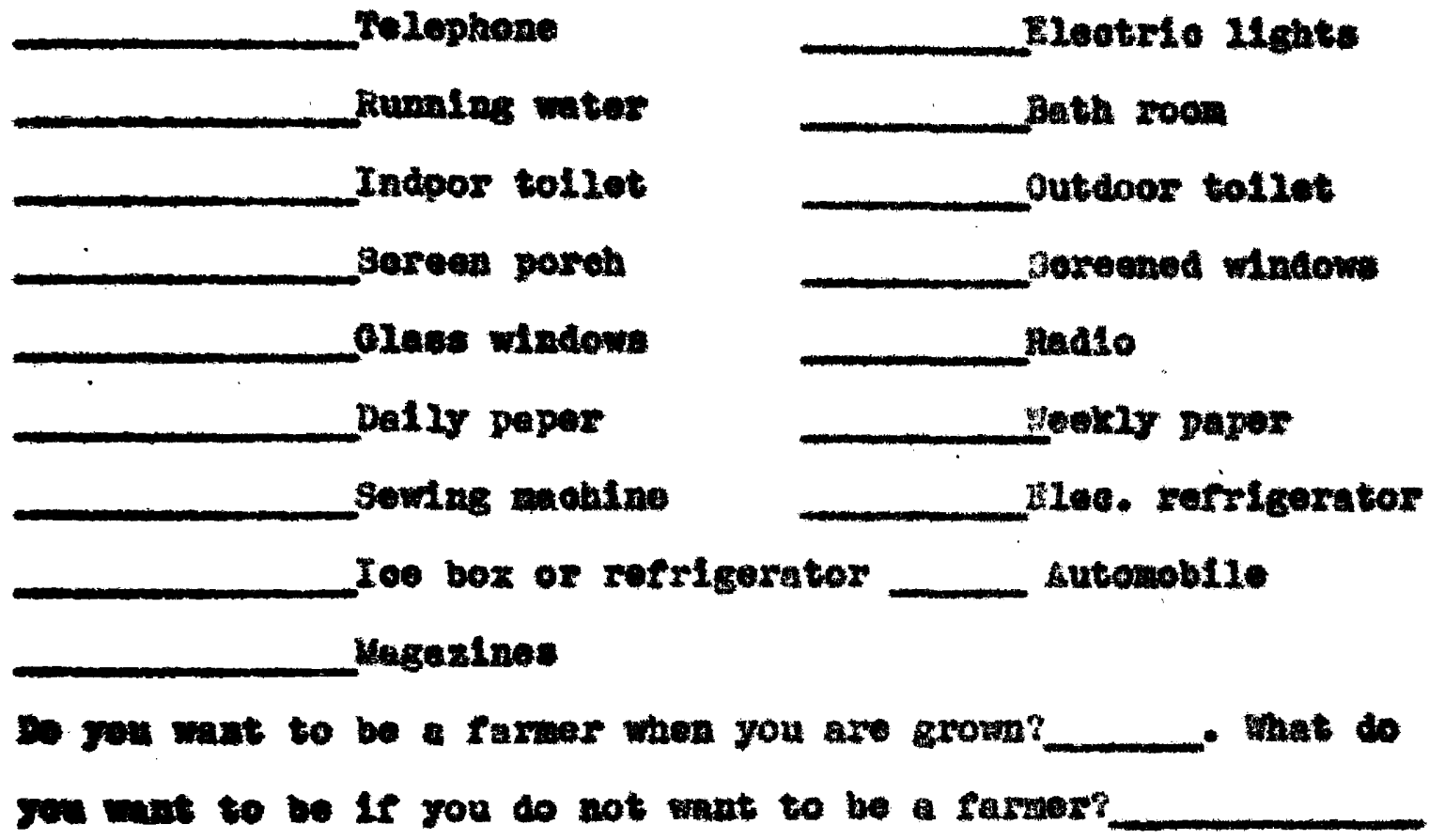

Ion las is jou 11 ve from ghool? How to you got to atmese

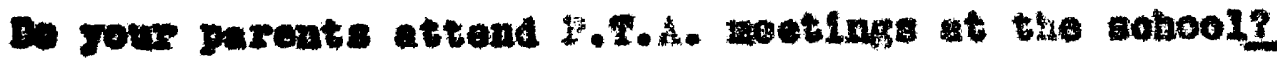

Tw ang the have your parents visitod the solool this year? Bo jour parente attend ontertatnetents in the sohooly 


\section{Mable II}

Sohoduleo Used in Braminlng the Rural Hlgh Sohool

Stedentse

Tow Nano

Iunters' thane

Int of on land workad
Age Grade

\section{arope releod}

Aanes in eotton augar vane Moe

Do son expeot to become a raxmer? If not, wat woula you 115 to beane?

wite rea before any orsanizetion which gou belons to, Wo if Jow do not belong: 4- olub

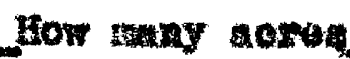
His Docupation Juture Pramern of Anertea L_Ebool Gles club of 2uartet Boy seoute - Sohool clubs. Whioh onen? an-r atrl Beout:

GLrI Recerves School tuletie teanu. thioh ones?

Gavor

gemeng sahool

wow roh bold and sohool ofrices? What

Ene you represented your soinooi in state or Distriet Rellien? wat

Bo row parente attend I.T.h.metings at the Behool?

Bow wan time have your parente visited the sohool this yeur Do rewe parente attend entortalurents given in the sehool If co, wo they attend regulariy or one in a the 
Tablo II (contiawed)

Bow any brothers and alster have you in achool? ant gradens.

Exolnore and af atere away from howe of through sehool: brother or slutar, age, Education, ihere de
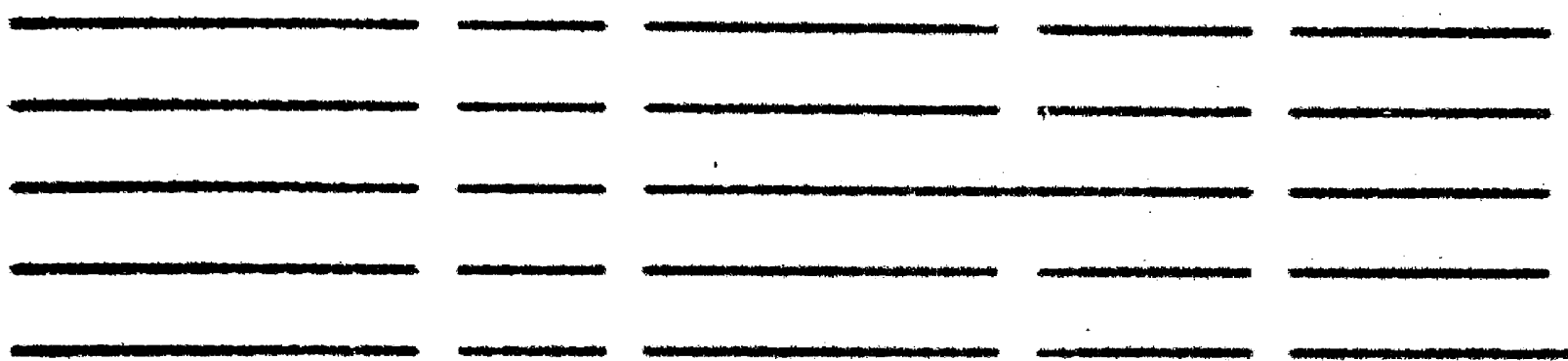

Imber of brothers and laters of sohool age but not in sohool

nower too young to go to sabool ages

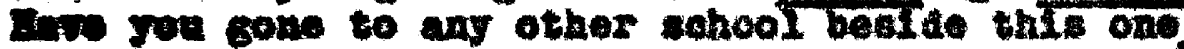
How many

Dow ter ala jour father 60 in sehool. your mother

If sen have the following in your howe or 15 you own the rollowing Ex res, If not, wite no: Telephoze turenlins water Intoos toliet soreaned porah Olase vindowe De $11 \mathrm{y}$ paper sowlug manine Ioe box of refrigerater Hagazines, which ones

Tleetrie 11 Bht: Bathroos. vutioor toliset Boreened intowa pradio Heerly paper kec. ieer igerntor intosobile

Do ren atten wotion ploture adhow? fbout how often

Het the mabjecta you axe now takias

Dow ter do you live from the nchool?

Eaw do rea get to sohool? 
DTBLTOENAFX

$-$ 


\section{- Drbrography}

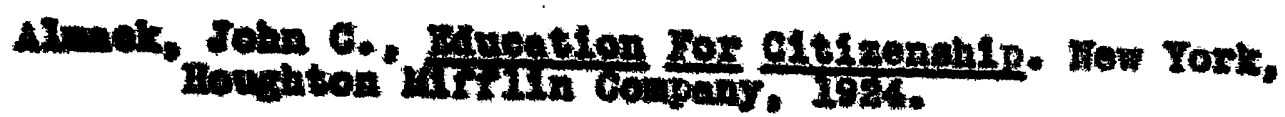

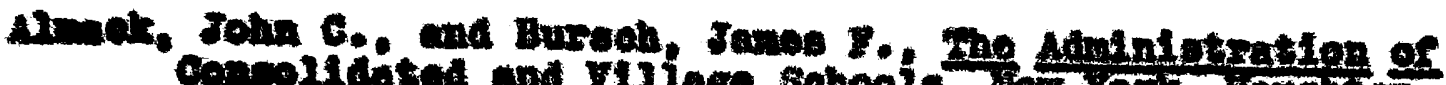

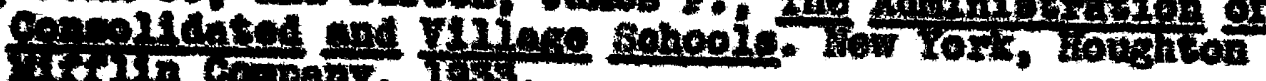

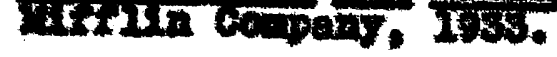

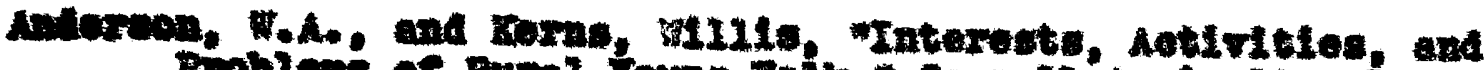
Problen of Rural Ioun 7oix, " Correvi Acrolontura

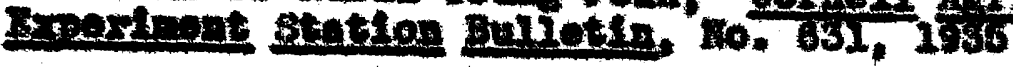

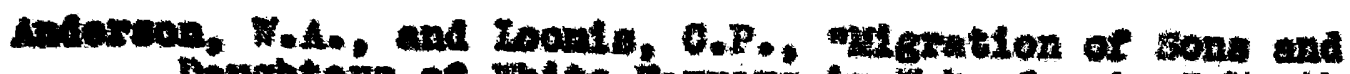

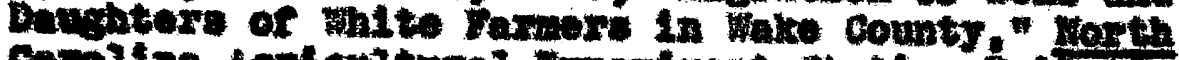

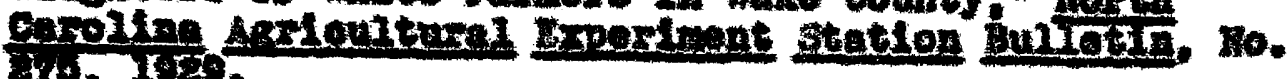
E.w. Iots.

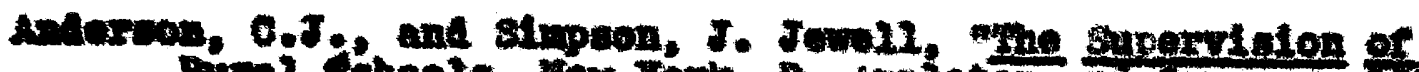

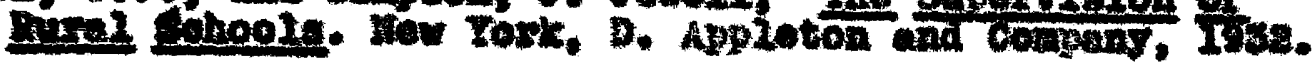

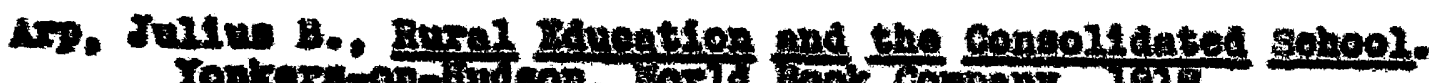

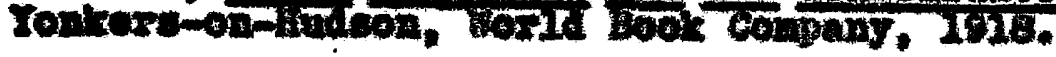

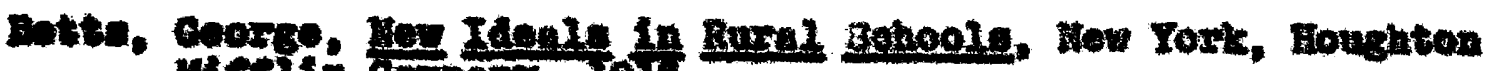
uiftin compars. Iob.

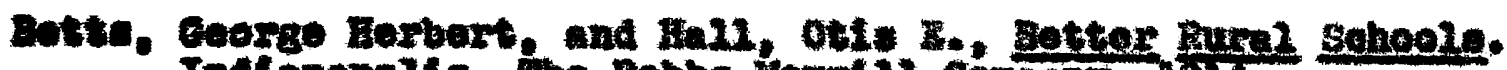
Indiandells, the Dobbe-inerrill company, 1916.

Bienten, A. H., "Ohile of the roxas One-Teacher sehool,"

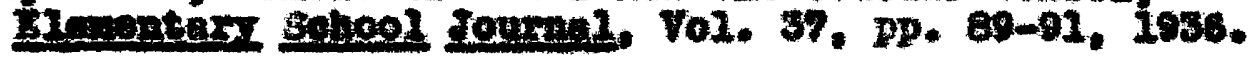

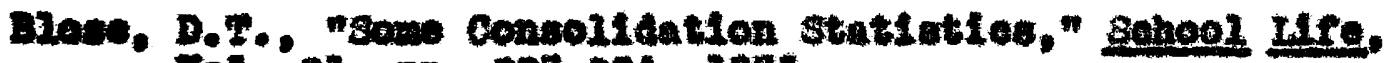
Vo1. 81. 2p. 2es-284, 1036.

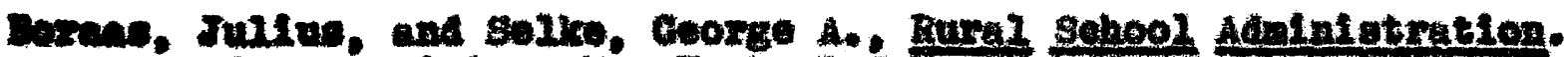

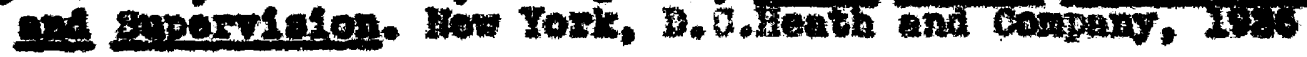

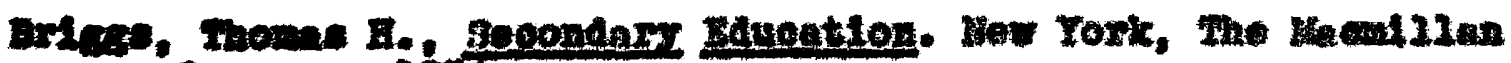
cempany. 1034.

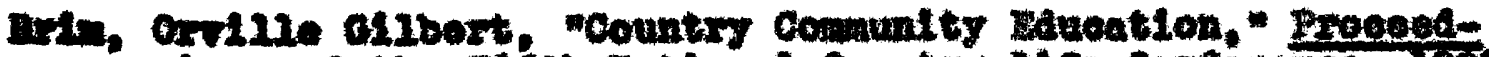

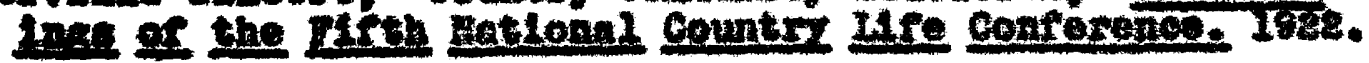

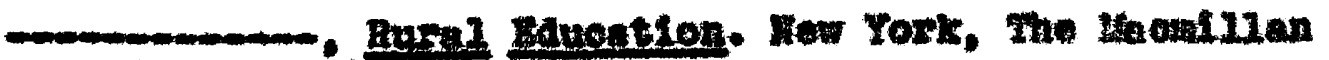
Company, 2150

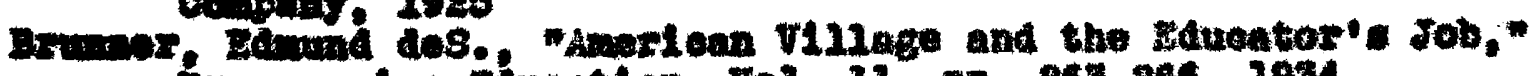

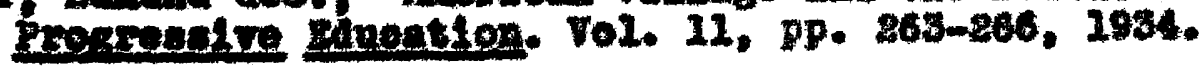

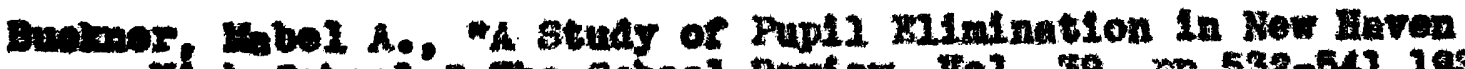

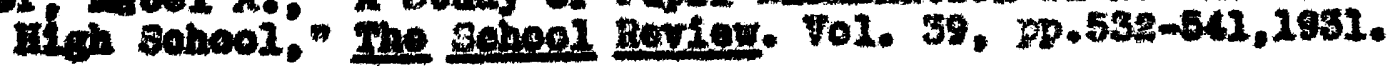

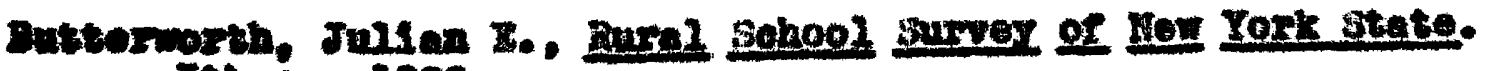
Ithaea, 1028.

- "Tactore of Rural kcuostion," Bducationel Butes, vel. 75, pp. 90-96, 2027 


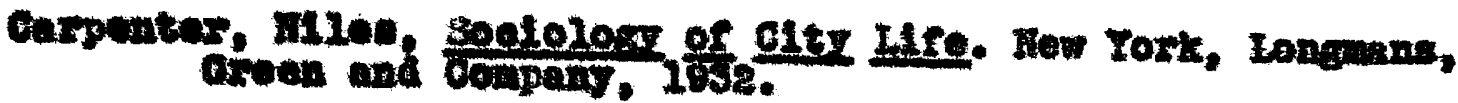

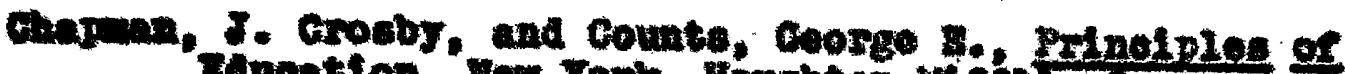

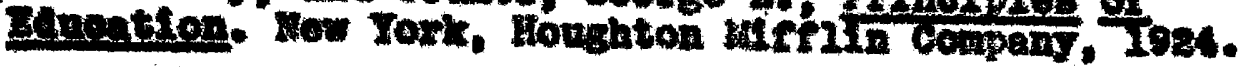

Cock. Donnis H.. "A Study of sehool surveys wth Hegard to

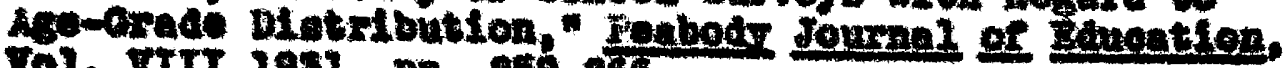
To1. VIII 1981, pp. $259-266$.

- Problene of the Tenching Peroopnel. Hov York. Yongmane, oroce and company. Iss\$.

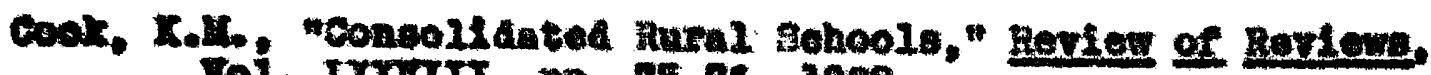
7oi. Irrmix, pe, 75-75, 1020 .

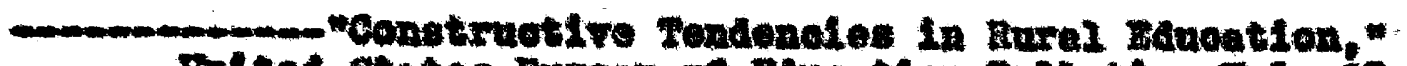

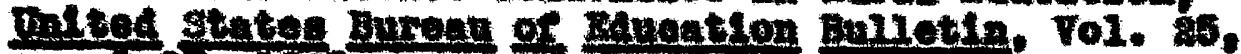
DP. 2-2r. IOES.

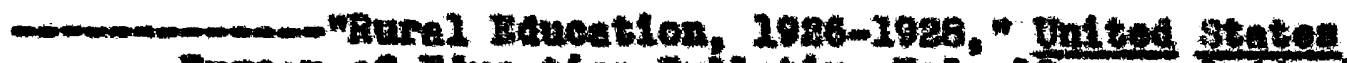

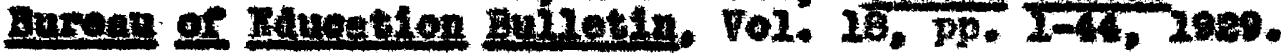

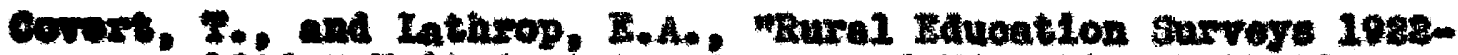
1026." Dnlted states guners of Zducation gumetin.

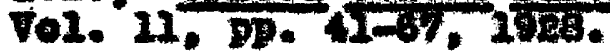

Crebtree, I. H., "Challenge of the Murel sehool," ItatLonal

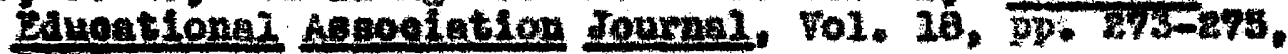
IDE.

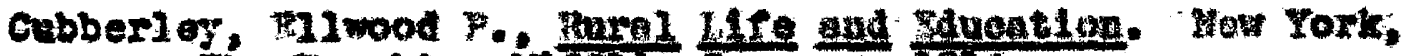
The Houghton itfrin company, IN4.

joblis zaneation in the United states.

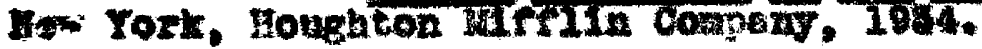

Gr. 1. H. Woeded Fesearoh on the Aleorganization of Sohool

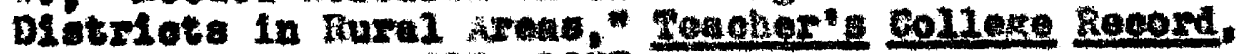
Vol. 30, $\mathrm{pl}$. $394-315,1937$.

Buwen, H. A. Maral Life and Wducation," Mational Mduestion Aneodation Journa?. Vol. 25, pp. 155-158, 1 S5E.

Doloh, z. w., "Coographioal and Deoupational Matribution of

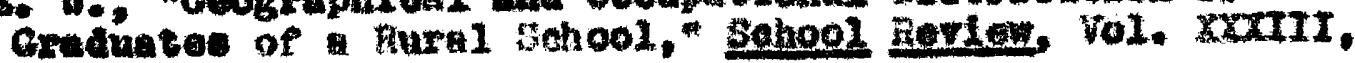
Dp. 415-421, 1925.

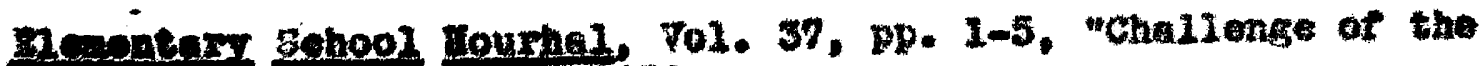
inral Bahools," 1936.

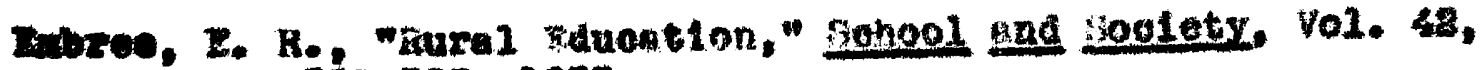
pp. 5e5-593, 2835. 
Fallon, J. J." "Gurrioulum Differentiations in Rural schools," Cathoile Sohool Journal, Vol. 36, pp. 31-33, 1936.

Forguson, Lare Watson, A Study of Commerolal Education in Loulslane Hlgh Schools. U. A. Thesis (Unpubilshed), Woulalana state tinlversity, 1936.

Noote, Irving P.. Tenure of Hligh Sohool Tegoherg in Loulslana. Baton Rouge, Loulsiana state University Press, 1931.

Galpin, Charlos Josiah, Rural Life. New York, The Century Company, 1918.

Gaumitz, W. H., "How Small Are Our Small sohools?" Sohool Life, vol. $20, p p=198-299,1935$.

- Economies Through the Elimination of Vexy Small Schools," Inited States orflce of Bducation Bullet1n, Vo1. 3, pp. 1-54, 1934.

- "Status of Teachers and Principals pholoyed in the Rural Schools of United States" "United States Orfioe of Education Bulletin, Vol. 3, pp. 1-22, 1932.

Gayaree, Charles, Histony of Louislane, New Orleana, F. F. Hansell and Brothers, 1903.

Conoral Education Board, Fublio Edueation in Kentuokr. A Report of the Kentucky dueationeI Comm sबIon, NeT York, 1922.

of the Indiana Educational Survey Comission, New York, 2923.

Gilette, John Morris, Rural Soolology. (Third Faltion) New Tork, The MaomiIItan Company, 1936.

a1at, Fool and Halbert, I. A., Urben Soelety. New York, Thomas Y. Crowell company, 1933.

Cood, Alvin, Soclolofy and Education. New York, Harper and Brother8, 1926.

Bale. F. M., "Renal Sohools; Conditlons Whioh Influenos Behartor and 'Montal Alertnese," Grade Teacher. VOI. 54, Dp. 58, 1937.

Hamilton, C. Horace, "Rural-Urban Migrations in North Carolina iszo to 1930," North Carolina Agrleultural Buperiment Station Bulltitin, No. $295,1934$.

Hart, Joseph $\mathrm{K}$., Light Trom the North. New York, Henry Ho1t and Company, 1927. 


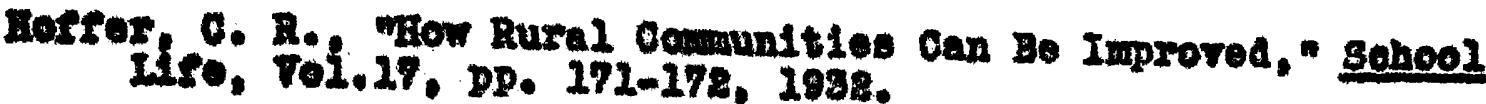

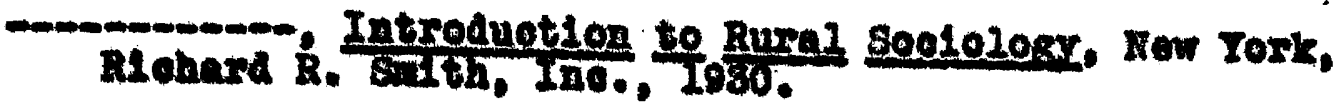

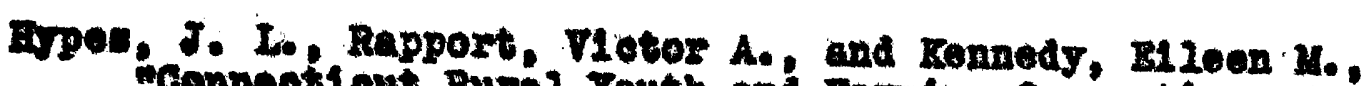
"Conneotl out Rural Touth and Farming Oocupationg," Starre

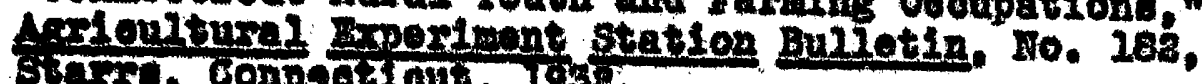

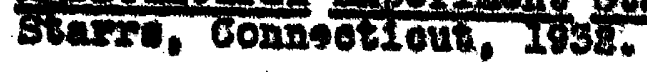

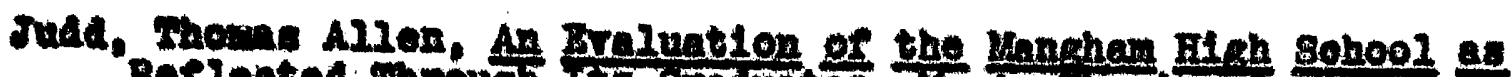

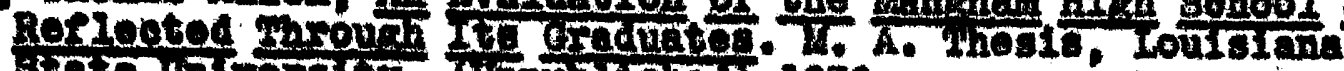
stato unitrarts. (unpubliated 1936.

dins, LoRoy Albert, "status of tho Rural Fonghor In Pennarivanla,"

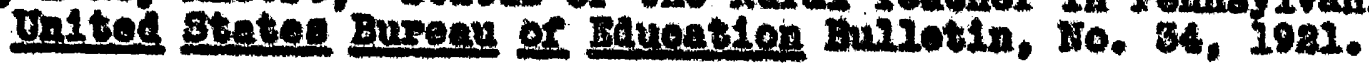

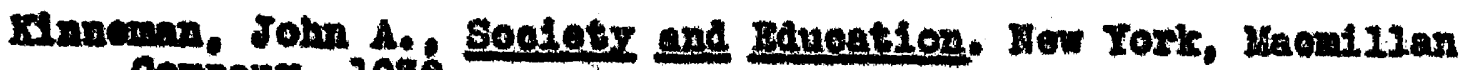
Compeny, 1938.

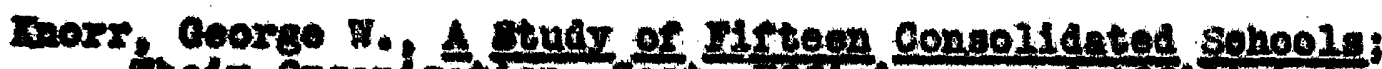

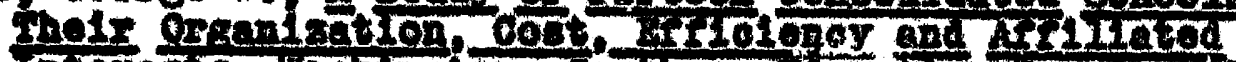

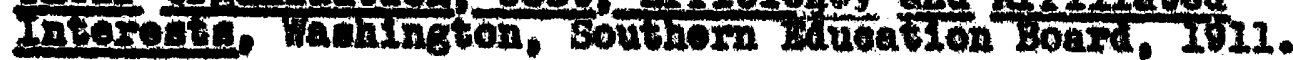

501b. J. H., and Brunner, Bdmend des., A study of Rurez Socletr. How Jori, Houghton Mirtin compeng, 1985.

Eo2b, J. H., and Poleon, R. A., mronds in Tom-Country Relations,

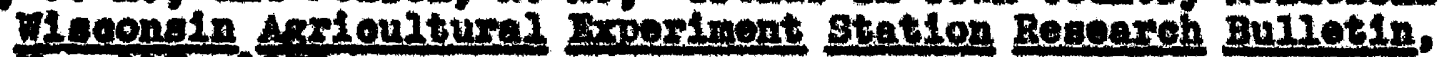
10. 1XY, 106s.

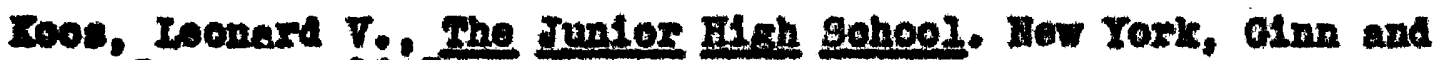
Company, 1987 .

mogerel, R. P., Wigh sehool Bdueation As a Ruxal Problem," Bohool and cogennity, 701. 21, pp. 288-289, 1085.

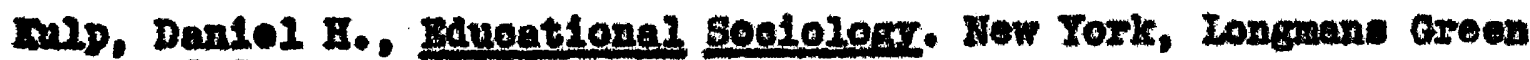
and Company, Itss.

Iecoh, Don R.. "Soholarahip and success in Lfe," gohool Rerler, V01. X2, P. B1, 2932.

Iott, EIno H:. "Aural Contributions to Drban Ioaderahlp in Hontana," Yontane Arrloultural Experiment Station Bulletin Do. 268, 206t.

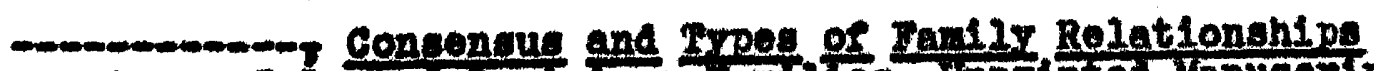

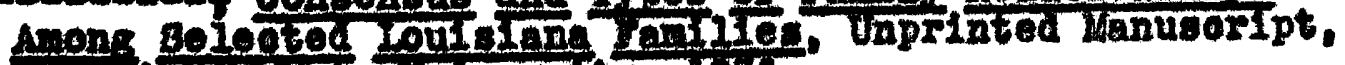

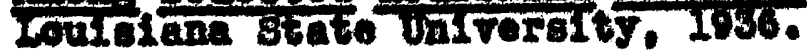

Loula1ane Department of Agrioulture and Imnigration, Loulalang 1087-1928.

Ioulalann, state Dopartmont of zduoation, Mighty-S1xth Annual Ropozt," Buliatin Bo, 309, 2035. 
coululame, State Depertment of Bducation, "Bdueat1 ons Directory," Enzletin Ho. 304. 1035 .

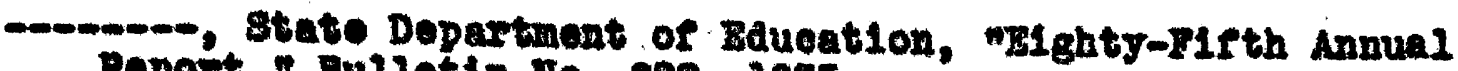
noport," Bullotin Ho. 288, 1985.

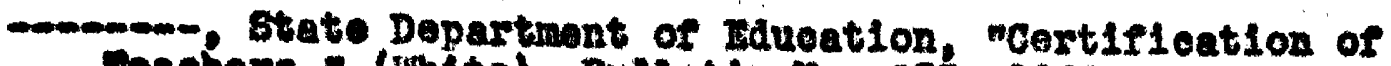
Itachers." (inite) Bulletin Ho. 275, 1934.

Ioulaiana state Unirersity and Agrloultural and Uoohanioal colloge, Univeraity Bnlletin, 1984.

Ioulatana, State or, Aate of State of Iouigiana, 1934.

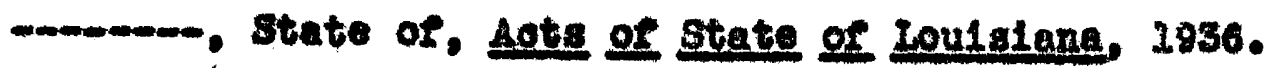

-mongent Def Agrioulture and Irmaleration, Loulciane 1982-1989.

Lowth, F. J." "Rural Banoation of Tomorrow," Joural of EAreat1on, Vo1. 116, pp. 356-357. 1935.

Inoky, Bamuel arags, Analvals of the Bagtrop II sh Sehoel Population ith spocial Rorerence to Paxente2

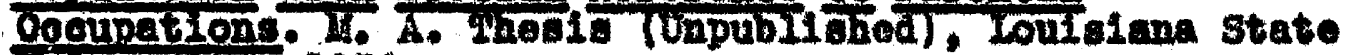

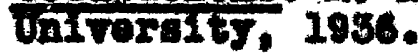

Wo corrilok, 2. C., "Rural Soolal Organization in the Rice Aree," Ariganges Afrioulturel Broeripont Station Bulzetin. 170. 206, 1968.

- Mutral soalal Organization in Mashington

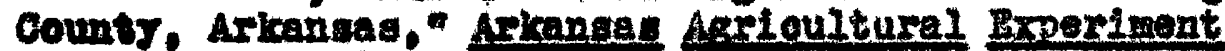

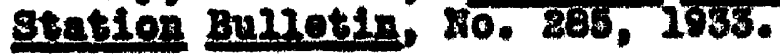

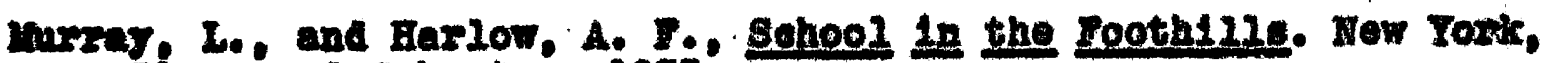
Simon and Sohuster. 1935.

Fatlonal Bduoational Association, Report of the Comaittee on

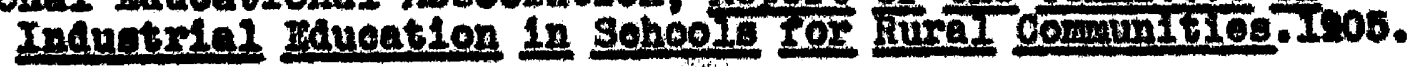

Deport of the compittee of

melre on Rural Sohoole. Chloge, Unirersity or Chioago Frose, IBS\%.

Oxanization of Gurrevourin

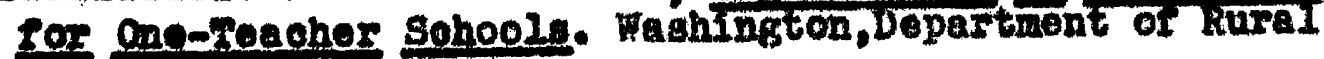

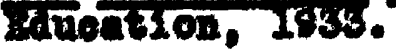

Awn, Howare W. Southern Reglons of the United States. Chapel H112. Univereity or trorth caroline press, 1936.

Ounonita Parieh High Sohool, Catalorue, 1903-1904, (Onpublished.) 
Potore, Oharies O11nton, Zoundetiong of Eduoation. new York,

Poters, R. I." "Good Word for the One-Room sohoold," Hationie
: Sohoojs, V01. 17, pp. 26-28, 1936.

Prencey, S. I. Psrahologr and the Her IAugatlon. New Tork, Haxper and brothore, 2083 .

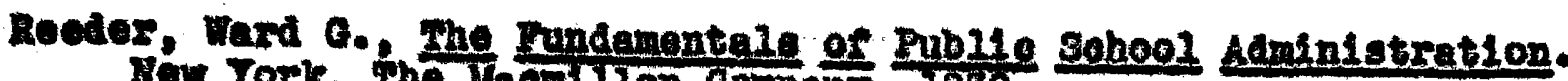
Now Tork, The thatullian 0ompany, 1930 .

Bolnoohl, Oheries Myron, "Anelytle survey of State courses of Study for Rurei Elemontary Sohools," Bureap of Bdvoation Builetin, No. 40, 1928 .

Rugs, H. O. Amerloan Life and the Bohoo 2 Ourriculun. How York, einn and compant. 1836.

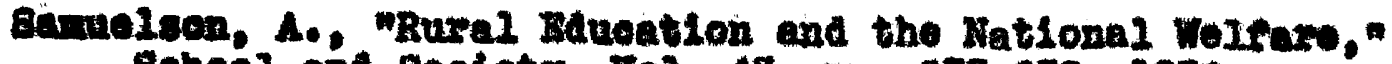
Echool end Society, 7ol. 43, pp. 273-278, 1986.

Sanderson Ditight, the Burel Commaitr. New Tork, Oinn ard Company. 2988.

Behool and Socletr, V01. 43, Dp. 8-9, Grural Sohools in Kantacippl, 1936.

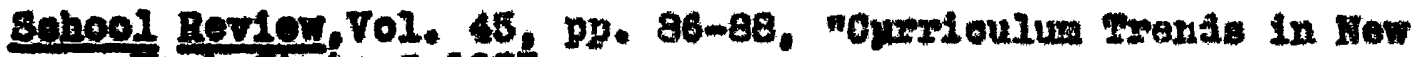
Yorz state," 1937.

Bonutte, R. H. Orlontation in Edueation. Hew Tork, The Inomizan Company, 1982.

Shan, H. H. "Civio Rosponsibillty of a High Bohool Prinolpal," EI th Sóhool Journel, Vol. 20, pp. 55-57, 2937.

81m, Mowell Loroy, Elemente of Aural goelologr. Now Tork, Thomas $Y$. Oxowe II Company, IS28.

-coment Tharles Sorlbnex's sons, 1080 .

Sedth, C. B., "Tho sohools and Improvement of Rural Itving,"

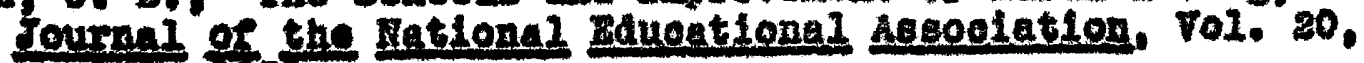
D. ES, I031.

Eith, Jamos vonroe, "The Tralning of High sohool Teachers in Loulalana," Contributions to Bduest 10n. Ho. 247, New Tork, Bureav or publioations, Toahor coliege, columbia Dalveralty. 1086.

Sulth, T. Lran, and Fry, Martha Ray, Whe Population of a

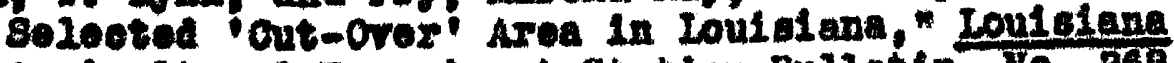
Aerlenitural Experiment Btation Bullotin, Ko. 268. Exton kougo, 10836 . 
Bath. T. Ionn, An Analyals of Rural Soolal Orgentzation Among the Fronch-9poalins Peoplo of Southern Ioulsiane,"

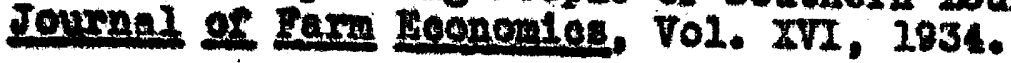

- "Eronth of Population In Ioulalana 1890 to 1980."

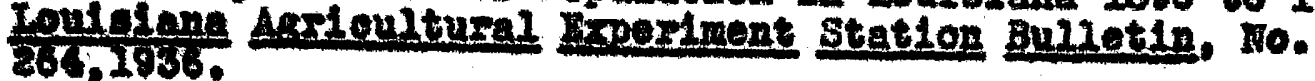

sutth, Haltor Robinson, Prinolples of Bancational goololong.

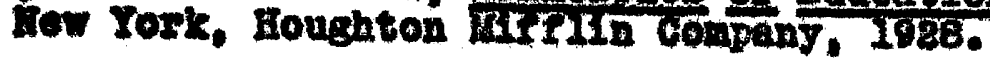

Bathers, Eower I.: "Oeoupationsl Oareere of High Sohool

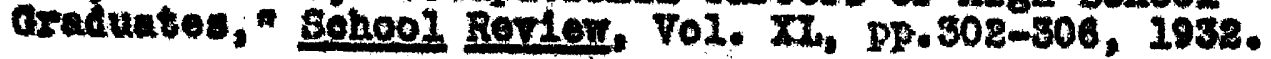

Enedded, Darid, An Introduotorr goolology for Teachers.

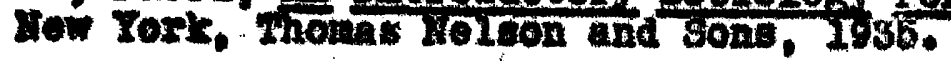

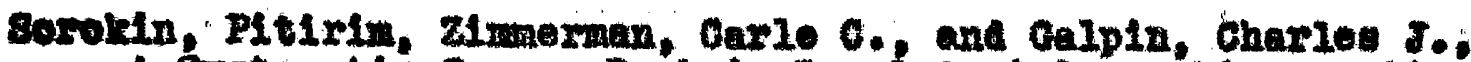
A Srateratio Bouree Book In Aural Soctologre Minneapolis. Entrorsity of Minnesote Preas, 19s1.

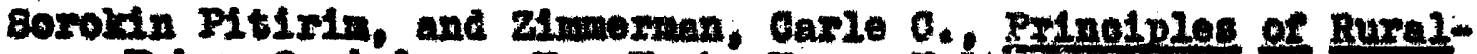

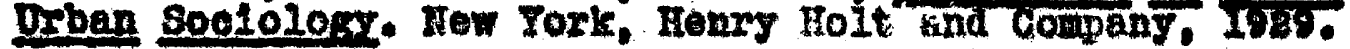

Berokin, Pitirin, Soeial Woblifty. Hew York, Harper and Brothers, 1987.

Southerz Association of Collegen and Becondary Bohools, Eroceedinge of the FortLeth Annue1 Heeting. Loulavi110,1958.

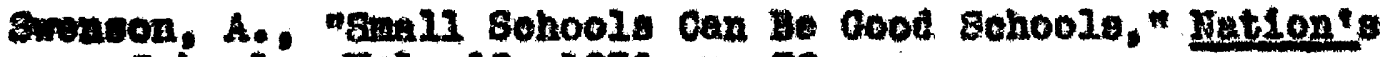
Behoolg, Fol. 18, 1986, p. 32.

Sylvont, Hezale Robert, the grall High Sehool, H.A. Thesis, Ioulalane state UniveraIty. (Unpubilshod) 2935.

syond, F. U. "Ifre Problems and Interests or Adolescents," Beheol Reriex, V01. 44, Pp. B06-518, 1936.

zarlor, Gar2 C., Rural goololos, How Yoxk, Harpor and Brothers, 1033.

Taylog, R. A., and Yoder, I. R., "Rural Social Orgenization in mateon counts," Rechington Anxioulturel Experiment getson Bu110tin, Ho. 216, 1987 .

Troknalke, seward I. Parehology of Learninge Hew York, Touohere' College, Colunbia taiterstey, 1921.

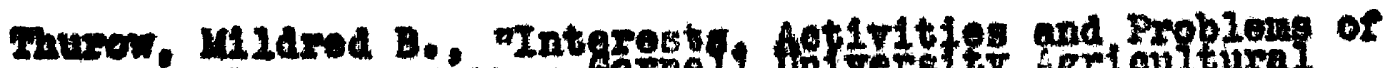

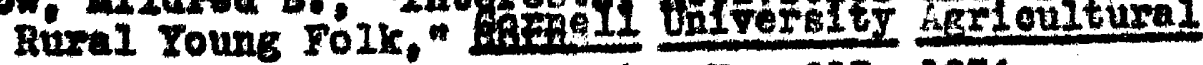
Experinent gtation Bulletin, No, 617, 1984. 
rutt1e, Barild s.. A seoiel Besis of Zdueation. Now York, Thoulas I. Crowill, I838.

Onlted States ore1 oe of Bducation, "Status of Teachers and PIInolpels Imployed in the Rural sohools of the Onited states," Bullotin Bo. 3. 2932.

Wobb, Jesse James. A gtudy of the Exreots of the consolidation

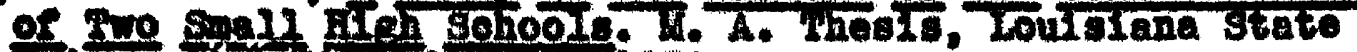
vitrerait $y$, (Uapuburshed 1036.

mitlow, C. H., "0oographioal D1atribution of H1gh Sohool Craduateo," Bohool Rerlew, V01. 30, pp. 213-216, 1930.

Onlvoralts of W1goonaln, Agrteulturel Experiment Statlon Besearoh Bulletin, Ko. 120, Iobs.

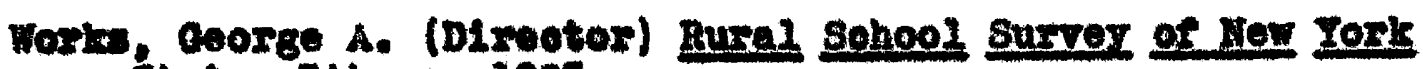
State. Ithuea, 1983.

Iouns, Ximball (Ma1tor) Source Book 10r Soololos. Hew Tork, Amortean Book company. 1086. 


\section{BIOGRAETY}

Sarion Bush Solth was born in Anthong, Harper County, Kansas, February 7, 1894. He rooelved his early training In the publie sohools of Anthony, Kansas and Santa Ana, California. His sooondary sohool training was recelted in the Northside Eigh Sohool of Denver, 0010z'ddo. In 1917 he reoulved an A.B. degree from the Unfvergity of Denver, and in 1928 ho was granted an H.A. degree by the Unlversity of Colorado.

Fe entered the teaching profession fin 1921 as athletic direotor in the Olla-Stanara High Sohool of La Salle Parish, Loulsiana. For the next twelve yeurs he aervod as teacher in the publio sohools of Loulstang.

In 1932 he cane to the Loulalane State Univeralty as a

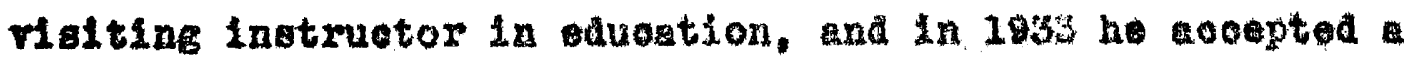
graduate assistentahip in Tenohers college. For two years ho sorved as a supervisor or preotlce teachers in the Dulversity High Sobool. Durine the aesurion of $2855-1936$ he was aseistant dean and regiatrat the Northesst Conter of Loulalana State Univoratty. In the fall of 1936 he returned to the eampus of the Loulaians State Univeratty as lastruetor of soolology in order to cormlete the work on a Doctor of Dhilosophy degree in eduontion and sooiology. 
EXAMINATION AND THESIS REPORT

Candidate: Mi sis I us in

Major Field:

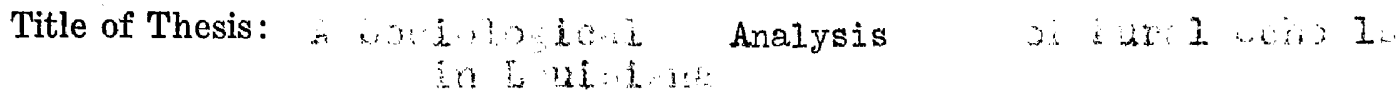

Approved:

Date : $\because \because ?$

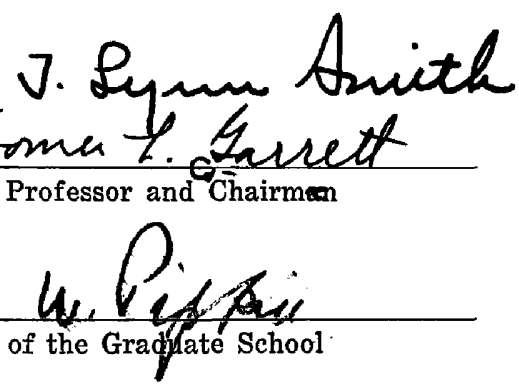

EXAMINING COMMITTEE:
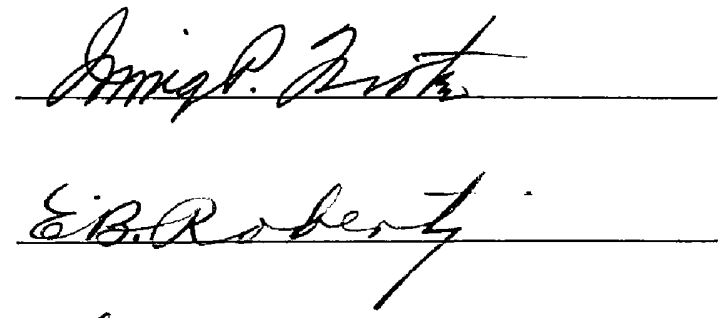

Black ed liffemen
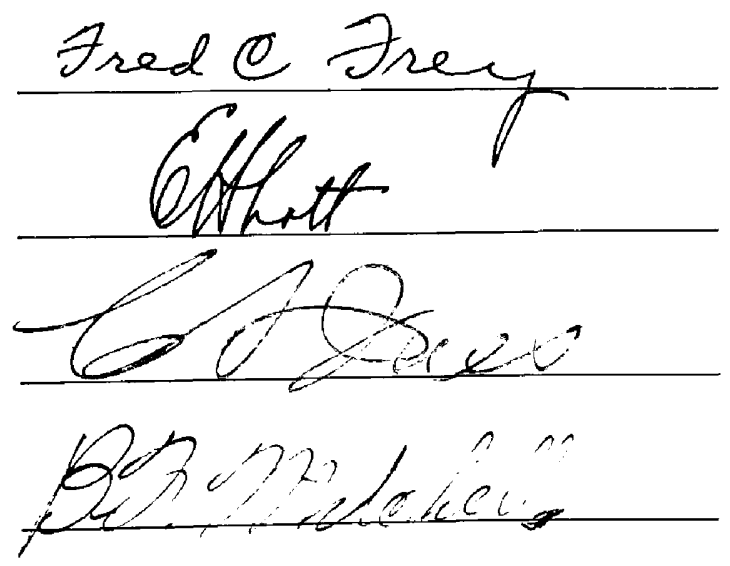